

N A T U R A L H I S T O R Y A N D

$A N$ T I $Q U, I T$ I E S $\mathrm{O} \mathrm{F}$

NORTHUMBERLAND: And of fo much of the County of
D
U
R
$\mathrm{H}$
A $\mathrm{M}$

As lies between the Rivers Tyne and Tweed;

$$
\text { COM MONLY CALLED, }
$$

NORTH BISHOPRICK.

I N T W O VOLU MES.

By J O H N W A L L I S, A. M.

$$
\text { V O L. II. }
$$

\section{O N D O N:}

Printed for the AUTHOR, by W. and W. STRAHAN; and fold by $S . B L A D O N$, in Pater-nofter-Row。

$$
\overline{\text { MDCCLXIX. }}
$$


d. If $T$

Y \& $0 . T 2 I H$ I A A U TA M. C $\nVdash \mathrm{A}$

2. I I U O I T KA

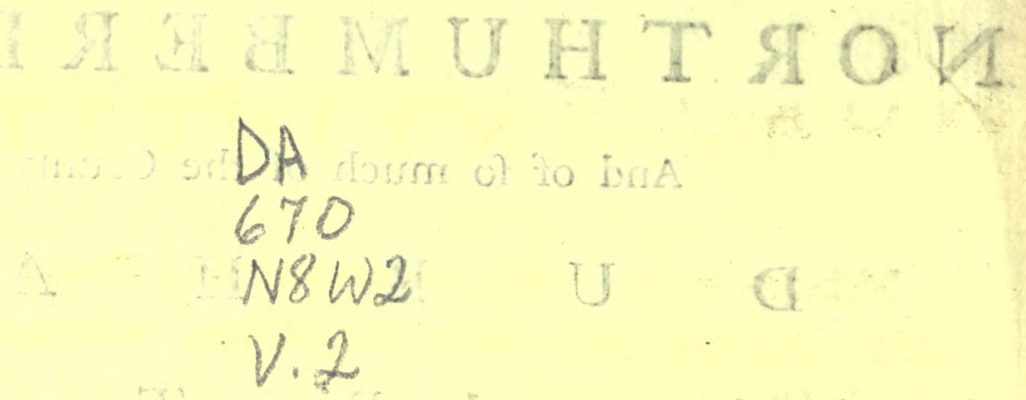

ght noowtgd asil aA

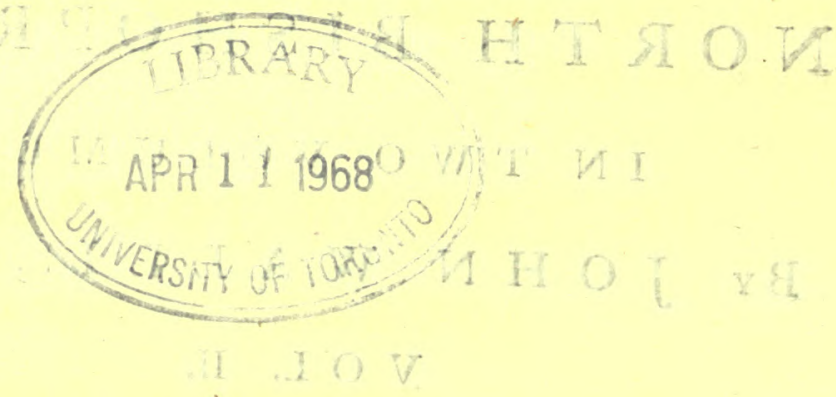

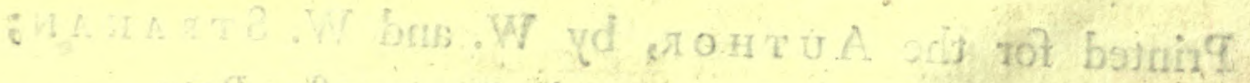

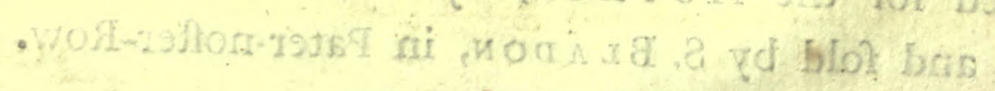

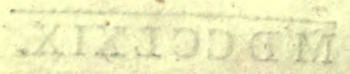




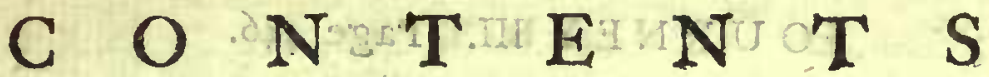

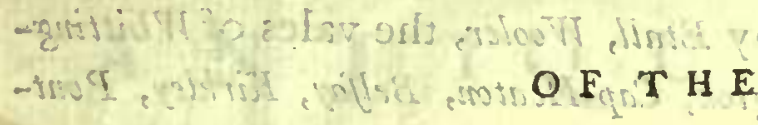

\section{SE C O N D VO L U M E.}

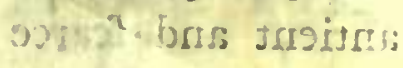

\section{The A N T I U I T I E S.}

Military ways, forts, incampments, Tumuli or barrows, urns, coins, fignets, and other curiofities, whether Roman, Saxon, or Britifh, of principal note.

Royal palaces, honours, caftles, feats, villas, monafterics, churches, market-towns, iflands and harbours, worthy of obfervation. Their antient and prefent ftate. With defcriptions written on the fpot.

\section{IN THREE JOUR NEYS. J OUR NEY I. Page I.}

From the Weft to the Eaft end of the famous Roman wall, and on part of the great military road.

\section{JOUREYII. Page $26 \%$}

From Newcafle upon Tyne, through Morpeth; Alnwick, Belford, to Berwick upon Tweed, on the great paft-road. 


\section{TO UTRNEY II. TPageT446. O D}

From Berwick to Cornbill, by Etall, Wooler, the vales of Wbittingbam, Rothbury, Witton, Wallington, CapHHeaton, Belfay, Kirkley, Ponteland, to Nerecafte upon Tyne.

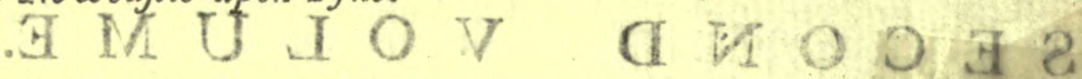

The whole illuftrated from monumental infcriptions, public and private records, curious manufcripts, antient and fcarce hiftorians, and other undoubted authorities. $\mathrm{A}$ oriT

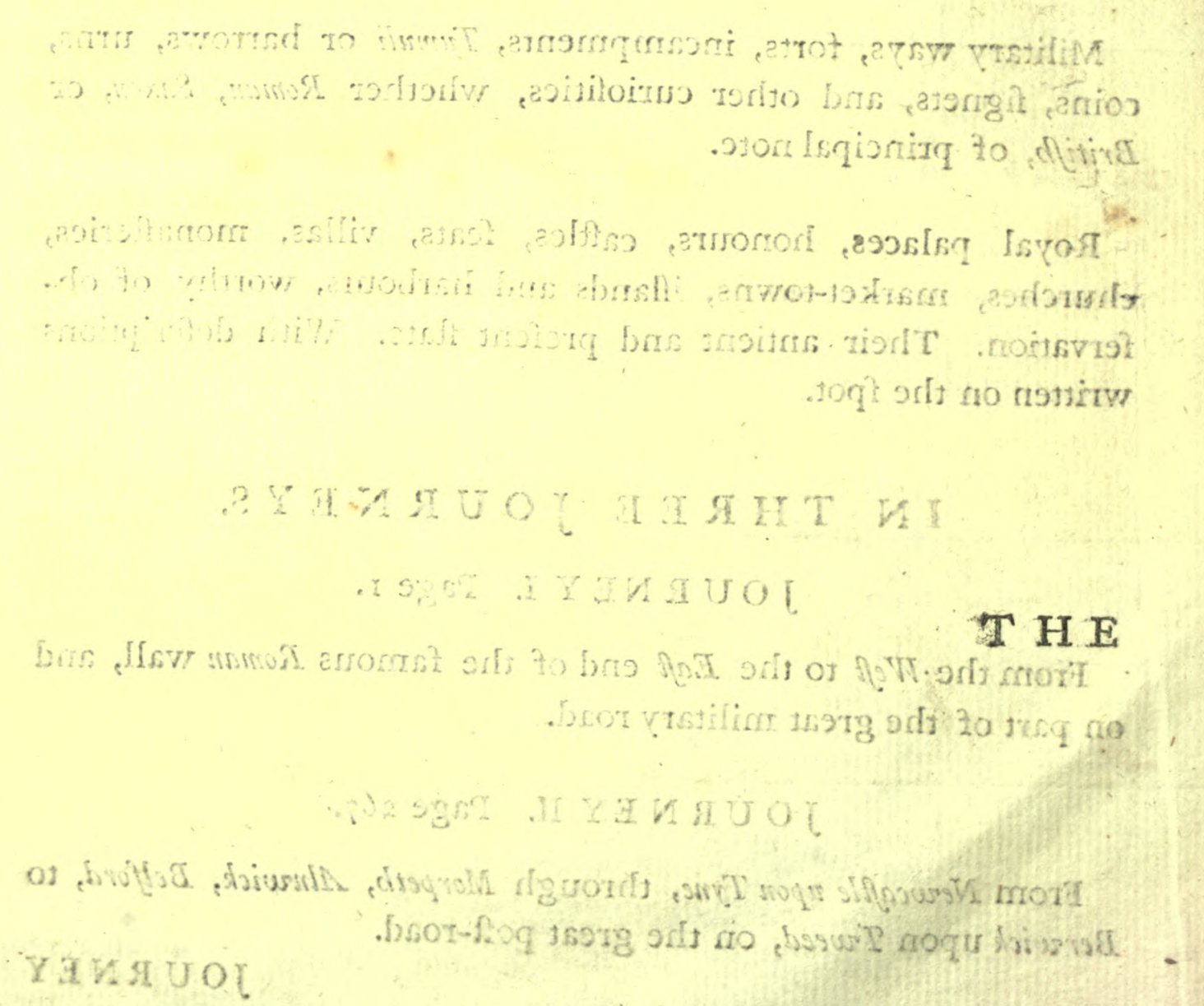




\section{T H E}

\section{$\begin{array}{lllllllllllllllll}A & N & T & \text { I } & Q & U & \text { I } & \text { T } & \text { I } & \text { E } & S\end{array}$ \\ O F}

\section{NOR TH U M B E R L A D, \&c.}

\section{$\begin{array}{lllllllllll}\text { J } & \mathrm{O} & \mathrm{U} & \mathrm{R} & \mathrm{N} & \mathrm{E} & \mathrm{Y} & \mathrm{I}\end{array}$}

From the Welt to the Eaft End of the famous Roman Wall, and on Part of the great military Road.

U

NDER the name of the Roman Wall are included three Protenture or defences againt the inroads of the Pits; viz. Hadrian's, computed to have been built Anno Chrifi r23; Severus's, Anno 210; and the laft made by the provincial Britons conjunctly with the Romans under the third confulate of Eitius, A. U. C. Irg8, Anno Chrifi, 444, or, according to Archbifhop U/her, 446. Hadrian's is acknowledged by all the learned in antiquity to have been cefpititious, or of turf, but they differ with refpect to Severus's; and the Roman writers, Spartian, Eutropius, Aurelins Victor, Caffrodorus, and $\dot{P}_{\text {anulus Diaconus, are not clear enough }}$ to decide the controverfy with precifion, whether it was of turf, or ftone, only exprefling it by the words Murus and Vallum (a).

(a) Epart. in Severo.

Eutrop. Breviar. Hift. 1.8. p 118 . Ed. Frorcf.

Aurel. Vietor in Sevsro.

Cafiod. in Severs.

Paul. Diacon. 1. 8.

VPL. II.

B.

Vene- 
Venerable Bede pofitively afferts, that Severus's Pretentura was originally no other than a ditch and rampart of earth, and that it was re-edified with ftone by a Roman legion, and the affociated frength and purfe of the whole Britifs nation, in the fpace of twelve months, after their fecond embafly to Rome for affifance: It is in length, fixty-eight Englift miles, and one hundred and fixty-nine paces, according to the furvey of the ingenious Alexander Gordon (b), which are equal to feventy-three Roman miles;and nine-hundred and fifty-nine paces.

By Sir Henry Spelman's calculation, the Roman militia along the wall amounted to 13,800 , allowing 600 to a colnort; befides a whole legion, and thirteen other detachments of horfe and foot, ftationed at other places, by the grand roads and paffes, and attending on the emperor, or his lieutenant. A great officer, ftiled, Cones Spectabilis Litoris Saxonici, created by Confantine the Great, had under him feven companies of foot, two troops of horfe, the fecond legion, and a cohort, to protect the fea-coafts from the Saxon rovers. The Roman army in Britain under Nero were $70,000(c)$.

The notion of their having a brazen trumpet in the wall, between one Caftellum and another, through the whole length, to give an alarm in cafes of danger, on the frictent enquiry is groundlefs. Some of our anceftors, indeed, held their lands by cornage, by blowing a horn on the approach of an enemy, which. cuftom was probably borrowed from them.

Rauco ftrepuerunt cornua cantî.

\section{Virg.}

(b) Iter. Septentr.

(c) Ph. Tr. No. 337 . 
This famous wall (d) croffes the rivulet of Poltrafs, the boundary between the two counties of Cumberland and Nortbumberland, at a place, called The Crooks. About a quarter of a mile farther eaft, a breach was made in it by the Scots, which to this day bears the name of The Gap. From hence it goes for a quarter of a mile, nearly in a ftraight line, to

Thirlwall-Cafle, the feat of the antient fainily of the Thirlwalls; of Fobn de Thirlwall, fon-in-law to Sir William de Swinburn, Knt. 7K. Edward III, I333; and of Robert de Thirlwall, 10 Q. Elizabeth (e). The laft and fole heir was Eleanora Thirlwall, married, 1738, to Matthew Swinburn, a younger brother of the houfe of Cap-Heaton, Efq; who fold it to the late right honourable Henry Earl of Carlifle. The caftle ftands on the weftern banks of the brook Tippal, whofe ftream glides under it in a winding current, guarded by a Vallum, or wall, of a vaft thicknefs, which with the brook, and a rocky flope, rendered it on that fide inacceffible. At the entrance, part of an iron-gate is titl remaining, within which, on removing the rubbifh, the flooring of a room was difcovered in 1759 , confifting of three courfes of flags one above

(d) Gual Sever.

$\left.\begin{array}{l}\text { Gual Sever. } \\ \text { Mur Sever. }\end{array}\right\}$ Britannicis.

Vallum Barbaricum. Romanis.

Scottis-Waith. Scotis.

Piets-Wall. Anglis.

$\left.\begin{array}{l}\text { Keep.Wall. } \\ \text { The Wall. }\end{array}\right\}$ Incolis Seplentr. Cumbriens. Northumbricns.

(e) Robertus Thirlwall fuit feifitus de et in manerio de Thirlwall, Lowbyre, le Hill, Chappel, Wade's-Gapp, Cruke, Wardhaw-hill, Shaw-field, Dirt-houfe, Over-hill, Browhoufes, Brunt-walls, Holly-houfe, cum terris in Hexham, Eftree, Newbrugh, Haltwefel, Byddleffe, et Blind-gapp, E_caet, de Anno ro Eliz. 
another, a fratum of fand lying between each. The walls now remaining are in fome parts three yards, and in others two yards and three quarters thick. The weft end, for the fake of the ftones, is entircly demolifhed. It has been large, and vaulted underneath, as moft of the old caftles are.

At a fmall diftance, and in fight, from the fouth front of Thirlwall-Cafle, is an encampment, with a cefpititious rampier and fors; the firt pretty high to the north, now called, the black dykes, wherein, on digging turf or fuel, lead-bullets have been found. A quarter of a mile to the weft of it, there is another encampment.

The Roman wall crofles the Tippal, under the fouth front of Thirluall-Cafle, and by a little cottage afcends the hill for a quarter of a mile to the Roman ftation.

Caer-vorran $(f)$, fo called from the Britifs Caer, a town, and Vorwyn, a caftle; i. e. a garrifoned town; Vorwyn being corruptly called Vorran by the Northern borderers. There is a notable fpecimen of their dialect in an infrument of truce made by the river E/k, near Salom, bearing date xv March, M. CCC. XX. IV; the right honourable Henry Percy, Earl of Nortbumberland, and Arcbibald Donslas, Lord of Galway, then governors of the borders. It is inferted in the Afta Regia (g). The poor people upon $E / k$, and on the waftes near this ftation, fpeak the fame dialect at this day.

(f) Caervorwyn. Britannicis. Lel. Itin. Vol. 6. p. 128.

Caervorran. Camden's Britan. p. 848.

Magna. Horfey.

$\left.\begin{array}{l}\text { Voreda. } \\ \text { Caftle Voran. }\end{array}\right\}$ Rictard of Cirtncefer. Dr. Stukcliy.

(g) Vol. I. 8vo. r. 394-5.

The 
The ftation or fort is nearly in the form of a fquare, the grand wall making a flexure round it to the fouth, and then afcending the precipices; the ground within it four acres and a half, as meafured by Mr. Waller, furveyor of the military road through Cumberland. At the eaft end of it, a Human fkeleton was found by the workmen employed in digging up the foundations for making that road; the offeous parts, particularly the fkull and teeth, frefh and fair, but on being expofed to the air, the whole turned to duft.

A fmall, but very fair Roman altar was found fome years ago, inferibed,

\section{Deo Viterino.}

Alfo a fmall brafs Lar. The Romans facrificed to the Lares on May-day; the violet then in bloom; their altars fragrant with it and aromatic drugs.

Prætitibus Maje laribus, videre Kalendæ Aram contitui, parvaqùe figna Deûm. Ovid.

Hic noftrum placabo Fovem, laribufqùe paternis Thura dabo, omnes Viole jactabo colores. Fuv. Sat. xii.

- Pancheis adolefcunt ignibus aræ. Virg. Gco. iv.

The altars blaze with rich Arabian fweets. Warton.

They are both in the poffeffion of Mifs Fanny Bacon, of Nervbrough.

A Roman ring, with a victory, on a coarfe Cornelian, was found and fold to Mr. Horley, of which he takes notice*.

* Brit. Rom: 
Mr. Thorefy has given a good print of a Roman altar carricd off from this ftation to Blekenfopp-Caftle, from a drawing of Mr. Cay's; the ftone neatly decorated, but the infcription a little injured ( $h$ ). Mr. Horfley has figured it in the condition he probably faw it, in ạ lefs agreeable form ( $i$ ).

A curious and beautiful fculpture of a Roman foldier, in ftone, of the white-rag kind, within a nich, and in relief, was digged up in 1760; helmeted; a Pallium or light robe down to his feet, faftencd at the breaft with a Fibila; an Hafa or fpear in his right hand; in his left, a Parma or fhield, refting on a thort pedeftal; above his left fhoulder, a lion recumbent, and a deer under it, kept down by the ftrength of the paws of that noble animal. It is fourteen inches and a half in length, and nine inches, in diameter.

It has been the work of an excellent artift. It was placed as a fide-fupporter in an aperture to let in the light in a new barn by Mr. Carrick, whofe fon was fo kind, with his confent, to prefent it to me, 6th Fune, 564 .

An abundance of Stags horns have been digged up ; alfo many fmall mill-ftones, three of them now lying at the door of $\mathrm{Mr}$. Carrick, owner of the ftation.

It is near the 38 th mile-ftone on the military road, at the head of the flope above Glenwbelt, to the north-eaft. It has a pretty vale and mountain profpect; the Orcbard-houfe near Wardrew, and the caftle of Thirlwall, in fight to the weft; the caftle of Blen-

(b) Ph. Tr. No. 231 .

(i) Brit. Rom. No. Lxx. 


\section{ANTIQUITIES OF NORTHUMBERLAND.}

kcrifopp, eâft and weft Cocnwood, Toufe-Bank wood, the floping hills of Kuarfale, and the mountain of Crofs-fell, to the fouth.- It is within the manour of

Blenkenfopp-Caftle, the feat of the antient family of the BlenkenSopps; of Ralph de Blenkenfopp, I K. Edward I (k); of Thomas de Blenkenfopp, 39, 42. K. Edward III (l); and of William Blenkenfopp, 10 Q. Elizabeth (m); who held it of the honour of Langley, paying annually for all fervices $6 \mathrm{~s} .8 \mathrm{~d}$. one half at Martinmas, and the other at Whitfontide. In the fouth-weft end of Haltwefel church is the ftone-effigies of one of the family, recumbent, in armour, his legs a-crofs, and hands elevated; the habit and attitude of a Knight Templer, or fuch as made the Crufate; on which, and for the ranfom of our Caur de Lion, K. Richard I, fo much money was fwept out of the kingdom, that not one genuine coin of his

(k) Ranulphus Blenkenfopp tenet Blenkenfopp per dimidium marc. de Baronia de Tynedale.

$$
\text { Efr, de } A n^{n} . \text { I. Ed. I. }
$$

(1) Thomas de Blenkenfopp tenet villam de Blenkenfopp libere de manerio de Langley, pro fidelitate, et pro fervicio $6 \mathrm{~s} .8 \mathrm{~d}$. per annum : et valet per annum in omnibus exitibus, 101 .

Inquifit: ex bundello Efcaetr. Turri Londinenfí, No. 17. capta apud Nev. Cafirum fuper Tynam die Veneris proximè poft feftum Sancti $P_{c t r i}$ in Cathedra, 39 Edvardi III. coram Willielmo de Ryegate, Efcaetore Dom. Regis in comit. Northumbr.

Thomas de Blenkenfopp tenet manerium de Blinkenfopp, cum pertinen. de manerio de Langley, pro fidelitate, et profervicio redúendi $6 \mathrm{~s}$. $8 \mathrm{~d}$. per annum, pro omnibus ferviciis ad terminos Pentecoft. et Sandi Martini in Hyeme, ad æquales portiones.

Inquifit, ex"bundello Efcactr. turri Londinens. $\mathrm{N}^{\circ} \cdot 37$. capta apud Langley in comit. Nortbumbr. Die Jovis in Fefto Sanct. Andree Apoftoli. 42 Edvardi III.

(m) Wrllielmus Blenkenfopp fuit feifitus de et in Blenkenfopp, Glenwhelt, Darles, Hillhoufes, Driburn-haugh, et Wry-tree, cum terris in Haltwefel, et le Oufett.-Efcaet. de Anno 10 Eliz. 
is faid to be met with in the cabinets of the clirious; his ranfom alone cofting one hundred thoufand pounds in filver; equal to three hundred thoufand pounds of our prefent money (n)..

Gawen Blenkenfopp, D.D. is on record for being a benefactor to that renowned feminary of learning, Pembroke-Hall, in Cambridge, of which he was fellow ( 0 ).

The caftle of Blenkenfopp is about a mile to the fouth-eaft of Thirlwall-cafte, on the fouthern banks of the Tippal; upon an eminence, and overlooked by another; the weft and north-weft fide of it protected by a very high cefpititious wall, and a deep. fofs; a vault going through it, north and fouth, thirty-three feet in length, and in breadth eighteen feet and an half; two leffer ones on the north fide. The facing of the weitern wall has been down beyond the memory of any perfon now living in the neighbourhood. It has been a very ftrong building. It is now in the poffeffion of Fohn Blenkenfopp Conlfon, of Fefmont, Efq.

We procecd with the wall from Caer-Vorran for half a mile, when we have the pleafure of feeing a piece of it ftanding of the height and breadch of nine feet. We only go half a mile farther, before we come to

Wall-Town, the lordhip and feat of Fobn Ridley, Efq; in the reign of K. Edward VI; of the antient houfe of Willemotefwick, and brother to that excmplary and learned prelate, Nicholias Rid$l e y^{\prime}$, D. D. Bihop of London, whom his lordfhip mentions in his

(n) $\Lambda$ d pondus Colonize moneta publice probatx._- Rad. de Diselo, inter decem fcripto es.

(o) Parier's Hift. of Cambridge, p. 49 .

Farewell- 
Farewell-letter with the warmeft affection. A plain monument is erected over him on the north fide of the chancel of Haltraiefelchurch. His feat was a caftellated building, of which nothing now remains but a poor fragment, juft fufficient to fhew its former frength, as if defigned to laft for arges. Out of its ruins was built a fmall manfion by the late poffeflor, George Marflall, Ef(; eminently beloved by his tenants, and the whole neighbourhood, for letting his lands at moderate rents ; in which he was fucceeded at his death by Mrs. Bacon, of Newbrough, and Mr. Hunter, of Dux-Field, in Hexhamflire.

To the eaft of the broken remains of the old tower, in an opening of the precipices, is the Well where Paulinus is faid to have baptifed King Egbert, and fome thoufands of his fubjects. It feems to have been walled round; fome dreffed flones lying by it.

We pars on with the wall for a mile and a quarter, and then come to the Roman flation of

Great Chefters ( $p)$; the ruins of which appear at this time very fair, on a fine flope, large and fpacious, nearly fquare, the angles obtufe or rounded. On the caft fide of it is an altar with a Patera fculptured on one fide, the infcription entirely effaced by the weather. By its fide is another ftone, with the figure of a man in a nich, his head gone, his left hand refting upon his fide, his right on a fhort column; no appearance of any infcription.

In digging up the foundations of a building in the upper part of the ftation, in the beginning of the year 1767 , a very large

(p) Fefica. Horfley.

VoI. II. 
ftone uvas found with a long infcription, but imperfect by two fractures at each corner at the bottom, whereby half of four lines are wanting, befides fome letters. Part of the fecond line is alfo injured. So much of it as is perfect runs thus.

IM. CAS M. AVR SEVE RVS. MEDCANDER. PFE AVG. HORREUM VETV STATE CONR. AR SVMM. COH II ASTVRVM SA A SOLO RESTITVERVN PROVINCv. ARECNT MAXIMO LEG. WT GPRP SAL MARTI MED LEGA TVS CO. II. ET DEX'T.

The ftone is of the fine rag, nearly fquare, with a handfome moulding.

About a quarter of a mile to the fouth of the ftation, near a mill, called, The Wall-Mill, is a funeral-ftone fixed in the ground, with the figure of a child in a nich, and an infcription underneath, dim and obfcure by being expofed to the weather, four feet and a half in height above ground. Hard by is another fepulchral memorial converted to a polt for a gate to hang on, called Wall-Mill-Gate. The infcriptions on both are publifhed by $\mathrm{Mr}$. Horfley (q).

(g) No. 64. B. $\gamma$. 
At a fmall diftance from Wall-Mill, and very near the 35 th MileStone on the military road, on a ridge of moor, are four tumult, twenty yards afunder north and fouth, twenty-eight eaft and weft; cut through by the late obferving and curious Mr. Currey, a diffenting minifter, who found both entire human bones and an urn with athes and falt in it ; the falt well preferved, white and fair.

The Romans were not very careful to feparate the hunan afhes from the reft, but fometimes put coals and other things into the urn. Their urns were of gold, of filver, and other metal; of glafs, of ftone, and of marble, but mont generally of potter's earth. This was of that kind. Trajan's was of gold. They were of all figures, but commonly round and bellied; thofe of metal generally embellifhed with fculpture and bafs-reliefs. Urns for perfons of diftinction were either fet under marble-monuments, or in niches of fepulchral chambers. Severus provided his before his death $(r)$. It is faid to have been of porphyry (s), or of alabafter $(t)$. The afhes of perfons of quality were ufually fprinkled with wine, before they were collected into an urn.

Poftquam collapfi cineres, et flamma quicvit,

Reliquias vino et bibulam lavere favillam;

Offaqùe lecta cado texit Chorinaus aheno.

Soon as the pile, fubfiding, flames no more,

With wine the heap they fprinkled o'er:

Then Chorineus took the charge, to place

The bones felected in a brazen vafe.
(r) Spon.
(s) Dio.
(t) Herodotus. 
Salt was ufed in their folemn, facrifices, as well as in urn-burial:

\section{Dant fruges manibus falfas.-_ Virg. Rn. xii. v. 173 .}

Urn-burial is not fo antient as the prefent practice of interment. Burning the dead is firt attributed to the Greeks, and Hercules is faid to be the firtt of the Greeks who ufed it. This he did to free himfelf from the obligation of an oath. He had fworn. 10 bring back a youth (u) to his father (v) from the fiege of Troy, and he had no other way of doing it, but by prefenting him with his afhes. From the Greeks this cuftom paffed to the Romans, but it was not general among them. From the authority of Pliny (w), it appears, that î was not ufed by many families, and that Syllo the dictator was the finf of the Cornelii whofe body was burnt; which is the reafon affigned by Antiquaries why we find Roman bones both burnt and unburnt. It was the choice of fome, becaufe they would preferve their bodies from the refentment of their cnemies. This was probably Sylla's motive. It is fuppofed the Crumls had it from the Romans; the Celtics or antient Britons from the Cauls; but it is not fo eafily accounted for how the Danes, and other nations, called Futi and Angli, Saxons and Germans, came by it. It is believed they had it from the Grecian cuftoms and learning, and that they all laid it afide on the introduction of Chriftianity.

To diftinguifh which are Roman, Britifh, or Danifh tumuli, has bcen obferved to be difficult. Some antiquaries pretend to fix them from their Shape. But that is reckoned guefs-rvork, unlefs infcriptions, arms, or coins, be found in them; the latter of gold, filver, or copper, but neither of them of brafs; inftruments and
(ii) Argius.
(v) Licimnius.
(w) L. 7. C. 54 . 
coins of that metal belonging to the northern nations, and where they are found in tumuli unqueftionably Roman, they are fuppofed to have been taken from the enemy, and thrown into it in honour of the deceafed. The Roman tumuli were cefpititious, or mounts of earth, like thoie here. Such was Hector's, viridi cefpite $(x)$; fuch was Dercenmus's, terreno ex agsere bufum (y). Such was that made by zineas.

— Pius E⿱tneas ingenti mole fepulchrum

Imponit, funqùe arma viro, remumqùe, tubanqùc,

Monte fub aërio.

Tirg. Iin. v. ver. $232, \varepsilon$ \&.

No greater misfortune could happen to a Roman, than to be denied the honos tumuli, the folamen bumandi. The atheift, niezentius, could not die in peace, without begging it of his enemy with his laft breath.

Corpus humo patiare tegi-

Et me confortem nati concede fepulchro. Virg. An $x$.

If a vanquilh'd foe this grace may crave,

Oh! let me find the refuge of a grave.

- Guard my coarfe, and lay me by my fon.-

Grant, grant that pleafure, e're I yield my breath,

To thare his dear fociety in death. Pitt.

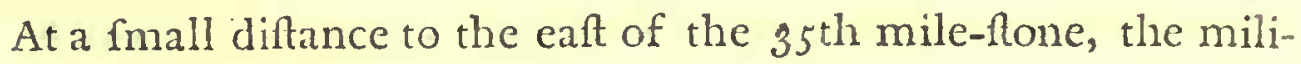
tary road is croffed by Haltwefel-burn, over which is a ftonebridge of one arch. In fight from it is a farm-houfe, called Lees-

(x) Virg. Æn. iii. v. 302, \&c.

(y) ZEn. xi. v. 849, \&c, 
Hall, paft which is a road leading by a pleafant and eafy defcent to the villa of

Haltwefel, which was plundered by the Scotch-outlaws in the reign of Queen Elizabeth; for which they received fevere correction from the lord warden of the middle marches, Sir Robert Cary, created Baron of Leppington by K. Fames I, I62 I; and Earl of Monmouth by K. Charles I, youngeft of ten fons of Henry Lord Hunfdon, warden of the eaft marches; his Lordihip's fon-in-law, Thomas Lord Scrope, knight of the garter, being warden of the weft marches; both likewife famous for their courage, conduct, and abilities, in defending the borders $(z)$. It hath an inconfiderable weckly market on Thurdays. There is a manufactury in it of coarfe bays, belonging to two worthy Quakers; their fullingmill finifhed, and approved of by trial, I 7 th September, 1762 ; pleafure and chcarfulnefs appearing in every face on the occafion; giving a profpect of better bread to the induftrious poor. It is fituated on a rifing ground on the north fide of the river Tyne, the church and vicarage-houfe to the fouth of it; the churchyard forming a tcruace, and giving a profpect of the vale, and the winding courfe of the river; the church confifting of three ifles, pewed with oak, the roof lofty, as is the acute arch into the cliancel, the window above the altar gothic and fately.

By the river Tyne is a piece of ground, now part of the vicarage-glebe, called The Church-yard, where it is fuppofed the church antiently ftood; grave-ftones and bones being frequently digged up.

Lady Capel, among other charities at her death, left a finall fum, at the requeft of one of her domeftics, born in this neigh-

(z) Monmatis Memoirs, p. $87 \cdot 150$.

bourhood, 
bourhood (a), for the endowment of a reading and writingfchool; the mafter's falary reputed at this time about eight or ten pounds per annum; the fchool-houfe built by the Rev. Mr. Pate, vicar of the parin $(b)$.

Nicholas Ridley, Efq; an alderman of, and governor of the nuerchants company in, Nerucafle, by his laft will and teftament, bearing date 7 th December, 1710 , gave to the poor of the parifh forty thillings per annum, out of a little farm or tenement, called Wagtail-Hall; to be diftributed to the more aged and infirm, eight days before Chriftmas (c).

On an eminence, called Cafle-Banks, ealt from the church, is the veftiges of a fort, guarded by a cefpititious wall on all fides, except the fouth, where it is open, and has a pretty fteep flope, and a large fpring towards the middle, now a bog; a fine vale, river, wood, and moor-profpect before it ; the villas of Haltwefe', Redpeth, Widen, Bellefter-Cafle, Plenmeller, and Unthank, all vifible from every part of it; the fight of the river loft under hanging woods; the meadows and corn-ficlds between it and the river forming a fpacious arca or amphitheatre, projecting to the ftreams like a peninfula; thefe laft belonging to Mrs. Cutbbertfon, widow of the late George Cutbbertfon, of Newcafte, Efq; who was Lord of the manour.

About a mile fouth-weft from Haltwefel, on the other fide of: the Tyne, is

(a) His name, Fetherfonbaugh.

Lady Capel's Will.

(b) Collectan. Warburton.

(c) Bourne's Hitt. of New.afle upon Tyme。 
Bellefier-Cifle, the feat of a younger branch of the Blenkenfopps, of Blenkerfopp-Cafle; of Thomas de Blenkenfopp, 6 K. Edward VI. (d); of George de Blenkenfopp, ro Q. Elizabeth (e). It now belongs, with its demefnes, to George Blenkenfopp Coulfon, of Fefmont, Efq; and the - manour to Robert Ellifon, of Park-bouse, in the bifhoprick of Durbam, If 1 . The calle ftands on an artificial mount, and had a park belonging to it.

The river Tyze makes a flexure under a hanging wood near this place, and a little higher up is croffed by a ftone-bridge of one bold arch, founded on a rock at each end, called Fetherfonebridge; near half a mile above which is

Fetherfon-Cafte, the feat of the antient family of the Fetberfonhaughs; of Thomas de Fetherfonbaugh, I K. Edward I. $(f)$, and 2 K. Fdward II. (g); of Alexander de Fetherfonbangh, 39 K. Edward III. (b); of Thomas de Fetberfonbaugh, 42 of the fame reign (i); of

Sir

(d) Bip. Nicbolfon's Border-Laws, p. 240.

(e) Georgius Blenkenfopp fuit feifitus de ct in Bellefer, Over-Warden, Barnc-Houfes, Park, Lin-Beels, Dodlawood, cum turris in Haltwefel. Écact. de Anno ro Eliz.

(f) Thamas de Fitherfonhaugh tenet Fitherfonhaugh per Dimid. Marc. Baron de Tynedale. Efcact, de Anno I Edvardi I.

(g) Ercaet. de Anno 2 Edvardi II. No. 78.

(b) Alexander de Fetberfonbaugb tenet villam de Fetberftonbaugb de manerio de Langley per homagium et fervicium 2s. 7 d. et fectam curiz de Langley; et valet per annum, io Marc.

Inquifit. ex bundello Efcaetr. turri Londinenfs, No. 1\%. capta apud Novun Caftrum fuper Tynam, Die Veneris proxime poft feftum Sancti $P_{\text {etri }}$ in cathedra, $39 E d$ vardi III. coram IVillielmo de Rygate, Efcaet. Dom. Reg. in Comit. Northumbr.

(i) Thomas, hares Alexandri, de Fetherftonbaugh, tenet manerium de Fetherftonbaugh, de manerio de Langley, pro homagio et fidelitate, et pro fervicio reddend. per annum $20 \mathrm{~s} .10 \mathrm{~d}$. 
Sir Albany Fetherftonbaugh, Knight, high fleriff of Nortbumberland, 2 Q. Elizabeth (k); of Alexander Fetberfonbaugh, alfo high theriff, 32 of the fane reign (l). In later times, the manour was fold to the right honourable the Earl of Carlifle; and the caftle and eftate came into the poffeffion of Mattbew Fetherfounbaugh, of Newcafle upon Tyne, Efq; father of the prefent pofreffor, Sir Matthew Fetberfonbangh, of Up-Park, in Suffex, Bart. a reprefentative in parliament for Portfmouth, in Hampsjire.

The caftle is vaulted underneath, and has two fpeculating turrets, one to the north-weit, and the other to the fouth-eant. It is in a low fituation, in a fertile vale or haugh, on the eaft-fide of the Tyne, which glides paft it under fhady banks of wood in pleafant murmurs,

On the weftern margin of the fame river, about two miles higher up, is

Lambley, where was a priory founded for Benedictine nuns, and dedicated to St. Patrick, but by whom is not determined with pre-

ad terminos Pentecoft. et Sancti Martini in hyeme, ad equales portiones; et pro fecta curix per tres vices per annum; et valet ultra fervicium predictum 10 marc. per annum.

Inquifit. ex bundello efcaetr. turri Londinenfs, No. 37. capta apud Lang'ey in comit. Northumbr. Die Jovis in fefto Sancti Andrea, apoftoli, 42 Edvardi III. coram $7_{00}$ banne Hender/kelf, efcaet. Dom. Regis in prædicto comitatu.

(k) Fullcr's Worthies.

Aibanus Fetherftonhaugh fuit feifitus de et in Fetherftonbaugh, Fetherfontaugh-row, Whitwham, Lambley, Redpeth, Widen, Widen-efles, Horfe-clofe, Kellaws, Greenriggs, Harper-houfes, cum terris in Haltwefel, nill-houfes, et umbres.

Efcaet. de anno to Eliz.

(l) Fuller.

Vol. II. 
cifion by authors $(m)$. K. Folm gave and confirmed to them by charter the fite of the abbey, and its appurtenances, and right of pafturage on both ficles of the Tyue, at Lambley, the manour of Adam de Tynedale, and his lady. He alfo gave them the chapel of: Sandiburnfele, and a glebe at the fame place, containing four acres of lind, and all the tythes and offerings belonging to the fame, and within the whole Lordhip of Lambley. Hc alfo confirmed to them the lands given them at Brenerigs and Sandiburnfele by Adam de Tynedale's nephew, and other lands given them by that young gentleman's mother $(n)$. They had a fifth part of the village of Widen (0). A houfe in Nerweafle, at the end of Painter-bugh, was charged with the annual payment to them of

(m) King Foin. Compendium compertun.

K. Febm, or Adian de Tynedale. Bp. Tamer.

Lord Luy. Cinudin. Speid.

(n) Gubanes I) gratia, \&c. Sciatis nos concellfle ct prxfenti carta confirmafie Deo, et fanćtæ Marie, ct Sancto Patricio, et fanctimonialibus de Lambeleya, locum abbatia de Lam. bcleya fuper Tinm, liberum et quietum in perpetum, cum pertinentiis fuis, \& pannagium liberum, \& communem pafturam cx utraque partc Tina in toto fcodo Ada de Tindale, \& Hel.wife uxoris ejus. Et captllum de Sandiburn.fele, cum quatuor acris terra in eodem loco, Exon:nes decinas \& obventiones totius wafti ipforum Adae \& Helewife de fcodo fuo. Confirmamus ctiam eis tationabiles donationes quas / Helyas nepos ipfius Adee eis fecit de Brenerigs \& de Sandidurneficle, \& donationem quam nater ipfius Helye cis fecit de terra fua. Quare volumus, ct firmiter precipimus quod pradictx fanctimoniales habeant $\&$ teneant omnia pradįta benè $\&$ in pacc, liberè $\&$ quietè, integrè, plenariè $\&$ honorificè, cum omnibus libertatibus \& liberis confuetudinibus fuis, ficut carta prædictorum Adre \& Helewife rationubiiitc̀r teftatur. Teftibus, Willielmo de Stutevill, Hugone Bardulph, Roberto de Ros. Dat, per manum S. Wellenfis archidiachoni, apud Hextoldesam xvi die Februarii, regni noftri anno fecundo.

Char. 2. Johan. n. g. m. 12. Vid, etiam Pat. 31. Ed. III. p. I, m. 20:

(o) Écsit. de anmo I Ecivarai I. 
I s. granted by William Porter to Gobn de Cbanbers, a burgefs of that corporation $(p)$

At the fuppreffion, this priory had fix nuns, when its annual revenues were valued at $5 l .15 s .8 . d$. It was granted, $7 \mathrm{~K}$. $\mathrm{Ed}$ ward VI. to Gohn Duke of Northumberland ( $q$ ); and was in the porfeflion of Sir Albany Fetherfonbangh, of Fetherfon-Cafle, Knight, I Q. Elizabeth; and now belongs to Sir Lancelot Allgood, of Nunwick, Knight; the fite of the convent wathed away by the river Tyne.

Two miles from Lambley, on the fame fide of the river, is

Knarefdale-Hall, which, with the manour, was taken from fohn Prat by the crown, $8 \mathrm{~K}$. Edward I. for his difloyalty; and given to Sir Robert de Swinburn, knight ; the grant fealed in council with a large green wax-feal $(r)$; the manour of tithiamffon, held of the manour of Frarefdale, being alfo given to Sir William de Swinbum, knight; its owner Bartholonew Prat, confirming the title by a releafe, in the fame reign, and 3 r of Alexander, King of Scotland (s); a year remarkable for a grievous peftilence in that kingdom. "The heir to Sir Robert, was Thomas de Sruinturn, who, befides the

(p) Bourne's Hir. of Nerceostl.

(a) Compend, compertum.

(r) Coillins's Baronage.

(s) Omnibus hoc fcriptum, Exc. Bartbolomeus Prat, Cahutem, Exc. Noveritis me remifili, et relaxafle, \&ic. Dom. Trilielmo di Swinburn, \&ic. totum jus ct clamum, \&ic. Mancrio de Williamifon, in feodo de Tharefale, Stc. Sigillat his tchibus, Dom. Thom. Ranulph. Simon. fratres, tunc jufticiarii itinerantes; Fohame Cumyn, Fobame de Sw:nburn, Reberto de Infula de Chipcles, Milit. Fohanne de Sbittlington, Gilberto de Grialdn, Odardo de Ridley, et aliis. Dat apud Wark in Tynedale, anno regni Alewandri regis Sistia tricefimo prino.

D)

manour 
manour of Knarefale, held the manour and hamlet of Chirdon of the crown, $3 \mathrm{~K}$. Edward III. under the manour of Wark, in Tynedale, by the fervice of one knight's fee $(t)$. In the reign of $Q$. Elizabeth, Knarefdnle-Hall, and other eftates near it, were poffeffed. by Williom W Wallace, of Copeland-Caftle, Efq; $(u)$; who married Eleanor, the fecond daughter of Fobn Swinbum, of Edlingham, Efq; by Anne, cldeft daughter of Sir Cutbliert Collingrwood, of Eflington, knight;: her eldefl fifter, Anne, marrying William Shaftoe, of Bavington, Efq; : His defcendant, Ralph Wrallace, fold it to the late Fohn Stephenfon, an: alderman of Nervcafle upon Tyne, brother to Sir William Stephenfon, Knight, an alderman, and twice Lord Mayor, of London; both: born at Crofslands in Aldfon-moor.

About three miles from. Kinarefale; on the fame fide of the Tyne, is

Whitley-Cafte, the Roman ftation Alione (v), on an irregulà flope; by a rivulet of the fame name, the fouthern boundaries between the two counties of Nortbumberland and Cumberland; the famous Roman military. way, called, The maiden way, coming to it from

(t) Thomas de Swinburn, filius et hrores Roberti de Sroinburn, tenet manerium de Knarefdale, in Tyneda'e, et manerium de Chirdon, cum hamlet. de rege, ut de manerio de Wark in Tynedale, in manerio regis exiftens, per fervicium unius feodi militis.

Mich. Fin. Anno 3 Edvardi III.

(u) Walles.

Wallafe.

Wallace.

Vid. Ayden-Castle.

Willielmus Walles fuit feifitus de et in Knarefdale, Knarehope, Elifide-houfe, Burnes, Hanging-how, Knare-houfes, I.ufley, Slagiford, et Thornhope.

Efcaet. de Anno ro Eliz.

(v) Dean Gale's Antoninus. 


\section{ANTIQUITIES OF NORTHUMBERLAND.}

Caer-vorran. A corpfe of the twentieth legion, called, Valens Fic- trix, repaired it, as attefted by a centurial ftone, infcribed,.

\section{VEXILATIO LEGIONIS VICESS LMK. \\ V. V. REFECIT.}

The third cohort of the Nervii was quartered at it, as mentioned in the Notitia ( $w$ ), attefted by two infcriptions on altars, infcribed to the Emperor Caracalla; the latter holding forth a long train of titles: There is a beautiful print of it in Dean Gals's Antoninus. They are all among Mr. Horfley's Romana.

Alione is thought to have been garrifoned by the Romans to the laft. Mr. Warburton has placed it in his map of this county at Old Town, by Catton' Beacon, near the 'union' of the two rivulets, Eaft and. Weft Allen: of which hereafter. The ruins here are large, the ditches and ramparts ftill confpicuous. The Maritcis Way is continued from it to Whellop-Cafle, or Firby-Thore, in We/smorland.:

Notice is taken by Mr. Horfley of an altar in the church-yard at Kirk-baugh, on the other fide of the Tyne, infcribed,

DE床 MINERVE, ET HERCULI VICTORI.

We now continue our courfe from the bridge over Haltwefelburn on the military road for near a quarter of a mile, when on the left hand, on the ridge of a hill, we have a view of three upright pillars of whin-ftone, two of them broken off towards

(w) The title of it, as publihed by Pancirollus, is, Notitia utraque Dignttatum cun Orientis, tum occidentis ultra Arcadii honoriique tempora. It is fuppofed by the editor to have been written . before the Romans deferted Britain, and near the clofe of the reign of Theodofus Junior. 
the middle. Some perfons imagine they were fet up for rubbingftones for cattle, but they ftand too clofe together for that end; and, befides, the fetting up more than a fingle ftone in one place for that ufe is not known to have been ever practifed. As thofe at Little Salkeld, in Cumberland, are called Long Meg and ber Datghiers, fo thefe here are called the Ihe Mare and ber two Foals. The former are acknowledged to be Britifh. The latter are moft likely of the fame origin, religious and funcral memorials.

From a rifing hill, a little beyond the $32 \mathrm{~d}$ mile-ftone, we have a flight view of

Millimotefrick $(x)$, i. c. the Mote, or Keep, and Villa of William; built, as ufual, on a rifing ground, to obferve the motions of an encmy. It was the anticnt feat of the Ridleys; of Sir Nicboles Ridley, high fherift of Nortbumberland, I, 2, 3, 23 K. Henry VII; and I, a, 3 K. Henry VIlI $\left(y^{\prime}\right)$; anceltor to Nicbolas Ridley, Birhop of $\operatorname{Lonh}$ on $(\approx)$.

The bithop was the ornament of the houfe of Thillintefwicke, and of Nothumberland. He Cuffered at Osford with Bifhop Latimer, 16 October, 1555 , on the aet de Heretio comburendo, made in the 1cign of King IIenry VII. IAIO, againt Wickliff's followers; Wit liam Santre being the fret who fuffered $(a)$; the next being Fobn Badby, who was burnt alive in parliament-time, and in the face of the whole houfe, in contempt of the commons, who had

(*) Willimotefwicke, Camlin.

Wyllimountwick. Nihop Ridiry.

- (j) Fullur's Worthies.

(z) Ses Bimop Ridly's own account of his family, in his Farewe'l Letter.

(a) Acta Regia, Vol. 2. 8vo. p. 105, 106, \&c. 


\section{ANTIQUITIES OF NORTHUMBERLAND.}

petitioned the king for the repeal or mitigation of that cruel fatute.

There was another eminent divine of this family at the reformation, Lancelot Ridley, D. D. He was fellow of King's-Hall, in Cambridge, about the year 1532. one of the fix preachers of Canterbury, and author of a Commentary on St. Paul's Epiftles (b).

That great civilian, Sir Thomas Ridley, Knt. L. L. D. derived his defcent alfo from this antient ftock. He was born at $E l y(c)$; educated at Eaton-fchool, of which he was afterwards a fchoolmafer, and fellow of King's College, in Cambridge. For his juridical erudition, and other liberal accomplifhunents, he was promoted to a mafterhip in chancery, to the honour of knightehood, to the Chancellorhip of Winchefer, and the high ftation of vicar general to Dr. George Abbot, Archbifinop of Canterbury. He was member of parliament for $W^{r} y$ combe, in Buckinghamflire, 28 Q. Elizabeth. He was author of a treatife on the Eucharin, and of a book, intieled, A view of the civil and ecclefiaflical law. He died, 22 January, 5 K. Charles I. I629 (d); and was interred in St. Bennet's church, near St. Paul's wharf', London.

The Ridleys of Willimotefruicke feem to have been a family of Literati and divines. Three of them were rectors of the parifh of Simonburn, in Northunberland; viz. Robert Ridley, D. D. nominatcd, 1510; Fobn Ridley, 1532; Cutbbert Ridley, 1635 (e).

Willimotefwicke was the feat of Sir Nicbolas Ridley, Knt. Is Q. Elizabeth; then high theriff of Nortbamberland, and poffeffed of a .

(b) Cartur's Hitt. of Cambridge, p. 308 .
(c) Id. p. $149 \cdot$
(d) Id,
(e) Regiftr. Dunelm. 
confiderable property $(f)$; alfo of Richard Ridley, Efq; high theriff of Nortbumberland, 27 th of the fame reign $(g)$. In the reign of 1L. Charles I. it was in the poffeflion of Ricbard Mugrave, Efq; (b) ; the manour of Henfhaw, and the foreft of Lowes, and other lands, being then held of the.crown, dunder the manor of Wark, in Tynedale, by William Ridley, Efq; by the fame fervice as his father, of his own name, performed (i). Willimotefwicke now belongs to Sir Edward Blacket, of Weft Matfen, Bart.

A little higher up from the military road we have a view of the Roman ftation of

Little Chefters ( $k$ ), eafily diftinguifhed by the clumps of trees and brufhwood in it, like natural arbours, from which it has obtained the name of The Bowers. It is of the ufual form, nearly

(f) Fuller's Worthies.

Nibblaus Ridley fuit feifitus de et in manerio et villa de Wyllymontfwycke, Henhaw, CraggTheel, Horny-fteed, Legget, Rofes-bower, Crook-bank, Chefter-wood, Haddon, WoodTheel, Ridley-hall, Beltingham, Shaws, Woodburn-houfe, Midmaw, Style, Braydwood, Furnes, Allington, Fenpugh, Wood-hall, Melkridge, High-houfes, Whitchelter et Whitchefter, cum terris in Haltwefel, Haidon-bridge, Morylee, White-theel, Thorn grafton, Birkfhaw, Mill houfe, Bradley eaft, Grindon-dikes, Toy-houfes, Hunter-Cragg, et Badon-Mill.

Efcaet. de Anno ro Eliz.

(g) Fulik.

(h) Richardus Mufgrave, Arm. tenet in capite manerium dc Willimontfwicke, Ridley, Ridley-hall, ct Melkridgc, ac diverfa mefluagia, et terras ibidem, ac Rector. de Haltwefel.

Ex Lib. Fcodar. Petri Ofborne, Milit.

(i) Willielmus Ridley, Arm. filius Willielmi, tenet de rege, ut de manerio de Wark in Tynedale, manerium de Henhaw, et foreftam de Lowes, cum molendino aquatico, et diverfa tenem. infra dictum manerium et foreftam. Ex prædicto Libro Feodar.

(k) Ph. Tr. No. 278 . 
fquare, containing about an acre and an half; the wall round it of earth and ftone, very fair ; a pleafant flowing rill, called Bardon-Burn, wafhing its eaftern fkirts, in its courfe to Bardonmill, overlooked by Barkbam-hills : a deep ditch or hollow, called in this country a clugh, to the fouth; one of the natural arbours large, compofed of white thorn, birch, oak, and nut-bufhes, giving a pleafant thade.

The Via Vacinalis from Caer-vorran to Walwick-Chefters comes clofe up to the north fide of it, on which a Roman military ftone is ftill ftanding, by a gate called Caudley-gate, near the brink of Bardonftreamlet; alfo another a mile weft from it, in a ftraight line; the road very fair; the mile-ftones in fine prefervation, of white rag, fix feet, four inches, in diameter, and near as much in height above ground, of a round figure, like large rollers.

Some Roman fhoes and fandals were digged up by Mr. Wrarburton, the late Someryet-herald, which he gave to the royal fociety. A winged image, wanting the head and feet, about three inclics long, was found and prefented to Dr. Hunter. A Roman Hypocauftum or fudatory has been alfo difcorered, of which the latt mentioned inquifitive and induftrious antiquary gives this account. "Some years ago, on the went fide of this place, about "fifty yards from the walls thereof, there wals difcoverch under a " heap of rubbih a fquare room frongly vaulted abore, and pared "with large fquare ftones fet in lime, and under this a lower rion, "whofe roof was fupported by rows of fquare pillars of about " half a yard high: the upper room had tro niches, lite (and " perhaps in the nature of) chimneys on cach fide of every corner " or fquarc, which in all made the number fixteen; the parement " of this room, as alfo its roof, were tinged black with finoak. "The ftones ufed in vauling the upper room have Lcen marked VÓL. II. 
" as our joiners do the deals for chambers; thofe I faw were. "numbered thus x. xi. xiii" (l).

Roman baths were firft introduced in Britain by Agricola, to give the natives an agrecable picture of a polite and well civilized. community.

Fornix - et uncta popina

Incutiunt urbis defiderium.—Hor. Epift. Lib. i. I4.

A fculpture in flone of Mercury, the Caftos Manium, and god of the highways, was found here; an engraving of which, with fome others, may be feen in the Britannia Romana. The mercantile part of Britain held a folemn fettival to Mercury, i 5 October.

Canden gives us an altar, found at this place, of $A$. Licinius Clemens prefectus cobortis prime Hamiorum, dedicated to the Syrian goddefs, Afarte; the reading fcrupled by Mr. Horjay, but confirmed by the Greek altar to Aftarte at Corbridge, in the judgment of Dr. Stukely (m).

In digging up the foundations of a Caftellam or milliary turret, in the wall, in an opening of the precipice by Crag-Lake, called, Lough-End-Crag, or Milking-Gap, for ftones, for building a farmhoufe, belonging to Willian Lorves, of Nerucaftle, Efq; to the north-eaft of this ftation, a centurial ftone was found by the mafons, very large, infcribed,

\section{IMP CAES TRAIAN}

\section{HADRIANI AVG}

LEG II AVG

\section{A PLATORIO NEPOTE LEG P R $P$ R}

(l) Magna, Camden.

(m) Caraus. Vol. ii. p. Ito. 


\section{This ftone is now at Mr. Loques's Seat at Ridley-Hall.}

A large ftone, in the altar-form, was lately digged up at this ftation, with the fculpture of a red decr in the center, leaning againft a tree, and two fawns at the bottom, in rclicf. It is now ftanding in a field on the north fide of the houfe of Hugh Ridley, at Archy-flat, adjoining to the ftation, who placed it there to anfwer the ufe of a rubbing ftone for cattle. It was two fect thick, when it was turned out of the ground, but he fplit it nearly in the middle downwards, to make it eafier to remove. It is of the fine white rag, adorned with moldings.

Many fags horns have been digged up; fome of an unufual fize; one, prefented to me, meafures round at the bafe ninz inches; ftriated lengthways, and fudded with fmall irregular tubercles. The feftival of the Romon hunters, facred to Diana, was I $3^{\text {th }}$ Auguf, when ftags were facrificed $(n)$. A temple, pcrhaps built in honour of her, was difcorcred by fome mafons in digging for ftones, fome years ago, adorned with doric pilafters and capitals, which perifhed under the ftrokes of their tools, being unacquainted with the valuc of fuch a curiofity. It was at the weft cnd of the flation.

Urns, of various fizes, with athes in them, were found in digging by the above-mentioned Hugh Ridley, on the north fide of his houfe; both of fine and coarfe pottery, incautioufly broken by his fpade; one of them as fmall as a pint-mug.

In the fouth-wett end of the Well-Houfe, belonging to William Smith, built about twelve ycars ago, at the weft end of the flation, by the fuburbs, is an altar inferibed,

(ii) Stukeley's Richard of Cirencefter, p. 43 .

$\mathrm{E} 2$ 


\section{MARTI VICTORI \\ COH III NERVIORVM \\ PRAEICT I CANINIVS}

It is thirty-four inches long, and twelve inches and an lialf broad; the under part hammered off by the incurious mafons; the infcription within a neat molding or raifcd border, much injured by the weather, though cut upon that durable flone, the fine white rag, found plentifully on the neighbouring moors. The fentival of Mars, was ift March. In the cabinet of the Revd. Mr. Wralton, vicar of Corbridge, is a brafs coin ftruck in honour of it, Narti pacifero; the deity in armour, helmeted; a Parma or fhield. on his left arm; a fprig of olive held forth in his right (o).

He is fometimes on coins in armour, dancing. The Saltatio armata of the Roman militia on their feftival Armiluftrium, celebrated inth October, is ftill practifed by the country people in this neighbourhood, on the annual feftivity of Chriftmas, the ruleTide of the Druids. Young men march from village to village, and from houfe to houfe, with mufic before them; dreffed in an antic attire, and before the Veftibulim or entrance of every houfe entertain the family with the Motus incompofitus, the antic dance ( $p$ ), or Chorus armatus, with fwords or fpears in their hands, erect, and thining. This they call, The froord-dance. For their pains they are prefented with a fmall gratuity in money, more or lefs, according to every hourholder's ability. Their gratitude is expreffed by firing a gun. One of the company is diftinguifhed from the reft by a more antic drefs; a fox's fkin generally ferving him for a covering and ornament to his head, the tail hang-
(0) Stukelcy.
(p) Virg. Gco. L. 1. v. 350. 
ing down his back. This droll figure is their chief or leader. He does not mingle in the dance. Like the frantic Bacchinalian Arufpex, -

\section{Ninciet Orgya Bícchr.}

This Chorus armatus is prettily defcribed by Claudian.

Armatos hic fixpe choros, certaque vagandi

Textas lege fugas, inconfufofque recurfus,

Et pulchros errorum artes, jucundaque martis

Cernimus: infonuit cum verbere figna magifter.

Mutatofque edunt paritur tot pectora motus,

In latus allifis Clypeis, aut rurfus in altum

Vibratis. Grave parma fonat mucronis acuti

Murmure, ct umbonum pulfu modulante refultans;

Ferreus alterno concentus clauditur enfé.

Claud. de vi. Conful. Honor:

Here have I feen the armed rings revolve, In artful flights, in order then advance; Attack, retire, in all the forms of war, Their eye till on the fignal of the chicf. Then face about, ringing their brazen fhields Againft their corflets, or uplifted high

Threaten the echoings $\mathrm{kkies}$, whilft fteely blades

Harn murmur, and the clanging trumpets found :

Alternate ftruck, the martial confort clofe.

The unlettered Roman called this feftal chorus; The Phyrric clance; the better fort, The Trojan game ( $q$ ).

(q) Suton. in Tibcrio. C. 27.

Virg. Æin. v. 596.

Stuk. Itin. Curios. p. 92-3.

Some 
Some other feltival-entertainments of the Romans were obfervable among the fame people fome years ago. Their youth ufhered in the new ycar by taking their rounds in the neighbouring viliages from houie to houfe; one of the moft fprightly and ingenious among them being their bard, who recited fome verfes, compofed in honour of the feafon, with a chorus, in which all the relt joined, in giving their congratulations. Thus the Romans.

Nec non Anfonii gens milla, coloni,

Verfibus incomptis ludunt, rifuque foluti.

$\operatorname{virg.~Geo.~2.~v.~} 3^{8} 5$, \&c.

Nor lefs th' Anfonian fwains deriv'd from 'Troy,

Sport in rough numbers and unweildy joy.

Warton.

Their Chorus.

Ergo rite fuum Baccho diccmus honorem

Carminibus patriis, lancefquc et liba feremus $\quad$ Il. v. 393-4.

Then let us Bacchus' praifes ing,

And confeciated cakes and chargers bring. Trarton.

Our Britifin youth bcing rewarded for their new ycar's compliment of poetry to their neighbours, retiucd to the mollia Prata, the foft meadows, fpent the fefal hours in wrenling, lcaping, and other exwciles. So the romans.

Pars in gramineis exercent membra palæetris, Conteudunt ludo, et fulva luctantur arena,

Pars pedibus plaudunt chorcas, ct carmina dicunt. Virg. En. vi. v. 642, \&c.

Some 
Some wreftle on the plains, and fome in play,

And games heroic, pafs the hours away.

Thofe raife the fong divine, and thefe advance

In meafur'd fteps to form the folenin dance.

Pitt.

The prefent owner of this ftation is Mr. IrFilliam Lowes; his houfe behind it, within the manour of Henfouwe, belonging to Sir Edward Blacket, of Wefl Matfen, Bart.

On the other'fide of the Tyne, by the confinence of the brook Allen into that river, is

Ridley-Hall, antiently belonging to the Ridleys of Wilim tefuicke, and in later times to the antient fanily of Lore's; a local name, from the neighbouring foreft of Lowes; now the feat and iondthip of William Lowes, of Nervafle, Efq; whofe anceftor, Rolurt Lowes, was one of the gentlemen who had the dires on of the watch at Thorngrafton, $6 \mathrm{~K}$. Edwerd VI (r). The fartind to on a rifing ground, built by its prefent owner; the buth-iront of brick; a pleafant garden before it; a windis tem $1.7 .9 \mathrm{~g}$ from it fouthward above the banks of $1 \%$ anding num ftreams, under a hanging wo nd near its termination a precipice of broken rows, called, The Rnven-ira from its being the refort of thofe birds; yews and hollics prowing in the clefts and crevices; one yew affording an agreeable fhade and verdure; at a fmall diftance the woody banks of Kingswood, which clofe this romantic fcene.

From a hillock on the weft fide of the houfe, the chapel of Beltingham, the caftle of Willmotefruicke, the new bridge over the:

(r) Bifhop Nicholfon's Border-Law's, p. 240. 
Tyne, the floping fields, woods, and little dwellings on its oppofitc banks, and the villa of Hayden-bridge, are agreeable objects.

Oppofite to Kingswood, and a mile and an half from the RavenCragg, on the eaftern banks of the Allen, is the ruin of

Staward le Peel, or Starvard Caftle. It ftands on the ridge of a rocky peninfula or promontory, between the Allen and Harfingdale-Bum, a fnall rill; entered to the caft by a narrow, lofty terrace, whofe fides are cloathed with trees; rocks and precipices appearing through them; under it is a triangular area in tillage, with a hutt in the midlt of fome fcattered trees, the Allen paffing by in broken murmurs, enlarged by the ftreamiet of Kingswood, the northern boundary of the Lordinip of Whitfield; a femicircular hanging wood adorning its weftern margin; the rocks of Sherving-fhecls, and the villa of Thorngrafton, in view to the north. A fragment of the gateway is flill ftanding, where was a drawbridge, an iron-gate, and port-cullice. There are alfo nine courfes of it flanding at the weft end, of the white rag-ftone, and hewn work; the cement fo ftrong, that one ftone can hardly be feparated from another without brealking them; guarded by a $F o f s$, and a Vallum of earth and ftone. It belonged to the friers Fremites of Hexham; granted, with its demefnes, by Edward Duke of York; to hold by the anrual payment of five marks (s). It is in fight from High, but not from Low, Staward; as are nuany of the beauties of the Allen, whofe banks from its Ofium to its afrociation and union with Eaft Allen, prefent us with fuch groups of ruial imagery, as are not to be furpafied by any fpot

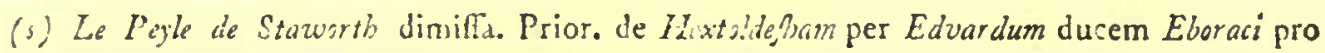
ermino annorum reddend. per annum 5 Marc.

Pat. 10 Ricardi ii. p. 2. m. 9 . in 
in this county, for the like fpace. Among others, is a crag, called, Fudas's-Crag, well known to hunters, for giving protection to foxes, in their diftrefs by the chacc.

The two Stawards, and the Peel, were in the poffeflion of the crown, 10 Q. Elizabeth $(r)$, and are now the property of Fobn William Bacon, of Etherfon, Efq; *

About half a mile from High Staward, under a hill, the two Allens pafs in a pleafant ftream, immediately after their junction, through a handfome new bridge of three arches, of white freeftone $\uparrow$. At the oftum of Weft Allen is a lead-refining mill, called The Cupilo, belonging to a wealthy company of quakers. On the weftern, hady margin of that rivulet, is a handfome road, about two miles and a quarter in Iength, leading to

Whitfield-Hall, the feat of the antient family of the Whitfields; of Fobn de Wbitfield, $22 \mathrm{~K}$. Richard II (s); of Sir Matthew Whitfield, Knight, I 2 K. Henry VI. then high theriff of Nortbumberland ( $t$ ); of Ralph Whitfield, 10 Q. Elizabeth (u); held by the annual rent of 6 s. $4 d$. of the prior and convent of Hexbam, Lords of the Manour, to whom it was granted by William King of Scotland $(v)$;

pur-

(r) Eicaet. de anno ro Eliz.

* Since dead.

† Lately carried away by a flood.

(s) Efcaet. 22 Ric. II. n. 39 .

(i) Fuller's Worthies.

(u) Rudulphas Whitfeld fuit feifitus de et in Whitffeld-Hall, Hunter-Sheels, Burn-Mouth, Old-Town, Dews-Green, Whittingftaw, Soft-laws, Elme, Mill-Houfe, Hope, Parmanlee, Parmanlee-Hall, et White-Walls.

Efcaet. de anno 10 Eliz.

(v) Prior et conventus de Hextoldefpam tenent et habent dominicum totius villa de Whitfield, et fexdecem folidat. et quatuor denariat. reddit. in liberam, puram, et perpetuam eleVor. II. 
purchafed and annexed to the eftate, after the diffolution of that monaftery, by the Whitfields; the laft of whom, Mattbew Whitfield, Efq; high theriff of Nortbumberland, 1728, fold his antient patrimony, of Whitfield, to William Ord, of Fenbam, Efq; who hath made great improvements by buildings, enclofures, and planting.

The feat-houfe is at a fmall diftance from the villa, on a rifing ground, by the ftreams of Weft Allen, the eaftern boundary between this manour, and the manour of Hexham/Bire. Before the eaft front is a hanging bank of wood, called Monk, remarkable for its beautiful bollies. There is a water-fall from a limeftonerock, about a mile to the fouth, by a precipice of a prodigious height, nearly perpendicular.

At Limeftone-Cro/s, in the manour of Whitfeld, there was formerly a lead-mine.

On Whitfield-Fell is a chalibeat fpring, called Redmires.

About a mile from the Cupilo, is

Old Town, fituated partly on an eminence, and partly on a flope, extending to Eaft Allen; the houfe next the moor, called Stony-Law, from a little craggy mount, compofed of earth, and large fingle mafles of coarfe rag-ftone, ftreaked with red and white. There is not the leaft memorial of its being a Roman ftation, as fuppofed by Mr. Horfley, either by funeral-ftones, altars, infcriptions, coins, or foundations of buildings; not even a tradition from any body on the fpot of its being of Roman original. A quarter of a mile to the eaft of it, upon the moor, is a hillock mofinam, de donoWillielmi Regis Scotice, et inde habuerunt cartam, et tenuerunt a tempore quo non extat memoria.

Rot. Cart. 27 Edvardi III. n. 35. 
of flones whereon about fourteen years ago ftood an upright piece of timber or pole, called Catton-Beacon, to which was affixed a veffel with fire in it, to alarm the country on any public danger. The alarm was communicated from it to another beacon on Whitfield-Fell, called Whitfield-Law, vifible both from it, and from the mount of Stony-Law; from which laft place we have a fine vicw of the hanging wood leading to Whitfield by $W_{\text {eft }}$ Allen, of the rivulet of Eaft Allen, of the lead-fmelting-mill belonging to Fobn William Bacon, of Etherfton, Efq; of the capital town of Allon-dale, called,

Allen-dale-town, fituated on the banks of Eajt Allen, on an cminence, and overlooked by others on both fides of that rapid brook. It is inhabited chicfly by miners; the church fmall, confinting of one ifle; near the altar, a flat fepulchral ftone to the memory of Fobn Bacon, Efq; and his wife Cicilia.

At Bride's Hill, near this town, is a free-fchool ; founded by Mr. Chriftopher Wilkinfon, of Chapel-Houfe, who by will, dated 27th February, 1700, gave 250l. for its endowment.

The reverend Mr. Thomas Wife, minifter of the parifh, born at Thornbill, in Yorkfoire, by the codicil to his will, dated ad February, 1702 , left to it rol.

Mrs. Cicilia Bacon, of Catton-Lee, widow of Fobn Bacon, Efq; by will gave to it $50 l$.

Mr. William Hutcbinfon, of Port-Gate, in the fame parifh, by will gave a houfe and garth in Allendale-town, called the Tinker-houfe, valued at $24 l$.

The fchool-houfe was built, 1704. It colt $50 \mathrm{l}$. 
A road leads by a gradual afcent from this town, fouthward, over a moor, to the villa of

Allen-Heads, inhabited alfo by miners; both belonging to Sir. Wralter Calverley Blacket, Bart. the alpine country round it reputed. rich in veins of lcad-orc.

'To this villa, Mr. Burnand, a Cumber!and-clergyman, retired, on his being filenced for nonconformity at the reftoration, and employed himfelf in a little farm, till by the favour of Sir IVilliam Blacket, Bart. he was appointed minifter of the chapel here, built for the conveniency of the miners, with a falary of 301 . per ammm; the mines then profperous and rich (w). Sir William gave alfo" 10\% per annum to a fchoolmafter, for teaching the miners children to real and arite.

To the caft of, and only half a mile from, this mineral villa, is the mountain, called Shorn-Gate, over which the Scots made a road by paring the mofs, and tumbling in ftones, (to which it owes its name) in their precipitate retreat homewards from Stanlope-Park, I. K. Edward III. 1327 ; in fear of correction from the Jinglifo army, commanded by the king in perfon, after they had made themfelves merry at the regimental trim and mien of his foldiers, their cloathing being coats and hoods, embroidered with flowers and branches, very prettily, and their beards uncut, it being the fallion then for the foldiery to wear them.

The boundary-line, called The Scotch-Dike, extends from this place northwards by Catton-Beacon, and crofles the Roman wall at

(w) Bihop Kennet's Hift. Regift. p. 89.r. 
Bufy Gap; between which and Houfefeeds, from a rocky eminence, called The King's Crag, a little to the north, it is in view.

There is nothing more remarkable by the ftreams of the two Allens.

We now continue our journey from the afeent between the 32 and $3^{1}$ mile-ftone on the military road, for about two miles, till we come to an exploratory mount, with a cut through it, on the right hand, midway between the 3 oth and 2 gth mile-ftone, when we have a near view; on the left hand, of the Roman fation of

Horfe-feeds ( $x$ ), cafily diftinguilhed by the ruins and foundations of buildings; garrifoned by the firn cohort of the Tingyi, or Lehgic Ganls, as attefted by no fewer than fix inferiptions in the Britannia Romana. It is on a large flope; the Picts-wall behind it, on a lofty precipice; Grundon-I.ake in fight before it.

Thofe two celebrated antiquaries, the late Roger Gale, Efq; and Dr. Stukeley, wcre both at this ftation in Ausuft, 1725; of which we have an account by the latter in his Caraufus (y), who had tranfcripts and drawings of an incredible number of altars, infcriptions, and fculptures, in large letters, and cxcellent work, taken on the fpot by himfelf, and unpublihed; many of them engraved by Mr. Gordon and Mr. Hsr ley, but, in his opinion, inferior to the originals. The three females, Des Matres, on one ftone, with globes in their hands, and fhort pallia down to their knees, are ftill remaining; their heads broken off. They were the tute-.

(z) Borcovicus. Horflcy.

Houfe-fteeds.

(y) Vol. 2. p. I52, \&ic. 
lary deities of the chace or foreft of Lowes. Both Venus Venatrix, and Venus Papbia, are reprefented as attired in a fhort robe, nuda genu $(z)$. Thefe here with globes in their hands, and in thort coats, are fuppofed to have been made by a corpfe of Thracian or Syrian auxiliaries, expert in the chace, and excellent horfemen; their horfes remarkable for their beauty (a).

The globes in the hands of their deities may intimate not only the univerfal empire of the Romans, but their reliance even in thcir pleafures on the protection and guidance of heaven. They had a temple on a liillock, now called, The Chapel-Hill. It was of the Doric order; a large fragment of a Doric capital lying proftrate by it fome years ago, confifting of two Torus's, plain; alfo many broken columns. Thofe deities were worthipped in open temples, and in groves. Herd by is a wet meadow, which might then have been a grove, now over-run with brufhwood, particularly with the fwcet-fcented willow, whofe foliage, after the morning and evening dew, yield a moft grateful fragrance.

Through an opening of a ridge of limeftone rociss, a little on this ficle of the 28th mile-ftone, on the right hant, fourh from, and almoft oppofite to, Shewingfaeels $h$ ), is a good vicw of

Langley-Cafle, the feat of the burons of Tynedale; of the two Adams de Tynedale, father and fon, in the reign of K. Henry III. (c);

(z) Virg. Æn. I.

Viillant. Numi:fmat.

(a) Virg. ÆEn. v. ver. $5^{6} 5$.

(b) Seavenihale. Camden.

Shewingtheels. Horfey.

(c) A'am de Tynedale tenet in capite de domino rege baroniam fuam de Langley per fervicium unius feodi milit. (viz. Wardons, Fourfones, Allerwes, Langley, Wyden, Haiden-

Brigges, 
of Richard de Bolteby (d), fon-in-law to the laft Adan de Tynedale, who died $57^{\text {th }}$ of the fame reign, and was fucceeded by his fon, Adam de Bolteby, then of full age; from whom it paffed to the noble family of Lucy, barons of Fgermond and Cockermouth; their baronial inheritance for five defcents; firt polfefled by Thomas Lord Lucy, who died 33 K. Edward I. (e); by another Thomas, who died 2 K. Edward II. (f); by Antbony Lord Lucy; by Thomas Lord Lucy,

Brigges, Blenkinfoppe, et Fetherftonehaugh ;) ct omnes antecefforcs fui tenuerunt per idem fervicium poft tempus domini regis Henrici, qui eos feoffavit; ac de illo tenem. nihil eft alienatum aut datum, per maritag. aut elinofin. aut aliqu's alio modos unde rex minus habeat de capit. Servicio fuo.

Tefta de Nevill.

(d) Richard's de Boltby tenuit in capite de dom. rege in comit. Nortbumbr. de harediate Pkilippa uxoris luæ, filiæ et et heredis cujuld. Adam. de Tindale, fcilt. Langhly, Iraildon, Allerwas, et Fourfones, perfervic. feod. unius militis; et Riibardus tenuit de aliis in comit. Northumbr.

Et dicunt juratores, quod Adamus Boltby eft hæres propinquior iplius Ricbardi et Plilitpec matris fux, et eft plina etatis.

Inquifit. ex bundello efcaetr. turri Londinenf. No. 3. capta apud Morpeth Die Jovis, 20 poft feftum Sancti Clementis, 57 Hunici.II. per Thomam Fitiserfonbaugh, jun. \&c.

(e) Thomas de Lucy tenui ite domino rege in cai)ite manerium de Langley, cum pertinent. in comit. Northumbr. die quo cbitit, per fervicium fredi unius militis, et pro cornagio annui reddit. ad caftum Nov: Caflri fuper Tyram, et facienco fectam comit. ad caftrum Novi Caflri fuper Tynam. Et dicunt jurators, quod Thomas dibti Thombe filius, cft hæres ejus propinquior, et erit æatatis 24 annorum ad feftum Dic Afcenfionis proxime futuro.

Inquifit. ex bundello efcaetr. Turri Londinenf. No. 79. facta apud Corbridg in comit. Northumbr. Die Veneris proxime ante feftum Sancti Marci evangel. 33 Edvardi I.

(f) Thomas de Lucy tenuit mancrium de Langley, cum pertinen. in comit. Northumbr. de dom. rege in capite, per fervicium feodi unius militis, et per fervicium faciendi fectam ad comitat. Novi Caftri fuper Tynam, et per cornargium de 8 s. 6 d. per annum. Et dicunt jura- 
Lncy, who diod, 39 K. Edward III. $(g)$; by Antbony the lalt Lord Lucy, who died 42 K. Edward III. (b).

The firf Antbony Lord-Lncy, 'I 6 K. Edward II. I323, by order of his Majefy then feized Andrew de Herkley, Earl and Governor - of Carlige, for treafon, in the caftle of that city, affited by Sir Richard Denton, Sir Hugb Lowtber, and Sir Hugh Moriceby, Knights, and four Efquires; Sir Lichard Denton killing the porter of the

tores, quod prediitus Timmas de Lucy nil tcnuit de aliquo alio in comit. prædiglo; et quod Antonius de Lucy, filius fradicti Thome, eft heres propinquior, ejuflem Thome, et eft atatis - annorum, et amplits.

Inquifit, ex bunde!lo efcaetr. Turri Londinenf. No. 78. capta per Thoonam Fetherfonbaugh patrem, et Thoman FetberRonbaugh, fil. apud pontem de Hayden, in comit. Northumbr. Dic Martis 20, puft feftum Sancti Micbaelis, (die quo obiit diQtus Thom. de Lucv) 2 Edvardi II.

(g) Themas de Lucy (fil. Antonii de Lucy) tenuit in dominico fuo ut de feodo, die quo obiit, de dom. rege in capite, mancrium et caftrum de Langliy, cum pertinen. in comit. Nortbumbr. par homag. ct fervic. rediendi dito dom. Regi and cornag. $8 \mathrm{~s} .8 \mathrm{~d}$. ad fefta S. Cuthberti in Sept. et Novembr. per æquales portiones, per manus vice-comitis Northumbr. qui pro tempore furrit. Et dicunt juratores quod dialus Thonas obiit Die Jovis proxime poft feftum S. Andrea, apoftoli ; et quod Antonius de Lucy, filius predicti Thome de Lucy eft hæres ejus p.epinquior; et eft ætatis 24 annorum, ct amplius.

Inquifit. ex bundello efcaetr. Turri Londinenf. No. 17. capta apud Novum Caflum fuper Tynam Dic Veneris proxime poft feftum S. Petri in cathedra, 39 Edward III.

(b) Antonius de Luy, defunclus, tenuit in dominico fuo, ut de feodo, die quo obiit, manerium ct caftrum de Langley, cum membris et pertinen. fuis. Et dicunt juratores, quod Fohanna, filia prædidt Antraii de Lucy, eft hæres ejus propinquior; ct eft atatis 2 annorum, et urius quarterii.

Inquifit. ex bundel:o efcaetr. Turri Londinenf. No. 37. capta apud Langley in Tindale, in comit. Nortinumbr. Die Jovis in fefto Sancti Andrea apoftoli, 42 Evardi III. 
inner gate, for attempting to fluut it againft them; one fervant of the Earl's efcaping to the Peel, a calle at Heibead, the feat of his Lordfhip's brother, Micbael Herkley, who by that means was informed of his difafter, and fled into Scotland, with sir Willian Blunt, a Scotch Knight, and others of their party.

The year following his lordfhip obtained a grant of free warren within his Lordhips of Langley, Hayden, Four-ftones, Allerwafh, and $W$ arden (i).

The laft Antbony Lord Lucy dying without ifluc-male, and his daughter and heir Fohama furviving him only five years and three quarters, he was fucceeded in his baronial honours and eftates by his fifter, Matilda, wife to Sir Gilbert Humfranoil, Earl of Angus (k);

(i) Rex Archicpifc. \&e: falutem. fciatis nos de gratia noftra fpeciali conceffife, et hac carta noftra confirmafte, dilccto et fidcli noftro Antonio de $L u c y$, quod iple et hreredes fui in perpetuum habeant liber. Warren. in omnibus dominicis, terris, de Langley, Hayden, Fourfanes, Allerwafe, et $W$ arden, ill comit. Narthumbr. dum tamen terre illa fucrint infia metam foreftx noftre, vel librx parcx noftre. Itcm quod nullus intrat turras illas ad aliquid capiendum quod ad Warren. pertinet, fine licentia et voluntate ipfius Antonii, vel hæred. fuorum. Quare volumus, et fermiter precipinus, pro nobis et hxedibus noftris, quod pradictus Antonius et hxredes fui in perpetuum habeant liberam Warrenam in omnibus dominicis, tcris, fuis pradiftis, dum tamen terre illie fuerin, \&ec. Item quod nullus, \&ic. Sicut prædictum cft his teftibus, venerabili patre $I V$. Arcbiepifopo Elor. Angl. Primat. Edmund comice de Aundell, Hurone le Defferfer, et aliis, dat. per man. noftr. apud Holland, i 8 Die Octobris, per breve de privato figillo.

Calta turri Londinens. 17 Edvardi II. No. 33 .

(k) Gilbetus de Humfranvil, cones de Angus, et Matilia, uxor cjus, Antonii Lucii confanzuinea et hares, foon. Fil. et hæeses. cjufd. Anton. tenuerunt de rege in capite medietatem Baronix de Alderdale, vicefinan parton Baronia de Esremond, et tertian partem refidui ejufden Baronia de Fgrcmond, ac manerium de Langley in crmit. Nartibumbr per Servic. reddendi regi per annum viiis. ad cornagium per vicecom. disi comit. Northurbro nec non caftrum th honorem de Cockermouth, cum pertinen. ac mincrium de Papcofer, cum pertinen. in Ailerdale, quod ad dominicum, caftrum, et honorempertinent, per fervicium unius feodi nilizis. Rot. turri Lonlinins. Palchx Fin. Anno 47 Earoardi lll.

Vol. II. 
after whofe death the married Henry Percy, Earl of Nortbumberland, and fettled her whole fortune upon his Lordhip, and his. heirs-male, under the cafy condition, that as their hearts were, the arms of the two noble families might be, united, for a memo:ial of her affection ( $)$.

(7) Matida conitifia Nombulir. obiit feifita, Henrico com. Nort?umbr. fuperftite, dè reverfione cafri et manerii cie Longley, cum pertinen. in com. Northumbr. ex concellis Fohannis de

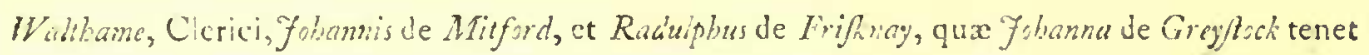
in doten ad vitam fuam, habcus. pradicto comitc et Matilda, ct harcdibus mafculis de corporc ipforum cicunt. de Dom. rege et haredibus fuis per fervicium inde debitum, et confuet. in perpetuum. Et fi pradictus comes et Matila fine haredibus malculis de corporibus e rum exeunt. obierint, quod tunc poft mortem corum caftrum et mancrium prædinun, cum pertinen. remaneant integre hareditus de corpore pradicta Matille excunt, tenend. de dom. rege, cum pertinen. fuis, per fervicium inde debitun, in re, ct confuctudine, in perpetuum. Et fi cadem hintildu, fine haredihus de corporc fuo cxcunt. ohierit, quod tunc pradictum. cafrum, et manerium, cum pertinen. remaneant Honrico de Percy, flio practicti comitis. Norliumbr. et haredibus fuis mafculis de corpore fuo exeunt. tenend. de dom. reje, ct ham. redibus fuis per fervicium predictum.

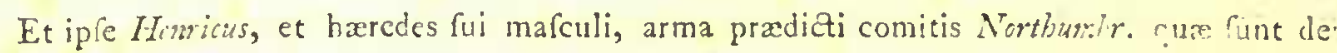

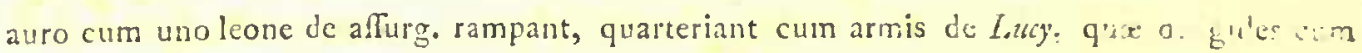
tribus Luciis argenteis confftunt, gerunt in omnibus venellis pro cm.itus tah nuis armorum, et omnibus aliis armaturis fuis, qua de pictura cognitione armorun folita conripet. adorari, quoties cognitiones armorum in artibus bellicis, vel a!ib: frendere voluerint, ubicunque.

Et fi idem Herrius filius pradicti comitis Nortbunbr. fine harede mafcul :e corpore fuo

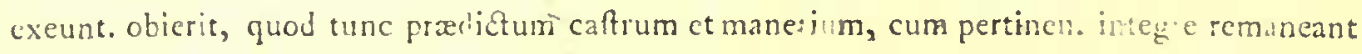
Thome de Percy, certo flio pradicti comitis, ce haredibus fuis mafculis de corpo c fuo exeunt. tcnend. de dom. rege et hxredibus fuis per fervicium prædictum in perpetuum, et gerend. Arma pradicta in omnibus modis et formis.

Et fi idem Thomas fine hared. mafcul. de corporc fuo exeunt. obicrit, quod tunc prædictum cafrum et manerium. cum pertinen. integre remaneant Radulpio de Pcrcy, filio pradiat comitis, et haredibus mafculis de corpore fuo exeunt. tenend. de dom. rege et hæredibus fuis per fervicium pradictum in perpetulim. 


\section{ANTIQUITIES OF NORTHUMBERLAND.}

In later times, the barony and cafle of Langley came into the poffeffion of the Ratcliffs of Dilfton; and gave the title of Vifcount and Baron Langley to Sir Francis Ratcliff, Bart. 7 March, 4 K. Fames II. 1688 ; then created Earl of Devwentwater; and were forfeited to the crown by Fames Ratclif; the laft Earl of Derwentwater, and given to Greenwicb-hoípial.

The caftle is on a rifing ground, on the fouth ficlc of the Tyne, in the form of the Roman letter, H. win fom towers, flanting north and fouth; many of the windows large; four fimall firerooms remaining entire to the caft; alfo eight others, fourground-rooms to the eaft, and as many to the weft; the roofs arched with ftone. The walls are fix feet, ten inches, thick; and the north-eaft tower fixty-fix feet high; to the welt, the fors or ditch ftill vifible.

In fight from it, about a mile to the north-eaft, on the banks of the Tyne, is its appendant manour and villa of

Hayden-Bridge (m), to which the fint Anthony Lord Lucy procured a weekly market on Tuefdays, and an annual fair on . Fuly $2 \mathrm{r}$, and

Et dicunt juratores, quod prædiaum caftrum et mancrium, cum pertinen. in omnibus cxitibus, tam in fervicio, quam in dominico, ultra reprifas, juxta verum valorem, valent per annum cen:um merc. et mon plus iis diebus, propter deftructionem Scotorm; ex tenentur de dom. rege per fervicium militarc. Et dicunt, quod difa Matilda obiit Die Mercurii, proxime ante Feftum natale Dom. ultimo; et quod Wiiklmus de Mclton, Chr. eft cjus pro. pinquior hares, viz. Filius Fobanna de Melasn, fororis Dom. Thome de Luiy, patris Miatilla et eft ctatis 24 annorum, ct amplius.

Inquifit ex bundello efceatr. turri Londinens. No. 39. capta apud Morpath, coram Willielmo de Lowther, cfceat. Dom. Regis in comit. Northumbr Dic Luna, decimo Die Martii, 22 Ricardi II.

(in) Haiden-Brigges, Inquifit.

Aidon. Camden.

Haydon-Bridge. Horfey. 
three days after; now difcontinued. The Tyne is croffed by a bridge of fix arches; on the fouth fide of which, on a little eminence, is a grammar-fchool, over the entrance of which is the following infcription.

\author{
Hæc fchcla fundata et \\ Munifice dotata fuit anno \\ Domini MDCXCVII, a \\ Reverendo et doctiffimo viro domino \\ Johanne Shaftoe, A. M. ecclefix \\ Netherwarden in hoc agro vicario; \\ In tam benigni capitis elogium \\ Deefle nequit : hoc unum opus pro \\ Cunctis aliis fuis beneficiis fama loquetur.
}

For the ufe of this fchool, and the relief of poor loufe-keepers within the chapelry of Hayden, the Revd. Mr. Shaftoe, vicar of Nether-warden, left his cltite of Monfen, near Belford, by a deed of gift, bearing date I7 Fune, I Fames II, 1685 ; afterwards confirmed in chancery, on account of a fubfequent will, bearing date is May, 5 William and Mary, I693; the deed being uncancelled (n:) ; the eftate now lett for upwards of 1501 . per anmum; the granmar-mafter to be of the degree of mafter of arts in one of our univerfities; his falary at prefent upwards of 501 . and the ufher's 15 . per anmum.

On the right hand of the military road, by the $25^{\text {th }}$ mileAtone, in an opening between two rifing hills, giving a view of part of the vale of South Tyne, is,

(n) See both in the Appendix. 


\title{
ANTIQUTTIES OF NORTHUMBERLAND.
}

Carraw-Brough, the Roman ftation Procolitia, garrifoned by the firt cohort of the Batavi, as attefted by an altar found near it, infcribed,

\author{
FOR TVNAE \\ COH. I BATAVOR \\ GVI PRAEEST \\ MELACCINIVS \\ MARCELLVS PRAE.
}

The firf notice taken of it was by Dr. Cay, by whom a copy of it was prefented to Mr. Thor $/ b y$, and publifhed in the Philofophical Tranfactions (0). It was then in fine prefervation, the flone handfome, and the infcription fair; in the poffeflion of Mr. Forfer at Carraw, 1697; and removed to the library at Durbam, by the late Mr. Warburton.

Carraw-Brough has its name from the Saxon Burgos or Brough, and the Emperor Caraufus who repaired it; of Britifs defcent, and a noble and graceful perfon, as reprefented on coins.

In craffo jurares Tre natum.-HoR.

To him is attributed the origin of the Britifs empirc by fea. He had the high poft of Comes Litoris Saxonici, inftituted by Confantine, for the correction of the Saxon rovers, whofe vifits were then bold and frequent. He was alfo an admiral in the Roman navy under Maximian. On his defection, that Emperor, and his affociate Dioclefian, came with their whole naval powcr on the Britifs coaft to deftroy him. He faw them, beat them, and made them acknowledge his fovereignty over his countrymen and fricnds,

(o) No. 23r. 
the Britons; maintaining it cver after in full fplendour, both by fea and land, ageant the whole Roman power. That celebrated Sca-vietory orer the two emperors was gained on the coaft of the Ifle of Iright, near Carifbrook-cafte, fo named in honour of the vicor, Caraufus. That Caraufus, whom the Roman arms could not fubdue, fell a facrifice to private envy. He was killed in his imperial palice at Tork by an infidious fricid, Allectus; who furvived him but three years, before he met with the like fate.

Among the coins of Caraufus in the collection of the Revd. Mr. Walton, of Corbrage, there is one of brais, which exhibits a galley, with Felicitas Aug. Atruck on the fentival-day of Neptune, 5th November.

A curious fculpture of Neptune, lown to the knees, in a reclining attitude, with his trident by him, in thone, of the fine white rag, was digged up at this ftation, and built up in the caltern gable of a cottage at Corraw, belonging to Ralpb Soulfoy, of Halyton, Efc].

From an afcent by the $23 \mathrm{~d}$ mile-fone, we have a diftant profpeet of

Tone, the fent of Alan Hodflon, Efq; grandfon to Sir Alan Swinburn, Knt. a younger brother of the houfe of Cap-Heaton; who hath made great improvements at it by repairs and additions, by cnclofures, hedge-rows, and good roads, and raifing plantations about it for thade and thelter.

From the fame place we have a full view of 
Chipchace-Cafle (p), the feat of Peter de Infula, I K. Edward I (q); and afterwards of a branch of the noble family of the Herous, of Ford-Cafle, by the river Till. In the reign of K. Henry VII, it was in the poffefion of Sir Foba Horon, Knt. whofe daughter, Lryflla, married Roger Fenwick, Efg; of Bitchfeld, in the parin of Stamfordbin, fecond fon of Sir John Fenzerick, of Wallington, Knt. by Marsery the daughter and heir of Jobn Hurbotell, Efel; $(r)$. In the next reign it belonged to Sir George Heren, Knt. then keeper of Tynedale; high theriff of Nortbumberlund, I 3 of Q. Elizabeth (s). He waskilled in a fray with the Srotch borderers in Fuly', I575, in company with Sir Folon Forfer, Lord warden of the middle marches, and his fon-in-law, the Lord Ralfel, who were taken prifoners, but releafed, and the regent of Scotland, Anrey, obliged to make fatisfaction by the beft offices in his power. He was fuccecded by his coufin, Cutbbert Heron, Efq $(t)$; high theriff of

(p) Chipchace-caftle. Lel. hin. Vol. vii. p. 59 .

Chipches. Camlen._Inquifit, et eficaetr.

(q) Petrus de Infula tenet Chipches et IF'bithill per tertiam partem unius feodi milit. veteris feoffament. Baron. de Prudbow._-Efcaet. de anno i Edvarai I.

(r) Ms. penes Gulielm. Finwick, de Bywoll, Arm.

(s) Georgins Heron fuit feifitus de et in maneis de Chipches, cum villa, et Symonburn, Pigdon, Hawbarnes, Overton, Sharplawe, Tcppermoo:e, Billerley, Shetlington-hall, Bromeleifes, Efhecs, Brig-houfes, Nether-Crag, Snatdaugh, Chirden, Heyrigges, Pinderhawe, Morkeley, Roughfide Ramphawe, cum terris in Butand, Gofton, Hetherington, Boidon, et Suingfhcele;:

Efcaet. de anno to Eliz.

(t) Cutbbertus Heron, confanguin. et lreres Gesrgii, eft feiftus de et in manerio de Chipches, cum villa; et tenet in capite de rege manerium de Simonburn, ut de manstio de $\mathbb{W}$ ark, per fervic. milit. Villam et manetium de Shetlineton, Suapdaugh, F picficudnepe, Ha. therington, Harelawe, Le Cragg, Newbiggen, Blackaburn, Chefterhope, et unum meflag. five caftrum vocat. Sewingheeles-cafle, et tenement. ibid. et tenet de rege per fervic. milit. Manerium de Pigdon, ut de manerio de Mitford.

Efcaet, de anno it Carcli T. 
Nortbumberland, 1625 ; created a baronet, I2 K. Charles II, I662, for his loyalty to K. Charles I; in whofe fervice his brother, Colonel Gcorge Heron, was flain at the battle of Marfon-moor. In the 1 gth of K. Faires I, he built on to the old caftle a very handfome ftucture; the intial letters of his name, C. H. cut in ftone, on each fide of his coat of arms, with the date of the year, I $62 \mathrm{I}$, above the fouth entrance. He married Elizabets, the third daughter of Sir Ricbard Grabam, of Netherby, in Cumberland, Bart. mafter of the horfe to K. Charles I, and afterwards Lord Prefton, by whom he had three fons, viz. Cutbbert, Foln and Charles; the two laft of whom lived to fucceed him in honour and eftate. His grandfon, Sir Hirry, only fon to Sir Charles, fold Cbipchace to Georye Allgood, Efq; of whom it was purchafed by the late Fobn Reed, Lfa; high therift of Northumberland, 1732 ; defcended from a younger branch of the antient family of the Reeds of Troughchl, by the river keed. Mr. Reed added much to its beauty by fafhing the whole building, making gardens, plantations, and cnclofures, rebuilding the chapel, and finithing it neatly at his own cxpence. He died, 2oth March, I754, and was interred in his own chapel. He was fucceded by his nephew, Clorifiopher Sortloy, now Chriftopher Reed, Efq; inigh fheriff of Nortbunberland, 1764 . He married the eldent daughter of Francis Blake, of Twifel, Ef Knt. of Ford-Cuffle, by the river Till. He hath given many embellifhments to Chipchace, by buildings; by laying it open to groves and plantations, and cafting the fields before it into a park-like form. It has a very lovely fituation, on a declining eminence, to the eaft of the river of North Tyme; a profpeet from it of Nunwick, and of Simonburn-Caftle, diverfified with the fight of woods, of moors, of rocks, and of the winding motions and meanders of the $\mathcal{T}_{y}$ ne, which oppofite to the houfe forms under 


\section{ANTIQUITIES OF NORTHUMBERLAND.}

a hanging bank of wood a large and deep canal; a fhady, projecting cliff on the other fide.

Under the hill, a little beyond the 23 d mile-ftone, on the left hand, a road branches off to

Nunwick (u), formerly a village, as its name imports, but now the feat of Sir Lancelot Allgood, Knt. It belonged to the Herons of Chipchace, and was fold by Sir Harry Heron to Robert Allgood, Efq; whofe only daughter and heir marricd its prefent owner, fon and heir of Ifaac Allgood, Efq; of Brandon-White-IIoufe, by the rivulet of Bramifh. Sir Lancelot was high fheriff of Northumberlund in 1746 ; one of its reprefentatives in parliament on the death of Fobn Fenwick, of Bywell, Efq; and on the acceflion of his prefent Majefty reccived the honour of knighthood. His feat at Nunwick is of his own erection, after a gentecl defign; of white free-ftone, and hewn work. It ftands on a rifing plain, which to the eaft has the appcarance of a park. The offices are to the north, a grore to the weft, a grafs-lawn to the fouth, and a tcraced gravcl-walk to the eaft, which commands a view of Chipcbace at one end, and a variety of profpects on the other. Two brooks unite their loquacious ftrcams to give beauty and ornament to a neat garden, and render it an cntertaining, as weil as ufeful recefs; and thence take their courfe by another grore, on a declining hill, to the fouth front of the houfe, and fall two or three fields below into the river of North Tin.

In an adjoining field, called, Numwid-caft-field, were five upright ftone-pillars, in a circular order; four of them perfect and

(u) Ninwick. Cancien. Bimop Nichalfon.

Nunwicke, Rol. Alitiq. ex informat. Lancé. Allgool, Milit.

Vol. II. 
entire in I7I4, the other broken; the perfect ones eight feet high, and nine feet and an half over; the circumference of the area in which they ftood, ninety feet. Mention is made of them by Bifhop Gibfon in his Canden (v). In fuch kind of cirques, the Britons held their public affemblies, both civil and religious*.

Sir Lancelot has given a new face, as it were, to the country about Nunwick, within the fpace of a very few years, by making plantations, enclofures, and good roads, one of which leads to the villa of

Simonburn, at the diftance only of half a mile from his feat, and in fight. It is fituated on a rifing ground, by a pleafant brook, fron which, and the dedication of the church to St. Simsn, it takes its name. It is remarkable for being the largeft parith in the diocefe, extending northward from Chollerford-bridge to Liddefdale, in Scotland; a fpace of 23 computed, or 32 meafured, miles; in which are only two chapels of eafe, Bellingbam, and Falfone; the laft of which had Qucen Anne's bounty, by a donation of 2001 . from the late rector, the Revd. Mr. Stainsforth, one of the proctors for the clergy of this county in the houfe of convocation in I7I7; prebendary of the collegiate church of Soulbwell; in Nottingbampoire; and father-in-law to the Right Revd. Dr. Terrick, the prefent Bithop of Landon.

The patronage of this rectory was taken from the See of Durbam by K. Edward I, together with the Lordhip of Wark upon North Tyne, and the patronage of the living of Penretb, in Cumberland, in refentment of fome undutiful behaviour from Antbony

(v) Page, 870 .

* See Borlaje's Antiquities of Cornwallo. 
Beck, then Bifhop (w). We find it afterwards in the poffefion of the Darcys. In the reign of K. Edward III, Folnn Darcy left it at his death to that king's amiable confort, Queen Pbilippa, who gave it to the college of Windfor (x). The Ratcliffs of Dilfon, Earis of Derwentwater, had it in later times. By the attainder of the laft earl it reverted to the crown; on whofe prefentation Mr. Stainsforth was fucceeded at his death, 1719, by the prefent rector, the Revd. Mr. Henry Waffell, A. M. Fellow of Peter-Honje, in Combridge; to whom the rectory-houfe, garden, and little glebe, owe their neatnefs and culture; the fouth front being entirely built

(w) Provocatus rex contra Antonium Epifc. Dunclm. co çud pacta inter ipfum et privicm Dunelm. Ricardum, rege mediante inita non obfervaret, et ex aliis caufs, caftrum fiernarli cum pertinen. ab co abftulit, et comiti de líarwich contulit; Hert. et Hertness, Roberto de Clifford; Kcverfon, Galfrido de Hortlipole, qux epifcopus habuit ex forisfactura folian. de Baliol. Robcrti de Brus, et Chriflopheri de Seton. Abfulit eo etiam rex IVorke in Tynedale, Penreth, et ecclefian de Symordourn, quam appropriavit menfe fux.

Monat. Angl. Vol. ii. p. 846.

Canul. Brit. Ed. I722. p. 1020.

(x) Edvardus, \&c. Sciatus quod cum Pbilippa, Regina Anglie, confors noftra chariffima, advocationem ecclefix de symond.ßurne, quam ipfa nuper habuit ex dono, \&z concefionc Gobannis Dariy, Chivaier. defuncti; \& Eivardus princeps Wallice \& Dux Cornulir, filius nofter charifimus, advocationem ecclefix Sancti Stepbani de Saltefl, quam nuper habuit ex concefrone noftra, nobis dederint \& concefferint, habend. nobis \& haredibus nofris in perpetuum: Nos de gratia noftra fpeciail dedimus, conceffimus, \& afignavinus dileclis nobis in Chrifto cuftodi \& collegio capella noftra de $W_{j}$ ndifor advocationes fuperarlictas; hatendas fibi \& fuccefforibus fuis, de nobis \& haecdibus nofris, per fervicia inle debita \& confueta in perpetuum. Concefimus infuper \& licentiam dedimus, rro nobis \& haredibus noftris, quantum in nobis eft, eifdem cuftodi \& collegio, quod ipfi ecclefias illas appropriarc, $\&$ eas fic appropiatas in proprios ufus tenere pofint fibi $\&$ fuccefijibus fuis in perpetuun, ftatuto de terris \& tenementis, ad manum nortuam non ponendis edito, non obfarte. In

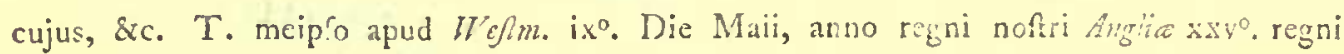
vero Francie $\mathrm{x}$ xiin.

Pat. 25 Edunrdi III. p. I. m. It.

Monaft. Angl. Vol. iii. de Collegcat. Ecclefis. p. po.

$\mathrm{H} 2$ 
by him, and the old houfe repaired, which was built by $\mathrm{Mr}$. Stcinsforth's predeceffor, Mr. Allgood; grandfather to Sir Lancelot; the following infeription ftill remaining over the entrance in memory of it, much injured by the weather.

Non tam fibi, quam fuccefforibus fuis,

Hoc redificium extruxit Major

Allscod, anno mirabili, 1666.

Nune mea, mox hujus, fed poftea nefcio cujus.

The church was repaired in 1763 ; the walls of the fide-ifles raifecl; three fafh-lights put in, on each fide; and another at each end, to the caft.

By the pulpit and window at the eaft end of the fouth ifle, is the effigies in flone of one of the antient family of the Ridley's, the Revd. Mr. Cuthbert Ridley, rector of this parifh, in a fupplicatory attitude, on his knees, venerable with years; a ruff about his neck, the drefs of that age. Near him are three of his family fculptured in flone likewife; one at the fouth corner of the window, in the fame attitude; his drefs a ftraight-bodied coat, a fword, and a cloke loofely caft over his thoulders; the head broken off; before him, the following infription under the bottom of the window.

SENSUS VIVUS.

RECORDOR MISERICORDIAM

DEI ERIPIENTIS EX HAC VITA

IN VITAM ETERNAM ALBANIUM

RIDLEY, FILIUM GUTHBERTI RIDLEY, MISERI PECCATORIS, ANNO DOM. I625. 
Above this ftone figure, is another of a child on the fouth ficle of the window, in the devout pofture of prayer, kneeling. The effigies of one of fomewhat riper age is in the bottom of the window, recumbent, with this mural infcription underncath.

\section{DEFECTUS MEMORIN.}

In making a grave in the pew under the next window, 1769 , for Mrs. Robley, relict of the late Revd. Mr. Robly, formerly curate of this place, a very remarkable fkull was turned up with the fpade; on the back part of it, the figure of a large fealiopfhell; at one of the auditories, the figure of a torcular fhell, like a fkrew.

Within iron-rails, on the north ficle of the chancel, is the burial-place of the family of Sir Lancelot Allgood, Knt. above it a mural monument of marble, with the following infeription.

$$
\text { NeAr }
$$

this place lieth the body of the Revd. Mr. Ma jor Allgood, M. A.

Rector of this parifh, cldeft fon of

LANCEIOT AlLGOOD, F.f.; Efcheator for this county of Northaiberiand, lineally defcended from Jolin Artuood, of Salberne, in the county of Devion, Ef,; who attended John Duke of Lancaster in his expedition to Spain, againft the pretended King of GAstiLe, Anno 1386 , the 9 th of Richard II. He died the 3 oth day of December, 1696 , aged, 59.

\section{Alfo}

the body of Mary, relict of the above MAjor ALLGOOD,

Daughter 


\section{Daughter of the Revd. Mr. Joh N PYE,}

Rector of Morpeth, in this county: The died the 28th day of $F e b .17$ 12, aged 60, and left

Iffue 3 fons, and 2 daughters; viz. IsAAC, Major, Lancelot, Mary, and Margaret. Alfo

the body of Is.AAC ALLGOOD, of BrandonWhite-Houfe, Efq; eldelt fon of MAjOR ALLGOOD and MARY his wife aforefaid, who died the gth day of July, 1725. aged 42 .

\section{Alfo}

the body of LANCELOT, 2 d fon of LANCELOT AlLGOOD, Efil; who died the 6th day of Sep. I747, aged two ycars and nine montlis.

On the fouth fide of the chancel, within the communion-rails, is a llat funcral-ftone to the memory of Giles Heron, of Wark, in this parifh, interred I684; who by induftry and extreme parci$1212 y$ acquired the fum of $800 \mathrm{l}$. which he left by will, dated a $3 \mathrm{~d}$ Setember, 1679 , for the relict of the poor of this parifh, the maintenance of a fchoolmafter at Wark, and the binding out the poor children apprentices; his truftees purchafing after his death the cftate of Tecket, adjoining to the rectory-glebe, now let for $72 l$. per $\operatorname{annum}(y)$.

In a grave in the church-yard, about three feet below the furface, a fmall, bright, filver coin of K. Edward II, was found in $175^{6}$; now in my poffeffion. On the obverfe is the profile of that king; on the reverfe, civitas Lincoln, the place of mintage;

(y) See the will in the appentix. 


\title{
A'NTIQUITIES OF NORTHUMBERLAND.
}

the arms of England and France not being on the reverfes of our common filver coins till the reign of K. Henry VII.

\begin{abstract}
About half a mile north-weft from the village of Simonburn, is
\end{abstract}

Simonburn-Cafle, which belonged to the IIcrons of Chipchace (z), and was fold with its manour and demefnes by Sir Chorles Heron, Bart. to Robert Allycod, Efị; now poffelled by his fon-in-liw, Sir Lancelot Allgood, Kt. It is fituated upon a thady eminence of tall fir and beach, with a fmall fream, carrying the name of Cafle-burn, gliding under it, between two hanging woods. It was pulled down to fatisfy a violcnt curiofity the country people had for fearching, like King Fobn at Corbridge (a), and Nero at Carthage, for hidden treafure; where they fucceded no better than thofe two royal money-hunters, who got nothing but rubbifh for their pains. Part of the weft end was rebuilt, i 766, with two fmall turrets at the angles. It is a pleafing object from Nunwick, and other places, in view at a conficierable diftance.

Three miles north from Simonburn, on the weftern banks of North Tyne, is

Wark, the manour of which was part of the poffeffions of the crown, ro Q. Elizabeth (b); granted to Sir Theophilus Howard, Earl of Suffolk, I K. Fames I; afterwards fold to Sir Francis Ratcliff, of Dilfon, Earl of Derwentwater, and by his fon's attainder reverting to
(z) See the records under Chipchace.
(a) Lel. Itin.vol. 7. p. 65. Canden.
(b) Efcaet. de anno 10 Q. Eliz. 


\subsection{ANTIQUITIES OF NORTHUMBERLAND.}

the crown again, was given to Greenwich-hofpital. An extenfive common belongs to it, carrying the marks of the plow, for the divifion of which an act of parliament paffed 1765 . By the river is a hill, called Mote-Hill, exploratory, for obferving the motions of an enemy; on which was a manfion-houfe belonging to the Ratcliffs; under it, on the north fide, is the fchool founded by Giles Heron; the mafter's falary, $12 . l$. per annum.

About four milcs north from Wark, on the eaftern banks of North Tyne, is

Bellingshan, two parts of the manour of which belonged to the archbihop of rork, $3 \mathrm{~K}$. Henry V (c), and the villa and lands to at family of the fame name; to Robert de Bellingham, $2 \mathrm{~K}$. Richard II (d), 3 K. Henry IV (e); to Richard de Bellingban, 33 K. Henry $\mathrm{VI}$ (f); their feat an antient caftle, hard by, now in ruins; their arms, are 3 hunters horns, fable, ftringed, gules.

It hath a weckly market on Saturdays, and two annual fairs.

It is a fmall, but pretty well built town, belonging chiefly to Chrigopher Reed, of Chipchace, and the heir of Eitruard Charleton, of Reedfinouth, Efqrs. the manour claimed by his Grace the Duke of Nortbunberland; the fituntion pleafint, on the flope of a hill; the church-yard forming a fine terace above the river; the church

(c) Do ninus Epifcop. Ebo; ac, obiit feiftus de et in duobus partibus manerii de Bcliingham, et Gyndin, infra Tyredale.-Efcact. de anno 3 Henrici V.

(d) Eicaet. de anno 2 Ricardi II. n. 49.

(c) 3 Henrici IV. n. 2 I.

(f) 33 Hinrici VI, n. 17 . 
fmall, but antient, dedicated to St. Cutbbert; the roof of the body of it arched with ftone, of rib-work, not a ftick of timber in it ; many graveftones in the pavement, fculptured with fwords; no infcriptions upon them. In the chancel, on the north fide, is a mural monument, of blue and white marble, erected by the late Joln Reed, of Cbipcbace, Ef(]; to the memory of his father.

A mile from Bellingham, on the weftern banks of North Tyne, is

Hezleyfuce, the feat of the antient family of the Charletons; of William Charleton, Efq; in the reigns of K. Edward VI, Q.Mary, and 10 Q. Elizabeth ( $\mathrm{g}$ ); of another William in the reign of $\mathrm{K}$. Charles I, who married Fane, daughter to William Swinburn, of Cap-Heaton, Efq; (b); of Edward Cbarleton, Efq; created a baronet, 2ift of the fame reign, 6th March, 1645 ; fon-in-law to Sir Edward Widdrington, of Cartington, Bart. (i); his eftate fequeftred by the parliament for his dutiful affection to his fovereign, November 8th, 1652; his title extinet at his death: of William Cbarleton, Efq; 1722 (k); father of Edward Charleton, Efq; the prefent poffeffor, who married Terefa, fifter to Sir Edward Swinbuin, of Cap-Heaton, Bart. The feat-houfe is modern, of white-freeftone, and hewn work, built after a plan refembling that of Lowther-kall, in Wefmorland, and

(g) Bißhop Nicholfon.

Willielmus Charlcton fuit feifitus de et in Reeds.mouth, Hezleyfde, Old-boufe-bills, Breridge, Oldtrom-hill, et le Grenes.

Efcaet. de anno 10 Eliz.

(b) Collins's Baron.

(i) See Cartington.

(k) Fuller.

VoL. II. 
like that alfo had the misfortune to fuffer greatly by fire. It ftands. on the top of a gentle declivity, under a hanging bank of wood; the town of Bellingham in fight; an avenue extending. from it through fhady enclofures to the river Tyne; a varied profpect to: the north; woods, rocks, and moors; the latter pleafant in fummer by a moving fcenery, the theep and cattle grazing on them.

About four miles north-eaft from Hezleyfide, on the eafterni banks of the river Reed, is

Rifinghom, i. c. the hamlet on a rifing ground; of note for being: the Roman ftation Habitancum, by their famous road, called Watling freet (l); on which, a mile to the fouthward of it, was ftanding fome ycars ago one of their milliary ftones, like that by their ftation at Little Chefters. Brafs coins and medals of Roman mintage, of the Antonines, are frequently turned out of the ground by that induftrious pioneer, the mole; one of the latter found, 1701; the emperor's name on the obverfe worn out, Aug. Pius very legible; on the reverfe, a wolf, without any infcription. Mention is made of it by Dr. Hunter, in the Philofophical Tranfactions, to whom it. was prefented $(\mathrm{m})$.

This ftation is not mentioned by Antonine in his Itinerary, yet it muft have been a Roman garrifon in the time of Aurelius Antoninus, as appears from infcriptions on altars found at it, mentioning his name (n). Some take this Aurelius to be the philofopher An-

(l) Camden.

Horfey.

(m) Ph. Tr. No. 278.

(n) Horf. No. Ixxxvii, No. xciv. d. 


\section{ANTIQUITIES OF NORTHUMBERLAND.}

tomine, and that it might have been deferted before the reign of $\mathrm{Cll}_{\text {- }}$ racalla, the reputed author of that Itinerary. It muft be antient, as fhewn by Camden ( 0 ), and others ( $p$ ), from an imperfect infcription difcovered and publifhed by them, mentioning a public edifice_-Vetuftate conlapsum,-gone to decay through age.

At Elifsaw, a fmall village on the fame fide of the river, are foundations of large buildings; the river croffed by Watling freet, by a bridge of arches; fome of the ftones ftill to be feen, with iron-cramps in them, and melted lead. Elifbaw belonged to the crown, 10 Q.Elizabeth (q); a chapel at it, now in ruins.

Near two miles eaft from Watlingfreet, is

Elfden ( $r$ ), a town of great antiquity; fuppofed to have been a Roman town in the time of M. Aurelins Antoninus; two Roman altars, with infcriptions found at it, in a hill, called The Mote-Hill; one of them infcribed to the tutelar deity, Matumus; mention made of both in the Britannia Romana, with engravings (s). This hill is trenched round, ten yards deep; a breaft-work to the north for its defence. Jaw-bones of beafts, a large ftag's head,

(o) Cand. Brit. p. 1078

(p) Horfley. No. Ixxxix.

(9) Domina Regina Elizabetha fuit feifita de et in Elyfhawe, in provinc. de Rildefdale. Efcaet. de anno ro Eliz.

(r) Hellefden.

Elróen.

Elfdon.

(s) Page 244. No. xcviii. No, xcix. 
and a fmall urn, with athes of burnt bones in it, were digged up by the late Mr. Warburton, and fome imperfect Roman altars obferved by him about the hill. It has been fepulchral and exploratory:

The Lordthip of Elfden was in the poffeffion of Luke Clenell, of Clenell, Efq; I 8 K. Edward I ; in which, and in his Lordhip of Clenell, he then luad a grant of Free Warren ( $t)$. In the reign: of K. Edward VI, it was in the porfeflion of Sir Ralph Grey, of Cbil-lingham, and of his fon, Thomas Grey, so Q. Elizabeth, then a mi-nor ( $u$ ); and lately of Charies Howard, Iff; of Overacres, whofe fon fold it, with the patronage of the rectory of Elfden, and his. paternal feat and eftate of Overacres, to the prefent poffeflor, the Duke of Northumberland.

(t) Rex archiepifcopis, \&ic. falutem. Sciatis me conceffife, et hac carta noftra confirmaffe, dilecto et fideli noftro Thome de Clenbil, quod ipfe et haredes fui in perpetuum habeant liberam Warrenam in ommibus dominicis terris fuis de Clenbil et Helleflen in com. Northumbr. Dum tamen terræ illæ non fint infra Metas foreftæ noftræ. Ita qund nullus intrat terras illas ad fugand. in eis, vel ad aliquid capiend. quod ad Warrenam perineat fine licentia et voluntate ipfius Thoma vel haredum fuorum fuper forisfacturam noftram decem librarum. Quarevolumus, et firmiter precipimus, pro nobis et haredibus noftris, qund pradictus Thomas, et fucceffores fui, in perpetuum habeant liberam Warrenam in omnibus dominicis terris fuis pradictis. Dum tamen illæe non fint infra Metas foreftre noftra. Ita quod nullus intret terras illas ad fugand. in eis, vel ad aliquid capiend. quod ad Warrenam. liertineat, fine licentia et voluntate ipfus Thomee, vel hæredûm fuorum, fuper forisfacturam noftram decen librarum, ficut prædictum eft. His teftibus venerabilibus patribus J. Archiepifcopo Ebor. Anglia Primat. R. Bathan. et Wellen. F.. Wynton, et Dunelm. Epifcopis. Willialmo de Valente, avunculo noftro. Elmundo Comite Cornub. confanguineo noftro. Gilberto de Clare, Com. Glouc. et Hertford. Henrico de Lacy, Comite Linc. Willielmo de Bello Campo, Comite Farr. Roberto de Tibtot. Reginaldo de Grey. Waltico de Bcllo Campo. Hugane de

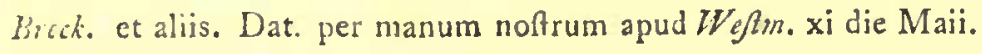

Ex Rotulo Cartarum anno 18 Edvardi I. n. 79.

(ii) Ste Chillingham. 


\section{ANTIQUITIES OF NORTHUMBERLAND. GI}

The church is fmall, on the weft fide of the village; an old tower at a fmall diftance, which is the rectory-houfe; the arms of the Himfranvils upon it; argent, a fefs, between fix cinquefoils, gules; an infcription underneath, not legible.

At Berrenes, is the ruin of an old chapel; a Britifs temple near it, on Berrene's-Knowl; the ftones numerous, of various fizes, in a circular order.

On a green hillock, on a moor, called The Todd-Law, north ot the river Reed, are three large ftones in a triangular order, twelve feet diftant from each other, and each as many fect in diameter; repulchral, in memory of the like number of valiant chieftains flain in battle.

Near a fmall village, called the Paunch-Ford, is a hill of indurated argillaceous earth, refembling Ranan mortar, ufed with. fuccefs in hufbandry.

On the weft fide of the river Reed, is

Trough-end, the feat of the antient family of the Reeds; of Foln Reed, Efq; in the reigns of K. Edward VI, Q. Mary, and Io Q. Elizabeth $(v)$; great improvements made at it by enclofures and planting by the late Mr. Reed, father of Mr. Elrington Reed, who fold it to his near relation, Cbrifopher Reed, Efq; of Cbipchace.

(v) Bihop Nicholfon's Border-Laws.

Fohannes Rede fuit feifitus de et in Trowend, Thedes, Felling, Whefton-houre, Steid-law-hill, Bromehope, Steil, Langley-clofe, vocat. Calf-clofe, Hind-haujh, Dunshoufe, Old-Town, et le Bogge, cum tersis in Grene-chefters, Farnyclugh, Soppet DunTheel, et Chefterbope.

Efcaet. de anno 10: Eliz. 
About a mile from Troughend, is

Otter-bun, fo called from its fituation by the brook Otter; remartiahie for the bloody battle fought at it between the Englifh and S'ots, 5th:Auguft, I 2 K. Ricbard II, I388, by moon-light; the forma: commanded by the Earl of Nortbumberland, and his two fons, It ry and Ralph Percy, young noblemen of diftinguilhed bravery and courage; the latter, by Earl Douglas, who being defirous of atchieving glory by encountering Henry Lord Percy fingly, reputed the braveft man in Englund (w), frnamed Hotpur, for his martia: prowels, was overmatched with ftrength, though. cqual in courage, and flain. Intimidated by the fall of their chiefrain, the Scots werc on the point of yielding the victory, but a large borly of forces arriving to their affiftance, under the leading of the Earl of Dunbar, the Englifo were in their turn forced to give way, and, at length, after a glorious ftruggle, to give up the laurels; 1800 of them being flain; among the prifoners were Lord Percy, and his brother, Sir Robert Heron, Sir Robert Ogle, Sir Fohn I.ilbum, Sir Fobn Colwell, and other knights of Nortbumberland; the Durbam-militia not arriving till after the battle, when they were frightened home again by a manouvre of the Scotch General, who on their approach caufed every man in his army to blow it horn as loud as he could, the found of which from fo many. mouths being multiplied in the echo from the hills, made them feem more numerous and formidable than they were $(x)$.

The encampments of the two armies are fill confpicuous, alfo tumuli or fepultures of the flain.

(w) Rapin.

(x) See Sir Fobn Froifart's account of this battle in Holing fhed, allowed to be the belt. 
The manour and villa of Otterburn were part of the eftate of the noble family of Humfranvil( $(y)$; and belonged to the crown, Io Q. Elizabeth (z).

Four miles from Otterburn, and eight miles from Rifing bam, is

Rochefer, the Roman ftation Bremenim (a), on the brow of a fleep rocky hill, as its name imports-qiunfi caftrum in rupe-near the head of the river Reed, by Watling ftreet, the courfe of the firft Iter of Antoninus; reputed the ftrongert garrifon of ariy the lio mans had in the north (b); the capital of the Ottocini, and itipendiary (c). The tribunes, Cepio Charitenus, and Lucius Celius Optatus, were both commanders in it; the latter having under hin a body of Spanifh auxiliaries, the firft cohort of the Vurduli, from Hispania citerior. An abundance of coins of M. Aurelius Antoninus have been digged up at it. Dr. Hunter of Durham (d), and Dr. Taylor, Chancellor of Lincoln (e), have both publithed an infeription upon an altar infcribed by this colsort to the Emperor Cara-

(y) See Prudhow.

(z) Domina Regina Elizabetha eft feifita de et in manerio et villa de Otterburn.

Efcaet. de anno yo Eliz.

(a) Bremenium. Camden.

Rocheiter. Camden. Burton. Dr. Hunter.

Riechefter. Gordon. Horfly. Stukeley.

Rutchefter. Dr. Taylor.

(b) Dr. Hunter. Ph. Tr. No. 278 .

(c) Richard of Cirencefler. Dr. Stukeley.

(d) Ph. Tr. No. 474.

(e) No. 482 . Vol. 44. p. 34t 
calla. It was found among fome rubbilh, fanding upon two fupporters. The name of the Prxfect is effaced in the laft line. It is now in the poffeflion of the Revd. Dr. Fobn Sharp, Archdeacon of Nortbumberland.

There is nothing more worthy of remark by the alpine ftreams of Reed and North Tyne.

From the floping cminence, where the road branches off to Nunwick, we are prefented with a fine view of

Swinburn-Cafle ( $f$ ) which in the reign of K. Edward I, was in the poffeffion of Peter de Gunnerton, who held it of the barony of Bywell, by the fervice of two knights fees, of the old feoffment (g). In the reign of K. Edward II, it.was the feat and manour of Adam de Swinburn, on whofe death it came to Sir Fobs de Woodrington, of Woodrington-Cafle, Knt. by marrying Chrifian, his daughter and coheir (b). It continued in that antient houfe for many generations (i).

(f) Swinburn-Caftle.

Great Swinburn.

Weft Swinburn,

(g) Pctrus Gunnerton tenet Gunnerton et Swinburne per duo feoda vet. feoffam. Baron. de Bywell.

Efcaet. de anno I Edvardi I.

(b) Adam de Swynburn obiit feifitus de et in manerio de Suynburn, de et in manerio de Itaughton, et Humfaugh.

See Cap-Heaton, in Collins's Baronetage.

Efcaet. de anno 20 Edvardi II.

(i) Fobannes Woodrington, miles, fuit feifitus de et in manerio ac villa de Swynburn magna, et Sroynburn parva, et Haughton, cum medietate villæ et manerii de Humfaugh, \&c.

Ercact. de anno ro Eliz. 
It is now the feat and lordhip of Thomas Ridell, Efq; defcended from Sir Furdan de Ridell, Knt. who had a mediety of the lordhip and villa of Tinmouth, in Norbamflire, 1 K. Edward I ( $k$ ): ancefor to Sir William de Ridell, Knt. high fheriff of Northmberland, $8 \mathrm{~K}$. Edward II ( $l$ ); fon to Walter, grandion to Patricius, and great grandfon to Dukentinus de Riddel, lords of the manour and villa of Whickbam, in the Bifhoprick of Durbam (m). Sir Trilliam was in the poffeffion of the whole manour and villa of Tilmouth, of the manour and villa of Troifet, of the hamlets of Dutbow, and Old Grindon, and two parts of the manour of Upfetlington; inlierited by his three grandaughters, by his cldef fon, Willian; his family-name being preferved in his younger fon, Hugh, from whom defcended a numerous and opulent race. Thomas, his great grandfon, marricl the daughter and heir of - Herbotell, Knt. Peter, great grandion to Thomas, married the filter of Sir Robert Brandling, Knt. and another Tbomas marricd the daughter of Sir, Fobn Coniers, Knt. Baron of Sockburn, in the Bifhoprick of Durbam (n).

Sir William Ridell, Knt. in the reign of Queen Elizabeth, was one of the grand leffees in truft for the corporation of Nervedfle upon Tyne, of the lordfhips of Gatefread and Whickbam, in the Bifhop-

\section{(k) See Tilmouth.}

(l) Rexomnibus ad quos, \&xc. falutem. Sciatis quod commiffmus dilecto ct fideli noftro Willielmo Ridell, militi, comitatum Northumbria, et caftrum noftrum novi cafri fuper Tinan, cum pertinen. cuftodiend. a fefto pafchæ proximo praterito, quamdiu nobis placuerit, ita quod fermas debitas nobis reddat annuatim ad fcaccarium nofrum, et debitis noftr. et omnibus aliis ad vicecomit. illius ad cuftodiam caftri prædicti fpectantibus nobis refpondeat, ficut alii vicecomites comitatus ejufdcm, et cuftodes illius lactenus tedderc, et inde refpondcre confueverunt, in cujus, \&c. Tefte rege apud. $l \mathrm{Veftm}$. 3 Die Maii, anno regri fui 8.

(m) Ms. penes Thom. Ridell, Arm.

(n) Ibid.

Vol. II. 
rick of Durbam, and the parks, waftes, and coal-mines belonging to them, fiid by Dr. Craddock, Archdeacon of Nortbumberland, to be then worth 56000 l. per annum (0). Sir William's feat was the abbey of St. Edmund, in Gatefhead.

Sir Thomas Ridell, Knt. feated at Fenbam, was a reprefentative in parliament for Nerecafle upon Tyne, $18 \mathrm{~K}$. Fames I, I620; alfo, 3 K. Charles I, I628, with Sir Peter Ridell, Knt. Sir Thomas, by his active zeal, and fteady loyalty to his difteffed fovereign, King Charles I, fo provoked the Oliverians, that they offered by proclamation $1000 \mathrm{l}$. for taking him. He narrowly cfcaped their vengeance by retiring beyond fea from Berwick upon Tweed. His great, great grandfon, Mr. Ridell, the prefent poffeffor of Swinburn-Caftle, married the daughter and fole heir of the late Horfley Widdrington, of Felton, Efq. His feat at Swinburn is of his own. erection, out of the ruins of the old caftle, after a very neat defign. It ftands on the fouthern banks of a rivulet, whofe ftreams aftcr heavy rains pafs in rude majely, loud and fonorous, between rocks and precipices, on whofe eaftern fummits the mountain-pink difplays its nodeft bloom in Fune and $\mathscr{F} u l y$, alike fearlers of the tumultuous torrent, and bluftering winds. It is theltered with a few tall foreft-trees to the eaft and weft, and before it is a fpacious field, floping and verdant, in the neighbourhood of a wood; the range of rocks at Shewing-fheels, and the Roman ftation of Houfe-feeds, the mountains of Crofs-Fell, and of Kilhope, the moors and cultivated plains of Hexbamfloire, fo fatal to the royal Rofe of Lancafter, are in full view on a clear day.

From the fame floping eminence on the military road we have a flight profpect of 
Haugbton-Caftle, on the weftern banks of Nortb Tyne, fhaded with trees; remarkable for its ftrength, a neat little bed-chamber being cut out of the walls, holding two or three chairs, a table, with a fire-place; one fafh-light in it. It has been a large, as well as a ftrong, building; moft of it now uncovered; the entrance by a flight of fteps; a ftable near. it without any timber in the roof, arched with ftone; alfo a domeftic chapel, now in ruins; belonging formerly to the Swinburns, and the Widdringtons (p); and now to Mr. William Suith, Gent.

We continue our journey down the hill to

Walwick, i. e. the village on the wall; which is here in-better prefervation than it is any where through its whole length in Northumberland, except at Wall-Town. The villa belongs chiefly to Thomas Dixon, Efq; whofe feat was lately repaired, with handfome additions; commanding a variety of agreeable profpects; the caftles of Haugloton and Swinburn, the town of Hexbam, the fine river of North Tyne, the bridge over it at Chollerford, the villages of Humphangh and Chollerton, being in view.

A little below Walwick, on the right hand, is

Walwick-Chefers, the Roman ftation Cilumum, garrifoned by the Cobors prima Vangionum ( $q^{\prime}$. The ruins are ftill vifible, covering a fpacious area, with a flope to the fouth, beautifully diverging to the trout-ftreams of North Tyne. The Romans chofe fuch pleafant fituations whenever they could have them, and the heights only from neceffity.

(B) See the Records undir Swinburn-C.Ale.

(q) Horfley. 


\section{Lucis habitamus opacis,}

Riparumqùe ţoros, et prata recentia rivis,

Incolimus :

Dehinc fumma Cacumina:

Virg. En. vi, ver. 673, \&c.

$\Lambda$ confular medallion of Hadrian, of the old mixed brafs, was.. found near this ftation by fome labourers in making the military road, now in my polfellion. It is four inches in circumference; his but in bold relief on the obverfe; the legend round it, Hadrimo Ang. Caefari; within a laureated border, or civic garland---

$$
\begin{aligned}
& \text { S. P. Q. R. } \\
& \text { OPTIMO PRINGIPI, } \\
& \text { S. C. }
\end{aligned}
$$

It was ftruck on the firft of January, a day facred to Fanus, obferved with great folemnity, as prefaging the felicity of the new ycar. The confuls entering on their high office on that day, their coins were then minted, with S. C. in area, i. e. ob Cives fervatos.

The Romans crofled the Tyne at this fation by a bridge of arches; fome of the flones of which may be feen when the river is low.

A little farther down the river, and in fight, is

Wralwick-Grange, the feat of Antbony Errington, Efq; 6 Edward VI. (r); a younger branch of the antient family of the Erringtons, of Errington; anceftor of the late William Errington, Efq; high

(r) Bimop Nicholfon's Border Laws, p. 335. 
fheriff of Nortbumberland, 1739; father of the prefent poffeffor, Jobn Errington, Efq. His feat is a modern ftructure, built on to an old tower, in a low fituation, on the brink of Nortb Tyne, ujon a rock.

The large funeral-ftone, in memory of a Roman lady, with her effigies; the altar, with a female cleity, fuppored to be Cybele, and the figure of a lion gently raifing up the head of a man, profrate, at full length; the effigies of a foldier on horfeback; defcribed and engraved by Mr. Horfley, in his Romana (s', are fill at the Grange, in the face of a wall, on the right hand, in going to it; brought from Walwick-Chefer's.

In a field fouth-wet of the Grange, by the road to Netber-warden, is part of a flone-crofs, or upright pillar, in a fquare pedeftal; upon one fide of it, the figure of a fword, in relicf, theathed.

About a mile fouth-eaft from the Gronge, by the 21 mile-ftone, we crofs the Tyne, by a ftone-bridge of four arches, called, Chollerford-bridge. A releafe from pennance for thirteen days was granted by Walter Skirlaw, Bifhop of Durbam, to all fuch as fhould contribute by labour or money to the repair of it, $17 \mathrm{~K}$. Ricbard II ; as attefted by the following inftrument, to which is an old feal appendant, of white wax.

"To all Clırifian people, to whom thefe prefents thall come, "Walter, Bifhop of Durbam, health in our Lord everlatting. "Whereas the bridge of Chollerford, as we hear, is decayed by the .

(s) Page, 215, \&rc, No. xxii. No, xxiii, No, xxiv. 
" inundation of the waters, by which there ufed to be a fre" quent paffage, and now wants repair, whereby the inhabitants ". in the neighbourhood are in great danger. We therefore conss fiding in the mercy of Almighty God, and the fufferings of his "Holy Mother, and all the Saints, do releafe unto all our parifh" ioners, and thofe in other diocefes where this indulgence thall "be received, I 3 days of their enjoined pennance, upon condi"tion they lend a helping hand to the repairing of the faid "bridge, or contribute their pious charity thereto. Thefe pre"fents after three years nothing availing. Given at Chefter the " 8th Kalends of Augul, of our pontificate the 7 th year."

\section{A milc and a half above the bridge, is}

Chollirian, i.c. the town by Cbollerford; a pleafant villa on the caftern banks of the river, belonging to Sir Edward Swinburn, of Cap-Heaton, Bart.

The parith is large; the chancel of the church lately rebuilt; the roof fealed; a handfome new tower at the weft-end. The vicarage-houfe is a neat ftructure, buit, with all other conveniences, by the prefent incumbent, the Rev. Mr. Stoddart, fatherin-law of Fobn Errington, of Wallwick-Grange, Efq.

From the bridge we afcend the hill, crofs the Hexbam-road, by Brunton, to the turnpike-gate; oppofite to which, on the right hand, is a flight of terraces, on a bank, called,

Hanging-Show, of the fame ufe as the Mote-Hills, exploratory, for the militia to retreat to on any fudden alarm, to obferve the motions of, and fhew themfelves to, an enemy, rank above rank. 
We continue our courfe up the hill by St. Ofwald's chapel to the rgth mile-ftone, a little beyond which we are prefented with a fine view of

Hexbam, fituated chiefly on an eminence, by the little brook Hextold, and near the united ftreams of South and Nortb Tyne, giving its name to a large tract of country, called, Hexham/inire. It is a town of great antiquity. The moft learned antiquaries believe it to be Roman, and all, except Mr. Horfley, give it the name of Axelodunum, or Uxelodunum, importing the fame thing as the Celtic or anticnt Britifis word Uchelodunm, i. e. a high fituation. Mr. Horfley will have it to be the Roman Epiacum or Ebcheftir of Camden ( $t$ ), and that Brough on the Solway-fands in Camberland, was their Axelodunum, and the ftation of their Cobors prima Iripanorum (u).

In the year 1726, Roger Gale, Efq; and Dr. Stukeley, antiquaries of great name, were in this country in fearch of antiquities, and at Hexbam. In a vault at Hexbam-church, the burial-place of the late Rev. Mr. Andrewes, A. M. they difcovered two inferiptions, both Roman, and both, in their opinion, curious. Mr. Gale, in his letter to Baron Clerk, inferted in Mr. Gordon's Appendix, obferves, that the firft is of very ill work, but what makes it curious is, it contains a new name of a Legatus Augufti, viz. 2. Calpurnius Concelfnius, and that of a body of horfe at Cor-cbefter, called Equites Cafarienfes, or Cafariani Coronotate, not mentioned cither in the Notitia Imperii, or any where elfe. The other is of Lucius Septimins Severus, of the beft fculpture, the letters large, but very imperfect. The curiofity of it confifts in its having fo diftinctly the name of that emperor, and its being the only genuine one found

(t) Camden's Britannia, p. 955 .

(u) Hors. Britannia Romana, f. rog. 
fo near the wall with his name upon it. They are both publifled by Mr. Gordon, with his own, and Baron Clerk's, and Mr. Gale's. Obfervations upon them ( $v)$. To his, Mr. Gale hath farther added this, That the whole vault, and the long winding fubterraneous paffages to it, are all built out of the Roman ruins; carved fones and fragments of other inferiptions appearing every where in the walls; and he fuppofes them to have been brought from the neighbouring Roman flation at Cor-chefter, on the firft foundation of the church.

Hexhom in the Saxon times was called Hextoldefram, and Haguftald. In the reign of Fgfird, King of Nortbumberland, 674, it was crected into an epifcopal fee by St. Wilfrid (w), Arbihop of York, and afterwards confirmed by Theodore Archbithop of Conterbury $(x)$. As Theodore was the firt who affumed a jurifdiction over the northern bifhops and churches, it will not be amifs to enter a little into his hiftory, before we proceed to give an account of the bifhops of this fee.

He was born at the city of Tarfus in Cilicia (y), a famous univerfity in the days of St. Paul, wherein that apoftle had his education (z). Here he alfo had his learning, and took on him the monaltic habit. Being at Rome on the death of Deufdedit, Archbihop of Canterbury, he was chofen by the Pope to fucceed him

(v) It. Sept. Append.

Hors. p. 108, 109.

(w) Browne Willis's Survey of the Cathedral, Vol. i. p. 224.

(x) Id. p. 3 .

(y) Hol, Chron, Vol. i, p. 120.

(z) Bimop Bull's Difcourfes. 
at the age of 76 . This was done on the recommendation of his learned friend Adrian, who out of modefty and humility declined accepting it himfelf. Adrian came over with him. Another of his learned attendants was Benedict Bifcop. Thefe three, on their arrival in England, found learning and the arts at a very low ebb. They united their endeavours to make them flourih. Schools were founded under their patronage for the education of youth in Latin and Greek. Mufic and painting met with particular encouragement. Artifts of all kinds were fent for from Rome. Benedict made five journeys to that city, and founded two monafteries himfelf, Girwey and Wecrmouth, both in the Bifhoprick of Durbam. But the Archbihop's principal labour and fudy was to extend the fplendour of the Sce of Canterbary, by fubjecting the northern churches to its jurifdiction. In this he met with much oppofition, efpecially from St. Wilfril. The eafier to effect his purpofe, he divided the kinglom of Northumberland, by leave from King $E_{S}$ frid, into more diocefes. It now copfifted of Tork, Lindisfarn, and Hexbam.

The firt Bifhop of Hexbam, after the founder, was

Eata, An. 678. He was fucceeded by

Tumbert, 680. Tumbert not liking that the See of Canterbury thould have any jurifdiction ovcr his, and the other diocefes, openly cenfured Archbihhop Theodore's ambition. Theodore, to punifh him for being fo bold, took a journey on purpofe into Northumberland. He called a council of bithops at Twiford, near the river Aln, 684, at which was prefent King $E_{g}$ frid himfelf. Tumbert was cited to appear before them, and depofed. They proceeded to a new election. The perfon agreed on was Cutbbert, a monk of Lindisfarin, better known afterwards by the name of St. Cutbbert. It was not without a fort of violcnce that Cuthbert could VoL. II. 


\section{4 \\ ANTIQUITIES OF NORTHUMBERLAND.}

be prevailed on to be a bifhop. At length, through the forcible: perfuafions of the king, and the importunity of the bifhops, he. complicd to be bifhop of Lindisfarn, and

Eata, who had it, was tranflated to Hexham, which he had before held with Lindisfarn. He was fucceeded by

Fobn of Beverley, 685, a Saxon of quality, born at Harpbam*; in Yorkflive; firtt a fcholar of St. Hilda's, abbefs of Wbitby, and. afterwards of Archbihhop Theodore's, and a ftudent at Oxford, where he compleated his education. The humility, piety, and. lcarning, for which he was remarkable, made him much careffed. The See of York being vacant, by the death of Archbifhop $B$ of $a$, he was tranflated thither, $687(a)$. He there lived in high reputation and love for upwards of 33 years. Finding age come upon him, and epifcopal cares weighty, he refigned 718 . He retired to the monaftery of Beverley, of which he was abbot. There he fpent the remainder of his days in devotion, and in educating his foul for the glories of another life. When he was at Hexham, all the leifure he could get, he ufed to fpend this way. It was his cuftom to retirc, on every opportunity that offered, particularly in Lent, to his country vill, or epifcopal feat, where he had a little chapel or oratory, dedicated to St. Michael. This place is on the north banks of the Tyne, a mile and a half north-weft from Hexbam. Both Bede and Prior Richard fpeak of it. Bede fays, it ftood among a few fhady trees, enclofed with a rampier (b). The Prior calls it Mons Aquile, Mount-Eagle,

* Browne Willis makes him to be a native of Bcverly.

- Survey of the Cathedr. Vol, i. p. $3^{1 .}$

Bed. Eccles, Hift, L. 5. C. 2. 
and Erneflow (c). It is fuppofed to be the prefent village of Nether Warden. The dedication of the church, the diftance from Hexham, and the fituation, under a hill, on a peninfula, by the union of the two rivers of North and South Tyme, all correfpond to fix it there.

In this fweet recefs, Bifhop Foln and his chaplains fpent thcir leifure whilft at Hexbam, never weary of fpending it well, in aes. of devotion, of charity, and in reading. Excmplary men! wor. thy of imitation! The bifhop died in $72 \mathrm{I}$, and was buricd in his own monaftery. For his piety and good works he was canonized after his death, and became celebrated by the name of St. Fobn of Beverly. He was fucceeded in the fee of York by his chaplain, Wilfrid the younger, and in this of Hexbam by

St. Wilfrid, or Wilfrid the elder. In the difputes above mentioned with archbifhop Theodore, he was overmatched, and on the lors of the fee of York, given to Bofa, in his abfence at Rome, he was glad on his return to be re-inftated in this his favourite one, of his own foundation. In the height of his archiepifcopal grandeur he obtained a grant from King $E_{g}$ frid, by the favour of his Queen, Etbeldreda, of the town of Hexbam, and the large tract of country, called Hexhamflire, with the regalities, giving other lands in exchange for them. He annexed them to this bifhoprick. The fine church in Hexham, dedicated to St. Andrew, fo much extolled by Prior Richard, Heddins, Hovedon, Malmfoury, and others (d), was of his crection. The workmen were brought from Rome. The model, finifhing, and decoration, were then above any in Ens-

(c) Tractatus de ftatu \& ęiifopis Harufald, inter decem feriptores Hift. Angl. p. $29 \mathrm{r}$.

(d) Lilard's Cullcetanea, vol. ii. p. 259. vo!. iii. p. 103. 
lund, or on this fide the Alps. He alfo built three other churches, of two of which there are now no remains. One was dedicated to St. Mary. It ftood in the place now called St. Mary's Chare; part of the foundations of which have been difcovered in digging, and raifing buildings upon it. The other was dedicated to St. Peter. It is uncertain where it ftood. The third was his predeceflor's favourite church of St. Michael at Nether Warden. This. has been in the cathedral-form, or in the form of a crofs, and longreduced almont to a mere ruin, to the great regret of that parih, who in 1760 , obtained a brief for its being rebuilt. Themonaltery of Hexbalm, which is incautiounly affigned by Creffy (e.) to St. Ofavall, was of his foundation (f). He died Oet. I2, 709, and was buried in the monatery of Rippon, of which he was likewife aubot; and was removed to Canterbury by Archbinhop Odo, 940. His fucceffor in his fee and abbey here vas,

Acca, his chaplain, companion and friend. Acca's education was under Bifhop Bofa, till his admiffion into his friendhip and favour. He attended him in his worft fortunes, and was with him at Rome. There he learned to chaunt and fing well in the Roman choir, and at his return was one of the beft voices, the moft mufical and graceful, in the church of Hagufald. He was fo charmed with church-mufic, that after his election to this fee, he engaged one Maban, an Italian, who taught the quire of Canterbury with great applaufe, to teach his, and detained him twelve years. He improved himfelf all that while, and with delight took the lead in the facred chorus. He was a moft heavenly man, Vir magnificus, a great foul, fays Bede $(g)$. He gilded the

(e) Creffy's Ch. Hift.

(f) Spelm. Conc, vol, i. p. 203.

(g) Bel. Eccler. Hift. 1. v. c. 20. 
walls of his cathedral with filver and gold, and, to add to its fplendour, prefented it with rich coverings for the altars, with communion-plate, and candlefticks to illuminate the whole glorious dome; and, laftly, with a library, collected at no fmall pains and expence, confinting chicfly of facred biography, and church-hiftory. Bede loved him mof dearly, dedicated many of his compofitions to him, and gave him all the marks of refpect and efteem in his power. How deferving focver he was of it, and how much foever he was liked and carefled by all good men, and was as a guardian angel among them, to train them to glory, and fit them for hearen, there were thofe, as there cver will be, who could not bear the thoughts of either, who could not cndure the light of his precepts and example, and turned him ont of his bihoprick, after he had held it, with fo much honour and dignity for 24 years. This was done in the year 732 , or 733 . He died Nov. 20,740, and was interred in the confiftory of his own: cathedral, but was afterwards removed to Durbam ( $b$ ).

The Binops that fucceeded $A c c a$, were .

Fredbert, Bp. 34 years.

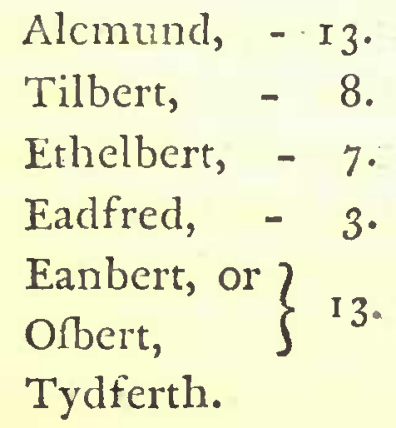

Of thefe nothing remarkable is recorded. How long Tydferth was bihop is not known (i). The incurfions and outrages of

(b) Bed. Ecclef. Hift. 1. v. c. 20.

(i) Pr. Ric. inter $X$ fcriptor. 
the Danes made him refign his fee, and for the fame reafons others declined accepting it. He died on a journey to Rome, about the year $82 \mathrm{I}$, as is fuppofed. His bifhoprick, after a long vacancy, was united to the diocefe of Lindisfarn at Chefer-le-freet, $88_{3}$, by Bifhop Eardulph. It continued in the poffeffion of the Bithops of Durbam till the reign of K. Henry I. That King being offended with Bifhop Flamberd, gave it to the fee of York. Thomas, Archbihop of York, the fecond of that name, coming to Hexham to vifit the monaftery, was fo much moved with the fight of it, and the cathedral, its folemnity and grandeur, which prefented to his mind the great prelates that adorned it by their piety, extenfive charity and learning, that he refolved to become its friend and patron. He placed in the monaftery a prior and regular canons of St. Aufin, I113, and generoully endowed it. Befiles other donations, very handfome and liberal, he gave it the cathedral and all its privileges, all the tithes within his manour, and the parifh, of Hexham, both great and fmall $(k)$. The parifh was then a rectory, appropriated to the parifh of Holm in the church of York, and in the poffeffion of Ricbard de Maton, a canon of Beierley (l). His vicarius, or vicar, was named Eillan, junr. He had a houfe and a caracut $*$ of land in Hexham, and fix bovats $\dagger$ of land in Ainwick. The rector, Maton, for fome confideration out of the common revenue of the chapter of York, refigned all his rights to the priory; but the vicar, Eillan, did not give up his till after the death of the firt prior Afcbtill, March ${ }_{1} 7 \mathrm{th}$, II $30(\mathrm{~m})$.
(k) Id. 1. 2. c. 8. Dugd. Monaft. Angl.
(l) Pr. Ric.

* A Fizile, or Plough-Land, which was not of any certain extent, but as much as one plough could in the courfe of hubandry plough in one year. It was of the annual value of five nobles, or 1 l. $13^{\text {s. }} 4$ d. Lord Coke. I Inft. fo. 69, \&ic.
† Six Oxgangs.
(m) Pr. Ris. 
There is a houfe in Hexham, belonging to the lecturer, which ftill, bears the name of the vicarage; and a ftreet, called Eillans-gate, from the vicar Eillan.

Archbihop Thurfian had a like regard and veneration for Héxbam-priory, as his predeceffor. For the better fupport of the prior, he gave it the prebend of Salton in his cathedral of York, which was the impropriation and advowfon of Salton-vicarage, antiently rated at 80 marks, or 53 l. $13 s .4 \%$. His munificence' did not ftop here, as will appear from the following account of its revenues, and by whom given, confirmed by an incluifition taken at Newcafte upon Tyne, 25 K. Edward I, July 7, 1297; William de Halton, then high theriff of Nortbumberland.

"The prior and canons held, befides the church and priony of "Hexbam, with the appurtenances thereunto belonging, the m?"nour and village of Ainwick, and the villages of Sandtsoe and " Yarnzigg, with a mill upon the Tyne and the mill-race, and all "the fect which belongs unto, or ought to belong unto, the faid "mill; and the tithe of all things (whether belonging to the " archbifhop or other perfons) within the liberty of Hextildefarm; "as alfo Soke (n) and Soken (0), and other privileges, as the "power of regulating the aflizes of bread and bee", and that their "fervants thould bear a virge on their making diftreffes, fum"mons's, and attachments, and on correcting offences of the "tenants in the prior's court: Given by Thonas, Archbinhop of "York, the fecond of that name, and confirmed by the chapter of " that fee, to hold as a free, pure, and perpetual alms.

"They alfo held certain lands in the town of Hexham, viz. the " whole intire ftreet of Cockfore ; twenty-four meffuages in the
(n) Vid. Bract. lib: 3r
(o) Id.

"ftreet, 
"Atrect, called Prief-pople; fourteen meffuages in the ftrect, " called the Market-place; and fixteen meffuages in the flreet, called "Hencotes: alfo the villages of Dotland, Knitillbefell, and the two "Grotingtons, with the tithe of all animals within the liberty of " Hexban; - the gift of Thurftan Archbihop of York.

"They held alfo half the village of Bingfield, without doing "any fecular fervice, of the gift of one Germund; and a rent of "fix marks in the fame village; - the gift of Robert de Skipton."

"They held alfo twenty-four acres of land, and two water"mills, in the villages of Hambum and Newbiggin, with the fect " of all new lands brought, or to be brought, into tillage, by the "fervice of twelve merks per annum; as alfo one rod of land in "the village of Acome, one rod in the village of Wall, one rod " in the village of Halyton, one rod in the village of Kepreick, one "rod in the village of Catteden (or Catton), one rod in the village " of Ninebanks, and one rod in the village of Rouley for the build"-ing a grange or tithe-barn;- the gift of Walter Gre", and Walter "Gifford, Archbihhop of York, by the fervice only of two fhillings "per annum, for each.

"They held alfo the whole manour and church of Warden, "with the chapels of Stonecroft, Hayden, and Langley; likewife all "the lands of Byres, through the right divifions, and common " of pafture without the divifions of the faid lands, and one mef"fuage, feven acres of land, and common of pafture for two " hundred and fixty theep in Hayden aforefaid; - the gift of "Adam de Tynedale, confirmed by the Bihop of Durbam. 
"They held alfo forty acres of land, and fix acres of meadow, "and two meffuages, in Scttling-fones; - the gift of Adom de "Settling-Aones. And in Whinetley two mefluiges, and forty acres " of land, with their appurtenances, and a rent of ten fhillings; "-the gift of Adam de THornyrafto".

"They held alfo the mill of Aller-rafl, with its appurtenances; " - the gift of Uetre? de Aller-rooßs; and one plow-gate of land " in a certain place of the faid village, called Outmers; - the "gift of Richard Bailiff, of Hcxban.

"They held alfo the church of Chollerton, with its chapels, viz. "Birtley, Cbipibace, Gunnerton, and Sweinbum; alfo Little Heton, and "Colveell, with their appurtenances, and cight ox-gangs of land " in the village of Chollerton, of the endowment of the faid church, " together with five acres of land, which are called Le Michels " eroft, lying on the north ficle of the faid church; - the gift of "Odinell de Humfranvil.

"They held alfo the hamlet of Bumont, through their right "divifions; - the gift of Gilisert de Humfranvil. And one toft, " and feven acres of land, in Birtley, alfo the lands and pature "of Coleden, through their right divifions; - the gift of Richard " de Lumfranvil.

"They held alfo common of pafture in the moor of Gunncrton "for a hundred cattle going out of Coleden, as wcll when the "hedges were up, as when all was open; and two tofts, and "two ox-gangs of land, in the village of Chefer-lope; - the gift "of Ralph de Gumerton.

VOL. II. 
"They held alfo two tofts and thirty acres of land in the vil"lage of Barrwesford; _- the gift of Margery de Humfranvil. One "plow-land in Neruton, in Coquet-dale; - the gift of Walter de Infula.

" They held allo common of palture for thirty-two oxen, and "for two hundred and forty theep in Colwell; - the gift of $W$ alter "Corbet.

"Alfo the manour of Little Heton, and of Cald-frother, with their. "appurtenances; - the gift of Alice de Bolam, Fames de Caus, and " Alice his wife.

" They held alfo fix acres of land in Little Bavington;-the gift " of Stephen Bataille. And in the fame village, two tofts and three " acres and a half, with their appurtenances, and common of " pafturc for fifteen cattle, fixty theep, and two horfes;-the gift " of Gilbirt de Wircefre.

"They held alfo three tofts, with a tithe-barn, and two ox"gangs, and twelve acres of land; in the village of Gunnerton, " and Tburkilby, de Caderon.

"They held alfo the church of Slealey, and one plow-land of " the endowment of the faid church, and a common of pafture " in the fame village for two hundred and fixty theep, and a " common of pafture in Le Stele for" the fame number of theep ;" the gift of Gilbert de Slealey.

"They held alfo one meffuage, and one acre of land in the "village of Chipcbace;--the gift of Robert de Infula. 
"They had alfo a rent of forty thillings and four-pence arifing " out of eight meffuages in the town of Nervaftle upon Tyne, and "a rent of three and forty thillings and two-pence iffuing out of "fifteen meffuages in the village of Corbridge;---the gift of diffe"rent perfons.

"They held alfo an acre of land in the ficld of Weft Swinburn;-" the gift of Fobn de Wirceftre.

"They held alfo the whole manour of Nomb Mitnbur", with a " common of pafture on the monr of Crekelagly;---the gift of Sir "Thomas de Divilfon.

"They held alfo all the land of Shilden, by the fervice of three " and twenty thillings per anmun;---by the ceffion of the Abbot of "Nereminfter.

"They held alfo the whole demefne and village of Whitfeld, " and a rent of fixteen thillings and four-pence;--the gift of wil. "liam King of Scots. Alfo a certain moor, called Carraw-mos, ;-" the gift of the fame King of Scots.

" They held alfo a certain hamlet, called Carraw, with its ap"purtenances, and one plow-land in Ri-fleels through its right "divifions, together with a common of pafture in Hethenfhalsh, " and one toft and thirty acres of land in Stone-sroft; ;---the gift of "Richard Cummin.

"They held alfo fix tofts and one plow-land in Thirwall, and a "common of pafture for four and twenty cattle, four and "twenty bcalts with their young, four and twenty fwine, and 
" twenty goats;--the gift of Bricius de Tbirlwall, and Roger, his " fon.

"They held alfo a certain pafture, called Prief-dale, through. " its right divifions; alfo eight mefruages, and one plow-land, " in Aldfone; alfo a rent of thirteen fhillings and four-pence in the " mill of Elrington;---the gift of Irode Veteri Ponte.

" They held alfo a rent of eight thillings in Tecket;-- the gift "s of Laurence de Tickat.

"They held alfo a rent of eight thillings in Ald-foeels;---the "gift of Hcury de Graban.

"They held alfo half of the manour of Ecbwick;--- the gift " of Robert, fon of Hubert, de Delivale, and Ricbolda, his mother.

"And in the fame village they held ten icres of land;--- the "gift of Thomas de Ecbreick. Alfo feven acres of land in the fime "village;--- the gift of Pcter de Farvdon.

"They held alfo a rent of thirteen fhillings and eight-pence in "the village of Stockfield; paying out of the fame for the ward of " the caltle feven fhillings per annum;--- the gift of William, fon of "Bofo.

"They held alfo in the fame village a rent of three fhillings; "-.-the gift of Jobn, fon of Elias.

"They held alfo five tofts, and ten acres of land, and three " acres of meadow, in Thornton;--- the gift of William de Infula, " and confirmed by Walter de Bolbeck. 
"They held alfo one manour, and three acres of land, in Ben. "well;--- the gift of Hugh de Delaval. Alfo two acres of land, "and a rent of fixteen thillings, in the village of Throckley, the " gift of Robert de Sneftones, and Cbriftion de Throckley.

"They held likewife in Eajt Matfen one manour, fix mefluages, "and three plow-lands; --- the gift of Thomas de Fenwick, and con" firmed by Robert de Infula. .

"They held alfo in the viliage of Stanington one toft, and two "ox-gangs of land, and a rent of eighteen pence;--- the gift of "Roger de Merlaj.

"They held alfo a rent of one mark per amun arifing out of the " mill at Brinkley;--- the gift of Hinry de Ferlington.

"They had alfo in the village of Whalton one toft and croft, "and two and forty acres of land and a half, and a common of "pafture for forty yews and their lambs; and in the village of "Riplington a rent of eight fhillings;--- the gift of Walter, fon of "William, and Ifabell, his wife.

"They had alfo two fifheries in the river $T$ yne, and a place to " dry their nets on; one of the fifheries called Dripentell, and the "other Fonl; ;-- the gift of Roger Bertram.

"They had alfo in the village of Stamfordham one toft, and two " plow-gates; - the gift of Fobn de Normanvil.

"They held alfo the manour of Chefeburgh (or Cheeflum) and "Nefeet, with all their demefnes, fervices, bondages, and other " appurtenanees;--- the gift of the fame Fobn de Normanvil. 
"They held alfo a certain portion in the church of Stamfordham, "viz. The tithes of the theaves of corn in the villages of Matfen, "Eaft Nefbet, LTlkefon, Harukwell, and Bitchfield;---by the ceffion " of Richard Bihop of Durbam, and confirmed by the Chapter of " the fame.

"They had likewife the manour of Stelling, with its appurte"nances; and in the village of Newbiggin by the fea one toft, " and two acres of land; alfo a rent of forty fhillings in the vil"lage of Seaton;--- the gift of Bernard de Baliol.

"They held alfo the third part of the village of Dalton;--. " the gift of $R a^{\text {p }}$ b de Gunnerton. And in the fame village four ox"gangs of land, and a rent of five fhillings and fixpence iffuing " out of the mill of the faid village;---the gift of William de "Dalton.

"They had alfo in the village of Pradbow one toft, and eight " acres of land ;--- the gift of Richard de Hunfianvil.

"They had alfo the homage of Fobn de Swinburn, and his heirs, "and a rent of one thilling per amum for his capital mefluage of "Swinburn;--- the gift of High de Baliol.

"They had alfo the homage of Nicbolns of $W e f$-Swinburn, and "the fervice of three thillings per a.mum for the chantery of the " chapel of Wef Swinburn;--- by the ceffion of Fobn de Wirceftre.

"They had alfo the homage of Fobn de Canzhore, for the land and tenements which he held in Little Heton, and Cald-ftrother; ---the gift of Alice de Bolbam, Fames de Caur, and Alice, his wife. 
"They had alfo the homage of Ricbard de Thirlwall, and a rent " of three thillings per anum for the lands he held of them in "Thirwall; ;-- the gift of Bricius de Tbirlwall, and Roger, his fon.

"They had alfo the homage of Adan de Whitley, and the fervice " of four fhillings of annual rent of the fame;--- the gift of Adan " de Tynedale.

"They had alfo the homage of Thomas, the fon of Richari, the "fon of Bricius, de Thirlwall, for the land which he held of them "in Thirwall;--- the gift of the fame Adam de Tynedale.

"They had alfo the homage of Fobn de Nomanvil, for the lands " of Stockfield and Apperley, by the fervice of thirteen fhillings and " eight-pence per annum; ;-- the gift of William, the fon of Bofo.

"They had alfo the homage of Robert de Ribill, and the fervice "of ten fhillings annual rent, and three writs annually at the "prior"s court againft fuch as refufe to do fuit and fervice ;--- the " gift of Theopbania de la Bataile.

"They had alfo the homage of Matthere de Whitfeld, for the land " and tenements in Wbitfell, which he hold of them;--- the gift " of William, King of Scots.

"They had alfo the homage of Robert de Throckley for the lands " and tenements he held of them;--- the gift of nobert de Snefones, " and Cbrifian de Throckley.

"They held alfo a tithe-barn, and a garden, in the village of "Eaft Swinburn;--- the gift of Hugh de Baliol ( $p) . "$

(p) Inquifit. facta apud Nov. Cafrum fup. Tyn. $25 E d$. I. Cart. 2\%. Ed. I. n. 35. poft. incend. priorat. per Scctos. Confirmat. Cart. $35 E$ \&. I. n. 2

Monaft. Angl. vol. ii. p. 92, \&c. 
All which denations were confirmed by royal charters, 27,35 K. Edward I, on the lofs of their title-deeds by their priory being burnt by the Scots; which occafioned the above inquifition to be taken.

Edruard, Duke of York, granted then a lcafe of Le Peyle de Stawortb, or Staward Peil, on the caflern banks of the river Allen, of which I have before taken notice. In the rental, or priory-regifter, called, The black book of Hexbam by the vulgar, is an ample account of all their revenues. It has been fo carefully gleaned by thofe two celebrated antiquarics Mr. Dodfrworth and Sir William Dugdale, for the ufe of that elaborate and excellent work, the Monaficon Anglicanum, that nothing is left worthy of the public attention, either for curiofity or ufe, for others to tranfcribe.

They had the impropriation of the church of Aldfon (q), and of the church of Renwick, declicated to St. BenediEt $(r)$; and the impropriation of the church of IJell, dedicated to St. Bridget (s); in the county of Cuiberland.

They had alfo the impropriation of the church of Ilkley, dedicated to All Saints $(t)$; and the impropriation of the church of Edfon (u); in the county of rork.

Their conventual church of St. Andrew had the privilcze of fanctuary for a mile round it, till $25 \mathrm{~K}$. Henry VIII, I 534, when

(a) Browne Willis's Cathedr. Vol. i. p. 315.

(r) Id. 281 .

(s) Plac, in Com. Cumberlani', 20 El.1. quo War. Rot. 66. de terris in Ifell. Rot. 75. de advocatione ecclef. de Aldfon et Ifell.

Erowne Willis's Cathedr. Vol. i. p. 3'3.

(t) Id. p. 188 .

(ii) p. 22. 
it was cnacted, that grofs offenders againft the laws taking fanctuary at the altar, or any confecrated place, fhould be out of the protection of churches.

Their revenues at the diffolution were valued at I 22 l. I I s. I d. per annum, Dugd. 1381. Is. 9d. Speed. There were then in the abbey fourteen religious; the Prior's name, Edward Fay (v). The fitc of it, with fome lands, was granted to Sir Reginald Carnaby (rv).

They had an hofpital for leprous perfons, of the foundation and patronage of the archbihops of $r_{a r k}$, as antient at leaft as the reign of King Folm, dedicated to St. Gilcs, in theftrect, called, from him, Gilligate. It had revenues valued at four marks per annum. It was granted at the fame time with the priory to Sir Reginald Carnaby $(x)$.

They had alfo an hofpital for the fick, called, The Spital, about a mile weft from the town on a pleafant hady eminence by the Tyne, which glides patt it in a flow and filent ftream.

The archbithops of York had great powers and privileges belonging to their manour of Hexham, being a county palatine affirmed by the king's council in parliament, 2 I K. Edward I (y);

(v) Hol. Chron. Vol. ii. p. 938. (w) Tonne's Notitia Monaft.

(x) Id.

(y) In antient times, the Archbihop of York had a royalty, with great powers, belonginer to his manour and county of Hexbam. In the one and twenticth ycar of $\mathrm{K}$. Edward, his liberties and powers in Hextildefham were affirmed by the King's Council in parliament. His cafe was of this nature. In an Iter of Hugh de Crefingham and his companions, a writ of Quo Warranto was brought to warn the Archbihop of York, to fhew by what warrant he claimeth to have all capitulas of the crown d.livered to his bailif; to be pleaded by his juftices whom he will affign for that purpore, conccming all thitg gemerging' in his manour VOL. II. 
of which it was ftript, $2 \mathrm{~K} \cdot H c n r y \mathrm{~V}$, for being an afylum to outlaws and robbers $(a)$. The tenants within the manour were exempt from the payment of the public fubfudies (a). Under a vacancy of the Sce of rork, a chancellor or guardian was appointed for the fpiritualities of Hexbam (b). Robert Ho!gate, Archbithop of York, within a month after his tranlation from the See of Landaffi, Gih Fouruary, $36 \mathrm{~K}$. Henry VIII, 1545 , gave the manour of Hexhan to the crown, in exchange for fome impropriations and advowions, parcels of abbey-lands, retaining nothing but the fpiritual jurifdiction (c). It was united to the county of Northumberland, 14 Q. Elizabeth (d). In the 21 it of her reign, it

of Hcxtildipam; and that all pleas, as wcll of the crown, as of other pleas, be pleaded by his writs and his juftices in his faid manour; and to take and have the iffues and profits arifing thereby; and to do and execute by his minifters all things pertaining to the office of Theriff and coroner; and that no bailiff of the King do enter into the faid. manour, to exercife any officc; and to have the cuftody of prifoners, and to make delivery of them at his will ; and to have a market, gallows, chatells of fugitivcs and felons condemned in the faid manour, without leave and confent of the King and his progenitors; which things do pertain to the King's crown and dignity.

'The archbithop cometh by his attorney: and faith, that he claimeth all the faid liberties from antient time : and that he and all his predeceffors, from immemorial time, without any interruption, have ufed the faid liberties; and this he is ready to verify.

Madox's Baron. Angl. p. 152, 153, 154.

Hixham hath been formerly ftiled a county Palatine.--Ibid.

Stat. 27,833 K. Henry VIII. c. 10.824 .

(z) Stat. 1. C. 5. Madox's Baron. Angl.

(a) De liberatione tenentium de Hextildepam fubfidiis, Pat: 33 Ed. III. par. 2. m. $x 9$.

(b) Pat. ii. Ric. II. par. 2. m. 9 .

(c) Broune Willis's Survey of the Cathedr. Vol, i. p. Ig, \& 44 .

(d) Stat. 14 Elizer C. I3. 
swas fold by the crown to Sir Foln Forfer, knight-banneret, Lord warden of the middle marclies; and on the $43 \mathrm{~d}$ of the fame reign, devolved to his fon-in-law, Sir Folnn Fenwick, Knt. whofe grandfon, Sir Fabn Fenwick, Bart. fold it to Sir Willian Blacket, of Nerwcafte upon Tyne, Bart. in the reign of King William III. It' is now in the poffeffion of Sir Walter Calverley Blacket, Bart.

The chicf ftreets in Hexbom are

$\begin{array}{ll}\text { Hen-cotes, } & \text { Cockfhow, } \\ \text { Prieft-pople, } & \text { Puddling-charc, } \\ \text { St. Mary-gate, } & \text { Hall-garth, } \\ \text { Cofteley-row, } & \text { Hall-ftile-bank, } \\ \text { Meal-market, } & \text { Eaft-burn or Bond-gate. } \\ \text { Gilly-gate. } & \end{array}$

Hencotes is the place where the poultry belonging to the priory were kept, to which it owes its name. It is a good ftreet, through which is the road to Carlifle.

Prief-pople was the refidence of the poor people maintained by the alms of the priory. It is a broad and pleafant ftreet, at the entrance into the town from Nerwcafle.

St. Mary-Gate leads from the market-place to Prief-pople. It is well built, and regular.

Cofteley-Row goes from the Markct-place to the head of Priefpople. It is a good ftreet.

Meal-Market is between St. Mary-Gate, and Cofeley-Row. It is a narrow ftreet, but regular. 
Gilley-Gate, or St. Giles's gate, is a good ftreet, uniform, and furnifhed with many good houfes:

Cockflow is chiefly inhabited by tanners. It is an irregular Atreet.

Pualing-Chare is between the head of Gilley-Gate, and the fummit of the Hall-Stile-Bank. It is a fmall ftreet.

Hall-Garth, or Hall-Court, confifts of feveral fmall, irregular. freets ; fo named fiom the town-hall, or town-court.

Hall-Stile-Bank is contiguous to Hall-Garth. It is the entrance into the town from Morpeth.

Eafl-Bum, or Bond-gate, is a narrow, confined freet, as the name of Bond-gate imports. It has the name of Eaft-Burn to diftinguifh it from a freamlet at the weft end of the town. It is the entrance from Hexhamfoire.

The Market-Place is in the center of the town, large, fquare, well built, and paved. On the fouth fide, is a market-houfe on piazzas, or ftone-pilafters, lately built for the ufe of the town by Sir Walter Calverley Blacket, Bart. In the middle is a large fountain, with a refervoir under it, of freeftone, and hewn work. It was erected at the charge of the inhabitants of that part of the town. The water which fupplies it is brought, for near a mile, in pipes. Here are two weekly markets, on Tuefday and Saturday. The firt is of chicf note. Every Tuefday-fortnight, from the tenth of March, to the tenth of December, is a market for horned-cattle. On the $25^{\text {th }}$ of July, and on St. Simon and St. rude, are two annual fairs.

The 
The want of a bridge over the Tyne is often the occafion of thin markets and fairs. The floods after rains and fudden thaws of fnow fometimes come down fo haftily, that they furprize and drown the paffenger in an inftant, or elfe, which fometimes happens, force him to take refuge on an iflet, where he is at leifure to lament his fituation, till the danger is over. There are two boats, it is true, for the convenience of paffengers; one below the Hermitage, called, The Eaf boat ; and another by Netber-Warden, and the $W e f W_{\text {ood }}$, called, The $W_{e j}$ boat. But thefe, at fuch times, either cannot pafs, or are in danger of perifhing, with many ufeful and valuable lives. On this account, the inhabitants on the north fide of the Tyne for ten, fifteen, and fometimes twenty miles, prudently confult their own fafety by ftaying at home, under the want of many neceffaries for themfelves and families, as well as the town and neighbourhood, by their abfence. A good bridge would, therefore, be the greatef benefaction and blefiing that could be beftowed on this anticnt town*; the trade of which is fo inconfiderable, that many of the inhabitants have been under the difigrecable neceffity of taking up with other employments, befides their own callings, for their decent fupport; as appcars by the following petition prefented by them to their patron, the Lord of the manour, Sir Fobn Fenwick, Bart. in the reign of King William III.

' The humble petition of the inhabitants of the town of Hextram.

'Humbly fheweth,

'That the faid town of Hexbam, or the greateft part thercof, ' confifteth of mechanics, handicraftemen, or tradefmen, who for

* Since this was written, the firft Atone for a bridge was laid by Sir Walter Calverliy Blac ie* . Bart. 15 th October, 1767 . 
'the better fupport and maintenance of themfelves and fami" lies have, time whereof the memory of man is not to the con"trany, kept thops, and traded in buying and felling of groce'ries, and all other forts of merchandife, whereby they made a "very good thift to live very creditably and honently, and dif"charged the merchants of Newcafle, and others they dealt and "traded with, from time to time, to the great comfort and fatis'faction of their friends and relations, and benefit and advan' tage to themfelves and families, and never troubled or molefted ' for fodoing, until now of late fome wicked and malicious per' fons envying the happy eftate and condition of the faid tradef"men, out of a peevilh and perverfe humour, and felf intereft, ' go about and endeavour to foment and fet up fuits againft the ' faic tradefmen and thopkecpers of the faid town, and threaten 'to indict them in the crown-office, and at the affizes and feffions "upon the ftatute of the fifth of Elizabeth, and for following ' more trades than one, which will be a very great lofs and preju" dice to the faid tradefmen, and to the impoverifhing, undoing, 'and ruining of them and their pofterities, and in a manner de"populating of the faid town, fome tradefmen being fo nume"rous there, viz. tanners, glovers, and hocmakers, that they ' are fcarce able to maintain their families by one of thefe fingle 'trades, without making malt, keeping thop, or following fome 'other employment, which if they continue to do, they are 'threatened to be indicted, and if fo, they muft be forced to ' look for a livelihood fome where elfe for themfelves, and leave " part of their children to the town to be maintained, which will " be a gieat and infupportable burden for the faid inhabitants to ' undergo.

- May it therefore pleafe your honour to take the premifes into 's your ferious and judicious confideration, and not to give any en- 
"couragement to any fuch promoters and informers, but rather 'to aid and affift your petitioners in making their juft defence to ' fuch hard and vexatious dealings and pleadings, and your peti"tioners, as in duty bound, fhall ever pray, \&c.'(b)

On the weft fide of the market-place, are the remains of that celebrated and admired fructure, the priory-church or old ca-. thedral. The beft view of it is from the north-eaft. In the center, on four ftrong pillars, is a fquare tower; in which were fix mufical bells, dedicated to

\section{The Bleffed Virgin Mary, \\ St. Andrew, \\ St. Foln, and other faints.}

St. Mary's bell was the largeft. It was commonly called, The Fray-bell, being never rung alone, but on occafion of fire, the approach of an enemy, to raife the Poffe Comitatus, or Fray, as it was ftiled.

St. Andrew's bell was the next in fize. It was called, The Hotly bell, being ufed for funerals.

Eight new bells have for fome time fupplied their place.

The roof of the middle inle is lofty. It is lined with oak-pannels within, and covered with lead without. The fide ifles are arched with ftone. The nave and crofs-ifles are fupported by pillars. In the walls are two rows of galleries, one above the other. At the entrance into the quire is a gallery, in which ftood :

(b) Collectan. Warburton, MS.: 
the organ. The portraitures of our Bleffed Lord, and his Apoftles, and the Virgin Mary, are painted on the pannels. The quire is a fine fabric, the altar.large, with a good light. The latter was repaired by the late Sir William Blackett; as was the whole church by a brief, 1725, towards which $1040 \mathrm{l}$. was collected. It ftill calls for farther afliftance, and implores the chasity of fome benevolent and good patron. The floor is moftly corcred with anticnt grave-ftones. Many have been inlaid with brafs, and others with croziers. They are very intire, after they have been trod under foot for fo many ages.

By the north door, at the entrance into the crofs.ifle, on the left hand, is the efligies in ftone of Henry Beaufort, Duke of Somerfet, a Knight 'Templer, taken prifoner and beheaded at Hexham by K. Edward IV. He is habited as ufual, in a coat of mail, with a fword and 'fcutcheon of arms, viz. or on a fez. az. three garbs proper. At his fect is a dog couched, an emblem of watchfulnefs. It has no infeription.

Near the fame door, on the right hand, is a flat funeral-ftone, very antient. It has a crozier upon it, and this infcription.

\section{HIC JACET THOMAS DE DIVILSTONE.}

On the pavement of the fame floor, near the nave of the church, is a ftone-coffin, with a ftone-cover.

Under an arch, at the entrance of the north ifle of the quire is an antient funeral monument, faid to be the fepulture of Alfwold, King of Nortbumberland, affaffinated by Sigga, a factious Lord of his court, at Cilchefer, now Walwick-Chefters, Sept. 23.788.(c).

(c) Hol. Chron. Vol. i. L. vi. p. r35: 


\section{ANTIQUITIES OF NORTHUMBERLAND.}

At the upper end of the north-eaft inle of the quire, near the altar-table, is a tomb with the effigies of a Religious, recumbent, and veiled; the arms of the priory at the top, viz. argent. a faltier, gulcs. Contiguous to it is a pillar on which is a helmet fixed. It is fuppofed that the perfon here interred had been of the military, before he was of the religious, order. By the arms, it is thouglit, he was the prior.

Oppofite to it, on the other fide of the quire, is another fepulchral memorial of a Knight Templer, with his effigies, and the ufual fymbols of his order, cut in ftone. By the fhield, it appears to have been one of the baronial-family of the Umfranzils, cminent benefactors to the priory; their arms, gules, a cinquefoil between eight crofs mollins, 3. 2. 3 .

On the fame fide of the quire, a little lower down, is a monument to the memory of Sir Robert Ogle, of Ogle-caftle, with this infcription in a brafs-plate, on black-marble.

Hic jacet Robertus Ogle, filius Eleanore Bertram, filia Roberti Bertram, militis, qui obiit in vigilia omnium fanctorum, Anno Domini, I 40. Cujus animæ propitictur deus.

In another brafs-plate, are fculptured the arms of the two baronial houfes of Bertram and Ogle, quartered; firt, argent. a fefs. between three crefcents. gules. fecond, Or. an orle. az. the third as the fecond, the fourth as the firft.

In the quire, near the reading-lenk, is a fiat funeral-fone of blue narble to the memory of the Rev. and learned George Ritfchel, a Bohominn by birth, lecturer of Hexhan, with this infeription. 
Sub hoc marmore facræ reconduntur reliquiæ.

Georgii Ritfchel, patria Bobemi,

Religione reformati : qui fæviente in proteftantes

Ferdinando 2 do. omnibus gentilitis

Hereditatibus exutus, fed Higentorati

Lugduni Batavorum, aliarumque acade-

miarum extcrnum, fpoliis onuftus

Quicquid cruditonis in iftis florentifimis

Mufarum Emporiis viguit, fecum

Detulit Oxoniam Anno Domini 1644 .

Qua celeberrima academia confummatis

Studiis aliorum commodo ftudere cœpit.

Et contemplationibus metaphyficis,

Vindiciis ceremoniarum ecclefiæ Anglicane,

Aliifque fcriptis eruditiffimis editis toto

Orbe ftatim inclaruit.

Tanta fama auctus, ecclcfiam

Auguftaldenfem, ad quam electus erat,

Et cui præfuit annos plus minus 27,

Magis Auguftam, et tantum non

Cathedralem, qualis olim fuit, reliquit:

Natus Anno Domini, I6r6.

Dcnatus, 1683 .

The book here alluded to, concerning the defence of the ceremonics of the church of England, is taken notice of by Bifhop Kennet in his Hiftorical Regifter. It is intitled,

Differtatio de Cercmoniis Ecclefic ANGLICANe, quä ufus earum licitus ofenditur, et a Superfitionis et Idolatre crimine vindicatur. Autbore Georgio Ritschel, Hexhamle, in Northumbria, Miniftro. LONDON. r66r. 
This work of Mr. Ritfchels procured him the love and friendthip of that eminently learned and good prelate, Bifhop Cofins. He was both minifter and lecturer of Hexbam.

The lecturefhip was founded by the Mercer's company in London, who alfo founded another at Berwick upon Trueed. For the maintenance of the lecturers they purchafed feveral tithes, according to the tenour of the will of Richard Fi/hborn, Efq; dated zoth March, 1625, which is as follows.

"Item, I give and bequeath to the wardens and commonalty " of the myftery of mercers, of the city of London, the fum of " $2800 l$. therewith to buy and purchafe two or more parfonages, "rectorics, or church-livings, antiently appropriated to fome " abbey, monaftry, or religious-houfe, or houfes, and now com" monly called impropriations, the fame to be in Lincolnfire, "Yorkfire, or fome other northern county or counties of this land, "where the faid company of mercers fhall beft fit themfelves "with fuch a purchafe, and find moft want of preaching of the "word of God to be. And the faid church-livings and impro"priations fo purchafed and had, my will is, thall be from time " to time, fucceffively, for ever, by the faid wardens and com" monalty of the myftery of the mercers of Iondon after their "wonted cuftom of election by moft votes at their gencral courts " conferred, beftowed, and conveyed upon two or more minifters "refpectively for and during fuch tcrm or terms, and in fuch "manner and form, and with fuch cautil and provifion, that if "they, or any of them, hall prove non-refident, or have any "other benefice or church-living with cure of fouls, then the " faid wardens and commonalty, and their fuccceflors, from time "to time, for ever, thall and may remove difplace, difmirs, de- 
" prive, and cject them, or any of them, out of the faid impro"priations, or any of them, and elect and place another, or. "others, in his or their room, according to their good difcre"tion. And I heartily intreat the faid wardens and commonalty, "for God's fake, that they will be very careful from time to time "to make choice of fuch as be" well known to be honeft, difcreet, "lcarned men, fearing God, and painful in their miniftry, that "by their life and doctrine they may win many fouls to Chrift" "Jchus."

In 1628 , the mercers company purchafed of Sir Folsn Fenwick, Bart. a meffuage and an orchard in Hexham, all the great tithes arifing in the town, parifh, or fields of Little Swinburn, in Keproick, Errington, Bing ficld, and Colwell. In $163 \mathrm{r}$, they purchafed the great titlies of Cbollerton and Barwesford. They alfo purchafed a moiety, of the great tithes of Woodborn, Widdrington, two Steeds, North Seaton, Creffruell, Horton, Horton-Demefnes, Hirft, Hutton, Ellington, Lynton, and Lymmonth, all in this county.

They latcly took off from the lecturefhip of Hexbam $50 \%$. per ummm, and applied it to the fupport of an alternate lecturefhip in the parifh-church of Chollerton, and the chapels of St. Ofwald and Bingfield, belonging to the church of St. Fohn-lee.

In 1759 , Sir Walter Calverley Blacket, Bart. gave 380 l. towards the augmentation of the living of Hexbam, which generous donation was attended by another of $100 \%$. for the fame end, from Sir Edward Blacket, Bart.

Mable Ord, a widow-gentlewoman, gave, $\mathbf{1} 634$, a double gilt chalice and patin, weighing 32 ounces, to this church; alfo the altar-table cloath, and a cloath or pall for funerals. She alfo gave 
100 l. to the poor of. Hexham; who had alfo the following benefactors.

Fobn Tyfon, of Hexham; yeoman, by his laft will, dated $25^{\text {th }}$ September, 1673 , gave $10 l$. to the poor of the parifh of Hexham, the intereft to be diftributed amongft them at Chriftmas and Eafter, annually, for ever.

Fames Creffwell of Hexbam, tanner, by his laft will, dated 28th. October, 1675, gave an acre of land in Hexbam-haugh, comnonly called Reab's acre, the annual rent to be diftributed to the poor: of the town of Hexham, on the $3 \mathrm{~d}$ of October, his birth-day.

Robert Farbridge, of Hackforth, in Hexbamflome, by his laft will, dated 9th of March, 1677 , gave 10 l. to the poor of the high and middle quarters of Hexbamfloire; the intereft to be diftributed annually at Whitley-chapel upon All Saints day.

Madam Mary Fenwick, daughter of Sir George Seluy, of Neweafile upon Tyne, Kt. and widow of Colonel Fobn Fenrvick of Hexbamabbey, flain at the battle of Marfon-moor, July $2 \mathrm{~d} \mathrm{I} 6_{44}$, by her laft will, dated December 25th, 1679, gave $100 \%$. to the town of Hexbam, to bind poor children apprentices.

Mrs. Urfula Mountney, of Stcnecroft, widow, by her laft will, dated July $16 \mathrm{th}, \mathrm{I} 680$, gave an annuity of $12 \%$ per anmun to different parifhes; $3 l$. per amm of which to be diftributed to the poor. of the parifh of Hexham.

Tbomas Craig, of Hexbam, Rkinner and glover, by his laft will, dated 28 th December, I68r, gave $20 \%$ the intereft to be diftributed 
buted annually to poor widows and orphans of Ilexham, on St. Thomas's day.

Robert Forfter, of the upper Efhells, in Hexbamfhire, by will, dated I sth July, 1684, gave rol. to the poor of Hexbamfaire; the intereft to be clifributed annually at Eafter.

Homy Simpon, of the hole-houfe, in the low quarter of Hexhamflire, by will, dated 1694 , gave 10 l. to the poor of Hexhamfoire, and $10 \mathrm{l}$. to the poor of the parifh of Slealey, but clying before it was exccuted, his fon-in-law, Thomas Wadefon, of Thimbley1ill, in the Bifhoprick of Durbam, gave so $l$. to the free-fchool of Hexban.

Thomas Gibfon, of Hexham, cordwainer, by will, 1686, gave $20 l$. to the poor, out of a certain clofe in Hexbam-fields.

Maclam Elizabeth Ratcliff widow of Sir Edward Ratcliff, of Dilfon, Bart. by her Iaft will, dated I 8 th December, 1688, gave 4.7 per anmam to the poor Roman Catholics in Hexham, to be diftributed on St. Luke's day, or thereabout.

Antbony Farbrige, of Newcafle upon Tyne, born at Hackforth, in Hexhampire, by will, dated 3 d November, 1690, gave 14\% to the poor of the high and middle quarters of Hexbamfloire; the inteieft to be diftributed annually on Good Friday at Wbitley-church.

Fobn Couljon, of Hexham, tanner, by will, dated 26 th Septem. ber, 1692 , gave $20 \%$ to the free-fchool, and $20 \%$ to the poor of the town of Hexlanit. 
Margaret Broadley, of Hexham, widow, by will, dated 3 oth Oetober, 1693, gave 10 l. to the poor; the intereft to be diftributed annually; IIth November; provided it was not claimed by the friends of one William Wilkinfon, within the term of feven years, which it was not.

Richard Walton, of Peacock-houfe in Hexhamflire, by will, clated I 8 th April, I695, gave 3 l. towards the having a minifter at Whitley-chapel, and in cafe a minifter could not be had, the interct to be difributed to the poor in the high quarter of Hexlsam/hire.

Henry Dixon, of the Staples, gave 20l. to the poor of the high, low, and middle quarters of Hexbamfloire, 1 oth Oetober, 1700; the intereft to be diftributed annually at Chrifmas.

Madam Anne Ratcliff, of Dilfon, fifter to the Earl of Derwentwater, by will, gave $10 \%$ per anmm to the poor in the parith of Hexham, to be diftributed $13^{\text {th }}$ of Junc.

Mrs. Margaret Allgoad, widow of Lancelot Allgood, of Newcafle upon Tyne, attorney at law, by will, dated 8th June, r 707 , gave $100 l$. to the poor of the town of Hixbam, of which her hurband was a native; the intereft to be diftributed annually on Chrifmasday, after evening fervice by the principal inhabitants, with the advice of the minifter.

Mrs. Mary Allgood, daughter of Mr. Thomas Allyood, bailiff of Hexbam, by a nuncupative will, (a little before her death, which happened, $5^{\text {th }}$ November, 1709 ) gave $40 \%$ to the poor of the town of Hexham; the intereft whereof hath fince been diftributed amongtt them. Her brother, the Rev. Mr. Fames Allgood, rector 
of Ingram, her adminiftrator, promifed to confirm and make it perpetual.

Nicholas Ridley, of Nerecafle upon Tyne, Efq; and an alderman of that corporation, by will, dated 7 th December, I 710 , gave $20 l$. to the poor of the town of Hexban; the intereft to be diftributed annually to the morc aged and infirm, cight days before chrifmas.

Mrs. Dorothy Allgood, elden daughter of the above-mentioned Ar.Tbomas Allyood, bailiff of Hixbam (who died 6th September, I 7 i 2), lime time before her death afligned and made over her fortune to her brother, the Rev. Mr. Fames Allgood, before mentioned, on condition that if the died unmarried, the interent of $4.0 \%$. fhould be annually dillibuted to the poor of the town of Hexbam, which he agreed to perform.

Elizabeth Gibjan, of Hixhan, widow, by will, dated 29 th December, 17 I2, gave $20 \%$ to the poor of the town of $H$ xham; the inteach to be difributed annually $(d)$.

At the weft end of the church of St. Andrew, are the remains of the anticnt Priory. It has been a fpacious and noble building, quadrangular, with a large cloifter; the ambulatories very confpicuous on the weft fide of the garden a fer ycars ago; alfo an oratory at the fouth-eaft corner of the garden, the roof raulted with flone, and fupported with four Ionic columns.

It was burnt by the Scots, $24 \mathrm{~K}$. Edzeard I. I 296, together with the weft end of the church, and the fchool-houle. In another

(d) Mr. Rit.b.l's Account of the charities in Tynedult, 1713. Newe. finall 8vo. p. 29. hontile 


\section{ANTIQUITIES OF NORTHUMBERLAND. 105}

hoftile vifit the year following, they lodged in the town, and mal-treated the religious, after letters of protection granted for one whole year to the prior and his conrent, with liberty to pafs and repafs at pleafure for one canon, one fquire, and two fervants; figned by their leaders, the Earl of Murrey, and Sir Willian Wallace. They burnt the town of Ryton in their way callward. Newcafle was too frong for them (e).

It was pillaged by David, King of Scots, $20 \mathrm{~K}$. Edterard III. I 346. He entered the borders by Liddel-caftle, with 40,000 men. They marched to the abbey of Lanercoft, Naverd-cattle, and Redpeth, to this town. They ftayed three days. They had determined not to burn this, and three other towns, viz. Corbridge, Durbam, and Darlington. They fared them for their convenience, to lay up ftores and provifions, for their fupport. They marched from hence to Ebchefter, and after committing many ravages and barbarities, were defeated by the Englifh at Nevil's crofs, near Durban $(f)$.

Fobn de Hexham, and Richard de Hexban, two eminent hiftorians, both prefided over this monaftery. Prior Foln made an addition of twenty-five years to the hiftory of Simeon of Durban; from the gth of K. Henry II. to the Ift of K. Richard.

Prior Ricbard drew up a hort chronicle from Adam to Henry the Emperor. He alfo wrote the hiftory of K. Stephen and Henry III. But the chief of his hiftorical writings is, An Account of the State and Bifhops of the church of Hexbam, which make a part of the valuable edition of the Decem Scriptores.

(c) Hol. Chron. vol. ii, p. 299 , and p. 300 .

(f) Vol. i. p. 240-1.

Vox. II. 
Part of the priory was repaired by Sir Reginald Carnaby, whore coat armorial is over the coach-houle, built by him. It was lately: repaired by the prefent lord of the manour, Sir Walter Calverley, Blacket, Bart. who made a handfome gravel-walk round a large ficld, on the weft fide, watered by Hextold's little ftream, and on. the higher part of it planted fmall clumps of foreft-trees, at agrecable diftances.

On the caft fide of the Mimet-place, is an antient ftone-building, with a clock in it, which was the town-hall, or town-court belonging to the bilhops and priors of Hexbam. It is ftill put to the fame ufe. The lori of the manour holds his court in it. It is alfo the feffions-hall.

Some have imagined, that it was the palace of the Bifhops of: Hexban, which is a miftake. The IBifhops lived in the monaftery, over which they prefided.

At a finall diftance from it is an old tower. It was antiently the town-jail. It is ftill ufed for the fame purpofe.

A little farther calward is a grammar-fchool, founded by Q. Elizabeth; her letters patent dated $25^{\text {th }}$ June, in the 4 ift year of her reign, $1598(\mathrm{~g})$. The mafter's falary is $20 l$. and the ufher's 4l. per annum. The fchool, and a convenient dwelling for the mafter, were built at the expence of the town and neighbourhood, 1684. They colt $150 l$. They ftand upon the brink of an eminence, which forms a fine natural terrace, commanding a moft agrecable profpeet of the river Tyne, and the neighbouring feats and villas upon its banks.

(g) Ritfchell's Account of the Charities in Tymedale. 
The civil government of the town is by a Builiff. He is appointed by the lord of the manour, and is commonly continued for life. He is an officer of great antiquity. He has the fame power within his jurifdiction, as the mayor of a city, or a juttice of peace, within the county.

In Hexbamfirie, on the plitins, called the Levels, by the rivulet of Divil ( $b$ ), a bloody battle was foughe between the two houfes of Lancafer and York, ${ }_{4} 6_{3}$; and a decifive victory obtained by the General of the litter, the Mreruis of Montasite, who forced the intrenchments. Of the victorious party, were the Ogle's, and the Mamers's, of this county. Of the ranquifhed were the Percy's, the Roos's, the Nevill's, the Tailboy's's and the Grey's. 'The unfortunate K. Henry rode full flecel out of the field. His attendants were many of them taken in the purfuit; the furniture of their horfes of blue velvet. Upon one of them was found the high cap of ftatc called Abacot, adorned with two rich crowns, which was prefented to the victorious Edward at York, May 4. His competitors, Henry and his 2 ueen, and fome of their partizans, were abandoned to extreme mifery. Singte and alone, the Queen wandered with her little fon in her arms, expofed to dangers, and the affaults of robbers, till the reached France, her native land. The duke of Exeter, their friend, became an exile in Burgundy, where he had neither fhoes or flockings to put on, and begged his bread from door to door (i). The Duke of Somerget

was

(b) Dowill. Hol. Chron. vol. ii. p. 666, 66--

Dowell. Draylon's Poly-Olbion, p. 154 .

(i) During the civil wars between the two houfes of Lanenfor and York, were fought in Englans feven or eight cruel battles, and in them nain three or fourfere princes and lords of the blood royal. The reft that efcaped being all young lords, whofe fit'iers died in thefe battles above 
was infantaneoufly executed at Hexbam, after the battle; being. a changling and a deferter from Edward. His tomb is in Hexbanchurch, as before-mentioned. A field near the fcene of action, called Dux-field, is fuppofed to take its name from him. Sir Witlim Tailboys, Sir Humpry Nevil, and Sir Ralpb Grey, knight of the mof noble order of the garter, and captain of the caftes of Roxborongh and Bambrongh, were all three belncaded; Sir Ralph being firt degraded of his ligh honour, by cutting off his gilt fpurs,

mentioned, lived as banihed men in the Duke of Burgundy's court, who received them as his kinfmen of the houfe of Lama/ir, before his marriage with King Edward's fifter. I have feen them in fo great mifery before they came to the Duke's knowledge, that thofe that beg fiom door to door were not in poorer ftate than they: for I once faw the Duke of Exeter ("Henry Holland") run on foot and bare legged after the Duke of Burgundy's train, begging his bread for God's fake, but he uttered not his name. He was the neareft of the houfe of Lancafir, and had married King Edruard's fifter, but when he was known, the Duke gave him a fmall penfion to maintain his eftate. They of the houfe of Somerfet, and. divers others, were there in like manner, who died all afterwards in the wars.

There were three things that contributed to K. Edward IVth's fuccefs: Firft the gentlemen that were in the fanctuaries, and the new born prince: The fecond, the great debts the king owed in the metropolis; in refpect whereof the merchants, to whom he was irdebted, thought it their beft way to take part with him: The third, a great many women of honour, and rich merchants wives, with whom in times paft he had been familiar, perfuaded their hufbands and friends to incline to him.

After he was quiet in his realm, he received yearly out of France fifty thoufand crowns, paid him in the Tower of London, and was grown fo rich, that richer he could not be.

He was the beautifulleft prince in the world. He gave himfelf wholly to pleafures, as to dames, feafting, banquetting, and hunting, after he had vanquifhed his.enemies. He feared no man, but fed marvcliounly fat, by means whereof in the flower of his age difeafes grew. upon him, fo that he died in a manner fuddenly of an apoplexy.

Philip de Cumine's (fecretary to Lewis XI, and to Charles VIlI, )invaluable Memoirs, tranflated by Donet, fmall fol. p. 63: AndUvedule's tranlation, with Sleidan's notes, Vol. I. p. $2+0$. 
defacing his coat armorial, and breaking his fword over his head. The Marquis of Montacute was made Earl of Nortbumberland for his fervice.

Oppofite to Hexham, on the north margin of the Tyne, is the

Hermitage, formerly belonging to the priory of that town. It was then called Hamefalg (k), i. e. the hamlet in the Hulg, haugh, or vale. It was furrounded with wood, and was the firvourite recefs of St. Folm of Beverley, to whom the church on the hill behind it is dedicated. On the diffolution of that moniffery, it came to the crown, and was not granted away 10 Q. Elizabeth (l). It was in the poffeflion of Gobn Coatfroorth, E.Iq; 1724; then ligh theriff of Nortbumberland, on whole death it defecnded to his eldeft.fon, Edward, who, dying fome years after, left it by will to his brother Michael and his heirs, and failing them to Dr. Furin and his heirs. Michael dying without hcirs, 1754, it came to Fames Furin, Efq; fon and heir of Dr. Fames .furin, fellow of Trinity College, in Cambridge, $17 \mathrm{II}$, and afterwards an emincut phyfician in London, well known and efteemed in the lcarned world for his curious experiments and indefatigable pains in promoting natural knowledge. He was editor of Varenius's geography $(m)$, and author of many learned differtations in the Philofophical

(k) Heddius. Pr. Ric.

(l) Domina Regina Elizaletha fuit feifita de certis terris in Fexham, viliamque Dallon, Echuick, Halyden, Warden, Carraw, Bingfield, Todderley, Grotington, Acome, Sandhow, Wall, Hermitage, Chantry-clofe, Weft-wood, Chollerton, Kirk Heton, Gunnerton, . ut de poffeffionibus monafterii de Hexhan. Efcaet. de anno 10 Eliz.

(m) In 2 vol. 8 vo. Lond. I 7 I r. publihed at the requeft of Dr. Bentliy, to which is added an appendix, containing the difcoveries fince that authar lived. 
Trunfations. His diflertation de Potentia Cordis, in No. 35 g, and epiltle in defence of it, in No. 362 , both.addrefled to Dr. Mead, writen in an clegant Latin filc, and his conduct towards his 1 adverfary, Dr. Keil, is genteel and handiome, wherein ved the fernmum bonos, and virax gratia, fo much defired "wity conteits ( $n$ ). The was fellow of the College of PlyyA of the Royal Society, alfo their fecretary on the refig3r. Killey, I 79 r, and their prefident fome months before plijfician of Guy's hofpital, governor of St. Thomas's, at....... by boltaire, in the Fournal de Sçavans, the famous Furin. 纴 diel, a 2 March, 1749.50 , in the 66th year of his agc. His fon, Fames .Furin, Lff; was educated at the fame college, in Cambridge, and in the latter end of the year $175^{6}$, was chofen fellow of the Royal Society. In September, i 757 , he married the daughter of Gobn Simpfon, Ef(l; and alderman of Neweaftle upon Tyne, whofe nother was one of the daughters and coheirs of the anticnt family of the Anderfons, merchants of, and reprefentatives in parlianent for, that corporation, from the 7 th of K. Edwand VI, $1552-3$, to the I6th of K. Charles I, 1640 ; two of whom, Sir In..... and Sir Francis, were knights; their country feat was at Bradley, in the bifhoprick of Durbam, now in the poffeffion of $\mathrm{Mr}$. s.mon, and lately rebuilt by him after a handfome manner.

Mr. Furin died in July, i 762 . His feat of the Hermitage is now in the pofefion of his widow, Mrs. Furin. The front of it was built by the late Mr. Contfworth; of white freeftone, and hewnwork; the back-part and the offices by Mr. Furin, to whom the whole place is indebted for its prefent genteel appearance. To

(n) Sce Ph. Tr. No. $355,356.358,359.361,362,3^{5} 3.369 .373 .379 .453 .472$. $47^{5}$

DiRertationes Phyfico-Mathenatica, 8vo. Linh. Ir32. pp. 127. 
the eaft of the houfe is a fmall, but neat garden, fheltered by a clump of tall foreft-trees. Before it is a grafs-lawn, adorned with fmall clumps of young trees, and extending to a terraced road by the margin of the trout-Atreams of the river Tyne. To the north-weft is a fmall pendant copfe, or natural grove, thro' which is a terrace-walk, and at the top of it a feat to refl on. Here the melody and hamony of the birds, the whifting winds through the trees, the voice of falling waters, and the fight of the town of Hexbam, and of that venerable dome, the church ot: St. Andrew, form a moft bcautiful fcene.

At the termination of the terace-walk, is the church of

St. Fobn-lee, confiling at prefent only of one ifle, in the juritdiction of the fee of rork.

A little farther eaftward, on the brow of a hill, thaded with wood, is

Beau-front, i. e. bellus Locus, the feat of David Carnaby, Efq; 10 Q. Elizabeth (O); and lately of Thomas Errington, Ef(1; and now of his fon, Fobn Errington, Efq; of the antient houfe of the Erringtons, of Errington, by Erring-Burn, on the north fide of the Roman wall, from which he derives his name. His anceftor, Willian de Errington, was high theriff of Northumberland, $47 \mathrm{~K}$. Edward III (p). Another of the family, Sir Thomas de Errington, was one of the confervators of the borders, I2 K. Henry VI (q). Sir Gilbert

(0) David Carnaby fuit feifitus de et in uno capitali mefluagio de Beufront, Gith-n, Beumont, Conck-riding, cum certis terris in Port-Yet, et Hexbam. Efcaer. de anne
(p) Efcaet. de anno 47 Ed. III. n. 84 .
(q) Bp. Nicholfon's Border-Lav: 
de Errington, Knt. was of the party of K. Edruard IV, againt the houfe of Lanciafer.; by whom, and Sir Folnn Manners, of Etall, at the head of 400 men, Queen Margaret, of Anjou, was hindered from landing with her company at Bambrough, and forced to take Shelter at Berwick upon Tweed. Nicbolas de Errington died in the beginning of the reign of Q. Elizabetb, poffeffed of Errington, \&c. (r); now in the polreflion of Mr. Errington of Beanfront.

The fituation of Beanfront is generally admired, having both fun and fhade, and a delightful vale and river profpect.

From the s 8 th mile-fone on the military road, on the left hand, we have a fine vicw of

Ifrly-den, i. e. the Holy Den or Vale, famous for the victory obtained by Ofruald, King of Nortbumberland, over the Britifs ufurper, Cidcoll, who had Main his apoftate brother, Anfred, King of Bernicia, in a pitched battle, and made a terrible flaughter of his little army. Ofruald, to revenge his brother's death, and fave his country from deftruction, boldly marched at the head of a few brave troops to oppofe the tyrant. He chofe a convenient camp Which he fortified, and relying not on his own arm or his own nlecugth, but on the goodnefs of his caufe, and the protection of heaven, erected a crofs before it. Then he and his army on their knees implored a blefling on their arms. The enemy trufting to their numbers, advanced in full confidence of victory. Cedruall in inagination reckoning the day his own, and tranfported with the thought of having full vengeance on the humble ofwald, in

(r) Heredes Nicbol. Errington fuerunt feifiti de et in Errington, Cockley, Fallowfield, Kepwick, Wharneley, Wharneley-Hill, cum terris in Acome, Hexham, Stonecroft, PriorHoufe, Hill-Houle, Nakedalc, Ha-plow-field, et Umbres.

Efcaet, de anno ro Eliz. 
perfon attacked his intrenchments. An arrow met him, and ftruck him dead. Terrrified at his fall, his men in confufion began to retire. King ofrold feizing the happy moment, ruthed upon them in their fright with his brave followers, and put them entirely to the rout. His fuccefs was fo much above all human expectation, that the ficld of battle was called Hefenfelth, i. c. Heaven's Field ( $r$ ), and Halyden (s). It is watered by Erringr-burn, called by Bede, Denifurne, i. e. the Burn in the Den or Valley, on whofe banks, he affures us, the battle was fought. A church was afterwards built by the convent of Hexbant, and dedicated to St. Ofwald, on the top of the hill by the public road, to commemorate the bleffings of that day, and to put paffengers and others in mind of it, and of their own particular obligations to heaven for the daily mercies they receive. It is ftill ftanding, and was lately repaired, being an appendage to the church of St. Fobn-lee. A large filver coin of St. Ofwald's was found near the place where it was built. His head is reprefented on one fide, fceptered, and the crofs on the other. It was for a long time ufed by the convent at Durbam as their common feal, in honour of him. There is a good print of it in the appendix of the learned Dr. Snith's edition of Bede's Church-Hiftory $(t)$. In the fame vale is a village called Halyton, and Hallington (u), i. c. the Holy Town; in the demefnes of which is a neat modern ftructure of white freeftone, called,

Halyton-'Mefnes *, the feat of Ralph Soulfoy, Efc; clden brother of Cbriflopber Reed, of Cbipchace, Efq; and brother-in-law to William Fenvick, of Byzuell, Efq. Before it is a grafs area extending
(r) Bede.
(s) Lel. Itin. vol. $7 \cdot \mathrm{p} 5^{8}$.
(1) Append. p. 2.21.

(u) Ibid. Rotulifq; Northumb.

* Hallyden-Mains. Rot. 10 Eliz: infra citat.

VOL. II. 
to the brink of a deep gill, wherein is a fmall ftream, which falls a little below into Erring-burn.

A mile and a half eaft from Halyton, is a hill with a fquare intrenchment, and a hearth-ftone in the center, trenched round, called the Mote-laze, i. e. the hill for obferving the motions of an cnemy, and giving an alarm by fire on any imminent danger. Both it and Halyton are in view from the 18 th mile-flone on the military road. From the fame place we have alfo a view of

Little Bavington, the feat of the antient family of the Shaftoes; of William Shaftoe, 33 K. Edward I (t); of William Shaftoe, $47 \mathrm{~K}$. Edward III (u); of William Shaftoe, I6 K. Richard II (v); of Alexander Shaftoe, 5 K. Henry V (w); of William Shaftoe, 5 K. Edward IV $(x)$; of Fobn Shaftoe, 6 K. Edward VI $(y)$; and in the beginning of the reign of Q. Elizabeth (z); of William Shaftoe, ig K. Charles I, I 643 (a); alfo of William Shaftoe, I K. George I. It is now the feat of George Shaftoe Delaval, Efq; high Theriff of Nortbum-

(t) Efcaet. de anno $33 E d$. I. n. 79 .

(u) - 47 Ed. III. n. 84 .

(v) 16 Ric. II.

(w) 5 Hen. 5. n. 3 r.

(x) 5 Ed.IV.

(y) Bp. Nicholfon's border-laws, p. 214, and p. 332.

(z) Fobannes Shaftoe fuit feifitus de et in parva Bavington, Thockrington, Weft Harle, et Halliden-Mains, cum tertia parte de Brenckley, ac certis terris in Benwell, magna Bavington, Buteland, et Kirk-Heton.

Éćàt, de anno 10 Eliz:

(a) See Parliament. Hift. of Engl. vol. 12. p. 233. 
berland, 1740 , and a reprefentative for it in the prefent parliament. By raifing plantations, hedge-rows, and buiklings, he hath given a kind of new form to it, excecdingly agrecable: To the fouth-weft is an artificial ruin on an eminence; a large and beautiful piece of water to the fouth, under a bank planted with foreft-trees, and a Tcmpiato at the top; all in vicw from the fouth front; a ferpentine walk leading to the latter, edged with flowering thrubs. It is in the chapely of

Thockrington (a), a peculiar of the church of Tork, which was impropriated to it by Richard Bifhop of Durban, 1904. It is a prebend, and the loweft in that cathedral; the firft fruits, 2l. I 7 s. I $d$. The chapel was lately repaired. It ftands on an eminence, and is in view from St. O/ruald's chapel, and the r $8 \mathrm{rh}$ mile-ftone; from which we pafs on to

Port-gate, near the i 7 th mile-ftone; fo called from its giving a paffage through it. On a hill by it is a farm-houfe which takes its name, and was in the poffeffion of Odonell de Carmby, roth Q. Elizabetb (b), and lately of Willian Errington, Efq; and now of his nephew, Henry Errington, Efq; of Sandboe, younger brother to .Jobin Errington, Efq; of Beanfront. By its high fituation, and one or two foreft-trees by it, it is diftinguifhed at a great diftance. The very foundations of the Roman wall, and fofs, have becn digged up, plowed, and fown with corn.

(a) Tockrington. Broume Wiliis's Survey of the Cathedr. vol. i. p. 168 ; where is a lift of the prebends.

(b) Odonell de Carnaly fuit feifitus de et uno capitali meffuagio vocat. Port-Yet.

Efcáto de anno ro Eliz. 
A little below Port-gate, we come to the Hermen-freet, fo called from Hermes, Mercurius, the god of the high ways, and Cufos Malnium. It is more gencrally known by the name of Watling/ereet (c). It croffes the Tyne at the Roman ftation,

Cor-chefer (d) by the oftim of the Atreamlet Cor, famous for theRoman curiofitics and antiquities found at it. It is not mentioned in the Notitia, and therefore is thought to have been abandoned before that defcription of the Roman empire was penned. It contains feveral acres. A fmall fpace within it is called Corbow,. fuppofed to have been the Pretorium.

The Romans had a bridge of arches over the Tyne at this ftation, as well as at Cilcbefter, the fabric of which muft have been very curious, where the current is rapid and formidable after heavy rains, and fudden thaws of fnow from the mountains and hills. The arches of their bridges were ufually wide over fuch rivers, formed with the greateft geometrical nicety, the pillars multangular, the bafe of each fecured by horizontal arches gradually contracted, every ftone in them of a vaft length and wedge-like,

(e) See Mr. Horkey's Brilain. Roman. on the four grand Roman ways in Britain, p. 387 . Eflay on the fame in Mr. Tho. Herne's Lel. Itin.

(d) Corftopitum. Antoninus. Dean Gale. Camden.

Corftopilum. Burtsn. Hen. Surita.

Corfopilum. Ricb. of Cirencefer.

Cor-chefter.

The Curia or Coria Ottadinorum of Ptolmey affigned to this ftation by Camden, is referred to Scotland, to the Gadeni, by the Hon. Baron Clerk, the ornament of his country, and of learning. His judgment is confirmed by the monaftic antiquary, Ric. of Cirenceffer, and by Dr. Ethkeliy, the latter placing it at Corfon-law in Lothian,-the Coria of the Godeni, their metropolis. 
laid level with the water. Such ftones are now lying in the river by both thefe ftations, with iron-cramps in them. In the upper part of the pillars were apertures or openings to give a paffage to impetuous and raging floods (c).

An abundance of Roman coins of the later empire have been turned up by the plow; now in the cabinct of the Rev. Mr. Wratton, vicar of Corbrilge.

The Roman moneys were often notorioufly adulterated, as ap: pears from fome coining molds of their's found about the year I.697, in delving a field near Thorp on the hill, by Wakeficld, in. Yorkflive, and defcribed by Mr. Thoresby $(f)$. In later times there have been counterfeits, for the fake of the high price they bore.

Many feals of Roman work are in the pofferfion of Mr. Walton, found at this and the neighbouring ftations; but none of them antiques; all of the lower empire, engraved on carnelians, and ftones of the lower clafs. They are all entaglios, not one cameo among them. Greek and Roman antiques were always of the molt exquifite workmanfhip; engravings on gems, pebbles, and ftones. of the firft order for beauty and lufte. The beril, the chalcedony, the emerald, hyacinth, the topaz or modern chryfolite, and the garnet, were favourites. The chryftal pebble, and the amethyft, were alfo efteemed. They alfo ufed the onyx, the fardonyx, the agate-onyx, the jafper, the hæmachates, or blood-flone, which they valued for cameos. Other kinds were not ufed by the Romans till the lower empire, when the arts were upon the:
(e) See the figure of a Roman bridge in the Ph. Tr. No. 160.
(f) Ph. Tr. No. 234 .

decline: 
decline. Then carnelians, and ftones of an inferior clafs, were incroduced. Of this order and fpecics are the intaglios, found at our Rsman ftations, hardly worthy of a defcription, having neither crudition, good workmanfhip, beauty and politure, which conflitute the merit of antiques, and recommend them to the notice and efteem of the curious.

- The Greek matters cxcclled the Romans in the art of fculpture and engraving, who refigned their genius more to oeconomical and political refinements. This is allowed by a great Roman.

Excudent alii fpirantia mollius æra, Credo equidem; vivos ducent de marmore vultus;

Orabunt caufas melius; caliqùe meatus

Deficribent radio, et furgentia fidera dicent.

Tu regere imperio populos, Romane, memento;

Hre tibi erunt artes, pacifque imponere morem,

Parcere fuljectis, et debcllare fuperbos.

Virg. An. vi. ver. 847 , \&c.

"rhe fubject nations with a happier grace,

From the rude ftone may call the mimic face,

Or with new life inform the breathing brafs:

Shine at the bar, defcribe the fars on higl,

The motions, laws, and regions of the fky:

Be this your nobler praife, in times to come,

Thefe your imperial arts, ye fons of lRome!

O'er diftant nations to ftretch your awful fwey,

To bid thofe nations tremble and obey.

To cruth the proud, the fuppliant foe to rear,

To give mankind a peace, or thake the world with war. 


\section{About a quarter of a mile caft from Cor-chefter, is}

Cor-bridge, an antient borough on the north banks of the Tyne, croffed by a bridge of feven arches; the manour of which was granted by the crown, $6 \mathrm{~K}$. Fobn, to Robert, fon of Roger de Clavering, baron of Warkworth, to hold, with all its regalities, in feefarm, by the annual fervice of $40 \%$ with the privilege of a weekly market, and an annual fair on the eve, day, and day after the feltival of St. Jobn the Beptift (s). It had alfo the privilege of fending two members to parliament, which privilege was difufed on the account of the burthen of the members expences; the names of two of whom are on record, viz. Adum Fitz-Alan, and Hugh Fitz-Hugh, 23 K. Edward I (b). Folm, the laft Baron Clavering, granted the reverfion of his honour of $\mathrm{W}$ arkworth, and of this and his other manours in this county, to the crown, 6 K. Edward I (i); which were given by K. Edward III, to Henry Lord Percy $(k)$; and are now in the poffeffion of his Grace the Duke of Nortbumberlend.

(g) Teftibus P. Danelm. epifc. Data per manum focelini de Welles, apud Eboracum, 8to die Marcii, anno. R. Fobannes fexto.

Rot. Clauf. de an. Gto R. Fobannis, m. I4.

Robertus filius Rogeri tenet in capite de domino rege villam de Corbrigge cum omnibus ferviciis pertinent. ad feod. ferm. quam dom. rex ei dedit ad fermam, et per chartam fuam confirmavit, reddendo inde annuatim ad fcaccarium dom. regis xxx. lib. de vet. feoffam. et nunc de increm. per ann, xl. lib.

Tefta de Nevill.

Fobannes filius Roberli tenet in capite de ómino rege Corbrigg, et eft burgus ad feodi fermam per ann. xl, lib. folv. tamen dom. rex talliat burgenfes ejufdem vil' $x$ cum dominicis fuis comitatus. Certificat. Hug, de Bolbeck, vice-comitis Norlbumbr.

Of this manour, and the crown-rent, 3 K. Fobn, fee Madox's Ferma Burgi, cap. iii. p. 54.

(b) Browne Willis's Notitia Parliamentaria.

(k) Pat, de anno 2 Ell. iii. p. I, m. 20. (i) Rot. Clauf. de asıno 6 Ed. I. in. 2. See Warkworth. 
Cor-britge is a large, populous, well-built-village. The church is an antient ftructure, dedicated to St. Andrew. Under an arcli, at the end of the north ifle, is a grave-ftone with the following infcription.

hIC IACOr IU reRRIS ASLIUI FIIIUS hUGO.

K. Henry I, gave the impropriation and advowfon of this church and of the churches of Warkworth, Whittingbam, and Rotbbary, to his chaplain, Richard de Aurea $V_{a l l e}$, and after his death to the . churcla and canons of St. Mary in Carlife (l).

To the poor of this parih, Madam Elizabeth Ratclif, widow of Sir Edruard Ratcliff, of Diffon, Bart. and mother of Francis, Earl of S) erientrater, by will, dated, 18th Deccmber, I668, gave, out of an annuity or rent-charge of $20 \%$ per anmum, which the then had of Mr. Francis Sutton of Grecn-Croft, sol. to the poor of this parifn; to be difributed annually on St. Lucie's day, or thereabout.

Mrs. Urfula Mountney left 20 s. per anmun, for the fane ufe.

Mrs. Anne Swinburn, of Dilfon, by will, gave $46 \%$. to the poor of this parifh, to be diftributed at Dilfon, upon St. Thomas's day before Chrifmas.

(1) Herr. Rex Anglize Ran. Dunelm. Epifcopo \& Rogero Picoto \& omnibus fidelibus fuis francis \& Anglis \& miniftris de Norlbumberland, falutem. Sciatis me dedife Ricardo de Aurca Valle Capellano meo, quatuor ccclefias de quatuor meis maneriis; fcilicet Werebeorda, \& $C_{0}-$ lcbruge, \& in Wilingbam, \& in Rodeberia, tam in terris quam in decimis $\&$ in hominibus qua ad terras harum ecclefiarum pertinent, cum Seca \& Soca, \& Tol \& Tean \& Infanjentetph, cum omnibus fuis confuetudinibus volo ut ipfe habeat \& teneat : tu věro Rogere Picot. . . . cum inde, aut Aiuricus de Colebruge, aut Hamo Balifarius præpofitus, aut Emezvinus propofitus. T. Roberto Epifcopo Lincoln. \& Willielmo de Worlewaft, \& Eurardo filio comitis, \& Thoms capellano apud Circefriam, in natale S. Fob. Battifre.

Carta Regis Howici I. Monaft. Angl. Vol. ii. p. 73. 
Madam Ann Ratcliff, of Dilfon, Sifter to Francis Earl of Derwentwater, gave to the poor of this parifh $10 l$. per annum; alí $30 l$. per annum, to bind apprentices.

The Rev. Mr. Robert Troutbeck, vicar of this parifh, by will, without date, made in the time of health, and declared and publifhed to be his will, I2th May, I706, gave to the poor of the parifh of Corbridge and chapelry of Halton, a certain melfuage and lands in Corbridge which coft him $100 \%$. the annual rent to be diftributed to them by one of the name of Troutbeck, or by the minifter and churchwardens for the time being. He alfo gave $50 \%$. to the poor of the parifh of Dacre in Cumberlant, where he was born; and another $50 l$. to the parilh of Borvnefe in the fame county.

On the fouth fide of the cliurch, is an old tower, which was the town-gaol; and near it is the market-crofs, now diffufed.

A large piece of Roman plate was found in the bottom of an enclofure on the fouth fide of the town, by the river Tyne, in March, 1735. It was found in a boggy place by a little girl bclonging to a Smith, as the was at play with two or three other children. The clofe belonged to Richard Camaby. The fine raifed work, and fculptures upon it, induced the children to carry it home to the Smith's to play with. The Smith foon difcovered it to be worth his care. He took it privately to Nerecofle, and fold it to Mr. Cookfon, a Goldfmith, in that town; with whom it did not remain long, before it came to the knowlege of his Grace the Duke of Somerfet, who claiming it as Lord of the manour, it was fent to him; and is now in the poffeffion of his Grace the Duke of Nortbumberland. It weighs 148 ounces. It is in Thape Vor. II. 
like a tea-board, twenty inches long, and fifteen broad, hollowed about an inch deep, with a flat brim an inch and a quarter broad, neatly flowered with a vine full of grapes, \&c. Under the middile of it was a low frame, about feven inches long, four broad, and one and a half decp. This was broken off by the Smith. The following curious account of the fculptures, and of the ufe of it, was given in a letter to $\mathrm{Mr}$. Cay of Nerucafle, by that learned: and cminent antiquary, Roger Gale, Efq.

"I fhall begin from the right hand of the plate as you look at " it, where Apollo, the principal figure in the whole plate, is "placed under a fmall 'Temple, or Fanum, fupported by two " wreathed columns with flowered capitals, almoft naked, hav"ing only a Pallinm hanging down from his left thoulder over " his back: In the fame hand is his bow, which he holds up to"wards the top of the column on that fide; his right is extended " downwards with a branch in it, perhaps of laurel, crofs the "other pillar; againf which rifes a pyrimidical pile of eleven " pieces, beficle the top; for what it is intended I mult confefs " my ignorance. Againft the bafis of the left hand-column refts " a Lyre, whofe form is truly antique: beneath it grows a plant "with three fpreading flowers upon its three extremities, de"figned, as I believe, for a Heliotrope, and clofe by it couches a "Griffn with its wings elevated over its back. The antients had " a high opinion of the fagacity of this fictitious animal, and " therefore confecrated it to their God of Wifdom. In Bergerus's "Thefaurus Palatin. is a medal of Commodus, the reverfe whereof " is Apollo drawn in a chariot by two Griffins, and the poet Clau" dian alludes to his manner of riding thus in the following " diftich. 
"At fi Phœbus adef, et frenis Gryphá jugalem

"Riphæo, Tripodos repetens, detorfit ab exis, \&c.

"Clofe to the right hand column, and this pyramidal pile, "fits a woman upon a fquare four-footed ftool, though no more "than two of its legs are vifible; the looks backwards over her "left thoulder towards Apollo, is wrapt up in a long garment, " or Stola, from head to foot, and veiled: by this drefs and attire, " and an altar with the eternal fire burning upon it juft by her, " which was brought with her from Troy, I take her to beVefta.

"_- Manibus vittas, veftamque potentem,

" Eternumque Adytis effert penetralibus ignem. Virg.

"Et vos virgineâ lucentis femper in arâ

"Laomidontiæ Trojana Altaria flammæ.

Sil. Ital.

"The next is a woman crect, her hair gathered up, and tied " with a knot behind; upon her forehead rifes a Tutulus, and the " is habited in a Stola from the fhoulders to the ground. Her "right arm is wrapt up crofs her breaft in her garb, only the " hand appearing out of it; in her left the holds a fpear, the " thaft twifted, the iron of it fomething obtufe. This feems to " be the only human figure in the company; but a very learned "gentleman of my acquaintance thinks it may be defigned for "Funo, who is often thus accoutred with a fpear. If fo, it muft "be the effigies of the Funo Curis, or Funs brafata; we have it from "Ovid,

"_- Quod hafta curis prifcis cft dicta Sabinis.

"She was the fame with Funo Promuba. "Cclebri hafta nubentis "caput. comebatur, vel quia funonis Curitis in tutela effet, vel ut R 2 "fortes 
"fortes viros ominaretur"; but as there is no Peacock, or any " other attributes of her divinity attending her, and her appear" ance no ways majeftic, nor adequate to the

"_ Divum Regina, Jovifque

" Et foror ct conjux-

"I cannot be entirely of his opinion, cfpecially as the follows, " and feems to be an attendant of the next figure, which is

"Pallas, Galea effulgens et Gorgone Savâ, the head of that monfter, " as ufually, bcing fixt upon her breaft. In her left hand the " holds a Tharp pointed fpear, her right is extended towards "Diana, with whom the fecms engaged in a very carneft dif" courfe, to which alfo that other Goddefs is very attentiva "She is

"The laf figure of the group, (though called a man in all the "accounts I have feen of this table) and reprefented here as the "Diana Venatrix by the feminine drefs of her head, tucked up "with a knot behind like the hair of the third figure; by the "bow in her left, and arrow in her right hand; her thort Tunica, " which reaches down a little more than to the middle of her " thighs, and her butkins that come up no higher than the calf " of her leg, have occafioned this miftake of her fex; but Ovid "tells us,

"Talia fuccincta pinguntur crura Diane "Cum fequiter fortes, fortior ipfa, feras.

"Berween the two figures of Pallas and Diana rifes a tall flender " tree; with a crooked waving ftem, the branches of which are s difplayed 
"difplayed at the top almolt over $\frac{2}{3}$ of the plate. "On the main "branch is perched an Eagle, with one wing expanded. This is " of raifed folid work like the ref of the figures, but there are "feveral fmall birds fitting among the boughs that are only "punched, or cut in with a tool, as are alfo feveral feltcons hangr" ing down from the tree, and other little fhrubs and fowers in. " terfperfed all over the area of the table. The great bird fitting "directly over the head of Pollis, and the attendance of the little " birds about it, made me think it was her Orel, tili I had feen the "original, which convinced me, that it can be defigned for no" thing but an Eagle.

"Under this tree ftands an Aliar, and fo clofe to Diana, that fhe "holds her left hand and bow over it. It is but a fmall one, and " has nothing upon it but a fmall globular body, perhaps a " mafs of the Libamina ex Farre, Melle, et Oleo.

"I Ihould have told you, that below the feer of Pallas grows a "plant that feems to bear two ears of corn upon the ftalk, but " cannor fay what it is, or how it belongs to her: beneath the " tree, and the little altar, ftands a thin-gutted dog, like a Grey" bound, his nofe turned up in a howling or barking pofture, as "often exhibited with this goddefs on medals, and in other "reprefentations of her, fome

“_ acutx vocis Hylactor

"Aut fubftricta gerens Sicyonius Ilia Ludon._ Ovid.

"Under her, in the very corner of the plate, rifes a Rack; upon " which the fets her left foot, and again the fide of it lies an "Urn, with its mouth downwards, difcharging a plentiful ftream. 
" of water. As the ftands upon this rock, or hill, and fo near to. "this fpreading tree, I cannot but think of Horace's addrefs to " lier

"Montium cuftos, nemorumqùe, Virgo.

" The whole table is encompaffed with a border, raifed near " an inch high, and ornamented with a creeping vine; the grape " and leaves are in relievo, but the falk only tooled.

"The work of this curious piece is neither of the beft nor " worft of times; the figure of Vefa particularly is extremely "well exccuted, the pofture very free, the drapery foft and eafy; " and what is very remarkable, the Infita or borler, an orna" ment of the Stola appropriated to the Roman ladies of quality,

"Quarum fubfuta talos tegit inflita vefte,

Hor.

" is neatly worked all round this our $V$ efla: nor is the next figure "much inferior. I camnot, nor any body elfe that has feen it, " difcover that the plan has any relation to any fory in the Hea"then Mythology, but feems only an affemblage of the Deities " it reprefents. This may be fome argument of its antiquity, for " had a modern workman had the defigning of it, he would, in " all probability, have taken fome known piece of hiftory for his " fubject: to which I may add, that all the fymbols are genuine, " and truly adapted to their owners.

"I once thought it might have been the cover of an Acerras " but the foot, which fupports it, puts an end to that furmife. "We do not well know what the Anclabris was; the definition of " it is in Fefus, "Menfa divinis minifteriis apta, dicebantur autem" 
"Anclabria et Anclabris, ab anculare, quod erat miniftrare." "This is big enough to contain the Exta of a fheep, and other. "fmall victims, which feems to me the likelieft employment for " it: and that it was one of thofe facrificing utenfils that Virgil " morc than once calls Lances.

"Lancilis et pandis fumantia reddimus exta.

"_-_L_Lancefqùe et liba feremus.

"Dona ferunt, cumulantque oneratis lancibus aras.

"The Lances were both round and fquare; the Difiss, ufed in "facrifices for the fame purpore, fcems to have been always "round."

A print of it was publifhed by Mr. William Shaftoe.

Two famous altars, with Greek infcriptions, were found in Corbridge church-yard; one in honour of the Tyrian Hercules, dedicated to Diodora the prieftefs; large, hollow at the top, as ufual . for incenfe.

$$
\begin{gathered}
\text { HEPAK EI } \\
\text { TYPI } \Omega \\
\Delta I O \Delta \Omega P A \\
A P X I E P E A .
\end{gathered}
$$

The other is in honour of the Syrian Goddefs, Aftarte, and thus read by the learned Siukeley (l).
A C T A P TH C
$B \Omega M$ M N .
ECOPA C T
T O Y A X P M
$A N E \Theta H K E N$.

(l) Caraus. Vol. ii. p. 161. 
Marcus Eforaft, the fon of Acherm, dedicates this altar to Aftarte. He fuppofes thefe names to be Syrian, Arabic, or Punic: Marcus, the Prenomen to be adoptive, to romanize him; and that he is the prieft, who fet up the altar.

That of Hercules was publihed by Mr. Horfley, who reputed it one of the greateft curiofities of the kind in Britain. It is now in the poffeflion of his Grace the Duke of Nortbumberland. The other is in the poffeflion of Mr. Walton*. The honourable Mr. Baron Legge gave the infcription to the Royal Society, and it has been elaborately explained by one of their learned members, Mr. Bowman.

Hercules was the fymbol of the Sun. Fulian informs us ( $m$ ), that magnificent fports were celebrated at the conclufion of the year

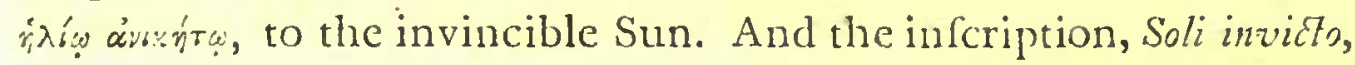
is found upon the medals of many of the Roman Emperors.

Divine honours were paid to him in open temples and groves, the inftitution of which is very antient.

Primufque Potitins auctor,

Et domus Herculei cuftos pinaria facri

Hanc aram luco ftatuit, quæ maxima femper

Dicetur nobis, ct crit quæ maxima femper.

Virg. An. viii. ver. 269, \&c.

* Since dead, and his collection of Roman and other antiquities fold by his executors to the Hon, and Rev. Mr. Grabam, of Nciberby, in Cumbirland.

(m) Orat. iv.

See Maundrall's Travels, or Journey from Alappo to Ferufalem, p. 21. 


\section{Potitius firt, his gratitude to prove,}

Ador'd Alcides in the facred grove;

And, with the old Pinarian facred line,

Thefe altars rais'd, and paid the rites divine,

Rites, which our fons for ever thall maintain ;

And ever facred thall the grove remain.

Pitt.

Aftarte was the fymbol of the Moon, being worhipped by moonlight in open temples and groves, firft with pure, and afterwards with impure, rites. In the facred writings the is fliled Aftaro: $b$, alfo the Deity and abomination of the Sidsnians ( $n$ ); a mercantile people, to whom a curious author afcribes the firt invention of building long thips of war, and the contrivance of filling them with oars, in fuch a manner that no void fpaces might be left (0). The Prophet complains, that Solomon went after Afotaroth, the Goddefs of the Sidonians. Fezabel firt paid her divine honours in Ifrael; the moft antient Temple that of Afcalon; 400 Prophets attending her.

Her altar here is thought to have been made by a marine legion, raifed by Hadrian in Syria, called, The Ulpian legion; which in Maximian's time followed the fortunes of Caranfius.

She is reprefented on coins as cloathed in a fhort garment, muda genu. On the reverfe of a medal of Antonimus Pius, fruck at Orothofia, a maritime town in Syria, we have her treading on a river $(p)$. That antient city and Corbridge have in one refpect a fimilar fituation, being both built on a rifing ground, and on the northern banks of a river ( $q$ !.
(n) Judr. 2. 13 .
(o) M. Meilomii de rabica Triremium, Lib. 4to. Amf. 16-1.
(p) Stukeiey's Caraus.
(a) Dr. Sharc's Travels.

VoL. II. 


\section{In fight from Corbridge, on the other fide of the Tyne, is}

Dilfan, a contraction of Devilfone, fo called from its fituation on the eaflern banks of the ftony brook Devil; the villa, manour, and feat of the antient family of the Devilfone's; of Sir Thomas dc 1)evilfone, in the reign of King Henry III $(r)$; and of Sir Simon de Devilfone, in the reigns of King Edward I. II (s). It was aftervards fucceflively poffeffed by the Tynedales ( $t)$, the Crafters (u), the Claxtous ( $v$ ), and the Ratcliffs. It was in the poffeffion of Sir George Ratclif, of the antient houfe of the Ratcliffs of Car-

(i) Thomas de Dcuilfone tenct de Dom. Rege in capite villam de Devilflone per tertiam partem unius fcudi militis : et omnes anteceflores per eund. fervic. poft tempus conquefti tenuerunt. Et idem Thomas mortuus eft, ac hered. terr. ejus funt in cuftodia Roberti fil. Rogeri pro commiffione Dom. Regis durante placito fui majeftratus. Et de illo tenemento nulla eft alienatio five donatio, \&c. unde Dom. Rex minus habeat de fervicio fuo.Tefta de Nevill.

(s) Efcaet. de anno $18 E d$. I. et de anno is $E d$. II.

Certificat. Hug. de Bolbeek. Vice-comit. Northumbr. Simonus de Devilfone tenet in capite de Dom. Rege villam fuam de Devilfone per tertiam partem unius Feod.. Milit. vet. Feoffam. Efc. de anno I $E d$. I.

(t) Efcaet. de anno I Ri. II.

(u) Crawfer obiit feifitus de et in mancrio de Devilfone, cum advocatione unius Cant. Sanctr Maria Magdalen. infra idem manerium.-- Efcact. de anno I Hen. IV.

Richardus Crawcicfer tenet manerium de Devilftone cum pertinen. in comit. Northumbr. de rege in capite por firvic. tertiæ partis unius feodi militis.

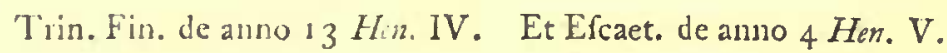

(v) Gulielmus Claxton, certus filius Willielni Claxton, filii Edvardi Claxton, filii Dionifra, Groris Willitmi de Tynedale, patris Willielni, Emma nuper uxoris Richardi Crawcefer, confanguin. ct haer. ejufdem Emme tenet manerium de Deviljone in comit. Northumbr. de rege in capite per fervic. tertiæ partis unius feodi militis.

Mich. Fin. de anno 2 Her. VI. 


\section{ANTIQUITIES OF NORTHUMBERLAND. 131}

tington, 10 Q. Elizabetb (w); and of Sir Edward Ratcliff, Bart. whofe eftate was fequeftred by the parliament, 4. K. Clarles II. I652; and whofe fon and heir, Sir Francis Ratcliff, Bart. married the Ladly Mary Tudor, natural daughter of that King, by Mrs. Mary Daris, and was created Baron of Diffon, Vifcount Langley, and Earl of Derwentwater, 3 K. Fanes II, I68\%. He was fucceeded by his fon, Fames Earl of Derwentwater, who marrich Mary-Ante, the daughter of Sir FolonWebl, of Dorfetflaire, Bart. His Lordhip being under attainder, 1715 , this and his other eftates $(x)$ were forfeited to the crown, and given to Greentuich-hofpital. His relict, Lady Derwentwater, died on the igth of Augut, 1723, of the fmall pox at Bruffels, aged about $3 \circ$ ycars. Her corpfe was carried the day after the died to Lowvain, to be interred there in the church of the Linglifh regular canoneffes of St. Auftin. In December $173 \mathrm{I}$, the young Lord Derventwater died; whofe fifter, a fortune of 30,000, married the Lord Pctre, 2d May, 1732.

Half a mile eaft of the i6th mile-ftone on the military road, on the right hand, by a fmall cottage, is the Roman ftation,

Hunnum, or Halton-Chefers, at the head of a pleafant flope ( $x$. As fome labourers were turning up its foundations for the fake of the flones to mend the road, they met with a centurial fone with the following infcription, within a civic garland, the creft of the imperial eagle at each cnd.

(w) Georgius Ratiff, miles, fuit feifitus de ct in manerio de Devilfone, de ct in mansrio, caftro, et villa, de Cartington, cum medietate villæ dc Throckley, et certis terris in Sniter, ct. in Thrompion._- Efaet. de anno ro Eliz.

(x) See the Rental in the Apsent. publifhed by Order of the Parlianient.

(y) Horylay's Eritain. Reman. 


\section{E G. I I. A V G. \\ F.}

It is now in the cuftody of Sir Edward Blacket, Bart. They alfo found one of thofe inftruments, called, Extipicia, ufed by the Auppices in examining the bowels of animals. It was in the form of a pencil, or Roman Stylus (z), of wood, very hard.

They found another centurial ftone, broken off at one corner, infcribed,

\section{E G. X X. V V. H O R T E N S.}

\section{P R O C U L.}

This legion performed an annual folemn facrifice of a hog or boar to Ops, the Earth, and to Ceres, after harveft, in grateful return for it $(a)$.

An abundance of ftag's horns, lying by heaps of mufcle-fhells, were digged up at the fame time; alfo fome fmall copper-coins of Conftantine, and his two fons, and of the two ufurpers, Magnentius and Decentius (b).

A filver coin of Nero's was found at or near this fation, which came into the poffeffion of Mr. Walton.

(z) Baron Clerk's Differtation, de ftylis veterum, et diverfis chartarum generibus, $\mathrm{Ph}$. Tr. No. 420 .

(a) Stukeley's Caraus. Vol. i. p. I 98.

(b) Of which, fee Thorefby's Topogr. of Leeds, from p. 326, to p. 131; and p. 336. 
Many urns, both of finc and coarfe pottery, have been digged up, but all broken by the incautious workmen.

A little below this ftation, and in fight, is

Halton-Toreer, the feat and manour of the antient family of the Haltons; of Gobnde Halton, in the reign of K. Henry III (c), and part of the reign of K. Edward I ( $d$ ); and of his fon, Witliam de Halton, of Denum, I7 K. Edward I (d), high fheriff of Nortbutnlerland, 25 of the fame reign (e); on whofe death a medicty of it came to his fifter, Murgaret, who was fucceeded by her kinfman, Robert de Lowether $(f)$; the other mediety being poffefed by a branch of the Carnaby's, of Carnaby, ncar Bridlington, in Yorlhthir, by marrying another fifter and colicir. On the death of Robert de Lowther, in the beginning of the reign of K. Richers II $(g)$, the family of Carnaby had the whole manour, by whom it was

(c) Fohannes de Haiton tenet in capite de dom. rege Halton, Clarervood, ct W'itingtm, in Dringagium, et redüit dom. regi per ann. $x$. et debet talliuri cum dominicis regis, ac dehet Heriotam, et Merchet.

Certificat. Hug. de Bolbeck, vice.comit. Nirtbumbr.

(d) Willielmus, filius Fobannis de Halton tenct Denum per reddit. x. Baron de Bolam.Certificat. ejufd. Raron de Bolbck.

Willitmus de Halton, filius et hxes fohannes de Halton, dat regi vi Marc. pro rclevio fuo, pro fex annis quas folvit regi pro manerio de Haiton.

Mich. Fin. de ann. 16, et I7 Ed. I.

(e) Dugd. Monalt. Angl. vol. ii. p. 92.

(f) Robertus de Lowiber, confanguines et hæres M'argarita filiæ Fobannis de Halton, tenet medietatem manerii de Halton ct Clarewcod de regge in cafite, pro fidelitate, per fervicium xxxviii, in Dringugio, et vii. ad Cornagium, per annum, pro omnibus ferviciis.

Trin. Fin. de anno $3^{8} E d$. III.

(g) Efcaet. de anno ro Rir. II. 
poffeffed for many generations; by William Cumaby, 9 K. ITen. IV, $6 \mathrm{~K} . H_{c} n . \mathrm{V}$, and $7 \mathrm{~K}$. Hen. VI, then high theriff of Nortbumber land (b); by Sir Golon Carnaby, 35 K. Henry VI, and 4 K. Edward IV (i); by Sir Reginald Carnaby, high theriff of Nortbumberland, 33 K. Henry VIII (k); by Sir Cutbbert Carnaby, high theriff of Nortbumberland, 9, and 5 Queen Elizabeth (l); by Sir Willian Carnaby, knt. who was a reprefentative in parliament for Morpeth, $21 \mathrm{~K}$. Fames I, 1603 , and for Northumberland, 3 K. Charles 1, 1628; of which he was high theriff, in th of the fame reign. He was a member for Moipethagain, 16 K. Charles I, 1640, and was expelled the houfe, 26 Augut, 1642 , for refufing to attend it, and raifing forces for his majety. He was at the battle of Marfon-moor, in the Northumberind-regiment commanded by the Marquis of Newcafte, with whom he retired beyond feas after the battle. Serjeant-major Cumaby was taken prifoner by the parliament-forces at the battle of Thakefield, 21 May, $19 \mathrm{~K}$. Charles I, 1642.

In one of the rooms joining on to the tower, is preferved an old fword of the Cambly's, 64 inches long. .

Such fwords as this were ufed by the Gauls in their wars with the Romans; as a defence againft which, the Roman general, $\mathrm{Ca}$ millus, contrived a thield or buckler, of iron-work, of the Parma -

(b) Efcaet. de annog Hen. IV. 6 Hen. V. No. 37. 7 Iten. VI. Fuller's Worthies.

(i) Efcaet. de anno 35 Hen. VI.
$\longrightarrow{ }_{4} E d . \mathrm{IV}$.
(k) Fuller.

(l) Cutbertus Carnaby fuit feifitus de et in manerio de Halton, Halton-theels, Clarewood, Lyham, et Satlingtones, de et in medietate villæe de Magn. Whittington, cum terris in Newbiggen, ac de in White-houfe, Ayden-Hall, et Carr-Hou'es, cum terris in Harnham, et Morylee. Ercaet. de anno ro Eliz. 
kind, of a round form, and adorned with ftuds of brafs. Mars Bellator or Gradivus, not Guirinus, is ufually defcribed with fuch a fhicld. It was part of the Armatura Equitum, and carried in the left hand. The ingenious and humane antiquary, Mr. Ralph Thoresby, of Leeds, was poffeffed of one, of which he publifhed a defcription, and a neat print, with a learned difiertition $(m)$.

At the time that this country was infefted with thore thieves, called Mofs-Troopers, one of this family had a commiffion to apprehend and try them. Whilft he was decply engaged on the trial of fome of them, a very notorious and defperate villain was feized by his fon, who afked his father what he fhould do with him; Do with him, faid the father! Why, hang him. As foon as the trial was ended, he ordered the man to be brought before him, but was told he was hanged inflantly, according to his order. On complaint being made to the crown, a fine of ${ }_{4} l$. per ann. was laid upon Halton-eftate, which is ftill paid.

It was purchafed by Foln Douglas, of Newcafle upon Tyne, Lfy; who, 1706 , fet forward the rebuilding of the old parochial-chapel, towards which he gave $146 l$. 17 s. $2 d$. and the frecholders of Wbittington gave $78 \mathrm{l}$. 1 s. I $d$.. It ftands at a fmall diftance from the towver, on the eaft fide. Divine fervice is performed at it every third Sunday in the forenoon by the minifter of Corbridge.

Fobn Douglas, Efq; was fucceeded in this and his other eflates by his fon, Oley Douglas, Efl; a reprefentative im parliament for Worpeth, 1713, whofe only daughter and heir marrying Sir Edward Blacket, Bart. they are now in his poffeffion.

(ni) Ph. Tr. No. 24 I. 
Halton-Tower is fmall, and fquare, having four fpeculating turrets at top, and is covered with lead. It ftands on the caft fide of a fimall fream, above a bank of tall foreft-trees. About a milc fouth from it, is

Ayden-Cafle, fo called from its fituation on the brink of a high or ftecp den or gill; the borderers pronouncing high, $A y$. It was the feat of Emma de Ayden, a rich heirefs, I K. Edward I, who was difpofed of in marriage by that King to Peter de Walles (n), who had it for the term of his own life. He alfo had Burneton, i. c. the town by the burn, or brook, and Little Whittington, for the fame term (0). His name was local, from $V^{r}$ alles in France, the caltle and vill of Sir Ricbard de Walles, 34 K. Henry II, II 87 , fituated between Erie and Gifors; whore fon, Ralplo de Walles, was flain, and many of his father's fervants wounded, in an encounter with Henry Vere, conftable of Gifors, under the Englifo general, William Earl of Albermarle, in the defence of his workmen, fortifying his calle of Walles. One of the three itincrant judges appointed by K. Henry I, i i $7^{6}$, for the northern counties, was Robert de Wralles $(p)$. The orthography of the name of the celebrated Scotch patriot, Sir William de Walles, or Wallafe, and that of Peter and Robert de Walles, are alike in our old annals $(q)$; and it is not improbable, but that Sir William was derived from the fame ftock; and that their anceftors came into Britain at the Norman conqueft.

(n) Fmma de Ajden fuit feifita de Aidin, cum Caftro; eft de dono dom. regis, ct marriata it Petro de livalles.

Efcact. de annu I Ed. I.

(0) Petrusde Walles tenet Ayden, cum caftro, Burnton, et parva IVlittington.-

Id.

(b) Hol. Chron. vol. ii. p. 98 ; and p. 103.

(a) Id. 


\section{ANTIQUITIES OF NORTHUMBERLAND.}

The manour, caftle, and half of the village of Ayden, came afterwards to the antient family of the Raymes's, of Bolbam; and were in the pofrefion of Willian de Raymes, $43 \mathrm{~K}$. Edward III $(r)$, high theriff of Northumberland, $16 \mathrm{~K}$. Richard II $(\mathrm{s})$; alive, $3 \mathrm{~K}$. Henry IV (t); of Edruard de Raymes, $35 \mathrm{~K}$. Henry VI (u). We find a medicty of them poffefled by Robert de Raymes, ro (. Elizabeth (v), high theriff of Nortbumberland the year following (w); and by Henry de Raymes, in the reign of K. Charles I (x); the other mediety of the manour and caltle of Ayden being in the pofleffion of the Carnaby's of Halton $(y)$.

Ayden-Cafle, with the manour of Ayden, was purchafed by Golne Douglas, Efq; and is now in the poffeffion of Sir Edward Blacket, Bart. The caftle ftands on the weft fide of the den, watered by' a fmall ftream, above a precipice, the eaft end of which, being the fteepeft, is called Fack's Leap, from a young man's cafting

(r) Willielmus de Raymes obiit feifitus de et in manerio de Ayden, medietate villa de Ayden, medietate manerii de Bolham, et una placea in Cramlington. Efcaet. de ann. 43 Ed. III.

(s) Efcaet. de anno 16 Ric. II.

(i) - 3 Hen. IV. n. 2 I.

(ii) 35 Hon. VI.

(v) Robertus Raymes fuit feifitus de et in medietate manerii de Bolham, cum villa, et de et in Short-fiat, South Middleton, cum medietate de Ajdch, Witton, et certis tcrris in Hawkwell, et Stamfordham.

Efcaet. de anno ro Eliz.

(w) Fuller's Worthies.

(x) Henricus Raymes, arm. confanguin, et hæres Roberti, tenet in capite medietatem hamlet. et maner. cum caftro, de Ayden, et fex meffuag. et terras ibidem.

Ex Lib. feod. Pet. Ofoorne, Militis.

(y) Vid. Halton.

Vót. II. 
himfelf headlong from it. It has been a large and ftrong building, but moft of it is now in ruins. It is encompalfed with a high ftonc-wall, pierced with arrow-holes; within which is a ftable built cutirely of ftone, without any timber, the roof of: arch-work, and the mangers of ftone. It has a finc profpect of Hexhom, of Benufront, and the river Tyne.

Between the 14 th and $13^{\text {th }}$ mile-fones, on the military road; a ncat road branches off from a handfome gate on the left hand.: to

liselt Matfer, which in the reigns of K. Fobn and Henry III, was. the manour of Pbilip de Clcote, who held it by grand Sergancy, by: the fervice of keeping the pleas of the crown $(z)$. He was join-. ed in commiflion witl Hugb de Baliol, i 7 K. Fobn, 12 16, to hold. the caftle and town of Berwick upon Treed againft the barons ( $a$ ). He was high theriff of Nortbumberland, 16, 17 K. Fobn (b), and I, $2,3,4 \mathrm{~K}$. Henry III (c). He died, I $5^{\text {th }}$ of the lat reign. . He was fucceeded in this and his other eftates by his five fifters, viz. Alice, Margaret, Fuliana, Ifabell, and Confance, as was found by an inquifition in that year (d).

(z) Pbilippus de Ulcote tenee $1 V_{\text {eft }}$ Matfen et Nafferton per ferjanc. profervicio cuftodiendi placita coronæ.

Tefta de Nevill.

(a) Hol. Chron. vol. ii. p. 189 .

(b) Efcret. de annis, 16, 17 fob.

(c) - $1,2,3,4 \mathrm{Hen}$. III.

(d) - de anno 5 Hen. IlI.

Alice de Ulcote, Hameline de Buggthorp and Margaret his wife, Alured de Barnely and fuliana his wife, Thomas de Stration and Ifabell his wife, and Daniel Nicholfon arid Confance his wile, 
It was afterward in the poffeffion of the Feltons; of Sir Willitin "de Felton (e), high theriff of Nortbumberland, 5, 6, 7, $8 \mathrm{~K}$. Edward II $(f)$; and $12,13,14,15,16,17 \mathrm{~K}$. Edreard III $(g)$; alfo a repre"fentative for it in parliament with Sir Robert de Manners of Etall, $14 \mathrm{~K}$. Edward III, $134^{\circ}$; who were allowed by the county, $23 l .4 s$. for their expences $(b)$ : of Sir Foln de Felton, $42 \mathrm{~K}$. Edward III (i); of his fon, Sir Foly de Felten, high theriff of Nortbumberland,

wife, gave fourfcore maiks, that they might have the land of Safferton and Matfen, aud tw:o meffuages in the town of Newcafle upon Tyne, which late were of Philip de Ukct, tonther with the cuftody of the king's coronerhip and forefterhip is the county of Nortisinubriand, belonging to the faid lands: which lands, together with the faid cuftody, do belong to the faid Alice, Margaret, Fuliana, Ifabella, and Confanie, fifters and coheirs of the faid Plilip of Ulcot. And the faid Alice, Hameline, Morgaret, and others, attorned the faid Daniel and Conffance by their confent, to render the faid fine, and to anfwer to the ling for the fuid cuftody.

Hadx.s Hift, of the Exclueguer, 1). 320 .

(e) See Mitford-Cafte.

(f) Efcact. de annis, 5, 6, 7, $8 \mathrm{Ed}$. Il.

(g) $12,13,14,15,16,17 \mathrm{Ed}$. III

(b) Madox's Hiftory of the Exchequer.

Willielmus de Felton tenens terras (in Matfen et Nafferion) qux fuerunt Thome filii Roberti de Blythe, dat regi $\mathrm{V}$. pro relevio ipfius Thoma, pro $\mathrm{xv}$ acris terræ, fex acris prati, et fex villanis.

Rot. Mich. Fin. anno 2 Ed. 10.

Willieinus de Feltontenens terram qua fuerat Richardi filii et hæredis Fohannis de Bromferton, dat regi x. pro relevio dicti Richardi, pro quibufdam tenementis in Matfen, in comit. Northumbr. Tenet de rege in capite per fervicium $x$. per annum dom. regi.

Rot. Mich. Fin. anno 7 EdII.

Willielmus de Feiton obiit feifitus de ct in manerio de Wef Matfen, \&ic.

Efcaet. de anno 33 Ed. III.

(i) Fobannes de Folton obiit feifitus de et in mancrio de Ir'el Matfen, \&xc.

Efcaet. de anno 42 Ed. III. 
14 K. Richard II (k). He died, 4 K. Henry IV. He left one daughter, Elizabeth, married to Sir Edward de Haftings (l), who at her mother's death, I $\mathrm{K}$. Hcwry V, fucceeded to this manour and other lands, according to a deed of fettlement made by the above-mentioned Sir Willian de Felton ( $m$ ). She, and her hufband, Sir Edvord, had a confiderable eftate in Matfon and Nafferton, $8 \mathrm{~K}$.. Henry IV (u). He was high Theriff of Norbumberland, $6 \mathrm{~K}$. Henry. $\mathrm{V}(\mathrm{o})$. He was fuccecled by his fon, Fabn de Haftings.

\section{(i) Efiact. de anno 14 Ric. II.}

(l) Dicunt juratores fuper facrum furm, (viz. Thomas Heren, fenr. de Melden, Nichalous Turpin, de Whitclefer, Fobannes de la vale, de Benzuell, et alii) quod Gobames filius Fobannis de Felton, chro obit Die Mercurii proxime ante fefum Purificationis beata Maria ult. præter. Et quod E izabetha filia predial Fohannis Folton, chr. uxor Ecivardi Haylings, chr. eft hæres pradiati fohannis propinquior, virtute cujufdem donationis quam Willielmus de Felton fecit patri pradicti fohannis de Felton, chr. ct haredibus de corpore fuo exeuntibus, viz. filio pradict 'Gohannis de Felton, chr. filii prædicti Irillielmi, cui dicta donatio in feodo talliato facta fuit.

Inquifit. ex bundello efcaetr. turri Londinenfs, capta coram Wilitehn de Mitfort. a aetor. dom. regis in Northumbr. apud caftrum de Novo Cafro fuper $\tau_{y n}$. proxime poft feftum Annunciationis beatæ Marie, anno $4^{\text {to }} \mathrm{Hcn}$. IV

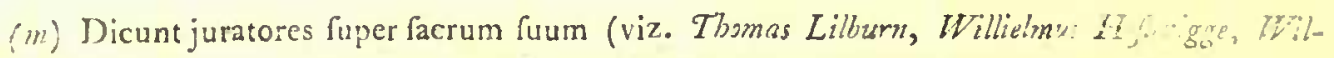
lielmus Bednell, et alii) quod Elizabotha, qux fuit uxor Fohanis Felion, decuncit, tenuit dis quo obiit manerium de $M a t f e n I V e f$, \& c. et quod Fohannos Haflings eft rectus et propinquior hares diai Gohannis Felton, viz. filius et hæres Elizabetbx, filix et hæredis ejuftem follannis Filton.

Inquifit. capta apud Morpatb Die Sabbati proxime poft Afcenfionem dom. Io Hen. V. cx bundello efcaetr. turri Lond. n, 23 .

(n) Edvardus Hafings, chr. et Eliz. uxor ejus, filia et hreres Fobannis de Felton, tenent fexaginta acras terre, fex acras prati et fex villanas in Matfon et Nafferton, in comit. Northumbr. de dom. rege in capite, \&c.

Rot. Hillar. Fin. turr. Lond, anno 8. Hen. IV.

(o) Efcaet. de anno 6 Hen. V. 
In ro Q. Elizabeth, this manour was in the pofleflion of Sir Ralph Lawfon, of Biker (p); who was fucceeded by his nephew and hcir, Henry Lawfon, Efq; anceftor of the prefent Sir Harry Lawen, of Brough, near Ricbnond, in Yorkflsire, Bart.

It was afterwards in the poffefion of a branch of the Fenavicks, of Fenwick-tower; alfo of Fobn and Oley Douglas, Ef(q; and now of Sir Edward Blicket, Bart. high theriff of Nortbumberland, 1757. Sir Edward's fear is a neat thonc-building, on a rifing ground; a grafs-llope before it by the rivulet of Pant, croffed by a findt bridge; a vifta extending from it for two miles to the military road ; tall foreft-trees on cach fide of the flope for thelter and ornament; a walk of a confiderable length to the eaft, with borders of flowers and flowering fhrubs.

In a field, on the eaft fide of the vifta, about three quarters of mile from the houfe, is a circular mount, with a round cavity in the middle, of the form of the Celtic tumuli, or temples; an upright ftone pillar ftanding by it, of a great fizc, nine feet high above ground, with flat fides, three fect broad, and a foot and a half thick. This ftone now bears the name of the Stob-ftone, and gives its name to a farn-houfe hard by. The mount is compofed of earth and numerous maffes of ftone of the coarfe ragkind, many of which have been digged up for the ufe of this farm, and among them were difcovered two ftone-chefts or coffins, confifting of four flags fet edge-ways, with a bottom-fone, and a ftone-cover, containing the alhes of the dead, appearing like a white duft.

Temples and funeral memorials like this, with cepititious or ftone-altars, and an upright pillar, untouched by the chiffel, are (b) See Byker. 
the moft antient of any in the world, were raifed in Fudea, and all over the Holy Land, by the caftern princes and patriarchs, by whom they were called Betbels, and Elbotbets. The manner of confecration was with oil poured on the pillax. One of thefe pillars mas crected by Gacob, and he called it the Houfe of God. ..." Facob rofe up early in the morning, and took the ftone that " he had put for his pillows, and fet it up for" a pillar, and pour"ed oyl upon the top of it. And he called the name of that place "Bcther: but the name of that city wa's called Luz at the firft. "And he faid, this ftone which I have fet up for a pillar, thall " be God's Houfe (p)...-Gacob came to Luz, which is in the land " of Canaan (that is, Bethel) he and all the people that were with " him. And he built there an altar, and called the place Elbes "thel (a).--A And Facob fet up a pillar in the place where he talked " with God, even a pillar of ftone, and he poured a drink-offer" ing thercon, and he poured oyl thereon. And Facob called the " name of the place where God fpake with him Bettael (")."

The making of the altars of earth, or of natural ftone as formed in the earth, was by the direction of God to Mofes.--." An "altar of earth thou fhalt make unto me. And if thou wilt " make me an altar of ftone, thou fhalt not build it of hewn " Rtonc: for if thou lift up thy tool upon it, thou haft polluted " it (s)."

Thefe temples were generally erected on the lighet ground, fuch as were moft confpicuous and obvious to fight. Thus one was built by Mofes ( $t$ ), and another by 70 fua, on
(p) Gen. xxviii. ver. I\&, I 9. 22.
(5) Exod, $x x$. ver. 24,25 .
$(q)-$ xxxv. ver. $6, \%$
(t) Deut. xxvii, ver. 2, 3, $4,5,6$.
(r) xiv. 15 . 
mount Ebal, compofed of whole natural ftones, or pillars plaiftered with plaifter, whercon they wrote the divine laws, in a great and general affembly of all Ifrael, of all the princes, great officers, judges, and people of every rank and quality, ftrangers and others; old and young (u.).

Single pillars were alfo ereted by thefe holy men over the graves of "the" ilfuftrious dead by fome public and mucle frequented road, to have their memories preferved, and to put the traveller in mind of their exemplary virtue and piety, of his own thort continuance on the ftage of life, and to fit and make himfelf worthy of fuch another honourable memorial at his death, and of an eternal diadem. Thus facob buried Rachel, the folace and partner of his cares, who died with the birth of their fon Benjamin.--.." Rachel died and was buried in the way to "Epbrath, which is Bethlebem. And Facob fet il pillar on he: " grave: that is the pillar of Racbel's grave unto this day ( $\omega) . "$

Perfons of inferior condition and figure were buried under the thady oaks that flourithed at the bottom of the mounts on which the Betbels or temples ftood. They were called the Oaks of Weeping,__ "Deborah, Rebekab's nurfe, clicd, and the was buried be" neath Bethel, under an oak : and the name of it was called $A l$ "lon-backuth (w)."

Heaps of ftones, rudely caft together, were the tombs they affigned to infidel-enemies after execution, even crowned heads, in avenues and places of great concourfe, to be warnings to the reft of mankind, how they rofe up againt the God of Ifrael, dif-
(u) Jor, viii. ver. $3^{0}, 3^{1}, 32,33,34,35$ :
(2) Gen. xxxy. ver. 19, 20:
(w) Gen. xxxv. ver. 8. 
honoured his Betbel, or holy temple. Such a memorial had the king of $A$, executed by $\mathcal{F}_{0}$ 乃 uab.__ "As foon as the fun was "down, Jofunab commanded that they fhould take his carcafe "down from the tree, and caft it at the entering of the gate of "the city, and raife thereon a great heap of ftones, that remain" etli unto this day $(x)$."

Such a memorial likewife had Achan and his family, whofe bodies were firft burnt to athes, with all their treafure and wealth $(y)$.

Hence the open temples, the pillars, the obelifks, the confecrated groves of oak, the heaps of ftones, reared by the pagans to their falfe gods, and to the memory of the dead. Hence the AEgptian pyramid. Hence the fair column of the Greeks (z), of the Romans, and of the feveral nations taught and ruled by the Druids; the primitive religious rites accompanying mankind upon their grand difperfion at the tower of Babel, about the 4ooth year after the flood, according to the Samaritan computa $\operatorname{tion}(a)$.

A road branches off from the I 4 th mile-ftone, on the right. hand, to

(x) Jof, viii. ver. 29 .

(y) Jor. vii. ver. 24,8 c.

(z) Hom. Odyfi. lib. 1. Clemens Alexandrin. lib. 1. Herod. lib. 5. Paufan, in Barot. et in $A c b$. Arnob. contra Gentes, lib. 1.

(a) Borlafe's Antiq. of Cornwall, p. 6, 7.

See Stukeley's StOneHenge, and Abury.

Byweill, 
Bywell, the barony of Hugh de Baliol in the reign of K. Henry III (b), high theriff of Northumberland for ten years together (a); of Foln de Baliol, in the latter part of the fame reign, and $\mathrm{K}$. Edward I (c); one of the twelve great lords, chofen by the ba-. rons, to treat in the three parliaments, $42 \mathrm{~K}$. Henry III, $125^{\circ}$, with the king's council, for all the commons, upon public burinefs; no more being chofen to make a parliament, or to repiefent the community, to fave, fays the record, the public charges, the members expences being defrayed by their refpeetive conft:tuents.

It was afterwards in the poffefion of the Nevills, Lords of Raby and Bolbeck; of Sir Folnn Nevill, I, and I2 K. Richorrd II (d); of Sir Ralph Nevill, created Earl of Weftmorland, 2 ift of the fame reign; and earl marhal of England by K. Henry IV ; his patent, dated

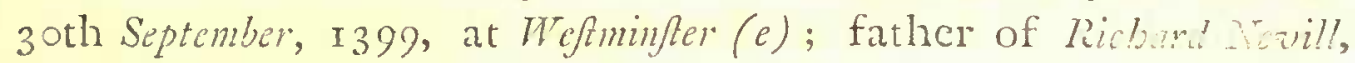
his fecond fon, who marricd Alice, only daughter and fole heir

(a) Hugo de Balizl tenet in capite de domino re ge baronian de Byw.ll, cum pertinen. per fervicium quinque feod. milit. et cum debit, ad wa:d. Avoi Caffit luper Tymanxx milit. omnes anteceffores fui tenuerunt per idem fervicium poft tempus domini regis tWillitmi $R n_{1}$ thi qui eund feoffav. et de tenemento illo nulla eft alienatio vel donatio, Ecc. unde dominus rex minus habeat de fervic. fuo Terta de Neri\%.

(b) Fullir's Worthies.

(c) Fobannes de Balicl tenet in capite de domino rege Newhygyns; Woodhorne, cum I,ynmouth et Hirf, membris fuis; Halywell, Lynton; dillington, cum Crefsweil et Aidon, membris; Bitchfield, Heddon nig. Stamfo:dham, cum Ulkfton, membr. Nuton et Tuton, Acomb, Stelling, Ovington, Eltringham, Micklcy, Whetinflaw, Falderfhaw, Bromeley, et medietatem de Bywell, per quinta feoda vet, feoffamenti. - Efcact. de anno I Edvolrali $\mathrm{L}$.

(d) Dugdale's Summons to Parliament. Efcaet. de anno 12 Ricarili II.

(c) Rym. Fod. Angl. tom, viii, p. 89. Acta Regia, rol. ii. 8vo. p. 6g.

Vol. II. 
of Thomas Montacuite, Earl of Salifury, flain at the fiege of Orleans in France, 7 K. Henry VI. I 428 ; lamented throughout England, the glory of its arms declining in France from that period; favouring the prediction of K. Henry V, in the gth year of his reign, at the fiege of St. Maur in France, That Henry of Windfor fhould lofe all that Henry of Monmonth had won, alluding to his own, and his fon's, nativity. This Ricluard, whofe feat was at the caftle of Middleham, in Torkfbire, was created Earl of Salifoury, in right of his lady, by whom he had three fons, Richard, Fobn, and George. Richard married Ann, fifter and heir of Henry Beaucbamp, Earl, and afterwards Duke, of Inerwick, in whofe right he was created Earl of Warwick. Folon was the famous Marquis of Montacnte, who commanded the forces of the houfe of rork at the battle of Hexbam, before mentioned. George was Archbihop of York, famous for his infallation-fcaft.

The old Earl of Hefmorland, their grandfather, was living in the glorious reign of $\mathrm{K}$. Henry.V, and was then high warden of ile marches towards scotland, and eminently diftinguifhed by his clocuence in the Britif? fenate $(f)$. I He had his cducation in Italy, Iis fuccellors, Earls of Wefmorland, were all named Ralph, in honour of him, till the time of Hewy, Earl of Wefmorland, fummoned to parliament, 1 Q. Mary, 1553; and I Q. Elizabeth, I558; one of the lords who, 2 Q. Mary, carricd before her, and her confort, Pbilip of Spain, one of the fwords of ftate to the parliament, in their robes of flate, on horfeback.

Henry was fuccedicd by Cbarles, Earl of Wefmorland, one of the eleven lords who protelted againft the act declaring the validity

(1) Ses his freech in the Parliamentary IIfitory of England, vol. xia. 


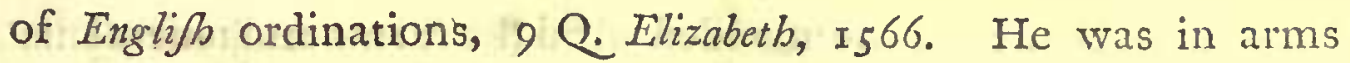
againft the Queen, 12th of her reign, 1569 , for which his honour of Bywell, and all his other honours and lands, his feat of Brampetb-caftle, near Durbam, where his followers reforted to him, were forfeited by a bill of attainder, $15 \mathrm{May}, 157 \mathrm{r}$. He efcaped beyond fea, where he died $(g)$.

The following furvey was taken, among his other honours and eftates, of the baronies of Bywell and Bolbeck, by Fidmonil Hall, and William Homberfon, by her majefty's commiffion, bearing date i 8 th March, 1569, and izth of her reign.

"Bywell and Bolbeck are two antient baronies, and are fituate in " thic extreme fouth part of Nortbumberland, between the rivers of "Tyne and Derwent; and albeit they be joined and mixed toge"ther, yet are the rents and tenants fevered and known the one "from the others. And to the barony of Bywell belongeth a fo"reft of red decr, well replenihed with game, which extendeth "alfo into the barony of Bolbeck, and the faid two baronies or "lordhips are thus abuttaled. That is to fay, the lordhip of "Hexbam on the wett, and the loidhips of Prudbow and Cloipreell " on the eaft, the river of Tyne for the mont part on the north, and "the river of Derwent on the fouth, and containeth in compafs "twenty two miles; that is to fay, in length from the cafl to the "weft fix miles, and in breadth from the river of Tyne to the ri"ver of Derwent five miles; within which two baronics are many "gentlemen and freeholders who hold their lands of the fird "baronies by feveral fervices, and are always attendant upon "the lords of the faid baronies in time of fervice, when

(g) Camdin in Koniact. 
" they thall be thereto commanded: And the farms and tenements " in the faid baronies are wcll planted with coppice woods for the "prefervation of the red decr; and in the waftes are divers woods, " and very fair courfing with greyhounds; whereof one wood is "called Ilighley wood, growing difperfed one mile and-a half "from the town of Bywell towards the wett, planted with oaks, " and part old birches of 80 and I co years growing, containeth " 100 acres. Onc other wood, called Bailiff wood, on the fouth "part of the town of Byzuell, and well fet with birches of $5 \circ$ and "60 years growth, difpofed in divers parts, containeth 80 acres. "And one other wood, called Through-Deane, in Eaftwood, which "was a large wood, contining by cltimation 140 acres, and was " all old birch and fallen about 30 ycars paft, and never inclofed, "by reafon whereof the fyring was utterly deftroyed; yet is "there birch fprung up agin, of the very nature of the foil, in "great plenty, fo as in the procefs of time there will be a wood " of birch again.

" The town of Byruell is builded in length all of one ftreet upon "the river or water of $7 y n e$, on the north and weft part of the "fame; and is divided into two feveral parihes, and inhabited "with handicraftimen, whofe trade is all in iron-work for the " horfemen and borderers of that country, as in making bitts, "flirups, buckiles, and fuch others, whercin they are very cx"pert and cunning, and are fubject to the incurfions of the thieves "of Tyndale, and compelled winter and fummer to bring all "their cattle and theep into the ftreet in the night-feafon, and " watch both cncls of the freet, and when the enemy approach" eth to raife huy and cry, whereupon all the town prepareth for "refcue of their goods, which is very populous, by reafon of " their trade, and ftout and hardy by continual practice againft "lie cnemy. 
"To the barony of Bywell belongeth the fithing of Salmon of "the water of Tyne, in-length three miles, which is a great " commodity, and great plenty of falmon taken, and a dam or "bay over the river, marde very flrong of late years for the pre"fervation of the faid filhing.

"Alfo in Byruell town, on the north fide of the river of Tyn", "the anceftors of the Earl of Wrefmorland builded a fair tower or" "gate-houfe, all of ftone, and covered with lead, meaning to "have procecded farther, as the foundations declare, being the "height of a man above the ground, which were never finithed, " and the faid tower is a good defence for the town, and will "foon decay, if it be not maintained.

"The barony of Byruell extendeth into the towns and lamlets " of Bywell St. Peter, Byruell St. Andrew, Acomb, Nuton, Ovington, "Mickley, Bromley, Nezulinds, Ridley nova, Styford, Shyryden, and Eyf"Jinghope; and the barony of Bolbeck extendeth into the towns "and hamlets of Brome-bangh, Riyding, Helcy, Sbotley, Slaley, Myn" Jreacers; all which towns and hamlets are inhabited with men " of good fervice, and have very good farms, and able to keep " much cattle, and get plenty of corn and hay, were it not for the "continual robberies and incurfions of the thieves of Tynedale, "which fo continually afrault them in the night, as they can "keep no more cattle than they are able to lodge either in houfe " or like fafety in the night; and all the tenants hold their lands "by indenture for term of ycars, which are very fineable when " their leafes are expired.

"The lord of the faid baronies hath the leet within all the "limits of the fame, and all waifes, eftrays, felons goods, and 


\section{0

" amerciaments, and all other royalties, cafualties, and profits, "rifing or growing by reafon of the leet." (b)

Byrell, after its forfeiture to the crown, was purchafed by a branch of the anticnt family of the Fenvicks, of Fenwick-Tower (i); and was in the poffeflion of Wrilliam Fentick, Efd; high theriff of Nortbumberland, I2 Q. Anme, 1713; and of the late Fobn Fonvick, Efr; high Ancriff of Noribmberland, 2 K. George II. I 728 ; and a reprefentative of $i t$ in feveral parliaments till the time of his death; father of the prefent poffefor of Bywell, William Fenwick, Efq; who marricd Margaret, finter to Folun Bacon, of Nerton-Cap, in the Bifhoprick of 1$)_{\text {wh }}$ ban, Ef $q$; $(k)$; and was high theriff of Nortbumberland, 1752 .

His feat is at the weft end of the village. It is a modern, genteel fructure, after a defign in Mr. Pairis architecture, of white frectone, and hewn work. It is in a bounded, low, but delightful fituation, beatifully runal, by the banks of the river Tym, having a grafs-lawn before it to the fouth, with a dwarfwall, and a high road between it and the wiver, the fouth borders of which are adorned with ftately oaks, and other foreftrees, ind fome picces of fatuary, which on a funny day are finely imaged by the water. To the catt it has in view not only a plealant garden, noted for early productions, but alfo two churches within fo fmall a diftance almoft as a ftorc's-caft from each other, a falmon-weir, two pillars of ftone in the river which formerly fupported a bridge, the ruin of the old baronial-caltle, and another of the dometic chapel, facing it, on the fouthern margin of the river.

(b) MS. penes Guliclmum Fenzuick, de Bywell, Arm.

(i) See Finwick-Tower.

(k) See Etherflon. 
A perfpective view was publithed of this villa fome ycars ago, before Mr. Fenwick rebuilt his feat, and made all the other agreeable improvements about it.

One of the churches is dedicated to St. Peter, to the poor of which parifh, Maclam Elizabeth Rateliff, of Dilfon, wiclow, by will, dated 18 December, 1668 , gave 4. l. per anmun out of an annuity or rent-charge; to be cliftributed annually on St. Lucie's Day.

Fofeph Tenfdule, of Bromley, by will, dated r6th Feb. 1699, gave. to the poor of the fame parifh, $I l$. per anmum.

Mr. Thomas Brozen, of Newton-Hall, by will, dated izth Scptember, 1703, gave $10 \%$. to the poor of the fame parin.

The other church is dedicated to St. Andices; to the poor of which parifh, Mr. Thomas Broren, by will, gave $5 l$. One of its vicars, the Rev. Mr. Hutton, afterwards vicar of Warden, augmented the vicarage by the clonation of a tenement in Byrucll, called, Three-Quarter-Land, which he had bought for the term of fixty years, of which about forty were then remaining. Iris fucceffor in this parifh, the Rev. Mr. Hall, made it perpetual, by purchafing the fame tencment of Sir Fobn Fenrovick, of Wallingtsh, Bart. the indenture bearing date, sth July, 1651. In 1713 , it was valued at $8 l$. per annum (l).

In the year 1760 , as one Robinfon, a maion, was angling in the river Tyne at Bywell, after a fall of rain, he took up a fmall filver

(1) Account of the Charities in Tynedale by the Rev. Mr. Ritflkcl, Miniter of Hexilem. 
cup, as it was rolling on the waves, full of earth, of Roman fabric; the following infeription round the brim, -

\section{DESI D E R V VI A S.}

He fold it to Mr. Longlands, a goldfinith in Nerucaftle upon Tyne, for I 5 s. of whom it was claimed by William Fenwick, Efq; as Lord of the manour, who now has it. It was probably walhed out of the banks about Corbridge, where other Roman veffels of filver are firid to have been formerly turned out by the floods.

The Romans were very curious in their drinking-cups. Some of them had the portraits of their friends in enamel-painting at the bottom, which they ufed in the hours of good fellow thip to trink to their memorics. 'This cup feems to have been for fellivals, and birth-days, when it was cultomary-Genio indulgere. Defuteri is the name of the perfon to whom it is inferibed.

On the other fide of the Tyne, near the river Derwent, is

Bolbek ( $m$ ), the barony of Golmn de Bolbeck, in the reigin of $\mathrm{K}$. Honry III (n); and of Fiugh de Bolbeck, I K. Edruard I (o); who dying

(n) Bolbeck.

- Bulbeck.

(n) Fobannes de Bolbeck teret in capite de Dom. rege Baroniam fuam de B.lbuch per fervicim quinque feod. milit. Et onnes anteceffores fui per eund. Servicium poft tempus dom. regis Henrici primi tenuerunt, qui eos feoffav. Et de tenemento illo nulla eft alienario, \&c. unde dom. rex minus habeat de fervic. fuo.

Tefacie Nevill.

(0) Hugo de Bolleck tenet in capite de dom. rege Bolbcch, Stiford cum Spereden membro fuo, Brome-haugh, Hcley, Shotley, Heddon fuper murum, Hedwyne wef, Hedwyne eaft, 
dying without iffuc-male, it came to his four daughters and coheirs; viz. Margery, married to Nicholas Corbet, and afterwards to Ralph, fon of William, Lord Greyftock; Alice, to Walter de Huntercomb, Baron of Wooler; Pbilippa, to Roger de Lancafer ; and Maud, to Hugh Baron of Delaval. Alice and Maud having no iflue, the whole Barony was divided between Nicholas Corbet, and Roger de Lancaffer $(p)$. We find a mediety of it in the poffeflion of Robert

de

Whitchefter cum Houghton membro fuo, Thornton, Wallington, cum fuis membris, vir. Camhoe, Farnilaws, et Fawnes; Benwell, Ecbwicke, Elfwicke, Fenham, Hartburn, Angerton, Middleton fouth, Middleton north, Hugh, Burton, Berle, Fenwicke, Matfen eaft, Hawkwell, Harnhain, Shaftoe, Shortflat, Harterton-hall, Hawicke, Kirk-Harle, Rotheley, Newton-grange, Swethope, et medietatem de Bywell, per quinque feoda veteris feofiumenti.

\section{Efcaet, de anno I Ea. I.}

(p) Dicto Hugone defuncto ei quatuor filix cohxredes: quarum Margeria prima fuit maritata Nicbolas Corbet; IValtero de Huntercombs Alicia fuit maritata; dua alize forores, una videlicet eft maritata $R$ gero de Lancafer, et alia Hugoni de la vale. Et tota hæreditas ejus divifa fuit inter eas. Poftmòdum, Alicia qux fuit uxor Walteri de Huntercmbe, et uxor Hugnis do la vale obierunt fine prole, et tunc iterata eft partitio inter dict. Nicholaum Corbet et Niargerian uxorem ejus, et Rogerum de Lancafter et uxorem ejus, ut per cedulam quam Edvardus de Elhet quondam Sencf́callus terrar. predict. confervavit, et huic rotulo gallicè confcriptam.

Seur account les fees et les fervices de le Baronie de Bolbeck a le purpartie Nichul Corbet et margere fe feme en allowance del auties feeset fervices allotes a le purpartie Roger de Lancaftre et fe feme, et le autres perfoners fuper la mort Hughe Jadys Baron de Bolbeck.

Le fervice Robert de Raymes de fee de Sho:that. Item, les fervice Julan. de Fawdon du fee de Echewyke. Item, les fervice Johannis de la Vale de fee de Benwell : les fervice Willielmi de Seton de fee de Proudehewland. Iten, les fevice Johannis de Wcitdena; a Nichol. de Loun de fee de Thomburgh. Desfervices, fubditt. les anantditez Nichol. ct Marger. fuerunt fefiez. Rog. de Lancafter y mort qr. ęat Monfieur Robert de Herleclayme anoire.

La moyte de la purpartie Hugh de le vale et fe feme allotz de les purpartie feifejtz en va. loue des autres fervices allotes de la purpartic l'ananditez Rog. et fe feıne, de la moyte de ia VOL. II. 


\section{ANTIQUITES OF NORTHUMBERLAND.}

dc Herle, of Kirk Herle, heir of Roger de Lancafer, 24 K. Edward III (q); in which he was fucceeded by Sir Ralph de Haftings, his nephew, by his filter Margaret $\left(r^{\circ}\right)$; the other mediety belonging to William Lord Grevflock, s.).

The Barony or LordThip of Bolbeck, called the Barony of Kyrklant in the record fubjoined, was in the crown, 12 Q. Elizabeth; 1,59 , when a furvey of it was raken, as before-mentioned $(t)$. It now belongs to George Baker, of Ellemere-Hall, in the Bihoprick of Durbam, Efq; allied to George Baker, Efq; the founder of fix cxhibitions, in St. Fobn's College, Cambridge; and to Tbomas Baker, B. D. Fellow of the fame college, a celebrated antiquarian, author of the reflections on learning, and who left many MS. volumes in folio to the public library of that univerfity.

By the river Derwent, near Bolbeck, is the abbey of

Guartic partie le Barone de Kyrkland; I d. ob. de Nichol. de Skyrmynton; I s. 2 d. ob. de Abte Blaunchland de Byrkyngyde, \&ic. \&uc.

Les fervices allotes a la purpartic Monfieur Rauf Fitzwilliam et la ananditez Margerie fe fere, sic. per brief de Roye direct. ad efcactor. comit. Northumbr. per evident. de eis fact. ct retorn. en la Chaunceliarie.

(q) Robertus de Horle, filius et hares Willielmi de Harle, dat regi $5^{1}$ Marc. pro relevio fuo, pro medietate Baronix de Bolbeck.___._Pafcha Fin. 24 Ed. III.

(r) Radulphus de Hafings, miles, filius Margarite, fororis et haredis Roberti de Harle, militis, tenet de rege in capite medietatem Baroniæ et Bolbeck in comit. Nortbumbrice.

Pafchæ Fin. 40 Ed. III.

(s) Willielmus de Greylock, Baro de Greyfock, tenet alteram medietatem Baroniz de Bolbeck.—Ibid.

( 
Blancbland (u), founded by Walter de Bolbeck, 1175, and dedicated to the Bleffed Virgin, for twelve Pramonfratenfian canons, with liberty to exceed that number, with the confent of the Bihop of Durbam. He'gave it the Lordhip, and demefnes, and advowfon of the church of Blancbland, the appropriations and advowfons of the churches of Herelaw and Byzuell, of Stiford, of Shotley, of Apperley, and of the church of Heddon on the Wall, dedicated to St. Andrew; the tithes of the village of Wulwardhope, and ten finhes for their table out of his filhery of Stiford, in lieu of tithefirhes $(v)$.

The abbot was fummoned to parliament, 23, 24 K. Edward I. At the fuppreffion it had fourteen canons. Its annual revenues were then valued at $40 l$. os. $9 d$. Dugl. $44 l .9 s$. I $d$. Speed. It was granted to Fobn Bellow and Fobn Broxholin, $37 \mathrm{~K}$. Hery VIII. It came afterwards into the poffeffion of Sir Fobn Forfer, knightbaneret, and of Sir Claudius Forfer, created a Baronet, I 7 K. Fomes I, March 7 th 1619. It was forfeited to the crown by the attainder of Thomas Forfer, junior, Efq; in 1715 ; and purchafed by the

(u) Blanca-Landa.
Abba-Landa.

(v) Tonner's Notitia Monaft. fo. p. 393 .

Vid. in Mon. Angl. Vol. ii. p. 611, 6r2, Cart. 54 Hen. III. m. I3. per infpex. recit. Cartas duas Walt. de Bolveck fundatoris, unam de fitu, fundatione, et donationibus fuis Abbatiæ; alteram de ecclefia de Heddon; cartan Hugonis de Bolbcck, de divcrfis terris et pafturis juxta flumen Derwent, \&c. conceffis.

Confirmat. Cart. Abbat. de Blanca Landa, in Ed. II. n. 72.

Claus. 3 I $E d$. III. m. 36 . de advocationite abbatia.

Stev. Append. p. 5 .

'Bourne's Hirt, of Newc. p. I 42 , of a Houfe in Newcafle. 


\section{ANTIQUITIES OF NORTHUMBERLAND.}

Right Honourable and Rev. Lord Crew, Bilhop of Durbam, his uncle, who left it to charitable ufes $(w)$.

Between the $\mathrm{x}$ 2th and it mile-ftones, on the right hand, by Weiton-burn, a road branches off to

Welton-Tower, a corruption of Wall-Town, i, e. the Town by the Wall $(x)$, where Sigebert, King of the Eaft Saxons, and Penda, King of the Mercians, with all his great Lords and attendants, -were baptized by Finan, Bihop of Lindisfarn $(y)$. It was the feat of the antient family of the Welton's; of Simon de Welton, to K. Henry IV (z), 9, ro K. Henry V (a), and $14 \mathrm{~K}$. Henry VI (b); of Thomas de Welton, 25, 35 K. Henry VI (c); of Simon de Welton, 5 K. Edward IV (d); of Michael Welton, I9 K. Charles I, I643, who was then one of the parliament-commiffioners for fequeftring lands in Northumberland, an act being paffed the year before, in June, that this and the other northern counties fhould be on the fame footing as Ireland, and the lands and eftates of many great families fhared among fuch as would advance money to bring them under their power.

(w) See Bambrough.

(x) Welton. Bihop Kennet's Hift. Regift.

Walton. Camden's Britan. Burton's Itin.

Ad Murum. Bede.

Weltden.

Welden.

(y) Bed. Hift. Eccles. Ed. Smilh, 1. 3. c. 2I.

(z) Efcaet. de anno ro Hen. IV. n. 26.

(a) - 9,10 Hen. V. n. 54, et, n. 28.

(b) ${ }_{14}$ Hen. VI. n. 34.

(c) 25 , et 35 Hen. VI. (d) $=5$ Ed. IV. n. 30 . 
The tower is on a rifing ground, and in fight together with the village, from the Wall, being only a field's length from it.

At the reftoration, the Rev. Mr. Fobn Davis, fellow of Magdalen college, in Cambridge, and minifter of Bywell, being difplaced for not complying with the act of uniformity, retired to this village. He died in $1670(e)$.

A road branches off by $W$ elton-burn, on the right hand, to

Fenwick-Tower $(f)$; the feat of the antient family of the Fenwicks; of Thomas de Fenwick, in the reign of K. Henry III, a benefactor to Hexbam-priory, to which he gave fix meffuages, and three plow-lands in Eaft Matfen $(g)$; of Robert de Fenwick, $33 \mathrm{~K}$. Edward I (b); of Fabn de Fenwick, high Theriff of Nortbunberland, 32 K. Richard II (i), who married Mary the youngeft daughter and coheir of William de Strother in the reign of K. Henry IV (k), with whom he had the eftate of Wallington(l); which, with this of Fenwick-Tower, continued in his family till the beginning of the reign of K. Willian III, when they were both fold to Sir William.

(e) Bp. Kennet's Hiftor. Regift. p. 892.

Dr. Walker's Sufferings of the Clergy, Part II. p. I 5 I.

(f) Fenwyke-Pile. Pile. Lel. Itin. Vol. 7 .

Fenwick-Hall. Camden's Britan. p. 855.

(g) See Hexham-Priory.

(b) Efcaet. de anno 33 Ed. I. n. 79.

(i) 22 Ris. II.

(k) - 3 Hen. IV. n. 20.

(l) See Wallington. 


\section{I58 ANTIQUITIES OF NORTHUMBERLAND.}

Blacket, of Newcafle, Bart. by Sir Fobn Fenwick, Bart. fon-in-law to the Right Honoura!lle Charles Howard, Earl of Carlifle.

The tower is now in ruins, on the weft fide of a fmall ftream, in a low fituation, the grounds on the fouth ficle to the banks of the river Pont watry and fenny, from which the village obtained the name of Fen-ruick.

\section{A mile eaft from Fenwick-Tower, is}

Stamfordham, a pleafant, well-built village on the banks of the Pont, the manour of which, with le Hugh, was granted by Sir William de Hilton, to Sir William de Swinburn, 23 K. Richard II.. 1399 (m) ; and was given, with the fame le Httgh, to Fobn de Swinburn, of Nafferton, by his kinfman, Sir William de Szoinburn, 2. K. Henry VII, $1506(n)$ and is now, with the faid le Hugh, in the poffeffion of Sir Edward Swinbum, of Cap-Heaton, Bart.

(m) Omnibus hoc fcriptum, \&c. TWalielmus dominus de Hilion, miles, falutem, \&ce. renifite, sic. Willilmo de Swinburn, militi, Exc. totum jus, \&c. in Stamforilharn, le Hugh, Eic. Sirillat. Histeftibus, Rulerto de Ogli, Roberto De la val, Fohanne de Fenuich, militibus; Jobanne de $M$ u'grave, et aliis. Dat. apud Stamfrabam, anno regni regis Rilardi foculdi polt coriquefum Angliae viceflimo tertio.

(n) Sciant, \&x. quod egoWilizimus Swinburn, miles, dedi, \&c. Fobanni Swinburn, confanguineo meo (de Nufferton) et hæredibus de corpore fuo legitime procreatis, omnes terras, Kc. de $l \mathrm{Hugl}$ et Stanfordham, \&c. et fi contingat prafatum Zobannem obire fine hæredibus, tunc revertere præfato Willichs de Swinburn, et haredibus fuis in perpetuum. Egovero dicus IVillidmus, et haredes mei omnia, \&rc. pafato Fohanni Swinburn, et haredibus de corpore fuo legitimè excunt. warrantizabimus et defondimus. Sigillat. his teftibus, Raberto Ogle, Fobanne Bartrann, et R.birto Harbutlle, militibus. dat. apud Hughe, Die Sabbati proximè ante feftum purificat. Beatæ Marix Virsinis, anno regni regis Kelencici Sept polt conqueftun Arglia viceffimo primo.

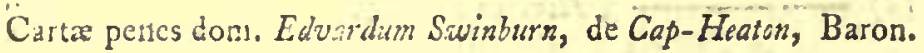




\section{ANTIOUITIES OF NORTHUMBERLAND.}

It is a well-built town, of one long and wide ftrect, on a flope; a covered market-crofs, nearly in the center; on a fquare pinacle at the top, on the eaft fide, this infcription, -

Erected by Sir Foln Swinburn, Bart. 1736. His coat armorial on the other fide.

It has an annual fair, April 21; and another on Holy Thurfday; alfo one the Thurfday after the 26 th day of Augut.

Oppofite to the market-crofs, on the fouth fide, is a free-fchool, founded by Sir Thomas Widdrington, Knt. 1663, who endoweal it with the land at the Hugh, pleafantly fituated at the eaft end of the town; floping to the river Pont, valued, at that time, at $10 l$. and in 1797 , at $4.0 \mathrm{l}$. and now at $80 \mathrm{l}$. per anum.

On the weft fide of the market-crofs, is the church. It has three ifles, and a gallery at the wert cnd. In the north wall of the chancel, in a nich, is the effigies in ftone of a knight templer, in the ufual habit and attitude, faid to have been one of the Fenwicks, of Fenwick-Tower(0).

To the poor of this parifh, Henry Paffon, of Black Heddon, Gent. by a deed made, $14^{\text {th }}$ March, 1698 , gave 12 l. per annum, out of the rents of his eftate at Black Heddon and Wallidge; to be diftributed by the minifter and church-wardens at four feveral terms, viz. Ift May, rft Auguft, I th November, and ad February (p).

On the fouth fide of the church, is the vicarage-houfe; lately repaired, with large additions, after an elegant manner, by the

(o) MS. penes Gulielm. Fenwick, de Bywell, Arm.

(p) Account of the Charities in $T_{\text {ynedlale, by the Rev. Mr. Ritfchel. }}$

Rev. 
Rev. Thomas Dockwray, D.D. the prefent incumbent; orer the fouth entrance, the following infcription.

\section{RDES HASCE REFECIT THOMAS DOCKWRAY. MDGCLXII.}

The houfe and gardens contain about five acres; the latter caft into a new and genteel form by Dr. Dockwray; a flew-brick-wall in it of eighty feet; a fine terrace extending eaft and weft before the houfe; a mount of flowers on an irregular grafs-lawn below it; with borders of flowers and flowering-thrubs; encompaffed for about two parts by the Pont; with a variety of walks, fome of them under an evergreen-hhade, to the wef; a little ifland, formed by the Pont, to the eaft, crofled by a new none-bridge of two arches; a grove of tall forent-trees on its fouthern banks; the fmall villa of Hawkwell behind them, partly dicerned through the trees: the wefern vale-profpect bounded at the diftance of four or five miles by a femicircular ridge of hills; the villas of Ryal and Ing bow vifible through the clumps of trees in the meadows, both on eminences, the latter on limeftone, with a chapel in it.

A fhort mile eaft from Stanfordbam, on the fouth fide of the Pont, is

Cheefourn-Grange, the manour of which belonged to the priory of Hexham (q). It was the feat and eftate of Gowen Swinburn, Efq; 10 Q. Elizabeth (r); and of Thomas Widdrington, Efq; of Grey's Inn,

(q) See Hexham-Priory.

(1) Gazuinus Sisynburn fuit feifitus de et in uno capitali meffitagio, vocat. ChecfburnGrange. - Efcaet. IC Eliz. 
${ }_{4} \mathrm{~K}$. Charles I (s), afterwards Sir Thomas Widdrington, Knt. founder of Stamfordham-fchool, above-mentioned; brother-in-law to Thomas Eord Fairfax; for fome time recorder of York; alfo Lord Keeper of the Great Seal of England, 1647 , with a falary annexed of $1000 \%$ per annum; fpeaker to the parliament, $165^{6}$; and Lord Chief Baron of the Exchequer, $165^{8}$. He wrote the hiftory of York, of the MS. copy of which the ingenious and learned Mr. Drake hath given us a particular account in the preface to his hiftory and antiquities of that city $(t)$. He left four daughicrs and coheirs, one of whom, Mary, married Sir Robert Markbam, of Sedgebroke in Nottingbamflire, Bart. defcended from the famous Judge Markbam, difplaced for his integrity by K. Edruard IV. His eftate and feat of Cheefourn-Grange are now in the poffeffion of Ralph Riddel, Efq; brother to Thomas Riddel, of Swinburn-Cafle, Efq.

\section{A mile and a half from Welton-burn, is}

Harlow-Hill, corruptly for Hare-low or Here-low, that is the hill or ftation of the army (u), a fmall village on an eminence; at the fouth-weft end of which a road branches off to

Ovingbam, a village on the banks of the Tyne, where was a religious houfe of the foundation and endowment of - Humfranvil, Baron of Prudbow, for three black canons, fubordinate to the priory of Hexham. He gave it the appropriation and advorw-

(s) Toomas Wiadrington, Arm. flius Lodotici, tenet in capite per fervic. militare Chech bu'n-Grange. Ex Lib. Food. Pitri Oforne, militis.

(t) Initio.- See Wood's Athenre Oxonienf́es.

(u) See Thareffy's Topogrs of Leeds, p. 14.3.

Vor. II. 
fon of Ovingham (v). At the diffolution, $26: \mathrm{K}$. Henry, VIII, its annual revenues wcre valued at Ir. 2.2 s. $8 d$. Sancroft $(w) ; 13 \%$ 4 s. 8.d. Speed. The fituation is very pleafant, the river Tyne glicling under it, by a hanging garden, with three terraces, one above. another, having the ruins of the caftle of Prudbow, and of the chapel of our lady belonging to it, in full view. It came with the appropriated tithes, and the advowfon, of Ovingham, with a fine glebe, into the poffenion of the Addifons, and was their feat for a long time. It now belongs, with the tithes, advowfon, and glebe, to Thomas Charles Bigge, of Little Benton, Efq; the glebe of near the yearly value of $200 \mathrm{l}$. and with the tithes of Ovinghams reputcd worth 500 l. per annum.

Oppofite to the houfe of Black canons, on the north fide, is the church, in the cathedral-form, folemn and lofty within. In the tower are three bells, and near it a very neat veftry. On the north fide of the chancel, is a beautiful tomb of black marble, whereon is cut the coat armorial of the Addifons, without any infeription.

On the fouth fide of the chancel, is a flat fepulchral ftone, of blue marble, with the following infcription.

Herc lies the corpfe of a rare man interr'd,

On whom both wit and learning God conferr'd

To his great good: for all his works did tend

To Gon the object of his acts and end.

His abfract was from a religious race,

To which his proper virtue added grace.

(v) Pat. I Ric. II. p. 6. m. 28. pro eccles. de Ovingham approprianda, Priori de Hexham. (w) MS. Valorum. 
Was happy in his wife, his children feven:

Of which the prime:did follow him to heav'n:

A virtuous girl, above her age was the,

Of fin's foul deeds, and vile contagion, free.

With credit great, whillt he Lord Percy ferv'd*,

of high, of low, of all he well deferv'd.

He could get wealth, but got, he cared not for it.

And to conclude, he us'd things tranfitory,

As means to bring him to eternal glory.

William Ourd, Efq; departed this life the 27th of April, 1630 ; and his daugher the poth of December, ${ }_{1} \sigma_{3} \mathrm{I}$.

To the poor of this parifh, Edward Fletcher, of Ovington, by will, dated 29 th May, 1699, gave $2 l$. per annum; one half to be diftributed, If March, his birth-day; the other half, I $3^{\text {th June, }}$ the day of his death.

Fobn Blacket, of Wylam, Efq; by will, dated r 1 th Scptember, 1707 , gave $6 l$. per annum, to be paid out of his lands in Weft Denton, to the poor of this parifh, to be diftributed by the minifter and churchwardens on All Saint's Day.

On the fouth fide of the Tyne, and on the brow of a hill, oppofite to Ovinglam, is

Prudborv-Caftle (x), the Barony of the antient family of the Humfranvils $(y)$, in which Robert de Humfranvil was infeoffed by

* A furveyor and commiffioner of all the honours and eftates of the Right Honouratle Henry Percy, Earl of Northumberland, in the reign of King Zames I.

(x) Prudo. Lel. Itin. Vol. vii. p. 50.

Prudhow. Camden. p. 855 .

(y) Umfranvil. Camd. Madox.

Humfrevile. Hol. Chron. 
K. Henly I, who alfo gave him the Lordfhip and foreft, together with the royal privileges and franchifes, of Reeds-dale, and the callics of Ottcrburn and Harbottle, to hold by the fervice of defending them from thieves and wolves; by which fervice they were held by his fucceffors; viz. Odonel de Himfranvil, famous in our annals for his bravery, who with Bernard de Balial, and others, took Willian, King of Scots, prifoncr at Alnwick, 20 K. Henry II, 1174, after his retreat from the fiege of the caftle of Prudbow; by Rizbaid de Funfranvil, a bencfactor to Hexham-priory, and who fortified the cafle of Harbottle in the beginning of the reign of K. Henry III, dying i th of that reign; by Gilbert do Humfranvil, a right noble Baron and warden of the marches, fays the record, who held his Barony of Prudbow by the fervice of two knight's fees and a half $(z)$, dying 30 K. Henry III. $12+5$; by Gilbert de Humfranvil, who was Earl of Angus, and fummoned to the parliament held at Carlifl, 35 K. Edward I, in the octaves of St. Hilary, . Jan. 21, 1307 (a) and who founded a chantery in the chapel of our lady at his cafte of Prudbore, and endowed it with two tofts, and i 8 acres of land, and five acres of mealow, for the maintenance of two chaplians, to perform divine fervice daily, hold-

(z) Gillertus de Humfronvil tenet in capite de dom. rege Baroniam de Prübow, perfervic. duor. Feod. milit. de dimid. Feod. Et omnes antccefiores fui per eund. fervic. tenuere poft tempus regis Herrici primi. Et de illo tenemento nulta eft alienat. vel donat. unde dom. rex minus habcat de ferviciofuo.

Tefta de Nevill.

Certificat. de Baron. predicti Gilberti, per Hugon. de Bolbeck, vice-comitem Northumbr.

Idem Gilbcrtus tenet in capite de dom. rege-vallem de Riddifdale, per hoc fervicium, ut cuftodiat vallem prædit. a latronibus.et vulpibus.—Tefta de Nevill.

Idem Gilbertus tenet in capite de dom. rege parv. Ryle, redditquùe inde dom. regi per annum 女xs. Et omnes anteceffores fui per eund fervic. tenaerunt poft tempus regis Henrici primi, \&cc. -Turla de Nevill.

(a). Parliament, Hift, of Engl. Vol, i. p. 133. 
ing his barony by the fame fervice as 'above-mentioned ( $b$ ), dying I K. Edward II ; by Gilbert de Hunfranvil; who was fummoned to the parliament at Wefminfter, ${ }_{15}$ th July, 26.K. Edward III. I 352 , and 1 K. Richard II. $\mathrm{I} 377$ (c); by Gilbert de Humfranvil, $\mathrm{I} 1 \mathrm{th} \mathrm{K}$. Henry IV. I41. nephew to Sir Robert Htwrifranvit, Knight of the moft noble order of the garter, and vice-admiral of England, whom he attended in that fanmous expedition into Scotland, when he acquired the nick-name mentioned by Canden (d) of Irobin Mend-Market, from his felling them round penny-worths of their own goods, taken by pillage (e). He alfo attended K. Henry V, the glory of England in his expedition into France, 1419, by whom he was made governor of the cattle of Goumie for his bravery, alfo governor of Melun upon the river Seine in the fame kingdom (f). He. was flain on Eufter-Even, in the fame year, at a narrow pafs, called Viel Bauge, or Baugie, in Anjou, with his general, the Duke of Claience, and Fobn Grey, Earl of Tankervil, who were decoyed thither by a fervant of the Duke's, corrupted by the enemy $(g)$. He was fucceeded in his Lordhip of Reedfale, and caftles of Harbottle and Otterburn, by his kinfman, Walter Tailfoys, who was in poffefition of them, I 7 K. Henry VI.(b). By the attainder

(b) Gilbertus Humifranvil, dominus de Ridlifda'e, tenet de dom. rege in capite Prudbow, cum fuis membris, viz. Hedley, Horfley, Whithill, Rouchefter; Inghow, Heton magn. Hetón parv. Bavington parv. Bavington magn. Weft Harle; parv. Harle, Whelpington, Chollerton, Barrwasforth, Chipches, Rea, Biztley, Thockrington, Harelaw et Welton, perduo Feod. milit. et dimid.veteri Feoffamento.___ Sfeact. de anno I Ed. I.

(c) Parliament. Hift. of Engl. p. 279. ,

(d) Britannia, Ld. Opt. .

(e) Hol. Chron. Volv ii. p. 536, 537.

(f) - p. 578 .

$(g)=$ p. $579,580$.

(b) Walter Tuilboys, confanguineus et hares Gilberti Unzfranvil, nuper comes de Angis, tenet caftrum de Harbstle, et manerium de 'Harbsthle, et manerium de Otterburn, d: leg in capite, $:$ 
attainder of Sir William Tailloys, after the battle of Hexbam-field, 3 K. Edward IV. $146_{3}$, they came to the crown. This caftle and Lordhhip of Prudbow were given to Fobn Duke of Bedford, and afterwards to Henry Percy, Earl of Nortbumberland, and are now in the poffeffion of his Grace the Duke of Nortbumberland.

The caftle is now in ruins; as is the chapel of our lady, at the foot of the hill.

By the $9^{\text {th }}$ mile-ftone, a road branches off, on the right hand, to

Wylam, a populous village, which belonged to the priory of Tynemouth (i), and was in the crown, ro Q. Elizabeth $(k)$. At the weft end of it, is

Wylam-Hall, which was the feat of Fobn Blacket, Efq; high Theriff of Northumberland, 1692; and of his fon, Fobn Blacket, Efq; 1714, fon-in-law to Fobn Bacon, of Staward-Peel, Efq. It is now the feat of Foln Blacket, Efq; high Theriff of Northumberland, 1729.

Mr. Blacket hath made a handfome road for a mile in length on the weft fide of his houfe, leading from Ovingham, like a terrace, exceedingly pleafant and romantic, a bank of wood on one fide, and the river Tyne on the other.

Between the gth and 8th mile ftones, on the right hand, is the Roman ftation

capite, per fervicium cuftodiendi vallem et libertatem de Riddifdale, ubi dict. caftr. et maner. fituantur, a lupis et latronibus.

Mich. Fin. 17 Hen, VI:

(i) See Tyncmouth.

(k) Efcaet, de anno 10 Eliz. 
Vindobala (l), or Rouchefer (m). A fculpture of Hercules, in ftone, of the rag-kind, was digged up at it by fome labourers a few years ago, by whofe careleffrefs it had the misfortune to lofe both the head and'feet. Mr. Brown, of Throckley-Fell, faved it from farther harm by having it carried to his houfe. In $176 \mathrm{r}$, it was removed to London by a curious antiquary, Mr، Duane, a gentleman, fays Dr. Stikeley, who judicioufly indulges a tafte for the elegances of thefe learned curiofities, in the midft of the confinement and bufinefs of the law $(n)$.

The feftival of Hercules and Bellona was obferved, 3 d June.

Two Roman Fibule have been alfo digged up, both of filver. One of them was in the poffeffion of the Rev. Mr. Walton, of Corbridge, and the other of the late Mrs. Roberts, of Hexbam.

In paffing by this ftation, $\mathrm{r}$ th December, $176 \mathrm{r}$, I had a Roman brick and two coins from fome labourers who turned them up from among the ruins the day before. The coins were of copper, and of the later empire. Upon the brick is the following infcription done with a famp, the letters large and fair.

\section{I G G V I V}

In' the beginning of the year 1766 , two poor men being employed in digging up the foundation of a fence near this tation, .

(l) Horrfey's Brit. Romana.

(m) Rouchefter.
Rowchefter. Efcaetr. Northumbr:.

Routchefter. Camden.

(n) Dr. Stukeley's Caraus. Vol. i. p. 187. Vid. Hercules Ethnicorum, ex variis Antiq. Relig. delin. \&cc. Bejero, cum 38 Fig. fol. 105. 
found a large quantity of Roman coins in a fmall urn, which they difpofed of to different people in and about Nerucafte for their weight of our own money, which coming to the knowlege of the Iord of the manour, William Archdeacon, Efq; he claimed them as treafure-trove, and recovered near five hundred-filver, and fixtecn gold, coins; almott a compleat feries of thofe of the higher: empire; among them feveral 'Otbo's ; molt of them in fine prefervation.

'In June, in the fame year, a coffin hewn out of a rock was difcovered in digging near the fame place by fome labourers, about tivclve fect long, four broad, and two deep; a hole clofe to the bottom at one end; a tranfrerfe partition of ftone and lime about three feet from the other end; many decayed bones, teeth, and vertebræ in it; fuppofed by their thape and fize to be the remains of fome animal, facrificed, perhaps, to Hercules.

At the foot of the fation, is

Rouchefer-Tower, the feat and manour of Robert de Rouchefer, I K. Edvalard I (o); and of Gawen de Rotberforth, IO Q. Elizabeth (p; ; now in the poffeffion of William Arcbdeacon, Efe; abore-mentioned.

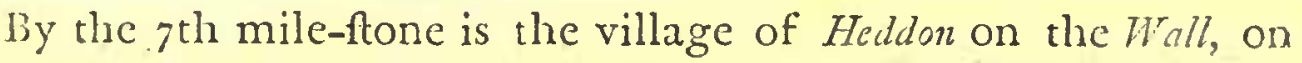
the fouth-weft fide of which we have a good view of

Clofe-Houle, the feat of Robert Bewick, Efq; high therifl of Northumberiand, 1695; and of Robert Bervick, Efq; high theriff of

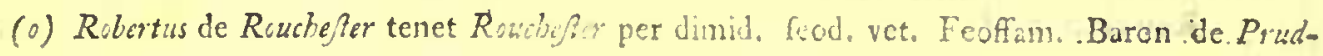
botv, Efcact, de anno I Ed. I.

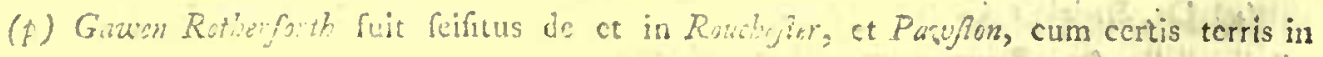
Barmere Efcaet, de anno to Eliz. 
Northumberlaid, 1726; alfo of Sir Robert Bewick, high theriff of Nortbumberland, 1960, who received the honour of knighthood on prefenting the Northumberland-addrefs to his prefent Majenty on his acceffion to the throne.

It ftands on the fide of a thady hill, having an anticnt chapel at the eaft end, and a tower at the other. Before it is a floping lawn, and near it an iflet with two or three tall oaks upon it. The river Tyne, the inclofures, the clumps of trees prettily difperfed, the handfome feat of Fobri Simpfon, Efq; at Bradley, the villa and church of Nerobum, are all in fight; but the greateft boaty in view, is a flexure in the river, above which the fpire of Rytonchurch appears like a ftately gothic column or obelifk.

Between the $5^{\text {th }}$ and $4^{\text {th }}$ mile-ftone, a road branches off, on the right hand, to

Neruburn, an antient borough on the banks of the Tyne, the manour of which, with all its regalitics, was given by $\mathrm{K}$. Fobn to Robert, fon of Roger, de Clavering, Baron of Warkworth (q).

(q) Robertus, filius Rogeri, tenet in capite de dom. rege manerium de Newbum, cum pertinentibus, fervicioqùe Roberti de Throckley, et hæred. fu. per fervic. unius feodi milit, quam dom. Rex Fobannes ei dedit, et charta fua confirmavit. Et de tenemento illo nulla eft alienatio, \&c. unde dom. rex minus habeat de fervicio fuo.

Tefta de Nevill.

Teftibus H. Sarum, et Phil. Dunelm. Epifc. Data per manum S. Ciceftenfis electi apud Porcefre, quinto Maii, anno regni noftri quinto.

Carta antiquix, litera $\mathrm{z}, \mathrm{n}^{\circ}, 2$.

Dominus fobannes rex dedit Roberto, flìo Rogeri, $N_{\epsilon}$ wburn cum pertin. per fervicium unius feodi milit. cumqùe fervicio et homagio ac confuetudine Roberti de Throckley de tenemento ipfius Roberti de Throckley; falvo tamen dom. regi reddit. xls. per annum. Atque ipfe $R_{0}$. berlus tallietur cum dominicis dom, regis.

Certifcat. Hugen de Bulbcck, vice-comit. Northumbr.

VOL.II.

'

Fobn, 
Fobn, the lant Lord Clavering, granting the reverfion of it to the crown, 6 K. Edward I (r), it was given to Henry Lord Percy, 2 K. Edward III (s); and is now in the poffeffion of his Grace the Duke of Nortbumberland.

It is a fmall village, inhabited chicfly by perfons employed in coal-works, and in carrying timber and goods down the river in boats; the tides flowing a little above it.

The church is at the north-weft end, on a rifing ground, in the form of a crofs, with a fmall tower. King Henry I. gave the impropriation and advowfon of it, and of the church of St. Nicholas in Nerucafle upon Tyne, to the church and canons of St. Mary in Carlife $(t)$. In the chancel, on the north fide of the altar, and againft the wall, is a tomb of blue marble, with the following infcription.

Here licth Sir Gobn Delaval, of Nortb Difington, Knt. who died the 12th of Augult, $16 \mathrm{gz}$. Alfo Robert Deluval, Efq; his fon and heir, who died the 6th of February, 1666, and gave to the poor of this parifh 5 l. to be paid by the lands of North Difington, the Thurfday before Eanter yearly for ever. Alfo William Delaval, buried Augult the zoth, I684. George Delaval buried March the

(r) Ex Rot. Claus. de anno 6 Edl. I.

(s) Pat. de anno 2 Ed. III. p. 1. m. 20.

The appurtenances or members of this manour of Newburn, mentioned in the records, are Wallbottle, Dulky, Butterley, Whorleton, and Throckley._-Efcact de anno I Ed. I.

Of the crown-rent paid by the tenants of Newburn, $3 \mathrm{~K}$. Foln, fec Madox's Firma Burgi, Ch. 3 . p. 54 .

(t) Sce St. Nicholas's Church, in Newcafle. 


\section{ANTIQUITIES OF NORTHUMBERLAND.}

18th, 16y4. Mary, wife of Edward Delavat, Efq; daughter of Si: Francis Blake, of Ford-Caftle, buried Dec. 7th, 17:1, aged 17. The aforefaid Edward, eldeft of George Delaval, Efqr.'s fons, who died Augutt the $3 \mathrm{~d}, \mathrm{I} 744$, aged 80 years, and left 50 l. to be diftributed amongt the poor inhabitants of the four following parifhes, to Newburn $20 \%$. to Heddon on the wall $10 \%$ to Stamfordham $10 l$. and to Pont-Eland 10 l.

Copfl, one of the favourite Lords of K. Trillam I, was flain as he entered this church, by ofulf, his competitor for the government of Nortbumberland, who was foon after run through with a fpear and killed by a thief, as he was endeavouring to feize him; which thews how fpecdily murier is often punithed by a juft providence, and by the meancf infruments $(w)$.

The living of this parifh being reprefented to Dr. Smith, Bifhop of Carlifle after the reftoration, as an infufficient maintenance for a minifter, his Lordhip, among his other excellent charities, augmented it 25 l. per annum (v).

At this village, Lord Convery, at the head of 1200 horfe and 2000 foot, oppofed the paffage of the Scois over the river Tyme under General Lefey, a7th Augut, I6 K. Charles I, 1640. The foot by a fmart fre from under a breaft-rork forced 300 Scotch troopers to repafs the river, but on the playing of nine picces of ordnance, concealed the night before by tefley in fome bruthwood, they cant down their arms, and ran away, leaving the

(u) See an account of this charitable and good prelate in Browne Frallis Survoy of the Cathedr. Vol. I. p. 30 r.

(v) Hol. Clron. Vol, ii. p. r 3 . 
horfe under commifiry-general Wilmot, and many gentlemen of lank with him, expofed to the fury of the enemy's cannon and cavalry, who ftood their ground, firm and intrepid, till the impetuofity of numbers forced them to a precipitate retreat, with the lofs of 300 killed or taken prifoners. Lord Clarendon calls this defeat of Conreay's an irreparable rout. Whitlock fays, " his con-"duct was enquired into on his return to York, to tell the ftory " of his defeat to the king, where he was accufed of cowardice " or rreachery, that he ufed his beft art and flourithes to vindi" cate himfelf : yet fomething fuck upon $\operatorname{him}(t) . "$

Near the ad mile-fone, on the right hand, is the Roman fation

Condercum, or Benzell (u). A Roman fudatory was difcovered a few years ago by the curious and oblerving Robert Sbaftoc, Efq; in a field eat of his houfe. The pavement was not in chequer-work or mofaic, but in unequal irregular figures, red and white; a compofition of calx viva, and broken brick; refembling a pebble-marble. Of the true mufive or mofaic, I have not heard of any being yet difcovered in the Roman fructures of this or the other ftations with. us; though $I$ make no queftion but the Romans of quality had them here, as well as in the more fouthern flations of Britain. They are of great antiquity, invented by the luxurious Afatics, the builders of Babylon, of Palmyra, of Perfepolis, of the famous pyramids of Memphis, the jutt wonders of the world. At Sufa, they had a royal banquet on a Litbofiraton, compofed of rich and curious ftones $(v)$. At ferufalem our Saviour had his fentence pared on him by Pilate from a throne in a place called by way of eminence, The Pavement (w). From Afia, thefe Litboftrata
(i) Whitl. Memor. p. 34.
(u) Hor. Brit. Rom.
(v) Efther. ch. i. v. 6.

(w) John, ch. xix. v. 13 . 
paffed into Greece; from Greece to Rome $(x)$, and from Rome to Britain, into the palaces of princes, the fate-rooms and tents of generals, the facred temples, magnificent therme, and other places of elegance and pleafure. The Balnezm and Lithoffroton, according to Varro (y), made a compleat and elegant villa. Baths and fhady piazzas were firf introduced here by $\operatorname{Agricola}(z)$. .

Mr. Shaftoe hath two fmall Roman mill-ftones found at this fation, one of rag-ftone, the other factitious, of potters work, of a bluifh-afh colour. The Romans, as well as the feaftern nations, the Agyptians and Ferus, put their captives and flaves to the employ of grinding corn, who wcre placed poff molas $(a)$.

A fimall gulofim fictile, or drinking-cup, of Roman pottery, was alfo digged up, and in poffeflion of Mr. Shaftoe, but now loft.

The neck and handle of a cruife, of brown pottery, unglazed, was found at the fame time.

Mr. Horley has taken notice of a fine urn found in that part of the ftation, called Chapel-hill (b); where large foundations of buildings have lately been turned up for the fake of the. ftoncs, but no more urns or curiofities of value found.

Though the Roman urns were depofited by their temples and military ways in cefpititious mounts, yet they were not placed at any great depth below the furface.

(x) The firlt at Rome in the Temple of Fortune, Jaid. by Sylla, 170 years tefore our Savi-i our. Spsn's Referches curieufes.
(y) De Re Ruftica. Iib. 3.
(z) Tait. Agricoía. c. 2 r.
(a) Tharefoy's Topogr.
(b) Brit. Rom. p. 213. 
Dii majorum umbris tenuem et fine pondere terram, Spirantefque crocos, et in urna perpetuum ver!

Juv. Sat. vii.

A medicty of the village of Benwell belonged to Richard de Benwell, and the other mediety to Robert de Whitcbefter, and Henry de Delaval, I K. Edward I; held of the barony of Bolbeck (c). The Delaval-lands were poffeffed by Jobn de Delaval, $3 \mathrm{~K}$. Henry IV (d), and ro K. Henry V (e); and by Willian de Delaval, I4 K. Henry VI $(f)$

Robert Sbaftoe, of Little Bavington, Efq; had lands in Benwell, i॰ Q. Elizabith (s); which, with the antient tower and capital manfion-houfe, were in the poffeffion of Mark Shaftoe, Efq; a reprefentative in parliament for Newcafle upon Tyne, I659, a younger branch of that antient family; ancentor of Robert Shaftoe, of Benzell, Lfq; high fheriff of Northumberland, $8 \mathrm{~K}$. William III, I696; and of Robert Shaftoe, Efq; high Theriff of Nortbumberland, $4 \mathrm{~K}$. Grorge I, I 7 I 8 ; alfo of Robert Shaftoe, Efq; high fheriff of Nortbunberlaud, $27 \mathrm{~K}$. George II, I 754 , the prefent polferlor, lord of the manour.

His feat, built on to the old tower, ftands at the eaft end of the village, on a floping eminence; pleafure and profit diffufed round

(c) Richard de Benwiell tenet medietatem de Benwell per quartam partem unius feodi milit. baron. de Bolbeck.

Rabertus de Witibelir et Henricus de Delazal tenent alteram mediet. de Bywell per quartem partem, \&c.

Efc. de anno I Ell. I.

(d) Ercaet de anno 3 Henry IV.

(e) $10 \mathrm{Hen}$. V. n. 28.

(f) - I 4 Hen, VI.

(g) See Littie Bavington. 
it, mixed with judgment; to the eaft is a park-like inclofure, with fmall clumps of trees; to the weft, a winding walk through a Mrubbery and plantation to a Cbinefe cottage, and near it a tempiato, from which is a fine view of the vale belew, and of the river Tyne, and of the little ifland formed by it, called the King's Meadows, and of the handfome feat of Sir Thomas Clavering, of Axwell-park, Bart. on the fide of a thadly hill. Before the fouth front is a grafs-area, from which the towering pyramid rifing through the trees of Gibfide, above the banks of the river Derwent, is in vicw, a beautiful object!

We now pafs on to Benwell-lill, where the military road goes through the ftation, and on the left hand is that part of it called Chapel-hill, lately digged up for the fake of the ftones, as beforementioned; a little beyond which a road branches off, on the fame fide, to

Fenham, the manour of which, with the manour and lands of Threpervood, near Hayden-bridge, belonged to the priory of the knights Hoppitallers of St. Folon of Gerufalem (b); remarkable for acquiring by an act of parliament, $18 \mathrm{~K}$. Edweard II, 1324 , the large poffeffions of the knights Templers, diffolved $2 d$ of that reign (i). It was alfo diffolved by an act of parliament, 3 I K.

(b) As appears by a receipt from the prior to the corporation of $\Lambda_{\text {eqvinfle upon Tyne for }}$ the coal-mincs within the manour of Fenham, mentioned by their late chorographer, Mr. Bourne.-Prior hofpitalis fancti Jobanis tenet Threpewood de manerio de Lanjly, pro homagio ct fidelitate, et fecta curiæ.

Inquifitio capta apud Langley in Tynelale, in comit Northumbr. Dic Iovis ante feftum S. Andi. apoftoli, $42 \mathrm{Ed}$. III, coram Zcbanne Henderfkelf, efcaetor. dom. regis in comit. pradicto._Ex bundel!o efcaet. No. 37. Turri Londinenfs.

(i) Hol. Chron. vol. ii. p. 335 . 
I76 * ANTIQUITIES OF NORTHUMBERLAND.

Henry. VIII, 1540. The prior, Sir Willian Wefon, died of grief. The priory-lands were annexed to the crown, except 6 co marks per annum given to four knights and two gentlemen for their valour; 100 marks to each, with a dwelling-houfe, for ever. Their names were Sir Fobn Dudley, Sir Thomas Seimour, Sir Thomas Poinings, Sir George Canerw, Anthony Kingfon, and Richard Cromwell (k).

Fenban was afterwards in the pofferfion of the antient family of the Riddels, anceftors of Thomas Riddel, of Swinburn-Caftle, Efq; (l).

It is now the manour and feat of William Ord, Efq; high fheriff of Northumberland, 1747. His feat is a modern ftrueture, large and handfome. From the eaft front is a fine profpect of the river Tyne, of the thips in the river, of the church $(\mathrm{m})$ and villa of Girroy, famous for its monaftery, the refidence of venerable Bede, of the villa of Chirton, and the admired ruin of the priory-church of 7 'nemouth, on a clear day.

(k) Hol. Chron. vol. ii. p. 35 r.

(l) See Swinburn-caftle.

(m) Built in the reign of K. Egfrid, as attefted by the following infcription in the churchwall.

DEDICATIO BASILICAE SCI PAVLI VIIII KL MAI

AN NO XV EGFRIDI REG CEOLFRIDI ABB EIUSDEM

Q. ECCLES DO AUCTORE

CONDITORIS ANNO IIII

Thus read,

Dedicatio Bafilicac Sancti Pauli gno Kal. Maii Anno ${ }_{5}$ Egfridi regis. Cleofridi Abbatis ejufdem Ecclefiae, Deo Auctore, Conditoris Anno (Electionis, fcilt.) $4^{\text {to. }}$ 
By the turnpike-gate, and near the Ift mile-ftone, a handfome road branches off, on the right hand, to

Elfwick, a fmall vill on a pleafant flope, which belonged to the priory of Tynemouth ( $n$ ), and after the reformation was in the poffeffion of the Fennifon's; of William Fennifon, Efci; an alderman of Nerucafle upon Tyne, and a reprefentative in parliament for that corporation from $3 \mathrm{I}$ Q. Elizabeth, $157 \mathrm{I}$, to the $44^{\text {th }}$ of the fame reign, I60I; of Ralph Fennifon, Efq; high theriff of Nortbumberland, 1717 , and a reprefentative of it in parliament for many years together.

It is now the feat and lordhip of Fobn Hodgfon, Efq; whofe father purchafed it of Mr. Fennifon. His feat is an old ftructure. Before the fouth front is a terrace of a confiderable length, extending eaft and weft, with a dwarf-wall; the admired pinnacle of St. Nicholas's fteeple of Nerucajle, the artificial ruin on the hill at Biker, the church and town of Gate/head, in view to the eaft; the grounds beautifully floping to the river Tyne to the fouth, beyond which is a fine opening into the inclofed and fhady vale of Lamelley in the bifhoprick of Durbam, gradually enlarged, the caftles of Ravenfworth and Lumley in fight.

After paffing through the turnpike-gate, we come by a fhort and eafy defcent to

Nerwcafle upon Tyne, a town of great antiquity. Two late curious antiquaries were of opinion, that it was a Roman villa; its name Pons Elii, from the Roman emperor, Elinus Hadrianus; gar-

(n) Pa!. 16, Ric, II. p. I. m. 6, pro manerio de Elfwick. See the Priory of Tynemoutb. 
rifoned by the Cobors Cornoviorum (a). They obferved fome remains of a military way leading to it from Cbefter-le-freet, which was carried over the Tyne by a bridge of arches, where the prefent bridge itands. The fagacious Dr. Stukeley imagines it is the Ad Murum of Richard of Cirencefter in his map of Roman-Britain-(b). The Picts wall goes through the vicarage-garden, and St. Nicloo las's church-yard. Part of a turret upon it is ftill vifible by the gate at the foot of the royal Saxon villa of Pampeden; alfo a tower on an eminence in the fame villa, called The Wall-Knowl, or Carponter's tower, hereafter defcribed. No other Roman building, no forts, palaces, temples, batlis, fepulcbralia, or fepultures, altars, medals, or coins, of any value or curiofity, have hitherto been difcovered. Thofe valuable treafures werc undoubtedly deftroyed by the northern emigrants, the martial, unlettered Saxons and Danes, who generally built upon Roman foundations, and retained part of their old names, as Caftrum, Cbefter, or Chefters, Burgos, or Brough, importing their being places of ftrength, fafety and fet curity. On their being converts to Chriftianity, it was ufual with them, in the impetu of religious zeal, to efface and break to picces every thing that carried the image and features of ethni cifm; Roman curiofity, and Romas grandeur, meeting with no protection. On their fettling in communities, they built this town, and gave it the name of Monk-Chefter, for its being a fafe and fecurc retreat to the profeffors of a monaftic life. It retained this name till the Norman conqueft by K. William I; whofe fon; Robert Curtoife, thinking it a fit place for a garrifon to reftrain the martial, indomitable fpirit in the North, built a citadel on an eminence, commanding the river, and called the town, Nerucafts

(a) Dr. Hunker, and Mr. Horfey. Brit. Rom. p. 104.

(b) Dr. Stukeley's Account of Richard and his Map, 4to. Lond; $1757 \cdot$ p. 48. 
upon Tyne, to difinguifh it from the old monaftic caftle, fituated in the fame place, and faid to have been of a round figure (c).

The geographers place it in 21 degrees, and 30 minutes longitude; and 54 degrees, and 57 minutes of north latitude. It is encompaffed with a ftrong ftone-wall, ditch, and rampier of earth; has feven gates or ports, with many round towers, and fquare turrets, built at different times, and by different perfons, fome of them ftill retaining the names of their founders. Their names are,

Cloose-Gate;

White Frier Tower;

White Frier Gate;

Nevil-Tower;

Weft Spital-Tower;

Stank-Tower;

Gunner-Tower;

Pink-Tower ;

WEST-GATE;

Durbam-Tower ;

Heber-Tower ;

Black Frier-Gate;

Morden-Tower;
Eure-Tower;

Andrezu-Tower;

NEW-GATE;

Bertram Monboucher-Tower;

Ficket-Tower ;

PILGRIM-STREET-GATE

Carliol-Tower;

Pampeden-Gate;

Wall-knowl-Tower;

Habkin-Tower;

SAND-GATE;

BRIDGE-GATE.

Close-Gate is fituated at the weft end of a narrow ftreet of the fame name, on the margin of the river Tyne. It hath two good rooms in it, of freeftone, and hewn work.

The White Frier-tower is on the extremity of an entinence, of a circular form, well pared, and feated at the top. The accefs to

(c) Lib. de Rebus Novi Cafrit, citat, per Bourne. 
it from the Clofe-gate is by r 40 ftone-fteps, fteep and difficult, called Break-Neck-Stairs. It affords one of the fineft and moft varied profpects about the town. It was built by the Fratres $\mathrm{Ca}$ mcli Monte, or White Friers, oppofite to their monaftery. It is now the hall of the company of mafons.

The White-Frier-gate was built by the fame religious fraternity. It was a poftern, or private pafiage, convenient for their pleafure in walking into the fields in time of peace, and for their defence in time of war.

Nevill-Torver was built by the Nevills, Earls of $W_{e}$ ffmorland, for the fecurity of their houfe in Wef-gate. It is alfo called Denton-tower, from its having in ward, as is thought, Denton-chare. It is now the hall of the mafons, bricklayers, and plaifterers. They repaired it in 7711 ; Ricbard Fletcher and William Fobnfon, wardens.

Wref-Spital-tower, or St. Mary's tower, was built by the mafter and brethren of St. Mary's hof pital, to which it is very near.

A Pofern was made beyond the two next towers, for a communication between the Forth and Weft-gate, 1705; Thonias Waffe, Efq; mayor; Matthere Matfen, Efq; theriff.

WEST-GATE is a ftrong building, of ftone, and hewn work, with a port-cullice, iron-gates, \&c. at the weft end of a fpacious, well-built and handfome flreet of the fame name. It was built by that eminent patron of Newcafte, Roger Thornton, Efq. It is now the hall of the houfe-carpenters who lately repaired it. 
Heber-Tower, next neighbour to Durbam-tower, is the hall of armourers, curriers, and felt-makers, who were incorporated, or made one fellowhip, $36 \mathrm{~K}$. Henry VIIr.

The Black-Frier-gate was built by the Fratres Pradicatores, or Black Friers, for a paffage from their monaftery to their gardcn, by licence from K. Edward I (d).

Morden-Tower is the hall of the plumbers, glaziers, \&c. who had a grant of it in 1619 , and repaired it in 1700 . They were made one fellowhip in 1536 .

Eure-Tower was built by the antient family of Eure, Lords of Kirkley, by the river Blyth, and barons of Witton, in the bihoprick of Durbam. It is now the hall of the colliers, waggoners, and pavers.

Andrew-tower owes it name to its fituation, by St. Andrero's church.

NEW-GATE is fituated at the north end of a broad, well-inhabited ftrect of the fame name. It exceeds all the other gates for

(d) Evardus Dei gratia rex Anglia, dominus Hibernic, dux Aquitania, omnibus ad cruos prefentes literæ pervenerint, falutem. Sciatis quod de noft a gratia fpeciali concefimis dilectibus noftris fratribus preuicatoribus de Novo Cafro fuper Tynm, quod fer medium novum murum circumagentem villam predictam, quem per medium gardini pradictorum fratrum fieri oportebit, ut dicti facere poffint quandam ftricham portam ad ingrefium in gard:num fuum, habend. portam fuft. fibi ct fuccelforibus fuis tencre in perpetuum. Dum tamen porta illa ad voluntatem noftram, vice-comitis Nortbumbric ad conftabuli nofri ibid. qui pro tempore fuerit, obfruatur. In cujus rei teftimonium has literas noftras fieri ratentes; tcfle meipfo apud Dunelm. decimo-octavo dei Septembris, anno regni noftri octaro.

frength, 
frength, and is fuppofed to be-the-mon antient. On the north fide of it, in a nich, is the ftone effigies of K. Charles II. crowned, with a fcepter in his hand; the nich adorned with a pediment, cntablature, and chartoons; below, the arms of England, and the arms of the corporation; which are, gules, three caftles argent; the creft, out of the battlements of a caftle, argent, a demi-lyon iffuing; the fupporters, two fea-horfes, argent (e). Two new wings have been added on the fouth fide; one in 1702 ; Milliam Ramlay, Efq; mayor, William Bontfower, Efq; theriff; the other in 1706; Sir Ralph Carr, mayor, William Ellifon, Efq; Theriff. It has been for many years the town-jail for debtors and felons.

Bertram Monvoncher-tower owes its name to its founder, Bertram Honboucber, high Theriff of Nortbunberland, 49 K. Edward III. and I, 2, 3 K. Richard II.

Pilerim-Street-Gate is at the north end of a fpacious, liandfome, pleafant ftreet of the fame name; fo called from the great refort and entertainment of pilgrims in it, in the monaftic iines, in their way to perform their devotions at the fhrine of the Blencel Virgin in the neighbouring villa of $\mathcal{F}_{\mathrm{e}}$ mont. It is a throng gate, flat-roofed, and embattled; has a port-culice, irongates, \&c. It is the hall of the company of joiners, who repaired it in ryc; Thomas French, and Paul Cook, wardens.

Carliol-tower owes its name to the antient family of the Carliols, cminent merchants of this town, of which Nicbolas de Carliol was mayor, $2 \mathrm{~K}$. Edrorid II *. A ficld near it allo bears thcir name,

\section{(c) Browne IFillis.}

* Againft whom, and the reft of the burgefies of the merchants gild, the poor burgefles of Newcafte recovered $50 \%$. damages in the exchequer.

Placita coram baron. 2 Fid. II. Rot. 25 . a. Matox's Firma Burgi, p. 96. 
called Carliol-Croft; through which is an agreeable walk, prefenting a profpect of many hanging gardens. This tower is the hald of the company of weavers, who repaired it in 1682.

Anflin-tower was built by the friers of St. Aufin, for the fecurity of their monaftery, which ftood oppofite to it. It is now the hall of the ropers, who repaired it in 1698 ; Fobn Longlends, and Fobn Daweon, wardens.

Pampeden-gate is at the foot of an'anticnt villa of the fame name, at the north-eaft of the town. It has folding iron-gates, but no port-cullice. It is afcended to the top by a pair of ftone-lairs, two yards wide.. In the opinion of a judicious antiquary $(f)$, it was part of the Picts wall. The remains of a Roman turret are flill confpicuous.: The gate gives its name, and the wall a paffage, to a Atreamlet, called Pampeden, or Panden-burn,

Wall-knowl-tower is on an eminence in the fame villa. It was Roman. . It is now the hall of the carpenters, who, in 1716 , erected a handfome quadrangular tower on the uncler-part of it, adorned at the angles. with four fair turrets in the form of a lanthorn. Under it is an antient poftern-gate, for accefs to a field, enclofed, and laid out. in gardens... It belongs to Matthew Ridley, of Heaton, Efq. .

Sand-Gate receives its name from its fituation by the fhore of the river Tyne. It is arched at top; but has no tower or caftellated building upon it. There were many openings or paffages through the wall next the river, for the conveniency of trade. It was

(f) Canden. 


\section{4}

fately pulled down, and part of the key railed with iron-rails, which gives a fine view of the river.

BRIDGR-GATE has its name from its fituation at the north end of a ftately bridge over the Tyne.

Between moft of the towers on the wall were two quadrangular, fpeculating turrets, with ftone effigies, at the angles, of the fpeculatores or watchmen; with fquare vacant fpaces to annoy the enemy $(g)$.

The north part of the wall is thought, from the ftile of the mafonry being different from the reft, to have been firt built, and to be as antient as the time of K. Fobn (b). That part of it which extends from Sand-gate to the gate of Pampeden, and from thence to the Aufin-Friers, is faid to have been built in the reign of K. Edwaid I, by one of the burghers of fpirit and fortune, whom the Scots had furprized in one of their predatory expeditions, and extorted a large fum from him for his liberty (i). K. Edward III. granted the corporation the duties and cuftoms of the town for the term of feven years to compleat the whole, which being neglected, he feized their franchifes, and would not reftore them till they agreed to do it at their own charge $(k)$. It was fo much the

(g) MS. of Mr. Fobn Milbank, cited by Bourne, p. ry.

(b) Grry's Chorograph. inter Miccell. Oxfordiana, vol. iii. 4to.

(i) Camien.

(k) De confuetudinibus, de rebus venialibus ibidem capiendis pro termino $\eta$ annorum in auxilium villæ Novi cafri claudendæ, \&c. Pat. I R. Ed. III. p. I. m. 3; 7 . 
the object of attention of future kings, that in the reign of $\mathrm{K}$. Henry VIII, it is faid by the moft eminent antiquary of that age, to have out-done, both for the ftrength and magnificence of the mafonry, all the walls of the cities of Englant, ant mot of the towns of Europe (l).

Nori Cafri fuper Tynam villa capta in manum regis, et jam reflituitur burgenfibus ibid, quod ipfi affumpferunt coram rege defectus murorum villæ piædictx ad fumplus (uns re arationem facere. Eicact. 16 R. Ed. III. m. 22. ct Fin, 18. R. Ed. III. m. 2.

The cuftudy of the town was granted to Henry de Percy, Raiph de Nevill, Yolin de Fenwik, Walter de Creyk, and Robert de Ferwyk, high theriff of Noribumberlant, who accounted to the exchequer for the profits, cuftoms, and liberties of it, and were allowed 401 . pro ammm during their commillion; as attefted by the following record.

De cuftodia villa Novi Caftri fuper Tynan commiffa. Edvardus Dei gratia rex Anglia et Francix et dominus Hibernix, dilecto fibi Roberto de Turhale faiutem. Sciatis quod cum nuper affgnaverimus dilectos et fideles noftros, Henricum de Percy, Radulphum de Nevill, Johannem de Fenwyk, Walterum de Creyk, et Rohertum de Fenwyk vice [comitem] Northumbr [ix] ad libertates villæ Novi Caftri fuper Tynam, pro quibufdam contemptibus $\&$ inobedientiis nobis per majorem \& communitatem dictæ villæ factis, in manum noftrum capicndas, \& ad dicham villam cum omnibus ad eam fpectantibus falvo \& fecure cuftodiendam, quoufque aliud inde duxerimus ordinandum : Ac iidem Henricus, Radulphus, Johannes, Walterus, et Robertus, vos loco ipforum, ad libertates et villam prædict as in forma predicta cuftodiendas fubftituerint ut accepimus : Nos de fidelitate et circumfpectione veftris plenius confidentes, commifimus vobis cuftodiam villæ prædict x ac libertatem ejufdem; habendum quamdiu nobis placuerit; ita quod de exitibus de villa \& libertatibus predictis, a tempore captionis carundem in manum noftram provenientibus, nobis refpondeatis ad fcaecarium noftrum; percipiendo pro cuftodia illa quadraginta libras per annum, quamdiu cuftodiam babueritis antedictam. Et ideo vobis mandamus, quod circa præmiffa intendatis, \& de falva \& fecura cuftodia ejufdem villæ taliter difponatis, quod eidem villæ damprum vel periculum non eveniat ullo modo. Damus autem univerlis \& fingulis villæ prædictæ tenore præfentium in mandatis, quod vobis in omnibus quæ ad cuftodiam villæ prædictæ pertinent intendentes fint $\&$ refpondentes. In cujus, \&c. Tefte meipfo apud $\mathrm{Wefm}$. xxvi ${ }^{\circ}$ die Januarii, anno regni noftri Angliæ decimo nono, regni vero noftri Francix fexto.

Originale, sg Ed. III. Rot. I. Mrallox's Firma Burgi, p. 258 ,

(l) Lel. Itin. vol, v. p. 108.

Vor. II. 
From the antiquity, fituation, and fortifications of Nerucafte, proceed we to its charters, privileges, civil government, and commerce.

ISing Henry II. granted it by charter great franchifes and libertics $(\mathrm{m})$.

King $\mathcal{F}_{0} \mathrm{~h}$, his fon, in the third year of his reign, confirmed them, on the payment of 100 marks, and two palfreys $(n)$. He enlarged them by charter in the fourteenth year of his reign, on the annual payment of $100 \mathrm{l}$. in two equal portions, at Eafter and. Michaelmas, referving to himfelf the rents, prizes, affizes, and leafes in it. In compenfation for the loffes fuftained by the inhabitants on taking down their houfes for making a fors or ditch under the caftle, next the river, he granted them an annual rent of 100 l. 10 s. 6 d. of Effaet, to be paid by him and his heirs; in proportion to their feveral damages (0). He alfo granted it,

(m) Gardiner, Ch. ii. p. 7 .

(11) Homines de novo caftello fuper Tinam [debent] 100 Marcas et 2 Palefridos, pro habenda villa de novo caftello fuper Tinam in manu fua, per veterem firmam, fcilicet $50 \mathrm{l}$. \& $10 l$. de cremento, \& pro habenda confirmatione de libertatibus fuis quas habent per cartam Henrici regis patrem; fed poftea mandatum eft per breve regis, quod eft in forulo Marefcalli, quod nec prædikta firma neque crementum ab cis exigatur; quia rex conceffit vicecomiti ut refpondeat de firma ejufdem villa, ficut confuevit antequam-crementum efiet pofitum, per prædictum breve.

Mag. Rot. 3 Fob. Rot. 18. a. Tit. Northumberland. Madox's Firma Burgi, p. 54 .

(o) Præterea conceffimus eis, et carta noftra confirmamus pro nobis et hæredibus noftris centum et decem folid. \&c. ad dividendum et afignandum illis qui redditus fuos amiferunt occafione forfati et novæ operationis factix fubter caftrum verfus aquam, \&ic.

Lib. Cart. p. I. 
for its loyalty and faithful fervices, as the record expreffes it, exemption from the power of the theriff and conftables in matters relating to themfelves; and that no burgefs thould be arrefted out of it for any debt, unlefs he was the capital debtor.

King Henry III, by his charter made it a Mayor-Town, I251 ( $p$ ); being governed before by four bailiffs; and to his other royal favours, added this gracious one, a grant, during pleafure, of all the demefn-lands belonging to the caftle, called, The CafleField $(q)$, containing 850 acres, for free pafture, with liberty to dig coals, and ftones, and to difpofe of them for their ufe to the beft advantage, upon payment of $20 \mathrm{~s}$. into the Exchequer; the bounds and limits of it taken upon inqueft, 3 I Q. Elizabeth ( $r$ ). His bounty did not ftop here. He gave them a field, called, The Forth, adjoining to the other, for the fame ufes, containing in acres, as furveyed by order of the parliament, 1649, and then valued at $12 l$. per annum; for which they were to pay 40 s. into the exchequer (s). It was alfo provided by his charter, that no Ferw fhould refide among them.

King Edward I. directed a writ of fummons to Newcafle in the tenth year of his reign, 1282 , to fend two members to parliament; which is the earlieft upon record for Boroughs to fend any, or for the Commons to fit, except that fummoned under Montfort's

\section{(p) Browne Willis.}

(q) Bourne.

(r) Inquifitio de inetis et bunderiis in terra Novi Cafri fuper Tynam, vocata Caflle-field, et terra prioris de Tynemouth, 31 R. Eliz. n. 56. Tom. 4. Rot. turri Londinenfo.

(s) Gardincr, Ch. iii. p. gs 
ufurpation in the name of the King's father, King Henry III ( $t)$. He annexed to it the villa of Pampeden (u).

(t) Rex majori, civibus, et vicecomitibus Londin. Vobis mandamus; quod duos de fapientioribus et aptioribus civibus prædictæcivitatis eligi faciatis, et eos ad nos mittatis, ita quod fint ad nos apud Salopiam in Craftino Sancti Michaelis proximo futuro nobifcum fuper hoc et aliis locuturi, et hoc nullatenus omittatis.

Tefte rege apud Rotheland, 28 Die Junii.

Eodem modo inandatum eft omnibus fubfcriptis.

Majori ct civibus Winton.

Majori et Ballivis villæ Novi Caffri fuper Tynam.

Majori et civibus Eborum.

Majori et Ballivis Brifgol.

Majori et civibus Exon.

Majori et civibus Lincoln.

Majori et civibus Cantunr.

Majori et civibus Karleal.

i. Ballivis Norwici.

Majori et probis hominibus Northampton.

Ballivis Nottinghom.

Ballivis de Scardeburgls.

Majori et Ballivis de Grimeßy.

Majori et Ballivis de Linn.

Ballivis de Colecefler.

Ballivis et probis hominious de Yarmouth

Majori et probis hominibus de Hereford.

Majori et probis hominibus Cefrice.

Ballivis et probis hominibus Salop.

Majori et probis hominibus $W_{y g}$ born.

Sub forma prædicta mandatum eft univerfis et fingulis vicecomitibus per Angliom, quod in quolibet comitatu eligi faciant duo milites de difcretioribus et aptioribus comitatus illius ad regem pro communitate ejufdem comicatus venturos; ita quod fint ad regem in Craftino Sancti Michaelis pradieto, apud Salopiam, cum rege fuper his et aliis locuturi: Et hoc nullatenus omittatis. 
By antient cuftom, the real eftates of the freemen were confidered as chattels, and they difpofed of them by will at their difcretion as fuch, which upon an inquifition was allowed and confirmed, 4 K. Edward I (v).

King Edward III, confirmed the franchifes of Nerwcafle, and granted it the perpetuity of the moor and lands, called Cafle-moor, and cafle-fields, to hold of him and his heirs, by the payment of $40 \mathrm{~s}$. annually into the exchequer $(w)$. . He exempted it from the jurifdiction of the admiralty of England, \&c. $(x)$; gave leave for

Itèm, fub eadem forma, mandatum eft ömnibus ubfcriptis, quod fint ad regem, ed diem pradictum, cum rege his et aliis locuturi. Richards de Holbrok, \&ic. judicibus.

Rym. Fœd. tom. ii. p. 247. \&c.

(u) Sciatis quod dedimus et conceffimus, et hac carta noftra confirmavinus, pro nobis et-hæredibus noftris, dilectis burgenfibus, et probis hominibus naftris, villæ Novi Cafri fuper Tynam, omnes tcrras et tenementa, cum pertinentibus, in Pampeden, in Biker, juxta frædictam villam Novi Cafti, \&ic. Et quod prædicta villa Novi Caftr, et terræ et tencm. prædict. in Pampedon unica villa de cet. funt, et unus Burgus, ad uniend. et concludend. dictam villam Novi Caftri in emendationem et augmentationem ejus villa.

Lib. Cart.

(u) Confuetud. fact. in Nivo Caftro quomlibet burgenfem tenementa fua, in manu fuo, tanquam catella fua poffe legare, \&c. de inquirend. Pat. 3 R. Ed. I. m. 24 . in dorfo.

Burgenfes Novi Caftri fuper Tyzam polfint legare terras et tenementa faa tanquan catella cui voluerint, \&ic. Pat. 4. R. Ed. I. m. 24. Tom. 4. Rot. Turri Londinenfi.

(w) Novo Cafrofuper Tynam licential fodiendi carbones et Petras extra muros civitatis in loco vocato le Cafle-field, Pat. 24 R. Ed. III. p. 3. m. 6. et anuo 3r. p. I. m. 5. Dorfo: Et commift. tangentem eand. mater. m. 25. Ton. 4. Rot. Turri Lond.

(x) Villa novi caftri fuper Tynam libera fit a jurifdictione, \&c. conftabuli mafhall. et Admirall. Anglia, et cuftod. marchio. vocat. Eurle. Pat. 6. 22 R. Ed. III. n. 39. ibiu. 
purchafing lands to a certain value $(y)$; confirmed feveral byliaws of the magiflrates for well-governing and improving it $(z)$; and iflued an order for the manner of electing the mayor, magiltrates, and other officers (a); and another concerning the meafire to be ufed by the venders of coals $(b)$.

King Richard II, confirmed its charters in the firft year of his reign, 1378 . He afterwards granted fome pieces of ground for the conveniency of making high-ways, and a bridge (c). For its greater honour, he alfo granted, I390, that a fword, the enfign of royal ftate and authority, fhould be carried before the mayor.

King Henry IV, on his acceffion to the throne, granted it farther privileges and immunities; that it hould be a town and county of itfelf, independent of the county of Nortbumberland; that it thould have a theriff, inftead of bailiffs, who thould hold a court, account before the Barons by their attorney, and have the return of all writs, \&c. that it fhould have fix aldermen, to be elected from among the burgeffes, with power to act as juftices

(y) Pro fatuitate novo caftro fuper $T_{y n a m}$ facta ad terras acquirendas. Pat. 37 R. Ed. IIl. p. I. m. 2. Ibid.

(z) Confirmatio ordinationis factæ pro melioratione et traniquillo regímine villit et incola* rum novi caftri, Pat. 16 R. Ed. III. p. 3. m. 5. Ibid.

(a) Ordinatio facta de modo majorum, et alior, offic. Novi Cafri eligend. Pat. $3^{8}$ R. Ed. III. p. 2. m. 34. Ibid.

(b) Nou, Caf. fuper Tynam de carbonibus maritimis menfurandis. Pát. $3^{8}$ R. Ed. III. p. 2. m. 34. Lid.

(c) De ôuibufdum placeis terræ in novo caftro fuper Tynam, burgenfibus ibidem conceflis; pro ponte et vis conftruend. Pat. 18 R. Ric. II. P. 2: m. 27. et 40 . Ibid. 
of the peace within their jurifdiction; that it fhould have the royalties of the river Tyne, from Sparrow-Hawk to Hedwin-freamis; with a prohibition for any thip to load or unload any fort of goods in any part of the river within thofe limits, except at Nerecaftle (d).

K. Edruard VI, on the diffolution of the bifhoprick of Durbain . by act of parliament, 20 March, 1552, granted to this corporation the town and liberties of Gates-head (e). He alfo defigned to have erected a bifhoprick at Nervaffle, and another at Durban, out of its revenues. The preamble to the ait fets forth,

That this bifhoprick being then void of a prelate, the gift thereof was in the king's pleafure, and the compafs of it being fo large as to extend itfelf into feveral thires far diftant, it could not be fufficiently ferved by one bifhop; and fince the king by his godly difpofition; was defirous to have God's Holy Word preached in thofe parts, which were wild and barbarous for lack of good preaching, and good fearching; therefore he intendeth to have two bihopricks for that diocefe; the one at Durham, which fhould have 2000 marks yearly revenue, and another at Nervcafte with 1000 ; and alfo found a cathedral church at the latter place, with a deancry and chapter, out of the revenues of the faid bithoprick. Therefore the bifhoprick of Durbam is utterly extin-' guifhed and diffolved; and authority given for letters patents to erect the two new bihopricks, together with a deanery and chap-" ter at Nerwcafle; with a provifo, that the rights of the deanery,

(d) Novi caftri fuper Tynam burg. quod fit comitatus per fe, et alias habeat libertates: Cart. I Hen. IV. p. 1. n. 8. Tom. 4. Rot. Turri Londinens. Northumbr.

(e) Stat. 7 Ed. VI. Biurne, vol. ii. p. 172. 
chapter, and cathedral of Durbam, nould fuffer nothing by this act $(f)$.

:The king's death defeated this defign. An act of parliament paffed, I Q. Mary, 1554, for reftoring the bifhoprick of Durbam to its antient ftate, after much oppofition from this corporation, and warm debates in the Houfe of Commons, by a great majority, 201 againft I 20 . The preamble to the bill fets forth,

That certain ambitious perfons taking advantage of the late king's minority, made an intereft by finifter practice to procure the diffolution of the bifhoprick; that it was done out of mercenary views, to enrich themfelves, and their friends, by feizing the lands of that See, rather than upon juft occafion or godly zeal. That Tunfal, Bifhop of Durbam, was deprived upon untrue furmifes, and falfe accufations, and that procefs againft him was foul and illegal. That upon a full examination of the matter, by the queen's commifioners, the fentence of deprivation was declared void, as may be feen at large by an authentic inftrument. That the queen had new founded the bifhoprick by her letters patents, and reftored all the lands in her poffeffion. But, that neither the fentence of deprivation, nor the queen's letters patent, were of fufficient force to recover the honours, lands, \&x. to the See of Durban. Therefore to reftore the bifhoprick to its former intereft, privileges, and revenues, the two diffolution-ftatutes of the laft reign were hereby repealed $(g)$.

(f) Strife's Memorials, Vol. ii. p. 396.

(g) Statutes at large, I Mary. chan. 3 .

Acta Regia, vol. iii. 8 vo. p. $3^{87}, 3^{88 .}$

Collier's Ecrles. Hift. p. $3^{66 .}$ 


\section{ANTIQUITIES OF NORTHUMBERLAND.}

Queen Elizabeth confirmed to the town of Nervafle the favours of her progenitors, and added new ones, by her charter, bearing date, $22 \mathrm{~d}$ March, and $42 \mathrm{~d}$ ycar of her reign ( $b$ ).

So much for the royal Cbarters and Privileges granted to Newcaffle. Next, of its

Civil Government. This is admirable, and docs honour to it, in its minuteft branches. For the adminiftration of juftice, it hatl: feveral courts ;
The Mayor's Court ;
Ward-Moot ;
Sheriff's Court;
Court of Confcience;
Pyepowder-Court ;
Admiralty-Court ;
Court of Common-Council;
and,
Three gilds, annually.

The Mayor's Court is held cvery Monday at the weft end of the Guild-hall in the Exchange. It is a court of record, and of great importance. It preferves the rights, laws, franchifes, and cuf- h. Rum toms of the corporation. In it are tried all actions for debt, tref- in Pram paffes, accounts, covenants, broken attachments, fequeftrations, or other matters arifing within the town and liberties, to any value whatfoever. No attorneys are allowed to plead in it, but fuch as are free of the corporation, who are fworn at their admiffion. It hath fix fergeants at mace to attend it. If the clerk of this court takes infufficient bail, and the defendant abfconds, the plaintiff, upon judgment obtained, may oblige the clerk to pay the debt or damage, by petition to the court.

(b) Sce an abftract of it, and other chartcrs and grants to the corporation, in Gardiner, 4to. Lond. with many cuts, and a map of the river Tjne, Pages 204.

Vol. II.

$\mathrm{C}$ c An 
An action commenced in it, may be brought to trial for 30 s: but will coft more money and time in the fheriff's court, out of which an action may be removed into the mayor's at any time before a jury is fworn, but not out of the mayor's into the theriff's.

An action entered in it, will for ever remain in force, though. no procefs be thereupon.

The juries of this, and the fheriff's court; are the fame. They are returned every Chriftmas by the feveral wards of the corporation, at their ward-moot-inqueft; where particular wards appoint perfons to ferve as jury-men for every month in the year. They are entered in a book by the town-clerk, of whom the officers of thofe courts receive copies.

Upon a caufe being removed out of the theriff's court into this, and it appearing to the-mayor that a verdict hath been obtaincd againft the plaintiff for more than his juft debt, the mayor may remit the caufe to judgment for the juft debt only. The recorder for the time being is judge hereof, but the mayor and aldermen may fit as judges with him, if they pleafe.

The Sberiff's Court is a court of record, held on Wedneflays and Fridays in the fame place, for trials, and entering proceedings, as rules, appearances, judgments, pleas, \&c. The attorneys who plead in it are appointed by the mayor and court.of aldermen. They are allowed three fces in every caufe; viz. one for the Appearance, another at iffue, and a third upon fummons for trial; or to have a fee on every fummons, if the caufe be fummoned more than once. The fees for trial are, 


\begin{tabular}{|c|c|c|c|c|c|c|c|c|c|}
\hline & & & & s. & & & & & \\
\hline Attorney's fee & - & $-\quad-$ & - & I & 8 & The fupena & - & - & \\
\hline The action & - & - & - & o & 4 & Council, at leaft & & - & \\
\hline Arreft - & - & - & - & I & $\circ$ & Jury's verdict & - & - & \\
\hline Declaration, if & ger & neral & 1 - & i & 4 & Judgment - & - & - & \\
\hline Court-fees ther & reon & & - & 0 & 8 & Execution & - & - & \\
\hline Deletur - & - & & - & 0 & 4 & Prothonotary's & $\mathrm{s} f \mathrm{f}$ & e, if & \\
\hline he iffue and at & ttorn & & fee & & o & the declaration & & fpe- & \\
\hline $\begin{array}{l}\text { Summons of } \mathrm{tl} \\
\text { and attorney }\end{array}$ & $\begin{array}{l}\text { he ju } \\
\text { 's fe }\end{array}$ & $\begin{array}{l}\text { ury } \\
\text { ee }\end{array}$ & & & 8 & $\begin{array}{l}\text { cial, every thee } \\
\text { ing and engrofl }\end{array}$ & et & raw- & \\
\hline
\end{tabular}

The defendant's fees are,

The attorney's fec for appearance, and ithe The attorney's fee for appearance, and the court fees, 26 The copy of the declaration per theet - - $\quad 04$

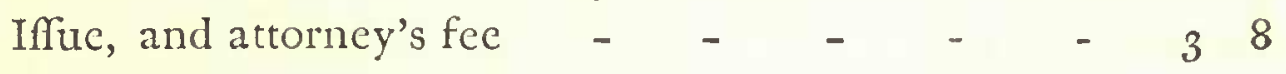
Attorney's fee upon the fummons. $\quad$ - $\quad$ I 8

The defendant may (after the verdict is given, and before judgment is entered) ftop judgment, by taking the caufe before the mayor, for time to pay the money recovered.

In this court may be tried actions of debt, trefpaffes, accompts, covenants, broken attachments, and fequeftrations. If either party cannot ftay in town till the day of trial, his teftimony in writing will be allowed for good evidence. The heriff, if he pleafes, may fit upon all trials with the recorder, who is alfo judge here.

The Court of Confcience is eftablithed by act of parliament, and kept in the fame place. It is fo called, becaufe all debts under C c 2 403. 
40 s. are recoverable in it, upon the creditors making oath, that the fin judges. They adminifter oaths, and commit to prifon offenders. They proceed firt by fummons. This cofts but three-pence. If the defendant appears, there is no farther charge. If he does not, they proceed to attachment and execution. All perfons, whether free or not, if within the freedom, may profecute, or be profecuted in this court. Freemen may be profecuted though they live out of the liberty.

The Court of Admiralty is held before the mayor for the prefervation of the river Tyne, at fuch times as he fhall direct. His deputy, the water-bailiff, gives notice of all offences committed contrary to the orders made for the prefervation of the brood of filhes, and takes effectual care that they may be proceeded againft according to law.

The Court of Common Council is after the model of the fupreme council of the nation. It confifts of two houfes. One is for the mayor and aldermen. The other is for the commoners. They make all by-lays for the benefit of the corporation. In this court are recorded all deeds and evidences. The mayor can call and adjourn it at pleafure.

In the court, called the Ward-noot-Court, are chofen the officers for the government of each particular ward, as common council-men, conftables, \&c.

The Court of Pyeporuder is held at the time of the fairs and Lammas and St. Luke, for cxamining and trying all fuits brought for petty differences and offences committed contrary to the following proclamation, made on the firft day of each fair. 
"The Right worthipful mayor of the town and "county of Newcafte upon Tyne, and his worthipful brethen, "the aldermen of the faid corporation, ftreightly charge and " command on belualf of our fovereign Lord the King, that all " manner" perfons of whatfoever eftate, degree, or condition "they be, having reconre to this fair, keep the peace of our " faid Sovereign Lord the King.

" That no manner of perfons make any congregations, con"venticles, or affiays, by which the faid peace may be broken " or difturbed, upon pain of imprifon "rent, and fine to be made, "after the difcretion of the mayor and aldermen.

"Alfo that all manner of fellers of wine, or beer, fell by mea"fure, fealed, as by gallon, pottle, quart, pint, \&c. upon pain " that will fail thereof.

"And that no perfon fell any bread, but if it keep the aflize, " and that it be good and wholefome for man's body, upon pain "that will fail thereof.

$*$ And that no manner of cook, pyc-baker, nor huckfter, fell, " or put to fale, any manner of vicual, but it may be good and "wholefome for man's body, upon pain that will fail thercof.

"And that no manner of perfons buy, or fell, but with true 'weights and meafures, fealed according to the fatute in that "behalf made, upon pain that will fail thereof.

"And that no manner of perfon, or perfons, take upon him "or them within this fair to make any manner of arreft, at"tachment, fummons, or execution, but if it be done by the "officers 
IDS ANTIQUITIES OF NORTHUMBERLAND.

" oflicers of this corporation, thereunto affigned, upon pain that "will fail thereof.

"And that no manner of perfon or perfons, whatfocver within "the limits and bounds of this fair prefume to break the Lord's " clay in felling, thewing, or offering to fale; or in buying, or "offering to buy, any commoditics whatfoever; or in fitting; " tipling, or drinking, in any tavern, inn, or ale-houfe, tipling"houfe, or cook's houfe, or in doing any other thing that may "tend to the breach hereof, upon the pains and penalties con" tained in feveral acts of parliament, which will be feverely in" flicted upon the breakers thereof.

"And, finally, that what perfons foever fund themfelves grieved, "injured, or wronged, by any manner of perfon in this fair, "that they come with their plaints before the ftewards in this "fair, afigned to hear and determine pleas, and they will ad"minifter to all parties juflice according to the laws of this land, "and the cultoms of this corporation."

Befides thefe courts, the mayor holds

Three Gilds annually, for the enrolling and turning over apprentices, and making others free who have performed the obligations in their indentures; and for hearing and determining differences between mafters and their apprentices. Any mafter refufing to make his apprentice free when he ought, on complaint thercof to the mayor, he will fummon the mafter before him, and if he thew no good caufe to the contrary, the mayor will make him free.

If a rnafter mifufe his apprentice, either by beating him, neglecting to influs him, or to find him neceffaries, the mayor will 
fúmmon the mafter before him, and relieve the fervant, or direct him to take his remedy in the mayor's court.

If a freeman refufe to appear before the mayor upon fummons, the mayor and recorder will grant a warrant to oblige him to appear. This will coft is.

If any apprentice be difobedient, or diforderly, \&c. the mayor will fend one of his officers for fuch apprentice, and fend him to the houfe of correction at $W_{e}$ t-Gate, or otherwife punih him, as the offence deferves.

When an apprentice is to be turned over to another mafter of the fame trade, it cannot be done before he is turned over before the company where he was bound. If he be turned over by the company only, it is no obligation on the fecond mafter to keep fuch apprentice, nor is the apprentice obliged to ferve fuch fecond mafter. He may leave his fervice at pleafure, and fue out his indenture againt his firft mafter. Therefore it is necefliry, that all apprentices be turned over before the mayor. This difcharges the firf matter, and obliges the fecond, and alfo the apprentice to ferve him the full term fpecified in the indentures.

On any difference arifing betwcen a rnafter and an apprentice, it is the intereft of both to refor it to the mayor. He will hear both parties, and decide the controverfy, for this fmall charge, viz. for the fummons one fhilling, and two fhillings to the clerk for the order.

If any apprentice hall omit to take his frecdom within convenient time, he is liable to be fined by the mayor at his pleafure. 
If a frecman thall privately turn his apprentice over to a foreigner, and let him ferve him, and teftify to the mayor that the apprentice ferved a freemen, the mafter and fervant may both be disfranchifed, and fined at the pleafure o the recorder, and the mayor may caufe the freeman's fhop to be fhut up.

If a mafter connive at his apprentice's fervitude, and make him free too foon, they are both liable to be disfranchifed; the former acting contrary to the oath which he took, when he himfelf was made frec, and which ought to govern all freemen afterwards. The oath is in the following terms.

"Ye fhall fwear that ye thall be good and true to our fove"reign lord K. George III, and to the heirs of our fovereign lord "the king, obeyfant and obedient ye fhall be to the mayor and " minifers of the corporation, the franchifes and cultoms thereof "ye thall maintain, and this town kecp harmlefs in that That "you is.

"Ye fhall be contributary to all manner of charges within "this town, as fummons, watches, contributions, taxes, tallages, "lot and fcot, and to all other charges bearing your part as a "freeman ought to do.

"Ye thall colour no foreign goods under or in your name, " whereby the king or this town might or may lofe their cuftoms "or advantages.

"Ye fhall know no foreigner to buy or fell any merchandize "with any other foreigner within this corporation or franchife " thereof, but ye thall warn the mayor thercof, or fome minif"tering under him. 
"Ye fhall implead or fue no freemen out of this town, whilft "you may have right and law within the fame town.

"Ye fhall rake no apprentice but if he be free-born, that is to "fay, no bondman's fon, nor the child of an alien, and for no "lefs term than for feven years, without fraud or deceit, and " and within the firft year ye thall caufe him to be enrolled, or" " elfe pay fuch fine as thall reafonably be impofed upon you for "omitting the fame: and after his term's end, within conveni" ent time (being required) ye thall make him free of the cor"poration, if he have well and truly ferved you. Ye fhall alfo "keep the king's peace in your own perfon.

"Ye fhall know no gatlierings, conventicles, nor confpiracies, "againft the king's peace, but ye hall warn the mayor thereof, " or lett it to your power.

"All thefe points and articles ye thall well and truly keep, ac"cording to the laws and cuftoms of this corporation, to your "power. So, God you help!"

It muft be remembeted to the honour of the magiftrates of Newcafle, that their attention and zeal has ever been confpicuous, unremitted and ardent, in maintaining harmony and good order among all ranks of people within their jurifdietion, and ftigmatizing bold and impudent miftemeanours. Ever inclined to lenity, rather thin rigour, and confcious how much fome delinquents are more afeeted by being expofed to public thame and ignominy, than by any other fort of punifhment, they had an antient cuftom of punihing drunkards and brawling women by caufing them to pafs in revicw through the frects, each in a machine, fymbols of their notorious mifconduct. A great barVól. II.

Dd re! 
rel or tub, with the ficies open, and one end perforated, was put over the drunkard's head, 'which covered his fhoulders and body to the fmall of his legs, where it was faftened. This was called, The Aeru-fafioned Cloak. An iron-engine, in a crown-like form, enclofer the head and face of the female brawler, an irontongue entering her mouth, and fo contrived, that her face might be feen. This was called, The Branks (z).

For preferving peace, tranquillity, and order, in preventing accidents in the night-time, an act of parliament was obtained by the corporation, $I 76_{3}$, for having lamps and a night-watch. Thus diftinguifhed is Nerecafle for its good government. It is as emincnt for its

Commerce, trade, and revenue. It is the great Enporemm of the north of England, and of a good part of Scotland. In the carly reign of K. Elward III, it was fo powerful in thipping, that in his expedition againf the French, it fent him an aid of 17 Ahips, and 314 men, as appears from the roll of his fleet before Calais, cxtant in the king's great wardrobe in London, and cited by Hakluyt in his Englifo Veyages (a). That great king, for the cncouragement of its tradc, granted the merchants leave to carry their goods to any part of Englond toll or cuftom-frec(b). It is in the lin of the trading towns to which Sir Thomas White, lord nayor of London, i Q. Nary, I553, gave $100 l$. per anuum

$(\approx)$ Gardizer, P. 110, III. Where there is a print of a woman under this difcipline, attenued by an ofin of the cosporation; hor name, Anne Bialsone.

(a) Vol. i. p. 176 .

(b) Homines Novi Caftri fuper Tyram pofint mercimonia fua in qualefcunque partes regni transferre finc folutione fubfidii.

Clauf. 20 R. Ed, III. p. I. m. 16. 


\section{ANTIQUITIES OF NORTHUMBERLAND.}

for ever, to be lent to four merchant-cloathiers for ten years without intereft $(c)$. It firf received that bounty in the year $152 \%$ and ever fince in its turn. The merchant adventurers have a governor, twelve affifants, and a fecretary. They lave a ftately court, to the eaft of the town-chamber, built upon part of the antient lofpital of St. Catharime. Great and gencrous ertor:; have been lately made by the corporation to give life and vigour to the commercial arts. A bank has been eftablined. A fund has been raifed for carrying on the herring and Greenland fincrias. But the chicf trade of Neweafte is derived from the coal-mines, the Potof of Northmberland, and Durbam. This fives bical to fome thoufands, and enriches individuals. The vat extent of it may be partiy gueffed at, fiom the i s. per chairion granted by the corporation to Q. Elizabeth, in the licu of an arrear of $a d$. per chaldron, fince given to the noble family of the Duke of Richnond, which anounts to about 14,000l. per annum. The coal-flects fometimes amount to 500 fail. Their ftation is at Shields, and at the keys of Girwy or Farroze, and Willington; the former on the fouth, and the latter on the north fiele, of the Tyne. All that parcel of ground within the liberty of Fillington, between high and low-ivater-mark, in length from eaft to weft I 245 yards, and in breadth 190 yards, was granted by the corporation to Sir Francis Anderfon, Knt. on a lcafe for 1000 years, with leave to ereet keys, and caft ballaft, on payment fof $2 d$. per ton, gth Scpt. $x 665$. Ships take in their loading of coals by the help of keels. It was cnacted, 9 K. Ifen. V. Isigx, that the keels fhould be of the burthen of 20 chaldrons, and no more, according to cuftom; (fome being of the burthen of 22, and fome of 24 chaldrons, to defraud the king of his cutoms;) and that they fhould

(c) Hol. Chron. vol. ii. p. Icg2. 
be fealed by the king's officers (d). Small fhips, loaden with merchant goods, only come up to the key at Nervafile. It is efteemed one of the beft keys in England. It is in length, from. calt to welt, ro3 rods.

Great contels were anticntly between this corporation, and the priors of Tynemouth, and the bithops of Durbam, concerning the jurifdiction of the river Tyne. A decifive decree was obtained againft the prior of Tynemouth, $34 \mathrm{~K}$. Edward I (e); and another againft the bifhop of Durlsam, $8 \mathrm{~K}$. Richard II $(f)$.

A grant of the confervation of the river Tyne was given to Fobn Earl of Hamfead, I a K. Edward If ; but was recalled in the fame year, on the king's being informed that it was an infringement of the liberties of the corporation $(\mathrm{g})$.

The town is well fupplied with provifions both by land and water. It hath two excellent weckly markets. They are held.

(d) Novi Cafri fuper Tynam de cufuma regi debita pro quolibet quarterio carbonum maritin:orum ibidem vendendo gentibus franchefiam non habentibus, et de vafis vocatis Kecls ibiden menfurandis. Pat. 9 R. Hen. V. p. 2. m. 19. tom. 4. Rot. Turri Londin.

(e) Bourne, p. 161.

(f) Quod gaudeant major et communitas Novi Cafiri fuper Tynam libertatibus et privilegiis conceflis, praceptum eft epifc. Dunelm.

Clauf. 8 R. Ric. 11. in initio Rotuli \& in dorfo. in 51 . intus inter epifc. p. 100. et in 42 . dorfo.

(g) Tyne aqua concelfa Gobanni de Hamfed. Pat. 12. R. Ed. II. p. 1. m. 2. 7 .

De cuftodia aqua de Tyzo concefla pridem Folsanni de Hamfed, revocata, quia rex intelligit, quod commifarius prædi@tus agit in prejudicium libertatis burgenfium Novi Caftri.

Clauf. 12 Reg. Ed. II. m. 26. 
on Tuefdays and Saturdays. It hath alfo two great and noted annual fairs. One is on the firf of Auguft, and continucs cight days together. It was granted by K. Fobn. The other is on St. Luke's day, in the fame place. It was granted by K. Heiny VII. On thefe two days they are alfo held on the town-moor. It has been before obferved, that whilf they continuc, the corporation have a court of pye-powder, which has all the privilcges that a court-leet can have. The tolls, booths, fallage, picage, and courts of pye-powder, of each of the fairs, in the times of the ufurpation, were valued at $12 l$.

The revenue of the corporation of Nerwafle, which they hold in their own right, is upwards of 8000 l. per annum. They have the royalties of the river Tyne from Sparrow-Hazok, by TynemouthBar, to Hedwine-ftreams, above the village of Nervburn; a fpace of 14 miles. The circumference of their boundaries is 10 miles, and 50 yards. The revenue for coals, falt, grindftones, ballat, \&e. are received by eight chamberlains. They alfo keep the town-fecurities. Their office is in the exchange. They are commonly decayed merchants, eminent for their integrity, chofen annually. Twenty-four auditors, chofen out of the twelve companies, examine their accounts once a year; and conjunctly with the mayor and aldermen fee that the overplus of their annual revenue is put into the toron-fock, or butch, as it is ufually phrafed. The chamberlains give daily attendance at their office.

Nereafle is not more eminent for its wealth and commerce, than for its zeal in cherifhing religion. It is famous for its monafteries, its hofpitals, alms-houfes, and churches. The monaAteries were,

St. 


\section{ANTIQUITIES OF NORTHUMBERLAND.}

St. Bartbolomew's,

'The Francifcans,

The Domus Fratrum Predica-
The St. Aufin's,

The Domus Fratrum de Penitentia,

The Domis Fratrum Carmeli Monte.

torkin,

St. Bartbolonerw's was founded by K. Henvy I, for Benedictine Nuns. It was in Neregate-1rect. A back-gate leading to it fill retains their name; as does their garden (b), which is in a fquare vale, and reaches to a place called High-Frier-Chare. Befides other poffefions, not now certainly known, they had the pleafant village of Stella on the fouthem banks of the river Tym, in the bihoprick of Durisan, afterwards in the poftefion of Sir Nicbolas Tempeft, Bart. as attefed by an antient rviting, in the cuftody of the late humane and judicions antiquary, Dr. Hunter, of Durham (i). It is believed they had a very large property in Nerveafle, in waftes and houfes. The garden of the pofthoufe was one of thefe waftes $(k)$. A plot of ground adjoining to the torvn-moor was

(b) Boume, p. $48,49$.

(i) I zmo die Septembris, anno 2do Carrali regis comperium puft mortem Nicbolai Tempith, de Sulle; ; in com. Dunelm. mil et baronet. Qund fuit feifitus de et in manerio de Stellingley, - alias vocat. Stclliy, fituat. et cxift. prope aquam de Tyne, in parochia de $R_{y} t o n$, in epifeopatu Duneim. cum fuis juribus, membris et pertinentiis univerfis: Ac de omnibus terris arabilibus, pratis, pafcuis, pafturis, hofcis, fubbofcis, communis, pifcationibus, mineris, carbonum infra folum et fundum ibidem commoditatibus, proficuis, emolunentis, et aliis dran. tagiis, cidem manerio de Stelling'cy, alias Stelicy, pertinentibus, vel ullo molo fpect tibus, nuper parcello poliefionum domus five monaterii S. Bartbolsmi infra villam Novi Cafti fuper Tynam diffuluti.

(k) Ubi nulla remanent antiqui monafterii Uiani: Veftigia recentioris quidem, pu'clerrimam videmus eapellam vix adhuc ruinis fuccumbentem. Traditio eft cellam fuiff fanctimonialium Novocaftrentium, licet ejus hiftoriam apud autores vix inveneris.

Smith in Not. Bed. 1. 3. c. 21.-Bourne, p. 213, $214,215$. 


\section{ANTIQUITIES OF NORTHUMBERLAND.}

their's, and ftill carries their name, that of the Nun-Moor. The monaftery and chapel in Gateßhead, called Gateßhead-Houfe, is faid ro 'have been a cell to them, and paid an annual rent of $a s$. St. Mary's hofpital, in Weftgate-Arcet, was alfo dependent upon them (1). Their annual revenue, $26 \mathrm{~K}$. Fenry VIII, was valued at 36 . 10s. Diugd. 37 l. 4 s. 2 d. Spied. They furendered Jan. 3. 1540. The abbefs was allowed a penfion of 61 . per ann. for iffe. Her name was Agnes Law one. The monallery came into the polfeffion of Lady Gaveere, of whom it was purchafed by Mr. Robert Anderfon, who, to diflodge itinerant, pedling traders, and ftrollers, (for whom it was become a lind of fettlement and a home, and a grievance to honef freemen and tradefrimen of the town) pulled it down, cleared the garden of rubbifh, and made it a very plcafant fpot, being reputed from corner to corner eleven fcore yards, which is now a meadow, and belongs to Sir Walter Calverley Blacket, Bart (m).

The monaftery of the Francifcans, Grey Friers, or Friers Minors, was founded in the reign of K. Henry III, by the Carliols, wealthy merchants in Nerecafle ( $n$ ), whofe great eftate went by marriage to the family of the Thutrgills of the Holds in Yorkfbire (0). It was fituated by a lane, now called High Frier Chare,_ricus qui ducit

(1) Hewius res (II.) \&c. Sciatis me concefffe, et charta confrmaffe monialibus fandi Baribol niei de $\Lambda$ vo Cafillo fuper Tynam omnes donationes quae eis rationabiliter facke funt: videlicer, ecclcham Sandi Bartholomi, et hofpitale de Sancte Maris de predicro caltullo, ct terram, Ex. Eixx acras de fcala, et ix tofta-Et duos foldos de Gabiseal, et onnia alia qua cis raionabiliter data funt, vel dabuntur. Quarevoloct fermiter pecipio, \&c. Tin.

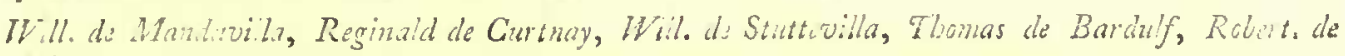
Stutievilita, Richard de Gosford.

(n) Mis. of John Miribank, Efq; citcd by Bourne.
(n) Eourne, p. 19.
(o) Lel. Itin. vol, 6. p. 55 . 


\section{$3=8$

ad fratres minores; near Pilgrim-gtreet-gate, and oppofite to FicketTower, in the garden of Sir Walter Calverley Blacket, Bart. (p). It confifted of a warden, eight friers, and two novices. It furrendered 9 Jan. 30 K. Henry VIII.

The Domus Fratrum Predicatorum, or the monaftery of the Preaching Friers, Black Friers, or Dominicans, was founded in honour of St. Dominic, born at Cologna in Spain, by Sir Peter and Sir Niclolas Scott, father and fon, both merchants in Newcafle, and owners of the lordfhip of Ejoet, ncar Felton(q), on a piece of ground given by three fifters in Weftgate $\left(r^{\circ}\right)$, whofe names are not now to be learnt from any records. Sir Peter was the firit mayor of Nerucafle, 1251. He was mayor three years. Sir Nicholas, his fon, was one of its four bailiffs, I254, 1257, and 126\%. Its remains thew it to have becn a very handfome ftructure. The grafs-area is about 87 feet in length, and as many in breadth; on the eaft of which was a chapel, now the hall of the fmiths company; and on the weft, an antient wcll, called our Lady's Well; on the fouth, is the Cordwainer's ball, turned into apartments for three widows; on the north, were the gardens $(s)$. It confinted of a prior, and
(p) MS. of fobn Milbank, Efq;
(a) Lel. Itin. vol. 6 .
(r) Ibij.

(s) Edwardus Dei gratia, rex Anglice, dominus Hibernia, dux Aquitania, omnibus ad quos prefentes literæ perveniunt, falutem. Sciatis quod de noftra gratia fpeciali concefimus dilectis nobis fratribus predicatoribus de Novo Caftro fuper Tynam, quod per medium Novum Murum circumagentem villam prædictam, quem per medium gardini prædictorum fratrum fieri oportebit, ut diat facere poffint quandam frictam portam ad ingreflum in gardinum fuum habend. portan luft. fibi et fucceffuribu fuis tenere in perpetuum. Dum tamen porta illa ad voluntatem noftram, vicecomitis Northumbrix aut conftabuli noftri ibi s. qui pro ecmpore fuerit, obßruatur. Pat. 8 R. Ed. I.

Fratres Predicalores monafterii in Novo Caffro fuper Tynam kabent licentiam faciendi quentdam pont m vergatilem uliza Novum Foffatum, \&c. Pat 5 R. Ed. II. p. 2. m 5 . 
twelve brethren, dependent upon Tynemouth. They furrendered ro Jan. 30 , Henry VIII. Their annual revenue was then $21.19 \mathrm{s.} 6 \mathrm{~d}$. The priory was granted to the corporation of Newcafle, in confaderation of $53 l .7 s .6 d$. In which gift are mentioned, befides the buildings, two gardens, a whole clofe within Wreftgate, another clofe adjoining to the north of the priory, a third containing three acres, and a houfe upon the fame without the walls, and a houfe near Wrefgate, called The Gate-boufe; the king referving to himfelf and fucceffors the bells, lead, iron, and ftone of the abbey-church, and other buildings. The priory is preferved from delapidations by fevcral trades or companies of the corporation, who have their halls in it.

The monaftery of St. Auftin was founded by William Lord Ros, Baron of Wark upon Tweed ( $t$ ). It was fituated in the ManourChare, formerly called Cow-gate (u). It was a handfome edifice, adorned with cloifters, and had a curious chapel. It was fometimes the refidence of the kings of England, in their expeditions againft Scotland. It furrendered 9 Jan. $30 \mathrm{~K}$. Henry VIII; and for fome time was niade ufe of by the government for a magazine and a ftorehoufe, and was called by the townfmen, The Artilleryyard. K. Fames I, gave it to a Scotchman, who uncovcred it, and

(t) Lel. Itin. vol. 5. p. 108.

(u) Fratr. Sancti Augufini in Nors Cafiro fuper Týnam confumatio Cotæ Terræ qux jacet in Cew-gate ibidem, conceff. per Willielmum Ros.

Pat. 2. R. Ed. II. p. I. m. 23 .

De meffuag. in Novio Cafro fuper Tynam, parcell, pofteffron. Roberti le Widdleton, attinßi, conceffis per regem pro manfo elargendo.

Pat. 2. R. Ed. II. p. 2. $\mathrm{m}$ 3I.

Fratr. Sancti Augufini monafterii in Niovo Cafro fuper Tynam de quadam Placea Terra

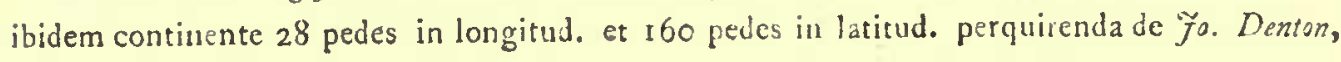
pro manfo elargendo.

Pat. 16. R. Ed. II. p. 2. m. i5.

VoL. II.

E $\mathrm{c}$

fold 


\section{0 ANTIQUITIES OF NORTHUMBERLAND.}

fold the lead, which was caft away at fea before it reached a market, and fold fome of the ftones to Sir Peter Kiddel, with which the fouth end of his fine houfe was built $(v)$. Out of its ruins has fince arofe a work-houfe for the employment of the poor; a houfe of correction; a charity-fchool for the parifh of All-Saints, anda dwelling for the mafter built in 1723. The Surgeon's Hall, and two of the town's hofpitals, ftand on part of the ground which was the gardens belonging to it.

The Domus Fratrum de Penitentia I. Chrifti, or the Monaftery of the Brethren of the Penance of Fefus Chrift, was at the foot of Wrefgate, near the White Frier-Tower. K. Henry III, by the defire of Robert Bruce, gave it a place, called Stable-Gartb (x), fuppofed by Sir Fobn Fenwick to be in the clore of the

Domus Fratrum Carmeli Monte, or Monaftery of Thite Friers (y); which was founded by K. Edward I. in honour of the Bleffed Virgin, for a prior, feven brethren, and two novitiates; and furrendered soth Jan. $30 \mathrm{~K}$. Henry VIII; valued at 9 l. I i s. 4 d. It was almoft at the foot of Weftyate, oppofite to the White Frier Tower. The enclofure belonging to it, wherein was the Stable-Garth, came into the poffeffion of Sir Ralpb Delaval. It then had the name of Domus Fratrum de Penitentia (z).

The Carmelites had another monaftery, fituated on the WallKnowl; the founder, Lanrentius de Aiton(a), or Roger de Thorn-

(v) MS. of Jum Milbank, Efq; cited by Burne, p. 136, 137 .

(x) Nou. Caftr. Yuper Tynam fratres de penitentia Iefu Chrifi de quadam placea ibidem rocata Stab'e. Gartb contigua claur. dictorum fratrum canceffa ad placeam fuam elargendam. Pat. 5I. R. Hen. III.
(y) MS. de rebus Novi Caffit, cited by Bourne, p. $3^{8 .}$
(z) Ibid.
(a) Lel. I in. vol. vi. p. $5^{6}$. 
ton (b); but, which of them is not known by the authority of any record that is decifive. It is certain, Roger de Thornton, the elder, was a benefactor to it. By lis will he left two fother of lead to repair the church or chapel belonging to it (c). It was dedicared to St. Michael, from whom, and the height of its fituation, it had the name of St. Michael's Mount. At the diffolution, K. Henry VIII, gave it, and its revenues, to Sir Fobn Grefham, an alderman of the city of London, viz. The priory-houfe, garden, and orchard, about an acre of ground; an enclofure near the town-walls, about four acres; thirty-four meffuages, three gardens, and one enclofure; alfo an enclofure called Cole-riggs, and four Les Rigges in the Shield-field. The priory, with a houfe, orchard, and garden, came afterwards into the poffeflion of William Dent, an alderman of Nereafte, Efq; and his fon William, who conveyed them, 24 Q. Elizabeth, to William Fennifon, Efq; then mayor, and Richard Hodsfon, Efc; of that corporation (d).

Befides thefe monafteries, two others were intended to have been founded. A grant was obtained, $37 \mathrm{~K}$. Edward III, for founding one in honour of the nativity and refurrection of our bleffed Lord, which was repealed the year following (e). A grant was alfo obtained, $5 \mathrm{~K}$. Henry IV, for founding another in Ironour of St. Folon the Baptift, and St. Folnn the Evangelift ( $f$ ).

(b) Dugd. Baronag, in Familia de Lumly.

(c) Bourne, p. $210,2 \mathrm{rr}$. (d) Id. fect. vi. p. I 39, \&c.

(e) Pro fraternitate in Novo Cafro fuper Tynan faciend. in honorem nativitatis et refurrectionis Iefu Chrifi.

Pat. 37. R. Ed. III. p. 2. m. 30. et anno 38. p. 2. m. 33. pro revocationc ejufdem, et m. 12. in dorfo. et anno 39. p. I. m. 24. tom. 4. Rot. Turri Londinen/3, Northumbr.

(f) De fraternitate Sancti fohannis Baptifle, et Johannis Apoftoli, in Novo Caftro, farienda et fundanda.

Pat. 5. R. Hen. IV. p. 2. m. 25. Ibid. 
The hofpitals were

St. Mary Magdalcn's;

The Bleffed Virgin's;
The Hols Trinity;

The Maifon Dieu, or St. Catbarine's.

St Mary Magdalen's hofpital was founded by K. Henry I, for a mafter, brethren, and fifters, to receive leprous people. After that ficknefs abated, it was an afylum for the poor of the town in time of peftilence. Fourteen within the houfe were allowed every one a room, $8 \mathrm{~s}$. per month, and coals. Fifteen without the houfe had a different allowance: Some 8 s. per month, fome $5 s$. and fome $2 s .6 d$. In the reign of K. Edward III, Laurentius Acton had the firft fruits of it, amounting annually to 200 marks. Foln Bland, who was then matter, paid him for his own right $4^{\circ}$ marks. He is upon record for being a confiderable patron to it. Hc freed it foon after his accellion to the matterfhip of two annual penfions; one paid to Richard Spereman, and the other to Hugh de Mitford. He built the confiftory, and ornamented the chapel. He alfo raifed fome other buildings at his own charge. He died $48 \mathrm{~K}$. Eldward III, I374, and was interred in his own chapel, near the high altar $(g)$; after having preficled over the hofpital five years. It was a donative, in the patronage of the corporation. It Ateod without Pilgrim-freet-gate, near the Barrow's bridge, on the fummit of a hill, under which was a well of its own name, and feveral meadows about it, now called The Maidlin-meadows; one of which was the Barrow, or burialground, belonging to it, and gave its name to the bridge. Hard by, on the other fide of the bridge, was a chapel, dedi-

(g) Fobannes de Bland obiit die menfis proximo ante feftum Sancti Micbaelis archangeli, hora nona illius diei, A. D. I 374. Cujus corpus humatum eft juxta fummum altare ex parte boreali cancellarii, in capella Beatx Maria Maglalena.

Lib. Cart. 
cated to St. Fames; fuppofed to have been a chapel of eafe to the parifh of St. Andrezu (b).

The hofpital of the Blefed Virgin, or St. Mary's hofpital, claims three foundations. But at what particular time any of them were founded, and by whom the firt was, cannot be determined with precifion. To the firft Wralter de Bolbeck was a benefactor (i). The latter, and the chapel belonging to it, were founded by a gentleman of Killingruorth or Fillinghore, near Niwcafle, of the name of Afelack, whofe charter, which is without date, runs thus,__ "I Ajelack of Killinglore have founded the hofpital and "chapel of St. Mary the Virgin, upon my own land, for two bre"thren to be regulars, and one chaplain, to ferve God, and take "care of the poor (k)." Though the very time of its foundation cannot be afcertained, yet that it was in being in the reign of $\mathrm{K}$. Richard I, is certain from his confirmation of the charter, wherein Afelick is ftiled, his burgefs of Nervcafle (l). The third foundation was by the corporation. It was to be a fort of an afylum to lodge the helplefs ftranger, and indigent traveller in, an eleemofynary for the fick and ncedy, and to give fepulture to fuch as died in it. It was allowed nime chaldrons of coals annually,

(b) Bourne, p. I51, I52, 153. (i) Camt. Brit. ed. opt. p. 855 .

(k) Ego Afelack de Killynghowe fundavi hofpitale Sanctx Marice virginis et capellam fuper terram mam in Novo Caftell, fuper Tynam, et ibi polui duos fratres regulares, ct unum capellanum, ad ferviendum Deo, et pauperibus; reddidi meipfun Deo, ct Bertze Rlariar, et fratribus ejufdem hofpitalis ibidem Deofervicntibus, ad horpitandum pauperes, et egenos clericos, et pro falute animarum omnium hofpitalis benefactorum.

Lib. Cart.

(l) Sciatis me dediffe et conceffife Domino et Sanctre Maria, et fanctimonialibus de Now Caffllo, pro falute anima mex, et antecefforum meorum, Ajeluck, burgeum meum de Nicro Cafello, \&c.

Lib. Cart. 
and had a chaplain to attend it; its ycarly revenue, 33 l. 15 s. $(\mathrm{m}$ ). K. Farvard III, by letters patents granted it the fum of a hundred fhillings, tam in feodo fuo quam in alieno, as a compenfation for fuch lofles as it had fuftained by the incurfion of the Scots. Ricbard de Bury, Bifhop of Durbam, confirmed to it all its lands, rents, rights, and immunities whatever, 8th Jan. 1335, the, fecond year of his confecration, at Gatefhead. In the mayoralty of William IIarding, I 444, the following lift was taken of the plate, facred vefments, and other things belonging to it.

Three chalices gilt with gold, one cntire vefment of bloody relvet, woven about with golden fringe, with one cap, onc cafule, three albs, for the principal feltivals.

A cap of cloath of gold, of a red colour, wrought with golden images, with one cafule, three albs.

A cap of a black colour, woven with dragons, and birds, in gold.

A fingle veftment wrouglit in with peacocks, with a corporal belonging to the fame.

A fingle veftment for the prieft, white, bordered with rofes, with a corporal belonging to it.

A fingle reftment for the prefbyter, of a bloody colour, with a corporal belonging to the fame.

Another veftment for the prefbyter, of cloath of gold. (m) Bourne, p. $3^{1}$. 
ANTIQUITIES OF NORTHUMBERLAND. 215

Another veftment of cloath of gold, interwoven with leopards and birds.

A hood or cap; one cafule, one alb, with a ftole.

A cover of bloody velvet for a fepulchre.

Two cafules, the middle part of them white.

A hood of a red colour, an ornament for the altar of St. Nicholas.

Two linen cloaths of a red colour for the fide-ornament of the altar.

A frontale of fattin, of a bloody colour, woven with golden figures for the altar.

A quadrigefimal vale, of linen cloath, white, with a white crofs below in the fame.

A table fet apart as an ornament for the linen of the altar.

A table gilt, with the image of the Bleffed Virgin Mary.

Two tables with the $P a x$, one of them gilt, and adorned with precious ftones, \&c. \&c.

A charter was obtained by the corporation for this hofpital, 9 K. Fames I. There is a lift both of its benefactors and mafters in their late chorographer $(n)$, but no regular feries. In the chapel belonging to it, is the effigies of the Virgin Mary, with the Holy Fefus upon her knees. It was converted to a grammar-fc'.? ?

(n) Bourne, P. 30 , to p. 35 . 
The velty, at the eaft end of it, is ufed for the election of the mayor, aldermen, fheriff, and other officers of the corporation. The mafter of the grammar-fchool is generally mafter of the hofpital. A writing-mafter has a fchool, and an apartment in it, fupported by the corporation. It is fituated in the pleafant ftreet of Hifgate, and is now called, the Weft Spittle (o).

The hofpital of the Holy Trinity was founded 37 K. Edward III, ${ }_{1} 3_{3}^{6}$, by William de Acton, mayor of this corporation in 1366 , 3367,1368 . It ftood on the Wall-knowl. The firft mafter of it was Willian Wakefield, chofen on the diffolution of a houfe of the fame order in Berwick upon Treed by Antbony Beck, Bilhop of Durbam, over which he alfo prefided $(q)$. It furrendered 10 Jan. зо K. Henry VIII.

The hofpital of St. Catharine was founded in the reign of $\mathrm{K}$. Henry IV, by that great patron of Newcafle, Roger Thornton, the elder $(\%)$. It was fituated on the fouth ficle of the Sand-bill. The chaplain
(0) Ibid.
(q) Lel. Itin. Vol, viii. p. 23.

(r) Rex Henricus IV. \&c، falutem. Sciatis quod de gratia 1roftra fpeciali et confideratione c1.jufdam fummx pccunix notis in camera noftra, per dileQtum nobis Rggerum nuper folutx, concefimus et licentia dedimus, \&c. præfato Rogero, quod ipfe quoddam hofpitale in honore Sanctx Katbarine, in quodam meffuagio fuo per ipfum Rogerum in parte nuper edificato in quodam loco vocato $L$ e Sand-bill, in villa noftra novi caltri fuper $T_{y n a m}$, continente C. pedes in longitudine, $x l$. pedes in latitudine, de uno capellana divina infra hofpitale prædictum pro falubri ftatu ipfius Rogeri dum vixerit, et pro anima fua cum ab hac luce migraverit, ac animabus patris et matris ipfius Rogeri, et Agnetis nuper uxoris ejus; nec non antecefforum et Jiberorum fuorum, ac omnium fidelium defunctcrum, fingulis diebus celebraturo; ac de novem viris et quatuor foeminis pauperibus in eodem hofpitale continùo refidentibus juxta ordinationem ipfius Rogeri, vel executorum fuorum in hac parte faciendam, de novo facere, creare, fundare, et ftabilire poffit in perpetuum : et quod hofpitale illud, horpitale per fe privatum et incorporatum exiftat in perpetuum; ac etian quod capellanus horpitalis prædicti, 


\section{chaplain prefided over it, and had the care of nine poor men, and four poor women. The corporation, $34 \mathrm{~K}$. Henry VI, had the}

qui pro tempore fuerit, fit cuftos ejufdem hofpitalis; ac quod idem capellanus cuftos, et pra.diati viri, et foeminx, fratres et forores hofpitalis Sanctx Katharina, vocati Tho nton's Hofpital, in Novo Caftro fuper Tynam, nuncupatur quodqùe cuftos, fratres, et forores, et eorum fucceftores, per nomen cuftodis, fratrum, et fororum hofpitalis Sanetre Katborinse, vocati Thornton's Itoppital, in Novo Cafro fuper Tynam, fint perfonæ capaces et habiles ad omnimoda, tetras tenementa, redditus, et fervicia, ac alias pofieflones quafcunque de quiburdam per. fonis adquirendas, capiendas, et recipiendas, tenendas fibi et fuccefloribus fuis, cu?tudibus, fratribus, et fororibus, hofpitalis predicti in perpetuum, licentia regia inde primitus obtenta. Nec non quod idem cultos, \&c. fint perfonæ habiles ad alios implaciandos, ct ab aliis implacitari, et ad defendendum in quibufcunque placitis et querelis per nomen cuftodis, fram trum, et fororum hofpitalis Sanctx Katharine, vocati Thornton's Huppital, in Novo Cafro fuper Tynam. Et quod licet unum commune figillum pro negotiis et agendis ejufdem hofpitalis deferviturum in perpetuum; et ulterius, \&ic. Licentiam dedimus, \&ic. præfato Rogero quod ipfe quandam cantariam de uno capellano divina ad altare Beati $P$ etri in capclla $O m$ nium SanEtorum in villa prædicta pro ftatu et animabus prædictis fingulis diebus celebratur juxta ordinationem ipfius Rogeri, vel executorum fuorum, in hac parte faciendam, fcilicet, facere, fundare, et ftabilire poffit in perpetuum. Conceflimus etiam, \&ic. præfato Rogero quad ipfe meffuagium fuum prædiłum, cum pertinentiis, quod de nobis teneat in burgagio, poftquam hofpitale prædictum fic factum, fundatum, et ftabilitum fuerit, darc poffst et affgnare præfatis, cuftodi, fratribus, et fororibus, hofpitalis predicti habendum et tenendum fibi et fuccefforibus fuis, tam pro inhabitatione fua, quam in auxilium fuftentationis fuæ in perpetuum conceflimus infuper, \&c. eidem Rojero quod ipfe, heredes affignati, vel executores fuí, terras, tenementa, et redditus, cum pertinentibus, ad valorem xL. per annum, tam ea quæ de nobis tenentur in burgagio, quam ea quæ de nobis non tenentur, acquirere et præfatis, cuftodi, fratribus, et fororibus, hofpitslis predicti, ac capcllano cantarix, cum fic facta, fundata, et ftabilita fuerit, juxta difcretionem et limitationem fuam divifam, et proportionabiliter dare, affignare, et concedere pofint, habend. \&ic. Tefe rege ąud Weftm. x. Junii.

Cart. R. Hen, IV.

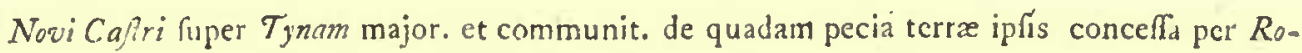
gerun Tharkton ad adificand. certis paup. perfonis in domo dei ibidem.

$$
\text { Pat. } 4 \text { R. } H_{i n} \text { IV. P 2. m. } 3^{8} \text {. }
$$

VOL. II. 
ufe of the hall and kitchen by leave of the founder for a very charitable and laudable purpofe, viz. for young married people: to have their wedding-entertainment in it, and receive the offerings and gifts of their friends (s). For fome years the fons of the clergy had their annual feaft in it. The hall is adorned with the arms of feveral generous benefactors, and fome very curious carvings in wood. In 1620 , Sir Richard Lumley, for $100 \%$ fold to the corporation that part of the hofpital ftanding to the eaft of the town-chamber, on the edge of the river, fixteen yards in length, and covered with lead, over which was ereeted the fately court of the merchant-adventurers of the old ftaple, beforementioned, firft refident at Antwerp, in Brabant, and fince in the more northern provinces under the ftates $(t)$.

To thefe eminent houfes of charity, I thall add two others of inferior note, commonly called after their founders, Chriffopher Brigbam, and Fobn Ward, merchants of this corporation,

$$
\left.\begin{array}{l}
\begin{array}{l}
\text { Brigham's } \\
\text { and } \\
\text { Ward's }
\end{array}
\end{array}\right\} \text { Alms-houfes. }
$$

The firlt ftood near the monaftry of the Francifons; the latter in the Manour-Chare, at the bottom of the garden belonging to Mat-

Profundatione hofpitalis vocati hofpitale Sandte Katharine, in loco vocato Le Sand hill, in Novo Capro fuper Tynam; et pro cantaria ibidem ad altare Sancti Petri in capella Omnium Sanklorum.

Pat. 13 R. Hen. IV. p. 2. m. I4.

(s) MS. of Fobn Milbank, Efq; cited by Bourne, p. 124.

(1) Grey's Chorograptial : inter collectanea Oxfordiana, 4to. Vol. iii. 
thew Waters, Efq; to which the mills at Panden-Gate are faid to have paid $I l$. per annum, to find it in coals $(u)$.

Thefe are all the charitable foundations which claim any re. gard from their Antiquity. Such as are modern, I thall be lefs particular upon, as they are known to every body. I fhall give them a place after the churches and fchools, among the Public Builit ings.

The parochial churches are,

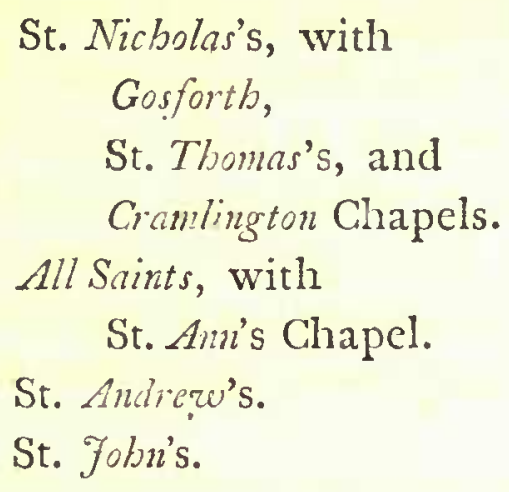

St. Nicholas's has the pre-eminence. It is a vicarage; the impropriator and patron, the Bifhop of Carlife; given to the church and canons of St. Mary in that city, together with the church of Nereburn, by K. Henry I. (v). The other churches are dependent upon it,

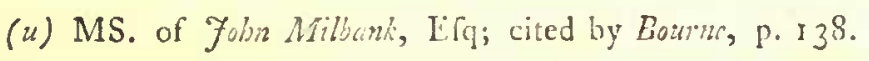

(v) Henricus rex Angliae, Archicpiffopo Ebor. et Eppifcopo Dunelm. et vicecomiti de Northumberlanda, falutem. Sciatis me dediffe et conceffife Deo et Sanctx Maria de Cairlelia et canonicis ejufdenı loci, ecclefiam de Novo Cafaclio fuper Tjuam, et ecclefiam de Nicuburna, et ecclefias quas Richardus de aurca V'alie de me tenet, poft obittm ejus, et Ricbardus, et clerici qui ipfis ecclefiis deferviunt, recognofcant de canonicis ipflus, et faciant eis fervitium quod mihi facere folebant, et polt obitum eorum redigantur ecclefix in manus canonicorum, ita quod clerici qui eis defcrviant, habeant inde neceffria, et canonici habeant reliquum.

Carta Hen. I. Monaft. Angl. Toun. ii. p. 73 . Cart. 8 Ed. If, n. 25. Et Cart. 6 Ed. III. n. 10. per $\ln f$ pex. 
and yet they are three diftinct parifhes. The vicar receives dues from them all. It is faid to have been founded in rogr. In the giant to the church of Carlife, mention is made of a fuitable maintenance to be given to the minifter, but it is not fpecified what it was. This was fixed in the reign of King Stepben, 24 Jan. I194. by Hugb Pudey, Bifhop of Durbam, with the approbation of the prior and convent of Carlifle $(x)$; who affigned him all the fiuts, annual profits, oblations, and obventions whatfoever, belonging to his church of St. Nicbolas, except the great tithes. It flands in an advantageous clevated fituation, almoft in the center of the town; its length 79 yards two feet, and three quarters; its breadth 24 yards, two feet and three quarters; of a proportionable height. Four flone-images, at full length, adorn each corner of a fquare tower; out of which rifes a curious fteeple; in height 64 yards, one foot, three quarters; decorated with 13 yinacles; two bold flone-arches fupporring a large and beautiful lanthorn, on which is a tall and ftately fpire; the whole much

(x) Hugo dei gratia Dunelm. epifcopus omnibus fanctæ matris ecclefiæ filiis ad quos literæ ifte pervenerint fulutem. Noverit univerfitas veftra quod nos anno dom. 1194, pridie ante converfionem Sancti Pauli, vicariam ecclefix Beati Nicholai de Novo Cafello fuper Tynam, noftræ dioces, alias in eadem ordinatam de unanimi confenfu dilectorum filiorum noftrorum prioris et conventus Karliol. didtam ecclefiam Beati Nicholai in ufus fuos canonicè obtinentium, fortionem infra fcriptam pro fuftentatione vicarii ejufdem, qui eft, et pro tempore erit in eadem ex noftri paftoralis officii debito taxamus, ftatuimus et ordinamus; viz. quod quilibet vicarius illius ecclcfire qui pro tempore fucrit, pro fuftentatione fua et portione congrua percipiat ot habeat omnes fructus, proventus, oblationes, obventiones, quafcunque ad dictam ecclefian qualitercunque pertinentes de quibufcunque rebus exiftentes, decimis gabaruin dictæ ecciefix duntaxet exceptis. In quarum infpectionis et compertionis teftimonium figillum noftrum fecimus his apponi. Dat. in manerio noftro de Auckland, fexto die Junii, A. D. 1360. et noftræ consecrationis 15 .

Ordinat. Vicar B. Nicholai, de Novo Caftro.

Vicar. Eccles. Sancti Nicbslai in Novo Calro redditns 13s. 4 d. exeund. de quibufdam mefluag. in eadem villa.

Pat. 10 Ric. 11. p. 2. m. 21. 
admired. It has eight mufical bells. It had antiently but five. The other three were added by the corporation, who had the old great bell new-caft at Colchefter. It weighed 3 raglb. The church is well illuminated. The caft or altar-window was antiently adorned with curious paintings in glafs, of the twelve Apoftles, and the Seven Deeds of Charity, done at the expence of the pious and inunificent Roger Thornton, the elder, who built the window, in which was this infcription,

Orati pro anima Rogeri de Thomton, et pro animabus Filiorum et filiarum $(y)$.

In the organ-gallery is a double organ; the prefent organift, the ingenious Mr. Avifon, author of a late Effay on mufical expreffion. On the north fidc of the organ is a porch called St. George's porch (z). It is vaulted undemeath, and fealed above; and was antiently adomed with curious carvings in wood, and the windows with paintings in glafs; fome of the latter ftill remaining in the eaft-window, particularly the portraiture of St. Laurence. It is fuppofed to have been one of the antient chanteries, and to have been built by one of our Englifts monarchs (a).

Nine chantcries were found in this church, in honour of
St. Fobn the Baptift;
The Bleffed Virgin;
St. Fobn the Evangelift;
St. Margaret;
St. Catbarine, two;
St. Cutbbert;
St. Peter and St. Paul;
St. Lyra.
St. Thomas;

(y) Grey's Chorographia, inter collectan. Oxfordiana. Vol, iij.

(z) Bourne's Newcafle.

(a) Ibid. 
The chantery of St. Fobn the Baptift and St. Fobn the Evangelift: ftood on the north fide of the church $(b)$. Its original foundation was by Laurence prior of Durbam, I 4 K. Stephen, I 149. It was refounded, 6 K. Edward III, by Richard de Emeldon, for three chaplains. By an injunction af Richard Bithop of Durbam, in the third year of his confecration, 1335, they were obliged to diftribute, after divine fervice, on the eve of the anniverfary of his death, the fum of fix fhillings and eightpence to I 60 poor people (c). It was founded again in the reign of K. Henry VI, by Robert de Khodes and his wife Agnes, for one chaplain; the annual value 7 1. 7 s. ro d. befides a houfe given by the corporation for the cliaplain to live in (d).

One of the chanteries of St. Catharine was founded by Alan de 1)wham. It was re-founded in the reign of K. Firvard III, by Wrilliam folmfon and his wife Ifubell, for one chaplain; the annual value, 61 . I $5 \mathrm{~s}$.

The other chantery of St. Catbarize was founded by Nicbolas and Fobn Elliker; the annual value 31 . I 4 s. $8 \mathrm{~d}$. arifing out of fome houfes in the Caftle-mote, in the Side, in the Clofe, and in Sandgate.

The chantery of St. Peter and St. Paul was founded by Adande Fenrotber and Alan Hilton in the reign of K. Henry IV; the annual value, 4 1. I3s. 4 d. which arofe out of fome houfes in Wefgate, in the fide, and in the clofe.

(b) In ccclefia Sancti Nicholai de villa Noui-caftri ad attare boreale Gónamis Baptiftx, et Fubannis Aport. et Evangel.

Lib. Cart. p. 22 I.

(c) Confirmatio ordinationis factx per epifcopum Dunelm. in cantaria fundata in ecclef. Sancti Nicholai afud Nıvum-cafrum per Riclardum de Emelion.

(d) Bourne, P. 59. Pat. R. Ed.III. p. I. m. 15 . 
The chantery of St. Thomas was founded by Foln Thapecope in the reign of K. Edward III; the annual value 4 l. 12 s. 6 d.

The chantery of the Bleffed Virgin claims as high' a foundation as the reign of K. Edward I. at leaft, but how much earlier, and by whom, is unknown, the deed of foundation being loft. It ftood on the fouth fide of the church, being a large porch; the annual value, 51. 16s. Nicholas de Carliol, capital bailiff of the corporation, I328, and Peter Graper, mayor of it, I305, paid each 2 s. per ann. to it (e).

The chantery of St. Margaret was founded by Stephen ithitgray and his wife, Mary, 17 K. Richard II, 1394. It ftood on the fouth fide of the church, near the porch-door, of a fquare figure; the annual value 10 marks; the chaplain chofen by the vicar, the mayor and bailiffs of the corporation, and four creditable parithioners of St. Nicbolas, after the death of the founders $(f)$.

The chantery of St. Cutbbert was founded by Thomas de Erringto and Willian Redmarflacl in the reign of K. Richard II ; the annual value, 7 1. 3 s. 2 d. raifed out of fome houfes in the Side, the Sandbill, and the Clofe. Thomas de Errington was one of the witneffes to the foundation-deed of St. Margaret's chantery.

The chantery of St. Lyra was founded by Robert Cafell in the reign of K. Edward III; the annual value ${ }_{4}$ l. Ios. which arofe

(e) Lib. Cart. p. 48, \& c.

(f) Pro cantaria facienda ad altare Sanctæ Margarite in parte aufrali in ecclefia Sancti Nicholai in Novo Caftro fuper Tynam, et prox. Marc. Redd.

Pat, 17. R. Ric. II. p. I. m. 36. et Pat. 3 R. Hica. IV. p. I. m. 22.

from 
from certain tenements in the Clofe, in Weftgate, and from a fielrl without the wert-gate, called, The Goofe-green-clofe.

In the north ifle is a large gallery, defigned principally for the boys of the grammar fchool. The eaft end was enlarged by one of its lecturers, the late Dr. Thomlinfon, for the accommodation of himfelf, and his fucceffors. The veltry is on the fouth fide of the chancel, above which is a library, to which the fame pious. and worthy lecturer at his death gave a large and valuable collection of books. The annual income of 251 per ann. for ever, has bcen fettled on a librarian by Sir Walter Calverley Blacket, Bart. The corporation make the vicar an anuual compliment of 901 . and the firft curate another of $40 \mathrm{l}$. per annum, who alfo receives 41. per annum, from the vicar, and 61 . I $6 \mathrm{~s}$. $8 \mathrm{~d}$. per annum from the crown, and the ufual fees of the church. He is ftiled in an antient writing, The parifh prieft, abfgue impedimento vicarii aut prefoyteri parocbialis. It was cuftomary till the year 1724 , to have two parifhclerks, when one of them dying, another curate was appointed, whofe annual income arifes out of the clerk's fees. The lecturer receives annually from the corporation $\mathrm{r} 00 \mathrm{l}$. for preaching every Sunday in the afternoon, and 201. for preaching on holidays. The prefent lecturer is the Rev. Thomas Dockwray, D. D. late fellow of St. Fohn's college in Cambridge, and vicar of Stamfordham; who was promoted by the corporation to this lecturefhip on the refignation of his uncle, of his own name; and to his vicarage by the crown, on the refignation of the Rev. Dr. Baker. Here are praycrs twice a lay; a catechetical lecture in every week when there arc no holidays; and a fermon twice a week, on every Wedneflay and Friday, in Advent and Lent, preached by all the clergy of the town in their turn. There are many funeral monuments, both mural and others, in this and the other churches, and many benefactions left to the parifh-poor, which 
are minutely enumerated by the late chorographer of Nervaffle, to whom I refer. The church-yard of St. Nicholus was enclofed by fubfcription, $176 \mathrm{r}$, with ftone, and wooden pales, neat and handfome. The vicarage-houfe ftands at the weft end of St. Fobn's church-yard in the well-built and pleafant ftreet of Weftgrate, on the north fide of it; the garden to the weft, open and airy; remarkable for having had the Roman wall pafs through the middle of it. The houfe is fuppofed to have been built by the corporation. It was repaired by the Rev. Dr. Ellifon, 1694, then vicar; and by the Rev. Dr. Brown, 1762.

Gosforth-chapel is at a fmall village, about a mile north from the town, on the eaft fide of the great por-road; nothing about it remarkable. It is fupplied by the vicar.

The chapel of St. Thomas is at the north-eaft end of Tyne-bridge. It is commonly called, The Bridge-End chapel, from its fituation. For the keeping it, and the bridge, in repair, feveral rents were fettled upon it $(\mathrm{g})$. It had alfo an annual rent of $20 \mathrm{~s}$. from the noble family of Percy, Earls of Nortbumberland, for their houfe in Newcaftle, called, Earl's Imb (b). Two chanterics were founded in it, in honour of

St. Ann, and

St. Mary, the Bleffed Virgin.

(g) De diverfis redditibus Novn Caflro pertinentibus, reparatione pontis et capella Sandi Thome, Efcaet. 43 R. Ed. III. Pt. 2. n. 56. Tom. 4. Rot. Turri Londinenf, Northumbr.

(b) Tenementum in Novo Cafro Super Tynom, vocatum, Earl's Inn of Nortbumberland, tenetur in Burgag. et redd. per ann. liberè capellæ Sancti Thome martyris cuftod. fuper pontem aqua de Tyne, 20s. polt mortem Fohomis ducis de Bedford; Efcaet. It R. Hen. VI. n. $3^{6 .}$

VoL. II. 
St. Ann's was founded by William Heron, who endowed it with an annual rent of fix marks, out of fome tenements on the Sandbill (i); valued, at the diffolution, at 4 l. $17 \mathrm{~s}$.

St. Mary's was endowed with an annual rent of five marks, out of five meffuages in the Clofe and Side; the founder unknown (k); valued, at the diffolution, at 4 l. 3 s. $6 \mathrm{~d}$.

Another chantery was founded in honour of St. Mary, by George Carr, merchant of this town, but never licenced. He fettled an annual rent upon it out of fome houfes on the Sand-bill, and the Side; valued, at the diffolution, at $51.6 \mathrm{~s} .8 \mathrm{~d}$ (l).

There are three cellars under the chapel. Gilbert de Mitford, a burgefs of Newcafle, paid annually for the middle one $14 \mathrm{~s}$. at the feaft of St. Martin, in the winter. It was confirmed to him 2 I K. Edward III, I347, by charter from William Spyn, then chaplain, and guardian of the alms for the fupport of Tyne-bridge, with the confent of the corporation; fealed with their feal, and figned by Peter Grafer, mayor, William de Acton, Hugh de Angerton, Hugh de Carliol, and Fobn de Emildon, bailiffs ( $m$ ).

(i) De cantaria facienda in capclla Beati Thoma in Novo Cafiro fuper Tynam, et de 6 Marcis redditus ibidem, concefs. per Williel. Heron, Pat. 2 R. Ed. III. p. 2. m. 26.

(k) De 5 meffuag. in Novo Caftro dimiffis ad firmam Thome Creindon pro termino annorum per capellanum cantaria Beati Thome ibidem redd. per annum 5 Marc. Pat. I 3 R, Ric. II. p. 2. m. 32 .

(l) See the Survey of the Chanteries, and the names of the patrons, $26 \mathrm{~K}$. Hen. VIII. 1535 .

(m). Bcurne's Hift. of Newcafle, p. 131. 
St. Mary Magdalen's hofpital has been annexed to it, which confifts of a mafter and three poor brethren, free burgeffes of Nerecafle; each brother allowed $31.6 \mathrm{~s} .3 \mathrm{~d}$. per annum; the curate for reading prayers, and one fermon annually, 4l. $6 \mathrm{~s}$. $8 \mathrm{~d}$. the collector of the rents about Il. I7s. $6 \mathrm{~d}$. the whole rental, 291. 7 s. $8 \mathrm{~d}(n)$.

It was made a chapel of eafe to St. Nicbolas, 1oth Sept. 1732, by the corporation; at whofe expence it was then repaired, who allow very handfomely to a morning and afternoon preacher (0).

Cramlington-chapel is fix or feven miles north-eaft from Nervcafle; nothing about it remarkable.

All Saints church is at the foot of Pilgrim-ftrect, on an eminence; its length, 55 yards, one foot; its breadth, 25 yards, two feet; a low fquare tower at the weft end, with one fpire rifing from it ; adorned with a clock, and fix good bells, caft out of the ftatue of K. Fames II, ftanding formerly on the Sand-bill. In fome of the windows were antiently feveral curious pourtraitures, painted on glafs; one of our Bleffed Lord, at full length, in the fouth-eaft window, at the eaft end of the chancel; his twelve Apoftles, in the window next the porch-door, but one; the pious family of Roger Thornton, two fons, and three daughters, kneeling at altars, in the window above the fouth door, leading into the quire, towards the porch. Moft of thefe were taken away, or defaced, in the late civil wars. At the weft end of it is a handfome gallery, built in 1712 ; an organ in the middle; the north end accommodating the children of the charity-fchool. At the eaft end is another for the ufe of the Butchers. There is

(n) Ib.

(o) Ib. 
allo one for the failors in the north ifle, built by the TrinityHoufe, 1618 , Fobn Holburne then mafter; beautified with paintings; 1720, reprefenting our Bleffed Saviour afleep in the ftorm; his taking St. Peter by the hand when he was finking in the waves; - Fonals vomited up upon the dry land.

The chancel ftands upon a large vault, of a fquare figure, and fpacious; a ftrong pillar in it; the fupport of eight large ftonearches; the entrance on the north fide of the church-yard. The altar-table is of marble, the donation of a perfon unknown. On the fouth fide of it, is a Protbefes, or fide-altar. The chan$\mathrm{cel}$ is adorned with wainfcot-ftalls, after the cathedral manner.

Seren chanteries were founded in this church, in honour of

St. Thoinas;

St. Mary, the Bleffed Virgin;

St. Fobn the Evangelif;

St. Peter.
St. Fohn the Baptift;

St. Catbarine;

St. Lyra.

St. Thomas's was founded by Fobn Putbore, clerk; the annual value, 4 l. 8 s. 4 d.

St. Mary's was founded by __ the annual value, 4 l. 5 s. Iod.

St. Fobn the Evangelif's was founded by Richard Willifby and Richard Fifhlake; the annual value, 41 . I5s. $4 \mathrm{~d}$.

St. Peter's was founded by Roger de Thornton; the royal licence granted, I 3 K. Henry IV. ( $p$ ) the annual value, 61. It was in the

(p) Pro cantaria ad altare Sancti Petri in capella omnium fanctorum, Novo Caforo fuper Tynam; Pat. 13 R. Hen. IV. p. 2. m. 14. 
'vacancy above the veftry, oppofite to the founder's fepulchral monument:

St. Catbarine's had the fame pious founder, the annual value, 5l. 3 s. $8 \mathrm{~d}(q)$.

St. Fobn the Baptifls was founded by Fohn Ward; the annual: value, 7 l. $15 \mathrm{~s} .8 \mathrm{~d}$.

St. Lyra's was founded in the reign of K. Edward III. by Ricbard Pickering, the annual value, $31.8 \mathrm{~s} .4 \mathrm{~d}$.

The minifter of this church is paid 4 l. per anmum by the vicar, and 5 l. per anmum by the crown. The reft of his income arifes from the furplice-fees, regifter, \&c. To leffen the weight of his parochial cares, an affiftant was appointed, 1708 , on the death

(9) Cantaria Sanctx Catharina, vocat. Thornton's Chantery, in ecclefia Onnium Sanciorum in Novo Cafro, pro quibufdam meffuag. et terris in eadem villa, Pat. 20 R. Ric. II. p. 3 . m. I2. et pro 2 mefluag. ibidem, Pat. 5 R. Hen. IV. p. 1. m. 8. Tom. 4. Rot. Turri Londinenfis.

From the authority of an old veftry-book, Mr. Bourne gives the honour of the foundation of it to Robert de Chirtos and his wife. See p. 92.

Vide Pat. fubfcript.

Cantaria in ecclefia omnium Sanctorum Novo Caftro, concefs. per Hen. Petlyng, Pat. 42 R. Ed. III. p. 2. m. g.

Et cantaria in ecclefia omnium fanctorum ibidem, pro tenem. in eadem villa, Pat. 44 . Ed. III. p. 2. m. 7 .

Et cantaria in capella omnium fanctorum ibidem, concefta per R. D. Pat. 42 R. Ed. III. p. 2. m. 22. et pro ten. ibidem, anno 43. p. 1. m. 2 .

Et pro cantaria in ecclefia omnium fanctorum ibidem, et terris in eadem villa, Pat. 39 R. Ed, Ed. III. p. I. m. 4. Tom. 4. Rot. Turri Londinenfs. Nortbumbr. 
of Fohn pinkney, one of the parinh-clerks; it being then cuftomary to have two. He is allowed the clerk's fees for weddings, burials, chriftnings, \&c. reputed about 5ol. per annum. Here are alfo two lecturers, allowed each rool. per annum by the corporation. On the high feftival of Eafter, they antiently prefented this church with 2 I gallons of wine. The facrament is adminiftred crery fecond Sunday in the month; prayers every day, at ten o'clock in the morning, and four in the afternoon.

St. Ann's chapel ftands in the fuburbs of Sand-gate, on the flope of a hill. After the reformation it was neglested and fell into decay. It was repaired, 1682. A lecturer was then appointed. He was to preach every Sunday-morning, and expound the catechifm in the afternoon, for which he was allowed 301 . per ann. At prefent, it has two lecturers; one allowed 40 l. and the other 501 . per annum, by the corporation; by whom it was lately rebuilt, after an elegant defign.

In the fame fuburbs was antiently another chapel, dedicated to

St. Laurence. It is faid to have been built by one of the Earls of Nortbumberland. It was dependent upon the priory of St. Fobn of Ferufalem. In confideration of $144 \mathrm{l}$. $13 \mathrm{~s} .4 \mathrm{~d}$. it was granted, among other things, to the corporation, 3 K. Edward VI ( $r$ ). Out of the ruins of it, arofe St. Laurence's bottle glafs-houfe.

(r) The rental, as follows, $155^{8}$.

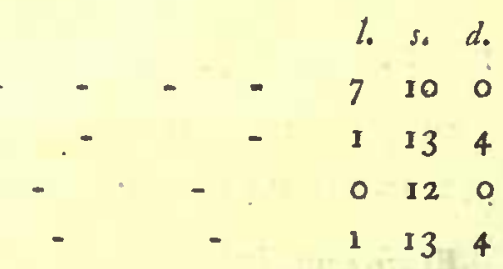

St. Laurence held by leafe, by fohn Laverock, - - - - 710 The filhery of St. Laurence, leafed by Mitford, _ - $\quad$ - 13134 A clore, called, St. Ann's clore, - - - - $\quad 0120$ A clofe, called, The coney-clofe, - - $\quad$ - $\quad 1 \quad 134$

A cottage in Killingworth, in the poffeflion of $\mathcal{F}_{0} b n$ de Killingworth, and certain lands in Heton, juxta Nov. Cafrum, belonging to St. Laurence.

Lib. Cart. 44 .

St. 
St. Andrew's church ftands near Nerw-gate, on the weft fide of the ftreet. From the ftile of the architecture, and its fituation, where old Monk-chefter chiefly ftood, it claims priority to the reft for antiquity. The old bells were taken down, 1726, and fix new ones put in their place, by a contribution among the inhabitants, the corporation giving $5 \circ \mathrm{l}$. A new porch was built at the fame time. At the weft end is a handfome gallery, erected, I7II, at the expence of the parifh.

Three chanteries were founded in it, in honour of

$$
\begin{aligned}
& \text { St. Mary, the Blefed Virgin; } \\
& \text { The Holy Trinity; } \\
& \text { St. Thomas. }
\end{aligned}
$$

St. Mary's was founded by - the annual value, 6 l. I2 s. 10d.

The Holy Trinity is faid to have been founded by Sir Adam de Atboll, Knt. whofe remains, and the remains of his Lady, are interred in it; their funeral-monument bearing their effigies, and this infcription- Hic jacent Dominus Adamarus de Atholl, miles, b. D'na Maria, uxor ejus, que obiit quarto decimo die menfisanno Domini millefimo tricentefimo_animarum propitietur. The annual value of Sir Adam's chantery was 4 l. 2 s. iod.

St. Thomas's was founded by — the annual value uncertain; a fmall part of its revenue in the poffeffion of Sir Robert Brandling, at the diffolution.

The minifter of this church receives annually from the vicar, 3 l. from the crown, 5 l. 2 s. $6 \mathrm{~d}$. and from the corporation, for being 
being lecturer, rool. The facrament is adminiftered every. fourth Sunday in the month; prayers twice a week, on Wednefday and Friday, in the morning. The corporation formerly gave ro gallons of wine to this church at the feftival of Eafter.

St. Fobn's church is in the pleafant ftreet of Wefgate, by the vicarage-houfe. Some of its chief ornaments are derived from the liberal fpirit of a pious tradefman, one of its parifhioners, Mr. Robert Percival. He bcautified the altar, i7ro. He built, at the fame time, the north gallery for thirty-three perfons. On the taking down the thrce old bells, 1707 , and procuring fix new ones by fubfcription, he gave $3 l$. This was his liberality in his life-time. At his death, Feb. 8, I729, he clofed it with the donation of a houfe, in the wool-market, to his beloved parifh, let at $20 \mathrm{l}$. per annum. He was only a pin-maker by profeffion, but thefe benefactions reflect a luftre upon his memory, and thew, that he had an elevated foul, though he was of an inferior figure in the world.

The communion-plate was the gift of another of its pious friends, Mr. Robert Rymer. He gave a large flaggon, a chalice, and a falver, valued at $60 \%$. 1722.

At the weft end of the church is another gallery. It had an organ in 1570 , which being a. long time perifhed, a new one was lately erected at the expence of the inhabitants.

Three chanteries were founded in this chureh, in honour of

St. Tbomas the Martyr;

St. Mary, the Bleffed Virgin;

The Holy Trinity.

St. 


\section{ANTIQUITIES OF NORTHUMBERLAND.}

St. Thomas's was founded in the reign of King Edward II, by Adam de Durbam, a burgefs of this town; the foundation-charter fealed with his feal, and figned by Richard de Emeldon, mayor; Thomas de Frifmarifco, Richard de Acton, William de Burneton, Gilbert de Hankyn, Sir Nicholas Scot, Knt. Nicholas de Carliol, Peter Graper, \&c. bailiffs; the annual value $4.3 \mathrm{~s}$. arifing from fome tenements in the Sand-bill, and in Weftgate (s).

St. Mary's was founded in the reign of K. Edward III, by Edward Scot; the annual value $4 l .4 s .4 d$.

The Holy Trinity was founded by Foln Dalton, William Akinfsarve, and Andrew Acliffe, clerks; the annual value 5 l. I3 s. $4 d$.

The minifter of this church reccives annually from the vicar, $3 l$. from the crown, $5 l$. and from the corporation, for being

(s) Sciant prefentes, \&rc. Quod ego Adam de Duneln. Burgenfis villa Novi Caftri fuper Tynam, \&c. pro falute animæ mex, et pro animabus Rogeri patris mei, \&ic. hac prefenti carta mea confirmavi Domino Rogero de Burneto, capellano, fingulis diebus ad altare bcati Thome, martyris, in ecclefia parochiali Sancti Johannis de Novo Caftro divina celebraturo totum illud meffuagium, \&ce. Et volo quod poft deceffum mcum, major et ballivi prædictæ villx Novi Caftri, quicunque pro tempore fuo fuerint, habeant jus patronatus dictæcantariæ, et quod ipfi una cum quatuor de probioribus et difcretioribus hominibus parochiæ prædictx ad hoc electis poffint ad dictam cantariam, quotiefcunque ipfam vacatam contingat, virum capellanum honeftum \& difcretum eligere \& $\approx$ inftituere.

Vid. Pat. fubfcript.

De cantaria in ecclefia fancti fohannis Baptifle, Pat. I2. R. Ed.II. p. I. m. I6.

De cantaria in eadem ecclefia Sancti Fohannis, et de I meff. cum pertinen. 2 toft. I acr. terrx, et IO s. redd. in eadem villa, Pat. 15. R. Ric. II. p. 2. m. 6.

Et pro cantaria fac. in ecclefia Sanci Zohannis in Novo. Caftro fuper Tynam, et pro 3 meff. et I toft, ibidem, Pat. 16. R. Ric. II. p. I. m. 12.

Et de cantaria facienda in ecclefia Sancti Fohannis in Novs Caftrofuper Tynam, et tenem. in eadem villa, Pat. 51. R. Ed. III. p. I. m. 34. et amno 4. R. Finn. IV. p. I. m. 22:

Vol. II. 
lecturer, $90 l$. The facrament is adminiftered every third Sunday in the month ; prayers three times a week, on Wednefday, Friday, and Saturday. At Eafter, the corporation formerly gave is gallons of wine to this church.

The church-yard was inclofed by fubfcription, 1762, with ftone, and a wooden pales, very neat; and planted round, in the infide, with young lime and elm trees. The church tower is aclorned with a clock.

I have only to obferve, before I conclude this account of the churches in Nervaffle, that four minifters placed in them by the parliament, conformed to the church of England at the Reftoration, viz. Mr. Cole, Mr. Richard Prideaux, Mr. Afburnbam, and Dr. Knightfbridge; and that a ffth, Mr. George Long, A. M. for not conforming, was filenced, and ejected from his fellowfhip in Trinitycollege, Cambridge $(t)$.

The principal fchools eftablifhed in Nerucafte, are

$$
\begin{aligned}
& \text { A free Grammar-School, and } \\
& \text { Four parochial Charity-Schools. }
\end{aligned}
$$

The grammar-fchool was originally founded by Thomas Horfley, mayor of Nervaftle in 1525 . He left to it by will his lands in the town, in perpetzum, after his own and his wife's death. It was refounded by Q. Elizabetb, as attefted by her charter. The impropiriated or great tithes of the parifh of Bolbam belong to it. The mafterfhip of St. Mary's hofpital was ufually annexed to it by the corporation, who are the patrons. The mafters have

(1) Bifhop Kenne?'s Hiftorical Regifter, p. 906. 923 ..

conve- 


\section{ANTIQUITIES OF NORTHUMBERLAND.}

convenient apartments to live in, in the hofpital, commonly called, The Weft Spitle, from its fituation in Weft-gate.

The charity-fchool belonging to the parifh of St. Nicholas, was founded by Mrs. Eleanor Allen, a widow-gentlewoman of Newcafle. By a deed of gift, bearing date Feb. 20, 1705, the afligned a farm-hold and tenant-right in the parifh of Walls-End, held under the dean and chapter of Durbam, of above the annual value of $60 \mathrm{l}$. for the education of 40 boys and 20 girls of this parifh, and the chapelry of St. Fobn. The fchool was opened I 709. Another gentlewoman, the widow of the Rev. Mr. Chifbolm, vicar of Wooler, at her death gave $500 \mathrm{l}$. to this generous and ufeful charity. By a parochial fubfcription, begun 1718 , they are annually cloathed, May r. The boys are inftructed in reading, writing, and accompts, and then put to fome honeft bufinefs; receiving each a Bible and a Common-prayer-book, the Whole Duty of Man, Lewis's Expofition of the Church-Catechifm, and 2l. The girls are taught reading, fewing, and knitting, and are put out to reputable fervices, or trades. They are prefented with the fame good books, and $\mathrm{I} l$. The fchool-mafter is allowed $25 l$. per annum, and $I l$. for coals; the fchool-miftrefs, rol. per anmun, and $10 s$. for coals.

The charity-fchool belonging to the parifh of All Saints is fupported by fubfcription, begun 1709 . It is conducted on the fame plan, receiving $4 \mathrm{I}$ boys, and ${ }_{1} 7$ girls.

The charity-fchool belonging to the parifh of St. Andrew, was founded by Sir William Blacket, Bart. for 30 boys; opened in January, 1707-8; the fchool-maiter allowed $20 \%$ per anmm, paying fchool-rent. 
The charity-fchool belonging to the parifh of St. Fabn, was founded, 1705, by Fobn Ord, Efq; for 44 boys. He fettled upon it a large field without Pilgrim-Atreet-gate, called Magdalen-clofe, and held by leafe of St. Mary Magdalen's hofpital. Mrs. Margaret Allgood, a widow-gentlewoman, gave to this excellent charity $100 \%$. her will bearing date, I 5 th July, 1707 . They are cloathed annually at midfummer, by fubfcription. The fchool-nitafter is allowed $24 l$ per annum, and for learning them to fing, $2 l$. and for pens, ink, and paper, i 6 s. per annum.

The public buildings of note in this town, are

The Caftle;

The Bridge over the Tyne;

The Town-Court;

The Trinity-Houfe;

The State-boufe of the Corporation;

The Freemen's Hofpital;
The Hofpital for Merchant's

Widows, \&c.

The Barber-Surgeon's Hall ;

The Hofpital for poor Maidens, \&c. The Keelmen's Hofpital;

The Infirmary.

The caftle belongs to the county of Northumberland. Several tenements and lands in the county were held by keeping it in repair (u). It ftands on an eminence; was antiently ftrong and ftately; the principal entrance to the fouth; encompaffed witl two walls of great ftrength and height; in the exterior wall, 4 gates; one large, with two port-cullices; the ground within

(u) Diverfx terræ et tenemen. in comitat. Nortbumlr. onerat. exiftunt ad reparand. et fuftentand. nomnulla xdificia infra caftrum in Novo Cafro fuper Tynam, Clauf. 6. R. Ed. I. Dorfo. tom. 4. Rot. Turri Londinenfi.

Inquifitio de reparatione caftri de Novo Caftro fuper Tynam ad diverfas perfonas pertinen. et de ufurpationibus fadtis fuper motum et folum regis, efcaet. 9. R, Ed. III. No, 68. Ibid. 
this wall, 3 acres, and one rod. In the caftle was a well of a confiderable depth; and a chapel of a handfome Gothic architecture. The great Barons, Heron, Delaval, Clavering, Bolbeck, Bertram of Bothal, Ros, Gaugy, Clifford, and Dilfon, had each a houfe within its liberties for its defence. The government of it was generally committed to the high theriff of Nortbumberland. At the acceffion of K. Fames I, one third of it was almoft taken away; the lead and covering embezzled and carricd off; the fquarc, old tower miferably decayed and fractured ; the malefactors confined in it in danger of perifhing by the weather; the expence of repairing it computed at $809 \mathrm{l}$. I $5 \mathrm{~s}$. The poor remains of it are decently kept, and ferve for the county-jail, and for holding the annual aflizes.

The Bridge over the Tyne is of great antiquity. From the veftigies of a military way leading to it from Chefacr-le-ftreet, it is believed to have been originally Roman. It had the misfortune to be deftroyed by fire, $33 \mathrm{~K}$. Henry III ; being then of wood. It was. rebuilt of ftone by contribution; for which indulgences were granted by Sewald, Archbilhop of York, Walter Bifhop of Durbam, Walter Bifhop of Rochefter, \&c. fome giving lands, as Adam de Fefmont; the witneffes to the grant, Gilbert Delaval, Adum de Pleffy, Gilbert de Ogle, William de Byker, \&c. It had twelve bold arches. It has now only nine; the reft, on building the key, were turned into cellars or ftore-rooms. Several tradefmen have their houfes and fhops on each fide of it. About the middle of it is an old tower, ufed by the magiftrates for the confinement of diforderly perfons and offenders, beyond which is a blue ftone, the boundary between Newcafle and Gateflead; and at the other end is. another tower, where has been a draw-bridge. That part of it, to the fouth of the blue ftone, was recovered from the corporation, ${ }_{4} \mathrm{~K}$. Henry V, I4 I6, by Thomas Langley, bifhop of Durbum, as. 
attefted by a letter of attorney made by his lordihip to feveral. perfons commiffioned to take poffeflion of it; which was done in the prefence of feveral gentlemen, worthy to be remembered for the fake of their pofterity, being perfons of good credit and antiquity, viz. "John Lumlie, Ralph Eure, Robert Hilton, Wil" liam Fulthrop, William Tempef, Thomas Suriees, Robert Co"niers, William Claxton, Sheriff of Durbam; Robert de Ogle, "John Bertram, John Widdrington, and John Middleton, knights, " of Northumberland; Chriftopher Horfley, William Ofmunder"low, knights, of Wefmorland; and alfo in the prefence of thefe "Efquires, Robert Hilton, Robert Eure, William Bowes, John "Conicrs, William Lambton the elder, John de Morden, William "Lambton the younger, Hugh Burunghill, John Britly, Wil"liam Bellingham, Robert Bellafis, Henry.Tailbois; Thomas "Garbois, John de Hutton, Thomas Cooke of Fifhburne, and "five others $(v)$."

(v) Thomas Dei gratia epifcopus Dunelmcnfis omnibus ad quos prefentes literæ pervenerint, falutem. Sciatis quod affignavimus \& deputavimus dilectos et fideles noftros Radulpbum de Eure, Chr. Senefchallum noftrum Dunelmie, Willielmum Chanceler, cancellarium infra comitatum \& libertatem Dunelniae, conjuncim et divifim, ad plenam et pacificam feifinam, de duabus partibus medietatis cujufdam pontis vocati Tyne-Eridge, in villa noftra Gateßead, infra comitatum et libertat.m Dunelmia exiftentis. Quæ quidem dux partes midictatis prædißtæ continent \& faciunt tertiam partem ejufdem pontis ufque auftrum in prædicta villa de Gatefhead. Super quas duas partes nuper mayor et communitas villa Novi Cafri fuper Tinam quandam turrim de novo æedificare cxperunt, \& quas quidem duas pirtes cum franchefi:s, jurifdictionibus, et juribus regalibus, fuper eafdem duas partes medietatis prædictæ, nupcr in curia domini regis verfus majorem \& communitatem dictæ villæ $N_{\text {vvi }}$ Caflri recuperavimus nobis et fuccefforibus roftris epifcopis Duneimia, et in jure ccclefiz noftre fancti Cuthberti poffidendas de viceconiti $W_{\text {eftncrlandia, }}$ pretextu ejufdem brevis dicti domini regis fibi directi nomine noftro recipiendas; \& turrim prædictam ad opus noftum fulvo \& fecurè cuftodiendam. Ra * tum \& gratum habiturus quicquid idem Radulphus, Williclmus, \&c. Nomine noftro fecerint in premiffis. In cujus rei teltimonium has literas noftras fieri fecimus patentes. Datum Dunelmia per manus cancellarii noftri 26 Octobris, anno pontificatus noftri undecimo.

Hol. Chron. vol, ii. p. 532-3. 
This part of the bridge was repaired by Thomas Rutbal, Bifhop of Durbam, famous in the reigns of K. Henrys VII, VIII; not only for being the richeft fubject then in Britain, but for the unfortunate miftake he made in delivering the book of his own private affairs to the afpiring cardinal Wolfey, inftead of one he had wrote on the ftate of the kingdom by the defire of his fovereign, whereby the cardinal effected his ruin, and ftept into his bilhoprick. A misfortune this, worthy of notice, and thews how God Almighty, by the flighteft means, does punifh us, when we are lefs faithful and diligent in his fervice, than that of men, and more concerned how to get rich and great in this world, than to difcharge our duty. For this Bifhop Rutbal, being a privy counfellor to K. Henry VIII, was fo ftudious of obliging that king, and fo afliduoufly attendant on the court, that he could find but little time to attend on the weighty affairs of his bifhoprick; fo when he moft needed felf-recollection, and prefence of mind (divine gifts!) God left him to his own ftrength, and gave his bihoprick to another (w).

The Tornn-Court is on the fouth fide of the Sand-bill, on the banks of the Tyne. Its original foundarion was by that munificent patron of Newcafle, Roger de Thornton. It was rebuilt by the corporation, $16 ; 8$, after a defign fuitable to the dignity of that opulent body. It coft upwards of $10,000 \mathrm{l}$. befides I $200 \mathrm{l}$. the donation of one of the magiftrates $(x)$. The effigies of K. Fames II, on horfe-back, placed in the area before it, coft $1700 \%$. It was of copper, large as the life; the horfe ftanding upon his hindfeet, raifed upon a pedeftal of white marble, encompatted with iron-rails; pulled down 1688.

(w) Hol. Chron, vol. ii. p. 796.

(x) Alderman Weimuth. 
The Trinity-Houfe belonging to the mariners of Nervcafle' is a monaftic-like building, of a fquare figure, accommodated with a ncat chapel, and with chambers for 14 perfons, allowed each cight fhillings a month, coals and cloathing. The hall in it is large and ftately. It was antiently called Dalton's Place. It was purchafed by this focicty, $20 \mathrm{~K}$. Henry VII, of Ralpb Hebburn, of Heburn-Tower, in Nortbumberland, Efq; and was confirmed to them by his fon, Thomas Hebburn, Ef, paying to him and his heirs for ever the compliment of a bottle of wine annually, if demanded, in Fune, on the eve of St. Peter and St. Panl. He was alfo to be made a member, to be intitled to their privileges, and to have the ufual funeral-honours at his death. The writing was fealed with the town-feal, and figned by the mayor, and the reft of the magiftrates. The focicty keep it in repair, at their own cliarge. It ftands very convenient for feamen, near the key, in the upper end of a well-built ftrcet, called The Broad Chare.

The mariners of Nezucafle are diftinguifhed in our annals for their bravery by fea, and their gallant behaviour in the national fervicc. In the reign of K. Edward III, 1335, they were called out on a naval expedition to Scotland, and burnt the town of Dun$\operatorname{dec}(y)$. In company with the mariners of Hull, 4 K. Richard II, I 380 , they took a Scotch pirate; the goods in the thip valued at 7000 marks (z).

They were honoured with a charter, $3 \mathrm{~K}$. Fames I; with another, I 7 th Ost. I6 K. Charles II, 1667; with a third, 26th Fuly, 3 K. Fames II, 1687.

The State-Houfe of the corporation is on the edge of the Tyne, above the bridge, in a ftreet called The Clofe. It is a modern
(y) Hol. Chron. vol, ii, p. 35 r.
(z) Id, p. 428.

building, 


\section{ANTIQUITIES OF NORTHUMBERLAND. 24}

building, very handfome, with an area or court before it, entered by a flight of fteps; within, not only convenient, but elegant, correfponding with the grandcur and hofpitality kept in it.

The Freeman's Hofpital, commonly called The Town's Hofpital in the Manours, is on the north fide of a pleafant field. It was founded by the corporation, $168 \mathrm{I}$, and dedicated to the Holy Fefus; for a mafter, and 39 poor freemen or their widows; the mafter allowed $x l$. ros. and the reft $\mathrm{i} l$. a quarter each. It ftands upon piazzas, the entrance in the middle, with a handiome fountain before it. Near the foot of the fame field, is

The Hofpital for the relicf of fix widows of merchants and clergymen, built by the corporation, 1725, and endowed by Mrs. Ann Davifon, the relict of Mr. Benjamin Davifon, merchant.

The Hall belonging to the Barber-Surgeons is on the caft fide of the fame field. It was rebuilt after a neat defign, I730. It ftands upon tall piazzas, with a garden before it, adorned with fome pieces of ftatuary, the effigies of thofe antient fathers of medicine, Efculapius, Hippocrates, Galen, and Paraceljus. Hard by is

The Hofpital for fix poor maiden-women, and fix poor men, built by the corporation, 1753 , after receiving a donation of r $200 \mathrm{l}$. of Thomas Davidfon, of Ferry-Hill, in the bilhoprick of Durbam, Efq; and his two fifters; and the like fum from Sir Walter Calverley Blacket, Bart. for its cnlowment.

The Keelmen's Hofpital is between the Carpenter's tower and Sandgate. It was built, 170r, at their own charge, by contribution, paying, each man, I penny a tide. It is a large, fquare ftrucVoL. II. 
ture, contang upwards of 50 chambers; but is at prefent neglected, to the great misfortune of the aged among that numerous and laborious people.

The Infrmary is belind the Atrect of Weft-gate. It was built by fubfcription for the bencfit of the town and county of Nerucafte, and the two countics of Nortbumberland and Durbam. It had a donation of roool. from Sir Walter Calverley Blacket, Bart. I75); by whofe appointment the annual intereft of $10 l$. is given to a clergyman to attend it. It is a large handfome building, in a pleafant airy fituation, in a field, called The Fortb; faid to have been given to the corporation by K. Edward III (a), containing eleven acres, as furveyed by order of parliament, 1649, and then valued at $12 l$. per annum; part of which is a fquare bowling-green, terraced round, and thaded with tall elms, much reforted to in the hours of leifure by the admirers of rural objects.

Subfcriptions have been lately fet on foot for the fupport of a Lying-in-hofpital, and of an Hoppital for Lunatics; which will undoubtedly meet with a generous encouragement, in a country thus diftinguifhed by acts of humanity and beneficence.

Beficles thefe public ftructures, there are fome private ones revered for their antiquity, remarkable for having been the palaces or temporary refidence of perfons of royal or baronial dignity. In Panden is a houfe, called,

Panden-Hall, which was the palace of the kings of Nortbumber lond under the Saxon heptarchy. In that part of the town, called The Side, is an anticnt houfe, an appendix to the caftle, which

(a) Grey's Chorographian 
whas the palace of the kings of England, in which they refided in their expeditions againft $S$ cotland ( $b$ ). It is now called,

Lumley-place, from its being afterwards the refidence of the Lords Lumley, of Lumley-caftle. In Neregate-Atrect is an antient houfe, called,

The Scotch $H_{m}$, from its being the quarters of the kings and nobility of Scotland, in the time of truce with that kingdom; alfo, The Earl's Int, from its belonging to the Earls of Nortbumberland (c). In the freet, called The Clofe, on the banks of the Tyne, is an antient houfe, with a great gate before it, called,

Northumberland-Houfe, from its being formerly the property and occafional refidence of the Earls of Nortbumberland. In Weftgate, near St. Mary's Hofpital, is a houfe, called,

Wefmorland-Place, which belonged to the Nevills, Earls of $/$. morland. In Pilgrim-ftreet is a houfe, called,

The Pilgrim's Inn, from the great crowd of religious devotees which frequented it, in their way to the fhrine of the Virgin Mary in the village of Fef-mont, i. e. the Mount of Fefus. In the fame ftreet, at the upper end, and on the weft fide, is

The houfe of Sir Walter Calverley Blacket, Bart. an antient building, the remains of the Francifcan priory, to which have been added two new wings. A large print of it, and of part of the town, was publifhed fome years ago.

(b) Efcaet. 14 Hin. Vì. n. 36.

(c) Rym. Foed. voli, ii. p. 593 . p. 600 . 
Thus much of the principal buildings in Newcafte: I thall now takc noticc of the moft remarkable State-tranfactions and. vicurrences in it.

Fobn Baliol did homage for his crown of Scotland to K. Edward I, in the great hall of his palace on the Side in this town, abovementioned, December 26, 1292, with great folemnity; and by the advice of the parliament at Weftminfter, K. Edward fixed the fees, for want of a precedent, at $20 l$. Aterling, for his vaffalage, louble the fum paid by an earl on the like account (d).

K. Edward II, for the prefervation of his minion, Pierce Gavefou, retircd with him to this town, I3Io, from which, on the approach of the incenfed Barons, under the Earl of Lancafter, called Contrariants and Ordainers, they took fhipping at Tynemoutb for Scarbrough, where Gavefton furrendered himfelf to Lord Percy (e), and not to the Earl of Pembroke, as affirmed in many of our hiftories.

A peace was concluded at Nerucafte, I323, about Afcenfionday, by the commiflioners of K. Edward II, and of Robert Bruce, King of Scotland, for I 3 years; the names of the Englifh commiffioners, Adomar Earl of Pembroke, and Hugh de Spenfer, junr. lord high chamberlain, \&c. of the Scots, the Bifhop of St. Andrews, the Earl of Murrey, \&c. (f).

(d) Apud Novum Caftrum fuper Tynam, in aula palatii ipfius domini regis infra caftrum, \&c. Rym. Fæd. vol. ii. p. 593. p. 6co. Acta Regia, vol, i. 8vo. p. 72, 73.

(c) Rym. Fæd. vol. iii. p. 334. Acta Regia, vol. i. 8vo. p. 110, \&c. Braáy's Ap-。 pend. to his Hiftory of England.

(f) Hol. Chron. vol. ii. p. 334, 
The whole militia of England, by the advice of the parliament held at Lincoln, were ordered to rendezvous at Nerwcafle, $8 \mathrm{~K}$. Edward II, 1315, fifteen days after midfummer; cvery village in the kingdom fending one ftout man, (cities and boroughs not excepted) furnifhed with armour, fwords, bows, arrows, flings, lances, \&c. and with travelling-money, and wages at 4 d. a day, during. the expedition, which was then directed agzint the $\operatorname{Scots}(g)$.

K. Edward III, kept his Whitfuntide at Nerucafle with great fate and magnificence, I333, wherc, June following, Edward Baliol did homage to him for his crown of Scotland in the prefence of a fplendid circle of lords and gentlemen of the two nations, to hold it for ever of the Englifb crown; making a formal furrender at the fame time of part of his kingdom bordering upon England, viz. Berwick, Roxbrough, Pebles, Haddingtsin, Edenburgh, Fedworth with the caftle and foreft, and the forefts of Selkirk and Etherick(b); the inftrument bearing date, is June.

The two kings were both at Newcafle, about Midfummer, i334, at the head of a powerful army, in their march for Scotland; the Englifs monarch taking the rout of Carlifle, and Edward Baliol the rout to Berwick, with his kinfmen, the Earl of. Surrey and: Arundel, and Lord Henry Percy, a Baron, fays the record, of great might and power (i).

K. Edward III. came to Nerwcafle, $133^{6}$, in his way to Scotland, big with the thoughts of conqueft, both. of the Scots, and the

(g) Daniel in Bilhop Kenneto

(b) Rym. Foed. vol. iv. p. i616-17. Acta Regia, vol, i. 8vo. p. 70r. Hich Chron. vol, ii. 35 o.

(i) Hol. Chron, vol, ii. p. 35 s。 
French, their confederates, under Balial, whom he met at St. Fobn's Town, or $P_{\epsilon r t b}$; firt iffuing out a writ, dated at this town, June 20, 1336 , for the Archbihop of Canterbury, high chancellor of England, the Bihop of Lincoln, treafurer, the Earl of Cornwall, his brother, to hold the parliament at Nortbampton in his ftead ( $k$ ).

The conventions between the Englifh and Scotch commifioners for the liberty of David Bruce, King of Scotland, were dated at Nerucafte, I 3 July, 1354 (l).

In the unhappy differences between K. Charles I. and his parliament, Newcafle was befieged by the Scots, under the command of General Lefley, I643; the Marquis of Newcaftle then governor for the King. The Marquis burnt roo houfes in the fuburbs. He made a fally, but was repulfed, and one of the outworks was taken. It was hard preffed both on the north and fouth fide at once, the Scots dividing their army, 1500 of them crofling the Tyne. General Lefley retiring, it was befieged again the next year by the Scots under the command of the Earls of $\mathrm{Ca}$ lender and Leven, who got poffeffion of the bridge, the inhabitants retiring to the high town for Ahelter; 3000 countrymen being fummoned by General Leven to affift him with fpades, mattocks, \&c. It was taken by ftorm. The mayor, Sir Foln Merlay, retired to the caftle, with three Scotcb Lords, Crawford; Rea, and Maxwell, 500 men, and many women and children. He furrendered it on condition of faving their lives, Oct. 29. The three Scotch Lords were fent into Scotland to take their trial. Moft of the townfmen faved their effects by compofition. An order came for the trial of the mayor by a council of war. Some of

(k) Rymel's Foedera, vol. iv. p. 701.

(l) Id. vol.v. p. 793, 812. Adta Regia, vol. j. 8vo. p. 315. 
the aldermen were disfranchifed, the corporation was new mo, delled, not according to their charter, but as might beft fuit the views of the parliament. The member, Sir Henry Anderfon, Kt. was expelled the houfe, for non-attendance, and joining the royal army. Fobn Blakrfon, Efq; was chofen in his room, who figned the warrant for beheading his fovereign. Robert Ellifon, of Helbarne, Efq; was his fellow-member, chrofen in the place of Warmouth, Efq; not fuffered to take his feat after his election. The plague was at the fame time in the town, and coals werc at a high price by a parliamentary impoit of $4 \mathrm{~s}$. per chaldron for the maintenance of the garrifon, and thipping them off to the fick and ftarving metropolis. For the relicf of the town-poor, they ordered $500 \mathrm{l}$. to be raifed upon coals, 1645 . They had the honour of the King's prefence, $164^{6}$, who came from Lumleycaftle, and lodged with the Scotch General Leven in the Francisan abbey, where his faithful and loyal fubjects were not fuffered to approach him. A fermon was preached before him by the Scotch metropolitan, fays Lord Clarendon (m), who was fo little touched with the prefence of fuffering majeny, and had fo fmall a portion of the grace of modelty, that after his difcourle was ended, he called for the $j^{2 d}$ Pfalm, which begins, - Why doft thou, tyrant, boaft thyfelf, thy wicked works to praife. His majefty that moment ftood up, and called for the $5^{6 \text { th }}$ Pfalm, which begins, Have mercy, Lord, on me, I pray, for men would me devour. The congregation fung his majefty's.

Of the town, and the neighbouring countics, the Scots raifed 8000 l. a month, before the arrival of his majefty, and 90001 . a month afterwards, upon pain of military execution; which caufed an abundance of the inhabitants to leave their homes. To engage the Scots to return to their native kingdom, the parlia- 


\section{ANTIQUITIES OF NORTHUMBERLAND.}

ment agreed to give them 200,0001 . to be raifed by the fale of the bifhop's lands. One half was paid at Topcliff, and the other after their leaving Nerucafle; except 40,000 1. ftopt by their defection, and changing fides.

I have only two things more cxtraordinary on record to mention concerning Nereafle.

It was almoft wholly confumed by Fire, 33 K. Henry III. I 249(n).

It had a great misfortune by WTater, 13 K. Edward III, I339; bcing furpized in the fill hours of the night with a rapid, impetuous flood, which made its way through the town-wall, bore down fix perches of it, and fwept away above 120 perfons, both men and women, who on their going to bed, liad not the leaft expectation of any fuch difafter $(0)$. Thefe were alarming and aftonifhing accidents to this antient town, which might be intended by a wife providence to preferve their more valuable ftores and acquifitions, to rouze and awaken the flumbering virtues of fome, to keep alive and cherifh thofe of others, and to make all intent upon internal excelience and perfection, before the tinfel elegance, and fleeting cmuellifhments of life.

We now pafs through Panden-gate, by the courfe of the Pict'swall on the right hand, over the hill and village of Panden, crofs the Oufe-burn by a new ftone-bridge of onc arch, and entering the Shield's road, afcend the hill through the turnpike-gate for about a quarter of a mile, when a road branches off, on the left hand, from a porter's lodge, to
(n) Hol. Chron, vol. ii. p. 24 I.
(o) Id. p. 355 . 
Heaton ( $p$ ); a mediety of the manour of which was held of the Barony of Guagy, by Sir Ralph Laweson, Knt. ro Q. Elizabetb (q), and now belongs to Sir Harry Lawefon, Bart. The other mediety was in the poffeffion of Fobn Mitford, of Segbill, Efq; 10 Q. Eliza beth (r), and of his fon Robert Mitford, Efq; it K. Charles I; and is now in the poffeffion of Mattbew Ridley, Efq; a younger branch of the antient family of the Ridleys of Willimotefwick (s), a reprefentative in parliament for Newcafte upon Tyne, and father of Sir Matthew White Ridley, of Blaigdon, Bart. His feat is at the fouth end of the village, modern, and handfome. Before the fouth front is a large park-like enclofure, fmall clumps of young foreft-trees, extending to the Shield's road, which is in fight; alfo an artificial ruin on the hill at Biker. On the fouth-weft and weft fide, are fhrubberies, flower-borders, and groves of trees, with a tempiato.

From the porter's lodge, we go by an eafy afcent for a quarter of a mile to Biker-hill, where a road branches off to the village of

Biker, the manour of which was held by grand Serjancy, by carrying the king's Writs between the rivers Tyne and Coquet, and making diftreffes of goods for the king's debts, and keeping and difpofing of them for his ufe; by which fervice it was held by

(p) Heton. Efcaet. Nortbumbr.

Heaton. Autographis recentior.

(q) Vid. Biker.

(v) Vid. Seghill.

(s) Ex informat. Matth. Ridley, Arm. de Heaton. See Willimotefwick.

VOL. II.

$\mathrm{K} \mathrm{k}$

$\sqrt{2}-$ 
Nickolas de Biker in the reign of K. Henry III $(t)$; by Robert de Biker in the reign of. K. Edward I (u); by Fobn de Biker, I 3 K. Ed-. ward III ( $v)$; and by Roger de Biker, I gth of the fame reign (w). It belonged to the noble family of Percy in the reign of $\mathrm{K}$. Henry VI. It was in the poffellion of the crown, $2 \mathrm{~K}$. Edward IV $(x)$; and was then given to the Duke of Clarence, the king's brother.

It came afterwards into the poffeflion of the antient family of the Larefons; and was poffeffed by Sir Ralpb Lawfon, Knt. ro Q. Elizabeth (y); by his nephew Henry Larvfon, Ef(1; in the fame.

(t) Nicbolcus de Biker tenet Biker in capite de dom. rege per fervicium ferjancii; viz. portando brev. dom. regis inter Tynam et Cocket, et ad cuftodienda in parka de Byker avaria capta prodebitis dom. regis cum opus fuerit, et ad faciend. attachament. coronæ, et alia attachament, quie pertinent ad vice comitem, ubi vice-comes et fervientes five ballivi fui non poflunt attingere. Certificat. Hug. de Bolbeck, vice-com. Nortbumbr.

Nichlaus de $B_{j}$ ker tenet Byker per ferjanceam, per fervicium portandi brevia dom. regis inter Tynam ct Cocket, et facit difrietiones de Warda Novi-caftri.

(u) Eicaet. de anno Ed. I.

Veredicta de comit. Northambr.

(v) Fobannes de Biker, frater et hares Robsrti de Biker, tenuit de rege in capite manerium de Biker, contin. Caricut, terre, et centum Aer. Bofci, et xvii s. viid. ob. anni reddit. pertinen, per fervic. folvendi regi per manum vice-comitis, qui pro tempore fuerit, xl. per ann. ad Ward. caftri Noxi Caftri fuper Tynam, et portandi brevia regis inter Tynam et Cocket, animalia capiend. pro debito regis, et vendend, eadem animalia pro dominicis deb. faciendis. Astachiamenta qux pertineat ad vice-comitem, et fervientes fuos, non poffunt attingere.Rot. Turri Londinens. Pafche Fin. 13 Ed. III.

(76) Efcat. de anno ig Ed. III. n. 53 .

(x) Pat. 2. Ed. IV. in. 3 .

(y) Radulphus Lnafon, miles, tenet in capite manerium de Byker et Weft Matfen, ac mudictatem manerii five Hamlet, in Heton, juxta Novum Caftrum.

Efcact. de anno io Eliz. 


\section{ANTIQUITIES OF NORTHUMBERLAND. 251}

reign (z); who was fucceeded by his fon Roger Laweon, Efy; (a); in whofe time we find a third part of it, with a capital mefluage, and other tenements, in Biker, polfefled by the family of the Dents; by. Henry and Robert Dent, Efqrs; who had a fifhery in the river Tyne, and a colliery, parcels of the manour of Biker ( $b$ ).

It now belongs to Sir Harry Law fon, Bart. and others. The vi?lage ftands on an eminence; in which is an artificial, cantlatch ruin. It has a moft cxtenfive and beautiful profpet ; of the tow of Newcafte on one fide, and of the fhipping in the river Tyne on the otlier.

A mile from Biker, a road branches off, on the left hanc. tr.

Little Denton, one of the manours of the Barony of Ficrocise,

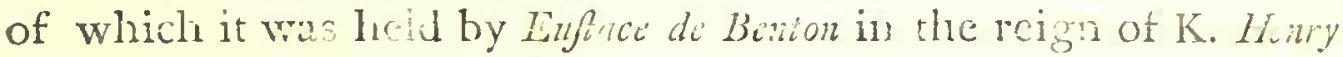
III, as was found by an inquifion, i K. Eidward I. (d)

It was lise feat and eftate of the late Hillimn Bigge, Lfq; ligh theriff $\mathrm{O}$ Loribumberland, $175 \mathrm{I}$; father of Thomas Charles Higge,

(z) Henricus Lawjon, Arm. nepos et hæres Radulthi, militis, tenet in capite per fervic. milit. maneriun de Byker.

Ex Lib. Feou. Petri Ofoorne, militis.

(a) Roger Lawfon, Arm. filius H mici, tenet in capite manerium de Byker. - Ib.

(b) Henricus Dent, confanguin. et hares Georgii Dent, tenet in capite per fervic, milit. tertiam partem manerii de Byker, ac capitale mefluag. ct tenem. ibidcm. -16 .

Robertus Dent, Arm. filius Henrici, tenet in capite per fervic. milit. capitale meffuag. vocat. Byker, ac diverfa cottag. et tenem. ibidem, et pifcarium in aqua de $T_{y n e}$ ac carbo. nar. Parcell, manterii de Byker.-Ib.

(c) See Ford.Callle.

(d) Hæredes Euffac. de Beviton tenent parvam Benton per feptimam partem unius feodi veteris Feoffamesiti.—Efcaet. de anno r $E d$. I. 
Efr; the piefent poffeffor, lately a ftudent of Cbrif-Cburch, in Oxford. His feat is a modern brick-ftucture, after a genteel defign; near it is another handfome feat, built by his uncle, Thomas Bigse, Efq; both on a-fine flope, in view from the Shield's road.

\section{A mile north from Little Benton, on a hill, is}

Long Benton, a pleafant village, one of the manours of the $\mathrm{Ba}$ rony of Morpetb (e). The church ftands near a quarter of a mile. north-eaft from it. It was given, with certain lands in the parifh, to Baliol-college, in Oxford, by Sir Pbilip Somerville, of Wickmore, in Stafordfizie, for the perpetual maintenance of fix fcholars.

We now leave the two Bentons, and continue our courfe on the Shieli's road about a mile, when a neat winding road branches. off on the right hand, to

Carr-vill, once the feat of the Cofen's, the Ewbanks's, of Sir Witfrid Laweon, of Braiton-Hall, in Cumberland, Bart. father of Sir Gilfrid, of Mr. Carr, brother of William Carr, of Etall, Efq; and now of Mrs. Proctor. It bore the name of Cofens's Houfe, till newnamed Carr-vill, by Mr. Carr, who rebuilt it, to which Mrs. Proctor hath added new ornaments and conveniences.

In a field adjoining, to the eaft of it, floping to the Tyne, called, The Well-Laws, belonging to Mattherw Waters, of Lincoln's In Efq; is the ruin of a Roman villa and fort; the latter in the ufual form, a parallelogram; the laft garrifon the Romans had at this end of the wall; the river ferving for a defence to Tynemouth, being navigable for their Naves luforie, or light frigates, deftined for fcouring the coafts, and chaftizing prædatory rovers. The

\section{(c) See Morpetho}


eminent antiquaries, Roger Gale, Efq; Dr. Hunter, Gordon, and Horfley, have afligned it the name of

Segeclumum, garrifoncd by the firft cohort of the Lergi. It feems to be derived from the Roman Seges, corn, and the Britifs Dunum, a hill, i. e. the fort or ftation on a high ground, furnifhed with magazines of corn, brought by fea from the more fouthern provinces, and landed here. I have frequently after high tides obferved large, well-wrought, afhler ftones lying on the thore of the river at the foot of this field, the fcattered ruins probably of a key. By the large ruins of foundations difcovered by the plow, it has been a flation of eminence, biclding fairer for being a capital town, than Richard of Cirencefer's northern alpine frontier of Rochefter; better fuited to the Roman tafte and elegance; fitted for pleafure and commerce.

In the walls of the old feat of Carr-vill, fome Roman ftones, with infcriptions, were difcovered by Mr. Horfley, and publifhed (f).

On the other fide of the Shield's road, nearly oppofite to Carrvill, a road branches off to the village of

Wall's-End, fo called from its fituation by the end of the PiEt's Wall. It was given, with the village of Willington, on an eminence, a mile to the north-ealt of it, to the monks of Durbam, i 6 K. William I, 1082, by William de Carilepbo, Bifhop of that See (g).

(f) Brit. Rom. p. 104 .

f8.) Et ego monachis tradidi congregatis - Ultra amnem Tynam duas villas Wyllynton et Wallefend cum fuis appendiciis.—Carta IVillielmi de Carilepbo Dunelm. Epifs, fuper li: bertat. et poffeflionibus monachis concefis, façta A. D. 5082. 
It is a well-built village; a lange grafs area in the center, with a neat raifed caufeway through it; two gentlemen's feats on each fidc, with excellent gardens; the moft rural and romantic, thofe of Games Rioncafor, Iff; a winding ftreamlet taking its courfe between two teraced flopes, and forming a canal, with a bridge over it.

At the eaft end of the village, is a neat brick-ftructure, confiting of two large rooms; the lower one ferving for a fchool, and the other for a mafter to dwell in; the donation of the eldeft fitter of Games Moncafer, Efq; to the parili.

The church is on an eminence, at a fmall difance from the village, to the north-eaft; the afcent to it fteep, by ftone-fteps.

A mile caft fiom it, a road branches off through a gate on the right hand, to

Howden-Pans, a populous village in the fame parifh, fo called from the falt-pans in it, and its fituation under a hill, in the Den or valley; How fignifying a hill. It ftands almoft clofe to the river $T y n e$, on whofe banks is a fine key for the thipping to heave their ballaft, of near a quarter of a mile in length, commonly called Willington-key, from the Ofium of Willington-burn at the weft end. A dock, a ropery, and a fmithery, at this place, furnifh employment for upwards of 100 people. The dock holds two Thips.

Near three miles farther eaft, the Sbields road makes a flexure on the right hand by a gradual defcent to the town of 
North Sbields (b), fo called from its northern fituation by the river Tyne, and being a Shicld or fhelter for the fhipping. 'In the days of K. Elward I, it was fo fmall, that it confifted only of fix cottages, inhabited by fihermen. It is now fo populous, that it refembles Wapping by the river Thames.

A little below it is a garrifon, called,

Clifford's Fort, which was taken by the Scots, 20 K. Charles I, I644, and in it five pieces of ordnance, arms, powder, and fome prifoners, nine Scotchmen killed on that occafion. It is a ftrong and handfome ftone-building, well mountcd with cannon; from which we afeend a hill by a large fquare building, of a late erection, called,

The Barracks, furnifhed with foldiers, and with artillery next the harbour; and come to the pleafant, marine villa of

Tynemouth (i), famous for its monaflery founded by ofwald, King of Northumberland, and dedicated to the Bleffed Virgin ( $k$ ). It was plundered by the Danifh rovers in three feveral defecnts or expeditions; firft towards the end of the eighth century (l), and next under Hinguar and Hubba in the reign of K. Ethelred, and laftly in the reign of $\mathrm{K}$. Athelftan. What made them the more intent upon ravaging the monafteries was, the mof valuable ef-

(b) Sheles. Autograslis perantiquis.

(i) Tynemouth. Lel. Itin. vol. vii. p. 59 .

Dunemuth. Collect. Vol. ii. 174. 297-

(k) $\longrightarrow$ Vol. iii. p. 43 .

(l) Vol. ii. 297. 388. 
fecis in the country were ufually concealed in them on the approach of an enemy, for their better fecurity. But covetoufnefs has no reverence for ficred things. The poor defencelefs monks, on the defent of the thicvinh and murdering troops of Hinguar and Hubba. ficd in a fright to fave themfelves in their church. The mercilefs cnemy fet fire to it, and burnt them and it to the ground $(m)$. A juf providence, ever awake to the cries of innocent blood, did not let theirs go unpunithed. Rouzed at the news of fuch an atrocious dced, their fovereign, K. Etbelred, and his father-inlaw, Offa, King of Mcrcia, with their united forces drove them in confufion and liurry to their thips, and a ftorm arifing, they were wrecked on the rocks, and almoft all drowned.

This looly fabric laid in its alhes, unrepaired, forlorn, and defolate, till the reign of K. Edward the Confeffor. Then Tofon, Earl of Northumberland, from the motive of ambition, and not of piety, rebuilt and endowed it for Black. Canons, to the honour of St. Mary, and St. Ofwin, Bihop Aiden's favourite, whofe remains had been fearched for, and difcovered, under its ruins.

That Earl being banithed for his many murthers and outrages, after feveral very cruel adventures, burning and plundering the coaft as an enemy's country, at length engaged Harold Harfagar, King of Norway, who was then pufhing his conquefts in the north of Scotland, to enter this harbour of $\mathcal{T}_{\text {ynenouth, and make a bold }}$ pufh for the crown of his own brother, K. Harold II. Not awed by the fight of his new foundation of St. Mary and St. Ofwin, he in concert with the Norwegian, plundered and wafted the country on both fides the river Tyne. They then put to fea again, and entered the Humber. There they landed and committed horrid

(m) Lel. Collect. vol. ii. p. $297,388$. 
barbarities. A body of forces marched to oppofe them under the Generals Edwin and Morchar. Thefe they routed. At Stanfords bridge, near Kork, they were checked in their career by King Harold himfelf. The two armics were about equal, eacl reckoned 60,000, and two fuch great ones had never been feen to engage in England before. With fuch aftonifing ardour did the enemy contend for victory, that a fingle foldier for a confiderable while, defended the pafs at the bridge againt the whole Englifs army. Thus animated by his valour, his countrymen fought moft defperately, from feven in the morning till three in the afternoon, but their Fing and Tofon falling, and the flower of their tronps flain, King Harold obtained a compleat, but bloody victory. Of the whole army that contered the Tyan, under the facred walls of this monalery, in 500 hips, 20 vefels ferred to carry home the furvivors to Norregy, with their young l'rince Olaus, by leave from King Haroll. On the credit of Ailan Bremonfo, it is faid, that the fpoil of the enemy confited of as much gold as twelve young men could with dificulty carry on their flowitiers.

Fron the tinc of its finf foundation by King Ofwald, this religions houfe preferved its independency, till the time of Tofon's brother-in-law, King Wilizan the Norman. He was then degraded to a ceil. It was firf made fubject to Benedict Bifcop's foundation at Girwy; next to Bifhop Carilepho's at Durbam; and laftly to St. Awn's in Hertfordfitire $(n)$. This was done by three governors or Ear's of Northumberland, Walteof, Alberic, and Robert Mowbray (o).

(n) Vid. Matthew Paris, vitas abbatûm S. Alkani, p. 51. 55. I15, 118, I19, 120, 198, 199.

Steven's Supplem. Vol. i. 234.

Tanner's Nutitia Monaf. fo. p. 180.

(0) Dugd. Monat. Angl. Vol.i. p. 45 .

Vox. II. 
Walteof pretended it was an unfit place for devotion, by its being - nimis religiofis borridus et incultus - fituated on a frightful precipice, and a noify tumultuous thore; but in reality it was to erect a fortrefs within its precincts, by the order of his fovereign, who had no regard for religion. Robert Mowbray's motive was of a very low kind. He bore a grudge to the Bilhop of Durbam, and thought to mortify him by that arbitrary act $(p)$. But he afterwards took fanctuary at that very altar, which he thus difhonoured, for treafon, and under it, if I may fo fpeak, interred all his honours, forfeiting by that rafh act 280 fiefs, left him by his uncle the Bifhop of Conftance.

The prior and canons of Tynemoutb had 27 villas in Nortbumberland belonging to them, with their royalties; viz. Tynemouth, Milnton, Shields, Eaft Chirton, Eaft Prefton, Monkton, Whitley, Murton, Erefdon, Backworth, Seghill, Wolfington, Diffington, Elfivick, Wylam, Hertford, Cowpon, Bebfide, Welden, Hauxley, Ambell, Eglingham, Bewick, Lilburn, Flatworth, Middle Chirton, Weft Chirton. Within thefe lordhips they returned the king's writs (q); and were exempt from cornage (r).

They had alfo the lands of Royeley and Demum.

They had the tithes of Corbridge, Ovington, Wylam, Newburn, Diffington, Callerton, Elfwick, Botball, Warkworth, Ambell, Rotbbury,

(p) Dugd. Mon. 1. c.

(q) Prior de Tyntmouth habet retorn. omnium brevium regis libertatem de Tynomouth tangentem.

Pat. in dorfo, 6 Ed. II. p. I. m. 10.

Tom. I. Rot. Northumb. Turri Londinenfi.

(r) Claus, 6. Foh. m. 5. quod monachi fint quieti de cornagio. 


\section{ANTIQUITIES OF NORTHUMBERLAND. 23̆)}

and Wooler, in Nortbumberland; alfo the tithes of Hirtness in the Bifhoprick of Durbam, and of Middleton upon Tees, in Yorkfoire.

They had the impropriations and advowfons of Tynemonth, Woodhorn, Whalton, Bolbam, Bewick, Eglingham, Hartburn, Shilbottle (s), and Haltwefel ( $t$ ), in Nortbamberland; and of Confcliff, in the Bifhoprick of Durbam.

They had feventeen meffuages, and a clofe, called, Wardensclofe, in Nerucafle upon Tyne (u).

They had a weekly market at their town of Bewick ( $v$ ); and an annual fair at Tynemouth (w); alfo a harbour, now called the Prior's harbour, much reforted unto in fummer for bathing.

All which poffeffions were confirmed to them by royal charw $\operatorname{ter}(x)$.

(s) Browne Willis's Survey, Vol. i.

(t) Pat. 8 Ric. II. p. I. m. 2. pro Eccles. de Hautwy/el in Tynedale approprianda.

(u) Pat. Is Ric. II. p. 1. m. 12. pro quibufdam mefluagiis, et reddit. exeunt. de tenem. in villa Novi Cafri fuper Tynam.

(v) Cart. 53 Hen. III. m. 2. pro mercat. apud Bewyke.

(w) Cart. $32 E d$. I. ก. 14. pro feria de Tynemouth.

(x) Vid. in Mon. Angl. Tom. i. p. 335, 336. Cartas duas Hen. I. et unam Fobannis regis.

Confirmat. Cart. monafterii de Tynemouth, 55 Hen. III. m. 34. Et 7, 9. Ed. II. n. 39.

Confrrmat. ampla Cart. et libertat. ejufdem monafterii, Pat. 3 Ric. II. p. 2. m. I4. Et 2 Hen. IV. p. I. n. 4. Et 3 Ed. IV. p. 3. m. I 2. 
By a grant from Fobn Lord Greyflock, and Sir Robert Somervill, 24 K. Edruard I, 1296, they had carriage-roads for themfelves and their tenants through Benton-moors, with liberty of pafture for 24 beafts, of any kind; which grant was confirmed by $R a l p h$ Lord Greyflock, I4 K. Richard II $(y)$.

\section{Ralpb,}

(3) Radulphus baro de Graiftok omnibus ad quos prefens fcriptum autograffatum pervenerit, faluten. In Ppeximus cartam qram Johannes de Graitok dominus de Morpath et Robertus de Somervill fecerunt Deo et Sancto Ofwino priori et conventui de Tynemouth in hae verba. Omnibus Chrifti fudelibus, quibus fcriptum vifuris vel audituris, Johannes de Graiftok, dominus de Morpath, et Robertus de Somervill, falutem in Domino. Noveritis univerfitas vaftra nos pro $f_{a}$ lute animarum noftrorum parentum et omnium benefactorum noftrorum dediffe conceflfte et hac prefenti carta noftra confirmafle D co et Sancto Orwino priori ct conventui de Tynemouth habere liberum introitum tranfitum et exitum in moris meis de Benton ad omnia neceffaria fua carianda, ducenda, et postanda per fe et fervientes fuos cum carris, carrettis, et aliis carragiis fuis fine damno bladi et prati, falvo nobis tamen appornamento vafti juxta legem Anglix. Et omnibus liceat dietis religiofis vias fuas de terra et lapidibus dictarum morarum tine damno bladi ct prati emendare. Item concedimus et dedimus iiflem religiofis efam pafturæ in dictis moris noftris cum quatuor-viginti animalibus cujufcunque generis voluetint, ita pacificè et quietè ut nulla unquam difringantur, nec alio modo impedircneur, nifi inveniantur in damno bladi et prati, habend. et tenend. dictas vias et dictam pafturam ficut poflidend. effe de nobis, hæredibus, vel afignatis noftris, dictis religiofis et corum fuecefforibus liberè, quietè, benè et in pace, func aliquo impedimento in liberam, puram, et perpctuam elimofinam. Et nos, et haredes noftri, vel noftri aflignati, dictas vias, ct dictam palturam, ut permittitur, dictis religiofis ct corum fuccefloribus, warrantizabimus et defendcmus contra omnes homines in perpetuum. In cujus rei teftimonium huic prefenti carta noftra figilla noftra appofuimus. His teftibus, dom. Roberto Bertram, Roberto De la vale, Hugoni De la vale, Johanne de Kirkeby, militibus; Johanne de Dudden, Nicholao de Vypons, et multis aliis. Dat. apud 'Tynenouth, dic purificationis Beatæ Mariæ anno Domini milles ${ }^{\circ}$. CC. nonagefimo fexto. Quam quidem cartam nos prædictus Radulphus Baro de Graiftok confirmamus, ratificamus, et pro nobis et hæredibus noftris prædictis viris rcligiofis. et corum fuccefloribus, in perpetuum. Approbamus per prefentes figillo noftro fignato alteri veriparti hujus indenturæ penes nos et hæredes noftos refidenti, figillum prioratus de Tynemouth eft appens. Liis teftibus Mattheo de Redemayne, Roberto de Ogle, Willielmo de la vale, Roberto de Euer, tunc vice-com. Northumbr. Jolıune de Manners, militibus; Jo- 


\section{Ralph, fon of William, Lord Greyftock, founded a chantery in their church of Tynemouth, 8 K. Edward II, I 3 I 5 (0).}

\section{Fobn,}

hrnne de Wodrington, Thomas de Witton, Johanne de Mitford, Nicholao de Raymes, et aliis. Dat. apud Tynemouth xxiv die menfis Novembris, anno millef. CCC. nonagefima primo Ricardi fecundi poft conqueftum Angliz quartodecimo.

Carta penes Ducem Norbumbria.

(0) Omnibus Chrifti fidelibus ad quos prefens fcriptum pervenerit prior et conventus de Tynemouth, falutem in Domino fempiternam. Noveritis quod cum venerabilis prior nofter Hugo Dei gratia abbas de Sancto Albano et ejuflem loci conventus cuncefierunt nobili viro domino Radulpho filio Willielmi baroni de Grayftok pro beneficiis et honoribus diverfis fibi et ecclefiz fux de Sancto Albano per ipfum Radulphum impenf. ad invenicnd. unum capellanum fecularem, ydoneum, et honeftum, et fuficicntem infia prioratum nofrum antedictum divina celetraturum in perpetuum pro animabus dicti Radulphi, domini Johannis quondam baronis de Graiftok cognati fui et omnium parentum dict. Radulphi ct Johamis, nec non pro animabus omnium fidelium defunctorum. Nos honores et beneficia per piratum Radulphum dicto domino abbati noftro et ecclefiæ fua Sancti Albani exhibita, ct in pofterum exhibenda, plenius confiderantes, ac predictam cantariam in forma predicta fieri cupientes unanimi voluntate et affenfu domini abbatis nofti antedicti voluimus et concedimus pro. nobis et fuccefioribus noftris quod quotiefcunque et quandocunque prædicta cantaria temporibus futuris ut permittitur faciend. deficit, Rallivus di@i domini Radulphi ct haredum fuor. qui pro tempore fuerit in manerio fuo de Morpeth, nos et fuccefores noftri in maneriis noftris de Cowpon et liobbeflet [Bebfide] pro fubtraatione diax cantarix licitì valeat deftingere quoufque de fervicio fubtracto plcnius fueric fatisfatum, abfque noftri vel fucceflorum noftrorum contentione feu impedimento: Volumus infuper et concedimus quad Ballivus cicti domini Radulphi et heredum fuorum apud manerium fuum de Morpath de noftro capellano qui ad prediftam cantariam ut prediftum eft faciend. quoties per nos aut fucceflores noftros afignari contigitur, per nos aut fuccefforcs noftros totics ratificctur. In cujus rei teftimonium figillum domini abbatis noftri antedicti, una cum figillo nofto capituli, et figillum predicti domini Radulphi, filii Willielmi, huic fcripto indentato altcrnatim funt impenfa. His teftibus domino Roberto de la vale, Adamo de Benton, Rogero Manduit, et Nicholao Scot, militibus; Thoma de Belfho, Bartholomeo Bennet, Henico de Harden, Johanne de Bakworth, Gilberto de Whitley, et aliis. Dat. apud 'Tynemouth Die Mercurii proxime polt feftum Annunciationis beatæ Mariæ Virginis anno Dumino mili. CCC. quintodecimo et. anno regni regis Edvardi, filii regis Edvardi, octavo. Carta penes Duccm Northumbrize. 
Gobn, fon of Sir Henry, de Harrington, gave to their vicar of Tynemoutb, Alan Whitchead, lands in L. Benton; for which he did hot mage to the lord's court at L. Benton, $8 \mathrm{~K}$. Richard II (p).

The fame Alan Whitebead, and Thomas de Whalton, in confideration of their honourable fupport and maintenance in the priory, were benefactors (q). Alan Whitebead was alfo a benefactor to the priory of Newminfer, near Morpetb ( $r$ ).

In hac cantaria Thoma de Bulmer ante primam peftilenc. Gilbertus Willynfon de Tynemouth, Robertus de Ambell, Johannes de Walfyngham, Johannes de Whalton, capellani.

Carta penes eund. Ducem Northumbr.

(p) Alanus Whitehead, vicarius ecclefix de Tynemouth, viii ${ }^{\circ}$ anno Richardi fccundi, fecit homagium pro terris et tenem. fuis, quondam Ingelrani de Umfranvill in Benton, quæ idem Alanus habuit ex dono et feoffamento Johannis filii et hæredis Henrici de Harrington militis._- Poftmodum Willielmus de Bsllingham, capellanus, fecit homagium pro iifdem terris.

Carta penes Ducem Nortbumbrice.

(q) Dicunt juratores, quod non eft damnum, nec prejudicium domino regi, nec aliis, ff dominus rex concedat Alano Whitehead, vicario ecclefiæ de Tynemouth, ct Thomæ de Whalton, quod ipfi quatuor cotagia, et quadraginta et octo acras terr. cum pertinen. in Tynemouth, Prefton, Chirton, et Milneton, et eidem Alano quod ipfe unum meffuag. et 9 acr. terr. cum pertinen. in Tynemouth, Prefton, Chirton, dare poffint et affignare priori et conventui de Tynemouth in auxilium fuftentationis fuæ, et ad quædam onera juxta ordinationem ipforum Alani et Thomæ in hac parte faciend. fupportand. habend. et tenend. eidem priori et conventui, et fuccefforibus fuis, in perpetuum.

Dicunt etiam quod 4 cotag. 48 acr. terr. cum pertinen. in Tynemouth, Prefton, et Chirton, tenentur de domino priore, per fervicium redditûs per annum, 7 s. et quod 9 acr. terr. cum pertinen. in Tynemouth, Prefton, et Chirton, tenentur de dicto priore per fervicium redditus per annum 4 s. \&c.

Inquifit. Turri Londinenf. capta coram efcaetore dom. regis in comit. Nortbumbr. Die Sabbati in feftum Sancti Bartholom, Apoftoli, 16 Ric. II.

(r) See Newminfter-Priory. 


\section{ANTIQUITIES OF NORTHUMBERLAND.}

Their annual revenues, feparate from St. Albans, were valued, $26 \mathrm{~K}$. Henry VIII, at $396 \mathrm{l}$. 10s. 5d. ob. Dugd. 5 II l. 4 s. Id. ob. Speed. The prior and 13 canons furrendered i2th January, 1539. They had all penfions. The fite of the priory and molt of the lands were granted, $5 \mathrm{~K}$. Edward VI, to Fohn Dudley, Duke of Nortbumberland $(s)$; but by his attainder in the next reign reverted to the crown, in which they remained, 10 Q.Elizabeth ( $t$ ).

The manour of Tynemouth is now in the poffeflion of his Grace, Hugh, Duke of Nortbumberland.

The priory-church appears by its ruins to have been a moft magnificent ftructure. At the eaft end is an oratory very entire, eighteen feet long, nine feet broad, and nine feet high; the roof arched with ftone, with fculptures in relief of the Blefled Virgin, and the twelve apoftles.

The gate-way, with a tower over it, belonging to the priory, is ftill ftanding.

It is fo far from being an unfit place for devotion, that few can exceed it for prefenting the mind with a variety of folemn objects, capable of raifing it to an adoration and awful reverence of the Deity. The very precipice it ftands on, lofty and almoft perpendicular, whofe femicircular bafe withftands the fury of

(s) Tanner's Notitia Monaft. fol. p. 390.

(t) Domina regina Elizabetha fuit feifita de et in caftro et manerio de Tynemouth nuper monafter. Sheles, Eaft Chirton, Prefton, Monk-feton, Whitley, Murton, Erefdon, Backworth, Wolfington, South Diffington, Elfwick, Benwell, Denton, Wylam, Hertford, Cowpon, Hauxley, Ambell, Eglingham, Bewick, Lilburn, Flatworth, Middle Chirton, Weft Chirton, Billimill, Whittingham, et Framlington.

Efcaet. de anno 10 Eliz. 
the waves, muft haveinfpired the religious with a firm reliance on him who is the Rock of ages. The calms, the ftorms, the fhips, muft all by turns have furnifhed them with occafions to praife him, whofe wonders are feen in the great deep.

On its being converted to a fortrefs, it was called Tynemoutbcaftle. It was befieged and taken by the Scots, $20 \mathrm{~K}$. Charles I, I644. Thirty-eight pieces of ordnance, and ftore of arms, ammunition, and provifions, fell into their liands, The garrifon were allowed to march out with their baggage, and obliged to fubmit to all the injunctions of the parliament. Six prifoners made their efcape by letting themfelves down through a privyhoufe with ropes and feveral theets tied together, under the favour of a violent ftorm of wind. The fum of 5000 \% was ordered by the parliament to repair it, and the works at Nerucafte, the town-walls, bridge, and garrifon. Colonel Henry Liburn was made governor of it, who being weary of their fervice, declared, with the lieutenant-colonel, and moft of the garrifon, for the king; on the news of which at Newcafte, Sir Artbur Hezelrigge immediately marched againf them from that town, of which he was governor, with a body of forces. For want of competent ladders, they entered the port-holes of the caftle in the face of the cannon playing upon them, and after a fmart encounter retook it. Colonel Lilburn, and many others, were flain. The reft received quarter.

On the north-eaft fide of the ruins of the priory-churcli, is a large houfe, built by Colonel Henry Villiers, governour of Tynemouth, by leave from the crown; who alfo had power.to erect a light houfe, and to receive i s. for every Englifh, and $6 d$. for every foreign thip, anchoring in the harbour of Shields, which 


\section{ANTIQUITIES OF NORTHUMBERIAND, 265}

brought him in an income of àbout $80 l$. per anmum. His funeralmonument is in the priory-church-yard, with the following infcription.

Hic fitæ funt mortales Reliquiæ

Henrici Villiers, Armigeri,

Stirpe antiqua prognati.

Unici

Honoratiffimi Comitis de Ferfey

Fratris.

Nec non hujus prefidii

Circiter viginti Annos,

Fidelis et perquam dilectus

Præfectus.

Vixit Annos 49. obiit I 8 Aug.

Anno Dom. MDCCVII.

Maicolm, King of Scots, and his fon, Prince Edward, flain on St. Brice's day, 7 K. William II, 1094, at Alnwick-caftle, were buricd at this church (u).

After the victory obtained over the Scots by K. Edward I, I298, his majefty vifited the thrine of St Mary and St. Oferin, at Tynemouth, and ftaid fome time; as did his queen whilft he was in Scotland, I $303(v)$.

Fobn Wetbamfede, abbot of St. Albans, a learned hiftorian, was a canon of this priory, and after his high promotion prefented it with a gold chalice of great weight $(w)$.

(u) Hol. Chron. vol. ii. p. 20, $2 \mathrm{I}$.

(v) - 308 ; and p. 3 r2.

(w) Foan Wethamfede de Rebus Anglicis, edit. per Tho. Hcarne. Stev. Monaft. Vor. II. $\mathrm{M} \mathrm{m}$ 
266 ANTIQUITIES OF NORTHUMBERLAND.

Fobn de Tynemouth, an eminent facred biographer, was born at Tynemouth, and is faid to have been vicar of this church $(x)$.

The prefent church of Tynemouth ftands a mile weft from it, near the flexure of the great road to Sbields. It was confecrated, ? 0 K. Charles II, I668, by Bifhop Cofins.

(x) Cat. Libr. MS, in Bibl. Cotton, per The. Smith. 


\section{TH E}

\section{$\begin{array}{llllllllllllllll}A & N & T & I & Q & U & I & T & I & E & S\end{array}$}

O F

\section{NORTH U M B ERLA N D, \&c.}

$$
\text { NOO U R N E Y II. }
$$

From Newcaftle upon Tyne, through Morpeth, Almwick, Belford, to Berwick upon Trweed, on the great Port-Road.

A MIL E from Newcafte, a road branches off, on the right A hand, to

Fes'-mont, i. c. the Mount of Fefus, famous for its chapel and hofpital, dedicated to the Bleffed Virgin, which were granted, $3 \mathrm{~K}$. Edward VI, to the corporation of Newcafle, and by the corporation the year following to Sir Robert Brandling, knight-banneret, and his heirs; the former now a ftable, and the latter a dwelling-houfe.

The manour of Fes'-mont belonged to the barony of Guagy, of which it was held, I K. Edward I, by Adam de Fes"-mont (a), who,

(a) Adam de Fefmont tenet $\mathcal{F}_{e}$ fmont et Hartlawe per unum feod, milit. vet. fecffam. Baron. de Guagy.

Efcaet. de anno r Ed. I.

$$
\mathrm{M} \mathrm{m} 2
$$


after the death of Adam de Guagy, 13 th of the fame reign, put in his claim for half of the barony of Guagy (b).

Near the $4^{\text {th }}$ mile-ftone, a road branches off, on the right hand, to the villa of

North Gosforth, which was lield of the crown by the antient family of the Surtees's, from the time of K. Henry I, down to the latter end of K. Henry VI; by Richard Surtees, in the reign of K. Henry III (c); by Ralph Surtees, I K. Edward I (d); by Thomas Surtees, high theriff of Nortbumberland, $47 \mathrm{~K}$. Edward III, and $2 \mathrm{~K}$. Richard II (c) ; alfo by Thomas Surtees, high theriff of Nortbumberland, 8, 9 K. Henry V $(f)$; their name local, from the river Tees, in the bifhoprick of Durbam, on whofe banks they were feated.

It came afterwards into the poffeflion of the knightly family of the Brandlings; of Sir Robert Brandling, created a knight-banneret, after the defeat of the Scots near Mulelburg, I K. EdwardVI,

(b) In rotulo decimo tertio regis Edvardi primi continetur quod Adam de Fefmont orat de medietate baroniæ quæ quondam fuit Adam de Guagy.

Rot. Turri Londin. Term. Finent, de anno 13 Ed. I.

(c) Richardus Surtes tenet in capite de dom. rege villam de North Gosforth per fervicium dimid. feod. milit. ct omnes anteceflores fui per eund. fervicium tenuerunt poft tempus regis Henrici primi qui eos feoffav. ac de eo tenem. nulla eft alienat. aut donat. unde dom. rex minus habeat de fervicio fuo.

Tefta de Nevill.

(d) Radulphus fuper Tayfe tenete in capiţe de dom, rege viliam de North Gesforth per dimid. feod.

Efcact. de zano I Ed. I.

(e) Efcaet. de ann. 47 Ed. III, et 2 Ris. II.

(f) $-8,9 \mathrm{Hen}, \mathrm{V}$. 
ANTIQUITIES OF NORTHUMBERLAND. $\quad 269$

I547 (g), a reprefentative in parliament for Newcafle upon Tyne in that year, alfo, 1, 2, 3 Q. Mary, and 5 Q. Elizabeth (b); of Sir Robert Brandling, Knt. high theriff of Nortbumberland, 15 K. Fames I, and a reprefentative in parliament for Morpeth, 18 th of the fame reign; of Sir Francis Brandling, Knt. a reprefentative in parliament for Nortbumberland, 2 I K. Fames I, I620, and I K. Charles I, r625, of which he was high theriff, 6th of the fame reign (i). It is now in the poffeffion of Charles Brandling, Efq; whofe feat is a mile north from it, on the fame fide of the road. It is a large, modern ftructure, of white frceftone, and hewn work, after a defign in Pain's architecture. It ftands on a rifing ground, from which the villa of Newbiggen, of Kenton, of Long Benton, and an opening between two diftant hills into the bifhoprick of Durban, are in view.

Three miles north-eaft from it is the villa of

Seghill (k), fuppofed by Canden and others to have been the Roman ftation Segedunum, fince fixed at Carr-vill. It was a feat and manour of a younger branch of the antient family of the Mitfords; of Fohn Mitford, $6 \mathrm{~K}$. Edward VI (l), and ro C. Eliza-

(g) Hol. Chron. vol, ii. p. $99 \mathrm{r}$.

(b) Robertus Brandling, miles, fuit feifitus de et in villa de North Gosforth, Fefmont, et in villa de Hadfon, Darres-Hall, et High Callerton._- Efcaet. de anno ro Eliz.

(i) Francifcus Brandling, miles, tenet in capite maneria de South Gosforth, et North Gosforth, et Hadfon, \&c.

Ex Lib. Feod. Petri Ofborne, Militis. Efcaet. de ann. 2I $\mathcal{F}_{a c}$. I. et, I, 6 Car. I.

(k) Seghill, Camd, Brit. p. 858.

Sighall. Autograph. perantiq.

(l) Bp. Nicholfon's Border-Laws, p. 332。 
beth (m); of Robert Mitford, his fon and hcir (n); of Robert Mitford, $25 \mathrm{~K}$ Charles II, I673, who in that year built the manfionhoufe on to the old tower; of Michael Mitford, in the reign of Q. Am, who marricd one of the daughters and coheirs of Sir Francis. 73lake of Ford-Cafle, Knt. It is now in the poffefition of Sir Lancelot Aligood, of Nunwick, Knt.

\section{About a milc from it is}

Cramlington, a plcafant villa on a rifing ground, a mediety of which was held of the barony of Guggy by the antient family of the cramlingtons; by Fobn de Cramlington in the reign of K. Edward II ; by Richard de Cramlington, $33 \mathrm{~K}$. Edruard IVI (0); by Wilham de Cramlington, I $6 \mathrm{~K}$. Richard II (p), who dying without iffue-

(m) Fohannes Mitford fuit reiftus de et in Seghill ct Brontsn, cum niedietate de Heton, et Ribill, et Keifey, cum terris in Ingliow, et villa de Brandon. Efcaet. de anno ro Eliz.

(in) Robertus Mitford, filius Fabnnis, arm. tenet de Rege, ut de baronia de Gaugy, unum capitale meffuag. et terras in Heton juxta villan Novi Cafri, ac terras in Rylill, de rege in capite, per fervic. milit.

Efcact. de ann. Fac. I. et if Car. I.

(0) Richarchus de Cranlington, frater et hares Fohannis de Cranlington, dat. dom. regi

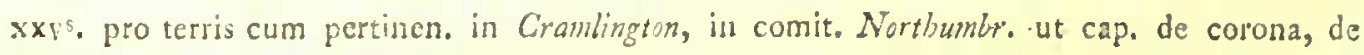
Guagy, in manu regis exift. per fervic. quart. partis unius feod. milit. et per fervic. reddendi regi per annum, per manum vice-comitis Northumbr. qui pro tempore fuerit, iiis. ivd. ad wardan caftri Novi Cafri fuper Tinan.

Rot. Mich. Fin, de anno 33 Ed. III.

(p) Willialmus de Cramlington tesiet unum mefluag. cent. acr. terræ, xxvii acr. prati et dimid. cum pertinen. in Cramlington in comit. Nortbumbr. de rege in capite, ut de baronia de Guagy, per fervic. quart. partis unius feod. milit. ct per fervic. reddendi regi per ann. per manum vicecomitis Northumbr. qui pro tempore fuerit iii s, iv $d$, ad wardam caftri Novi Caftri fuper Tinam.

Rot. Trin, Fin, de anno 16 Ric.II. 


\section{ANTIQUITIES OF NORTHUMBERLAND. $27 \mathrm{I}$}

male in the latter end of the reign of $\mathrm{K}$. Henry $\mathrm{V}(q)$, he was fucceeded in his cftate by his two daughters and cohcirs, Agnes and Alice, who were found by an inquifition to be in poficflion of it, $3 \mathrm{~K}$. Henry VI; the former firft married to Fobn Hejelrigge, and afterwards to William Lawen; the latter to Nicholas Gobeford( $r$ ); the Lawfons afterwards having the whole mediety; William Lawfon being poffefed of it, ro Q. Elizabetb (s); and Robert Larufon, Efd; 7 Q. Ann, 1708, then high theriff of Nortbumberland.

About three miles from Cramlington, and a mile from the fea, is

Delaval-Cafte (t) or Seaton Delaval, a principal manour of the barony of Delaval, in which Guy Delaval was infeoffed by K. Henry I. He married Dionifu, the fecond daughter of Robert Earl of Moreton, brother by the mother's fide to K. William I(u). From this royal ftem was defcended

Gilbert

(q) Efcaet. de anno 8 Hen. V.

(r) Gulielmus Lawfon, et Agnes, uxor ejus, nuper uxor Fobannis Hefelrigge, et Alicia, uxor ejus, foror predict. Agn. filiæ et hæredes Willielmi Cramlington, tenent duas partes manerii de Cramlington, cum hamlet. fuo de Whitlawe, in comit. Northumbr. de rege in capite per fervic. quart. partis unius feodi militis.

Rot. Mich. Fin. de anno 3 Hen. VI.

(s) Willielmus Lawfon fuit feifit. de et in medietate villa de Cramlington, cum terris in Hariley.Efcact. de anno io Eliz.

(t) Delavale Caftle, 4 miles from Tyne-mouthe, and within a mile of the fhore.

Lel. Itin. vol. vii. p. 59.

(u) Roberlus comes de Moreton, vel de Mortaing, frater uterinus Willielmi Conqueforis, habuit unicum filium Willielmum, qui ei fucceffit, capt. apud Tenericbley anuo 6to Hen. I. Idem Robértus habuit tres filias; una (Agnes) duxit Andr. de Vitre; fecunda, (Dionifia) Guido. de Delavale; tertia, (Emma) comitem Tholofenum, expeditione Hierofolomitona occifium, et 
Gilbert Delaval (c), one of the 25 barons who was fworn, augufto concilio, to fee the grand charters of Britifls liberty confirmed by the Roman pontiff, called L'Efatute de Magna Chartin, and Charta de Forefta, granted by K. Fobn at Ruming-Mede, between Windfor and Stains. His fucceffor

Hugh Delaval married Maud the youngeft daughter and coheir of the great baron Hugh de Bolbeck, in the reign of K. Henry III; her mother Theophania then living at Angerton (d). He gave to the priory of Hexbam a manfion-houfe and three acres of land in Benwell; to which Hubert de Delaval, and his mother, gave alfo half the manour of Echroick (e).

Hugh died without iffue. His heir was

Euface Delaval, as was found by an inquifition, I King $E d-$ ward I. (f)

ex ea habuit filiam nuptam Williclmo comiti Pidavienfí et Aquitania duci, e:: qua Willielmus filius qui fuccefit; pater fuit Elianore reginæ Anglize.

Ex vet. MS. remanente inter archiva Turri Londinitis.

(c) Gilbertus Delavale tenet in cápite de domino rege baroniam fuam de Calverton per fervicium duorum feodorum milit. è omnes fui anteceflores per eund. Servicium tenuerunt pof: conqueftum Anglia. Et de illo ténemento nulla eft alienatio, \&c. unde dominus rex, \&c.

Hol. Chron. vol. ii. p. 186.

Tefta de Nevill.

(d) Efcaet. 46 R. Hen. III. n. 25. Vid. Bolbcck.

(c) Monaft. Angl. vol, ii. p. 97 .

(f) Eufrachius De la vale tenet in capite de dom. rege Black Callerton, cum Seaton membro fuo, Newfham, et North Difington, per duo feoda de vet, feoffaménto.

Efeaet, de anno $x E d$. I. 
Robert Delaval married Margaret the only daughter of Williant Lord Greyftock, fon-in-law to Roger de Merlay, baron of Morpeth, in the reign of K. Edward I (g). He was coufin and heir to Margeret the wife of Andrew de Smethton. He paid rol. 7 K. EdwardII, to be relieved of the two knight's fees due to the crown for his barony (b).

William Delaval was high fheriff of Nortbumberland, $48 \mathrm{~K}$. Edwasd III (i). He married Chriftion, the daughter and coheir of Robert de Eflington ( $k$ ). He was fucceeded by

Sir Robert Delaval, Knt. who was upon an inqueft at Nerecajle upon Tyne, 2 K. Richard II (l). His fucceflor was

Sir Henry Delaval, Knt, who dying without iffue, his barony defcended to his fifter,

Alice, the wife of Fobn de Whitchefer, i $8 \mathrm{~K}$. Richard II (m), by whom the had

William de Whitchefter, who dying without iffue, a third part of the barony defcended to his fifter,

(g) Efc. 13 R. Ed. I. n. 10.

(b) Robertus Delavale, confanguineus et hreres Margarita, quxe fuit uxor Antree 6 S SmathInn, dat regi $\mathrm{x}^{\text {li }}$. pro relievio fus de duobus fectis milit, in Cialverton, cum membris in comit. Northumbr.

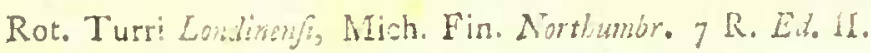

(i) Efc. Turri Londinenfis, 48 R. Ed. III. n. 23.

(b) Rot. Turri Londinenfe, 'Trin. Fin. Nortisunby', 3\$R. Ed, III.

(l) Efc. Turri Londinenfs, 2 R. Ric. II. n. 49.

(m) Alicia quxe fuit uxor Fobannis Iibitchefer, foor Henrici Delaval, chr. tenet villam de Calverdon, cum membris, in comit. Northunbo de rege in capite, per fervicium duorum foodorum milit. Rot. Turr Londinen, Mich. Fin, 18 R. Ric. II.

TOL. II. $\mathrm{N} n$ Elizabeth, 
Elizabeth, the wife of Fobn de Rouchefter, II K. Henry VI (az), on whofe death it came to

William Delaval, who had the remainder (o). He was upon an inqueft at Newcafle upon Tyne, ${ }_{4} \mathrm{~K}$. Henry VI (p).

Sir Fobn Delaval, Knt. was high theriff of Northumberland, $34 \mathrm{~K}$. Henry VIII ;-1 K. Edward VI;-1 Pbilip and Mary;-1, I3 Q. Elizabetb (q).

Sir Ralph Delaval, Knt. was alfo high theriff of Nortbumberland, I 7, 25,34 Q. Elizabeth,--2, 19 K. Fames I.

Sir Ralph Delaval, Knt. fon of Sir Robert, married the daughter of Major General Lefley in the reign of K. Charles I. He was reprefentative in parliament for Nortbumberland, $2 \mathrm{~K}$. Charles II, and

(n) Jobannes Rouchefer, et Eliz. uxor cjus, foror et hæres Willielmi Whitchefer, filii Alicia, nuper uxoris fobannis Whitchefter, fororis Henrici Delaval, cert. confanguin. et haredis ejufdem Henrici, tenent de domino rege in capite tertiam partem manerii de Seton Delavale, et North Difington, ct Callorton, una cum tertia parte unius meffuag. et xii. acr. terræ, cum pertinentibus, in Halywell, et tertia parte exitus, per fervicium fidelitat. fectæ curix et mokendin. de Seton; nec non tertiam partem cujufdem anni redditus xxvis. viiid. viz, viijs. $\mathbf{x}^{d} \cdot \frac{2}{3}$ recipiend. annuatim de omnibus terris et tenementis quondam Stephani le Scrope, chr. et Willielmi de Vefcy, Willielmi de Halywell, parcell. dicti manerii de Seton, ac etiam partem medictatis de Hertlawe, cum pertinentibus, per fervicium fextæ partis unius feodi militis.

Rot. Turri Londinenfi, I 1, 12, I3 R. Hen. VI.

(o) Efcaet. I4 R. Hen. VI. n. 34-

(p) Ib. Vid. Benwell.

(9) Fohannes Delaval fuit feifitus de et in manerio et villa de Seton Delaval, et de et in manerio de Black Callerton, et in villa de North Difington, ac Brandon, et in medietate villæ de Bydlifden, et villa de Hartelny, cum certis terris in Weft Hedwyne, Dinnington, et S. Myddilton. Efcaet. 10 R. Eliz. 
in the $12 \mathrm{th}$ of that reign was created a baronet, $29 \mathrm{June}, \mathrm{I} 660(\mathrm{r})$. He was fucceeded in honour and eftate by his fon, Sir Gobn Delaval Bart. who leaving only one daughter, married to Fobn Rogers, Efq; the title became extinct ( $s$ ) ; and his eftate and feat of SeatonDelaval came into the porfeffion of

George Delaval, Efq; an admiral in the Britifs navy (t), a younger brother of Edward Delaval, of North Difington, Efq; on whofe death it devolved to his nephew, Francis Blike Delaval, Eiq; grantfon to Sir Francis Blake, of Ford-Caffle, Knt. (u). He was a verec-

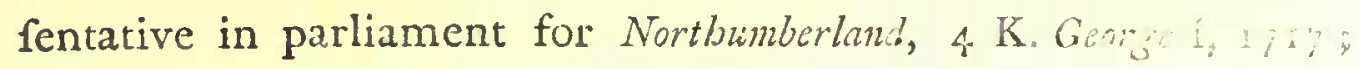
and was father of

Sir Francis Blake Delaval, knight of the bath, the prefe:t por:f-

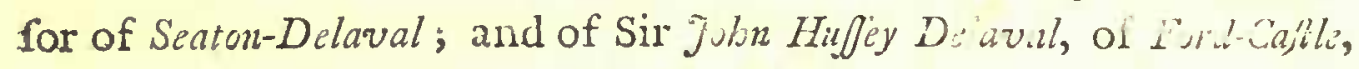

(r) Radulphus Delavale, con'inguineus et hæres Radulpbi Delaval, militis, tenct in capite per fervicium militare manerium de Seton Delavale, ac manerium ac villam de Black Callerton; ac reverfiones manerii de North Difington. Ex Rot. Turri Londinenfi, 14 R. Caroli I.

Radulphus Delavale; miles, filius Roberti, militis, tenet in capite per fervicium militare manerium de Seton Delavale, capitale mefluag. vocat. Whitrigg, diverfa mefluag. ac tenementa vocat. Le Sautb-more, et Weft-more, ac terras in Broom-bill, Earnflow, Blacklone, Segkill-Border, Erfden-Burn, Horton-more, et warrenam Cumckley in le Linke, cum pertinentibus, in Seton Delavale, ac Whitrigg, ac manerium de Black Callerton, ac manerium de Difjington.

Ib.

Radulphus Delavale, miles, et Robcrtus, arm. filius ejus, tenent in capite manerium de seton Delavak, Hartley, Black Callerton, ac North Diffington, ac medietatem rectorix de Tinmouth.

Ib.

Vid. Mag. Britan. Northumbr.

(s) MS. Foh. Warburton, Arm.

(1) Vid. vol. i. ch. xii. Of eminent Men.

(u) Vid. Ford-Caglte. 
96 ANTIQUITIES OF NORTHUMBERLAND.

Bart; of the Lady of Sir William Stanhope, knight of the bath, and of two other fons, gemelli et pares, like the Daucian Twins defcribed by the incomparable Mantuan, Thymber and Lcris.

- Simillima proles,

Indifcreta fuis, gratufqùe parentibus crror.

Iin. L. 10.

So like their features, that their parents look

On cither face, but cach for each miftook.

Puzzled, yet pleas'd, they gaz'd on either child,

And fondly on the dear delufion fmil'd.

Pitt.

Sir Francis was created knight of the bath, or of the Holy Trinity, as it was antiently called, at the coronation of his prefent Majefty, K. George III; being firft made a knight batchelor, then knighted by the King with the fword of ftate, and prefented with the red ribbon, and medal of three crowns, with the infcription on the exergue, Tria juncta in uno, in allufion to the union of the three kingdoms, England, Scotland, and Ireland; the old infcription, till the coronation of K. Fames I, being Tria mumina juncta in uno, in allufion to the Holy Trinity. He is a reprefentative in parliament for the borough of Andover. His feat of

Seaton Delaval is modern, after a defign of Sir Fobn Vanbrough's, the celebrated architect of Blenbeim, in Oxfordfsire; no remains of the old baronial caftle now vifible. When finifhed, it will be a perfect quadrangle, cach fide 220 feet. The main entrance is to the north, into a lofty and ftately hall, above which is a gallery. 
lery. In the niches of the wall are fix handfome forlptuind femalle figures, reprefenting the fciences, with their fymbols, viz. aftronomy, architecture, and fculpture, on one fite; and on the other, geography, painting, and mufic; the floor of the hall of black and white marble. Before the fouth front, is a grafs-lawn, clged with plantations; and beyond it, a fpacious avenuc, with fhady walks on each fide; a fwimming-bath about mid-way; terminated by an obelifk; the antient ruin of Tyncmoutb-priory, and the ocean being in fight. To the north, it has a profpect of about fixty miles, the mountain of Cherviot being vifile on a clear day. To the eaft, through feveral openings in litsle groves, are feen pieces of ftatuary; alfo a riding-houfe, large and fpacious; and a garden, very handfome, with a confervatry or green-houfe; and that magnificent object the fea, crery breaking wave of which is, if I may fo fpeak, a cafcarle, nttering with its folemn voice the tremendus majelty, wiflom and puver, of the great Fehovah. This gives Seaton-Delaval an air of dignity and grandeur, which Blenheim muft cver defpair of having for want of it. To the weft, is an avenue, a mile and a quarter in length, and an obclifk about half-way. Harl by, is the family-chapel in a grove. By the entrance, on the right hand, is an effigies in ftone of one of the family who made the crufade, recumbent, and in armour, his legs a-crofs, his feet refting on a lyon, his hands elevated. Oppofite to him, on the left hand, is another of a lady, recumbent alfo, and her hands elevated.

A mile from Seaton-Delaval is the fea-port and fifhing-town of

Hartley, which in the reign of King Fobn was held of the Barony of Gaugy by Adam de Fefmont $(x)$; and a mediety of it by Sir

(x) Vide fefmont. 
Henry Delaval, Knt. I 2 K. Richard II, his family afterwards poffeffing the whole $(y)$; now belonging to Sir Francis. It is a wellbuilt and improving marine villa, populous and induftrious, on a bold and rocky thore; the harbour to the north of it, by a fpacious fandy bay. Four great works are carrying on at it; a coalwork, a falt-work, a copperas-work, and a glafs-work; the latter a handfome building, 220 feet in front, the fide-walls to the roof $3^{6}$ feet, the property of Thomas Delaval, Efq; fourth brother to Sir Francis and Sir Fobn.

Near the 6th mile-ftone, a road branches off, on the right hand to

Bedlington, a large, well-built, and pleafant villa on an eminence, the manour of which belongs to the See of Durbam, as part of the patrimony of St. Cuthbert, including all that fpace on the fea-coaft between the rivers Blyth and Wanfbeck, known by the name of Bedlingtonfire (a). Out of cvery plow-land in this manour, the hofpital of St. Giles, near Durham, received a thrave of corn, for the relief of poor ftrangers and travellers, till it was agreed to pay nine hillings in licu of it at a ccrtain time, within fifteen days after the fealt of St. Nichael, and in cafe of failure to pay ten thillings ( $b$ ).

When

(y) Ef. 12 R. Ric. II.

Elc. 10 R. Eliz.

(a) Spearman's enquiry into the antient and prefent ftate of the county Palatine of Darbam, 4to. 1729. P. 2, 3.

(b) De novum folidis pro traviss carucarum de Bedelynflonfire hofpitali S. Egidii dattis. per irihabitantes ejufdem.

Omribus, \&re. Willielmus Halcor, Robertus Cnowald, Willielmus Birilot, Thonas filius Royerride Beddynson, Walterus et Robertus flilii Roberti de Nedderton, Adam et Elyas frater ejus de 
When the lands belonging to the See of Durbam were put up to fale by the parliament, this manour, and Choppington farm, were purchafed, 2 I January, 1649 , for 1296 l. Os. 5 d. $\frac{1}{2}$, by Robert Ferwick, Eff; a reprefentative in parliament for Northumberland, $1654,1656(c)$.

It was affirmed in a fmall tract, publifhed $1660(\mathrm{~d})$, that at the reftoration the purchafers of church-lands offered the king the round fum of five hundred thoufand pounds to confirm their right for ninety-nine years, on the payment of the old rents to the bifhops and clergy, which offer his majefty was fo far from

Chavynton, Thomas et Fobannes de Slykburne, Alanus, Adam et Walterus Caritas de Cambhufe, Edmundus filius Rogeri, et Laurentius filius Odardi, et Alam Servicns, et Ranulphus filius Petri, Robertus filius Henrici, et Robertus Palmere de parva Slykburne, falutem in domino. Cum antiqua conftitutione venerabilium patrum, et dominorum noftrorum Dunelm. Epifcoporum confitucretur, ut de fingulis carucis onnium dominiorum eorum daretur una trava bladi hofpitali S. Egidii extra Dunelm. caritatis intuitû ad fuftentationem pauperum et perigrinorun ibidem undecunque confluentium: Nos coruin conftitutionem approbantes et devote acceptantes, dedimus et conceffimus, \&c. pro falute animarum noftrarum patruin et matrum et omnium parentum noftrorum, deo et dicto hópitali St. Egidii extra Dunelm. fpontaneâ voluntate noftâ in puram et perpetuam elemofinam novem folidos pro travis carucarum noftrarum de Bedelynton-Bire; ita quod tam nos quam hæredes noftri ad hanc elemofinam præftandam in perpetuum tencamur ad feftum S. Michaelis folvendam; ita quod nifi infra xv dies proxime poft feftum S. Michaelis folventur, nos et hæredes noftri elapfis illis xv diebus pro novem folidis nomine penæ folvemus decem folidos. Et ut hæc noftra donatio rata \& incuffa futuris temporibus permaneat, præfens fcriptum Sigillorum noftrorum appofitione roboravimus, \&ic.

Pat. 4 Ric. II. p. 3. m. 20. per infpex.

Mon. Angl. Vol, iii. p. 94.

(c) See Whitlocke's Memorials, p. 29 r.

Sce Brinkburn-Priory.

(d) Printed at Lond, in three Cheets, by the Author of a Book, intitled, The Pillar of Gratitude. 
complying with, that lie granted a commiftion for enquiry after all fucl purchafes $(e)$.

The village confifts of one long and wide fleet, and forms a kind of floping avenue to the river Blyth, which is the fouthern boundary of the thire, and glides patt it between two fteep banks, in broken murmurs, and fupplies a large iron-work with water. The church is a finall ftructure, covered with lead, with an old tower. The Rev. Mr. Francis Woadmas, fellow of St. Fobn's College, in Cambridge, and author of learned notes on St. Chryfoftom, was vicar of it.

On the fouth fide of the river Blyth, and in fight, is

Bebfute $(f)$, the manour of which bellonged to the priory of Tynemouth; which, with their manour of Coupon, on the banks of the fame river, were affigned as fecurities to Ralph Lord Greyftock for the performance of certain conditions on their part, on his lordhip's founding a chantery in their church of Tynemouth, 8 K. Edward II, I3I5 (s). It belonged to Folm Ogle, Efq; ro Q.

(e) Printed at Lond. and intilied, His Majefty's Gracious Commifion to divers of his loving fubjects to fearch into and examine the pretended fales and purchafers of the honours manours, lands and hereditaments, of and belonging to his Majefty, his royal mother, the Archbihops, Bihops, Deans, and Chapters, Prebendaries, and other ecciefiaftical perfons; granting to the faid commiffoners fuch powers and authorities as are neceffary for the ends, intents, and purpofes, in and by the faid commifion fpecified and exprefled. Witnefs ourrelves at $\mathrm{He}_{\mathrm{e}} \mathrm{fminfler}$, the feventh day of Oetober, 1650 , in the twelfth year of our reign.

(f) Beblet. Aut grapho perantiquo.

Bebbeflet. Carta Fundat. Cant. de Tynzmatho

Bebficle.

(g) Vid. Tynemouth-priury. 
Elizabeth (b); and to Fobn Fobnfon, Efq; 2 K. George I, 17r5, then high Theriff of Northumberland. It is now the feat of his daughter, Mrs. Mary Fielding, relict of the late Captain Fielding, and aunt to the late Sir Matthere White, of Blaigdon, Bart.

\section{Near it is}

Newfam, which was the manour and feat of a younger branch of the Cramlingtons, of Cramlington; of Thomas Cramlington, Io Q. Elizabeth (i); and of Robert Cramlington, in the reign of K. Cbarles I, whofe eftate was fequeftred by the parliament, 18th November, 1652. It was afterwards purchafed by the city of London, and fold to Colonel Thomas Ratclif( $(k)$.

Two miles from it, is

South Blyth, a well built village and fea-port on the fouth fide of the river Blyth, from which it has its name; the Cramlingtons of Newform its antient owners; purchafed by a wealthy Londonmerchant, in expectation of great advantage; fold by him to Colonel Thomas Ratcliff, to whom alfo belonged the village of Pleffrs, Shotton, Nafferton-Hall, Whittle, \&c. (1). S. Blyth is now in the poffeffion of Matthew Rivicy, of Heaton, near Nerecafle, Efq.

A little beyond the 8th mile-ftone, on the left hand, and in fight, is

(b) Fobannes Ogle fuit feifitus de et in una villa vocat. Bebfyde.

Efcaet. de anno ro Eliz.

(i) Thomas Cramlington fuit feifitus de et in villa de Newham.

Efcaet, de anno ro Eliz.

(k) MS. inter Collectan. Warburto\%

(l) Ibid. 
Blaigdoin ( $\mathrm{m}$ ), one of the manours of the barony of Morpeth, of which it was held by Fohn de Plefis, I K. Edward I ( 1 ), a benefactor to the priory of Neze-minfer $(0)$. It paid annually for cornage, on the feaft of St. Cutbbert, in September, I $s$. I $d \cdot \frac{x}{2}$. It was the feat and manour of Mattbere Wlotite, Efq; high theriff of Nortlonmberland, 1720, who built a handfome houfe, to which his fon, the late Sir Matthew Wlote, made fome additions and ornaments. He was high theriff of Northumberland, $175^{6}$, and in that year received the honour of knighthood, and was created a Baronet. It is now in the poffeffion of his nephew, Sir Matthere White Ridle', Bart.

The poft-road croffes the river Blyth, by a ftone-bridge of one arch, and brings us to

Stannington, an antient villa, another of the manours of the Barony of Morpeth. In the old rolls of the Barony, it ftands diftinguifhed under the name of Cook's-land. It paid annually for cornage is. I $d .:$, on St. Cutbbert's day, in September. The church ftands on the north fide of the village. The third Roger de Merlay, Baron of Morpeth, founded a chantery in it, in honour of the Bleffed Virgin, for one chaplain, to be chofen by the Archdeacon of Nortbumberland, for the time being. He gave to it one

(ni) Blakeden. Rot. Cur. Baron de Morpeth.

Blaigdon. Efcaet. de anno I Ed. I.

Bilagdon. Carta recentiori.

(n) Pleffys.

Pleffes.

Pleffet.

Fohannes Plefes tenet Shotton, Blaigdon, et North.WVitfet, per quart, partem unius Feod. veto Feoffamenti. Efcaet, de anno I $E d$. I.

(0) See New-Minfer-Priory. 


\section{ANTIQUITIES OI: NORTIUMBRRLAND. $\quad 28 ;$}

toft and croft on the fouth fide of the church, with common of pafture for four cows, and thirty ews with their followers of one year old. He alfo gave to it ten acres of land, and half of a plough-land, in Clifton, and twenty acres of land in Coldwell, to hold of the priory of Hexham, by the annual rent of Is. $6 \mathrm{~d}$. to be paid on the feaft of St. Peter de Vincula, and anfwering to the prior's court. He gave to it three oxgangs of land in Colkuell, with common of patture in Clifton and Coldrell, to hold of Gillert de Coniers and his heirs by the annual rent of $\mathrm{s} s$. He gave to it a filver chalice, gilt within, of the value of 23 s. alfo velnents for the ure of the chaplain (q).

Roger

(q) Omnibus fanctx matris ecclefia filiis ad quos prefentes litteræ pervenerint, Rogerns de Merlay tertius falutem in vero falutari. Noveritis univerfitas veftra me divine pietatis intuitu, et pro falute anime mex, antecefforum et fuccefiorum meorum omnium fidelium defunctorum, dedifie, conceffife, et hac præfenti carta mea confirmafle, in liberam, puram, et perpetuam elemofinam, ađ fuftentationem unius fimpiicis capellani qui divina celebrabit pro animabus onnium fidelium defunctorum in perpetuum ad altare Beata Marie in ecclsfia de Stannygton, unum toftum et croftum ex parte auftrali ecclefia de Siannngton cum communa pafturx et omnibus aifiamentis ad dittam villam de Stannygton pertinentibus at quatuor vaccas et triginta oves matrices cum fequela unius anni: et decem acras terra cum pertincntibus in villa de Clifton, quas habui ex dono prioris et conventus Haguflbaldenfis; et viginti acras terræ cum pertinentibus in Couldwell, yuas habui ex dono didi prioris et conventus: et præterea in liberam et perpetuam elemofunam dinidium caracuta terræ cum pertinentibus in dißta villa de Clifton, quam habui ex dono fuperdicti prioris et conventus : et dimidium carucutz terra cum pertinentibus in eadem villa, quas habui ex dono Roleria de Cambou: Et tres bovatas terra cum pertinentibus in villa de Cauldwell, quas habui ex doro Gilberti de Conyers, cum communa pafturze, et omnibus libertatibus et aifiamentis ad terras in villis de Clifton et Cauldwell pertinentibus, ficut in cartis donatorum plenius continetur. Et ego Rogerus de Merlay et haredes mei idoneum capellanum ad celebranda divina in dicta ecclefia, ut fuperdictume:, Archidiacono Northumbrice, feu vices ejus gerenti, qui pro tempore fuerix, in perpetuum fucceffive prefentabimus. Et volo quod fi ego vel haredes inei infra tempus jure Atatutum poft ceffionem vel deceflum capellani qui pro tempore fuerit alium eidem fuccefurum prefentare negleximus, liceat dicto Archidiacono Northumbric qui pro tempore fuerit ad dictun officum explend. idoneum capelianum infituere, qui dictx clemofine pofit quidem honefte fe gercre. Et ego Rogerus, et haredes mei pradictas terras cum omnibus fuis perti- 


\section{ANTIQUITIES OF NORTHUMBERLAND. \\ Roger de Somervill gave the advow fon of the church to the priory of New-minfter $(r)$.}

\section{Near the igth mile-tone, we come to}

nentibus contra omnes homines et feninas warrantizahimus in perpetuum et déendemus capel'ano qui pro temporc fucrit, falva mihi et haredibus meis fecta molendini mei de dicta terra. Et ipfe capellanus facict fervic. contentum in cartis donatorum ordinatis, feilicet priori et conventui odtodecem denarios ad vincula besti Petri, et Willielmo de Conyers et harredibus fuis unum expernarum forum vel duodecem denarios ad cunden terminum et faciend. forinficum fervicium quantum pertinet ad unam carucutam terræ in villa de Clifion. Et volo quod capellarius qui ibidem divina celebrabit, omnibus horis canonicis interfit, nifi parte zgritudine vel alia honefta caufa fucrit impeditus. Et fi fortafis ob aliquam honeftam caufam de licentia mca abfuerit, vel ægritudine diuturna ita debilitatus quod cclebrare non poffit, alium capcllanum inveniat idoneum de licentia dicti Archidiaconi qui pro tempore fuerit, qui interim dictum expleat officium. Singulis autem dicbus dicat officium mortuorum, quod dicitur placeto dirige commendatio, ficut pro corpore prefenti. Præterea dedi et affignavi ad dictum fervicium fuftendandun unum caliccm argenteum, intrinfecus deauratum, de pretio xxiiis, et duo paria bonorum veftimentorum, et quinque taullia benedicta, et unum bonum miffale cum gradali ct unum porhois, ct duo troparia. Nec ifta ornamenta poterit capellanus gui pro tempore fuerit fibi appropriare, vel alio modo alienare, et fi vetuftate defidint, vel alio inodo pericrint, ex propriis bonis reftaurabit ; et capellanus vero quicunque illuc divina, ut predictum eft, celebraturus accefferit ctiam idoneam candelam unam oblat. domus fibi affignat. in bono ftatu fuftentabit. Et ad iftud opus officii faciend. in ecclefia tenetur capellanus qui pro tempore fuerit. Et idem capellanus dabit feipfum fidclitate rectori ecclefiæ de Stannyngton qui pro tempore fuerit, fcilicet de indemnitate ejufdem ecclefiæ confervanda. Et in hujus rei teftimonium huic cartæ chirograffatæ figillum meum appofui. His teftibus Hugone de Bolbeck, Euffachio De la Vale, Rogero Bertram de Bothall, Fohanne de Plefes, Adam Barret, Johanne filio Simonis, Thoma de Ogle, Willielmo de Horfey, Richardo de Saltwick, Willielmo filio Radulphi, Adam de Plefes, Nicbolao de Bekring, Walter de Witton, et aliis. Ifta carta eft chirograffata in quatuor partes. Unam partem habeo penes me et hæredes meos cum figillo archidiaconi Nortbumbric. Aliam partem habet capellanus penes fe figillo meo fignazum. Tertia pars apud Tynemouth, eft in cuftodia prioris et conventûs. Et quarta pars eft in cuftodia prioris et conventus Dunelmice ecclefix.

(r) See Newu-minfer Priory. 
Morpeth, a well-built borough-town upon the river Wanfbeck, a contrastion of Woden's-Beck, encompafted almoft with listle pleafant hills, on whole brows are plantations of fir, bcach, and elms. It is fuppofed to have its name from More-patb, on the road through the More or Moor. Under the Saxons and I Tanes it made no figure. Under the fint Nomans it rofe in dignity fuperior to a villa; being then erected into an honour, and filed the Barony of Morpeth, or the Barony of Merlay, from its polfeffors. To Ralph, fon of Roger, de Merlay, K. Hewy I. gave in marriagc Fulian the daughter of Cofputric, Earl of Dunbar, with the Lordfhips and villas of Witton, Horfley, Stomton, Ritton, Whingertes, and Liverchild (s); which were confirmed by her brother Edgar ( $t$ ).

(s) Honricus rex Angliae \& dux Normamia jufticiariis, vicecomitibus, miniftris, \& omnibus baronibus fuis, Francis et Anglis, falutem. Notum fit omnibus vobis me dediffe Ranulpho de Merlay fulianam, filiam comit's Cojpatricii, et per conventionem inter me et patrem fuum, dedimus in liberum mariale, fibi atque haredibus fuis, fcilicet Horfley, Stanton, Whittcn, Ritton, Wyndgates, et quandam villam ultra moras, tam libere quam aliquis poteft librrius inter maria terram alicui dare, tenendo in fuo dominico, $\mathrm{ct} c x$ hoc precipio meis juntciariis ut videant quod nihil ei defit, et fi aliquis ei contradicere voluerit, tune pracipio jufticiariis \& vicecomitibus meis, de comitatû Nortbumbrice, ut p'enum ręlum ci teneant. teltib. Patricio filio Fahanne Pevercll de Baelcamps, Williclmo de Aibunbuto, Hinrico filio fohannis, Willielmo del pant. Willielmo Maltravers, Willielmo Manduit, apud Wodjtok, \&ic.

(t) Edgarus, Cospatricii filius, omnibus amicis fuis Francis et Anglis, falutem. Sciatis nre dediffe, concefffe, Fuliance forori mex quam meus pater et fuus, fcilicet comes Cofpatricius ei dedit in franco maritagio, et conceffit, fcilicet Witton, Horfley, Stanton, Ritton, Wyndgates, et Leverchild, fibi et fuis hæredibus tenend. ex me et meis hæredibus, in tcrris, in aquis, in foreftis omnibus illis terris pertinentibus, et in filvis, in molendinis, in ftagnis, in pratis, in pafcuis, in viis, et extra vias, et rebus omnibus illis terris pertinentibus, exceptis pertinen. ferviciis, videlicet, communis exercitus in comit. in cornagio, et commune opere caftelli in comit. et volo ut tam libere et quiete teneat ut meus pater ei dedit has fuperdictas in franco maritagio. Va le te. Teftante Fohanne decano de Bewyk, Willielmo prebytcro de Stanton, Ofredo preßbytero de Hertburn, Alano clerico, Grimbauldo de Merlay, \&x. 
He founded the abbey of New-Minfer; on the north fide of the chapel of which he was interred, with his lady, and their fon ofert (u). William de Merlay was a bencfactor to an hofpital in Norpeth, of his anceftors foundation (v). The three laft Lords Merlay were all of the name of Roger; the firt of whom, by paying a fine of twenty marks and two good palfreys, I K. Fobn, I 199, acquired for his borough of Morpetb a weckly market on Wednefdays, and an annual fair $(w)$. He was interred at Neri$\operatorname{Minfler}(x)$. The fecond Roger Lord Merlay contributed much to

(u) Ramlphus de Merlay, una cum Fulinna uxor ejus, et Oferto filio ejus, fepulti funt in boreali parte domus capituli Novi Monafterii quod condidit.

Ex Aut grapbe perantiquo.

(v) Willielmus de Merlay omnibus fuis hominibus, \& amicis, et vicinis, clericis, et laicis, francigenis \& angligenis, nec non et omnibus dilectis filis fanct matris ecclefix, falutem. Notum fit vobis omnibus, tam præfentibus, quam futuris, ad quorum notitiam \& audicntiam litterx ifte pervenirint, me et meos homines dedife, \& concellfie, in perpetua elemofina, unam carucatam terre domui infirmorum de Morpatbe, \&c. Iftam donationem meam, \& meorum hominum fieri, \& teneri \& haberi, licut perennem elemofinam perennitur concedo, Sc cartula hujus infcriptione, \& figilli mei atteftatione confirmo. Teftibus iftis, Pctro de Morpathe, Helia facerdote, Gaufrito Parchier, Waltero de Rochefboro, Aldict de Windgate, Riginaldo filio . . Pciro Jânitore, \&ic._— Monalt. Angl. Vol. i. p. 80 .

(2v) Fobarnes dei gratiâ rex Anglic, \&ce. Sciatis nos conceffife, et prefenti carta confirmafie, Rogero de Morlay et hxredibus fuis quod habeant in perretuum fingulis annis unam Foriam apud Morpeth per unam diem duraturam, viz. in fefto Sancta Marice Magdalená, et fingulis Ebdomadis unum mercatum in die Mercurii. Quaı̀ volumus ct firmiter pracipimus, guod prædictus Rogrus et harecies fui poft ipfum prædictam feriam et prædiatum mercatun habcant bene et in pace ficut predictum eft in omnibus libertatibus et liberis confuetudinibus ad hujufmodi ferias et mercata pertinentibus. Ita tamen quod non fint ad nocumentum vicinarum feriarum, aut vicinorum mercatorum. His teftibus, Galfrido filio Petri com. de Ejiex, Willizimo Brewer, Hugone Bardon, Willielmo de Stwivill, Roberto de Ros, Exc.

Carta de anno I R. Fobannis.

(x) Cum Rogerus de Mcrlay primus hac et alia confilia complevifet, obdormivit in domino, et in domo capituli Novi Monafterii cum patre fuo fepultus cft. Et fucceffit ei Rogerus filius, q̨ui dicitur Rogerus de Merlay fecundus. -

Ex autographo perantiquo. 
the profperity of his borough of Morp.th. He confirmed all its privileges. Under his patronage and influence an hofpital was built at Catcburn. He was interred at the entrance of the priorychurch at Neru-Minfer $(y)$.

By the charter of the third Roger Iord Merlay, the burgefies of Morpeth, and their fucceflors, were freed from all taxes, fubsidies, or contributions, except on the hing's account, in military cxpeditions for the public defence, on the marriage of the lorel's eldeft fon or daughter, or for his own redemption ont of prifon. By the fame charter, the Prizes raifed by lis officers and fervants, or thofe of his fucceffors, on bread and beer, and other things, were affigned to the creditors within the borough, to be paid within forty days. Such of them as were not paid within that time, were enjoined to remain eafy till they could be paid. The lord was at liberty, in the mean time, to make other Prizes, at his pleafure. His Prize for beer in the whole year was three gallons, valued at one penny. Their accuftomed common-right, pafurage, and other conveniences, were confirmed to them and their fucceffors, and way-leave granted to and from the town, cornfields and meadows only excepted. He gave them liberty of pafture on his ftubbles of Wenberlaw, to the weft of the town, between New-Minfer priory and the fofs or ditch of the weft park; referving to himfelf and his heirs the eatage of them for 15 lays after the corn was carried off. They had fuel from his turbaries within the manour of Morpeth, at his pleafure, for a penny a load. For every horned beaft, and for every horfe, found feeding in his

(y) Rogerus de Merlay fecundus burgum de Morpalb decoravit, \& multa alia opera caritativa, et poft obitum fuum fepultus eft in clauftro ad introitum domûs capituli Novi Monaferii. Hofpitali de Catcbburn tunc per ipfum promoto; cui fucceffit Rogerus filius ejus.

Ex Autographo perantiquo. 
enclofed grounds, they paid a halfpenny, and the fame for five theep, as a compenfation, for three fereral trefpaffes, as well without as within the enclofures; and for the fourth trefpafs of every horned beaft in his enclofed rood or bofcage, they paid eight-pence, and four-pence for each taken without the enclofure, and afterwards taking only a halfpenny for a beaft trefpafling three times as at firt. If their cattle were taken among corn $\mathrm{cr}$ in the meadows, they made reparation according to the feafon of the year. He granted and confirmed to them and their fucceflors moft of the unoccupied ground, which was their antient market-place, with an injunction to build falls for the ufe of butchers and thofe that fold fithes; and a prohibition for any of their goods to be fold before the hour of nine o' clock, and in no other part of the town, except in grofs or by wholefale; his lordhip referving to himfelf and his fucceffors a power to build upon any of his lands wherein he had granted a right of common to the corporation. He confined them to grind their corn at his mill of Morpeth, according to former ufage ( $z$ ).

His

(z) Omnibus hanc cartan vifuris vel audituris Rogerus de Merloy tertius, falutem. Noveriis me audilie cartà Rogeri paris mei in hac verba. Onnibus hominibus has literas vifuris, sel audituris, Rogerus de Milky, falutem. Sciatis quod ego Ragerus de Mirlay dedi et conceff, et hac prefenti earta mea confirmavife, meis liberis burgenfibus de Morpeth, illis, et harcubu tuis, tenend. et habend. in perpetuum de me et hæredibus meis, omnes libertates, et omnes liberas confuetudines, honorabiliter, et libere, et integre, ficuti cartà domini regis purportat quam ego habco de dono fuo. His teltibus, IVillieimo de Merloy, Richardo de Pleffes, \&ce. Quàre volo, concedo, et confirmo, pro me, et haredibus meis, prædidtis burgenfibus, et hæredibus ruis, quod habeant omnes libertates prædictas ficut carta Rogeri de Merlay patris mei purportat et teftatur. Et praterea conceffi pro me et haredibus meis quod mafati burgenfes nec haredes eorum tallientur nifi quando dominus rex talliabit burgenfes fuos et ad promogenitum meum milit. faciend. et ad primogenitam filiam meam maritandam, et ad corpus meum de prifona redimendum. Item conceff eifdem quod fb ego vel haredes mei priazs ferimus per fervientes noftros de pane vel de cervifia, vel de ali- 


\section{His market of Morpeth proved fuch a detriment to the neigh- bouring market of Mitford, that Roger de Bertram, Baron of Mitford,

qua alia de re in dista villa de Morpalh, illa prize folvaniur creditori infra quadraginta dies; creditor autem cui non folutum fucrit infra quadraginta dies de prizis ab eis factis maneat quietus ab omni priza poft illas quadraginta dies quoufque ei folutum fuerit. Ita tamen quod bene licebit mihi et haredibus meis alias prizas facere infra terminum illarum quadraginta dierum. Et fciendum quod priza mea cervifixe erit in toto anno tres gallones pro uno denario. Conceff etiam eifdem burgenfibus et hæredibus fulitas communas pafturæ et aifiamenta confueta cum libero exitû et introitu ad eandem villam de Morpath pertin. cxceptis bladis et pratis. Conceff etiam fuperdictis burgenfibus ct hæredibus eorum communam in ftipuis mcis ejufdem manerii mei de Morpatb; fcilicet de Wenborlnwe verfus occidentem ufque ad divifas abbatis Novi Monafterii et uique ad folatum parci occidentalis. Ita tamen quod herbagium earundem ftipularum refervetur ad opus meum et heredum meorum per quindecem dies poftquam bladum meum fucrit cariatum. Et conceffi eifdem burgenfibus et heredibus eorum, quod quardo eis turbarias vendere voluero in turbariis meis de Morpath, ct quantum cis vendere voluero, fingulas cariatas turbarii profingulis denariis. Et fi contingat quod averia eorundem burgenfium capiantur in defenfis meic, pro quolitet averio dabunt unum obulum, et pro quolibet cquo unum obulum, et pro quinque ovibus unum obulum per tres vices tam extra quam infra, et ad quartam vicem pro fingulis corum averiorum captis infra bofcum dabunt octo denarios, et extra bofcum quatuor denarios, et poftea itcrum incipien.o profingulis averiorum obulum per tres vices, ut predictum eft. Et fi averia corum capiantur in bladis, vel in pratis, faciant emendas fecundum tempus anni. Concefli infuper, et confirmavi prefatis burgenfibus et eorum haredibus illam placeam quietam ubi forum eorum elle folebat (excepto tamen tofto Alicia Hudde, et piftrina cjufdem villa, et excepta quadam fabrica, quan Pbilifpus tenuit. In qua placea volo quod falla corum conftrunantur ubi carnes et pifces vendant ufqute in horam nonam. Et prohibco fuper plenam forisfacturam mei et haredum meorum ne quis prefumat vendere carnes nec pifes ante horam nonam, quoniam fervicii dict. ftall. nifi in grofio. Et fciendum quod bene licebit mihi et harcdibus meis facere adificia noftra ubicunque voluerimus in culturis noftris, in quibus eis conceffmus communia fine impedinento vel contradictione dictorum burgenfium, vel haredum eorum, in perpetuum. Ei fciendum quod disi burgeníes et haredes eorum fequentur molendina mea de Morpath ad tertium decinum vas multura, ficut prius fequi confuevcrunt. Et ego Rogerus de Merlay et heredes mei univerfa prænominata et concefla dictis burgenfibus et corum hæredibus contra ommes gentes in perpetuum warrantizabimus. Et in hujus rei teftimonium, unam partem hujus carta chi ographata: quam dicti burgenfes habent penes eos et haredes eorum figillo meo roberavi ; et aliam partem habeo penes me et haredes meos communi figillo dictorum burgenfium fignatum. His

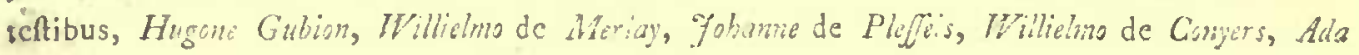
Vos. Il. 
$34 \mathrm{~K}$. Henry III, I 250 , commenced a fuit againft him in the countycourt of Nortbumberland, for damages, but was obliged to drop it by the interpofition of the crown. He founded a chantery in the church of Stannington, as before mentioned $(a)$. He died, $5^{\circ}$ K. Henry III, I 265 ; and was interred at New-Minfter, near his father (b). An inquifition was taken of his barony in the fame. reign (c); alfo, I K. Edward I (d); when it was found, that the burgefles paid annually for the fee-farm of the town to his lordfhip, ro 6 . that he received annually for felons goods, ftallage, and a falmon-fifhery in the river Wansbeck, $2 l .6 \mathrm{~s} .8 \mathrm{~d}$. that for the herbage in his wood, called Cotingwood, containing 284 acres, he had 3 l. 6 s. 8 d. per annum; and for his park, called Eaft Park, containing 418 acres, 6 l. I 3 s. 4 l. per anmum; and that he had

Barrt, Willielmo de Hurfey, WVillitmo filio Radulpbi, Riehardo de Saltwick, Richardo de Sancto Pitro, Willieimo Spurnelow, Ralulpho Grom, Thoraldo, Rogero Palmer, Waltero de Witton, clerico, et aliis.

Carta confirmationis et conceffionis Rogeri de Merlay tertii de quibufd. libertatibus facta jiberis burgenfibus fuis de Morpath.

(a) Vid. Stannington.

(b) Rogerus de Merlay tertius, qui contulit hominibus de Morpath plures libertates, in tempore fuo ordinavit quandam canteriam perpetuam in ecclefia de Stamyngton. Cum hæc autem et multa alia elemofinarum opera compleviffet, carente hærede mafculo, poft obitum fuum fepultus eft juxta Roger un Patrem fuum.

Ex Autogratho perantiquo.

(c) Rogerus de Mcrlay tenet in capite de dom. rege baroniam de Morpatb per fervicium quatuor feod. milit. et omnes anteceflores fui tenuerunt per eundem fervicium poft conqueftum Anglis; et de feodo illo nihil eft vendidum, alienatum, vel datum, undè rex minus habeat de fervicio fuo. Tefta de Nevill.

(d) Rogerus de Meriay tenet in capite de dom. rege Morpethe, cum Tranwell fuo membro Ulghan, Hepfoste, Sbilvington, Tuyfe, Saltivicke, Eaft Duddon, Wef Duldon, Clifton, Cauldwell, Stannington, Shotton, Blaigdon, Weth.t wrth, Witflet fouth, Killingrworth, Benton mag. c: Walter per quatuor feoda vet. feoffamenti.--

Efcaet. de anno I Ed.I. 
another park, called Wef Park, containing 149 acres, which he referved for his own convenience and pleafure (d). His barony came to his daughters and cohcirs, Mary, and fohann.

Mary married William Lord Greyfoch, by rolom he had two fons, and one daughter, viz. Folsn, William, and Margaret.

Jobanna married Robert de Somervill, by whom the had five fons, and one daughter, viz. Robert, Roger, Adam, Fobn, Pbilip, and Ifabell. Her hufband, and her fon Fobn, died Inth September, 25 K. Edward I, 1297. Her daughter, Ijabell, died $15^{\text {th }}$ Fcbruary, $33 \mathrm{~d}$ of the fame reign, 1304 . Her other four fons all lived to poffefs her moiety of the barony of Morpeth, in their turis, and died without iffue-male.

Morpeth fell to the lot of William Lord Greyftock, to whom, and is his heirs, K. Edward I. granted, that the annual fair in the

(d) Burgenfes Burgi pro firma burgi, $\mathrm{x} l$.

Pro pifcario falmonum in aqua de $\mathrm{W}$ anfpeck, cum felon. et ftallag. xlvi s, viii $d$.

Cotingwood, lxvis. viii $d$.

Eaft Park, vil. xiiis. iv $d$.

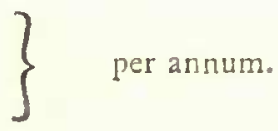

Weft Park, in manû comini.

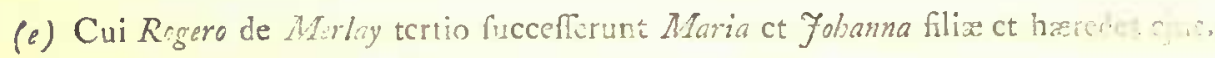
felmus Daro de Graiffock Mariam ccpit in uxorem, ct fufcicavit ex ca fobmm Robertus de Somervill duxit Fobannem in uxorem, et genuit ex ea quinque filios, gerum, Adamum, Fobannem, Philippum, et Ifabellam filiam.

Robertus de Somervill, pater, obiit, cum fobanne flio fuo, xio. die menfis Septemini. ann Jom. Mo. CCo. nonagefimo feptimo. Ifabella filia ipfius Roberti obiit xv die menís Februarif, :nn. Dom. Mo. CCCo. quarto. Poft mortem vero Roberti de Somervill, patris, Rutarl:, Rogerus, Adamus, et Philippus, filii ejus fuperdicti, unufque poft alium hæreditarie puffitiebant purpartem hæreditat. parentum fuorum, et obierunt fine hærede mafculo.

Ex Autograpbo perantiquo. 
borough of Morpeth Should hold for three days together, viz. on the eve, and on the feaft of St. Mary Magdalen, and the day. after $(f)$. His lordhip died izth of the fame reign, and was fuccecded by his fon,

Fobn Lord Greyfock, who was a benefactor to the abbeys of Tinemonth and New-Minfer, and caufed a divifion to be made of his grandfather Merlay's lands between him and his uncle, Robert de Somerall $(s)$. His brother William being dead, and having no iflue,

(f) Ediurdus Dei gratia tex Anglice, Sc. Sciatis nos concefliffe et hac carta noftra confirmafic Lilecto et fideli noftro Willielms, filio Thome de Greifock, Fobanni filio et hæredi fuo ct Marice qux fuit uxor ejufdem IVillielmi, quod ipfe, et hæredes ipfius Yohannis, loco Ferice qux ex concefinone dom. Fobanis quondam regis Anglice avi noftri effe confuevit in mancrio dictorum, Willielmi et G, bamnis, de Morpetb in com. Northumbr. fingulis annis per unam diem duratura, viz, in fefto Sanctx Marice Magdulana, de cetero habeant unam Feriam ibidem fingulis annis per tres dies duraturam, viz. in vigili.s, in die, et in craftino ejufdem fefti Sanctæ Morie Magdalina, nifi feria illa fit ad nocumentum vicinarum feriarum. Quàre volumus ct firmiter pracipimus pro nobis ct haredibus noftris quod præedictus Willielmus et Fobannes, et haredes ipfius $\%$ shanis in perpctuum habeant prodictam feriam apud manerium fuum prædiatum cum onnibus libertatibus ot liberis confuetudinibus ad hujufmodi feriam fpectantibus, sxc.

Carta, 9 Maii, anno 13 Ed.I.

(g) Ifte Fohames de Giaißlock, vir flrenuus et corpulentus, fecit partitionem fieri de omnibus terris et tenementis quxe fuerunt Rogeri de Merlay avi fui inter fe et Robertum de Somersill, avunculum; viz. in com. Northumbr. (Memorandum eft quod Rogerus de Merlay, dum vixit, enuit in capite de dom. rege in Northumbr. quatuor feoda milit.) et partitio facta ef, vilelicet, quod prædictus fobannes hæres predictus tencbit tria feod. milit. videlicet Morpath, Sbilvington, Heptrefotr, Sbadfen, Duddion wef, Duddon eaft, et Ulgham, pro duobus feod. milit. Item idem Fobannes, hæres, Manei ia tenebit de Stannyngton, Belafise, Tranwell, Saltuych, Plefes, Shotton per dimid. feodi militaris. Et etiam quod predictus Fobannes, hæres, tenebit medietatem de magna Benton, Kyllyngwarth, et Wulker, per dimid. feod. milit.

Et quod Rolicrtus dic Somcrvill tenchit aliam medietatem de magna Benton, Kyliynworth, Wit.fade vorth, et Weteflade fouth, per dimid, fcodi militaris. 
iffue, he fettled his moicty of them, and his other eftates, at his death, 34 K. Edward I, I307, on

Ralph Fitz William, his near relation, who affumed the name and title of Ralph Lord Greyfock (b). He married Margery, the widow of Nicbolas Corbet, one of the daughters and cohcirs of Hugh de Bolbeck, by which marriage he acquired a mediety of the barony of Bolbeck(i); and had two fons, William, and Ralph. His Lordthip founded a chantery in the church of Tyemonth, as before mentioned (k). He lived to a great age. Hic died, $9 \mathrm{~K}$. Edward II, 1316; and was interred at New/bam (!). His elden fon William, and his wife Catbarine, dying without iffuc, he was fucceeded by his younger fon,

Et fic Fohannes de Graifock tenet tria feod. milit, in capite de dom, rege ibi 'em, et faciebit fervicia tam in guerra quam in pace pro prædictis tribus feod. milit. et ad auxilium promogenitze filiæ regis maritandæ, et primogeniti f.lii regis mil'it. faciend.

Et Robertus de Somervill pro uno feodo, \&xc. Praterea, pradiaus fol annes et Robertus habuerunt in Chinagium, Horfey, Stanton, Witton, Ritton, et alteram Ritton, II ynlatcs cum le Shicles, et Leveriblild, quæe efceat. fuerunt ad auxilium primogenitæ filix dom. regis maritandx, et ad auxilium primogeniti fil $\mathrm{i}$ fui milit. faciend. tenend. per unum feod. milit. viz. Hor Rey, Stanton, et Levercbild, pro dimid. feod. Witton, Ritton, Iryndgates, et Sheles, pro alio dimid. feodi.

Ex Autograpbs perantiquo.

(b) Poltrèmo, Johannes de Grayfock, carcinte hxede mirculo, dedit Radulpbo, filio Willicimi, confanguineo fuo, omnes terras ct tenementa $\int: a$, tam in com. Nertbumbr. quam alibi infra Angliam, habend. et tenend. dicto Ran fuæ indè dicto Radulpho traditre, et infra brevec obiit.

Ex Autographo perantiquo.
(i) Vid. Bolbcck.
(k) Vid. Tyzemouth.

(l) Cùm autem Radulphus, filius Willielmi, multa probè egiffet, penfus mağna fencête, citra feftum Omnium Sanctorum obdormivit in domino, et apud Nerwfimam fepultus eft Ann. Dom. $\mathrm{M}$ o. CCCo. decimo fexto, ct anno regni regis Edvardi, filii regis Edvardi, nono. Willielmus vero filius cjus et Catbarina uxor ejus obierunt fine prole. Succeflit Robertus, filius, qui poftnodum infra breve obiit, viz. anno regni regis Edvardi, filii regis Edvardi, decimo.

Ex Autograplo perantiquo. 
Robert Lord Greyfock, who died the year following, ro K. Edward II, Ij! when an inquifition was taken of all his eftates in this county $(m)$. He was incered at Butlerwick $(n)$. His fon and hcir,

(m) Inqquifitio capta coram dom. Roberto de Cary, cfcactore dom. regis, die proximè ante feltum Pentecoftes, anno 10 Edvardi fecundi, fuper facrum Ricardi de Ogle, Antonii de Ervington, Putri de Eland, Fobunnes de Plifts, Thome de Witton, Wilielmi de Insehow, Fobannis

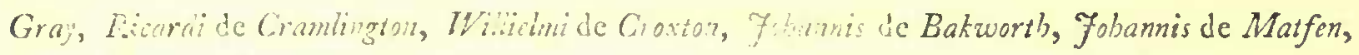
ct Alani de Ietfictes. Qui dicunt, fuper facrum futin, (uod Dominus Robertus, filius RaIulphi, obiit feifitus de jure in dominico fuo, ut de feche's, de manerio de Norpath, quod folebat valere tempore pacis in omnibus exitibus, ixxxiv l. vs. Item de manerio de Ulgham, quod folelat valcre tempore pacis in ommibus exitibus, xlviiil. xiiis. ivd. Et de villa de Heffotes, quæ folebat valere in tempore pacis in omnibus exitibus $x x l$. Et de medietate hamictti de Tranwoll, qua fulebat valere tempore pacis in omnicus exitibus livs. ix d. Et de quadam parte villx de Horfoy, qua folebat valere tempore pacis $\mathrm{x} l$. xvis. vi $\%$. Et de medictate ville de Stamingron, qiax folebat valere tempore pacis in omnibus exitious, ix $l$. Et de modetate villæ de Benton, quæ folcbat valere tempore pacis in omnibus exitibus, cum redditu libero de Kyllingwarth, xviii l. xiii s. viii d. Ee quod cenuit omnes prædictas terras, et tenementa pradicta, de dom. rege in capite per fervic. fcod. duorum nilit. fed nune nil 'rcddunt preter x l. quòd jaccnt vaftx. Item dicunt, Quod prædictus Rohertus obiit feifitus de jure in cominico luo, ut de feodo, de medictate manerii de Stifordet Heldon fuper Murrm, Angerton, Dodington, cum medietate ipforum hamlettorum cifdem maneriis pertinentibus de baronia de Bolbeck, et tenct dictam modietatem hamlettorum et maneriorum de dom. reze per fervicium feod. duor. milit. et folebant valere per annum in omnibus exitibus tempore pacis $\mid x \times x l$. fed nunc nibil reddunt, quòd jacent vall x. Et dicunt, Quod rredictus Robrrtus, et Iilaahetha uxor ejus, conjunctim feoffati de medietat. pradictorum mancriorun et hamlentorum, cum pertinentibus. Item dicunt, quod pradidus Radulphbs filius if fius $R$ o- berti, eft propinquior hares ipfius Roberti, et eft atatis xix annorum ad feftum Afumptionis beatæ Marice Virginis proximè futurum. In cujus rei teftimonium, \&c.

Item, alia inquifitio capta eft coram eòdem efcaetore ut fupra. Qui dicunt fupcr facrum, quod Catbarina et Fobanna filiæe liæredes Ade Barret, tencnt manerium de Walker de manerio de Morpath in capite per fervicium feodi unius milit. et fectam curiæ de Morpath, et molendinum de Benton ad xiii vas. Et quod prædictum mancrium de Walker folet valere per annum tempore pacis 1 merc. Et quod Elizabetha Conyiers tenet manerium de Clifton de ma- 


\section{Ralph Lord Greyfock, married Alice the daughter of Hugh Lord} Aitlley. He met with an untimely fate. He died by poifon at Gatefbead, I7 K. Edward II, I324; by the contrivance of the accomplices of Sir Gilbert de Middleton, whom his lordhip had been the principal inftrument of feizing in the caftle of Mitfort for treafon. Ite was interred at Newcafle ( 0 ); and was fucceeded by his fon,

Willian

nerio de Morpath in capitc per fervicium unius feod. milit. et fectam curia, et folebat valere

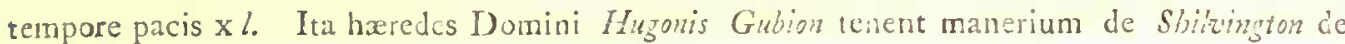
manerio de Morpath in capite per fervicium medietatis unius feodi militis, et fectan curix de Morpath, et folebat valere tempre pacis xxl. Itcm Elvardus de Duddon tenct mancrim de Dullon de manerio de Morpath per fervicium tertize partis unius food. milit. et fectan curiæ de Morpath, et valet per ann. tempore pacis x $l$. Item, Hugo Coins de Stan'yngton tenct terram fuam in Stannyngton per fervicium tertix parnis unius feod. milit. et fectam curiæapud Merpath, et valet per anu. tempore pacis $x l$. Item Alamus de Benton tenet teram fuam in Hyrmyngfelle de diato manerio de Mrpath por fervic. xiii $d$. ob. per ann. Ttem Thizlmas de Camera tenct terram fuam in Ky:lyngreorth, per homagium ct fectam curiæ de Benton, ct reddit per ann. vii $d$. $\frac{1}{2}$. Item IVillichnus Prudholme tenet terram fuam de Kyllyngroort's per redditum per ann. xv s. iii $d$. et fectam curia de Benton. Item Thomas Dryng lenet terram fuan in Kyllyngworth per fervicium zxxs. vii $d$. per annum, et feftam curiæ de Benton, ct fectam molendino cjufdem villæ ad xiii vas. Item Robertus do ecclefía apud Morpoth, tenet terram fuam apud Norpath per fervic. vilis. et fectam curize apud Morpath ct molendino ad xiii vas. Item Gahannes de Rukeby tentet terram fuam quare fecit Nicholui de Paro in Morpath per fervicium xii s. vi $l$. per ann. et feelam curiæe de Arorpalb. Item Rogerus de Horfley tenet terram fuam in le Whytwhome per fervicium unius libri Cumini pro omni fervicio. Item dicunt quod dictus Robertus flius Radulpbi tenuit de jure die quo obiit in doninico fuo, ut de feodo, advocationem ecclefix de Morpath, qux valet per ann. in omnibus exitibus tempore pacis $\mathrm{x} l$. Item dicunt quod idem Robertus tenuit cie quo obiit in dominico fuo, ut de feodo, ajvocationem ecclefix de Horfey, et quæ valet per annum tempore pacis in omnibus exitibus cum vicaria cjufdem, $x x l$. In cujus rei teftimonium, \&c.

(n) Ifte Robertus fepultus eft apud Butterwyke.

(0) Et fucceffit in hæreditatem Radultbus filius cjus et hæres. Quil cum magno excrcitu obfidifet Gilbertum Middilon et alios cum ipfo in caftello de Mitford propter proditiones per 
Trilliam Lord Greypock, who was fummoned by writ to the parliament at J efminfer, I 5 th July, $26 \mathrm{~K}$. Liderard III, I352. He firft married Lity, the daughter of Iord Lucy; and afterwards marricd Fobann, the daugliter of Heny Fitz Hugh, Lord Ravenfreath. He built the cafles of Greyfock and Morpetb. He died at Brmpatb in the bihoprick of Dubam, $32 \mathrm{~K}$. Fidruad III, I 358 , and was interred at Grayfock, near his mother, Alice, Lady $N_{e}$ will (p). He was fucceded by his fon, a minor, the thind

Ralph Lord Greylock, who was funmoned by writ to the parliament at 7 tefminfer, I K. Richard II, I377; and ift and 7 th K. Hen. IV ; and to the parliament at Leicefter, $2 \mathrm{~K}$. Henry V, I414. He married Catbarine, the daughter of Roger Lord Cliffort. He had the direction of the military expecition againft the Scots, $4 \mathrm{~K}$. Rivhard II, when he was taken prifoner at Horjige, in Glendale, by Ceorse Earl of Dunbar. His brother Williom went as an holtage for him to Dubor, where he was taken ill of a dangerous fever, then raging in Sotlond, of which he died, and was buried there, and afterwards removed and intered before the high altar

ipfos populo dom. regis actas in com. Northumor. quadam antem die cictus baro apud Gatefbead exift. ad jentaculum falfo confilio ipfus Gilberti et aliorum fibj adherentium proditorio impocionatus eft, et apud Norum Cafrum fepultus.

Ex Autographo perantiquo.

(p) Cui fucceftit nobilifimus baro Fillielmus filius et hieres ipfius Radulphi; hic prinus duxit in uxorem Luceam filiam domini de Lucy qua divorcio feperata eft, et mortua, apud Nczubam fepulta eft. Deinde confilio Alicire dominx de Aevill, matris ejus, cepit in uxorem Gohannam filiam Henrici Fitzbugh, Domini de Ravenefwath, dc qua fufcitavit prolcs, Radulpbum, Williclmum, Rsuestum, st Aieciam, qua fuit uxo: Roberti de Harringtan.

Ifte Willielmus victoriofus et in omnibus hoftitudiis gloriofus crat valdè ; et cum æudifieaffet caftellum de Graifok, et turrem de Morpath, et multa alia dignitatis opera, obiit apud 3ramplpeth, et apud Graiflok fepultus eft, uniente matse fua antedićta.

Ibid. Vid. Efcaet. de anno $33^{\prime}$ Ed. III. . . 43. 
at New-Minfter. His lordhip's ranfom colt 3000 marks; towards which the burgeffes of Morpeth paid 7 l. I 3 s. 1od. (q). By the advice of his mother Fobann, he gave the impropriation and adrowfon of Long Horfley to the priory of Brinkburn, $8 \mathrm{~K}$. Richard II; in confideration of which, the prior and convent agreed that her Ladyfhip and her heirs thould have the perpetual right of prefenfation of one camon in their convent. The firft canon prefented by her was Alan, fon of Fobn de Preftwick ( $r$ ). He was alfo a bencfactor to the priory of New-Minfer, i 3 th of the fime reign (s). He died, 6 K. Henry V, 14I7. An inquifition was then talien of his honours and efates, when it was found that he held the manour of Grimtlop and Helderfelf of the crown, under the honour of Cheger, by the fervice of carrying the fword before the

(q) Succeffit dicto Willielmo, Radulphus filius ejus, qui ratione minoris atatis fuit in cuftodia comitis Marbice Wallice, ex concefione Dom. Edvardi tcriii regis polt conqueftum A glia, et maritatus eft Catharine filix Dom. Rogeri de Clifford. Deinde, viz. die veniente proxime poft feftum nativitatis Sancti 'Fohannis Baptijle, anno Ricardi fecundi qualto, apu1 Horfridge in Glendale diatus baro, cum Wiliaclmo de Atm, et aliis militibus, ct multis validis, infeliciter captus eft por Georgium comitem de Dunbar; ob quod Wrillicimas frater ejurdem baronis miffus in hofagio pro eo apud Dunbur, tactus morbo peftilentinli mortuts e?, et fepultus ibidem; fed poft duos annos completos corpus cjus integra carne et pelle tranh itum eft, et coram fummo altari in Novs Monaferio juxta Mrrgeriam Dominam de Uighom fepultum efr.

Et nihilominus dictus baro madiante malicia Folannis duis $L$ meselrice, redemptus eft pro MMM marcarum; ał quam redenptionem Fohanta meter cjus fecit levari de burgenfibus de Morpath, per manus Fobannis de Paferban, receptotis fui, viil. xiiis. $\mathrm{x} d$ - Ibid.

(r) Poftmodum vero, viz. anno viii Ricardi fecundi, dictus baro jer conflilum matris fuæ dedit conventui de Brenkburn advorationcm ecclefix de Horfiog, pro qua prior ct conventus ibi-

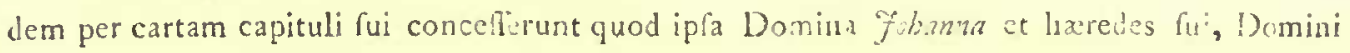
de Morfath, præfentarent unum clericum fubire ordinem fuum, et quol ipfi canones ipfum

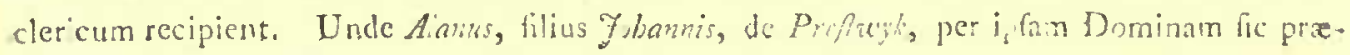
sentatus eft.

Ibii.

(s) Fid. New-minfter.

Vo L. II. 
the Earl of Chefter, for the time bcing (t). He was fucceeded by

Fobn Lord Greyfock (u) who married Elizabeth the daughter and coheir of Robert Lord Wemme. He died, I4 K. Henry VI; and was fucceeded by his fon and heir,

Ralph Lord Greyfock, who was fummoned to parliament, 2qth K. Henry VI, and 1 K. Edward IV; alfo I K. Richard III, and I K. Henry VII. He married Elizabeth the daughter of William FitzHugh, Lord Ravenfruath. He died, 2 K. Henry VII (v). His lord-

(1) Per ferutinium factum annotatur, quod Radu/pbus de Gray/tock, pater dom. Fobannis, cis quo obiit tenuit de rege in capite manerium de Thornton, per fervicium quartæ partis feod. milit. ac manerium de $N$ idde de rege ut de honore - per fervicium octavæ partis unius feodi militis; manerium de Grimtborpe tt Helderfkelf, de dom. rege in capite, ut de honore Ceftria, per fervicium portandi gladium coram comite $C_{f}$ frice qui pro tempore fuerit in prefentia fua, viz. pradictum manerium de Grymthorpe per fervicium xl. partis unius feodi militis, et prædictum manerium de Holderkelf per fervicium 1. partis unius feodi milicis.

Rot. Mich. Fin. de anno 6 Hen. V.

(u) Fobanncs de Greylock certus flius et bæres Radulphi Baronis de Grayflock, tenet de rege in capite mancrium de Morpath, in com. Northumbr. per fervicium medietatis unius Baronia, viz. Baronix de Merlay; manerium de Stiford, in com. prædicto, per fervicium tertiæ partis medietatis unius Baronia, viz. Baroniæ de Bulbcik, \&ic.

Ibidem.

(v) In the i 7 th year of K. Henry VI, Ralph Greylock, fon and heir of Fohn de Greyfock, Knt, and Chivaler, acknowledged in the court of Exclsequer, that the faid $\mathcal{F}_{0} \mathrm{bn}$, on the day of his death, held of the King in capite, the manour of Graylock by the fervice of one entire barony, to wit of the Barony of Merlay; the manour of Styford by the fervice of the third part of the moiety of one barony, to wit of the Barony of Bulbeck; the manour of Wemme (in the county of Salop), with the advowfon of the church of Wemme, by homage and fealty, and by the fervice of the twelfth part of one entire barony; and divers other lands, as the manour of Tlornton fupar Moran (in the county of York), by the fourth part of a Kuight's fee; and divers mefluages and lands in Thyngden, in Nortbamptonfire, by the 2oth part of a Knight's fee:— nec non manerium de Gymthorp, cum fuis pertinentiis, as manerium 
- Thip had one fon, Robert, who married Elizabetb the daughter of Edmund Gray Duke of Kent, and died before him, I K. Edreard V, leaving only one daughter, of her mother's name,

Elizabeth, baronefs Greyfock and Wemme. She married

Thomas Lord Dacre of Gilfand. His Lordfhip died, I7 K. Henry VIII; and was fucceeded by his fon,

William Dacre, Baron of Gilfland, Greyftock, and Womme, who was fummoned to parliament, 28, 3I K. Henry VIII, and I K. Edward VI, and I Q. Mary. He married Elizabeth the daughter of the Earl of Shropßire. He died, 6 Q. Elizabeth; and was fucceeded by

Thomas Lord Dacre, who married Elizabeth the daughter of Sir Fames Leiburn, Knt. He died, 9 Q.Elizabeth. An inquifition was taken of his eftate in this county the year following $(w)$. He was fucceeded by his fon,

George Lord Dacre, who dying under age, his honour's and eftates came to his two fifters and coheirs, Ann, and Elizabeth. Ann married Pbilip, Earl of Arundel. Elizabeth married Lord

de Henderkelf, cum fuis pertinentiis, in com. Eboraci, de don. rege ut de honore de ceftrix, per fervicium portandi gladium, coram comitx ceftrix qui pro tcmpore fuerit, in prafentio fua, \& Mador. Bar. Angl. p. 58.

(w) Dominus Dacre fuit feifitus de et in manerio, caftro, et villa de Morpeth, Stobhill, Catchburn, Hepfcotte, Clifton, Netherton, Ulgham, Stobfwood, Angerton, Commerton, et Killingworth, et Softley, de medietate villæ de Stannington, Benton mag. et Horley, de et in villa de Benrige, cum certis terris in Todburn, Bydleftone, Blindgappe, et Eftree. Etiam fuit feifitus de et in Newbyggen-houfe, juxta villam Novi Caftri, Gybbone-houfe, et medietate villæ de Heddon fuper murum.

Efcaet. de anno to Eliz. 
Wrilliam Howard, third fon of Thomas Duke of Norfolk. His Lordthip had a large cftate in this county $(x)$. He refided at his caftle of Naward, in Gilfland; wherein he had a good library, furnifhed with fome valuable manufcripts of Englifh hiftory and heraldry. He publifhed an edition of Florence of $W_{\text {orcefer. His }}$ grandfon, Charles, was created Lord Dacre of Gilland, Vifcount Morpeth, and Earl of Cirlifle. He was vice-admiral of the coafts of Nortbumberland, Cumberland, the Bifhoprick of Durbam, and the town and county of Nerucafle upon Tyne. He was Lord Licutenant of the counties of Cumberland and Wefmorland. He was governor of $\mathcal{F}_{a-}$ maica, privy counfellor to K. Chorles II, and his ambaffador extraordinary to the Czar of Mufcory, and the Kings of Sweden and Denmark, in the years 1663,1664 . He died 24 th Feb. 1684 , in the $5^{\text {th }}$ year of his age; and was fucceeded by

Edward Earl of Carlifle; whofe fon and heir,

Charles Earl of Carlifle repaired the caftle of Naward, and kepe the library in good order; in which the manufcripts above-mentioned were remaining in his time. His Lordhip had the pictures of all the Kings of England down from the Saxon times in his great hall, which were brought from Kirk-Ofwald caftle. He was fucceeded by his fon, the late

Henry Earl of Carlifle, who was Knight of the molt noble order of the garter. His Lordhip firt married Frances the only daugh-

(x) Dominus Willielmus Howard, tenet in capite Baroniam de Morpeth, ac maneria de Morpeth, Ulgham, Horfley, Angerton, Heddon fuper murum, Denton, Killingworth, et Stannington, ac foreftam de Horfley, ac diverfa tenementa in Morpeth, Netherton, Benridge, Todburn, Combton alias Newton, Hertburn, et Middilton-Morell, Newbiggen, Tinmouth, Weft Duddon, Stobhill, South-weft Steed, Prefton, Moreton, Stobbfwood, et Knarefdale, et advocationem ecclefix de Morgeth.

Ex Libro fcodario Petri Oforne, militis. 


\section{ANTIQUITIES OF NORTHUMBERLAND. 301}

ter of Charles Spencer Earl of Sunderland, by whom he had three fons, and two daughters. He afterwards married Ifabella the daughter of William Lord Byron, by whom he had one fon, and four daughters. He died, 2d Sept. I758, at his houfe in York, in the $64^{\text {th }}$ year of his age. He was fucceded by his fon, by his latt Lady, the right honourable

\section{Frederic Earl of Carlife.}

His Lordhip's borough of Morpeth never fent members to parliament till, I Q. Mary, 1553. It is governed by two bailifis, and feven burgeffes, who are all elected annually out of the principal inhabitants paying fcot and lot, who elect the members of parliament. Thefe are about two hundred. The bailiffs are the returning officers. The town-arms are, argent, barry of fix azure and gules, over all a caftle tripple towered within a bordure, azure, femee de martlets $(y)$.

It hath an excellent weekly market on Wednefdays, and two annual fairs, viz. on Holy Thurfday, and St. Mary Magdalen's day.

The market-place is in the center of the town. It has a neat market-crofs, on which is the following infcription.

The Hon. Plsilip Howard and

Sir Henry Belofyfe, Knt. the

only benefactors of this crofs, Anno Dom.1699.

On the weft fide of the market-place is the town-hall. It is a handfome ftructure, of white freeftone, and hewn work, with a piazza, and a tower at each end, erected in the year 17 I 4 , at the

(y) Browne Willis. 
expence of the Right Honourable the Earl of Carlife, whofe court is kept in it, alfo the quarter-feflions for the county.

At a finall diftance from it, is a neat tower of white free-ftone, wherein is a good ring of bells, and a large clock.

Between the town-hall and the bridge, is the county-gaol. It is a modern and decent fructure.

At the north-eaft end of the bridge, is a fmall, but neat chapel, of modern crection, of white freettone, and hewn work. At the weft end of it is a grammar-fchool, an antient building; which was founded by King Edward VI, and endowed with the lands of two diffolved chanteries in Morpeth, and one at Netber Witton.

The parochial church ftands on the fouth fide of the bridge, at a confiderable diftance from the town; on a hill, called Kirk-hill, in the weft park, on the weft fide of the poft-road. One of the chanteries in it juft mentioned was founded in honour of the Bleffed Virgin, of which Fobn Anderfon was chaplain, 8 K. Henry VII $(z)$. It has three good ifles, a gallery at the weft end, and another

(z) As appears from the following leafc which he and others took in that year of fom Lord Greyfock, of the wood, called Cottingruood, near the town, containing 284 acres, according to an antient furvey.

Thefe indentures made at Morpeth, the xth dai of the month of Oetober, the viiith yeare of the reigne of our fovereign lord king Henry the viith wittneffeth, that Fohn Lord of Graifock and Murfath hath diviled \& letten to farme to Fohn Anderfon, chaplain of the chantrie of our Lady in Morpath, Fohn Refl, and Thomas Norton of the fame towne, marchants, all the graffing and herbage that my fervant, William Lancafor, late held of me within the wood of Cottingwood, to the faid Fohn Anderfon, Fobn Reed, and Thumas Norton, and to their affignes from the feaft of St. Micbael the Arcbangel laft paft to the end and terme of xx years next following the date hereof; giving yearly to the faid Lord, his heirs, and his affgnes. xxxiii so iv.d. at 


\section{ANTIQUITIES OF NORTHUMBERLAND.}

another between the pillars of the north ifle, a veftry, and one bell. In the chancel is a flat fepulchral ftone with this infcription.

In obitum Henrici Graii nuper de

Novo monafterio, armig. qui obiit ultimo

Die Martii, anno domini I 597 ; pofuit

Thomas Grey, filius primogenitus

Pietatis ergo.

Underneath is the coat armorial of the Greys, of Chillingham, and on one fide this motto.

\section{De bon Valoir.}

Below are fome verfes in Latin.

two termes, Whitfontide and Martinmas by even portions. Moreover, the faid Folm, chaplain, Fobn Reed, and Thomas Norton, bind them, their executors, and affignes, to make and uphold a fufficient hedge about the faid ground of Cotingwood, enduring the faid xx years, whercunto the faid lord granteth them by his officer of the faid wood to affigne and deliver to them fufficient wood for hedging of the fame. And to allow them for their labor of the hedging thereof at the fight and difcretion of William Wardall, then auditor to the faid lord. And according as have been accuftomed to the tenants thereof afore time. In witnefs whereof, as well the faid lord, as the raid John, chaplain, Jobn Reed, and Thomas Norton, to the parts of thefe indentures, interchangably; have fet their feals, given the dai and yeare above faid.

On the fould of the indenture by the labell is indorfed thus.

To the intent, that all the fervants and tenants belonging to the faid Lord within the faid towne of Morpath thall have graffe to their borfes within the faid wood, and ilk man for his quantitie to paie as doth the faid Fohn Anderfon, Fobn Reed, and Thomas Norton, every one of them by himfelf. And for becaufe that they that be of abilitie have or hath promifed and granted themfelves to finde horfes to do fervice to the faid lord.

Sub figillis dictorum.

Fobannis, Fohannis, et Thome. 
Conditus hic jaceo quartus genitore Radulpho

Filius ex Graio milite fic jaceo.

Nupta fuit mihi Woddringtonia chara Maria,

Militis ac clari nata Fobamis ca.

Una dies partus nos, ut Baptifmata una,

Junxit fic una lex hymenea toro.

Annos bis feptem focialc fedcre juncti,

Rupcrunt tetrici vincula noftra dex,

Bis binos pueros mihi, trefqùc Lucina puellas,

Præbuit cxtincti pignora chara mei.

* $*$ * $\quad *$ * $*$ *

The rectory-houfe ftands on the eaft fide of the poft-road, and is little better than a ruin.

The baronial caftle is near the church, in the fame park. It has becn long in ruins. Only an old tower of it is ftanding, with part of two fpeculating turrets, on an cminence, commanding a fine view of the town, and of the winding courfe of the $H$ ans: leck, croffed by a bridge of two arches, and edged with hanging wools.

Half a milc weft from Morpeth, on the margin of the Hanfbeck, is the abbey of

New-minfler, founded by Ralph de Merlay, Baron of Morpeth, and his lady Gulian, 3 K. Stepben, I 138, for Ciftertion monks, from Fountains, in Normandy, in honour of the Blefled Virgin (a). They endowed it with the Lordthip of Ritton, part of the woods of Witton, and all the vale between Morpetb and Hebre, by the brook of Fulbeck to its fall into Cotingbum, and by Cotingburn to its fall

(a) Monaft, Ans' Vol. i. p. 800. 
ANTIQUITIES OF NORTHUMBERLAND. 305 into Wansbeck, \&c. (b); with feveral privileges, confirmed by their heirs, and fucceffors, and royal charters. Margery, the Lady of the fecond Roger de Merlay, Baron of Morpeth, gave to it three fitheries in the river Tyne.

William Bertram, Baron of Mitford, gave to it all the fine vale between it and his villa of Mitford. His great grandfon, Roger Bertram, fold to them the granges of Eland, Horton, and part of Peterick, which his father and grandfather, both of his own name, had before granted them a leafe of.

A clergyman, named Peter, fon of Fohn, vicar of Mitford, gave them the grange of Aldworth, which was confirmed to them by their laft mentioned patron.

Everard de Ros, Baron of Wark, gave them the grange of Sturtont, and his fon, Robert de Ros, confirmed his donation.

Robert Bertram, Baron of Bothall, gave to them an eftate, called, Forum. His grant was confirmed by his heirs, Richard and $R_{0}$ bert Bertram.

Sir Gilbert de Humfranvil, Baron of Prudbow, fold to them the moors of Cbeviot, and the granges of Felton and Tollard, which his anceftors, Odonel, William, Richard, and his own father and mother, Sir Gilbert and the Lady Matilda, had before granted to hold by leafe, and given them Turf-bill pafture.

Sir Walter, Baron of Bolbam, fold to them Newton-grange, which his father, Sir Gilbert, and his grandfather, Sir Fames de Bolbcin, had given them a leafe of. Sir Walter's daughter and heir, Alice,

(b) Monaft. Angl. Vol. i. p. 80 I. 
306. ANTIQUITIES OF NORTHUMBERLAND.

confirmed their title, as did Sir Walter, Baron of Bolbeck, and his fon of his own name.

Hugh, Baron of Bolbeck, and his Lady Theoplania, gave to them. the villa of Rotbeley.

Fobn de Kefern fold to them the demefnes of Keftern and Werebill, of the manour and regalities of the former of which they were before poffeffed by the donation of Robert de Greyfock (c).

Roger, Baron of Warkworth, anceftor of the Clavering-family, gave them a falt-work at Warkworth, and his fon and heir, Robert, confirmed it to them.

Henry Coniers, and his wife Ecla, gave to them Cauldwell, alias Scarplane-Grange, and an eftate in Clifton. The firt they exchanged for lands in the latter, with Willian Coniers.

They held Tritlington of the manour of Wark upon Tweed, by the fervice of Franc-Alnaigne (d).

Sir Richard Gubion gave them the annual rent of $\mathrm{xx}$ s. out of his mill of Shilvington.

Sir Roger de Merlay, of Stanton, gave them as much out of his mill there.

Sir Robert de Fenwick gave them two parts of his villa of Irdington, in Cumberland, who died, 1372.

(c) Cait. 18 Ell. I. n. 63. de lib. war. in Horton, Felton, Newton, Weft and Eaft Ritton, Keftern, Ulgham, Rotheley, Nortbumbr.

(d) Rot. penes comit. de Tankcrvill. 
Alan Whitehead, vicar of Tyucmouth, and William Fell, gave them lands in Stannington, with the licence and approbation of the third Ralph Lord Greyfock, 13 K. Richard II (e).

Fobn de Plefes gave them the mills of Stamington, and the grounds belonging to the fame mills, with their accuftomed liberties $(f)$, which had been granted to him by the third Roger de

(e) Ralulphus Baro de Graifsk tertius omnibus ad quos prefentes litere pervenerint, f.tlutem. Noveritis quod nos dedimus et quantum in nobis eft concedimus pro nobis et hasredibus noftris Alnno Whitchcad, vicario ecclefixe de Tynemouth, et Trilliclmo Kill, licintiam et liberam poteftaten quod ipfi dare poffint concedere et afignate religiofis viris, ablati et conventui de Novo Aongferio omnes illas terras et tenementa cum pertinentibus, cux? praxdictus Alanus et Willielmus habent ex dono et feoffamento Ade R'sos, et Rivirdi de Alkilunh, in Stamyngton, qux de nobis terientur; habend. et tenend. omnes terras et tenementa pradict. abbati et conventui et eorum fuccefloribus in feodo in perpetuum. Dedimus infuner dicto abbati et conventui licentiam tenore prædictorum omnes predietas terras et tenementa cum pertinentibus de dicto Alano et Ir zillicho recipiend. et ingrciend. et habend. fibi et haredibus fuis, in perpeturm, de nobis et haredibus noftris, libere, quicte, cum omnibus libertatibus et aifiamentis ad predictas terras et tenementa fpectantibus, faciendo nohis et hæ. redibus noftris fidelitatem et fectam curix id tres capitales curias de Mmpab, filvendo quo. libet anno ad feftum Sandi facobi, Apoftoli, fexdecem denarios pro warda eaftri et cornagio ad feftum Sancti Cubberli in Juncio, et fices capitân vel Hedepennys, quant. pertinent ad dißam terran, et ad feftum Sancti Martini in hieme quolibet anno pro quodau aqua curfu de Bradmyre habendo unum denarium et obulum fufentando unum ponten vitra eundem aqua curfum ibidem in perpetuum, pro omni alio fervicio, exatione, vel demand. In cujus rei teflimonium, Sic. Carta Radulph. Baron. de Grey?lack, 3 tii I 3 Ric. 'II.

(f) Omnibus hanc cartam vifuris : audituris Fohomis de Pldeto, filutem. 'Sciatis me pro falute anima mex, et omnium antecthorum, et haredum meorum, ded fi, concefife, et prafenti carta confirmafe Do et Batx Maria, whati et monachis Ngoi Munaferiz, in liberam, puram, et perpetuam elcnofnam, molendina de Stoningion, cum omuibus pertinentibus fuis; tenend. et habend. dictis, abbati et monachis adèo lioere et quiete ab onnibus ferviciis et rebus qux ab aliquo tenemento exigi polint, fieut aliqua elemofina melius et liberius dari poteft vel polideri. Et ego fohannes et haredes mei predicta molendina cum omnibus pertinentibus fuis ficut nelius pofridendum eft prædictis, abjati et uronaehis contra omnes homines et feminas warrantizabimus, adquietabimus, et defendemus in perpetul:m. His teltibus, \&ic.

Carta Fobonnis de Plefles. 
308 ANTIQUITIES OF NORTHUMBERLAND.

\section{Merlay (g), and confirmed to him by a royal cliarter, 4 I K. Henry} III (b):

(g). Omnibus Chriffi fidelibus præentem cartam vifuris vel audituris, Rogerus de Męrlay, tertius, falutem in domino.' Sciatis me dediffe, concefiffe, et hac mea prafenti carta confirmafle, Fobanni de Plefeto, et haredibus fuis, vel fuis afignatis, molendina de Stannyngton et de Plefet, cum ftagnis et aquis pertinentibus ad dieta molendina, et cum omnibus libertatibus et aifiamentis ad dicta molendina pertinentibus tam in pif́cariis, quam in omninodis aliis commodis, et totam fectam multurx, fcilicet ad terium decimum vas de omnibus hominibus qui fectam plenius aliquo tempore folebant facere dictis molendinis, exceptis de duabus bovatis terre quas prior de Hextoldibam tenet in villa de Stannyngton.

Concefir eriam et dedi, et præfenti carta confirmavi, pro me et hæredibus meis, dicto Jobanni et hxeredibus fuis, vel fuis affignatis, totam terram quæ vocatur Mill-syde ufque ad aquam de $B$ 'ye, et totam aquam de Blye a ponte de Stannyngton ufque ad caput occident. Aagni dicti molendini et illam placeam quæ eft inter veterem curfum aquæ de Blye et ductum dicti molendini de Stannyngton, qux quidem placea vocatur Milnbalgh; reddend. indè annuatim nihi et hæredibus meis dictus fobannes et haredes fui, vel fui aflignati, pro omnibus fuperdictis tantum unam papyram Carearum deauratarum ad feftum Sancti Cutbberti in Septembri pro omni fervicio, confueturline, exactione, et demandis.

Conceffi infuper et dedi et prefenti carta mea confirmavi disto fohanni et hæredibus fuis, vel fuis affignatis, totam fcifionem aqua quæ vadet per nedium Yerbalgh ufque ad terram meam folidam ex parte aquilone illius feiffionis, et totam illam particulam de $Y_{e}$ rbalgh qux cft ex parte aufrali dictx fciffionis, reddendo inde annuatim mihi et hæredibus meis unam libram Cumini ad natale domini, pro omni alio fervicio, confuctudine, exactione, et demandis.

Conceff etiam et dedi, et præenti carta confirmavi dicto Fobanni, et hæredibus fuis, vel fuis affignatis, totam illam landam quæ vocatur $L y n h a l g h$, quæ jacet ex parte aquilone aquæ de Elye, ficut eft inclufa foflato, per ipfum foflatum et aquam de Blye quæ fe jungit eidem landæ, quantum ipfa landa continet in longitudine; reddendo inde annuatim mihi, et hæredibus meis tantum unam libram Cumini ad feftum Sancti Cutbberti in Septembri, pro omni alio fervicio, confuetudine, exactione, et demandis.

Et idem fobannes et hæredes fui, vel fui affignati, facient omnimodum commodum fuum de dictis molendinis, et ftagnis, et de Mill-fyde, et de aqua de Blye, et de Mill-balgh, et de fcifione aqua per medium $V_{e}$ rhalgh, et de illa particula de $V_{\text {erbalgh }}$, qux eft ex parte aufrali 


\section{Fobn de Mitford gave them lands in Echwick, $3 \mathrm{~K}$. Hinry VI. :}

\section{They had a common-right at Stobbiford, and at U/gham, which} was taken from them by fome of the heirs of their founder, Ralph

disx feifronis de Ljnbalgh, cum fofiato, et de aqua de Blyz qua fe jungit cidem landæe, et de omnibus fuperdistis, ficut plenius potioratum eft quibuficunciue et quoticfcunque, et ficut melius fibi viderint expedire, fine contentione mei vel hæredun mcorum, vel hominum meo. rum, vel aliorum, quicunque fuerint.

Et cgo Rogerus de Merlay, et haredes mei, dißa molendina, cum omnibus pertinentibus fuis, et Mill fjole, et Miln-balgh, et aquatu de Blye, ct fcifionem aquae in $Y_{t}$ bal b, et illan

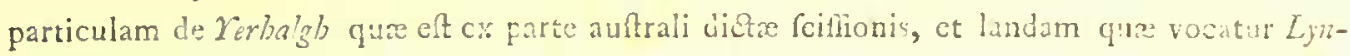
balgh, cum foffato, et cum aqua de Blye fe jungente eidem lande, cum omnihus petinentibus fuis, et omnia ficut plcrius predicta funt, cum omnimodis cummodis, qua in eis, et de eis, firti poterint, diato fohanni, et haredibus fuis, ve! fuis afrgnatis, varnntzabimus. adguietabimus, rt defendemus, contra omnes honines p.r prodica fervicia tenend. in perretuun.

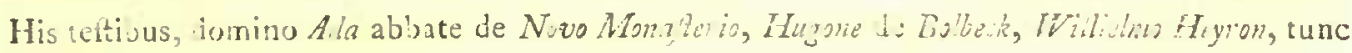
vice conte Arthumbri, Rggro Bertram de Boinall, Eufachio De a vale, Hinrio fratre fuo,

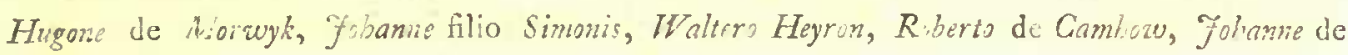

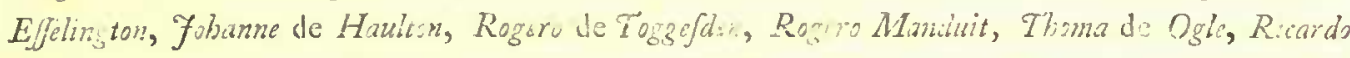

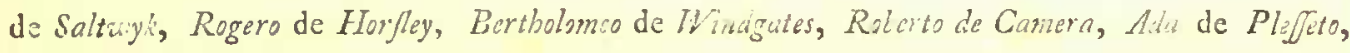
Radulp bo Gubion, Waltero de Witton, et aliis.

Carta Rogeri Merlay, tertii.

(b) Henricus, Dei gratia, rex Arglie, dominus Hibernia, dux Nornanix, Aquitain. et comes Audeg. Archiepifcopis, epifcopis, abbatibus, prioribus, comitibus, baronibus, jufticiariis, vice-propoftis, miniftris, et omnibus ballaivis, et fidelibus fuis, falutem. Infpeximus cartam quan Rogerus de Merlay tertius fecit dilecto et fideli Fobanni de Plefeto de molendinis de Stannington et Pleffeto, cum Atagnis, aqua, et omnibus libertatibus, et aifiamentis, ad ea pertinentibus, et de terris quæ vocantur Mill-gyde et Milnhalgh et aqua de Blye, et fciffione aqua in Yerbalgh, et illa particula de Yerbaigh, qua eft ex partc aufrali dictie fcifionis, et de landa qua vocatur Linbalgh, cum foffato et aqua de Blye jungente eidem landa.

Nos autem donationem et conceffionem pradictam ratam habentes, et gratam eam prædißto Fohanni, hæredibus, vel affignatis fuis, quantum ad nos pertinet, concedimus, et confirmamus in perpetuum, pro nobis, et hreredibus noftris, ficut prafcripta carta predicti Rogeri, quam dictus fobannes inde habet, rationabiliter teftatur. His teftibus, $P_{t}$ tro de $S a-$ 
Ralph Merlay, but were reftored to them by Fobn Lord Greyfock, who alfo confirmed all their other common-rights by charter, 26 K. Edward I, 1297(i).

Sir Roger de Somirill gave them the impropriation and advowfon of Stanington, as before mentioned (k).

baudin, Fobunne Misungell, Limrics de Bation. Philippo Loucll, Archilinitio de Sancio Romano,

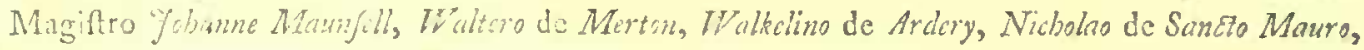
et aliis. Datum per manum noftrum apud $\mathrm{W} / \mathrm{mm}$. vicefmo quarto die Junii anno regni nofri quadragefimo primo.

Carta Regia, de anno 41 Hen. III.

(i) Omnibus hoc fcriptum vifuris vel audituris fohannes de Gray/ck, falutem. Quia Dominus Ramulpbus de Moriay, antecefior meus, ct fundator abbatiæ Novi Monaferii, dedit, conecfit, et carta fua confirmavit, abbati et conventui dictx domûs communam pafturæe to. tius tense fure; ac poltea quidam hæredum predicti Domini Rorulphi de Merlay prædictos religiofos de communa paftura fure de Stobliford et alibi apud Ulgbam per potentiam voluntarie ejeccrunt. E,ro jobamns nolens anima mea, vel anima antecefiorum, feu hæredum meorum, fint in poena vel pericula pænæ, perturbatione feu extortione prædictæ communæ pafture a præfatis religiofis injuftè ablatie, ad petitionem ct inftantiam dictorum religioforum, et pro balute animæ mex et omnium antecefforum et hæredum meorum, reddidi et conceffi cifdem abbati et conventui in liberam, puran, ct perpetuam elcmofinam pradictam communam pafturxe ad omnia animalia fua, exccptis Copris, in Stobbiford, ct alibi, tam in bofco, quan in plano, apud Ulglan ubi ex parte boreali de Lyne, cxceptis bladis et pratis, et excepto le bfye, fine impedimento mei, wh hxredun meorum, in perpetuum. Et fi contingat çuod animalia dictorum abbatis et conventus ex parte auftrali aquæ de Lyne antedictæ extra blada et prata, ut pradictum eft, aliquo modo inveniantur infra terras de U/gham, prædicta animalı abfque inparcamento feu aliqua alia occafione rechaceabuntur. - Volo etiam ct concedo, pro me et hredibus meis, quod Porci abbatis et conventus fint quieti de pannagio in bofco meo de Utgham. - Hanc vero redditionem et concelfonem eifdem, abbati et conventui prafenti fcripto nane confirmavi duraturam in perpetuum. In cujus rei te̊timoninm, \&x. Datum apud Uigham $\mathrm{M}^{\circ} \mathrm{CC}^{\circ}$ nonagefimo feptima.

Carta Fohann. de Greyfock, anno 26 Ed. I.

(k) Pat. 4 K. Ed. III. p. 2. Cart. 4 Ed. n. 85. Clauf. 4 Ed.III. m. 37. pro àdvocat. ecclef. de Stannington. Vid. Stannington. 
They had alfo the impropriation and advowfon of Kirk-Whelpington (l).

Roger de Thornton gave them as much lead as covered the nave of the abbey-church.

The third Ralpb Lord Greyfock gave them $20 l$. to adorn it.

His fon, Fobn Lord Greyfock, gave them, 60 l. for the fame purpoî.

Sir Ralph Nevill, at different times, gave them roo marks.

They had fome tenements in Thornion, Morpeth, and Newcafle (m).

The abbot was fummoned to the parliament held at Carlifle, 2 Ift Jan. 35 K. Edward I, $1307(n)$.

Their revenues at the diffolution were valued at roo $l$. I $s$. ' $d$. Dugd. 140 l. 10 s. 4 d. Speed. There were then about fiftecn religious in the abbey. A confiderable part of the lands belonging to it were in the crown, to Q. Elizabetb (o). The fite of it was granted,

(l) Pat. 8 Ed. III. p. 2. m. x8. pro eccler. de Wholpington.

(m) Pat. 38 K. Ed. III. p. 2. m. 21. pro tenem. in Thornton, Morpeth, Stannington.

Pat. 16 Ric. II. p. x. m. x, pro tenem. in Nov. Caffro.

Bourne's Hift. of Newcafle, p. I 42 .

(n) Parliam. Hift. of Engl. vol. i. p. 135.

(o) Dom. Regina Elizabetha fuit feifita de et in manerio de New Minfer, nuper monaft. Whitehoufe, Eaft Ritton, Colepark, Highbyrkhead, Cote-yard, Nunneykirk, de medietat. de Heley et Greenlighton, de manerio de Felton-more, Carricotes, Toan, Kelley-quarter, Highley, 
granted, 7 K. Games I, to Robert Brandling $(p)$. It now belongs to William Ord, of Fenbam, Efq. Its very foundations are erafed and gon:, and not a ftone left to fpeak its antiquity, only a fragment or two remaining of the portal or gate-way leading to it. Coffins, both of lead and ftone, have been turned up by fome labourers in digging for limeftone.

A mile weft from New-Minfter, on the Mady banks of the fame river, is

Mitford (q), which at the Conqueft by K. William I, was the villa and Lordthip of Sir Fobn Mitford, Knt. His only daughter and heir, Sibil, was given in marriage by that king to Sir Richard Bertram, Knt. (r), a Norman, by whom the had two fons, William and Roger. Her eldeft fon,

Sir.William Bertram, Knt. inherited her manour of Mitford, with its appurtenances, which was erected into a barony by K. Herry I. He marricd Alice the daughter of Sir William Merlay, of Morpeth, Knt. by whom he had two fons, Roger and Robert, and was the

Highley, Loninghead, Ulgham-grange, Newton-grange, Stoyke, Tratherwyke, et Morpeth.

Efcaet. de anno 1o Eliz.

(p) Tanner's Notitia Monaft. fol. p. 392.

(q) Mytford.

Mydford.

Mitford. (r) Bertram.

Bartran.

Barthram. 
founder of Brinkburn-priory (s). He was fucceeded in his barony by his eldeft fon,

Sir Roger Bertram, who by paying fifty marks to the crown, 3 K. Henry II, acquired a weekly market at his villa of Mitford. He was fucceeded by his fon and heir,

Sir William Bertram, who died about the $8 \mathrm{~K}$. Folsn; and was fucceeded by his fon,

Sir Roger Bertram, to whom K. Henry III. granted, on the payment of ten marks, that his annual fair at Mitford fhould laft eight days inftead of four $(t)$. He died, $26 \mathrm{~K}$. Henry III. His fon, the third

Roger Bertram, Baron of Mitford, being in the confederacy of the Barons againft that King, his honour and caftle of Mitford, and all his lands in this county, were feized for the king's ufe; of which an inquifition was taken in the fame reign (u), and $\mathrm{K}$. Edward I (x). The caftlc, and part of the caftle-demefnes, and

two

(s) Ex Autographo perantiquo.

(t) Rogerus de Bertram tenet de Dom. Rege in capite Baroniam fuam de Mitford per fervic, $v$ feod. milit. Et omnes anteceftores fui per eund. fervic. poft conqueftum Anglie tenuerunt; ac nihil eft alienatum, aut datum, unde Dom. Rex minus habeat de fervicio fuo.

Telta de Nevill.

(u) Madox's Hift. of the Excheq. p. 286.

(x) Rogerus Bertram tenet in capite de Dom. Rege villam de Mitford, cum fuis membris, viz. Newton-Underwood, Throple, Benridge, Meldon, Edington, Pigdon, Aldworth, Efpley, Grangium de Highley et Highley, Eland cum fuis membris, viz. Merdesfen, Kirkley, VOL. II. 
two parts of the foreft of Felton, were given by the queen dowager, mother of K. Eiward I, to Eleanor Stanour, the wife of

Robert de Stoteville, who died 34 K. Ectward I; and was fucceeded by his fon and heir, at the age of 24 , as was found by an inquifition then taken $(v)$.

In the next reign, the entire barony of Mitford was in the poffelion of

Adonar de Valence (w), Earl of Pembroke, who apprehended Sir. William Wallaje, of Cragy, the famous Patriot of Scotland, in February,

Calverdon-Valens, High Callcrton, Darre's Hall, Ovington, Brenkley, Preftwick, BarwickHill, Caldcote, North Milburn, South Milburn, Elfehet, Bokenfield, Horton-Grange, Felton cum membris, viz. Thrifton, la Hazaunt, Swarland, Overfgares, parvam Felton, Acton, Glantley, Framlington, et parvam Framlington, per vi feod. et tres partes unius feodi, veteris feofłamenti.

Efcaet. de anno i K. Ed. I.

(v) Robertus de Stoteville in com. Northumbr. die quo obiit apud Mitford, die Sabbati in vigilia Pentecoftes, anno regni Edvardi triceffimo quarto, tenuit caftrum de Mitford, et quinqueginta acras terræ arabilis in campo ejufdem, et duas partes foreftæ de $F_{e l l t o n}$, ratione Eleanorce de Stanour, quæe fuit uxor ejufdem, quæ quidem Eleanora dictum caftrum, cum terra et forefta ejufdem, habet de dono Dominæ Eleanore quondam Reginæ Anglix, matris regis Arglia qui nunc eft, tenend. fibi et hæredibus fuis in capite, per fervicium faciendi fectan ad com. Nortbumbr. Et idem caftrum, cum terris arabilibus, et cum ageftimentis paft. duarum partium furefte pradictre, valent per annum in omnibus exitibus $35 \mathrm{~s}$. Filius prædicti Roberti et Eleanor a eft propinquior hxres predictæ Eleanor a de terris et tenementis prædictis, et elt ætat. anno 2.4 .

Efcaet de anno $34 \mathrm{Ed}$. I.

(w) Adomar.

Odomare.

Aner. 
1305, by the treachery of Sir William's countrymen, Sir Jobn Monteith, and others, his intimate friends $(x)$.

Adomarus de Valent:a, nuper ccmes Penzbroclice, tenuit die quo obiit in domirico fuo, tt de feodo, manerium de Mitfurl in conn. Northumbr. de Dom. Rege in capite, per fervicium

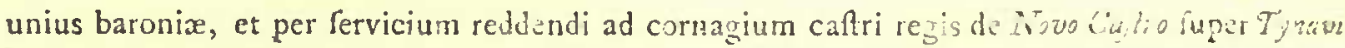
per annum xxxis. ivd ad duos feftos S:nnsti Cuthberti per equales pariones.

Eft apud Mitford fitus cujufdam cafri, et valet per annum modo nihil, quod omnino ef deftrula et combufta.

Solebant effe ibidem diverfi liberi tenentes, qui folelant tenere xxxvi acr. terre, et reddere pro qualibet acr. per ann. ivd. ob. ad terminos fancti Martini et Pintico, his, per eciual,s portiones; et modo nihil reddunt, quia prædictæe terræ omnino jacent vaftre et incultie.

Item, funt ibidem alii liberi tenentes, qui modo reddunt iis. $i d$. ad terminos prodialas, et duas libras piperi", duas capones, et octo ferra equina.

Et folebant efie ilidem diverfi burgi, qui tenuerunt diverfa burgagia, et redalere per annum iv $1 . x$ s. et modo non reddant in toto nifi xxxis. per annum, ad terninos prædictos.

Item, placita et perquifita curie mancrii predjicti et pertinen. Colebant valere per annum tempore pacis vis, viils. et modo nihil, propier inopiam tenentium, et de?tructioncm Scotorun.

Inçuifit. Turri Lonlis. capta apud Krovun Cafrum fuper Tjnam, 13 Sept. 10 Ed. LI.

Adumarus de Valentia, nuper Comes Pimbrochice, fuit feifitus in dominico fun, ut de feolo, die quo obiit, de feodis et advocationibus fubfcriptis in cam. Northunbr. viz. de ferviciis Roberti de Efington, Alicia de Prefon, Alami de Doxford, et hasedum cujufilit qui tenuerunt villam de Framlington de præfats Aliomaro, per fervicium vi s. viii $d$. per annum, ad wardam caftri de Mitforl; et dicta villa folebat valere tempore pacis $x 1$ marc. et modo nihil, pro deftructione Scotorum.

Item, de ferviciis.... de Swethope, qui tenet villam de Betchfeld de præfato Adomaro per fervicium Prioris de Hextsldefiam, qui tenet villam de North Milburn de prafato Alomaro per fervicium vid. per ann. ad vardam dicti caftri; et idem Priar tenet in perpetuam elcmolinan. 
Of this Adomar Valence, Earl of Pembroke, it is recorded, that from the time he fate in judgment, with other lords; on Thomas Earl of Lancafer, there was not one of his fucceffors Earls of Pembroke, to the time of Fobn de Haftings, Earl of Pembroke, $\mathrm{I}_{3} \mathrm{~K}$. Richard II, I390, who ever faw his father, nor yet any of their fathers who could rejoice at the fight of any of their fons, being taken away by death before the happy hour arrived $(y)$.

The Lady Mary de Valence, the third wife of Adomar Earl of Pembroke, Baron of Mitford, was on the fame day, maid, wife, and widow; her hufband, Adomar, being unfortunately killed on

Item, obiit feifitus in dominico fuo, ut de feodo, de advocatione hofpitalis Sancti Leonardi juxta Mitford, quæe valet annuatim tempore pacis lxv s. viii $d$. et modo nil valet per annum propter defructionem Scotorum.

Item, de advocatione capellæ Sancti Cutbbcrti apud le Cutre, quæ valet per ann. tempore pacis Ix s. ct modo nihil propter deftructionem Scotorum.

Efcact. de anno i $7 E d$. II. n. 75. inter feod. milit. Turri Lond.

Adomarus de Valeztia, nuper Comes Pembrochice defunct. tenuit in dominico fuo, ut de feudo, die quo obiit, manerium de Mitforl, manerium de Felton, manerium de Pont Eland, mancrium de Clareerdion, manerium de Merdesfon, cum pertinen. de Dom. Rege in capite.

Et dicunt juratores, quod manerium de Felton affignatum Marie, quæ fuit uxor ejufdem 4komari, in dote.

Et quod quædam pars manerii de Pont Eland affignata eft in dote Maria, quæ fuit uxor predicti Adomari defuneti.

It dicunt, quod fobannes de Hafings, atat. anno 30; Fabanna uxor comitis de Atboll, xtat. anno 26 ; et Elizabetha Comin, foror ejufdem Fobanne, atat, auno i6, funt confanguiur. et propinquiores hæredes prædißti Adomari.

Inquifit. 'Turri Lond. capta apud Novum Ca/rum fuper Tynan coram Folame de Halton, efcaet. Dom. Regis ultra Trentam, die .Iartis xx, anno regni regis Ed. III. 5 to.

(x) Hol. Chron. vol. i. p. 214 .

(y) vol. ï. p.. 467 . 
their wedding-day, in a turnament. She was in her own right Baronefs of Veiffer and. Montenact, daughter of Guy Cbafillon, Earl of St. Paul, in France, and his wife Mary, the daughter of Fobn the fccond Duke of Britany and Earl of Richmond, by his wife Beatrix, the daughter of K. Henry III. She was fo affected with the lofs of her hufband, who made her joint executrix wirl others, that the refigned herfelf entirely to a religious and contemplative life, and beitowed moft of her fortune on acts of piety and charity, raifing her faithful friends above want and indigence, and erecting roble ftructures in honour of religion and learning, with liberal endowments; Denney-priory, in Cambridgefhire, for nuns, of the order of St. Clare, being of her foundation, endowed with the manour of Stroul, in Kent, and other lands; alfo Pembroke-Hall, in Cambridge, moftly finifhed about the year 1347 , and endowed with lands for a warden and fellows, fome of whom the lived to fee preferred to the higheft dignities in England in the courfe of forty years or upwards. She died I th March, 51 K. Edward III, and was interred in her own priory of Denney, under a marble monument, between the two choirs of the nuns and feculars. She furvived her hufband 6I years; part of whofe barony of Mitford was afiigned to her for her life ( $z$ ). His Lordihip's heir's were Fobn de Haftings, Gobanna, the wife of David de Strabolgy, Earl of Atboll, and her fifter Elizabetb Ciminin.

The Earl and Counters of Atboll had this barony, except that part of it which was held by Mary the counters dowager of $P$ entbroke, and St. Paul (a). The Earl dicrl, I K. Edward LI, and was fucceeded by his fon and heir,

David

(z) Vid. Feiton.

(a) David de Strabolgy, nuper Comes Atboll, tenuit die quo obiit ad terminum vitre fux per legem Anglice de hæreditate Fohanne quondam uxoris ejus defunetæ, manerium de Mitford, 
David de Strabolgy, Earl of Atboll, at the age of eighteen; who granted to Fobn de Mifford the manour and lands of Mollgon, near Mitford, 43 K. Edward III ; in which his Lordhip died, and left two daughters, both in their minority, viz. Elizabeth, aged feven ycars, and Fobanna, aged fix years; afterwards married to SirThomas and Sir Ralph Percy, younger fons of the right honourable Henry Lord Percy (b). The younger fifter having no heirs by Sir Ralph, the

ford, cum pertinen. in com. Northumb. de Dom. Rege in capite per fervicium unius baroniz, et per fervicium reddendi ad cormagiun caltri segis de Noos Caftro fuper Tynam Xxxis. iv $d$. pet ann. ad duo.fetta Sancit Cutbierti, per equales portiones.

En apud Mitforld fitus cujufdam caftri, et nilhil valet per mmum, quod omnino cft defruc. tun ct combeftum per Scotos.

Item, funt ibidem liberi tenentes, qui modo reddun: per ann. iii s. i $d$. ad terminos prodictos, et 2 libr. piperis, pretii iii s. et 2 capones pretii iv d. et viii fersa equina, pretii iv $d$.

Item diatus David tenuit dei qquo o'iit per legen Anglia de hareditate predictæ Folanna, ut prædictum eft, terras et tenementa in Moileffen, Eland parva, Culverdon, et Miscrsen, qux funt de pertinen. predicti manerii, de Dom. Rege in capite, per fcrvic. pradilum.

Et dicunt juratores, quod Davila fallius et hæres propinquior prædieti David de Strabslgy, nuper com. de Atbsll, et predictx Ýbanne, et fuit $x$ tat. anno xviii, ad feftum Purficationis buate a arice Virginis, ulimum preteritum.

Inquifit. capto apud Nevum Coffrum fuper Tynom coram Simone de Grimelay, eicaet. Dom Regis ultra Trentam, die Martis xx, polt Diem Dominicum, in R.mis Palmarum, anno regni regis Edvardi, filii Ecoardi regis de Carnarvun, primo.

(b) Davill Le st abolgy, Comes de Atholl, tenuit de Dom. Rege in capite, die quo obiit, manerium et cantrum de Mitford, duas partes manerii de Pont Eland, parva Eland, Mersfen, Milleion.

Et dirunt juratores, quund predictus comes apul Nowton-Hall, die Martis xx, ante feftum

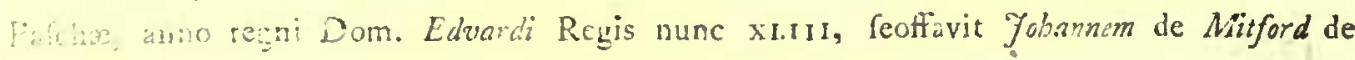
camrab:s terris et tenementis fuis infra villam de Mollefon, tenendis diato Fobanne et haredibus mafculinis de corpore fun le $e_{t}$ itime procreatis de predicto comite et heredibus fuis, per fervic vid. disto comiti et heredibus fuis per fingulos annos folvend. ad feftum Pentecoftes, 
the entire Barony of Mitford, and the Atboll-eftate, came to her filter's fon by Sir Thomas, viz.

Sir Henry Percy, Lord of Atboll, who died, Irth K. Henry VI; and left two daughters and coheirs, viz. Elizabeth, agcd 20 years, and Margaret, aged i 7 years (c). The elieft fifter, Elizabeth, firt

uro onnibus ferviciis et demandis quibufcunque. Et $f_{b}$ contingat prædictum $\mathcal{F}_{0}$ obannem de Mitford obire line haredibus mafculinis de corpore fuo legitime procreatis, tune ominia predicta tenementa et teriæ infra villam de Mo!lefton antedictam, integre dicto conuli et haredibus fuis iemaneant, et remittcntur.

Et dicunt juratores, quod dictus comes obiit 10 die Jan. ultimo preterito. Et dicunt

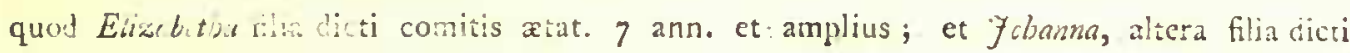
conintio, atat. .... ansplius, funt hæredes cjus propinquiores.

Thi he wri Lond capta apud Morteb xx die Jan. 43 Ed. III. coram Thoma de , elcac dom. re $e_{3}$ in com. Noitiumbr. Virtute brevis dicti regis.

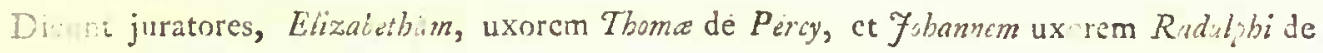

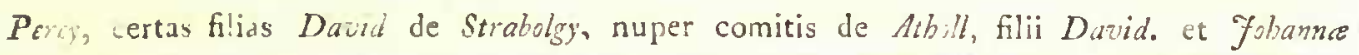
uxoris cjus, confanguin et unius hæred. prædicti Adomari de Vulentia, comitis Pembrocbice. Et dicunt quod El:zabetha eft ætat. ann. 17, et amplius; et dicta Yohanin eft xtat. ann. I4, et amplius.

Inquifit. capta apud Novum Caftrum fuper Tynam, $3^{\mathrm{I}}$ dic Maii, ${ }^{\mathrm{I}} \mathrm{Ed}$. Ill. coram. Fobanne Bygott, efcaet. dom. regis com. Northumbr. Virtute brevis dom. reg. prædicti.

Ex bundello efcaetr. Turri Lond. n. 20.

(c) Hinricus Percy de Atboll, miles, fuit feifitus in dominico fuo, ut de feodo tallia o, fibi et hredibus fuis de corpore fuo exeuntibus, de caftro et manerio de Mitford, cum warda caftri de Framlington, Eaft Aldworth, North Milburn, et villis dc Pont-Eland, parva Eland, Caluerdon-Darreyne, Merdesfon, et vi d. redditus in Mollefano

Et dicunt juratores, quod dictum caftrum et manerium de Mitford, nil valent per annum, ultra reprifas, quia ruinofa et vafta; et quod tenentur cum omnibus membris et pertinentibus de dom. rege in capite per fervicium reddendi dom. regi per ann. pro eornagio xxxis, iv $d$. ad duo fefta Sancti Cutbberti, et pro fervicium duorum feod. milit. integrè.

Et dicunt, quod Elizabetha, uxor Thome Burgh, una filiarum prædicti Henrici, et Margareta altcra filiarum ejufdem Henrici, funt propinquiores hæredes ipfius Henrici. Et dicunt, 
married Thomas Brough, Efq; by whom the had one fon, Thomas. She afterwards married Sir William Lucy, Knt. She died 28 th Sept. 34 K. Henry VI; and was fucceeded in her mediety of the Barony of Mitford by her fon and heir Thomas Brough, Efq; at the age of 24 (d). The younger fifter, Margaret, firft married Sir Henry

quod Elizaletha eft ætat. ann. xx, et amplius; et quod dicta Margareta eft ætat. ann, xvii, et amplius.

Inquifit. capta apud Novum Caftrum fuper Tynam 10 die Octobris, I I Hen. VI. coram Roberto de Whelpington, Efcaet. dom regis in com. Northumbr.

Ex bundello Efcaetr. Turri Lond. n. 37.

(d) Elizabetha qua fuit uxor Williemi Lucy, militis, obiit feifita in dominico fuo, ut de feodo talliato, fibi et haredibus fuis de corpore fuo exeuntibus, de medietate caftri et manerii de Mitford, cum pertinentibus, ex dom. Fohanne Lincoln, et Walter Topcliffe, facta Elizabetha, nuper uxori Thome Percy, junioris, et hæredibus de corpore ipfius Elizabethe exeuntibus; cujus quidem Elizabethe dicta Elizabetha Lucy fuit confanguinea et una hæres de corpore ipfius Elizabetha Percy per prædictam Thomam Percy, legitime procreata, viz. una filiarun et hæredum dom. Henrici, filii et hæredis dictæ Elizabetha Percy, hæredis prædicti Thome legitinis procreatx.

Et dicunt juratores, quod dictum caftrum integrum nihil valet ultra reprifas, quia ruinofum eft et vaftatum.

Et dicunt quod eft in eodem manerio integro unum claufum, cum gardino, circa diktum caftrum, quod valet per annum in herbagio, ultra reprifas, vi s, iv $d$.

Et dicunt quod funt ibidem in eodem manerio integro xxvs. iv $d$. de redait. burgag. Fohannis Mitford, folvend. ad fefta Pentecoftis et Sancti Martini in hyene xquis portionibus. Et eft ibidem in eodem manerio integro de libera ferma Fohannis Mitford, cum. redditû fuo vi $d$. per annum pro villa de Mallefon, cum novo incremento xiii s. iv $d$. ob. folvend. ad coldem terminos.

Item dicunt, quod predicta Elizabetha obiit feifita de advocatione hofpitalis Sancti Leonardi juxta Mitford, quod valet per annum xxs. et de advocatione capellæ Sancti Cutbberif fuper Coufe, quxe valct per annum $x$ s. 


\section{ANTIQUITIES OF NORTHUMBERLAND.}

Henry Grey, Knt. Lord Grey, by whom the had one fon, Henry. She afterwards married Sir Richard Veer, Knt. She died, 24 Sepiember, 4 Edward IV; and was fucceeded in her medicty of the Barony of Mitford by her fon and heir, Sir Henry Grey, Knt. Lord Grey, at the age of 28 ycars (e).

Et dicunt quod dista Elizabetha obiit xxviii die Scptembris, ultino prateito. Item dicunt, quod Thomas Burgh, arm. eft filius et hares propinquior diate Elizabcthe per Timam Burgh, Arm. nuper virum fuum, de corpore fuo ligitime procreatus, et eft xtat. anno xxir, et amplius.

Inqquifit. capta apud caftrum dom. reg. apud Noum Cafrum fuper Tynzm, 29 die Octobris, anno $34 H_{i n}$. VI. coran Riberto de Belfoy, efcact. dim. regis in com. Nortbumbr. Virtute brevis pradicti regis.

Ex bundello efcaet. 'Turri Lond.

(e) Margareta, quæ fuit uxor Ricardi F'cer, militis, et quondam uxor Hentiai Grey, militis, obiit feifita in dominico fuo, ut de fcodo talliato, viz. fibi et haredibus fuis de corpore exeunt. de medietate caftri et mancrii de Mitford, cum pertinentibus, ex dom. Fobanne Lincoln, elerico, et Wilter Topelife, inde facta Elizabethe nuper uxori Thoma Percy, junioris, harcubus de corpore ipfus Elizabetice cxcuntibus, cujus quiden Elizalethe Percy dicta Margarea fuit confanguinea ct una haredum de corpore ipfius Elizabtha Percy per pradian THomam Percy legitime procreata.

Et dicunt juratores, quod dictum caftrum integrum nihil valet per annum, ultra reprifas, quia ruinofum et vaftatum eft. Et dicunt quod eft in eodem mancrio integro unum claufum, cum gardino, circa dictum caftrum, quod valet per annum in herbagio, ultra reprifas, iii s. iv $d$.

Item dicunt quod pradicta Margarta obit feifita de advocatione hofpitalis Sancti Leonardi de Mitforl, quæ valet per annum xx s, et de adrocatione capolia Sanci Cutbirti fuper le Caufe, qux valet por annum xls.

Item dicunt quod dicta Margareła obiit xxiv dic Septembris, ulrimi pratcriti. Et äicunt quod Henricus Grey', miles, Dominus Grey, eft filius et hæres propinquicu prodicta Ma'garetce per Henricum Grey, militem, Dominum Grey, quondam virum pradictx Margarete, de corpore fuo legitime procreatus; et eft atat. anno xxviii, et amplius.

Inquifit. capta apud Mroreth, 5 dic Julii, 5 Ed. IV. coram Simone de W'elien, Efcaet. dom. renis com. Northumbria.

Ex bundello efcaetr. Turri Lord. n. 30. 
The caftle and manour of Mitford were in the poffeffion of Lord Brongh, in the reign of K. Henry VIII. $(f)$; and of

William Lord Brough, 4 Q. Mary, who in that year granted to Cutbbert Mitforl, and to his fon Robert, for cver, all his lands at Mitford, referving only to himfelf the fite of the caltle, and the royalties $(g)$; which cafte and royalties were in the crown in the jeign of K. Fames I, who granted them to

Fames Mnray, Earl of Amun (b); and being in the crown again in the reign of $\mathrm{K}$. Charles II, they were granted by his majefty to

Robert Mitford, Ef,; (i). He married Fane, the daughter of Fohn Mitford of Seghill, Efq; by whom he had three fons, Cutbbert, Folm, and William; alfo four daughters, viz. Barbara married to George Fenwick, of Long Sbarves; Eleanor, to Daniel Collingwood, of Brampton; Margaret, to Nicbolas Heron, of Meldon; Ifabell, to Richard Rowmotberley, Efurs. His fon, William, was fellow of Clare-ball, in Cambridge, and afterwards rector of Kirby-over-carr, in Yorkfoire. His fecond fon, Folon, lived at Mitford. He was fucceeded by his cldeft fon and heir,

Cutblert Mitford, Efq; who married Mary the daughter of Chriftopher Wharton, of Offerton, in the county of Durbam, Efq; by whom he had one fon, Robert. They both died in one day at Mitford. Their fon and heir,

Robert Mitford, Efq; married Pbiladelplia one of the daughters of Humpbrey Wharton, of Gillingrvasd, in Yorkfire, Efq; by whom

(f) Lel. Itin.

(b) Carta Jac. I. (g) Carta Dom. Gulielmi Brough.

(i) Carta Car. II. 


\section{ANTIQUITIES OF NORTHUMBERLAND.}

he had feven fons and fix daughters; viz. Humphrey, Cuthbert, Folnn, Edward, Robert, William, Micbael,---Barbara, Mary, I'biladelpbia, Ann, Eleanor, Elizabeth. He was fucceeded by his eldeft fon and heir,

Humplorey Mitford, Efq; who married Francis the daughter of Sir George Vane, of Long Neruton, in the Bihhoprick of Durlaam; by whom he had

Robert Mitford, Efq; who was high Mheriff of Nortbumberland, 9 K. William III, I697; and was fucceeded by his fon and heir,

Robert Mitford, Efq; the prefent poffeffor of the cafte and manour of Mitford, who was high theriff of Nortbumberland, $9 \mathrm{~K}$. George I, $1723(k)$.

The cafte ftands in the park, on a mount, the rork and labour feemingly of art. It was burnt, together with the village, by King Fobn's choice fpirits, the bucks, 7 January, 1216; fo called from Walter Buck, and Falques de Bient, two commanders of his German troops. The laft was a profligate facrilegious fellow, and afterwards banifhed the kingdom. The other, Walter Buck, had for his better manners, better fortune. He had lands given him by that King in Korkfhire, and Northamptonfhire, where his ponerity flourifhed down to Gobn Buck, who was attainted in the reign of King Henry VII. Matthew Buck, Efq; was fettled at Winterburn, in Gloucefterfbire, whofe fon, Fames Buck, inheriting the military fpirit of his family, was in the fervice of King Charles I. in Treland, and was honoured with a coat of arms, of which I have the original manufcript-grant, illuminated with painting.

(k) Vid. Mollefon, alias Mojeden. 
It was fortified by Sir Gilbert de Middleton, and Walter Sclby, to K. Edward II, I3I7, then in arms againft their fovereign, with the Scots. 'They were both feized in it, in that year, by the king's order, by Ralpb Lord Greyftock, Sir William Felton, and Sir Alan Heton, at the head of a large body of forces, who demolifhed it, and fent their two prifoners to London, where they were tried, and exccuted (l).

Mr. Mitford's feat is by the river, the ruin of the caltle and park before it to the fouth, ftored with deer. Near it is the church, the impropriation and advowfon of which were granted by $\mathrm{K}$. Edward I, May I7, and $35^{\text {th }}$ year of his reign, I289, to the priory of Laner-coaf, in Camburland ( $m$ ). In the chancel is a large mural monument of frectone erefted over the tomb of one of the Bertrams, with his coat of arms in a concave fquare molding, with

(l) Hol. Chron. Vol. ii. p. 323 .

Lel. Itin. Vol, vii. p. 6 c.

(m) Rex omnibus, \&c. falutem. Sciatis quod ob devotionem fpecialem quam erga beatam Marian gerimus et habemus, nee noyr et retentionem ftatus prioratus de Laner-conf, qui in honore cjufdem Sanctæ in marchia regni noftri Anglia, et tenuræ Scotice fundatus exiftit, et qui per combuftionem domorum, ct deftructionem bonorum ejufdem prioratus per $S$ cotos nuper inimicos, et rebelles noftros, ac ctiam per diutinam moram quam in prioratu prædicto nuper fecimus, adverfa corporis valctudine, dedimus ct concedimus dilecte in Chrifto priori et conventui prioratus prælicti ecclefiam de Mitford, in com. Northumbr. et eclefiam de Carleton, in. com. Cunbr. prodicto de prioratu moftro habend. tenend. pradicto priori et consentui et fuccefforibus fuis in perpetuum; et conceffimus iis pro nobis et hæredibus noftris quod ipfi ecclefias illas frbi ct fucceffuribus fuis in proprias ufus in perpetuum pofidendas appropriare, et cas fic appropriatas tenere poflent fibi ct fucceforibus fuis in perpetuum, fine moleftatione vel impedimento noftrorum hæredum, noftrorum jufticiar. efcaetr. aut aliorum Balivor. miniftror. noftrorum, quorum cujufqùe. In cujus rei teftimon. prædictus rex apud Baliolum, 17 dic Maii.

Per ipfum regem munc Covent. et Ricardo epifcopo.

Pat. 35 [d. I. m. 25 . 


\section{ANTIQUITIES OF NORTHUMBERLAND. 325}

- this infcription below it, in capitals of a middle fize, fair, and well cut.

Here,lyeth interred within this molde a generous and virtuous wight, whofe dewe deferte cannot be told, from flender fkil unto his right, He was defcended from a race of Worthipful Antiquitie. Loved he was in his life-fpace, of high eke of low degree. Reft Bartram in this houfe of clay reuf'ley unto the latter day.

Underneath is his effigies cut on the fonc-cover of his tomb, in relief; his hands lifted up, in a praying polture, and on the edge: of it thefe lines, in capitals.

Bartram to us fo dutiful a fon, if more were fit, it thould for

Thee be done, who deceafed. the 7 of October, Anno Domini, I622.

The villa is parted by the river, and is croffed on the north: fide, near the turnpike-gate, by a new ftone-bridge, of one arch. It was antiently croffed by one higher up, leading to the church and caftle, called, the South bridge, and Foufebrigg, for the watching of which on the eve and on the day of the Afcenfion of our 
Bleffed Lord, Walter de Swinbowe held forty acres of land within the manour of Mitford, 5 I K. Edward III (n).

Near the villa, on a hill, is

The Spital, which was antiently an hofpital, called, Mitfordhofpital; founded and endowed with lands for one chaplain, in honour of St. Leonard, by Sir William Bertram, Baron of Mitford, the founder of Brenkburn-Priory. It was found by an inquifition, 47 K. Edward III, that the lands belonging to it were in poffeffion of the abbot of Nezu-minfler (0); but they were reftored, I K. Edward II, by that king, who appointed Foln de Wendbugs, junr. to be chaplain of it $(p)$.

\section{At a fimall diftance from Mitford, is the villa of}

(n) Dicunt juratores fuper facrum, quod Walter de Swinbowe tenuit in manerio de Mitford $\mathrm{xl}$ acras terræ per fervicium cuftodiendi pontem auftralem de Mitford, vocat. Foufebrigg, in vigilia et die Afcenfcionis.

Efcact. de anno 5 I Ed. III. n. 20.

(0) Dicunt juratores fuper facrum, quod Dominus de Mitford, qui de dom. rege tenuit in capite mancrium de Mitford, dedit et conceffit diverfas tcrras et pertinentes ibidem ad inveniendum unum capellanum divina celebraturum in capella ibidem; invenitur guod abftrahitur pro longo tempore. Et dicunt quod Abbas de Novo Monaferio occupat terram et pratum, et valent per annum xxs. \&ic.

Inquifit. capta apud Corbrige coran Willielmo de Errington, efcaet. dom. regis in com. Nortbumbr. 25 die Jun, 47 Ed.III. Ex bundello efcaetr. Turri Lond. n. 84 .

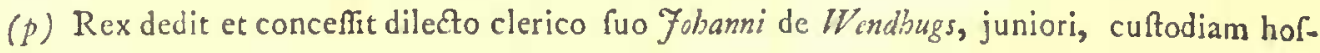
pitalis de Mitford, quod ad regem pertinet rationc cuftocize terre et hered. David. de Strabolgy, nuper conitis Atholl, defuneti, qui de dom. rege Edvards, nuper xege Anglie tenuit in capite, habendam ad totam vitam ipfius Fohannis, cum fuis juribus, et pertinentibus quibufcunque. In cujus rei teftimonium has literas noftras fieri feci per patentes; tefte rege Ricardo fecundo apud caftrum fuum de Wyndefore, xi die Auguft, anno regni noftro primo.

Septembre, de privato figillo.

Pat. I Ric. II. n. 20. 
Mollefon (q), the manour of which was granted by the fecond Divid de Strabolgy, Earl of Atholl, and Baron of Mitford, $43 \mathrm{~K}$. Edward III, to Sir Folnn de Mitford, Knt. defcended from Matthew de Mitford, younger brother, of Sir Fohn de Mitford, whore only daughter and heir at the conqueft married Sir Richard Bertram, before mentioned. He was high theriff of Nortbumberland, $3 \mathrm{~K}$. Henry IV $(r)$. He died, I 6 July, I Ith of that reign; and was fucceeded by his fon,

Willian de Mitford (s), who married Margery the daughter of Sir Robert Lifle, Knt. and was high theriff of Northumberlanl, 5, $6 \mathrm{~K}$. Henry V ( $t$ ). He died, I K. Henry VI; and was fucceeded by his fon and heir,

Fobn de Mitford, at the age of 2 I years, born 8 April, $30 \mathrm{~K}$. Henry IV. I 402 (u). He was a bencfactor to the abbey of Neru-

(q) Mollefton. $\operatorname{minffer}$.

Mollefden.

Moreden.

(r) Efcaet. de anno 3 Hen. IV. n. 2r:

(s) Fobannes de Mitford, Chr. obiit feifitus in dominico fuo, ut de feodo talliato, viz. fibi ct hæredibus fuis mafculis de corpore fuo legitime procreatis, de manerio de Mollefon, cum pertinentibus, et valct per annum centum folidos ulera reprifas.

Item dicunt juratores, fuper facrum, quod idem Gobannes obiit xvi die Julii, ultimi præteriti. Et dicunt quod Willielmus de Mitford cit fillius et hæres ejus propinquior, et eft ætat. anno xl, et amplius.

Inquifit. capta apud Novum Caffrum fuper Tynam, coran Roberlo de Herbord, efcactore dom. regis in com. Nortbumbr. die Veneris xx, ante feftum Apoftulorum Sinnonis, ct fudde, xi Hen. IV.

Ex bundello efcaetr. Turri Lond. n. 26.

(t) Efcact. de annis, 5, 6. Hen. V. n. 3 I, et n. 37 .

(u) Willielmus de Mifford, Arm. obiit. feifitus in dominico fuo, ut de feodo talliato, viz. fibi et bæredibus mafculis de corpore fuo legitime procreatis, de manerio de Mollefon, cum 
minfer. - He gave certain tenements in Nerucafle upon Tyne to the chantery of St. Thomas, in the church of St. Nicbolas, in that town. He died, 6 May, 35 K. Henry VI; and was fucceeded by his fon and heir,

\section{Fobn de Mitford, then 24 years of age $(v)$. He was fucceeded by}

pertinentibus, ex dono et fcoffamento David de Strabolgy, nuper comitis de Atboll; in quo manerio eft quoddum meffuagium capitale, vocatum Mollepon-Park, \&c.

Et dicunt juratores fuper facrum quod obiit feifitus quadam claufa, vocata Ifehaugh, in Mitford, continens in fe xvi acras terræ, quarum quælibet acra valet per annum i $d$. et $\mathbf{x x x}$ acrasterræ, vocatæ Cafle-Land, in eadem villa, quarum quælibet acra valet per ann. $\mathrm{j} d$.

Et dicunt quod diqum manerium et terræ, tenentur de rege in capite per fervicium $\mathrm{xl}$ partis unius feodi militis, et redditus Henrico de Percy, Domino de Mitford, vi d. perann.

Item dicunt, uxorem fuam, Margeriam, filiam effe Roberti de Lifl, Chr. adhuc fuperftitem.

Et quod idem Williclmus obiit 7 die ultimi præteriti, anno I Hin. VI. Et quod Yohannes de Mitford, filius dicti Williclmi et Margeria, eft hæres propinquior; ct fuit atat. anno 21, 8 die Aprilis ultimi præteriti; quia dicunt quod idem Fohannes natus fuit, 8 die Aprilis, anno dom. 1402 , anno $30 \mathrm{Hctz}$. IV.

Inquifit. capta apud Nocum Caftrum fuper Tynam, coram Fohanne Chefre, efcaetore dom. regis in com. Northumbr. ro die Junii, anno I Hen. VI.

Ex bundcilo efcaetr. 'Turri Lond. n. 40.

(v) Fabannes de Mitford obiit fcifitus in dominico fuo, ut de fcodo, de manerio de Mollesien, cum pertinentibus, com. Nortbumbr. Sxc. pro fervicio xl partis unius feodi militis, et reddendo hæredibus Henrici Percy, Dom. de Mitford, defuncti, annuatim vi d.

Et dicunt juratores, fuper facrum, quod dictus Johannes obiit feifitus in dominico fuo, ut de feodo, de uno capitali mefluagio in Mitford, et xxviii alia mefuagia, et de cviii acris terræ, et $\mathrm{x}$ acris prati, cum perinentibus, quæ tenentur de hæredibus prædicti Henrici Percy in foccagio, viz. pro fervicio et fidelitate tantum.

Et dicunt quad prædictus folhannes obiit 6 die Maii ultimi præteriti ; et quod Fohannes Mitford eft filius dicti $\mathcal{F}$ (hannis $M$ tford, et hæres ejus propinquior, et eft ætat. anno 24, et amplius.

Inquifit. capta apud Bywell, coram Ricards'Corlrigg, efcaetore dom. regis in com. Northumbr. die Jovis, 21 die. Octobris. 


\section{Bertram de Mitford, father of}

Gawen de Mitford, who married the fifter of Sir Thomas Forfer, of Etherfon, Knt. He was fucceeded by his fon and heir,

Cuttbbert de Mitford, to whom Fobn de Widdrington granted, ${ }_{4} \mathrm{~K}$. Edward VI, his tenement and lands in Mitford, called, our Lady's lands, from their being part of the poffeffions of New-minger abbey. He was one of the commiffioners for enclofures upon the middle marches, th of the fame reign $(w)$. He was fucceeded by his fon and heir,

Robert de Milford $(x)$, who acquired the caftle and maroun of Mitford by a grant from K. Charles II, as before mentioned ( $y$ ).

About three miles to the eaft of Morpeth, is

Bothall ( $z$ ), which was the barony of a younger branch of the Bertrams, Barons of Mitford; of Sir Robert Bertran in the reign of

(w) Bifhop Nicholjon's Border-Laws, p. 532.

Cutbbertus Mitford fuit feifitus de et in Mitford, Mofedsn, et Eftley, cum terris in Ifehaugh, et High Callerton.

Efaret. de anno 10 Lit.

(x) Robertus Mitforl, filius Cutbberti, tenet de rege, ut de manerio de Mitford, per ferviçium milit. iv meftuagia et terras in Mitford, et Newton-Underzucod, ac reverfiones villarum de Mollefden, et Eppley.

Eicaet, de anno ${ }_{14}$ Car. I.

(y) Vide Aritford.

(z) Botball.

Bothell.

VoL. II.

$\mathrm{U} u$

K. 
K. Henry III (a); of Sir Roger Bertram, I K. Edward I (b); and of another Sil Robert in the reign of K. Edward III, who by permiffion from that king built the caftle of Botball. His daughter and heir, Eleanor, married Sir Robert Ogle, of Ogle, Knt. whofe pofterity enjoyed this barony through a long fuccefion. In the contefts between the two hou fes of York and Lancafter, Sir Robert Ogle, Knt. bcing an affiduous and zealous friend to the former, was created Lord Ogle; and the fourth in defcent from him, Robert Lord Ogle, married Anr the daughter of Sir Thomas Lumley, Knt. by Elizabetb Plantagenet, daughter of K. Edward IV, by the Lady Elizabetb Lancy.

Cutblbert, the feventh and laft Lord $O g l e(c)$, was poffefled of a large fortune in this county. He married Catbarine the daughter and cohcir of Sir Reginald Carnaby, Knt. by whom he had two daughters, Fobanna and Catharine; the former married to Edward Talbot, Efq; younger fon of the Earl of Sbrewsbury; the latter to Sir Charles Cavendifls of Hellbeck, in Nottinghamflire, Knt. and by let-

(a) Robertus Bcrtram tenet in capite de dom. rege baroniam fuam de Botbell per fervicium trium feodor. milit. et omnes anteceffores fui per eund. fervicium tenuerunt de antiquo feoffamen:o; eft mortuus, ac hæres cum fratre in manu regis. Et de illo tenemento nulla eft alienatio, feu donatio, unde dom. rex minus habeat de fervicio fuo.

Tefta de Nevill.

(b) Rogerus Bertram, de Bothell, tenet in capite de dom. rege Bothell, et advocationem ecclefix de Botbell et Shipwafh, Whetworth, Nova Mora, Pigsworth, Hetburn, Cockley-Park, Fenrother, Tritlington, Erifden cum le foreft, Calcey-Park, Langhirf, Old Moor, et Eßhenden, per tria feoda milit. veteris feoffamenti.

Efcaet. de anno I $E d$. I.

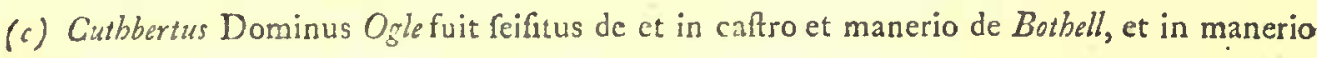
et villa de Heppel, de et in manerio ct villa de Ogle, Sbilvington, et Saltwick, de et in Shilbottle, Hirf, Long-birf, Hoblurn (juxta Mortcth), Fenrother, Erifden, Erifden-Foref, et Twygle (juxta Pont-Elan!), ac de ct in villa de Magna Tofjen, et parva Tofjen, cum medietate de Lowerbottle, et villa de North Middliton, cum turris in Sharperton, Warton, et tota villa de Flutterton. Efcaet, de anno ro Eliz. 


\section{ANTIQUITIES OF NORTHUMBERLAND.}

ter's patent was created Baronefs of Ogle. Her fon Sir William Citvendifh, was made Knight of the Bath at the creation of Henry Prince of Wales, $8 \mathrm{~K}$. Fames I, 1610; Baron Ogle, of Ogle, and Vilcount Mansfield, 18 th of the fame reign; Baron Bertram and $\mathrm{Bel}-$ fover, and Earl of Nerwafte, 3 K. Charles I; Marquis of Nerwecfle, Ith of the fame reign; Earl of Ogle, and Duke of Nerwafle, I6 'K. Charles II, 1664 ; to whom he had the honour of being governor, and Thewed himfelf worthy of royal favour, and of the friendhip and confidence of a king. When fo many were wanting in their duty to his old mafter, K. Cerarles I, he ftood by him with his life and fortune, put Newcafle, and the caftle and harbour of Tynemouth, in a ftate of defence, raifed a regiment in Nortbumberland at his own charge, confifing of a $1000 \mathrm{men}$, the officers of the beft families. He engaged and defcated the parliament forces under Lord Fairfax at Atberton-Moor, near Bradford, in rorkfjire, took all theirartillery, 22 cannon, and many colours and ftandards. Which victory fo frightened his majefty's enemies, that by an embaffy they invited and previailed with the Scots to come into England and join them, in extreme frofty and fnowy weather. At the battle of Marfon-Moor, he was at the head of his Nortbumberland regiment, where he had the mortification to fee it deferted by the horfe, yet fuch was their ardour, fuch their courage and magnanimity, that to a man they difdained either to fly from, or afk quarter of, the parliament-forces, but fuffered themfelves to be cut down by heaps, rank and file, as they ftood. Their regimentals were white, which made them to be called, WhiteConts. A colour worthy to diltinguifh fuch godlike fouls!

After this battle, the Iord Marquis of Nerucofle, his two fons, and his brave brother, Sir Cbarles Cavendifib, who was a man, fay's my Lord Clarendon, of the noblen and largent mind, though the leaft and mon inconvenient body that lived; General 
King, Lord Falconbridge, Lord Widdrington; the Earl of Cornwath, the bifhop of Londonderry, Sir Edward ITiddrington, Colonel Carnaby, Colonel Baffet, Colonel Mazen, Sir William Vavafour; Sir Francis Mackworth, and about eighty more royalifts, determined to go beyond fea, and landed at Hanburgh.

The eftates of the lord marquis were put under fequeftration, and fome of them fold, among which was the manour of Flawboilush, in Nottinglangfire, 1647. He was one of the feven perfons excepted from pardon.

After the reftoration, I3th K. Cbarles II, I661, in May the marquis retired in full favour from court to his feat at Wellbeck, on which occafion he received the following very handfome congratulation, in an epiftle dedicatory to a fermon, preached at Oxford on the 2yth of the fame month, by his chaplain, Mr. Clement Ellis (m).

"With much pleafure I have hearkened to you difcourfing of "that fatisfaction you reaped from that fweet privacy and re" tirement his majefty is pleafed to grant your lordhip here in "the country, where you live free from the noife and cumbe" rance of court and city. Indeed, the greateft reward his ma" jefty can poffibly recompence your fervices withal, is thus " to beftow yourfelf upon yourfelf, and I know you think it greater " happinefs to enjoy my lord marquis of Nerwcafle at Wellbeck, than "all the offices and honours which your exemplary loyalty has " merited. And there is all the reafon in the world for it, that " he who hath fo nobly facrificed the faireft of his years, and the " ampleft of his fortunes, to the fervice of his king and country,

(m) Printed at $O x f o r d$, 4to. 166 s.

" Thould 


\section{ANTIQUITIES OF NORTHUMBERLAND.}

"Should now have leave to confecrate the remainder to his " health and guiet."

At Wellbeck his lordhip enjoyed the fociety and the labours of the wife and the learned. Robert Sheringham, the famous antiquarian, infcribed his book or differtation to him-De Anglorum Gentis Origine ( $n$ ).

The Lord Clarendon has drawn his character in colours that caft a luftre on his name.

"He was a very fine gentleman, ative and full of coumge, " and molt accomplifhed in thofe qualities of horfmanhip, " dancing, and fencing, which accompany a good brecding, in "which his delight was. Befides that, he was amorous in poetry "and mufic, to which he indulged the greateft part of his time; "and nothing could have tempted him out of thore paths of plea"fure, which iac cujoyed in a full and ample fortune, but ho" nour and ambition to ferve the king when he faw him in dif"trefs, and abandoned by molt of thofe who were in the highen " degree obliged to him and by him. He loved monarchy, as it "was the foundation of his own greatnefs; and the church, as "it was weil conflitured for the fplendour and fecurity of the "crown; and religion, as it cherihed and maintained that or"der and obedience that was neceffary to both; without any " other paffion for the particular opinions which were grown up " in it, and diftinguifhed it into parties, than as he detefted what" ever was like to difturb the public peace."

His lordinip's only daughter and heir married Fobn Holles, duke of Nerucafle, who died by a fall from his horfe, isth July, I7rr.

(n) Cantabr. 8vo. 1670. 
His Grace's only daughter and heir, the lady Henrietta Cavendifh Holles, married the right honourable Edward Earl of Oxford and Mortimer on the laft of Auguft, I7r3, with whom his lordfhip had a large perfonal fortune, befides the baronial honours and eftates in this county, her mother's dowry, which devolved to their only daughter and heir, the Lady Margaret Cavendifs Harley, married, it th July, 1734 , to his Grace William Duke of Portland. He was knight of the moft noble order of the garter, granted only at the coronation of a king, or queen, or inftallation of one of the royal family, except on extraordinary occafions, as in the cafe of T\%mas Nevill, Efq; fpeaker to the houre of commons, brother to the Lord Abergavenny, who for his wife conduct and cminent fervices in that houfe, had that high honour conferred upon him in full parlianent, $7 \mathrm{~K}$. Henry VIII, I5 I6; no fubject before hin having it out of the common courfe 0 ). His Grace was fucceeded in honour and eftate by his eldeft fon and heir, now the moft noble Duke of Portland, owner of the baronial cafte and Lordfhip of Bstball.

Only an old tower is now flanding of the cafle, large and ftately, througl which has been the grand entrance. On the north front are the arms of its antient barons. On the fouth and fouth-eaft fronts are feveral plants, femperives, ivy, wallflowers, alfo feaverfew, pellitory of the wall, and the fimburus or flowering elder. It ftands on an agreeable mount, on the north fide of the winding trout-ftreams of the Wanbeck, gliding between pleafant meadows, and hanging woods.

Near it is the parochial church. It has three handfome ines; the pulpit well placed, againf the north pillar, on entering the

(0) Qund nemini mortalium, per ulla ante fecula, contigife audivimus.

Parliam. Journal. chancel; 
chancel; the lights neat, and part of them adorned with painting, and the walls very folemn with feripture-fentences, in neat black frames; the pews but indifferent. The roof is covered with lead. In a fmall fteeple are three bells, one of them cracked; and, hard by, is the veftry. At the eaft cnd of the fouth ifle is a handfome tomb, within iron-rails, of alibafter, over one of the barons of Ogle and Bothall, and his lady, recumbent; their hands and eyes elevated. His lordhip's head and feet reft upon the fupporters of his coat-armorial; a lyon under his feet; a chain of many links round his neck, with a pendent crofs. Under her ladyfhip's head is a cufhion, and another under her feet, with two cherub-like babes lying by her, one on each fide at the end of the cuthion, near her face, each holding in its hand a taffel of the cufhion; the head of one broken off; a dog by her feet, with a chain about its neck, the emblem of watchfulnefs.

On the fouth fide of the chancel, is the following mural geneological table, in the old black character, of the Ogles, barons of Ogle and Botball.

"Humpbrey Ogle, Efq; lived at Ogle-caftle at the conqueft, to whom "William the Conqueror, by his deed, without date, did confirm all " his liberties and royalties of his manour and his eftate of Ogle, in " as ample a manner as any of his anceftors enjoyed the fame be"fore the time of the Normans.

" From Humphrey Ogle, Efq; did defcend feven lords and thirty " knights.

"Robert, the firft Lord Ogle, married Ifabel, daughter and heir : " of Alexander Kirkby, knight. 
$33^{6}$ ANTIQUITIES OF NORTHUMBERLAND,

"Owen, the fecond Lord Ogle, marricd the daughter of Sir Willian " Hilton, knight.

"Ralph, the third Lord Ogle, marricd the daughter of Sir William "Gafcoign, knight (p).

" Robert, the fourth Lord Ogle, married the daughter of Sir Tho" mas Lumley, knight.

" Rebert, the fifth Lord Ogle, married Mary the daughter of Sir "Cutbbert Lertbram, knight (q).

"Robert, the fixth Lord Ogle, married Fane daughter and heir of "Sir Thomas Mamers, knight, and died without iflue (r).

"Cutbbert, the feventh Lord Ogle, married Katherine, one of the " coheirs of Sir Reginald Carnaty, knight ; (being brother to Robert "the fixth Lord Ogle) who had two danghters, Foan and fotberine."

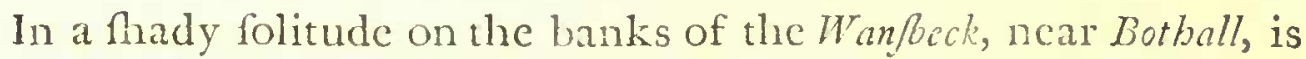
the ruin of an antient chapel, dedicated to the Blefred Virgin. It was built by this illuftrious family of $O_{g} l e$, as appcars by their coat armorial on the wall. The length of it is eight yards, the

(p) Of G izuthorp, comit. Ebor.

(q) The family-pedigroe, communicated by the prefent Duke of Newicafle, afirms, that he firft married Doroiby', daughter of Sir Hesly Wordrington, Kut. and afterwards Fane, daughter of Sir Cutbbert Ratcliff, Knt.

(r) In the fame pedigree, it is faid, that he married fone, daughter and heir to Sir Thomas Melvirer, Knt.

This mural pedigree feems to have been copied by an illiterate hand; I have therefore correated the orthography. 
breadth four, of well-wrought freeftone; the roof of the fame materials, after a curious manner; hardly vifible for trees, which have taken root in the very foundations.

The rectory-houre is about two miles lower down the river, at Shipwafts; fo called from its proximity to the fhipping in the little harbour of Cambois, and the grounds wafhed by the tides; the fituation folitary, under a hady hill; the garden extending to the river, croffed by a bridge of three arches; a road leading from it to Nerwafle; the mother-church faid to have been formerly at this place.

The laft rector was his Grace the prefent archbifhop of York. the honourable and right reverend Dr. Hay Drummond, brother to the right honourable the Earl of Kimnoul, whofe progenitors were ennobled by their glorious military atchievements, recorded in the Scotch annals, and by a late ingenious antiquary of the fame nation $(s)$.

\section{A mile eaft from Shipwajh, is}

Afrington, ( $t$ ), which was one of the manours of the barony of Bothall, and now belongs to George Sandiford Crow, Efq. It ftands on an eminence, well theltered with tall foreft-trees; a fine view from it of the fea, alfo of Seaton-Delaval, and Bebfide, through the openings of the plantations; the grounds loping regularly to a bank of oaks by the river Wansbeck, freeftone rocks confpicuous through them, under which is a fine grafs-area of a mile in

(s) Gordon's Itin. Sept.

(t) Efhenden. Alhington.

VoL. II. 
length by the river, which for all that fpace forms a moft beautiful ferpentine canal, a bank of oaks on the oppofite fide. On the weft fide of a ftreamlet, called the Den-Burn, by a grindlonequarry, the river Wansbeck makes a flexure, where is a beautiful flope, now in tillage, thaded by fpreading oaks and other timber on all fides but to the fouth, the river making another flexure a little to the weft of it, croffed by Shipwafh-bridge, in fight; a boat in it for the ufe of a falmon-fifhery. Mr. Crow's extent of ground by the river from within a fmall field's length of the bridge, or the rectory-glebe, weft, to the Stake-ford, eaft, is about a mile and a half, meafured; thus beautifully chequered with wood, rock, and river-fcenery; a foot-walk by the river the whole length.

About a quarter of a mile eaft from the grindftone-quarry, under a bank of oaks and other trees, clofe to a hedge, is a facred fountain, called St. Margaret's Well, pleafant and foft to the tafte, many of the fmall frefh-water buccine at the bottom; the north fide faced with ftone, natural, and femicircular, coated with mofs, and a thin cruft of earth, in which the primrofe and meadowfreet have taken root, emitting their pleafant odours round it in their feafon of flowering.

By the Stake-ford, is a hamlet, called, the

The Black Clofe, belonging to his Grace the Duke of Portland, where is a coal-work, a fteith, and a fmall fire-engine, fo contrived as to fill a large bafon with falt-water from a fmall refervoir below, overflowed by the ticles, for the ufe of a falt-work, and alfo to draw off water from the colliery. 
Two miles below the Stake-ford, is

Cambois, $¥$ fmall hamlet on the fouthern banks, and at the of tim um, of the Wansbeck, belonging to Mattherw Ridley, Efa; Here the river is ufually called Cambois-Water, and Cambois-Harbour. It is navigable to the Stake-ford for fmall veffels of about 30 tons burthen. There are two keys on the north fide; one called the Low, and the other the High, Key ; the latter on the cftate of Sir Thomas Clavering, Bart. a great export of corn and grindtones firom them, and a confiderable import of Norroy-timber and deals; and of limettone from Bednal, and Sunderland, in boats.

Near a mile north from the harbour's mouth, is a range of cliff's by the fea, called Hawk's-Hugh, from its being the recefs of Hawks in the breeding-feafon; ravens alfo and other birds frequenting it. Towards the north end, is a cavern, very large, with an aperture at the top, ufually called by the mine-men SelfOpens; the refuge of foxes and badgers in their diftrefs by the chace.

A little farther north; by a grindfone-quarry on the fea-banks, called the Spital-Quarry, an wm was found by the workmen in unroofing the quarry, placed between four ftones fet edge-ways, with a cover-ftone, at the depth of three feet from the furface; the urn of red carth, fmall, of the ufual form, bellicd, without any ornaments, left by the incurious finders among the rubbith.

About a quarter of a mile from the quarry, is

Nerubiggen, a marine villa, inhabited chiefly by fifhermen; confitting of one long, irregular ftreet; feveral granaries in it for export from one of the fineft bays before it on the coaft of this county, 
county, formed by two promontorics of freettone-rocks, fpacious, the bottom of fand; corn-fhips, of about fixty tons burthen, coming up to the town; large thips, farther in, riding in five, fix, or feven fathom water, in fecuricy from tempelts, from the north, and north-eait.

On the northern point of the bay, is the veftigies of an old picr; many of the ftones, and fome of the piles of wood, confpicuous at low water.

On the north-eaft fide of the harbour is the church, dedicated to St. Bartbolomew; the middle ine and the fpire only now remaining; a fmall gallery at the weft end; at the eaft end, above the altar-table, is the King's-arms, cut in wood, in high relief, faid to have been the ftern of a thip caft away in a ftorm upon the rocks; one bell in the fpire; the church-yard fmall; a delightful profpect from it.

On the north-eaft fide of it, about 100 yards from the feabanks, in the cavity of a rock, is a frefh-water fpring, called St. Mary's well, acceflible only at ebb-tides.

Two miles north from Newbiggen, is

Creffuell, one of the manours of the barony of Bywell (u), of which it was held by the antient family of the Creffrells; by Robert de Creffwell, and Simon de Creffwell, in the reigns of kings Fobn and Henry III; by Roger de Creffwell, 2 I K. Edward I ( $v$ ); by:

Robert:

(u) Vid. Bywell.

(v) Juratores dicunt fuper facrum, quod quidam Robertus de Creffrell, avus prædicti Ro. geri de Creffwill, tenuit præedicta tenementa, de quibus vifum fecerunt, in fuo feff: et inde obiit 


\section{ANTIQUITIES OF NORTHUMBERLAND.}

Robert de Creffrell, in the reign of K. Edward II (we); by Alexander de Creffrell, who was upon an inqueit at Nerucafle upon Tyne, I th February, 43 K. Edward III, with Thomas de Eflington, Rebert de Eland, Robert de Middleton, Richard de Cranlington, and Fobn de Killingroorth, \&c. and upon another at Morpeth, 2oth January, 49th of the fame reign, with the fame gentlemen; alfo upon another at Corbridge, $25^{\text {th }}$ June, $2 \mathrm{~K}$. Richard II, with Robert de Lorviber, William Shaftoe, Fobn Lawen, Robert de Eland, and others $(x)$; by Fabn de Creffrell, ro K. Richard II ; by Foln de Crefruell, in the reign of K. Henry V; by George de Creffuell, in the reign of K. Henry VI; by Robert de Creffwell, in the reign of $\mathrm{K}$. Hinry VII, who married Elizabeth, the daughter of Thomas Lord Lumley, by Elizabeth Plantagenet, daughter of K. Edward IV, by the Lady Elizabeth Lucy; by Ofwin de Creffrell, in the beginning of the reign of $\mathrm{Q}$. Elizabeth $(y)$; by Folnn de Creffrell, in the latter end of the fame reign ( $z$ ); by Fobnde Creffruell, in the beginning of the reign of K. Fames I (a); by Fobn de Creffrell, who had three fons, viz. Ephraim, Ofwald, and William, the laft of whom purchafed Crefl--

obiit feifitus; polt cujus deceffum Simon de Crefwell fucceffit in eifdem tenementis, filius et hæres, et inde obiit feifitus: Et fimiliter dicunt, quod prædictus Rogerus poft deceffum prædicti Simonis, patris fui, introivit in prædict. tenemen. per fuccellionem fuperdictorum, \&c.

Efcaet. de anno 2 I $E d$. I. .

(w) Robertus de Creffucll, inter nomina hominum in com. Nortbumbr. ad arma return. 17 Ed. II. 1324 . Rot. in Bibliotheca Cottoniana, Claudius; c. ii. folio $72, \mathrm{~b}$.

(x) Efcaet. de anno 43 Ed. III. p. 2. n. 16.

- $49 E$ d. III. n. 4 .

2 Ric. II. n. 84 .

(y) Inquifit. poft mortem, de anno ${ }_{3}$ Eliz.

(z) - 43 Eliz.

(a) - 4 farm I. 


\section{$34^{2}$ ANTIQUITIES OF NORTHUMBERLAND.}

well of his two brothers, who died without iffue (b). He was fucceeded by his fon, William Creffuell, Elq; father of the prefent poffeffor, William Creflivell, Efq; who hath one fon, Fobn, and feveral daughters.

Mr. Creffwell has built a handfome houfe on to the old tower. It ftands at a fmall diftance from the village, which is clofe by the fea, and inhabited chiefly by hardy and induftrious filhermen.

Two miles north from Creffwell, is

Widdrington-Cafle (c), which was the feat of the antient family of the Widdringtons; of Gerard de Widdrington, I K. Edward I (d); of Sir Roger de Widdrington, high theriff of Nortbumberland, $36 \mathrm{~K}$. Edward III (e), to whom Fobn de Pleffis fold the manour of Plefis, and the village of Shotton $(f)$; of Sir Fobn de Widdrington, his fon

(b) Ex informat. curiofi admodum viri Henrici Creffwell, de Windfor, arm. fratris Guliclmi: Creffuell, de Creffwell, arm.

(c) Woodrington.

Wodrington.

Witherington. Lel. Itin. vol. vii. p. 60. Camd. Brit. p. 859.

Widdrington.

(d) Gerardus de Woodrington tenet Woodrington, cum Druridge membro fuo, et medietatem de Burroden, per unum feodum veteris feoffamenti, baronia de Whalton.

Efcaet. de.anno I $E d$. I.

(e) Efcaet. de anno 36 Ed. III.

Fobannes de Pleffeto alienavit Rogero de Wodrington manerium de Pleffes et villam de Shotton.

Inquifit. post Mortem.

(f) Eft Fohannes de Wodrington filius et hxres Rogeri de Wodrington.

Inquifit. pradict. de anno.22 Ric. II.

Teltibus, Fobanne de Wbitlawe de-Hertford, Forfer de Sbotton, et aliis. 
and heir, 22 K. Rickard II (g), high Theriff of Northumberlant, i Ith K. Henry IV, and 4th and 8th of K. Henry VI ; of Sir Roger cle Widdrington, high theriff of Nortbumberland, I0, I4, 2 I of K. Henry VI (b); of Gerard de Widdrington, high theriff of Northumberland, 5 K. Edward IV ; of Fohn de Widdrington, high theriff of Nortbunberland, I2, I3, 14, K. Edward IV ; of Sir Gobn de Widdrington, high theriff of Nortbumberland, 32 K. Henry VIII, 6 K. Edward VI, and I Q.Elizabeth, of whofe eftate an inquifition was taken, roth of the laft reign (i). Sir Jobn married Elizabeth, the daughter of Sir Hugh Trevannion, who furvived him, and married Sir Robst Cary, lord warden of the middle marches, afterwards created Earl of Monmouth, by whom the had two fons, and one daughter. Her cldeft fon was made Knight of the Bath at the creation of Charles, prince of Wales, and married the daughter of Lionel Cranfield, afterwards Earl of Middlefex, and treafurer of England. Her daughter married the eccentric Duke of Wharton, as my Lord Orrery calls him. Her ladyfhip and the lord warden lived at Widdrington, which was her jointure, and at her death came to Sir Henry Widdrington, who was a deputy-warden of the middle marches under his lordhip. His other deputy was Sir Willian Fenwick. To one he affigned the government of Reed's-dale, and to the other that of Lidd's-dale; with each fix horfemen to attend them; out of his own appointment, which was forty; the bor-

(b) Rogerus de Woodrington obiit feifitus de et in manerio de Woodborate, dominio, villa, et portû, de Newbiggen fuper mare._

Ercaet, de anno 22 Hen. VI.

(i) Fohannes Woodrington, miles, fuit feifitus de et in caftro, ct manerio, ac villa de Woodrington, Druridge, Chibburn, Garret-lee, Coldwell, Whitfled-lawe, Swynburn magna, Shotton, Pleffis, et Haughton, cum mcdietate villæ et manerii de Humfhaugh, et certis terris in Weft Chevington, Bingfield, Stone-Hall, Eaft Chevington, Swynburn parva, et in Llaigdon, ac de villa de Woodhorn, Newbiggen, et in certis terris in Seaton, juxta mare.

Efcaet. de anno 10 Eliz. 
ders remarkably peaceable under their government, after a few examples being made of the boldeft thieves $(k)$. His deputy, Sir Henry Widdrington, was high theriff of Northumberland, 2 r Q. Elizabeth, and $3 \mathrm{~K}$. Games I; and a reprefentative for it in parliament, 1, 12, 18, K. Fames I; and was fucceeded by

Sir William Widdrington, who was high theriff of Nortbumberland, $12 \mathrm{~K}$. Charles I; and a reprefentative for it in parliament, 15 th, 16th and 17 th of the fame reign, with Sir Henry Percy. He, and Sir William Carnaby, and Sir Patricius Carrven, were three of the $5^{6}$ members who voted for faving the life of the Earl of Strafford. He, and his friend, Mr. Herbert Price, member for Brecon, in Wales, were committed to the Tower, for having candles brought into the houfe without a general order, 189 voices againft 172 . He was expelled the houfe, 26 th Augunt, $164^{2}$, for refufing to attend it, and raifing forces in defence of his majefty, who created him baron Widdrington of Blankney, 1oth November, 1643. After the battle of Marfton-Moor, he retired beyond feas with his noble friend, the lord marquis of Nerucafte, and others; and his eftate was fequeftred by the parliament (l).

On the march of his majefty, K. Charles II, to Worcefter, his lordthip ftaid behind at Wigan, in Lancafbire, with the Earl of Derby, and many loyal gentlemen, about 200 horfe, with a defign of taking the country-volunteers along with them, where they were furprized by a party of the parliament-forces at the dawn of the morning, and after a gallant difplay of valour, were either flain

(k) Monmouth's Memoirs, publifhed by Lord Orery.

(l) Whitlock's Memorials, p. 92, and p. $39 \mathrm{r}$. 
or taken prifoners. Among the former was Lord Widdrington, who difdained to take quarter.

"His Lordhip," fays my Lord Clarendon, "was one of the good"lieft perfons of that age, being near the head higher than moft " tall men, and a gentleman of the bet and moft anticnt extrac"tion of the county of Northumberland, and of a very fair for"tune, and one of the four which the king made choice of to "be about the perfon of his fon the prince, as gentleman of his " privy chamber, when he firf fettled his family. His affection " to the king was always mont remarkable. Affoon as the war "broke out, he was of the firt who raifed both horfe and foot " at his own charge, and ferved eminently with them under the " marquis of Nerecafle; with whom he had a particular and cn" tire friendhip. He was very nearly allied to the marquis, and "by his teftimony that he had performed many fignal fervices, " he was about the middle of the war made a peer of the king" " $\operatorname{dom}(m) . "$

His lordhip married Mary, the daughter and fole hicir of Sir Antbony Thorald, of Blankncy, in LincolnfJire, Knt. by whom he had

Willium Lord Widdrington, who was one of the council of ftatc upon the reftoration of the parliament by General Monk ( $n$ ). HC was fucceeded by his fon,

Willian Lord Widdrington, who by marriage acquired an additional eftate of upwards of $1200 \mathrm{l}$. per ammu. His lordhip's real

(m) Clarend. Hift, vol, iii. part 2. 8ro. p. 404.

(n) Bp. Kcnnet's Hift. Regitt. p. 66.

VoL. II. 
and perfonal eftate, valued, as fet forth in his petition to the $\mathrm{r}$... liament, $4^{\text {th }}$ December, 1722 , at above $100,000 \mathrm{l}$. came to the crown by his attainder in 1715, and was fold for the public ufe. He did not fuffer with Lord Derwentwater, but was moft graciouly pardoned. He left one fon, Henry, now living; his feat at Stella, by the river Tyne, in the bifhoprick of Durbam.

Widdrington-caftle is now in the poffeffion of Sir George. Warner Knight of the Bath. It is about a mile and a half from the fea: on a pleafant hhady eminence; from which is a diftant profpeet to the north-eaft of

Coquet-Ifland, in which was a cell of Benedictine monks, fubordinate to Tynemouth-priory $(0)$. At the diffolution it was granted tc Fohn Earl of Warwick (p). It now belongs to his Grace the Duke of Nortbumberland. It was taken by the Scots, 19 K. Charles I, I643, together with about 200 men, with their arms, feven pieces of ordnance, and provifions. They refcued and reftored to the owners a great herd of cattle taken away by the king's forces. Colonel Grey, brother to William Lord Grey, came in to them with a regiment of horfe, and took the covenant (q).

The illand is about a mile in circumference, and a mile and a quarter from the main land, ftored with rabbets. It hath pitcoal, as mentioned by Leland $(r)$; alfo white free-ftone, and

(0) Monacorum crtibus infignis. Bed. Hift. Ecclef. 1. 4. c. 24.

Lel. Collectan. vol. iii. p. 43 .

-Itin. vol. vii. p. 55 .

(p) Tanner's Notit. Monaft. fol. p. 360.

(q) Whitlock's Memorials, p. 77 .

(v) Lel. Itin. vol. vi. p. 60 . 


\section{ANTIQUITIES OF NORTHUMBERLAND.}

flates; the former of different finenefs, the worft with fome red Molecula; the latter ufually about three quarters of an inch thick. On the weft fide have been falt-pans; about fixty yards from which are the ruins of the monaftic cell and chapel; and juft below them is a bank of factitious fand, of a remarkable brightnefs, the diffolution of filvery rag-ftone, of which there are large Atrata on the fhore between Warkworth and Alnmoush, often left bare, and in view, after ftorms, and high tikles. Hard by, upon a rock, grows plenty of rape; probably firt brought there by fome fhipwreck.

Having taken notice of the molt remarkable places towards the fea near Morpeth, we now continue our courfe on the polt-rond for about fix miles, when a neat road branches off on the left hand to

Carefey-Park (s), onc of the manours of the Barony of Bothall (t), of which it was held by a younger branch of the noble family of Ogle, of Ogle-Cafle; by - de Ogle, in the beginning of the reign of Q. Elizabetb (u); by Fobn de Ogle, 3 xtt of the fame reign, the initial letters of whofe name are on the old tower, with the date of its erection, 1589; and whofe wife, Catharime, lies buried under a flat ftone in Botball-church, near a fine tomb of the Lords Ogle, with the following infeription,

Here lyeth Catbarine the wife of Fohn Ogle, of Caresey-Park, Efquire, daughter of

(s) Calci-Park.

Cawfey-Park.

(t) See Bothall.

(u) - Ogle fuit feifitus de et in uno fitu, five capitali mefluagio, vocat. Calci-Park, n Parka ibidem, et certis terris in Morfley. Efcact, de anno ro Eir. 
Robert Woodrington, Efquire, by Margaret his wife, which Margaret was fifter to Robert the 6th and to Cutbbert the 7 th Lord Ogle, She died May 23, 160\%.

His fon, fames Ogle, Efq; is interred in the chancel of St. Andrew's church, in Nerucafle upon Tyne, near the altar, under a marble monument with this infcription.

Hic jacet Facobus Ogle de Carefey-Park, in comitatu Nortbumbr. Armiger. Antiquitate domûs, utpote ex prænobili Baronia Ogle, de $O_{g} l e$, ftirpe recta linea oriundus, verè clarus; fed invicta in perduclles, graflantibus nupcris civilibus bellis, animi magnitudine, conftantia in regem, etiam in triftiffimo authoritatis deliquio fidclitate, in fuperiores obfervantia, in pares comitate, in inferiores benignitate, qux omnia juftiffmo titulo fua vocare poterat, multo illuftrior. obiit Dec. 4 die, annoqù Dom. 1664.

The late Itenry Ogle, of Coufey-Park, Efq; was high fheriff of Nortbumberland, 1737. He founded a fchool at Carefey-park bridge, on the eaft fide of the pon-road, and gave it the little field it ftands in, and $300 \%$. for the education of 30 children in reading, writing, and accounts. He died without iffuc, and was fucceeded by his brother, the prefent poffeffor, William Ogle, Efq. His fent is on a rifing ground; the gardens on a fine flope, bounded on the fides and bottom with handfome pieces of water, ftored with carp and tench, an opening between woods of tall oaks letting in a profpect of an enclofed and wcll cultivated country.

Near two miles north-weft from Caufey-Park, is 
Long Horfley, the manour of which was given by Coppatric, Earl of Dunbar, on the marriage of his daughter Fulinn, to Sir Ralpb Merlay, Baron of Morpeth(v); whole fucceffor, the third Roger de Merlay, in the reign of K. Henry III, granted lands in Long Horfley, and other places, to Adam de Plefes ( $u$ ); and at the fame time

(v) See Morpeth.

(w) Omnibus Chrifli fidelibus hanc cartam vifuris vel audituris Rogerws de Merliy tertius, falutem in Domino. Sciatis me dediffe, concefffe, et hac mea prafenti carta confirmafle Adamo de Pleffeto pro bomagio et fervicio fuo quinque bovatas terræ, cum pertinentibus fuir, et tres toftas et unum cotagium in villa de Horkcy et in Sheles, fcilicet, illas duas bovatas terræ, cum tofto et crofto, cum pertinentibus, quas Ranulphus de Efpelcy et Osbertus tenuerunt in Todburn et in Horfley, et illam bovatam terræ, cum tofto et crofto, quas Rogerus de Thrafrefon tenuit in Horfley, et illas duas bovatas terræ, cum tofto et crofto, cum pertinentibus, quas Robcrtus filius Matilide, tenuit in Sbeles, et illud cotagium cum pertinentibus quod .... medicus tenuit in Horky, et ad pradictorum meremium dedi et conceffi eidem Adame quandam lanóam de valto meo juxta culturam fuam de Tolbum, quæ vocatur Swinley, ficut includitur foffeto ad colendum et admoduni commodum fibi, faciend. habend. et tenend. de me, et hæredibus meis, prædicto Adamo, et hæredibus fuis de corpore fuo legitïnè procreatis, libere, quietè, folide et integre, cum libcro introi:û et exitu, cum communa pafturæe, et liberationem ad ædificandum, ardendum, ct fepem faciendum per vifum foreftariorium meorum, et hæredum meorum, et cum ominibus aliis aifiamentis ad prædictam villam de Horgey pertinentibus, reddendo indè annuatim mihi et hæredibus mais tantun unam libram, Cumini vel duos denarios ad feftum Sancti Cutbberti in Septembri, pro omnifervicio, confuetudine, auxilio, et demanda, quæ ah aliquo vel aliquibus exigi poffunt. Si autem contingat predictum Adlamum fine hærede de corpore fuo legitime procipato in futa decclere, volo quod tota terra prænominata cum toftis et vafto cum pertinentibus ad me et hxredes meos fine alicujus contradictione, vel impedimento, rcturnatura. Concedo etiam pro me et haredibus meis eidem Adamo et haredibus. fuis, de fe legitine exeuntibus, quod capiant marlam ad terram fuam de Todburn et Swonley-markland ubi infra fo'um meum videntur cis magis expedire. Et egro Rogerus de Merlay et hæredes mei præedicto Adam; ct hæredibus fuis, de corpore fuo legitime procreatis tatam terram prædictam cum toftis, vafto, et marla, cum pertinentibus contra omnes gentes in perpetuum warrantizabimus. In cujus rei teftimonium, parti hujus cartæ in modum chirographi confcriptre penes diatum Adamum refidenti, figillum meum appolui; et alteræe parti, qure penes met ct hxredes meos refervata, didus Adamus 
his lordihip compelled all the tenants within the inanour to keep the ways and ditches round their grounds in good order, on pain of being whipped the day after his court was held $(x)$.

Roger de Horfley, a witnefs to the antient deed fubjoined, held alfo lands in Long Horkey, which continued in his family through a long fucceffion; and was poffeffed by Gohn de Horfley, I K. Edruard III $(y)$; by Richard de Horfley high theriff of Northumberland, 37, 43, 44, 45, of the fame reign ( $z$ ); by Fobn de Horfley, in the reign of K. Henry VI (a); by Sir Gobn Horfev, I K. Edward $\mathrm{VI}, 1547$, who in that year was made a knight banneret, after the victory obtained over the Scots at Muffelburg by the Englifs army (b); by Cutbbert Hor/ley, Efq; a reprefentative in parliament for Northumberland, I Q. Mary, and for the borough of Morpeth, $2 \mathrm{~d},{ }_{3} \mathrm{~d}$. of the fame reign; by the late Edward Horfley Widdrington, of Felton, Efq; whofe only daughter and heir married Thomas Ridell, of Swinburn-Caflle, Efq;

fignum fuum imprufit. His teftibus, Domino Ad mo tunc abate de Novo Monafterio, Fohanme filio Simonis, Aldamo Barret, Fohanne de Pleffeto, Ricardo de Saltwyke, Rogero de Horßey, Berthotomeo de IVyndgates, Roberto de Camera, Andrea Coco, Waltero de Witton, et aliis.

Carta Rogeri de Merlay, tertii, Temp. Hen. III.

(x) Et ifte eft Rogerus, qui fubditos fuos in Horfley ad vias et foflatas circa campos de Horfey bone confervandas et diligentur fuftentandas, tractare ftatuit. Et quod quicunque convilus fuerit de aliquo fragmento in follatis vel viis prædictis in campo fuo, tenetur ibidem in craftino inventionis Sanctx Crucis, et craftino Sancii Martini in hieme, et reddet domino fuo pro quolibet delicto fuo duas Virgas ferveas quoties inde convictus fuerit.

Ex Autographo perantiquo.

(y) Efcaet. de anno i Ed. III. n. 85.

(z) Madcx. Ferma Burgi, p. 67 .

(a) Efcaet. de anno ${ }_{4}$ Hen. VI. n. 34. Fuller's Worthies, p. 310.

(b) Hol. Chron. Vol. ii. p. 99 I. 


\section{ANTIQUITIES OF NORTHUMBERLAND. $35^{\mathrm{I}}$}

The church ftands half a mile fouth-eat from the village, the impropriation and advowfon of which were given by the third Ralph Lord Greylock to the abbey of Brinkburn, 8 K. Richard II (c).

From the hill by the 7 th mile-ftone, on the right hand we have a fine profpect of

Warkworth-Cuffle, antiently the feat and barony of the noble family of the Claverings; their name local from their Barony of Clavering, in Effex; by defcent from Roger Fitz-Richard, enfeoffed in the Barony of Warkworth by King Henry II ; to whole fon, Robert, King Fobn granted a weekly market to be kept on Monday at New-town, near $W$ arkworth; and an annual fair there, to continue for three days; viz. the Even, and the day of St. Laurence, and the morrow of the faid clay; alfo the liberty of free warren in his barony of Warkworth (d).

Fobn de Clavering, Baron of Warkworth and Clavering, was fummoned to the parliament held at Carlifle, $25 \mathrm{~K}$. Edward I, I307; and to the famous parliament held at Wefminfer, 23 October, $3 \mathrm{~K}$. Edward III, 1329, which gave the king leave to affume the go-

(c) See Morpeth.

(d) Robertus filius Rogeri, tenet in capite de domino rege Baroniam de Warkworth, cum pertinen. per fervic. unius feodi milit. Et Rigerus, filius Rilcardi, patris ejus, tenuit per idem fervic. poft tempus Domini Henrici, patris domini regis Gobannis, qui prxdictum manerium cum pertinen. ei dedit in feodo. Et de feodo illo nulla efl alienatio, \&cc. unde dominus rex minus habeat de fervicio.

Tefta de Nevill.

Hæres filii Roberti tenet de domino rege in capite villam fuam de IVarkwoith, Acklington cum Parka, Birling, cum Budlefon fuperior. Membro fuo, et quartam partem de Toggefden, per fervicium unius feodi militis de veteri feoffamento. Efcact. de anno I Edvardi I. 


\section{2 \\ ANTIQUITIES OF NORTHUMBERLAND.}

vernment of his kingdom, though under age. He alfo fate in the next parliament at Wefminfer, called I2 March, 6 K. Edward III, I 332 ; remarkable for being the firf time upon record for the commons of England making a diftinct houfe from the Lords, though without a fpeaker; and it is believed, that from this period may be dated the firf appointment of Juftices of Peace, fuch as we have now.

His lordhip had a grant of crown-lands, during his life, of the value of $405 \%$ per ammm; the patent dated, 20 th Nov. $6 \mathrm{~K}$. Edreard I in confideration of making the crown his heir to his baronies of Warkworth and Rotbbury, and his manours of Corbridge and Nereburn (e); the reverfion of which were given to Henry

(c) Rex, \&ic. fciatis, quod cum dilcetus et fidclis nofer fobannes de Clavering concefferit nobis benevolè ct gratantèr, quod ipfe de caftro fuo de Warkworth, et maneriis fuis de $R m$ bury, Neubuin, et Corbrigg, cum perinen. in com. Nortlumbr. et de nranerio fuo de Eure cum pertinen. in com. Buck. quxe de nobis tcnentur in capite, feoffavit Stephanum de Trafforl; habend. cidem Steplano et hæredibus fuis, de nobis et hæredibus nottris, per fervicia inde debita et confueta in perpetuum: ita quod idem Stephontes habita inde plena et pacifica feifna de pixdict. Caftro et manerio de Rubury cum pertinen. refeoffet pradiatum Fohonnem; habend. et tenend. ad totam vitam ejurdem Fohannis; ita quod polt mortem ipfius Johannis idem caftrum et manerium de $R$ ubury remancant nob's ct haredibus noftris in perpetuum: et de pradicto manerio de Eure cum partinen. refeoftet pradictum Jubannm et Hawifam uxorem ejus; habend, et tenend, ad totam vitam ipfius Fobannis ce Hawife idem manerium de Eure cum perinen. nobis et hæredibus noftris reman. in perpetuum : et de prædiatis naneriis de Newbum et Corlrigg cum pertinen. refeoffet prædictum fohannem; habend. et tencnd. fibi et haedibus fuis mafculis de corpore fuo legitimè procreatis de nobis et hæredibus noftris per fervicia predicta in perpetuum; reverfione dictorum maneriorum de Nezuburn ct Corbrigg, pro defectû talis exitus, regg. et bæred. fatis fpectante. Quz caftra et mancria cum partinen. ad valorem $700 \%$ per amum fe exteudunt, unde finis levatus citra feftum purificationis beat Maria proximo futurum. Nos in confideratione præmifforum conceffimus eidem $\mathrm{F}$ chami in valoren $400 \%$. terra per annum, manerium noftum de Cotefey, hundred noftra de Lodwing, Knavering, Ho'te, Depewace, Henfede, North Erpingham, Soutb Erpinghan, Eafi Flegg, IF'ef Flegg, Happing, Haiham, Taverham, Blofe'd, et Humlerd, cum 
Lord Percy, the patent dated, 2 March, 2 K. Edward III (f); now in the poffeffion of his Grace the Duke of Nortbitmberland.

The caftle is on an eminence, above the village of Warkwortb; the principal tower, and fome other parts of the building, ftill remaining, magnificent in their ruins.

pertinen. in com. Suffol et manerium nofrum de Rodefon, cum pertinen. in com. Northampt. et manerium de Apethorp, cum pertinen. una cum xxviii s. reddit. de ferma terræ Oliveri A/pul, ibidem: quæ maneria et hundreda ad 405 li. $21 d$. extenduntur per annum; habend. eidem Fobunni ad totam vitam fuam, \&c. Tefte rege apud $W_{e} / \mathrm{min} /$. 20. Nov. per ipfum regem et confilium.

Ex Rot. Clauf. de anno 6 Edvardi I. m. 11.

(f) Rex dilecto et fideli fuo Fobanni de Clavering, falutem. Cum in quadain indentura inter nos et dilectum confanguineum et fidelem noftium Henricum de Pcrcy, fuper morâ fua nobifcum pro pace et pro guerra, procerto numero hominum ad arma, ad totam vitam jpfius Henrici, contineatur, quad idem Henricus caperet a nobis per annum pro feodo fuo quingintas marcas tempore pacis et guerre, concefferimus pro nobis et hæredibus noftris, quod caítrum de W'erkwortl, et omnes alias terras, et tenem. cum pertinen. in com. Northumbr. quæ vos tenetis ad terminum vitæ veftræ, et quæ $p$ if mo:tem veftram ad nos et hæredes noftros reverti debcrent, poft defceffum veftrum; ac etian omnia alia, terr. et tenementa, cum pertinen, in eodem comit. quæ vos tenetis vobis et hæredibus mafculis de corpore veftro exeuntibus, et quæ ad nos et hæredes noftros, $f_{1}$ vos fine hærede mafculo de corpore veftro obieritis, remaneant præfato Henrico, et hæredibus fuis; tenend. de nohis ct hæredibus noftris per fervicia inde debita et confueta in perpetuum; ita quod quandocunque idem $H_{\mathrm{c} n}$. ricus poft mortem veftram plenam feifinam de cafiro, et aliis terris et tenementis pradictis, virtute conceffonis noftre pradißtx, fuerit affecutus, quod tunc folutio dicti fcodi quingintarum marcarum ceffet ; et quod nos de eodem feodo penes ipfum Henricum exonerati fimus, et quieti ; ita quod fi prædictum caftrum, terræ, et tenementa, valorum prædictarum quingintarum marcarum per annum excedant; quod idem Henricus et hæredes fui, poitquam ipfi feifinam de iifdem, caftro, terris, et tenementis, polt mortem veftram erint affecuti, de furplufagio illo valorem dictarum quingentarum marcarum fic extendente, refpondeant nobis et hæredibus noftris ad fcaccarium noftrum et hæredum noftrorum, prout in literis patentibus inde confectis plenius continetur. Vobis mandamus quod eidem Henrico, de eo quod ad vos pertinet, attendentes fitis, et refpondentes. In cujus, \&c. Teßte rege apud Eboracum fed cundo die Martii. Pat. de anno 2 Edvardi III. p. I. m. 20. 
At the foot of the village is the church, with a tall fpire, a fine contraft with the oftagon-tower; the ftreet feeming as a fpacious avenue between them. In the tower is a large clock; the following infcription on the dial-plate.

W. R.

I 700 .

EX DONO GEO. LAIVSON, GLOSTER-HILL,

\section{GENEROSI.}

Within the church, at the fouth-weft end, by the entrance, is the funeral-monument and effigies of a Knight-Templer, with this infcription.

The effigies of Sir Hugh de Morwick, who gave the Common to this town of Warkworth.

In a pain of ftaincd glafs, in the caft window of the fouth ifle, are two female figures; the name of St. Hilda by them, in Saxon characters. It is a handfome church; a neat veftry in it; two good bells in the tower; the chancel wainfcotted to the bottom of the windows; the roof cieled, and adorned with arched and knott-work.

By the entrance into the chancel, on the right hand, is a very neat mural monument of the Berlin-freeftone, with this infcription.

$$
\begin{aligned}
& \text { Juxta'hunc locum } \\
& \text { Jacent icliquix } \\
& \text { Wilfridi Larejon, }
\end{aligned}
$$

Hujus ecclefix vicarii. Obiit

$$
\text { Apr. 1. I } 73 \%
$$

In vita, lábor et periculum, in moriendo

Pax, et refurgendi fecuritas. 
On the wet fide of the church, is the vicarage-houfe; the river Coquet on the north fide of it, croffed by a ftone-bridge of three arches; an upright ftone pillar on the middle, with the Percy-arms fculptured; a fquare tower at the fouth end; the gate formerly of iron, with port-cullices. Twenty marks were left towards rebuilding this bridge by $\mathrm{Mr}$. Folnn Cook, of Ninecefte upon Tyne, $2 \mathrm{~K}$. Richard II, 1379. The river enters the ocean about a mile below it, and is capable of being made navigable up to it for fmall veffels; the villa formerly much reforted to by merchants $(c)$; the fituation inviting commerce. It has three annual fairs, viz. on Thurfday before St. George's, St. Lumince's, and St. Martin's day; a weekly market on Thurfar.

A quarter of a mile weft from Warkworth in the antient park, on the northern banks of the river Coguet, is

The Hermitage, a cell of two Benedictine monks from Durban, for whofe maintenance Nicholas de Farnham, Biflop of that See in the reign of K. Henry III, appropriated the church of Brankfon, confirmed by his fucceffor, Walter de Kirkhim (d). It confits of a fmall chapel, and a bed-chamber, cur out of a folid rock of white rag-ftone, in the Saxon-gothic file; the chipel curioufly adorned with fide-pilafters, and the roof of knot-work. In the fole of a window, at the fouth end of the altar, is the enigies of the Bleffed Virgin, fculptured in flone, recumbent; another of the child Fefus on her right hand, ftanding, his left hand refing upon her fhoulder; at her feet, in a nich in the wall, is the

(c) Lel. Itin.

(d) Angl. Sacr. tom. I. p. $73^{8}$.

Bp. Tanner's Notitia Monafica, fol. p. 396. 


\section{ANTIQUITIES OF NORTHUMBERLAND.}

effigies of an hermit, in the attitude of prayer; by him a Bull's head; all in high relief. Over the entrance into the chamber, is a 'fcutcheon of arms, now effaced. Next the river is the ruin of a fimall building, with a firc-place; probably the kirchen; above, there feems to have been a chamber, from the appearance of holes in the rock for the timber. On the fouth-eaft fide of the rock, is a door and winding ftairs cut out of it, leading to their little olitory or garden. The range of rocks eaftward are of a confiderable height and length; a fountain of foft and pleafant water under them; above them, fpreading oaks and brufhwood; the river pafing by in a filent fteam.

Near the roth mile-ftone, we crofs the river Coquet by a ftonebridge of three arches, on the north fide of which is

Felton, a pleafant, well built villa, on a gradual flope. Here the Barons of Nortbumberland did homage to Alexander, King of Scotland, I8th of K. Fobn, I2I6; who in refentment laid it and feveral other places in athes. It was one of the manours of the Barony of Mitford. It was poffeffed by the Bertrams (e); by the Earl and Countefs of Pembrake $(f)$; by the Earls of Atboll; by Sir

Thomas

(e) See Mitford.

(f) Dicunt juratores fuper facrum fuum, quod Adomarus de Valentia, comes Pembrochie, tenuit in dominicofuo, ut de feodo, die quo obiit manerium de Felton, cum pertinentibus, una cum quibufdam tenementis in Thrißon, in com. prædicto, de dom. rege in capite.

Item, dicunt juratores fuper facrum, quod Fohannes de Hafings, ætat. anno xxx; Fobanna, uxor conitis de Athill, xtat. anno xxvi ; et E.tzabe:ba Cumen, foror ejufdem Fohanna, xtat. anno xvi; funt confanguin. et propinquiores haredes prædicti Adomari.

Inquifit. capta apud Novum Cafrum, 14 die Septembris, de anno 10 Ed. II. 
Thomas and Sir Ralph Percy; by Sir Fobn le Scrope (g); and by the antient family of the Lifles. It was in the poffeffion of Sir Robert Lifle, high theriff of Nortbumberland; i th K. Henry IV, and 9th K. Henry V; who died, 4th K. Henry VI; his Arms, or, a fefs, betwixt two cheverons, fable (b); of Thomas Lifle, $1 \circ$ Q. Elizabeth (i); of Robert Lifle, I4 K: Charles I (k). It was lately in the pofreffion of Edward Horley Widdrington, Efq; and now of his fon-in-law, Thomas Ridell, of Swinburn-Cafle, Efq.

Above the bridge, on an eminence, is the church, dedicated to St. Michael. On the north-caft fide is the vicarage-houfe, over the entrance of which is the following infcription.

Dicunt juratores fuper facrum fuum, quod Maria de Sanczo Paulo, ac de Pembrocbia, comitifia, tenuit in dote, die quo osiit, nanerium, villam et foreftarn de Felton, cum perti. nentibus, ex donatione Allomari de Vaienia, comitis Pembrocbia, quondam viri fui ; reverfron: dicti manerii, villæ, et foreßr, cum pertinentibus, fpectant. poft mortem præfatæ comitifle, Elizabethe, uxuri Thome de Per.y, et Fohanna, uxori Radulphi de Periy, certis filiabus Davil. de Strabol $y$, nuper comitis Atholl, filii David et Fohanne uxoris ejus, \&c.

Et dicunt juratores fuper facrum, quod dicta comitifia obiit circiter xv die Marcii, anno 5 I Ed.III.

Inquifit. capta apud Novum Caftrum fuper Tynam, 21 die Maii, anno 5 I Ed. III.

(g) Vid. Pont-Eland.

Ex bundcllo efczetr. Turri Londin. n. 20.

(b) Efcaet. de anno is Hen. IV. n. 3 I.

- Hen. V. n. 54.

- ${ }_{4} H e n$. VI. Robertus Lifle, Chr, obiit feifitus de et in manerio de Folion.

(i) Thomas Lijle fuit feifitus de et in villa de Felton, Elibaugh, South Gosforth, Cox-lodge, Cat-bugh, cum terris in Weldon.

Efcaet. de anno ro Eliz:

(k) Robertus $L_{i j / f,}$ Arm, filius Roberti, tenet in capite manerium de Fellon.

Efcaet. de anno ${ }_{4} \mathrm{Car}$. I. 


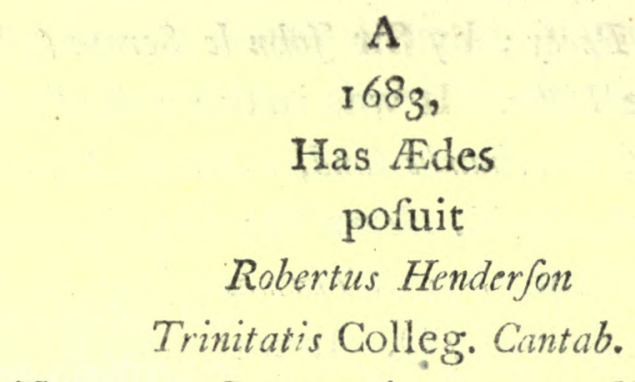

Tempore Barrowni, tempore Newtoni,

Socius :

Hujus et ecclefiæ

Non indignus vicarius.

Pietatis ergo pofuit

Hoc patri filius teftimonium, 1758.

At the weft end of the village, is a handfome modern ftructure, called,

Felion-Hall, the occafional refidence of Mr. Ridell, built by Mr. Widdrington; the gardens to the eaft; the river Coquet taking its courfe between two hanging banks of wood at a fmall diftance to the fouth.

By Alnwick-turnpike-gate, a road branches off, on the right hand, to

Alnmouth, a manour and fea-port of the Barony of Alnwick, belonging to his Grace the Duke of Nortbumberland. it ftands at the Ofium, and on the north fide, of the river Aln (l), on a rifing

(l) Alaunus. Ptolomy.

Alauna. Richard of Cirencelter.

Alne. Camden.

Awne. Stukeley.

Ail. Vulge.

ground; 


\section{ANTIQUITIES OF NORTHUMBERLAND.}

ground; three miles from Warkworth, and four from Alnwick. It is a fmall, well built town. The principal export is corn, kept in large granaries, the largeft, perhaps, in the county; the import, Norway-timber, and goods from London, Holland, and other places. On a hill, clofe by the fea, is the ruin of a church, which has been in the form of a crofs. The church-yard is ftill ufed as a burial-ground; on the eaft fide of which, bones of a very uncommon fize have been wafhed out by the fea. The tide flows about a mile up the river, to the village of Lesbury, where is now the parifh-church. The river is eafily croffed on horfeback at ebb-tides. A new hip, of near 300 tons, was built and launched at this port on Wednefday, I3th March, I765, fuppofed to have been the firft ever built at it.

A little beyond the turnpike-gate above mentioned, is the antient town of

Alnwick, which at the conqueft was the barony of a young lady, the daughter of a noble Saxon, William Tyfon, flain in the defence of the liberties of his country, and of his fovereign, K. Haroll, at the battle of Haffings (a). The victorious Norman, K. William I, difpofed of her in marriage, with this barony, and her baronial inheritance of Malton, in Yorkfhire, to one of his favourite lords, Ivo de Vefcy (b). His daughter and heir, Beatrix, was given in marriage by K. Henry I, with both thefe baronies, to Eufface FitzFobn; father of William, grandfather of Euftace, great grandfather of Williom, and great, great grandfather of. Fohn de Vefcy; who fucceffively held the barony of Alnwick of the king in capite by the fervice of xvin knights fees of the old feoffment (c):

The

(a) Dugd. Monat. Angl. vol. ii. p. 592 .

(b) Ibid.

(c) Euffacbius de $V_{f} f y$ tenet in capite de Domino Rege Baroniam de Alnewick, per fervicium xviii feod. milit, et præeterea tenet Bodill et Spinlefon; fcilicet duas villas et molendi- 
The Lord Euface had great alliances by marriage; his eldeft fifter, Matilda, marying Robert de Muscbamp, the firft Baron of Wooler; his younger fifter, Cicilia, marrying Hugb de Baliol, Baron of Brwell; and he himfelf marrying Agnes, daughter of William King of Scotland; and his own mother bcing of the noble houfe of Stutvile, of Knarefbrough, in Yorkfire, the daughter of Lord Robcrt Stutvile. He, and the reft of the Barons of Nortbumberland, in confederacy againft K. Fobn, did homage to his royal brother, Alexander King of Scotland, at Felton, I216; their arny, Atiled The Army of God and of the Holy Church, commanded by Robert Fitz-Halter, a General of experienced valour and prudence; in refentment of which defection, K. Fobn laid Felton, and many other towns, in athes. The two brothers, King Alexander and the Lord Euface, being before the town of Bernard Cafle in the fame year, to befiege it, and taking a near exploratory view of its Atrength on horfe-back, his lorlthip was killed by an arrow of one of the townfmen (d). His grandfon, Jobn $V e f c y$, was fum-

num de Warnet, quas Dominus Rex Henricus primus, dedit Euffach. fil. Foban. ante ipfe EuAacbius habuit ad incrementum fervicii fui : El omtres anteceffores fui tcnuelunt poft tempus, \&c. Et de feodo illo nulla eft alienato, \&c. unde, \& c.

Tefta de Nivill.

Willi:lmus V. fcy tenet in capite de Domino Rege Ainwick, Alnemouth, Denwicke, Huwkle, Bilton, Leburic, Shilbotle, Nuton fuper mare, Hazaunt, Guyfens, Rublye, Morwicke, Eaft Chevington, Houghton et Hougliton, Howicke, Rynington, Rocke, Charleton et Charleton, Falowden, Burneton, Batell, Nuton fuper Moram, Prefton, Tughall, Swynhoe, Newham, Cummyn; Lucker, cum Hoppen, membro fuo; Horton, Turbilmell, Edderfton, Spyndlefton, Budle, Elwicke; Doddington, cum Nerbet, membro fuo; Hezlerigge, Lyham, Chatton, Fowburye, Weitwood, Caldmarton, Yeardbill, Ingram, cum Revelye et Hartefyde, fuis membris; Prendwicke, Fawdon, Alneham, Hudbernelaw, Ambell, Hawxley, Weicwham, Bitlefden, Clenhill, Nethertor, Burraden, Alnewhynton, Hetton, Sharperton, Tharneham, Scranwood, Chillingham, Eworth, et Hebburne per xviii feoda vet. feoffamenti. Efcaet, de anno:1 Edvardi I.

(d) Hol. Chron. vol. ii. ,p. 158. 193.

Chron. de Mtlrofs. 


\section{ANTIQUITIES OF NORTHUMBERIAND. 36}

moned to fit in the famous parliament, $48 \mathrm{~K}$. Henry III, I264; which, with the parliament in the year following, and in another in the 18 th of $\mathrm{K}$. Eidward I, are believed to be the models of our prefent parliaments, confifing of Iorks and Commons; this, whereto his lordhip was fummoned, being the fint of that kind upon record for the commons to have a thare in the legiflature (e). In the expedition againft the Hchl, I $K$. Fintiall, 1282, his lordhip commanded the Galcoimenes $(f)$. He died in that king's reign. To his only daughter, married to Sir Gillort de Aiton, Knight of Aiton, by the river Derwent, near Surboush, he gave his barony of Malton. He gave his harony of Alnzeick to an illegitimate fon, William $F_{c} f y$, a minor, who for fome difcourtefy done to luis guardian and feoffce in trutt, Antbony Beck, bihop of Durbam, was not permitted to take polleflion of it $(\mathrm{g})$; being fold to Hemry Lord Percy, baron of Topeliffe and Spofford, in Yorkfhire, 3 K. Edword II, I 310 ; his Majefty and Sir Gilbori de Aiton: confirming the title in the lime year $(b)$.

Of the noble houfe of Percy (i) there were five Lords and thirteen Earls; William the firft Lord Percy coming into England with K. Willian I, and prefented with a barony of thirty knights $\operatorname{fecs}(k)$,

(e) Sce the Writ of Summons in the Fodera Anglicana.

(f) Hol. Chron. vol, ii. p. 283.

(g) Dugdale.

(b) Rym. Foed. vol. ii. p. 199.

(i) Perci. Madox.

Percie. Camden.

Piercy. Speed.

Percy. Rot. Mag. Northumbr.

(k) Madox's Baron. Anglic. p. 31. 93.224. 
Henry, the fourth Lord Percy, who added to the grandeur of his family by the acquifition of the barony of Alnwick, was fummoned to the parliament at Carlifle, 35 K. Edward I, 1307.' His Lordhip, with the Lord Robert Clifford, and the Earl of Pembroke, obtained a compleat victory over Robert Bruce, at Methfen, in Scotland, foon after his coronation at Scone. Among the prifoners was his Queen, daughter to the Earl of Ulfer, who at the folemnity of their coronation is recorded to have faid, "That the feared "they fhould prove but as a fummer-king and queen, fuch as " in conntry-towns the young folks choofe for fport, to dance "about may-poles." The king gave the earldom of Carrick, her liufband's inheritance, to Lord Henry Percy; who in endeavouring to fecure the rents from being feized, lof part of his armed retinue, horfes and plate, and was forced to take refuge in a Scotch fortrefs, till relieved by his fovereign, K. Edward. The Lord Robert Clifford was prefented by his Majefty with Hert and Hertne/s, in the Bifhoprick of Durbam, faving always the right yet that belonged to the church of Durbam, Totenham and Totenhampire (l).

Henry Lord Percy was one of the twelve barons to whom the government of England was affigned in the minority of K. Edward III, 1327. The year following he loft his Scotch poffeffions, no Engliffman being then permitted to hold any in Scotland, unlers he lived upon them, and became a Scotch fubject, faid to be owing to the counfel of the queen dowager of England, and the Lord Mortimer. He was fummoned to the famous parliament at Wefminfter, $23 \mathrm{~d}$ October, $3 \mathrm{~K}$. Eddward III, 1329. He was one of the lords fent to Paris to nerotiate a treaty, $5 \mathrm{~K}$. Edward III,

(l) Hol. Chron. vol. ii. p. 314 . 


\section{He died, I 7 th February, 26 K. Edward III, $135^{2}(\mathrm{~m})$. His fon,}

Henry, the fifth Lord Percy, was then thirty ycars of age, and fucceeded him in his barony of Alnwick, \&c. (n). He led part of

(m) Henricus Percy, qui dicm fuum claufit extremum tenuit de Domino Rege in capite die quo obiit in comit. Northumbr. caftum et manerium de Alnwick, et etiam villas de Lurnton, Prefon, Scranwood, quas Fohannes de Stryzlyn, miles, tenet de præfato Henrico in dominico, per homagium et per fervicium unius feodi, et tertiæ paris unius feodi milit. et profidelitate et pro fervicio reddendi annuatim 15 die Julii $9 \frac{\mathrm{T}}{2} d$. pro warda caftri prædicti, et valet per annum 20l. et etiam villas de Newton juxta mare, et Yarchill, ciu is Nitiolas de Sanko Matro tenet, \&c. Et dicunt juratores, quod prafatus Henricus obiic 17 die Februarii, ult. præterit. et quod Henricus, filius præfati Hcnrici, defuncti, eft hares cjus propinquior, et ætatis triginta annorum.

Inquifit. ex bundello efcaetr. Turri Londinenf, No. 52, capta apud Annwick in comit. Northumbr. viceflimo primo die Marcii, 26 Edvardi III, coram Fohanne de Coupeland, efcaetore Dom. Regis in prædicto comit. virtute brevis prædiati regis.

(n) Henricus de Percy, filius et hares Henrici de Percy, tenuit de rege in capite caftra, maneria, terras, et tenementa fubfcripta, per divería fervicia, viz. caftrum et man rium te Alnwick, et villam de Alnmouth, Benley, Lefbury, Magna Houghton, Tugha'l, Chatton, et quandam placeam paftur. vocat. Swynle-fheels, in comit. Norhumbr. per ferviciun noriz partis baronize de Alnwick, juxta quod fervicium dat. lxl. pro relievio fuo; ac cafrurn ct manerium de Warkworth, cum villa de Berlin, Acklington, Rothbury, le Newton, 'Thsopton, et Snitter, ad eundem caftrum et manerium pertinen. in comit. Northumbr. per fervic. duorum feod. milit. et $\mathrm{x} l$. et burg de Corbriggs in prædicto comit. per fervic. reddend. fcaccarium regis $\mathrm{xl} l$. per annum, de veteri ferma, et de incremento ejufdem; cujus burgi valor non dedicit excedere pradict. $x \mathrm{l} l$. per ann. et de diverfis aliis terris et tenem. ibiokm annotat.

Rot. Turri Londincnfs, Mich. Fin. viceflimo 8vo R. Ed. III.

Henricus de Percy, Dominus de Spofford, filius et hæres Henrici de Percy, nuper Domini de Spofford, cognovit fe tenere de rege in capite, caftrum et manerium de Alnwick, cum mcmbris fuis, in comit. Northumbr. viz. villam de Alnmouth, Denwike, Lefbury, Magna Houghton, Chatton, Alnham, et quandam placeam vocat. Swinle-fheels, cum pertinen. in prædicto comit. Northumbr. cum feod. milit. advocat. ecclef. dom, religiof. et hof rital. 


\section{ANTIQUITIES OF NORTHUMBERLAND.}

the firtt wing of the Englifs army at the battle of Nevill's Crofs, near Durbam, and Ralph Lord Nevill part of the fecond, under the heroic Queen Philippa, on the firft Saturday after Michaelmas, 20 K. Edward III, 1346; fix.weeks after the glorious victory obtained over the French at Ciefly. His brother, Sir Thomas Percy, was made governour of Poiclou, $44 \mathrm{~K}$. Edward III, 1370 , on the death of the famous Lord Chandois, whofe rare and excellent qualities endeared him both to the Englifh and Frouch nation.

His lordlnip was gencral of all the king's forces in France, marfial of lingland, and created Earl of Northumberland, I K. Richard II, 1377 ; and in the fane year was fummoned by writ to the parliament at Wefminfer; Sir Peter de la Mare, knight of the thire for Hereford/bire, being chofen fpeaker of the commons, the firt upon record. His brother, Sir Thomas Percy, was made admiral of England the ycar following, joined in commiffion in that high office with the famous Sir Huglb Calverley. Being on a cruife together, foon after their appointment, they took a Frencls man of war, and feven merchants fhips, richly loaden. They

cifdem caftr. maner. et vill. pertinen. per fervic. quatuor unius baroniæ, viz. Baroniæ de Alnwick, baronize integra in quinque partes; dominicum, et caftum, ct manerium, de Warkworth, cum pertinen. in prxdicto comit. Northumbr. cum villa de Aklynton, Berlin, Rothbury, Snitter, Thropton, le Newton, le Ncwburne, cum Buttelaw, Beanly, Walbotell, parcell. prædicti manerii de Warkworth, cum fuis pertinen. una cum feod. milit. ac burg. de Corbridge, cum pertinen. in prædicto comit. Northumbr, per fidelit. et fervic. reddendi eílem Dom. Regi in antiquo per ann. in fcaccarium fuum xll. de veteri ferma, pro omni fervicio; et poftea idem rex dedit ferman prædicto Henrico de Percy, et hæe edibus fuis in perpetuum, ac etiam manerium de Spofford ac Topcliffe, et Seimour, cum membris, viz. Thurfanby, et Bynnington, qua funt parcella dicti manerii de Seimour, cum pertinen. fuis in comit. Eboraci, una cum feod. milit. ac ctiam manerium de Swinhowe et Tughall, cum membris et pertinen. de rege in capite, per fervic. quartæ partis baroniæ de Alnwick, $\checkmark$ z. baroa, in quingue partes divif, nec non manerium de Leckenfield.

Rot. 'Turri Londinenfi, Mich. Fin. jmo. R. Ric. II. 
ANTIQUITIES OF NORTHUMBERLAND. $3^{6} 5$

were both at fea in the great ftorm, 1379. Sir Thomas being attacked by a Spanifs thip after the ftorm was over, engaged her with fo much refolution and fpirit, that he took her, and fold her cargoe at the firf port; and then failed, through many perils, to Breft, of which he and Sir Hugh were governors. Sir Itugh nillrowly efcaped being drowned in this tempett, only himfelf and feven men being faved of his whole hip's company.

Sir Thomas was admiral of the whole flect in an expedition to Spain, 8 K. Richard IJ, 1386, in the month of May; the good Duke of Lancafer general of the forces. Sir Henry Percy, coufin to the Earl of Nortbumberland, and the Lord Poinings, were commanders under him. They were both fwept away by a great ficknefs the year following, with half of the army.

Henry Percy, Earl of Northumberland, and his two fons, Sir Henry and Sir Ralph Percy, were defeated by the Scots, at Otterburn, I K. Ricbard II, I388; his two fons taken prifoners; and the Scotch General, Earl Douglas, flain (o).

His Lordhip being at his government of Caluis, $15 \mathrm{~K}$. Richard II, I391, he was recalled home, and made lord-warden of the went marches. His brother, Sir Thomas, was one of the threc ambafradors fent to France the year following. He was made lord theward of the king's houfhold, $17 \mathrm{~K}$. Richard II, 1393 ; and in the fame year, Sir Thomas Percy, junr. was made warden of Bonteaux and Aquitain in France. The lord fteward was created Earl of Worcefter, 21 K. Richard II, I397. His feat was at

Wrefl-Cafle, by the oftium of the river Derwent, in Yorkflire, purchafed of the Lucies, and rebuilt by him, after a defign fo mag-

(0) See Otterlurn.

nificent, 


\section{ANTIQUITIES OF NORTHUMBERLAND.}

nificent, elegant, and curious, as to exceed, in the judgment of an eminent antiquary, all the buildings on the other fide of Trent $(0)$ : the fituation fomewhat higher than the reft of the country; the walls of ftone, large and fquare, and fome of it fo fine, as to be thought to be imported from France; five towers at each corner; in one of them a ftudy, called Paradife, where was a clofet in the middle of eight fquarcs, latticed about; at the top of every fquare, a defk, ledged, to fet books on, with drawers within, and feeming as if firmly joined to the top of the clofet, yet one or all would come down, and ferve for book-defks. It was moted round, except the cntrance; a chapel and gardens within the mote, and orchards without, wherein were mounts opere topiario, with winding walks, to afcend to the top withour pain.

Henry Percy, Earl of Nortbumberland, and his fon, Sir Henry Percy, warclens of the $W_{e} \rho t$ and Eaft marches againft Scotland, with the Earl of Wefmorland, congratulated Henry Duke of Lancafter and Hereford at Doncafter, after his landing at Raven/pur, in Yorkfhire, whom the Lord Ros, Baron of Wark and Helmfly, and other Lords, had joined before, $22 \mathrm{~K}$. Richard II, 1399; all the noblemen and men of note in the nation following their example, and receiving him for their fovereign; King Richard being left without one confolatory friend. So general was the national defection, that Father Orleans, in his Hiftory of the Revolutions in England, fays, that even the king's favourite greyhound left him, and fawned upon the duke $(p)$. After his being taken at Conway-cafle, in

(o) Lel. Itin. vol. vi. p. I3.

(p) Pere d'Orleans, tom. ii. p. 188.

Stow's Chron. p. 316, 317 .

Collier's Ecclef. Hitt. vol. i. p.601, 602. 
Wales, and conducted to the duke at Flint-caftle, he was carried from one place to another for many days, in one fingle, plain fuit of cloaths, though accuftomed to clegance and magnificence in drefs, one coat of gold and gems being valued at 30,000 marks ( $q$ )

The new fovereign, K. Henry IV, to reward the fervices of the Earl of Nortbumberland, made him high conftable of England, his patent bearing date September 3oth, 1399, at Wcfminfer. He alfo give him the Ifle of Manl, with the privilege of carrying the fword, called the Lancafer-fword, at coronations; the patent dated November 1 gth, I399, at Wefminffer $(r)$. His brother, Thomas, Earl of Worcefer, had the poft of deputy high ferward conferred upon him, during the minority of Thomas Earl of Lancafer, the king's fecond fon, the patent dated OEtober 8th, r399, at $W_{\text {eff }}$ $\operatorname{minfler}(s)$. He was alfo made governor to the Prince of Wales ( $t)$; and appointed ambaffador to France, with Walter Skirlaw, bifhop of Durbam. He was fent the year following with his nepherw, Sir Hugh Hafings, and others, to reduce the revolting Gafcoigners to their duty on the death of K. Richard; which he performed, not by force of arms, but by his wifdom and addrefs, by the powers of perfuafion, and the engaging charms of affability and condefcenfion (u).

The Earl of Northumberland, and his fon, Henry Lord Percy, ftiled by an admired hiftorian, for his martial heroifm, " the

(q) See the record and inftrument of the renuntiation of the unfortunate K. Richard II, at the end of the $\mathrm{x}$ fcript. Hift. Angl. by Sir Roger Twifden, col. 2743; and in the Hift. of his Life by an anonymous perfon of quality, 8vo. Lond. 1681. p. 192, \& cc.

(r) Rym. Fœd. vol. viii. p. 89. 95. Afta Regia, vol. ii. 8vo. p. 62, 69, 70.

(s) Rym. Foed. vol. viii. p. go. Acta Regia, vol. ii. 8vo. p. 69.

(t) Hol. Chron. vol. ii. p. $5=9$.

(u) Id. p. 518. 
"braveft man in England ( $v$ )," obtained a great victory over the Scots at Nesbit in the Merfe, 22 Fune, $_{3}$ K. Henry IV, 1402 (w). They obtained anorher victory over them at Humbledon, ncar Wooler, on Holy lood-day, in September, in the fame year; an uprisht ftone-column ftill ftanding in memory of it.

The Larl of Northumberland firf married Margarat, the daughter of Ralph Lord Neqiil. He next marriedMatilda, the widow of SirGilFert Humfianvill, Larl of Ansuls, daughter to Thomas Lord Lucy, and fiffer and heir to Antbony Lord Lucy; who out of her great affection fettled upon his lordhip, and his heirs, all her honours and lanis, the baronics of Cackermoutb and Egermond, in Cumberland, and the baronies of Langley and Prudbow, in this county, on condition of quartering the arms of the Lucies, with his own $(x)$.

His fon, Henry Lord Percy, marricd Elizabeth, the daughter of Elmund Mortimer the elder, by Ploilippa, the daughter of Lionel Duke of Clarince. Fic was flain at Shrewefury, on Saturday, St. Mary Mugdalen's Even, 4 K. Henry IV, 1403 . His father was flain at Brambam-moor, in K. Henry IV, 1408 ; both lamented with a gencral forrow throughout the nation, for the glory of their arms, their princely magnificence, and patriotic fpirit $(y)$.

Ifin'y Percy, the fecond Larl of Northumberland, fon to Henry Lord Percy, was fummoned by writ to the parliament at IFifminfer, with Ralph Nevill, Earl of Wefmorland, 2 K. Heiry VI, 1423; and $29 \mathrm{~K}$. Henry VI, 145I. He was created knight of the moft noble order of St. George, commonly called the garter; and appointed lord warden towards Scotland.
(v) Rapin.
(w) Acta Regia, vol. ii. 8 ro. p. 80 .
(x) See Langley and Prathow.
Cand. Brit. ed. opt. p. 866 .
(y) Hol. Chron. vol. ii. p. 534 . 
His lordhip invading Scotland with 4000 men, ${ }_{14}$ K. Henry VI, 1435, was defeated by William Douglas, Earl of Angus, at Piperden; I500 Englifbmen flain at that battle, among whom were Richard Percy, and Jobn Ogle, \&c.

He entered that kingdom a fecond time with confiderable forces, 29 K. Henry VI, 1450. An experienced officer, named Magnus, commanded under him. They joined battle with the Scots near the river Sarc, commanded by Hugh Douglas, Earl of Ormont, and a valiant knight, Sir William Wallaje of Craigs. The Scots on the firft onfet were ready to fly, but being animated by the exhortatory and pathetic addrefs, exemplary bravery and fpirit of their knightly leader, Sir William, they obtained a compleat victory. The Earl of Northumberland efcaped by the help of his fon Lord Percy, whofe filial piety was fuch, that he chofe rather to be taken prifoner himfelf, than his father. Sir Gobn Pennington, a valiant officer, was taken prifoner with him.

The Earl of Northumberland in the time of peace and leifure patronized learning and the liberal arts. He moft generoufly beftowed three fellowihips upon Univerfity-college in Oxford, directing them to be filled up by fit perfons, born in the diocefe of Durbam, rork, and Corlifle; the natives of Northumberland always to have the preference, if equally deferving as other candidates.

His lordhip for the better fecurity of his caftle and town of Alnwick againt the Scots, encompaffed the litter with a Arong wall of ftone, and embattled the former, by leave from the crown, $12 \mathrm{~K}$. Henry VI, I4I ; the town having four large gates, and fquare towers; the caftle, originally of Saxon foundation, large, with tall towers, and exploratory turrets; two fpacious areas within, a chapel, and other buildings; the entrance to the weft, above VOL. II. $\mathrm{B} \mathrm{b} \mathrm{b}$ which 
which there has been the brabant-arms, born by the Percies, Or, a lyon rampant, azure; now effaced by the weather; the motto ftill legible, in the old Englifh black letter, in relicf;-

\section{ESPERANGE ME COMFORTETH.}

'This great nobleman efpoufing the caufe of his fovereign $\mathrm{K}$. Henry VI, againft the houfe of York, was flain at the battle of St. Albans, with Jobn Lord Clifford, and others, 23 May, I455. He was interred in the abbey-church of St. Albans, in the chapel of the Bleffed Virgin. He married Eleanor, the daughter of Ralph Earl of Weftmorland, widow of Richard Lord Spenfer. His fon,

Sir Henry Percy, Lord Poinings, the third Earl of Nortbumberland, was appointed Lord warden of the eaft marches towards Scotland, and juftice of all the royal forefts fouth of Trent, $33 \mathrm{~K}$. Henry VI, I459. his lordhip being with Queen Margaret at the battle of Towton, was flain with the Earl of Wefmorland and Lord Dacres, \&c. on Palm-Sunday, 29th March, x K. Edward IV, I 461. He married Eleanor, the daughter and heir of Ricbard Lord Poinings, Brian, and Fitz-Pain; and in his father's life-time was fummoned to the parliament at Wefminfer, by the ftile and title of Sir Henry Percy, Baron Poinings, \&c. 29 K. Henry VI, I 45 I. His fon,

Henry Lord Percy, the fourth Earl of Nortbumberland, was fummoned by writ to the parliament at Wefminfter, I $2 \mathrm{~K}$. Edward IV, I 472 ; and made general warden of the marches towards Scotland, and juftice of all the king's forefts fouth of Trent. He was one of the generals of the army fent againft Scotland, $22 \mathrm{~K}$. Edward IV, 1482, and commanded the foreward; Sir Fobn Middleton, of Belfay, the Lord Scrope, of Bolion, \&c. commanding under him; Ralph Lord Greyfock, Baron of Morpeth, bearing a command in the middlc 
middle ward; the whole army encamped and marlialled at Alnwick, about the beginning of $\mathcal{F}_{u l y}$.

His lordhip was fummoned to the parliament at Wefminfer, I K. Richard III, $\mathbf{I}_{4} 8_{4}$; and in the reign of K. Herry VII. was made Lieutenant of York/bire; in which high office endeavouring to fupprefs an infurrection on account of a fubfidy to be raifed for the public fervice, he was flain with many of his faithful atidants, 4 K. Henry VII, 1489 (c). He was interred in the cis!? at Beverley; a ftately tomb erected over him. His da: Eleanor, married Edward Stafford, the third Duke of Di...

His younger fon, Alan Percy, D. D. was the firit prove Fobn's college, in Cambridge, appointed by the executo. foundrefs, Margaret, countefs of Richmond. His fepultu. the inner chapel under a marble-flone, plated with brafs. lordhip's cldent fon,

Henry Lord Percy, the fifth Earl of Nortbumberland, was fummoned by writ to the parliament at Wefminfer, 25 th Fune, I K. Henry VIII, ${ }^{5} 509$. He was appointed general warden of the marches towards Scotland, I 4 K. Henry VIII, 1522; but not clioofing to hold that office, the Earl of Surrey was made general warden, the Marquis of Dorfet warden of the eaft and middle marcises, and the Lord Dacres warden of the weft marches.

His lordhip was at Alnwick, 15 K. Henry VIII, 1523, with the Earls of Surrey and Wefimorland, and the Lords Clifford, Dacres, Lumley, Ogle, Darcy, and others, with an army of 40,000 men, in their march againt the Scots. He died, $18 \mathrm{~K}$. Henry VIII, 1526.

(c) Hol. Chron. vol, ii. p. 769 .

Lord Bacon in Bifhop Kenizit. 
He married Catbarine, the daughter of Sir Robert Spenfer, Knt. His fon,

Henry Lord Percy, the fixth Earl of Nortbumberland, was fum- . moned to the parliament at Wefminfer, $21 \mathrm{~K}$. Henry VIII, I530; when both the Archbifhops, two Dukes, two Marquiffes, his Lordfhip and twelve other Earls, four bifhops, twenty-five barons, twenty-two abbots, and eleven knights and doctors, figned the famous letter or declaration to the Pope, concerning abufes in the church (d). He died without iffue, 29 th June, 29 K. Henry VIII, 1537. He married Mary, the daughter of George Earl of Shrewsbury. His brother, Sir Thomas Percy, being under an attainder, and incapable of fucceeding him, he gave a great part of his eftate to the crown. Queen Mary reftored it entire to his nephew,

Thomas Percy, the feventh Earl of Nortbumberland, fon to Sir Thomas (e); who by letters patent was created Baron Percy, and

Earl

(d) Lord Hurbert in Bp. Kennet.

(e) Thomas comes Northumbrice fuit feifitus de et in caftro et manerio de Alnwick, cum villa; de et in caftro, manerio, et villa de Warkworth; de et in caftro, manerio, et villa de Prudhow; de et in manerio et caftro de Langley, cum Haidon-Bridge; de et in manerio et villa de Newburn; de et in manerio et villa de Rothbury, cum forefta ibidem; de et in manerio et villa de Beanley; Hulm-Park, Hulm.Pilgrimage, Lerbury, Houghton longa, Alnmouth, Ovingham, Nether-theels, Over-theels, Snipe-houfe, Fawdon, Alneham, Overbufton, Berling, Acklington, cum Parka, Brotherwick, Thrifton, Hare-low-hill, Magna Whelpinton, Birtley, Ingho, Buteland, Eaft Hawdon, cum terris in Barresforth, et Gunnerton, Syde, Snapp, Smedwell-rigg, Hole, Hay-greens, Holinhead, Greenheld, Haugh, Black-middings, Sleley, Newbiggen, Came, Sydewood, Water-head, Gravefteed, S. Smaleburn, Smalemouth, Latham, Yarrow-hill, Fawftene, Crofs-hill, Yarrow, Cariteth, Walwick-grange, Park-(helde, S. Charleton, Chatton, Lyham, Fowbury, Caldmarton, Brenkeburn, Gyfaunt, Whitton, Barton, Bowmer, Denwick, Ellingham, Prefton, Newham, Lucker, Warneford, Tughall, Swinhow, cum certis terris et tenem. in Rinnington ${ }_{2}$ et villa 
Earl of Nortbumberland, with limitation to him and his heirs-male, and failing them, to his younger brother, Henry Percy, and his heirs-male; the patent dated April $30 t h$, and May ift I 557, at Wefminfter. He was alfo made lord warden of the marches towards Scotland, with Lord Wharton; the patent bearing date Auguft 2d, 1557, at Richmond $(f)$. The Scots croffing the Tweed in the fame year, under the conduct of Sir Andreze Karr, were defeated by his lordhip, and Sir Jobn Forfer, near Cheviot, after a very fevere and tharp engagement; Sir Fobn being thot through the mouth into the neck, and through the thigh, and his horfe killed under him; Sir Andrew Karr, the Scotch general taken prifoner. The year following, his lordhip's brother, Sir Hinry Percy, entered Scotland with about feven or eight hundred horfe, and two thoufand foot, and after burning the towns of Duns and Langton, engaged the Scotch forces at Swinton, and obtained a compleat vitory; his valour, and the valour of his officers, greatly applauded. The two brothers had another encounter with the Scots, and their French auxiliaries, in the fame year, at Grindon, which ended in their total defeat; many of them in their flight drowned in the Tweed; four upright ftone-pillars ftill to be feen on a hillock in a neigbouring field, memorials of the chieftains flain, and buried there $(g)$.

His lordhip carried the fword of ftate before the queen to the parliament-houfe, 5 Q. Mary, 1562. He was one of the eleven de Corbridge, cum certis terris in Titlington, Long-haugh, Newton, Boifhill, Red-mire, Larder-burn, Bowght-hill, Green-haugh, Brunt-bank, Burn-mouth, et Dunftede.

Écaet, de anno to R, Eliz.,

(f) Rym. Fæed. vol. xv. p. 46, 462, 468 .

Acta Regia, vol.iii. 8 vo. p. 409 .

(g) See Grindon. 
lords who protefted againft the validity of Englifh ordinations, 8 Q. Elizabeth, I566 (b). His brother,

Sir Henry Percy, the eighth Earl of Nortbumberland, was fummoned by writ to the parliament at Wefminfter, I8th February, I 7 Q. Elizabeth, 1575. He alfo fate in the parliament, 23 Q. Elizabeth, I581, when an act paffed both houfes for fortifying the borders. He died, 2 ift Fune, 27 Q. Elizabeth, $15^{8} 5$ (i). He married Catbarine, the eldeft daughter and colneir of Fobn Nevil, Lord Latimer, by whom he had eight fons and three daughters. His eldeft fon,

Henry Lord Percy, the ninth Earl of Nortbumberland, was created Knight of the moft noble Order of the Garter, for his fervices againft the Spanifh Armada, 30 Q. Elizabeth, I588. He was fummoned by writ to the parliament at Wefminfter, 2 I K. Fames I, 1623 ; and I King Charles I, I625.

His lordhip was an eminent patron and encourager of genius and learning, efpecially of fuch as diftinguifhed themfelves by making ufeful difcoveries, experiments, and obfervations. On Thomas Harriot, the learned friend, companion, and affiftant of Sir Walter Raleigh in the difcovery and furvey of Virginia, he fettled a penfion of $120 l$. per annum, on Sir Walter's recommendation. Thus liberal he was to two other ingenious men, Robert Hues, and Walter Warner, on whom he beftowed the like annuity. A donation to literary merit worthy of a Percy! being in Queen Elizabetb's reign a genteel fupport and maintenance. Thefe three learned men were called the Earl of Nortbumberland's three Magi.

(b) Camien in Bihop Kennet.

(i) Hol. Chron, vol. ii. p. 5403 . 
They were his companions in his beft and worft fortunes. In the latter, in his confinement in the Tower, he would never be without them, had them conftantly with him, provided them a table at his own charge. Sir Walter Raleigh being then likewife in the Tower, joined the fett, was much delighted in their company, and they formed a fort of philofophical fociety. Their prifon was as an academy, where their thoughts were elevated above the common cares of life, explored fcience in all its pleafing forms, penetrated her moft intricate, receffes, furveyed the whole globe, till Sir Walter's noble fabric arofe, his hiltory of the world, probably by the cncouragement and perfuafions of thefe his learned friends.

His lordhip died, $8 \mathrm{~K}$. Charles I, $16_{32}$; and was interred at Petworth, in Suffex. He married Dorothy, the daughter of Wralter D'Evereux, Earl of Effex. His fon,

Algernon, Lord Percy, the tenth Earl of Northumberland, was fummoned by writ to the parliament, 3 Nov. I6 K. Charles I, 1640, by the ftile and title of Earl of Northumberland, Lord Percy, Lucy, Poinings, Fitz-Pain, Brian, and Latimer, Knight of the Garter, and lord high admiral.

His lordihip was admiral of the Britifh navy, I2 K. Charles I, 1635. With fixty men of war he feized and funk many of the fifhing-veffels of the Dutch in the north feas, who fled to the king, praying his majefty's leave to filh and trade with his fubjects according to treaty. He was appointed general in chicf of the king's army againft the parliament, 1640 ; but he declined it, on account of his health. The next year he had orders from his majefty to have the whole Britifls navy ready for fea, but his indifpofition ftill continuing, the vice-admiral, Sir Fobn Pennington, 


\section{ANTIQUITIES OF NORTHUMBERLAND.}

had the care of it. In the fame year he was appointed by the parliament Lord Licutenant of Nortbumberland, the town and county of Newcafle upon Tyne, and the town and county of Berwick upon Treed; alfo of the county of Suffex, and of the ifle of Anglefey. On the parliament's motion to raife money by fubfcription, in $\mathcal{F}_{4 n e}, \mathrm{1} 64_{4}^{2}$, his lordhip fubfcribed $2000 \mathrm{l}$. and was difcharged from being lord high admiral by his majefty, in Fuly following, to which his lordthip, fays his majefty in his proclamation, paid a dutiful obedience. He was one of the four lords and eight commoners appointed by the parliament in that year to be commiffioners to the king at Oxford, where he lived in princely fplendour and magnificence. A bill for high treafon was preferred againtt him, and others, at Salisbury, 1643, but the jury would not find it. He was one of the five lords who affociated for the defence of the counties of Wilt/hire, Dorfet/Bire, Somerfetfoire, Devonflire, and Cornwall, and with the members for them and the boroughs, had power, any eight of them, to raife money, appoint colonels, and other officers. He was one of the parliament-commifioners at the treaty of Uxbridge, Fanuary anth, ${ }_{1} 6.44$. By their order, he took the charge of the education of his majefty's children. He was appointed one of the lords commiffioners of the admiralty, 1645 ; and had a grant at the fame time of $3000 \mathrm{l}$. per annum, for his care of the royal offspring. He was accufed to the parliament for affifting his majefty with money, but there being no better evidence againft him than hear-fay, he was acquitted, and at liberty to profecute the accufer ; and was prefented with r $0,000 \mathrm{l}$. in confideration of his loffes in the north. After a vifit fromi his majefty to his children at Sion-houfe, he got permiffion from the parliament to take them at any time to Hampton-court to fce their father,-exemplary and great in his fufferings! He was one of the comminioners at the treaty in the Ifle of Wight. Aftcr his majefty's death, he was an 


\section{ANTIQUITIES OF NORTHUMBERLAND.}

interceffor with the parliament for the fupport of the royal orphans.

His lordhip's brother, Henry Percy, was a reprefentative in parliament for Nortbumberland, but was expalled, oth December, it K. Cbarles I, 164I, for endeavouring to engage the Northern army to free his majefty from the parliament-fetters, pur mettre l: $2: 3$ bors de peine, as he called it ; to keep up his majelly's revenue. maintain bifhops in their rights and functions. He was betrayed. after a folemn oath taken, by colonel Goring, afterwards a genera! of horfe under the Larl of Nerecafle. With fome dificulty an peril he efaped their vengeance. Iiftory has drawn lis character in molt amialle colours. His countene: ce was awful, and commanded refpect Itis mind liberal, and form: with knowledge, civil and military. This mate him as able i general in the field, as he was a prudent and wife counfullor in the cabinet. In the former, he awed the pariament by his management and addrefs, and in the latter carbaratid their mofures; in both firm and intrepid; more fomidable by his wifdon, than his power, though that was great; which he cmployed with the ardour and zeal of a patriot in the fervice of a good mafer, who, to reward him, erented hin a pee: by the ftile and tirle of Baren Pepe", of atursuch, 28 th June, 1643. Ife alfo made him lord chamberlain, and gave him in charge a treafure he loved well, the conduct of his Queen to Oxfork. When the power of the parliament was too cnormous to oppofe, he retreated beyond fea, leaving behird hin a great cftate, and all its fplendid apparatus, preferring before them a fpotlefs loyalty, and an unwounded honour.

Atgernon, Earl of Northumberland, died, October 13 th, 1669 . He firt married Ann, the daughter of Wrilliam Earl of Sulisbury. He

Vol. II.

$\mathrm{C} \mathrm{C} \mathrm{c}$ after- 


\section{$378^{\circ}$ ANTIQUITIES OF NORTHUMBERLAND.}

afterwards married Elizabeth, the daughter of Theophilus Earl of Suffolk, by whom he had a fon and heir to his great eftate (k),

Foceline, the eleventh Earl of Northumberland. His Lordhip married Elizabeth, the third daughter and coheir of Thomas Wriothefley, Earl of Soutbampton. He died at Turin, May 2 ift, 1670 (l), leaving an only daughter, the Lady Elizabeth Percy, who inherited his fplendid fortune, and the antient baronies of the family. Her ladyfhip had thrce hufbands, Hemy Cavendifh, Earl of Ogle, fon and heir to the Duke of Newrafte ; Thomas Thyme, Efq; and Charles Duke of Somerfet. By his Grace her Ladyhip had, befides other children, Alsernon, Earl of Hertford, afterwards Duke of Somerfet, who was created Earl of Northumberland, and at his death leaving an only daughter and heir, Elizabeth, now Dutchefs of Northumberland, who in her own right is baronefs Percy, Lucy Poinings, Fitz-pain, Brian, and Latimer. The titles of Earl of Nortbumberland

(k) Algernon Percy comes Northumbr. filius Henrici, tenet in capite caftrum de Alnwick, Parcum vocat. Cawledge-Park, Weft-Park, et Hulne-Park, ac dominica, maneria, tcrras, et tenementa, et hæreditates in Denwick, Houghton, Lefbury, Alnmouth, Bilton, Tughall, Newham, Newfteed, Lucker, South Charton, Alnham cum Mora, Fawdon, Clynch, Chatton, Wooler, Rugley, Shield-dikes, Shilbottle, Renington, Lyham, Swinciere, Harecragg, Snipe houfc, Heflcy houfe, et Hall-Clofe. Ac caftrum, dominicum, et manerium, et perinen. de Warkworth, ac maneila, terr. et tenem. de Berling, Guifance, Thurfton, Toggefdon, Bufton, New-town, et Brotherwick, ac pifcariam in aqua de Cocket; ac caftr. baronia, ac doninica, et maneria de Prudhowe, et Beanley; ac doninica, ac maneria de Ovingham, Hely, Harelaw hill, Horfey, Whelpingtnn, Ingho, Birtley, et Barresforth; ac dominica, et maneria de Rothbury, et foreftam de Rothbury, ac maneria de New-town, 'Thropton, et Snitter, ac diverfa tenem. et hæeditat. in Newbiggen, Hedlcy, Penpugh, Thorn-haugh, et Eccleftrawe; et dominica, et maneria de Newburn, Corbridge, Wallbottle, Butterlaw, Throcklaw, et Dewley; ac diverf. $t$ nem. et hæreditat. in villa de Novo Caftra fuper Tynam; ac dominic. mancr. terr. tenem. et hareditat. vocat. Talbots, in Tinedale. Lib. Fœdr. Pet. Ofborne, Milit.

(l) See the Introduction to vol. i. 
and Baron Warkworth, devolved by the limitation in the patent to his Grace on his fon-in-law, the prefent Duke of Northumbrrland, knight of the moft noble order of the garter, lord lieutenant of the counties of Northumberland and Middlefex, of the city and liberty of Wefminger, and of the town, and county of the town, of Nertcafle upon Tyne, vice-admiral of the county of Northinberland, and of all America, one of the lords of his majefty's moft honourable privy council, and late lord lieutenant-general, and general-governor of the kingdom of Ireland.

Alnwick-Caffle, the feat of this noble family, was befieged, 2 K. William II, 1093, by Malcolm, King of Scots. Te had with him his fon and heir apparent, Prince Eilwarl. Robert litozubray was then Earl and governor of Nortbuaberland, a nobleman of great perfonal bravery, and military fkill. Vexed to fee his country invaded, for the fifth time, by that astive monarch, he refolved to take revenge $(m)$. Malcoln thought himfelf fecure by the abfence of the ling's troops. Mocubiay confiticred this, and came fuddenly upon him with the forces of his government. A fuart battle enfued. The Scots being deprived of their ufual courage by their furprize, gave ground. Their fovereign and his fon, aftonifhed to fee it, rode from rank to rank, cxhorting, intreating, and imploring them to remember the glory of the Seoth arms, and were both flain. This difafer compleated the rout, and left both the field and the cafle to the ristis.

By the firt mile-ftone on the pon-road, nowth from Alusich, there is part of a crofs or ftone-column ftill remaining, crected in memory of this event, called Malcolm's Crofs.

(m) Hol, Chros, vol ii, p. 2I, 
This calle underwent another fiege, 20 h K. Hinry. II, 1174, by Willian King of Scotland. He had with him an army of 80,000 men. Preferring plunder to a fiege, of which he had fmall hopes of fuccefs, he gave orders to raife it, and pillage the country. A body of 400 horfe at Newcafle, under the command of five gentlemen, hearing of their adventures, refolved to free their. country of them, or die in the attempt. Bernatd Baliol, a gentleman of great refolution, fpirit, and conduct, animated his companions, and led the way. They came upon the King unawares and on a fullen, his troops feattered and difperfed, intent only on fpoil and rapine. The king, alarmed at the danger of his fituation, by found of trumpet recalled as many of his men as were within hearing. The Englifis attacked them with great courage. The Scots, not inferior in courage, but almolt wearied to death with plundering, were over-matched, and viktory declared againt them. Their King, William, was taken prifoner, after the greateft efforts and ftruggles to prevent it. Many of his fcattered troops were taken prifoners cre they well knew their danger. Others fled. He was conducted to Richmond-caftle, from thence to Iondon, and was afterwards fet at liberty by K. Herry, II, for a large ranfom, the fum of $100,000 \mathrm{l}$. fterling, one moiety in ready money, and the other at an appointed time, delivering for fecurity the caftles of Edenburgh, Roxburg, Berwick, Fedruorth, and Sterling ; alfo doing homage for his crown to Englant, the fint cxample of that kind upon record, as a perpetual menorial of which he left his breaft-plate, fword, and faddle, to be kept in York-Minfter (n). This battle was fought on Saturday, $5_{\text {th }} \mathcal{F}_{u l} y_{1} 17_{4}$; and ought to be remembered to the honour of Northun:berlant, and of this cafte, which could make fuch formidable numbers defpair of taking it $(0)$.
(n) H. Knight, inter $\mathrm{x}$ feriptores.
(0) FIsl. Chron. vol, ii. p. 91,92 . 


\section{ANTIQUITIES OF NORTHUMBERLAND. $38 \mathrm{I}$}

Fufface de $V_{e} f c y$, I 4 King Fohn, I 12 , being under fufpicion at court of difaffection, orders were iffued for demolifhing his caltle of 'Alnwick, but on his fubmiffion it fuffered no harm.

After the battle of Hexban-field, $3 \mathrm{~K}$. Edward IV, I46 3 , the Earl of Warwick, the Lord Montacute, the Lords Fauconbridge and Scrope, prefented themfelves before it, and fummoned Sir Peter Brefly, and his Norman auxiliaries, in the fervice of K. Henry VI, to furrender. Sir Peter not yielding, they refolved to befiege it. Sir George Douglas, Earl of Angus, came on the firft notice to his relief with 13,000 Scotchmen. He then marched out with his friends, his enemies not daring to oppofe, who were glad to take polleffion of the caftle without a ftroke $(p)$.

It was fortified and put into a good ftate of defence, $1569(7)$.

It is now the feat of the Duke and Dutchefs of Nortbunberland, who have repaired the caftle in a very fplendid and magnificent manner, in the antient Saxon-gothic ftile; its fituation elevated; the river Aln gliding under it to the eaft; from which point, and from the hill on the weftern road by the entrance into the town, it is a moft ftriking and beautiful objcct.

Alnwick is the county-town, and a difufed borough, of which the principal officers are the Duke's bailiff, and four chamberlains, annually choren, who are freemen of the town. Thofe that are made free of it meet on St. Mark's day on the town-moor, formcrly called the foreft of Aidon, on horfeback, in white cloathing, attended by the caftle-bailiff, the four chamberlains, and molt of the freemen, when, by antient cuftom, they pafs
(p) Hol. Chron, vol. ii, p. 666 .
(q) Id. vol, i, p. 397 .

through 
through a deep bog, called the Freemen's Well, wherein they are fome times up to the chin.

The town ftands very pleafantly, on irregular flopes, within four miles of the fea, a ridge of hills, and one higher than the reft, called Rat/hugh-Crag, intercepting the profpect of it. Three ports and towers of the town-wall are ftill ftanding, viz. Bond-gate, a prifon for debtors and delinquents; Clay-port, converted to a poor-houfe; Potter-gate, the tower without a roof. It hath the following ftreets.

Bond-gate-freet; a good ftreet, long, and well built, the entrance from Nervafile.

Market-freet.

Nairow-gate-freet; a good ftreet, the road to Berrevick upon Treed.

Clay-port-freet; the road weftward to Hebberlaw, \&ce.

Bailiff-gate-freet; well built, leading from the caftle to the church.

Potter-gate-freet; leading to the moor.

Finckle-freet.

The market is nearly in the center. On the weft fide of it is a market-houfe lately built by the Duke and Dutchefs of Nortbunberland for the benefit of the corporation, after an elegant defign, 
ANTIQUITIES OF NORTHUMBERLAND.

in the Saxon-gothic ftile, containing feven apartments, with an ambulatory before them.

On the north fide of the market-place is a range of buildings, in which is the town-hall, entered by a flight of fleps, where the feffions for the county, and elections of the knights of the thire, are held; a tower over it, with a large clock.

The market is on Saturdays. It hath four annual fairs, viz. I 2 th May; the laft Monday in July; the firf Monday in October; $24^{\text {th }}$ December.

In the evening before the fair, on the laft Monday in July, the fteward of the court, and the bailifl, of the Duke and Dutchefs of Nortbunberland, walk from the caftle to the crofs in the marketplace, attended by perfons who owe fuit and fervice; that is to fay, the townfhips of Chatton and Cbillingham, 4 men; Cold-Marton and Forbury, 4 men; Hetton and Hezelrigge, $4 \mathrm{men}$; Fawdon and Clinch, 4 men; Ainham and Alubam-moor, 2 men; Tughall and Swinhoe, 2 men; Long Hougbton and Denwick, 4 men; Lesbury and Bilton, 2 men; Lyham and Lybam-hall, one man; with the principal inhabitants of the borough of Alnwick. The bailiff proclaims the fair in the name of the Duke and Dutchefs of Northumberland. The men who attend for the feveral towns in fervice are obliged to keep watch at all parts of the town the night before the fair, which has been a cuftom for time immemorial. The next day the tenants of the Duke and Dutchefs within the barony of Alnwick attend at the caftle, when the fteward and bailiff proceed from thence to the market-place, and proclaim the fair as before. They then go to the head of Clay-port-freet, and return to Clay-port-tower, where the fair is proclaimed again; and from thence to the cafle. The townfhips above mentioned, 


\section{ANTIQUITIES OF NORTHUMBERLAND.}

are exempt from paying toll for 12 months, for their attendance; but if they do not attend, they muft pay the fame till the next year.

In the upper end of Potter-gate-freet, is a grammar-fchool; the following infcription over the entrance.

Hec fchola primo in ufum municipum

Alannenfum xdificata Anno Dom. 1687.

Nunc demum inftauratur Anno Dom. I74I.

There is a neat fafhed houfe and garden joining on to it for the accommiodation of the mafter; the endowment reputed 25 . or 30 l. per anmum, arifing chiefly out of the tolls of the town.

The town was burnt by the Scots, 1448 , in refentment for the burning Dunfries by the Englifs (r).

It gave its name to Wrillian de Alnwick, L. L. P. Confeffor to Henry VI, 1424 , and keeper of the privy-feal, recommended by his Majefty and his miniftry for the Bihoprick of Ely, on the death of Foln Fordbam, who held both that See and Durbam, but miffed of it by the Pope's interpofition.

Alnwick-church ftands at the end of Bailiff-gate-freet. It is large; has three ifles, extending through as many arches into the chancel; has four galleries, twenty-feven windows, great and fmall, and three bells which are fmall. It is a good church, kept neat; the chancel cieled; and the whole covered with lead; a neat tower for the bells.

(r) Hol. Chron. vol. ii. p. 272. 
On the back of the royal arms, over the arch of the middle inle in entering the chancel, is this infcription, in Black characters:

Sumptibus Edvardi comitis cognomine Bedford;

Cognita preclari funt hxe infignia clara.

$$
\text { ANNO DNI. I600. }
$$

In a hollow nich of the wall of the fouth ifle, there are three human figures in ftone, recumbent; the hands elevated, in a fupplicatory attitude.

On the fouth-caft fide of the chancel, is a neat mural monument, with this infcription in capitals.

Intra altaris fepta,

Conceffu honeniflimæ matris Fane Graice,

Situs en

Alexander Banus, Scotus,

Juris patris in academia Edenburgena

xiv amplius annos interpres

Elegantis vir ingenii,

Limatique ftyli,

Quietibus blandis graviora temperans ftudia;

Nunc mechanica, nunc pißtura, prefertim vèro,

Qua, plurimum excellebat, mufica.

Hoc ille ingenio fimul et perpetua

Mortum honeftate fpectabilis,

Suorum lumen,

Diffidentium fanitas,

Miferorum levamen,

Sodalium delicium,

Vor. 11。

1) de d.

In 
386 ANTIQUITIES OF NORTHUMBERLAND.

In itinere ad

Thermas Somer-

Jetenfes obiit

$x$ Kal. Maii, A. D.

MDCCXXX VII Eitat. LII.
Splenduit.

Bene merenti viro

Monumentum fida

Pofuit uxor,

Maria Carfairs.

Above, is the effigies of the deceafed on a brafs plate, over which is his coat armorial, a wheat theaf and three thiftles, and under it thefe lines;

Di celant homines, et vivere durant,

Quam fit dulce mori.

A fmall houfe and garden in Clayport-freet, lately lett at $7 l$. per anium, was given by Mr. Grey, a merchant in Alnwick, for the ufe of the incumbent. The diffenters have built one for a minifter of theirs near Bond-gate, both handfome and convenient. They have two meeting-houfes; and a peoplc, ufually called Methodifts, have another.

Here was an Hofpital, dedicated to St. Leonard, of the foundation and in the patronage of the noble family of the Percies. Henry Lord Percy, afterwards Earl of Nortbumberland, gave it, to hold in pure alms, to

Ainwick-Abbey (s). This abbey was founded, 4 K. Stephen, I I 57 , by Euftace Fitz-Fobn, for Premonftratenfian canons, and dedicated to the Bleffed Virgin $(t)$. He endowed it with a great parcel of his

(s) Pat 50 R. Ed. III. p. I. m. 24. pro horpitali S. Lecnardi ibidem annectendo.

(t) Cronicon Mailros.

Leland's Collectanea, vol. iii. p. 73 . 
his baronial lands. He gave it the villa of Huicliff, and all the demefnes about it, on the left hand of the road from Alnvick to Rock, and the waftes belonging to it, extending from Hindon to the river $A h$, with the fervice of half the tenants. He gave it two parts of the tithes of the lordhips of Tughall, of Ambam, of Nerwham, of Heyfend, of Chation, and one moiety of the tirhes of Wooler. He gave it the appropriations and advowfons of Alnwick, of Wooler (u), of Long. Honghton, and of Lefoury. He alfo annexed to it the priory and church of $G_{y} / n e s$, now Gyfon, or Guizance, near Felton, dedicated to St. Wilfrid, of Richard Ty fon's foundation, to hold in pure alms, with all its privileges and endowments, a moiety of the tithes and two bovats of land at $G y f_{0}$, the church of Halgc or Haugh, the lands of Ridlcy, and Morwick-haugh, with liberty of crecting a corn-mill, on the river Coquet, and of raifing as much corn on his waftes there as they could plow, with liberty to grind it at his own mill, moulter-free. He alfo gave the canons for their table the tenth part of all the venifon and pork killed in his parks and foretts, and of all his filhes taken in his filheries by his order, and a falt-work at Warkworth.

The Lord William deVefcy, his fon, gave them the advowfons of Chatton (v), of Cbillingbam, and Alnbam. They had alio the ad-

Vill. in Monaft. Anglican. vol. ii. p. 59. Diploma Henrici Perey, com. Nortbumbur. recit. et confirm. Cart. foundationis.

Regift. et Cart. Monaft. de Alnwick, penes Franc. Brandling, Mil. A. D. 1639.

Collectanea ex ii.đem, MS. Dodfworth, vol. xlix. f. I I, \& c.

Cronicon. Monait. de Alnwick, MS. in Bibl. Coll. Reg. Cantab. et exccrpta ex eodem MS. Cotton. Vitell. E. xiv. 22. 10.

(u) Pat. I R. Ed. II. m. 4. pro eccles, de Wollore.

(v) Pat. 5 Ed. II. p. I. m. 23. pro eccles. de Chatton.

Cart. tres Will. de Vefcy, Fil. Euffacii; una pro.eccles. de Chattox; altera pro eccles. de Chillingham; tertia pro eccles. de Alinbam. 
rowfons and appropriations of St. Dunftan's in Fleet-frect, in London (w), and of Leckenfield, in rorkflire ( $x$ ).

They had twenty-four acres of turbary or earth for fuel, and liberty of pafturage on Edlingham-common $(y)$. They had lands at Chatton, and at Fallodon $(z)$. They had four tenementș and a garden in Nercafle upon Tyne (a).

The abbot was fummoned to parliament, $23,24,28,32$, and 34 K. Edward I; alfo to the parliament at Carlifle, 35 th of the fame reign, 1307; and to the parliament, I 9 K. Edward II.

Thefe are the chief, antient privileges and poffeffions of Alim reick-abbey. Its annual revenues at the diffolution, $26 \mathrm{~K}$. Henry VIII, were valued at i 89 l. i 5 s. Dugd. 194l. 7 s. Speed. It had then thirteen canons. The fite of it was granted, 4 K. EdwardVI, to Ralph Sadler and Laur. Winnington. It was afterwards fold, with the demefnes about it, to Sir Francis Brandling, Knt. of whofe family it was purchafed with the fame lands by Mr. Doubleday, father of Thomas Doubleday, Efq; the prefent poffeffor, whofe feat is built out of the ruins of it, which ftood in his orchard, fouth of his pleafure-garden. The only remains of this religious pile, is the court-wall to the eaft, through which is the entrance, of very curious architecture, with a modern-built turret at the

(w) Pat. 9 Ric. II. p. 1. m. 14 pro eccles. S. Dunfani in Fleetfreet, Londini, approprianda.

(x) Pat. $37 H_{6 n}$. VI. p. I. m. 4. pro ecclec.. de Lakcnfeld approprianda.

(y) Cart. 2 Fob. m. 12. pro turbaria.

Cart. $35 E d$. I. n. 25. recit. et confirm. donationes.

(z) Pat. 16 Ed. II. p. 2. m. 1. de terris in Chatton \& Falenden.

(a) Bourne's Hift. of Newsalle, p. 142. 
fouth end, beyond which is a building feemingly of a later erection; not correfponding with the grandeur of monatic ftructures; anfwering better the ufe it is now put to, viz. a ftable, than any other. Adjoining to it, is an antient and ftrong tower, with four turrets, two at each end.

The fituation of the abbey is extremely pleafant, at a fmall diftance from the caftle, in view from the church, and under a hill, on the extreme point of a peninfula by the eaftern margin of the river $A l n$, croffed by a bridge of two arches; whofe winding trout-ftream, in pleafint murmurs, glides paft it ; fhaded on the oppofite fide with a bank of wood, and here and there a broken rock vifible through it, variegated with ivy and woodbine.

There is a ftrect between the bridge and the church, a fort of fuburbs to the town, called Connon-gate; from its leading to the abbey, or houfe of Canons; a fmall manour belonging to them; and now in the poffeffion of Sir Lancelot Allgood, of Nunwick, Kt.

About three miles from the caftle of Alnwick, nearly in the middle of Huln-park, higher up the river, on an eminence, is the abbey of

Huln (b) founded by Ralph Fresborn, a gentleman of Northumberland, for Carmelite friers (c), and endowed by folm hord $V e f c y$,

(b) Holme. Camden.

Holm. Tanrer.

Hulne. Rot. Mag. Northumbr.

(c) Nerwcourt's Repertorium, vol. i. p. $567 \div$

Steven's Addit. vol, ii. p. $18_{4}$. 
with twelve acres of land, lying round it (d). A conduit of fine freh water was conveyed to it from the Holy Well, a mile to the nouth-eaf of it; in lead-pipes, called alfo the Friers Well. On the wet fide of it, is an antient tower, built by Sir Henry Percy, the fourth Larl of Nortbumberland, as appears from the following infeription, cut in relicf on a ftone ftill remaining.

\section{$\mathrm{XX}$}

In the year of Chrift thu. M. CCCC. IIII. VIIr.

This tower was builded by Sir Henr. Percy,

The fourth Iiarl of Northumberland, of great hondur and worth, That cfpous'd Maud, the good lady, full of virtue and beauty, Daughter to Sir Will. Herbert, right noble and hardy,

Earl of Pcmbroke, whole foulcs God fave,

And with his grace conferve the bilkler of this tower.

The founder of this monaftery, Mr. Tresborn, died $2 \mathrm{~K}$. $E d$ ward I, 1274 , and was interred in it. He chofe this fpot for its refemblance to mount Carmel, in Syria. It is on the north-eaft fide of the river Aln, whofe ftreams wah its floping 1 kirts, in a winding current through rocks, pebbles, and bufhes, awakening with its fymphony our attention to ferioulnefs and plcafure. In this delicious folitude, the famous biographer, Jolm Bale, lived and fudied, being a member of this little fociety.

The whole, except the tower, is now in ruins. It was given by Queen Elizabeth, to Sir Fobn Forfer, Knt. and in the reign of King

(d) Pat. 4 Ed. II. p. s. m. 3. Pro confirmatione donationum Fobamis de l'efos, et aliorum.

Pat. 9 Ed. I1l. p. 11. Vid. inter MS. Bibl. Bodl. Oxon. Dolfworth, vol. xlv. f. 15. excerpta ex cartulario Carmelitarim de Alnwyike olìn in cuftódia Dom. Will. Howuard, Domı de Nuworth, nuper penes Fohanmem $W$ arburton, Arm. Soncr jet heraldum.

Tanner's Notitia Monaft fol. p. 395 . 
Fames I, was in the poffertion of Fobr Salkeld, Efc; (e), and now of his Grace the Duke of Northunberland. His Grace has repaired the tower, made a handfome road to it from his caltle through the park, by the margin of the river, edged with flowering fhrubs and plantations, thored with game, and fong-birds, of various kinds. The odours of the flowers, the play and puftime of partridges, of hares, the cooing of turtles, the joyous harmony of the little fongters of the grove, all confpire to rende: it a charming walk. To the weft of the abbey, are the rocky hills, called, Brifsley-hills, containing about 200 acres, plantcd by his Grace with foreft-trees, of the beft kinds, which in a ferv years will add greatly to the beauty of this his facred Comel.

At the north end of Alnwick-bridge, a road branches off on the right hand, to

Howick, one of the manours of the barony of Alnwick, a mediety of which washeld by the antient family of the Grey's of Cbillingban; by Sir Ralph Grey, Knt. in part of the reign of King Henry VIII, in the reign of King Edward VI, and in the beginning of the reign of Quecn Elizabeth; and by his fon and heir Sir Thomas Grey $(f)$; the other medicty belonging to Robert Heron, a younger branch of the baronial family of the Herons of Ford $(g)$.

Thie

(e) Cart. penes ducem Nortbumbr.

(f) Radulphus Grey, de Chillingham, obiit feifitus de et in medietate villæ de Horvick, per dimidium feodi milit. veteri fcoffamento, baronia de Alnwick.

Themas Grey, de Chillingham, filius Radulpbi, eft in minoritate, et in manu reginx.

Efcaet, de anno to Eliz. Vid. Wark.

(8) Reberfus Heron fuit feifitus de et in medietate villa de Howick.

Efcaet. de anno to Eliz. 
The Greys afterwards acquired the whole manour; which was pofleffed by Fobil Grey, Efq; high theriff of Northumberland, $14 \mathrm{~K}$. Hrillium III, I 70 I ; by the late Sir Henry Grey, Bart. high theriff of Northumberland, I736; and now by his fon and heir, Sir Henry Grey, Bart. a reprefentative in parliament for Nortbumberland.

'The old tower of Howick, mentioned by Lelatd (b), is entered by a flight of fteps, and is ftill a fair ftructure, to the north end of which the late Sir Harry built a large, handfome houfe, and elegant oflices. It ftands within a mile of the fea, and on the north fide of a trout-ftream, called Howick-burn, croffed by a new ftone-briclge of afhler-work. To the north-eaft are the ftables. To the weft is a fhrubbery and plantation, through which the brook takes its courfe between grafs-lawns, and makes its Exit by a gentle fall. To the fouth-eaft is the church, dedicated to St. Niclaal, rebvilt after a handfome manner by the late Sir Harry, though not the patron. Near it is a free-fchool, for the chucation of his tenants children in reading, writing, and accounts, to which at his death he gave $200 \%$

A mile north-eaf from Hawick, is

Crafet (i), the manour and villa of the antient family of the Crafers; of William de Crafter, I K. Edward I (k); of Sir Edmund

Yom Heron, anceftor of this Rabert, held the manour of Little. Hougbton of the fame barony, I K. Ed. I.—- Gohawnes Heron tenet villam fuam de parva Houghton per unum feod. vet. - feoffan. Baronia de Alnwick. Efcaet de anno I Ed. I.

(b) Lcl. Itin. vol. vii.

(i) Crawfter. Crafter.

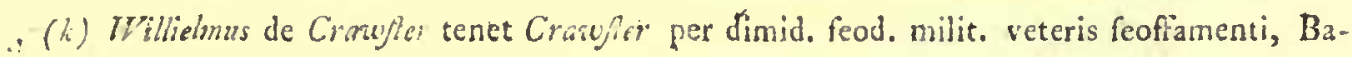
rouisi de Emeílon.

Efcaet. de anno I $E d$. I. 
de Crafer, Knt. 26 K. Edward III (l); of Ricluard de Crafer, I3 K. Henry IV $(m)$, who alfo had the Lordfhip of Diflon, near Hexham (n); of Gobnde Crafer, I2 K. Henry VI (o); of Eimund de Crafer, bailiff of Bambrough-Cafle before and after the battle of Hexbamfield, to whom, and to Richard Crafer, K. Fdward IV. granted lands for their faithful fervices to him; of Edmund de Crafer, ro Q. Elizabeth ( $p)$; of the late Foln Crafer, Efq; an eminent counfellor at law; and now of his fon, George Crafter, Efq. The village ftands clofe by the fea, and is inhabited chichy by fifhermen.

From Alnwick-bridge we afcend the hill, by Malcoln's crofs, to the third mile-flone, near Hefferley-tower, where we have a fine profpect of

Dunfonbrough-Caftle (q), which was built by Thomas Earl of Lawcafter, general of the confederate-army againf K. Edward II, I321, who after his defeat by the king's forces at Burton upon Trent, thought to have taken fhelter in it, but was taken in his flight at Borough-Bridge. He was conducted to his caftle of Pom-

(l) Efcaet. de anno 26 Ed. III. n. 52 .

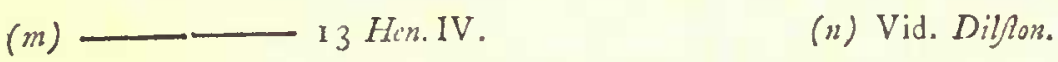

(0) He is among the names of the gentlemen of the county returued by the commiffioners in that year; Sir Thomas Lilbourn, of Lillourn, then high Theriff, and a commifioner.

(p) Edmundus Crawjer fuit feifitus de et in villa de Crawufer, cum terris in Dunfton, et Embletor. Efcaet. de anno to Eliz.

(9) Dunftaburge. Camd. Brit. p. 860, and p. 873 .

Dunftanborow. Lel. Itin. rol. vii. p. 60. Dunftonbrough.

VOL. II.

Ece fiet, 


\section{ANTIOUITIES OF NORTHUMBERLAND.}

fret, and tried in form, in the king's prefence, for treafon (i). He was beheaded on St. Thomas's hill, on the north-eaft fide of that town, 25 March, 1322; and was buried in the priory-church on the right hand of the liigh altar. The king remitted, on account of his being a near relation, grandfon to K. Henry III, the infanous circumftances of hanging and quartering; the firft example of which in Eingland was in the perfon of the unfortunate Ifelff Prince David, the laft of his family, and of the firft antiquity in Europe, 10 K. Edward I, 1282. He was canonized in the reign of $\mathrm{K}$. Richard II, and his picture hung up in St. Paul's church (s); af fer which time the hill of his execution was called St. Thrmas's liill. He forfeited five earldoms, viz. Lancafer, Lincoln, Sulisb:ry, Leirefter and Derby. He was the greateft fubject in the realm, and the mightieft Peer in Chriftendom ( $t)$. His attainder was taken off, and all his fignories, honours, and lands, reftored in the next reign to his brother, Henry Earl of Lancafer, on his petition to the parliament. He was one of the four Lords appointed by the twelve guardians of the kinglom to take care, of $\mathrm{K}$. Edreard HI, in his minority; who in the $25^{\text {th }}$ year of his reign, $135 \mathrm{I}$, created him Dukc of Lancafer, by his fpecial charter. He was the fecond in the kingdom advanced to that high dignity; Prince Edward being the firt, whofe brother, Fobn, marrying the daughter and heirefs of the Duke of Lancafer, fucceded both to his fortune and title; to the latter by creation.

Duke Henry of Lancafer on his inveftiture by the fword, had licence to hold a court of chancery within his dutchy, to fend

(r) Rym. Foed. Angl. tom. iii. p. 936.

Tyrrel's Hift. of England.

(s) Ada Regia, vol. i. 8vo. p. 113 .

(t) Hol. Chron. vol. ii. p. 331. 


\section{ANTIQUITIES OF NORTHUMBERLAND. $395^{\circ}$}

out writs, and try caufes; which is the rather to be noticed, as fome have thought, that Lancafer was not made a county palatine till the reign of $\mathrm{K}$. Henry IV.

The cafle was a frong and noble building. Its glory fell with the royal rofe of Lancafer, K. Henry VI, after the fatal buttle of Hexbam-field; when Sir Peter de Brefy, and five hundred Frenchuen taking thelter in it, it was befieged by Ralph Lord Ogle, Finumd and Richard de Crafer, fohn Manners, and Gillert de Errington, zacalous friends of the houfe of York, who took the whole garion prifoners, except Sir Peter, and demolifhed it; having held ont by its ftrength a long time; the befiegers being cncouraged by the hopes of rewards, which they had plentifully out of the forfeited eftates from the fortunate and victorious Edarard, who never failed liberally to remunerate thofe who faitifuily ferved him. It was in the crown, 10 Q. Elizabeth ( $u$ ); and was granted, 6th February, $22 \mathrm{~K}$. Fames I, to Sir William Gry, Baron of Wark, and confirmed by K. Willian III, 20 December, I694; and is now in the poffeffion of the right Hon. the Earl of Tarkirville.

It ftands on an eminence of feveral acres, floping gently to the fea, and edged to the north and north-weft with precipices, in the form of a crefcent, by the weftern termination of which are three natural ftone-pyramids of a confiderable heigis and by the eaftern one an opening in the rocks made by the fea, ruder a frightful necipice, called Rmble-cham, from the breaking of the waves in tempeftuous weather and high feas. Above this is the main entrance, and by it the ruin of the chapel. At the

(u) Domina Regina Elizabetba feifita de et in caftro, manerio, et villa de DunRonb:ough, Dunfon, Stamford, et Enclton, ut de poffefionibus nuper Fobannis Domini de Lan alicer.

Elcaet. de anno ro Eliz. 
fouth-weft corner is the draw-well, partly filled up. It is built with whin and rag-ftone.

Near the $4^{\text {th }}$ mile-ftone, a road branches off, on the right hand to

Rock, one of the manours of the barony of Alnwick, of which it was held by William de Rock, I K. Edward I (v); by Robert Lawfon, Efq; high theriff of Nortbumberland, 3 Q. Elizabeth (w), and a reprefentative for it in parliament, 5 th of the fame reign, who alfo had the eftate of Falowdon, as was found by an inquifition taken after his death, Ioth of that reign $(x)$; by Fobn Salkeld, Efq; $(y)$; and by the late Thomas Proctor, Efq; who fold it to the Right Honourable the Earl of Ferfy. It has a chapel in it dedicated to St. Pbilip and St. Fames. It ftands on an eminence, and has an extenfive fea and land-profpect.

Two miles eaft from Rock, and a mile from the fea, is

Embleton (z), the Barony of Fobn de Vifcount, in the reign of K. Henry III (a), and I K. Edward I (b). It was afterwards one of

(v) Willielmus de Rock tenet villam fuam de Rock per dimidium feodi milit, veteris feoffamenti, Baron. de Alnwick._Efcaet. de anno i $E d$. I.

(w) Efcaet. de anno 3 Eliz.

(x) Hæredes Roberti Larufon feifiti de et in villa de Rock et Fallcden.

(y) Camd. Brit. Edit. 1722 , p. 873 .

Lifcaet. de anno ro Etros

(z) Emleton.

Emeiton.

Embleton. Lel. Itin. vol. vii. p. 60 .

Embledon. Drowne Willis.

(a) Fobannes Vificunt tenct in capite de dom. rege baroniam fuam de Emleton per fervicium trium feodorum milit, et omnes anteceffores fui tenuerunt per eund, fervic. de dono dom. 
of the Lordhips of the Dutchy of Lancafer, and now belongs to the right honourable the Earl of Tankerville. It is an irregular built village, chiefly under the ridge of a hill, which intercepts the profpect of the fea. The church is on the weft fide of it, which is dedicated to the Holy Trinity. It is in the form of a crofs, the roof flat, covered with lead; a gallery in it at the weit end. It has alfo a fmall veftry, an a good tower. The vicaragehoufe and garden join on to the welt fide of the church-yard, on a gradual flope; in making which decent and convenient, a large fum of money was laid out by the late incumbent, the Revd. Mr. Parfons. One of his predeceffors, the Rerd. Mr. Edwards, founded a fmall Enslifs and Writing fchool on the top of the ridge of the hill, to which he gave an enclofed field on the eaft fide of it, valued at $5 l$. per anmun.

A littic beyond the $7_{\text {th }}$ mile ftone, a neat road branches off, on the right hand, to

Ellinghom, which was the Barony of Ralph de Guagy in the reign of K. Herry III (c), and I K Edward I (d). It was the Lord-

regis Henriciprimi, qui ecs feoffavit. Fe preferca item Johannes Vifcount tenet fex bovatas terra in burgo de Bambrotgh, reddendo ince jer annum vii . ad formam burs. quas dom. Rex Jchannes, pacer dom. regis Jemria, dedit $\mathcal{G}$ biznni, flio Edvardi, antecefiuri predicti Fohannis; et de eodem feodo nulia eit alienatio, aut donatio aliqua, unde dom. rex minus habeat de fervicio fuo.

Tefta de Nevill.

(b) Jobannes le Vifcount tenet in capite de dom. rege Emelton, Stamford, Buton, IVarnian, Craufer, et Dunfton, per tria feoda milit. de veteri feoffamento. Efcaet. de anno I Ed. I.

(c) Radulpbus de Gaugy tenet in capite de dom. rege baroniam fuam de Ellingbant per fervicium trium feodorum milit. et omnes anteceffores per eund. fervicium tenuerunt poft te:,pus regis Henrici primi, qui illos feofravit. Et de illo tenemento nulla eft alienat. \&c. unde dom. Rex, \&c.

Tefta de Nevill.

(d) Radulphus de Guagy tenet de dom. rege in capite Ellingbam, Osberwicke, Doxforde, Cramlington, Hcton juxta Novum Cafrum, Hartley, Fefmont, et Whitley, per tria feoda milit. veteris feoffamenti.

Efraet. de anno 1 Ed. I.

fhip: 
fhip of Sir Alan de Heton, I K. Richard II, I378; who in that year was at the taking of Berwick upon Tweed from the Scots, under the right honourable Hury Percy, Earl of Northumberland, and his fon Henry Lord Percy, where he had his particular poft affigned him in the affault, and acquired great honour by his valour (c). He died in the latter end of that reign, and left three, daughters and coheirs; viz. Elizabeth, married to Sir fohn de Fenwick; Mary, to Sir William Swinburn; Folsanna, to Sir Robert Ogle (f). It is now the feat and manour of Edward Haggerfon, Efq; a younger fon of the late Sir Carnaby Haggerfon, of Haggerfon, Bart. and brother to the prefent Sir Thomas. His feat is in a low fituation, by the fide of a fmall ftream. The church is on a higher ground, in a folitary field, in fight from the poftroad.

Trom the $9^{\text {th }}$ mile-ftone, we have a fine view of

Bambrough-Cafle (g); which ftands on the ridge of a fteep hill above the fea, and from the ftile of the architecture of the bate of the old tower now remaining, of the Doric order, is believed to be of Roman original. It is very probable, that whiln the Romans held poffeffions in Scotland, and north of the wall, they had their exploratory towers and forts along the coan, and did not leave it naked and defencelers, expofed to the inroads of an enemy,

(e) Hol. Chron. vol. ii. p. $42 \mathrm{I}$.

(f) Fobanwes de Fenwick, ct Elizabetha uxor ejus, una; Willidmus Swinburn, Chr. et Maria uxor ejus, altera; nec non Robertus $O_{g} l e$, Chr. et "̈ohanna uxor cjus, tertia filia, et hæredes Alani de Hcton, Chr. defuncti. fuerunt ad refpondend. regi pro relievio fuo pro omnibus terris et tcriem. quæ dictus Alanus tenuit de rege in capite die quo obiit, \&c.

Rut. Hillar. Fin. de anno 21 Ric. Ir.

(g) Bamburg.

Bambrough. Lel. Itin. vol.vii. p. 60.

Beficles, 


\section{ANTIQUITIES OF NORTHUMBERLAND.}

Befides, the coaft for fertility, and the conveniency of their navy and thipping, was of more value to them than all the reft, unlefs it can be fuppofed, contrary to the ufual pratice of that wife nation, that they preferred poverty to wealth, danger to fecurity, hardhips and difficulties to pleafure and convenience, and rifqued their lives for the acquifition of bleak mountains and hills, barren rocks, healhs and moraffes. The caftles of Tynemouth, Dunfonbroush, and this, ftand in a line, as Agricolis chain of forts did crofs the country between the two feas; and it is very likely that the firft foundations of all three were Roman. It is well known, that the Saxons built their cafles, when they could, on Roman foundations, and gave them the name of Burg and Brongh. The Danes gave them the name of Burgos. The Saxon king, Ida, has the honour done him by Roger Hoveden, and all our hiforians, of being the builder of this, and make its antiquity coeval with his kingdom of Northumberland. He firtt inclofed it with wooden pales, and afterwards with ftone. A well was made to accommodate it with water, which is much praifed by Hoveden for its goodnefs, and for the ftonc-workmanhip about it. When the Saxon-court afterwards became Clrifian, and Northumberland-kings ferved God with more pleafure than the world, a church or chapel was buile within it, confecrated by K. Ofrald to St. Aidon.

It muft have been a place of great ftrength, as it was the fanctuary of the Northumberland-kings, carls, and governors, on any imminent danger; withftood the fury of many fieges and blocades, and was the confinement of ftate-prifoners. K. Ofred, in his minority, and a nobleman under whofe tuition he was, called Britbric, thut themfelves up in it, on the death of K. Alfred, his father, in 705 ; to be fafe from the violences of Edulph, a rebcl lord, who had feifed upon the crown. Edulph befieged it with 
his partizans. The young. king and his governor made a brave and long defence, which gave his faithful fubjects time to rife and haften to his relief. The ufurper had turned the fiege into a blocade, but on their approach retired in confufion and hurry. He wals purfued by Britbric, the royal orphan's guardian. Brithric followed him with all the ardour of a good gencral, and with a refolution to take vengeance on his fovereign's wrongs. Edulph was prefently overtaken and feifed. There being no need of the form and ceremony of a trial for fo black a treafon, he was infantly exccuted. Young ofred was fecurcly fettled in the throne, and this cafle was no longer his prifon, but his palace.

Walteof, the firt of that name, Earl of Nortbumberland, being feeble and weak with age, and unable to oppofe Malcolm, King of Siots, at the head of a numcrous army, made this royal fabric. lis rerreat, till he was freed from his fears by the valour of his fon, Lchtred. Enraged to fee his country invaded, Uchtred marched araint them with a few troops, haftly raifed. With thefe, difpofed to the bett advantage, animated by his undaunted bravery and courage, with the view of glory, and the taking ample vengeance of thoir cnemies, he obtained a famous and compleat victory. A victoy, from which he would have reaped a greater harveit of honum, had he ufed it with lenity, and not fullied it with an act of cruel inhumanity. He had among his prifoners feveral Scotch nob!emen, generals and officers of rank. Thefe he beheaded. Their heads he placed upon poles round the walls of the city of Durbam. In this, he fhewed he had more of the fpirit of the tyrant, than of the hero, whofe foul has juft ideas of glory, and always extends a gencrous commiferation to the vangififed, and protects and applauds the faithful and brave Gencral in an cnemy. However, Uchtred's fuccefs, and not his cruelty, 
cruelty, was regarded at the court of his fovereign, K. Ethelved. Every body there talked of it in raptures. K. Ethelred himfelf in his tranfports was refolved to thew him one of the higheft marks of his favour. He gave him his daughter, the princefs Edyriva, in marriage, and with her, the carldom of Nortbumberlond, and the county of Yorkfhire, for a portion; old Wulteof refigning this royal fortrefs, and his other caftles, and goremment, to his fon, thus allied to the throne.

In the year 642 , it was befieged by Penda, the pagan ling of Mercia, after his victory over K. Ofurall. at Ofwefle, in Shrophsire; a prince as remarkable for his zealous patronage of chrilianity, as for his bravery. Cruelty feems to have been the characterific of Saxon paganifm. The favage Penla, not content with a vic'tory over that chriftian hero, harbaroufly mangled his body, and thought to have reduced this cafte to afhes, for making a gallant defence. He laid vaft quantitics of wood under the walls, to which he fet firc as foon as the wind was favourable, but no fooner was it in a flame, than the wind changed, and carried it into his own camp, and forced him to raife the fiege, to his own great thame, and the praife of that Being, who fets bounds to the rage of mercilefs men.

In the reign of K. Egrbert, Femulph, Bifhop of Landisfarn, being fufpected at court of a crime, of which he was innocent, was a Atate-prifoner in this caftle about thirty years, from $75^{\circ}$ to 780 .

It fuffered greatly by the fury of the Danes in the year 93.3 , but was foon repaired, and eftemed the ftrongeft fortrefs in the county. 
In the year 1095, Robert Mowbray, Earl of Nortbumberland, and his party, marched into it for fecurity, on the approach of the royal troops to chaflife them for their treafon. The king, Witliam II, befieged it in perfon. As traitors never think themfelves fife any where, Mowbray fecretly fled for fanctuary to-St. Ofwin's: Thrine at Tynemouth, where he was taken prifoner. His fteward and kinfman, Morel, with a courage that would lave done honour to a better caufe, defended the caftle in the abfence of his unfortunate I.ord. He defended it gainft all the forces of the king. The king had turned the fiege into a blockade, and raifed a fortrefs near it, called Malvoifon, i. c. Bad Neigbbour, fome time before the earl fled. Morel, not terrified by fo many bad neighbours, ftill held out, with an aftonithing perfeverance and refolution, to the furprize of the king, who beginning to be uneafy, tried to effect that by policy, which he could not do by force. Hc ordered the earl to be led up to the very walls, and a declanration to be made, that if the caftle did not furrender, his eyes fhould inftantly be put out. This fucceeded to his wilh. Morel no fooner beheld him in this imminent danger, than he confented to yicld upon terms. For his fidelity and affection to his Lord, and his gallant defence, the king took him into his royal, protection and favour. A godlike action, thus generoufly to reward a faithful enemy! For the fervant's fake, probably, the incenfed fovereign fpared the life of the mafter, and only kept him a prifoner in Windfor-caftle, where he remained thirty years.

In the year 1296, K. Edward I, fummoned Fobn Baliol, King of Scotland to appear before him at his caftle, and anfwer for breach of faith. Baliol not appearing, he went on to Berwick, and put the Scotch garrifon to the fword. From thence he directed his: march to Dunbor, and in his way met with the Scotcharmy going to 


\section{ANTIQUITIES OF NORTHUMBERLAND.}

its relief. That army he attacked, and made a dreadful flaughter. Twenty-two thoufand Scotchmen are faid to have fallen victims to his refentment. Dunbar was reduced. Baliol was taken prifoner. The victorious Edward brought him to England, together with the ftone-throne of the Kings of Scotland, kept at Weftminfter ever fince.

In 4 K. EdwardII, I3 Io, Peers de Gavefon, Earl of Cornwall, was placed in this caftle by that king, to fave him from the indignation of an injured nobility, who in 1312 , dragged him to juftice from the caftle of Scarbrough, in York/bire.

In the year $1_{4} 63$, it was taken and retaken by the Generals of kings Edward IV, and Henry VI. Sir Ralph Grey, Kuight of the moit noble Order of the Garter, was governor of it for the latter a little before the battle of Hexban-field ; but aifter that unfortunate action he was forced to furrender both himfelf and it to the Earl of Warwick, and the Lords Nontacute, Fauconbridge, and Scrope.

Between thefe two contending princes it muft have received violent fhocks. After that period, it went fpeedily to decay. K. K. Henry VII, and VIII, out of policy did not repair any caftles, but demolifhed many, looking upon them only as fanctuaries for rebels. It was in the crown, 1o Q. Elizabeth (b). Sir Yobn Forfer, of Bambroush-abbey, lord warden of the middle

(b) Domina regina Elizabetha fuit feifita de et in caftro et manerio de Bambrough, cum cértis tcrris et tenem, in villa de Banbrough, de et in certis terris in Clenhill, Ingram, et Wetherton, ac de et in villa de $X_{\text {y }}$ dland, Wryhill, et Whipperton, ac de et in villa de Bednel, Shofton, Sunderland, Emclton, Dunftonbrough, Dunfton, Stamford, Burton, cum terris in Newton, et Budle. Ercact. de sano 10 Eliz. 
mimarches, was then governor of it. He was made a knight ban-: werct, I K. Edward VI, after the victory obtained over the Scots by the Englifl near Muffelburg; and was. high theriff of Northumberland, $3 \mathrm{~d}$ of the fame reign; his arms, argent, a cheveron, betwixt three hunter's horns, fable. He refided at Alnwick-abbey (i). His daughter, Fulian, married Sir Francis Rufel, third fon of Fran-: cis Rufel, Earl of Bedford, the firlt heir apparent of a peer allowed to be a nember in the houfe of commons; that houfe voting, int Junc, 3 K. Edward VI, I 549, that on the death of his elder. brother he fhould continue in that houfe as he had done before. Sir Francis was high theriff of Nortbumberland, I9 Q. Elizabeth (k); and a reprefentative for it in parliament, 14 th, and 27 th of the fame reign. He was killed on the borders, on a march-clay, $27_{\text {th }}$ June, $15^{8}$. His father-in-law, Sir Fobn, lived to a great. age ; and was fucceded in his abbey of Bambrough, and his manour and abbey of Blancbland, by his fon, Niclolas Forfer, Efq; high theriff of Nortbumberland, 44 Q. Elizabetb (1); whofe fon and heir, Sir Claudius Forfer, Knt. was high theriff of Nortbumberland, Io K. Fames I, and created a baronet, izth of the fame reign. His brother and heir, Fobn Forfacr, Efq; obtained a grant from the crown of the caltle and manour of Bambrough ( $m$ ).

The caftle commands a moft extenfive fea-profpect. On a clear day may be feen the town of Berroick upon Treed, Tynemoutb-caltle,

(i) Mrmoutb's Menoirs, p. 147 .

(k) Efcaet. de anno 1:9 Eliz.

(l) Efcaet. de anno 44 Eliz.

(m) Fobannes Forfor, amm. frater et hæres Claudii, tenet in capite caftrum et dominicum deBambrough, ac tenet in capite fitum nuper cella de Bambrough, ac manesium de Belford, ac Rever.Gräge, vocat. Yefinglon-Grange, ac fitum monafterii de Blanchland, ac medietatem. capellae de Sholley, parcellam rector. de Bywell St. Andrew, ac decimas in campis de Unthank; Sbotliyy-Ficld, et alibi.

Efcaé. de anno 14 Car. I. 


\section{ANTIQUITIES OF NORTHUMBERLAND.}

and the greateft part of the cont between them. A ftately tower, whore bafe is Doric, as before mentioned, is the only monument. now left to fpeak its antient grandeur. It was lately repaired by. by the truftees of Bifhop Crew.

Below the cantle, is the villa of

Bambrough, which was a royal borough. 'To the $23 d$ parliament of K. Edward I, it fent two members, Fobn le Greyfang and William le Coroner. In the expedition of K. Edward IIl. againft Calais, it fent him one fhip. It is now an obfcure place. It gives its name to a large tract of country, called Bambrougbfoire, extending fouthwards to Warkwortb-bridge.

In the reign of $\mathrm{K}$. Henry $\mathrm{I}$, a monaftery of regular canons of the order of St. Aufin was founded here, fubordinate to the prior of Nofill, in Yorkfbire ( $\mathrm{n}$ ). Its revenues were valued at, $26 \mathrm{~K}$. Henry VIII, at $116 \%$. 12 s. 3 d. Dugd. 124l. I5s. $7 d$. Speed. It was, granted the year following to Sir Gobn Forfer (0).

Here was alfo an hofpital, founded in honour of St. Mary Magdalen ( $p$ ).

K. Henry III, in the latter part of his reign, founded a religious houfe near the villa for the Fratres Predicatores, or Friers

(n) A. D. Ir 37 , in the MS. annals in the library of the church of $V_{e} / m i n f e r$, are many things relating to this houfe.

vid. Cart. 77 Foan. n. II. et 36 .

Bp. Tannar's Notit. Monaft. fol. p. 392.

f.) Ibid.

(p) Pat. 7 Ed.II. p. I. m. I.

Pat. 22 Ed. III. p. x. m. 4. Pat. 37 Ed. IIT. p. I. m. 4r. Pat. 50 Ed. III. p.r. m. 28. Efcaet. Nortbumbr. 50 Ed. III. n: 56 .

Bp. Tanner's Notit. Monaft. fol. p. 397 . 
$406 \quad \triangle N T I Q U I T I E S$ OF NORTHUMBERLAND.

Preacbers $(q)$. This is the fair college faid by Leland to be " $a$ "little without Bamborrow ( $r$ )." The fite of it was granted to Thomas Reeve and Nicbolas Pinder, 2 Q. Elizabeth (s).

The church of Bambrough was of K. Ofruald's foundation, as well as St. Aidan's. K. Henry I, granted them both to the priory of Noftill ( $t$ ).

It is a neat church, confifting of three broad ifles. Within a nich of the fouth wall in the chancel, is the effigies in ftone of a knight templer, in the ufual habit and attitude.

On the north fide of the chancel, is a fmall mural monument erected to the memory of SirClaudius Forfer, with this infcription.

Scio quod Redemptor meus vivit in Coelis.

Claudius Forferus, eques auratus et baronettus, antiqua, numerofa, et nobili Forfterorum familia in Com. Northumbr. oriundus, Domini Nicbolai Forfteri, filii fortiffimi illius viri, Fobannis Forferi, qui 37 annos mediarum marchiarum Scotian verfus Dominus guardianus extitit, filius et hæres: honoratiflimis etiam Dominis Cumbrice et Bedfordie comitibus, nec non infigni et illuftri Fenwickorum progenie, totiqùe generoforum genti inter Tinam et Tweedam celeberrimo fanguine

(9) Rot. Pat. 50 Hen. 111. n. 17. et in. 125.

Cart. 5 I Hen. Ill. m. 4. pro decem acris terre ad oratorium conftruendum. Pat. 51 Hen. III. pro eifdem. Pat. 22 Ed. I.

Bp. Tumer's Notit. Monaft. fol. p. 396.

(r) Lel. Itin, vol. viii. p. Izo.

(s) Bp. Tonner.

(t) Confirmo donum quod feci ecclefre de Nofla, juxta caftellum Pontisfracti, et çnonieis ejufdem loci, videlicet ecclefias fancti Ofwakdi et Aidaxi de Bacnburch, ficut Algarus preBbiter unquam eas melius tenuit. Cart. Hen. I.

Monaft. Angl, vol. ii. p. 34 . 
ANTIQUITIES OF NORTHUMBERLAND. 407 conjunctus. Caftri denique Bamburg dominus Senefcallus et conftabularius : obiit in manerio fuo de Alba Terra in com. Nathumbr. anno falutis noftrx, 1623 . Memorix facrum lugens pofuit uxor ejus Domina Elizabetha, Gulielmi Fenwick, de Wallingtonia, equitis aurati, filia.

By this monument is another over the family of Sir William Forfer, with the following infcription.

In the vault below lie buried the bodies of William, Folmn, and Ferdinando, fons of Sir William Forfer, of Bamiburg, Knt. by Dorotby, daughter of Sir William Selby of Twizel, Bart. and by Eleanor, daughter of Ferdinando Lord Fairfax, of Denton.

William was born the 28th of July, 1667; married Elizabeth, daughter of William Pert, Efq; died the firt of Sept $\mathbf{7} 700$, without iffue.

Fobn was born the 29th Sept. 1668. Died the 15 th November I699.

Ferdinando was born the 14th of Feb. 1669 . Died the $22 \mathrm{~d}$ of Aug. 1701 : both unmarried. They had another brother,

Nicholas, who died young, and was buried in the church . of South Baily in Durbam; as alfo five fifters.

Eleanor, and

Dorothy, who died very young.

Frances, married to Thomas. Fonfer, Efq; of Etherfone, to whom the had feveral children. 


\section{Mary, who died unmarried. And}

Dorotby, wife to the Right Honourable the Lord Crew, Lord Bifhop of Durbam, of whom their mother died. She being the only one remaining of the family, fet up this monument in memory of her dear brothers, as the laft refpect that could be paid them for their true affection to the church, the monarchy, their country, and their filter, anno I $71 \mathrm{r}$. This being the burying place of their anceftors.

The fon of Thomas and Frances Forfer, of Etherfone, mentioned in this monument, of his father's name, being general of the rebcl-forces in the year 1715 , his manours and eftates of Bambrough and Blanchland were forfeited to the crown. At the very time of his defection, he was one of the reprefentatives in parliament for this county, and only in the $34^{\text {th }}$ year of his age. He efcaped out of Neregate to Rome, and died of an afthma at Bologne in France, in November, $173^{8}$ (u). Loid Crew, Bihop of Durbam, his uncle, purchafed his forfeited eftates, and at his death left them to charitable ufes. For the great eftecm he had' for an acadenical education, he gave by will, bearing date, 24th June, 1720, twelve exhibitions of $20 \mathrm{l}$. per aml. cach, to Lincolin-College, in Oxford, to be difpofed of by the rector and fellows to as many under-graduate commoners, natives of the diocefe of Durban? or of Nortballertonflire, or Howdenfliere, in the county of York, or of Leiceferflaire, Newbold-Verdon in OxfordßBire, or of Nortbamptonfire, to be held for eight years, and no longer, unlefs for an extraordinary reation by leave from the rector; the diocefe of Durbam to have the preference. His lordihip alfo"for the aug-

(u) For a farther account of him, of his efcape out of Nerugate, and the defcription of his perfon, See The Political State of Great Britain, Vol. ii. p. 166, $3^{9} 7,3^{88 .}$ 
mentation of the living of Bambrough gave $40 \mathrm{l}$. per anmum; and to the living of Sbotley, near Blancbland, $20 l$. per amum, for ever $(x)$. He died, I8th September, in the 88th ycar of his age, at Stene, the fcat of his ancclors, in Northamitonflire.

From Bambrough-cafle, we have a profpect of the

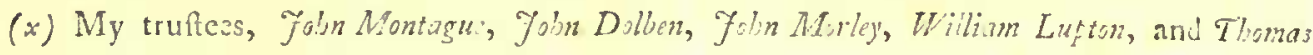
Eden, their heirs and afigns, thall out of the rents, iffics, and profits of my manours, hi:rediaments, and premifes, in the county of Nortianilerland, and Durbam, for ever lereafter pay or caufe to be paid the yearly fun of $20 \%$. to each ind every of tweive exhibitioners of Lincoh Coilege, in the univerfity of Oxford, whi.h I liave already numed and appointed, or which I thall hercafter name and appoint, and to cach and cvery of twelve exhibitioners to be elected and choren after my deceafe, as hercin aftementioned, who ha'l be uncicr. graduate commoners in Lincsln-college aforefaid, and who are or fhall le watives of the diccefe of Durham, and for want of fuch natics, of Northallertonbire, or Hawdenfirie, in the county of Yris, or of Laicficinire, and particularly of the parifh of Netebold Verdon of the diocefe of Oxforl, where of I was formerly Bithop, or of the county of Nortianiptsin, which is the county I was born in. And my will is, and I do hereby direet, that fuch exhibiiioner and exhibitioners on any vacancy or vacancies of any exhibitioner or chlnibitioners by me already named and appointed, or unon any other vacancy or vacancics whatfocver, nl+ll be from time to time, and at all times, for ever after my decealc elecled and chofen by the rector and fellows of Linoin-collese aforefaid for the time being, or by the major pait of them, and to enjoy the faid exhibitions or annual payments for eight years (if they refpcetively continue fo long in the cllege aforefaid), and no longer, unlefs they have leave from the rectur of the college afurefaid for the time being to be abfent, which 1 defire he will not grant but upon reafondble caufe. Aind I do hercby direct, that as often as any vacancy or vacancies thall happen of fuch exhibitioner or exhibitioners, others thall be elected in thcir room within three months in manner as aforefaid. And upon this farther truft, that my truftees, Foln Moutague, Fabn Dolben, Foln Morley, William Luptsn, and T'osias Eilen, the: hcis and affigns, do, and thall, out of the rents, iffues, and profits, of the faid mantours, lands, and hereditaments, in the faid counties of Nortbumberland and Durbam, devifed to them as aforefaid, for ever hereafter pay the annual fums hereafter mentioned, (that is to fay) unto the minifter of the faid parifh-church of Bambrough, in the faid county of Northumberiand, and his fucceffors, the yearly fum of $40 \mathrm{l}$. and to the minifter of the parinchurch of Shotley, in the taid county, and his fucceffors, the yearly fum of $20 \%$

VOI. II. 
Farn-Ifand, the recefs of St. Cutbbert. Here was afterwards a priory of fix or eight Bendictine monks, fubordinate to Durbam $(y)$. They received annually five quarters of wheat from the manours of Tughall and Suinboe ( $z$ ). The corporation of Nerecafle upon Tyme paid them an annual rent of 13 marks, and 10 s. (a). At the diffolution it was valued at $12 l .17$ s. $8 \mathrm{~d}$. Duscl. and Speed. It was granted to the dean and chapter of Durbam, 33 K. Henry VIII (b). It ftood on the noof romantic part of the ifland, on a pleafant lawn, edged with rocks, by a freh-water fpring. Near it was a fort, built for its defence by the lant prior of 1 muram, but one, Prior Gafte (c). On the nowh-eaft fide are five other fmall ilands, confifting of bleak, balren rocks.

A mile north from Bambrough, is

Iudle, onc of the manours of the barony of Almvick; of which a mediety was held by the three daughters of Sir George Bowes, of Stivtlam-Cafle, in the bithoprick of 1)urbam, Knt. I4 K. Charles I.

(y) Lel. Itin. Vol. vii. p. 6 s.

(z) Claur. 10 Ed. II. m. 25. de quinque quarteriis frumentifingulis annis c maneriis de Tuglall et Sivinbie.

(a) Vide in Bourne's Hift. of Nerucafli, p. 199. Afifam per priorem Dunclm. contra majorem et ballivos Nov: Caflri pro redditu annuo tredecem marcarum et decem folidorum conceflo domui de Farneland anno 25 Ed. III. p. 209, requictantiam prioris Dunelnn. pro redditu prædicto cebit. ad feftum S. Michaelis anno 5 Hen. V. p. 218, Hen. VIl, eonfirmationem iftius sedditus anno regni 7 .

Clatf. 2 Hin. IV. p. I. m. 13. de xiii. marcis annui redditus conceffis de redditu Novi Colri per regen Edvardum.

(b) Bp. Tanner's Notit. Monaft. fo. p. 394.

(c) Lir. Itin. vol.v. p. 108 . 


\section{ANTIQUITIES OF NORTHUMBERLAND. 4IT}

viz. Elizabeth, Ann, and Dorotby (d); whofe anceftor, Sir William Bowis, Knt. was chamberlain to the Duke of Bedford, brother to K. Henry V, and protector and governor in France, with whom he was fixteen years in that kingdom, and was called Monfeur de Arches. Ire was a great favourite with his grace, and accuired great riches. On his return home, he built the calle of Stretlan (e). He was high theriff of Nortbumberland, $6 \mathrm{~K}$. Edward IV $(f)$; his arms, crmin, thice bows bent, gules. Their father, Sir George, was in the expedition againft Scotland, 33 K. Henry VII, 1544, under Edward Seimour, Earl of Hrrtford, by whom, with many others, he was knighted, at Leith, near Edcnburgh (g). He was marthal of Berwick upon Trueed, I Q. Elizabeth, 1558, and had a fhare in the victory obtained over the Scots at Swinton, by Henry Percy, brother to Thomas Percy the fixth Earl of $\Lambda$. land; the forces on both fides confitting of the neight rifons (b). He was one of her majenty's privy coi lachlow the the

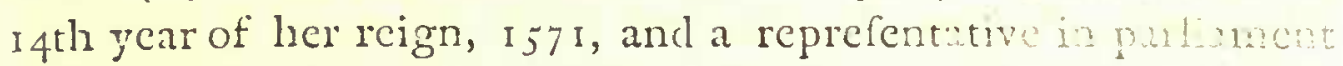
for the borough of Morpeth (i). He was of the chat ing for the government of the northern councics, the $y$ ing; Henry Haftings, Earl of Inntington, then Lorr' Plefilent. Itis brother, Sil Robert Bowes, Knt. was Captain of Norham-caftle, 83 K. Heny VIII, I5 1. Ye was in that year in the grand caralcade of the rorkfhe gentlemen, who, to the number of 200 , cloathed

(d) Elizalctha, Anna, et Dorothca, flix Georgit Bowes, militis, tenent de rege, ut de caftro de Airwick, per forvicium milit. mcdietatem mancrii five ville de Budle et Spindlefon.

Eicact. de anno 14 Car. I.

(e) Lel. Itin. vol. iv. p. 9, 10.

(f) Efcaet. de anno 6 Ed.I.

(g) Hol. Chron, vol. ii. P. 9'2.

(b) - vol. i. p. $3^{5 z-3}$.

(i) Parliam. Hit. of Engr. vol. iv. p. 108. 
in velvet, on fine horfes, with 4000 yeomen and fervants, tall and well mounted, made their fubmiffion on their knees to his majefty, and prefented lim with $900 \mathrm{l}$. on his entering their county. He was their f peaker ( $k$ ). He was taken prifoner the year following in an cxpedition againft the Scots, and detained without ranfom, contrury to the laws of the marches. He was releafed in 1543 , by the favour of the Earl of Arran, then regent of Scotland (l); and made treafurer of the army fent into France (m.) He was of the council at York, 29, $30 \mathrm{~K}$. Henry VIII, and $4 \mathrm{~K}$. Edward VI (n). Bernard-Cafle being befieged, 23 d November, 12 Q. Elizabeth, I570, the two brothers defended it by their valour for cleven days, and then obtained an honourable capitulation (0). Sil Willian Bowes, IKnt. was one of her majefty's commiflioners for border-caufes in Scotland, in the 4 oth year of her reign, I 597 (p). He was alfo her ambaffador extraordinary in that kingdom, in 1599 (q). He was of the council at York, 4r ft of her majefty's reign, and I K. James I. The late George Bowes, Efq; was a reprefentative for the county of Durbam in feveral parliaments to the time of his death. His only daughter and heir married the right honourable the Earl of Stratbmore, who by an act of parliament affumed the name of Bowes, and is one of the fixteen Pcers of Scotland.

This manour now belongs to his Grace the Duke of Nortbumberland. The village is finall. It ftands above a fine fandy bay

(k) Hol. Chron. vol. ii. p. 954 .

(1) p. 959.

(ni) p. 960.

(n) Drake's Antiq. of York. (0) Hol. Chron. vol, ii, p. 1212 .

(p) Rym. Foed. tom. xvi. p. 312. Acta Rrg. vol. iv. 8vo. p. 165.

(q) Rym. Fod. tom. xvi. p. 373. Acka Regia, vcil. iv. p. 166. 
of the fea, on the fouth fide of the Oftum of the river of Warn, which is accounted a tolerable harbour for fmall vefrels of about eighty tons; being about feven or eight feet water in full tides.

On Spinelfon-hill, near Budle, is an intrenchment, nearly round, with three deep ditches and high Valla to the north and fouth, and two at the weft, with a flope to the eaft, entered by a very wide port; two exploratory mounts, hard by, to the fouth ; and another to the north. It is Danifl.

A little to the weft of this intrenchment, is another, in the form of a crefcent, very large, with the fmall harbour of $W^{r} a r n$, to the north, and a romantic precipice to the fouth; three ditches and Valla to the weft and fouth-weft; the Vallia of turf and ftone, as ufual, and itill pretty high in moft places; the port to the north, the ground floping to the harbour, a hollow way extending almoft to it from the precipice. It has a moft extenfive fea and land profpect on all fides, of the two cantles of Bambrougrb and Holy Ifland, and of all thips pafling and repaffing. This is alfo Danifs.

On the north fide of the river, facing it, is

Ul-cheffer (r), i. e. Caftrum ulterius, the out-guard or fort to fecure the pafs of the river and the harbour. By its name it feems to be Roman. It was one of the manours of the barony of Wooler, of which it was held by Sir Robert de Ulchefer in the reign of K. Henry III, and I K. Edward I(s). He was one of the com-

(r) Ulchefter.

Outchefer.

(s) Roberlus de Ulcbefer tenct Ulchefer per unum feolum veteris feofïmenti Baron. de Wooler. Efcaet. de anno I Ed. I. miffioners 
millioners appointed, 33 K. Henry III, 1249 , to recognize the border-laws, and make new ones( $t)$. It was forfeited to the crown, I7 15, by Fames Earl of Derwentwater, and given to Greenwich-hofpital.

By the roth mile ftone on the pott-road we crofs the river by a ttone-bridge of one arch, at Warnford; and by the 12 th mileflone a road branches off, on the right, to

Eitherfon (u), which was the manour and feat of the antient family of the Forfters; of Sir Thomas Forfer, Knt. in the reign of K. Henry VIII, who married Dorotby the daughter of Ralph Lord Ogle, of Ogle, by Margaret the daughter of Sir William Gafcoigne, of Gawtborp, in the county of York, Knt. (w); of Thomas Forfter, Efq; high Theriff of Nortbumberland, 6, r4 Q. Elizabeth (x); of Matthew Forfer, Efq; high theriff of Nortbumberland, $18 \mathrm{~K}$. Fames I $(y)$; of Thomas Forfter, Ef,; in the reign of K. Charles I, II, who married Frances the daughter and heir of Sir Willian Forfer, of Bambrough-caftle, Knt. (z); of Thomas Forfer, Efq; ligh theriff of Northumberland, 2 Q. Ann, I703; of the late Thomas Forfer, Efq;

(t) Bp. Nicholfon's Bord. Laws, p. 2.

(u) EtlikrRone. Lel. Itin. vol. vi. p. 34, 35, 36. Etherfion. Eiderflone.

(w) MS. penes Gulielmum Ogle, de Carifcy-Palk, Arm.

(x) Efcaet. de annis 6, $x_{4}$ Eliz.

Thomas Forfter fuit feifitus de et in Edderfone, cum certis terris in villa ds Boufdon, et Spirelfion. Efcaet. de anno 10 Eliz..

(y) Efcaet. de anno 18 jac. I.

( $\approx$ ) See Bambrougb-Caftle. 
who died, 3 ift March, $176_{3}$, in the 20 th year of his age; and was fucceeded by Fohn William Bacon, Efq; high Thcriff of Northumberland in the fame year; of which his great grandfather, Fobn Bacon, of Stavard, Efq; was high theriff, 5 K. William III, 1693 ; alfo his grandfather, William Bacon, Efy; 1745. His father, Fobn Bacon, Efq. Fellow of the Royal and Antiquarim Societies, and governor of the hofpitals of Bridewell and Betbiehem, died in July, $175^{2}$.

Mr. Bacon, built a handfome houfe at a difance from the old one, near the wood by the rivulet of $W$ arn. He dicd, I; 67 .

$$
\text { By the } 4_{4} \text { th mile-ftone, is }
$$

Bulford, which was the manour and villa of Thomas de Helbum, I K. Henry V (a); of Fobn Forker, of Bambrongh-cafte, Efe; is K. Charles I (b); and now of Abraban Dixon, Efq; high theriff of Nortbumberland, 1759. It is a well built villa, on a gradual flope, within two miles of the fea, the profpect of which is intercepted to the eaft and north-caft by the ridge of a hill. At the north-caft cnd is the church, dedicated to St. Mary. It was built in ryoo, and fealed in 1759 . On the top of the hill is the ruin of the old chapel. On the north-weft fide, by a fine fpring, is the antient manour-houfe, behind which was formerly a wood, of half a mile in length, of large oaks, under a range of fteep rocks of

(a) Thonas de Hebburn, frater et hares Honrici de Hebburn, tenet manerium et villam de Beiford et Feflington de rege in capite, per fervicium quartæ partis unius feodi milisis. Et ibiden compertum eft per fcrutinium, quod Willielmus de Hebburn, anteceffor iplius Thome, tenuit de dom. rege in capite medietatem villæ prædictre, parcellam Baroniæ de IWoler, et unam carucutum terre in Belford de rege in capice, ut parcellam Baroniæ pradictx.

Ros. Mich. Fin. anno I Hen. V.

(b) See Bambrous-Caftle. 
whinftone, now fparingly thaded with young trees and brufhwood. On the fouth-eaft fide is Mr. Dixon's feat, a large modern building, after a gentecl defign, in Mr. Pain's architecture. On the fouth fide of it is a beautiful fhrubbery by a piece of water under a femicircular rocky mount, on the top of which is a neat little tower, with port-holes; and at an agreeable diftance to the fouth-eat, ncar a Chinefe-cottage, is an opening between two hills, which lets in a profpect of the fea.

A mile fouth-went from Belford is an encampment, nearly fquare, with a wide fofs, and a clouble rampier, the entrance to the north-eaft.

Five miles north from Belford, on the left hand of the poft-road, and in fight, is

Kiley (c), the villa of Euface de Filey, I K. Edward I (d); in which in the beginning of the reign of $\mathrm{K}$. Hewry VIII, the fuds of a knight's belt, and the hilt of a fword, of mafiy gold, were found between two ftones. They came into the polreflion of Dr. Rutball, Bifhop of Durban (c). It ftands on an cmincnce, and has an extenfive land and fea profpect. The church is in a field at fome diftance from it.

Oppofite to filley, on the right hand of the poftrcad, and in fight, is

(c) Kiley. Lel. Cand.

$\mathrm{K}_{\text {fioe. Browne IVillis. }}$

(d) Euffacius de Kyicy tenet villam fuam de Kyley, villam de Berrington, villam de Lnulin, in Chingium, et reddit inde per ann. x marc. et facit operationes dominicis de F.nwick.

Efcact, de anno I El. I.

(c) Lel. Itin. vol, vii, p. $5^{6}$. 
Lindisfarn, or Holy Ifland, which was a bifhop's fee, founded by Ofwald, King of Nortbumberland. Aidan, a Scotchinan, was the finft bifhop, and had that whole kingdom for his diocefe. Hiftorians have given him an excellent character. By his prudent conduct, and the unwearied pains he took in the miniftry, he acquired great efteem. His country-idion rnot being underitood by a Saxat audience, the king himfelf became the interpreter of his difcourfes; which had fuch an influence, that crowds thronged to him for baptifm. And no wonder, fince, befides the advantages of his own eloquence, and perfonal good qualities, his humility and condefcenfion, uncommon affiduity and humanity, he had the authority and example of a benevolent and goorl king, and the higheft and beft men ce his court, to back him. For how captivating is religion, how perfuafive her voice, when uttered from the throne, and her precepts explained in all the beauty and force of language? Aidan affected no fate. He travelled on foot, not by necelitity, but choice, (for he that was the favourite of a good king could not be in fuch circumftances) to win the Heathens to cmbrace and love Chriftianity. His care for the : was fuch, that he was their follicitor with the rich, to becon. their patrons and benefacors; ufing all his interef: 0 gain them favoux, to get them relict, and to fet them above mifery and diftefs. May they neree want fuch friends! After a life thus pioufly fpent in his bifhoprick for 17 ycars, he died, 3 st Auguft, $65 \mathrm{r}$. Iíc was fuccecded by

Finan, one of the fame monalery. Finan had orders from Gregory, the Roman Pontif, to remove his Sec to York, but Popes in thofe days having no influcnce in Northumberland, he continued it herc, preferring the model of government in the Eafern churches to that of Rome. He built a cathedral-church, which he dedicated to St. Peter. He thatched it, after the Scotch fafhion, with VOL. II. Is h h reeds. 
reeds. It was afterwards covered with lead by Bifhop Eadbert. His pains and fuccefs in making converts to Chriftianity were very great, He was fo fortunate as to gain two crowned heads to embrace it, Penda, King of Mercia, and Segibert, King of the Eaft Angles. He is faid to have baptized them at Wall-town, now Welton, twelve miles weft from Nerucafle. Their fubjects following their example, alfo turned Chriftians, under the miniftry and preaching of their Bifhops, Diuma, and Cedd, ordained and fet over them by Finan. Lindisfarn was governed by this bifhop ten years. He died, 14th February, 66I. His fucceffor was -

Coleman, a Scotchman alfo, who was bifhop only three years. Chagrincd at King Ofwy's taking part againf him with the Romanifs in the point of Church-government, he refigned his See, and returned to Scotland. Thirty Englinmen, and all his countrymen in the illand, devoted to a religious life, went with him. He lived to the year 676 . His fucceffors were fuch as adhered to the principles of the church of Rome, of whom the firft was

Tuda. He came into England with Coleman. He died foon after his election. The next chofen to the epifcopal dignity was

Chad, a modeft and humble man, who accepted it rather to pleafe others, than himfelf. He was ftiled, not Bithop of Lindiffarm, but of York, by the defire of his fovereign, King Alfred, who defigned it for his governor or preceptor, Wilfrid. He was twice confecrated, firft at Wincheffer, by Bifhop Wine, on the vacancy of the See of Canterbury, and next at York, by Theodore, the new metropolitan. In complaifance to that prelate, and the two. kings of Northimberland, Ofwy, and Alfred, he retired to his monaftery, and refigned his bihoprick in favour of 
Wilfrid, who held it but a hort while. King ofwy dying, and Alfred being dethroned, $E_{g}$ frid obtained both their kingdoms. In his reign came on the great revolution of the diocefe of Lindijfarn. In the time of Paulinus, rork had been dignified with the title of an archiepifcopal See. Theodore was refolved to leffen its power, and to mortify and humble Wilfird, with whom he was difgufted. He depofed him. He then obtained the royal licence to divide the kingdom of Northumberland into two diocefes, York and Lindisfarn; the firt containing Deira, the latter Bemicia. Wirfrid, in high refentment, went to Rome, to procure his reftoration by the Pope. The Pope ftood his friend, held a chapter, and fent him home with their refolution in form, that he fhould be reinftated. This, with the pope's letter, he prefented to the kirig, who, exafperatcd at his prefumption, reproached him with procuring them by bribery, and caft him into prifon, where he might have remained had it not been for the interecfion of Ebbat, the king's aunt, and on promife of his never entering Nortbumberland more. He retired to the monatery of Glafenburg, of which Bertbwald was abbot, Nephere to Etbelvel, King of Mercia. The abbot entertaincd him but a hort while. He was forced to fend him off by the commands of his uncle, Etbelred, to oblige King Egfrid. His next retreat is to the court of Adeluach, King of Suffex. Adelwach, on the converfion of his people, gave him the bihoprick of Sebfer. Now Theodore, grown fcchle and old, and defiring to be in friendhip with him before his death, got him reftored to the See of York, by his carnet interceffion with King Alfred, Egfrid's fuccelfor. When he left it, it was dirided into two diocefes, but now on his return he found it fplit into three; Hexham making the third. He attempted the re-union of rork and Hexbam, but wirh an importunity fo difagreeable at court, that he was again cxpclled. He withdrew to the court of Etbeldred, King of Mercia. He had the addrefs to make that mo- 
narch his friend, and to get one of the four bihopricks in his kingdom, the bifhoprick of Leicefer, then vacant. His paffion for pre-cminence, and immoderate love of power, hurt him in his new fituation. The king, and his nephew, Bertbwald, archbithop of Canterbury, being offended with him for fome undue liberties, they refolved, in concert with Alfred, king of Nortbunberlani, to clip the plumes of his ambition. They tried him by a fynod, charged him with many things, and at length requefted a formal refignation of his bifhoprick. On his refufal, he was depofed. Ile was now 70 years of age, yet not fo feeble, but he took another joumey to Rome for redrefs. The pope convened a council, and fent him back with a decree for his reftoration, with letters recommendatory to the two kings, and the archbinop. The archbihop, out of refpect to the pope, and the king of Mercia having taken on him the habit of a monk, and the king of Nortbumberland falling fick, and relenting on his deathbed, received him again into favour. But another difficulty came in his way. Alfred, king of Northumberland, died before lie could be replaced in his fee of York. However, he acquired fo much favour with his fucceffor, the young king ofred, as to have a council held near the river Nidd (c). With great difficulty he obtaincd the bifhoprick of Hexham, the third part only of the antient diocefe of Northumberland (d). But to return to Lindisfarm

On the reduction of this diocefe to the kingdom of Bernicia,

Eata was made bihop of it. He was one of Aidan's fcholars. Aidan, upon his firf coming to this fec, undertook the education

(c) Stelm. Confil. i. 203 .

ITidiuls. p. 58 .

(d) Vid. Hoxham 


\section{ANTIQUITIES OF NORTIUMBHALAND.}

of twelve Saxon children, whom he trained gup to piety and learning. Before his death, he had the pleafure of fecing Eita preferred to be abbot of Melros; who left that monatery to be abbot of Lindisfarn, in 664. He prefided over it fourteen years. He had not been long bihop before his diocefe of Bernicia was divided into two, Landisfarn and Hexbam, as before-mentioned. Tumbert was chofen to the latter. Being againft Theodore's having: any jurifdiction over the northern churches, he was depored in a full chapter of bifhops, convened by the archbihop of Treviford, by the river Aln, 684. 'They proceedcd, after his degradition, to clect another in his room. The choice fell on Cuthert, a monk of Lindisfarn. Catbbert was with difficulty brought to comply to accept it, and, at length, only on condition that he might remain at Landisfarn. It was agreed therefore to give him the fee of Landisfarn, and to tranflate Eata to Hexham.

Cutblort had his education in the monaftery of Melros, under Eata, who had brought him with him to Landisfarn, and fettled him in that abbey. He was an cxemplary, modeft, humble, and good man, took great pains to make others fo, would go for whole weeks and months into the moft unfrequented and uncivilized parts of the diocefe, moors and mountains, for that purpofe, by himfelf and alonc, where other learned perfons would not come. He was handfome, had a graceful elocution, and a perfuafive manner, which with his other good qualities, lis extenfive charity and good nature, were powerful and irrefintible charms. Finding his health declining, and unable to fuftain the weight of epifcopal cares, he refigned his bifhopric, after he had held it two years. He furvived his refignation only two months, dying zoth March, 687, at his hermitage or folitude in. the illand of Farn, and for his cminent virtues was canonized. 
The way of drawing and reprefenting faints among the Saxons, may be feen in that curious piece of antiquity found near Afselncy, in Someretflire, defcribed and figured by two eminent antiquaries (e); of pure gold, weighing about three guineas, in cnamel, covered over with chryftal, reprefenting St. Cutbbert, as is fuppofed, fitting in a chair, with this infcription on a plane rifing diquely, in Roman or Gallo-Italic letters, except two.

\section{AELERED MEL HETT GEWYRLAN.}

\section{Alfredus me juffit fabricari.}

On the reverfe are flowers. K. Alfred preferred thefe characters to the Saxon, and, when he fwayed the fcepter, brought then into ufe $(f)$. This curious memorial of St. Cutbbert was found in the very place of that glorious monarch's retreat and deliverance from the Danes, fortified by him in time of war $(g)$, and in time of peace converted into a monaftery (b). Dr. Mufgrave thinks this curious cimolium an undeniable infance of the ufe of images coming from the heathens into the Chriftian $\operatorname{church}(i)$.

On the vacancy of the fee of Lindisfurn by the death of St. Cutbbert, it was governed for one year by Wilfrid, bifhop of Hexbam, on the expiration of which,

(e) Dr. Mufgrave, Ph. Tr. No. 247.

Dr. Hicks, Thefaur, Ling. Septentr.

Ph. 'Ir. No. 260.

(f) Ingulphus.

(g) Milton.

(b) Malmibury.

(i) Geta Brit. Ph. Tr. No. 34 to. 
Eadbert was chofen to fucceed him. This prelate is recorded to have been a very pious man, to have underftood the holy fcriptures well, to have drawn them into his life and practice, and to have been a liberal father to the helplefs ftranger, the poor and indigent. In March, 698, he removed St. Cutbbert's body from the ifland of Farn to that of Lindisfarn. He furvived that act of kindnefs for his venerable friend and predecelfor but a few days, and was buried in the firme tomb with him, having been a bihop ten years.

Egfrith, or Eadfrith, was elected to fucceed him in the fame year. He was a monk of Lindisfarn, of which his father was abbot. In that retirement he tranflated the Gofpels into Latin, decorated after his deatl with gilding and jewels by his fucceffor, with painting by Bilfrid, an anchorite, and with an interlineary Saxon verfion by Aldred, a prieft. This book fell into the hands of Sir Robert Cotton, whom few fuch curiofities efcaped, and is now in his library in the Britifh Mufeum. He was cminent for his learning in the age he lived, and loved to encourage it in others. By his advice, Bede wrote the Life of St. Cuthbert in profe and verfe, whofe memory he fo much revered, that one of his firt epifcopal acts was, the repairing of his chapel or oratory in the ifland of Farn. Yet, though he venerated that exemplary and pious prelate, he did not altogether imitate him. Hc attended not the cares of his high office fo frictly as became him. For this he was warmly expoftulated with by his friend Bede, in a letter full of fpirit, piety, and good fenfe. He put him in mind of the weight of his charge, the duties of a Chriftian bifhop. He earneftly preffed him to remember his Saviour's commiflion, how he was to admonifh even the highen orders within his jurifdiction, and remind them of their duty; exhort them not to builk. 
build monaferies and churches to get a name and a reputation, but for the glory of God, and the increafe of virtue; find out and punith diffembling priets, who had the form, but not the power of gotliners; employ his epifcopal leifure not in pleafing the world, but God; in ftudying his holy fcriptures, and tranflating them into the Saxon language for the benefit of his own and other diocefes. The bihop, fo far from being angry with this frecdom of his friend, received his letter kindly, and returned an anfwer, calling it "An Anfwer of Gratitude." He fet about tranflating feveral of the facred books in to the Saxon tongue. This thews, that, however remifs he might be in fome things, in reproving the great for their ambition, or the little for their hypocrify, he had the true fpirit and temper of a Chriftian bifhop, and might be led into an over-forbearance and remiffinefs; by an excefs of humility and modefty, his natural candour and good nature. He was bilhop twenty-four years, dying in $72 \mathrm{I}$. He was fucceded by

Ethelwold, abbot of Melros, a fcholar, companion, and friend of St. Cutbbert. In his time king Ceolwulf diveted himfelf of his royalty, to add to the number of the religious in the monaftery of Lindisfarn. This bihop died in 740 . The next was

Kenulf, chofen the fame year. His epifcopacy abounded with troubles. K. Egbert imprifoncd him in the caftle of Bambrough, on fufpicion of a murder being committed with his knowledge and connivance on one of the royal line, named $0,5 a$, who had taken fanctuary within his jurifdistion. He did not get his liberty till the year 780 , and then with difficulty. Sorrow and age 'had brought him fo weak, that he turned over the burthen of 
his office to another, and fpent the remainder of his diys in a. courfe of ftrict piety and devotion. He clied in 783 .

Higbald, his coadjutor, was elected his fucceffor. He was not long bifhop before the Danifo rovers made a defcent upon the inand, cruelly ufed the monks, knocked fome on the head, drowned others, and robbed and burnt their monaftery. The abbey-church was fpared. The bifhop, and fome of his clergy, efcaped unhurt. He lived a great while after in his fec, unmolefted, and free from fuch alarming accidents. He died in 803 . His fee was filled up by

Ecgbert, who was bifhop eighteen years. He died in 821 . The next was

Heatbured. He had this dignity nine years. He died in 830 ; and was fucceedcd by

Egfrid, a gentleman of birth and fortune, of an cnlarged bcnevolence, and a free and liberal fpirit. He built the church of Norham, removed the tomb of K. Ceowenlf to it, gave that village, and five more, viz. Gedword, Gainsford, Ilcliff, Wieliff, and Billingbam, to his fee of Lindisfarn, which he governed fixteen years; dying in 845 .

Eadbert was chofen in his place, of whom there is nothing memorable, but that he was bihop eight years, and died in 854. The fame year

Eardulph fucceeded him, who had a moft troublefome time by another defcent of the Danes in 875 , under their General Halfden. In that year, Halfdrn made an entirc conqueft of NorVor. II. 
426 ANTIQUITIES OF NORTHUMBERLAND.

thumberland, fet a king or vice-roy over it, whom he dethroned the next year, and divided his kingdom among his officers; which had lafted 330 years, from the time of Ida, the firf king. Bithop Eardulph, on the firt news of their approach, fled, with his clergy. Defirous of laving St. Cutbbert's bones preferved, they carried them, and what they could of value, with them. They wandered long from one place to another, without a fettled habitation, for the tedious melancholy fpace of feven years. At length, they fet themfelves down at Chefer-le-freet, then called crivis, and by the Saxons Conceflure, from its fituation by the river Cone, five milcs from Durbam, and feven from Newcafle upon 7yme. Here Fordulph enlarged his diocefe, by adding to it the vacant one of Hexbam, in $88_{3}$, which had been without a bifhop for fixty-three years, from the time of Tidfortb's refignation. Both now go under the name of the Bifhoprick of Lindisfarn. He had no more troubles under his government of it. He was bifhop forty-fix years, and died in the year 900. His fucceffors lived here very happily till the year 995. Aldwin was then bifhop. The Danes infefting his diocefe, he and his clergy thought it prudent to remove for their fecurity, with St. Cutbbert's remains, to Rippon. There they ftayed only four months, all being quiet again. Bifhop Aldwin thought to have come back with them to Chefre-le-fireet, but by the occafion of a dream upon the road, fettled at Durbam ( $k$ ), where his fucceffors have continued to this day, many of whom have been as great lights to learning and religion, as their revenues were great and refplendent, derived from the pious munificence of thofe who held epifcopacy in veneration. Its friends were very many, and liberal to a high degree, as may be judged by fome of their gifts to this diocefe. K. Hardiknute gave all the land lying between

(b) Lel. Comment. in Cygn. Cant. in Itin. vol, ix. p. 56, 57,58. 
the river Tees and Tyne. K. Camite gave Staintborpe and Raby. K. Ethelftan gave South Weremonth, wíth eleven villages; befrites many church-ornaments to his clergy. Stire, a nobleman, gàre the lordthip of Darlington, with its appurtenances, and two plowlands in Lumley. Sruaculph, fon of Tikell, gave the lordhips of Bradburg, Morden, Grifeby, cum Saca \& Soun. K. Willian II, gave North Allerton, which bifhop Pulfey built, and gave Sudlers, purchafed by him of K. Ricbard. Bifhop Walcher gave Farrow; and Tillered, abbot of Hefferebam, gave South Yoden; bifhop Egfrid gave the church and village of Norbam, \&cc. K. Es frid gave Cbefer-lefreet (l).

St. Cutbert's thrine had this privilege, that whoever fled to it, fhould be fafe for thirty-feven days ( $m$ !

Such were anticntly the powers and revenues of this bifhoprick, called St. Cutbbert's patrimony. It is flill, perhaps, the beft in Englind, being a principality, vefted with large liegalin, erected in troublefome times for the fecurity and defence of the borders.

I have been the more particular in my account of this bihoprick of Lindisfarm, and its bihops, becaufe their hiftory is a picce of antiquity, which fhews the fpirit and temper of the firft profeffors of Chriftianity in Nortbumberland. The monaftery occafionally mentioned, of Aidan's foundation (n), was under the government of the bifhops (o). The abbot and monks were the

(b) Lel. Itin. vol. viii. p. 10, Ir.

(m) Hol. Chron. vol, i. p. 15\%

(n) Bed. Vita Cuthb. p. 24r, 242.

(0) De Epifcopis Lindisfarnenfibus Whartoni Anglia Sacra, tom. i. p. 6g1, \&cc. Monait. Angl. vol. ii. p. 845. de Exord. et Statu Lindisfarn. Ecclef. Ex Codice MS. Ellielwoldi Epife. Winton. Traactat. de Abbatibus Lindisf. 980.

Rec. in Scac. 2 I Ric. II. Mich. Rot recit. Cartam Ed. III. 
cathedral clergy. The cathedral, and the neighbouring village of Fenbom, the village and church of Norbam, with other pofleffrons, were given by Wrilliam de Cailepho to the monaftery of Durbam (p). Here was afterwards a cell of Benedictine Monks, fubordinate to that priory. lts annual revenues, $26 \mathrm{~K}$. Henry VlII, were valued at $48 \% .18$ s. I I $\%$. Dugd.. $60 \%$. 5 . Speed. In the 33 d of the fanc reign they were granted to the dean and cliapter of 1) whan, in whofe polefion they now are $(q)$.

The cathedral has becn a fplendid fuucture, of which there are ftill fome remains. 'Two towers are ftanding, alfo three ifles, with their beautiful pillars and arches. On the fouth fide, are the foundations of the abbey; both built with red freeftone.

On the weft fide, and within a few yards of the fine cathedralruin, is the parith-church, dedicated to St. Fobn $(r)$. It has three ifles. On the north fide of the chancel is a mural monument of white marble with the following infcription.

Here lyeth the Body of Ann Fones, fome time Wife to Henry Fones, Efq; which Ann died the gth of Feb. I625.

In obitum dilediffme matris, AN $x_{\text {I }}$ Jones.

Si quis forte rogat, cujus tenet ofra fepulchrum,

Ipfe tacens docui marmora dura loqui.

Si quæris proavos generofo fanguine ducta eft.

Si vitam, infignis regula jultitia.

(f) Carta Willielmi de Carilepho, Dussel. Epifc. Monaft, Angl. vol. i. p. 43. Hen, Huntington, lib. iii.

(q) Bp. Tanner's Notit. Monaft. fol. p. $3^{8} 9$.

(r) Browne Willis. 


\section{ANTIQUITIES OF NORTHUMBERLAND.}

Si quæris mores, mulier nec xqui amantior

Nec pietatis erat, nec probitatis erat.

Hæc pro te triftis fubfcripfit carmina natus, Qux funt officii figna fuprema fui.

Per me Petrum Fones.

The village is chiefly inhabited by finermen. To the nortlyeaft of it is a garrifon commanding the harbour. At ebb-tides both horfe and foot may come from the main land to the ifland. It is well delineated by Speed (s). It has its name of Lindisforn from its fituation by the offium of Lint-rivulet, and the Celtic Fitbren, Recefus. Egelwine, bifhop of Durbam, to efcape the rengeance of K. William I, after the defcetion of Northumberland, retired to it with his clergy, the church-treafure, the jewels, and the body of St. Cutbbert, for fecurity, in the year 1069; where they remained upwards of three months ( $t$ ). It gives its name of Holy Ifland, to a confiderable tract of country on the coaft, called Holy Ifand-fbire (u).

We next pars by the village of Fenwick, and Fenwick-Park, on the left hand of the poft-road, in the jurifdiction of Lindisfarn; alfo the village of Beal, on a pleafant llope, half a mile from the fhore (v), and in the fame liberty. It has its name from the famous Irifh female faint Begogh, the patronefs of Kirkby Begogh, and of a town called Beal in rorkfbire (w).

Near the $7_{\text {th }}$ mile-ftone, on the left hand, by Lind-rivulet, crofled by a fmall bridge, is

(s) Speed's Maps.

(ii) Lel. Itin. vol. vii. p. 61. 63. (i) Hol. Chron. vol. ii. p. 7 .

(v) Ibid.

(w) Stripe's Life of Archbihop Grindal, p. 291. 


\section{$43^{\circ}$ ANTIQUITIES OF NORTHUMBERLAND.}

Haggerfon, the feat of the antient family of the Haggerfons; of Fobu Haggerfon, in the reign of K. Heiry III, and I. K. Edward I $(x)$; of Sir Thomas Haggerfon, created a baronet, 19 K. Cbarles I, 1643 , who was a colonel in the famous Nortbumberland-regiment, active and faithful to his Majefty, for which his.eftate was fequeftred by the parlament, 16 July, 1651 ; of Sir Thomas Haggerfon, his fon, who was governor of Berwick upon Tweed; of the late Sir Carnaby Haggerffon; and now of his fon, Sir Thomas Haggerfon, Bart. His feat is the old tower in which K. Edward II. received the homage of Thomas Earl of Lancafer for the earldom of Lincoln, $1311 / \%$. It is kept in good repair. On the fouth-front is the family-arms, but no date. Hard by is the ruin of an old chapel. The gardens, in which is a confervatory, are bounded to the $f($ uth by the flow running ftrearn of Lind ( $z$ ).

Seven miles from Haggerfton, is the villa of

Treedmonth, fo called from its fituation by the oftium of the river Treed; memorable for the general multer of the army that was to march againft Scotland, 4 K. Edward I. Here the barons, knights, and tenants by warlike ferjanties made their Profrum Serviciorum, the profer of fervices, before Sir Bartbalomew Badlefmere, lientenant to the conftable of England, and Sir Nicbolas de Segrave, marefcal of the king's hoft, on Thurfday next after the Nativity of St. Mary, Ioth September.

(x) Fohumes Higger, Pon tenet villam fuam de Hoggerfon liber, et sed lit inde per annum C. mortuus eft, et terræ ejus funt in manu regis.

Efcact. de anno I Ed. I.

(y) Hol. Chron. vol. ii. p. 320.

(x) Lindif Lel. Itin. vol. vii. p. 60. 
Here was an antient hofpital, dedicated to St. Bartbolomer, now called, the Spital, the mafterhip of which was in the difpofal of the bithop of Durbam (a).

We crofs the Tweed by a Arong and handfome ftone-bridge, on the north fide of which is the antient town of

Berwick (b). It was given by Edgar, King of Scotland, to the fee of Durbam, with the lands of Coldingham to the priory of Durbam, in honour of St. Cutbbert, for a victory obtained under his banner over his uncle Donald. Canulpls was then bifhop, by whofe defection and difloyalty this noble jewel was loft to that fee; the pious Edgar taking it from that ungrateful prelate into his own hands $\operatorname{again}(c)$.

On the convention held for the ranfom of William, King of Scotland, in the reign of K. Henry II, at the round fum of I00,000\% it was one of the four garrifons delivered up for fecurity of the payment; the other three being Raxbrough, Edinburgh, and Striveling. K. Henry, in whom the antient royal Saxon line was reftored to the crown of England (d), fortified it with a caftle (e). The Scotch King did homage to him for his kingdom, as mentioned in another place $(f)$. The ranfom being paid, this and the other

(a) Rex dedit clerico fuo Roberto Gerlethorp cuftodiam hofpitalis S. Bartholomei de Twedemouth ratione vacationis epifcopatûs $D$ lunelm.

Pat. 5 Ric. II. p. I. m.

(b) Tuefis civitas antiquifima recte Ptolomao de nomine cognita.

Lel. Comment. in Cygn. Cantionem, in Itin. vol. ix. p. 93.

Bed. Hift, 1. 1. c. 12.

(c) Hol. Chron. vol. i. p. $18 \mathrm{r}$.

(d) Parliament. Hift, of Engl. 8vo, vol. i. p. I4.

(e) Polychronicon.

(f) See Alnwick. 
pledges were reftored by $\mathrm{K}$ Ricbard $\mathrm{I}$. It remained as an appendage to Scotland, till the reign of K. Edward I. That victorious. monarch, on the death of King Alexander, held a parliament at it for the election of his fucceffor; 1292. Among the powerful competitors, were William de $V_{e} f c y$, baron of Alnwick, William de lios, baron of Wark, upon Treeed, Folon Baliol and Robert Bruce. Jobn Balial was. chofen (g). He did homage to Edward for his crown at Nerecafte, in the fame year, 26 th December, on St. Stephen's day (b). In a little time he broke his oath of fealty. Incenfed at his perjury, K. Edward invelted Berwick with a large fleet and army. His fleet confifted of twenty-four fhips; his army, of 4000 horfe, and 30,000 foot, befides 5000 horfe, and 1000 foot, of the bifhoprick of Durban. The townfmen burnt threc or four of his thips, and forced the reft out of the harbour. By the bravery of his troops, and his manœuvres, he was an overmatch for his enemies, and made great flaughter. This victory he obtained in the $24^{\text {th }}$ year of his reign, 1296 . It is fivid about fifteen thoufand Scotclomen were killed, at leaft, and not above twenty-eight EnglifJmen. A commercial building, called The Red Hall, belonging to a company of Flemifts merchants, fortified in the form of a tower, was reduced to athes, with thirty of them in it, on their refufing to furrender. He lodged in the caftle fifteen days. He encompaffed the town with a ditch, eighty feet broad, and as many in depth. The furren$2 x c$.

(g) Apud Bcruyke fuper Tweelum, in aula caftri cjufdem villx, in pleno Parliamento, Rym. Fæd. tom. ii. Vid. Mat Wigm.

Acta Regia. vol. i. 8vo. p. 66, \&c.

Brady's Compl. Hift. vol. ii. App. No. ii.

(b) Rym. Fued. tom. ii p: 600 .

Acta Regia. vol. ii. 8vo. p. 72,73 . 
der of the caftes of Roxbrough, Dunbar, and Ediniurys, foon followed. When he was before tlie latter, he met with a remarkable inftance of honour in a Scotchman, the chief oficer of the cafte, who upon his majefty's letters to his council being brought to him by an unfaithful and treacherous meffenger, named Lervin, a Welcbman, delivered them back over the walls to the king unopened, and the Welchmon to be punifhed, who was hanged on a high gallows, and quartered (i). A rare example in an enemy, worthy of being remembered by thole poltrons who make a practice of opening the letters of others, to know their concerns!

K. Edward, in the abore-mentioned year, r296, having made a compleat conquen of Scotland, received the homage and fealty of all the $S$ cotch nobility at this town, Auguft $24 \mathrm{th}$, in the prefence of the Englifh parliament, fplendid and numerous. The oath of fealty was in the following terms, as tranflated from the old French of H. Knighton, canon of Leicefter ( $k$ ), in an ingenious modern hiftory $(l)$.

"Becaufe we are at prefent under the fubjection of the thrice " noble prince, and our dcar Lord, Sir Edfuard, King of England, "Lord of Ireland, and Duke of Aquitain, we do faithfully pro"mife, for ourfelves, and for our heirs, upon pain of body and "eftate, that we will ferre him truly and loyally againft all man"ner of people that may live and die whenever it fhall be re"quired or" commanded by our faid Lord the King of England or

(i) Hol. Chron. vol. ii. p. 298, 299, and p. 301 .

(k) De Eventibus Anglice inter Decem Scriptores. Col. 2482 .

(l) Parliament. Hift. of Engl. vol. i, 8vo. p. 100.

Vol. II.

$\mathrm{K} \mathrm{k} \mathrm{k}$

"his 
"his heirs; that we will hinder him from damage as much as "we can, and fet upon his enemies with all our forces where" ever they may be found. And to the end that we may firmly "keep and hold thefe prefents, we do bind ourfelves, our heirs, " and our goods; and we have fworn to this upon the Bleffed "Evangelifts. Befides all we that are prefent, and every of us "feparately, have done homage to our Lord the King of England, " in thele words,

"I will be true and loyal, and bear true faith and allegiance "to Edward, King of England, and his heirs, and ferve him with " life and limb, and do him all carthly honour againft all man" ner of people that may live and die; and from henceforth I "will not bear arms, nor be aiding in counfel, againft him, or " againft his heirs, on any caufe whatfoever. So help me God, " and all the faints.

"In witnefs of thefe things we have made thefe letters patents, " and fealed them with our feals.

"Given at Bervick upon Twced, this 28th day of Auguf, in the "ycar of the reign of our faid Lord the King of England twenty "four."

Among the Scotch pecrs thus doing homage in that auguft affembly, was Sir Gilbert de Humfranvil, Earl of Angus, in Scotland, and Baron of Prudboze, in Northumberland.

Not only the barons or great tenants in capite made their fubmiflion in form, but on giving the Scots a new chancellor, a new great foal, new judges, and a now treafurer, the leffer tenants were called upon to make theirs by a written deed, to remain as 


\section{ANTIQUITIES OF NORTHUMBERLAND.}

a memorial of their being fubjects by conquen to the crown of England.

The Scots revolting, King Edzuard reduced them by force of arms to obedience, in $\mathrm{I} 300$; a year memorable for the renewal of the great charters, and the new ftatute made for their confirmation, intitled Articuli fuper Chartas, or articles upon the charters $(m)$.

To hold the Scots in the greater fubjection through fear, he ordered one half of the body of Sir William Wallafe, after his execution, to be fet over Berwick-bridge, in the 33 d year of his reign, 1305 ; and the year following the Countefs of Boughan was fet by his command on the walls of Berruick-caftle in a woodencage, for putting the crown of Scotland on the head of Robert Bruce at Scone, in the abfence of her brother, the Earl of Fife, then at his manour of Whitwick in Leiceferflive ( $n$ ).

By the policy and valour of Edward, Berwick was in the poffeflion of the Engliff twenty years. After his death, the Scots acquired it, I I K. Edward II, I318, on the ad of April ; not hy bravery, but by corruption. Sir Pierce Spalding delivered it up to Thomas Randall, Earl of Murray, in confideration of lands given him in Angus, in Scotland (o). It remained in their poffeffion till 7 K. Edward III, I333; when it was recovered by a great victory obtained over them by his majefty on Hallidon-Hill, near the town,

(m) Statutes at Large, anno 1300.

Cokc's 2d Inft. 537 .

(in) ITol. Chron. Vol. ii. p. 31 3, 13r4,

(o) Vol. i. 22I-22.

Vol, ii. p. 322, 324. 
with very little lofs; his enemies lofing a prodigious number in the battle and the purfuit, 7 Earls, 900 Knights, 400 Efquires, and about 32,000 common men, and by their own confeffion 14,000. The caftle furrendered the next dily, being St. Margaret's $(p)$.

The Siats regained the town, but not the caftle, 29 K. Edward III, 1355, early in the morning of the fixth of November, by furprize. The king was then in France. In January following, 1356 , he came before it with a fleet and army. He cntered the caftle by a mine, to the great joy of the Englifs commander, and the whole gaxifon. The miners were brought from the foreft of Dean, in Gloucefterflire, and other parts of England. The Scots, perceiving this, gave up the town. Upon its reduction, his majefty repaired the fortifications (q).

The caftle was taken by furprizc, by the Scots, I K. Richard II, 1377. They were difpoffefled of it in the fame year by the Earl of Northumberland, the Lords Lucy and Greyftock, and others, who took it by ftorm, and put every Scotchman to the fword, except their captain, Sir Alexanler Ramey. The Earl of Nortbumberland entereit Scotlaid with 3000 men of arms, and 7000 archers, and wafted the lands of the Eirl of March for three days together, in refentment for burning Roxbrough $(r)$.

The caftle wastaken by the Scots, by furprize in the night the year following, on Thurfay before St. Andrew's day. The $E_{n-}$ lifh conftable of it was Sir Robert Bointon, who was flain. His

(p) Hol. Chron. Vol, ii. p. 350.

(9) - p. 386.

(r) - P. $418,420$. 
wife, children, and fervants, were permitted to depart on promife of paying 3000 marks within three weeks, or yielding themfelves prifoners again; but on the ninth dav after, it was retaken by the Earl of Northumberland, and his fon, Henry Lond Percy, with 400 men in two hours. Sir Mattbere Redman, who malried Fobanna, the widow of William Lord Creyjock, and afterwawls of Aitthony Lord Lncy, was made conftable of it (s). Sir Matibew's orders to guard the town were fo frict, that even the great inke of Lancafter was refufed admittance on his return from an emballage in Scotland $(t)$.

After the battle of Toreton, 1461, King Henry VI, refigned it to Fames III, King of Scotland, as a reward for his protection; from whom it was taken, $22 \mathrm{~K}$. Edruard IV, I482, Auguft 24 ; and continued in the poffeflion of the Englifh crown ever fince (u).

For fetting the boundaries and limits of it, commiffioners were appointed by K. Richard III, in the 2 d ycar of his reign, and K. Fames III, of Scotland, I484; when it was agreed, that the debateable ground thould remain in its anticnt flate, without culture, buildings, or inhabitants. The names of the Englifh co:nmiffioners were Henry Percy, Earl of Nortbumberland, Lord Grey-

(s) Nobilifimus Baro, Willielmus de Greyfock, filius Radulpbi, cepit in uxorem fohomam, filiam Henrici Fitzhugh, domini de Ravenfwath. Dieta Fohanna poltea defponfata fuit Antonio, Domino de Lucy, qui infra breve obiit in terra fancta. Deindè autem fuper feftum S. Barnaba, Apoftoli, anno Edvardi tertii quinquegeffimo primo, Mattbeus Rednayn cepit dictam dominam Fobannem in uxorem.

Ex Autographo perantiquo.

(t) Hol. Chron. Vol. ii. p. 439.

(u) Vol. i. p. 283 .

Vol. ii. p. 705-6. 
fock, Lord Scrope of Mafbam, Sir William Gafcoign, Sir Robert Confiable, \&:c. $(v)$.

The lord warden of the eaft marches was governor of the town for the time being, and appointed the officers of the garifon, for whofe conduct he'was anfwerable.

It was fummoned to fend two members to parliament by King Henry VIII. It is governed by a mayor, recorder, and four bailiffs, chofen annually by the burgefles, in number about 300 . They elect the two members of parliament. The mayor and bailiffs are the returning officers ( $w$ ).

IBy a treaty between King Edward VI, and Mary Queen of Scotland, dated at Norbam, icth June, 155 I, it was made a countytown, or as the record expreffes it, a free town, independent of the two kingdoms $(x)$.

By the charter of King Fames I, granted $x 602$, the mayor, recorder, and four bailiffs, or any three of them, the mayor always to be one; are impowered to hold in their Guild-hall, or Tollbooth, one court of pleas cvery Tuefday in every fecond week throughout the year; to have four ferjeants at mace, and no more, and a coroner; a merchant's guild with hanfe, and all other liberties, privileges, and free cuftoms belonging to that guild; to prohibit merchant-Atrangers to difpofe of any goods within their precincts, except in grofs or by wholefale.

(v) Hol. Chron. Vol. i. p. 285 . (w) Browne IVillis.

(x) Rym. Foed. tom. xv. p. 265 . Acta Regia, Vol. iii. 8vo. p. 373. 
They have full power and authority to frame, conftitute, ordain, make, and eftablifh, from time to time, fuch laws, ftatutes, ordinances, and conftitutions, as fhall appear to them, or the greater part of them, the mayor always to be one, good, profitable, wholefome, honeft, and neceffary, for thie good government of the town.

They may purchafe manours, meffuages, lands, tenements, rectories, tithes, rents, reverfions, fervices, and other poffefions, and hereditaments whatfoever, which are not held immediately of the crown, provided that the fame do not exceed the clear annual value of $60 \mathrm{l}$ per annum, the ftatute of laws and tenements not to be given in mortmain, or any other act, ordinance, provifo, or reftraint thereof had, made, decreed, or provided to the contrary notwithftanding.

They are exonerated or quit for cver of all Toll, Pontage, Paffage, Murage, Pamnge, Cranage, Laffoge, Cariage, Kaigge, Vinage, Acinate, and Rechaie, through his Majefty's dominions, with Seck, and Sack, and Toll, and Theom, Ward and Warl-Peny, and all other cultoms to be performed of their orvn proper goods and merchandife, alfo of all payment of fubfidies, taxes, impofitions, tenths, fiftenths, and exactions whatfoever; alfo of Prifage of Wines, Butlerage of Wines, and of all other impolitions, called the impots, Butlerage and Prifage of Wines, for any wines carricd, unloaden, or put to land within their own poit of Berwick, or in any other of the members or creeks of it.

The corporation have a power to impofe a reafonable tax or tallage upon the rents and other things of the inhabitants, without molctation or hindrance from the king's officers, provided they apply it only to the chamber's ufe. 
They have two weekly markets, on Wednefday and Saturday; alfo an annual fair; with a court of Pyeporvder, Tolls, Tallages, Picage, Fines, Amerciments, and all other cuftoms, liberties, profits, and emoluments whatfoever belonging to fuch markets, fairs, and courts of pycpowder. The mayor is clerk of the market.

They have a Court Leet and view of Frank Pledge of all the burgeffes, inhabitants, and refidents, within their jurifdiction.

The mayor has the cuftody of the gates, pofterns, and wickets, and the cuttody of the keys of the gates.

The mayor, recerder, bailiffs, and burgeftes, or any three or more of them, the mayor and recorder always to be two, may do judgment of Infangthiefe, and Outfaithiefe. They have the powcr of aflize over the prifoncrs a authority to encuire, hear, and determine all Felonies, Murders, Honicides, Robberies, Affanlts, Riots, Roitts, Forces, Outcryes, into lands or tenements, trefpaffes againft the crown, unlareful Conventicles, Ambidexters, Confpiracies, Contempts, Concealments, and alfo of all other Mipprifons, Offences, Mijkeeds, Defaults, Negrligenices, Caufes, and Aiticles, within the libertics of the corporation.

The coroner makes return from time to time of all juries, inquifitions, pannels, attachments, and indentures, taken before the mayor, recorder, \&c. He attends them in all gaol-deliveries, and does the office of a fherift. All fincs, ranfoms, iffues, amerciments, forfeitures, profits and perquifites of the mayor's courts are levicd and raifed under his authority, and go into the townchamber; alfo all goods and chattels whatfoever raved, Deodands, Chattels of Felons, Fugitives, and Outlaws, convicted and attainted.

The 


\section{ANTIQUITIES OF NORTHUMBERLAND.}

The mayor and corporation have all the Seignory, Mononr, Borong hTown, and Soke of Berwick upon Tweed, with all and fingular their rights, members, and appurtenances; all the houfes, edifices, buildings, ftables, ftore-houfes, lands, tenements, cottarses, wafte-grounds and foil whatfoever which belonged to the crown within the Signory, Nanour, or Borongly all the crown-lands and fields adjoining to the town, commonly called the Bounds and Fields of Berwick; alfo all thofe crown-lands, tenements, meadows, paftures, feedings, commons, demefne-lands, mefluages, mills, houfes, edifices, barns, ftables, out-houfes, orchards, gardens, waftes, heaths, furz, moors, marches, fruits, profits, waters, fifhings, fifhing-places, fuit, foke, rents, reverfions, and fervices, as well of free and cuftomary tenements, fermes, fecfermes, annuities, knights-fees, wards, marriages, efchaets, releafes, herriots, fines, amerciments, rights, jurifdictions, franchifes, privileges, and hereditaments whatfoever, of whatfoever kind, nature, or degree, or by whatfoever names they be known, lying or fituated within the Signory, Manour, and Borongh of Berwick.

This Signory or Manour is thus abuttelled; beginning at the port or haven, and extending northwards by the fhore of the fea, and the fea-banks, to a certain path or way, commonly called, The brown rod, and by the fame brown rod weftward to the rivulet of Witteter, and from the other fide of it by the fame brown rod to the river Tweed, and from thence by the banks of the Trueed eaftward unto the port or haven of the borough of Berwick.

The crown hath referved to itfelf the caftle, built on the townwall; all the edifices, and buildings belonging to it ; the watermill near the wall, commonly called, The caftle-water; all the lands, tenements, clofes, and other hereditaments, known, or V.oL. II. 


\section{ANTIQUITIES OF NORTHUMBERLAND.}

called by the feveral names of the Inner caftle-hills, enclofed, and the Outer caftle-hills, not enclofed, the New water-haugh, and Lumfden's avery, Gayn's-law, Gouk-Haugh, the Sunk, and the Maudlinficld, the Coney-garths, the Mar/halls meadow near Lammerton, the meadow, called, The Horfman's bat, the Horfman's meadows, the Yellow-Gowlon-meadow adjoining near or upon Latham, and extending to the eaftern and weftern Mortinton; all the fifhing and fifhing-places, beginning at Finche's-bowgh, and extending in and by the river Trued to the deep fea; all thofe lands and meadows commonly called or known by the feveral names of Broad's-baugh, Borrej-Avery, and Ethermouth-Avery, being within or nigh the town; alfo two wind-mills within its precincts.

The Seignory, Manour, Borough, Town, and Soke of Berwick are held of the crown in free and common burgage, by the payment of $20 \%$ annually into his majefty's exchequer, or into the hands of his bailiffs or receivers, at the feaft of the annunciation of the Bleffed Virgin Mary, and of St. Michael the Archangel, in equal portions for ever, for all other rents, fervices, exactions, and demands whatfoever due to the crown $(y)$.

A monaftery was founded in Berwick by Sir Fobn Grey, A. D. 1270, for white friers, Fratres Carmeli Monte, one of the four orders of friers mendicants. They officiated in the king's chapel belonging to the caftle, for which they had the ufual falary given by the crown $(z)$.

(y) Ex Carta fai. I. Dat. 30. Apr. anno reg. 20 Angl. 37 Scotice.

(z) Fratres Carmelite deferviant in capella regia in caftro de Berwick, et habeant confuetum Rigendium.

Rot. Pat. 2 Ed. II. p. I. m. 14 .

Tumm. 's Notitia Monaft. fo. p. 396 . 


\section{ANTIQUITIES OF NORTHUMBERLAND.}

Another monaftery was founded by the bridge, dedicated to the Holy Trinity. It is faid by Leland to have been diffolved by $A n$ thony Beck, Bifhop of Durbam (a); but that learned antiquary muft be under a miftake, as that prelate dicd, $5 \mathrm{~K}$. Edward II, $13 \mathrm{II}$, and mention of it is afterwards made as exifting, $2 \mathrm{~K} . \mathrm{Ed}$ ward III, and of its being founded pro Miniftro et Fratribus Sancte Trinitalis Pontis Berwici (b).

There was alfo one founded for the Grey Friers, or Friers Minors, who had a grant for twenty marks per anmm out of Wetberburn, for the payment of which K. Edward III. gave orders in the I 3 th year of his reign (c).

Mention is made in the Efchaet-rolls of Nortbumberland, and by Bithop Tanner, of an hofpital, or free chapel, dedicated to St. Mary Magdalen, fituatcd near Berwick, but not precifely faid where (d); to which was united an Hermitage, at a place called Segdon (e).

The town flands chicfly on the brow of a hill; the river $\mathcal{T}_{\text {rved }}$ to the fouth; the fea to the eaft; large barracks for foldiers at

(a) Lel. Itin. Vol. viii. p. 5 .

(b) Clauf. 2 Ed. III. m. I6.

(c) Mandatum R. Ed. III. anno reg. I3. de folvendo guardiano et fratribus ordinum minorum in villa de Berwico commorantibus viginti marcas per annum de ferma dicta villt, de elemofina regum Scotice de antiquo conftituta.

Rym. convent. tom. v. p. 104.

Notit. Monaft. fo. 397 .

(d) Rot. Pat. 29 Ed. I. m. prope finem.

Rjm. Fod. tom. iii. p. $7 \varepsilon 6$.

Rex dedit Nicholao Nuton cuftodiam liberæ cayellæ S. Marie Mag.laline, juxta Berroui, et hermitagii de Segdon eidem anex. Pat. $16 \mathrm{Hen}$. VI. ex colleclan. cl. M. Hutton.

(e) Rot. Pat. 4 I Ed. III. n. 39 ; where is an inquifition of the lands belenging to ito, Tanner's Notit. Monaft. fo. 397. 
the upper part of it, by a handfome area, called, The Parade, where they cxercife; the fortifications Atrong, well furnifhed ivith canno t. In the reign of K. Charles $\mathrm{I}$, it was put into a good fate of defence by the parliament, who held it againft his majenty. They repaired the town-walls, on which thirty pieces of orluance were planted. On the mount over-looking the fea, and commanding the liarbour, were ten brafs pieces $(f)$.

The church is on the north fide of the parade, in which Goan, the finter of K. Edriard III, was married on St. Mary Magdalen's diy, I328, to David Bruce, fon of Robert Bruce, King of Scotland. Their nuptials were celebiated with royal pomp and magnificence. Her mother, the Queen Dowager, was prefent, with the Lords Mortimer and Warren, the Bilhops of Ely and Norvich, and an abundance of other great Lords. The Lord Mortimer's retinue alone confilted of ninefcore knights, befides efquires, gentlemen, and yeomen. The Scots acquired by this marriage the re-delivery of their charters and patents, and of that famous one called, Ragman, whereby their kings became feodaries to the crown of England; alfo many jewels that had been taken from them; for: which, in return, they complimented their new queen with the title of Goan Make-peace $(\xi)$. It was rebuilt under the Aupices of Colonel George Eenwick, of Brinkburn, in the fcrvice of the parliament (b). It is dedicated to the Holy Trinity (i). The minifter of it at the Reforation was Mr. Nicholas Wreffel, who was ejected for not complying with the act of uniformity. He taught fchool at Stockwell for fome time, and ended his days at London, about the year $1695(k)$.

(f) Whitclock's Memor. P. 447 .

(b) See Erinklurn.

(b) Pilhop Kinre:"s Hifforical F egifter.
(5) Fiol. Chron. vol, ii. p. 347 .

(i) Broune Itrillis. 
In this town is a free Grammar fchool, of Q. Elizabeth's foundation; who alfo built the bridge over the Trueed. It was carried away by a great flood, 2 K. Fobn, 1200 . It was then of wood, and rebuilt by William, King of Scotland (l).

The Town-hall is a neat modern ftructure, of white freeftone and hewn work.

The Town-Arms are, A dog paffant by a tree; in feffe point, two efcutcheons with the arms of England and France quarterly, tied together by an arch ; in chief, a king fitting on an arch, with a fcepter in his right hand, and a mound in his left $(\mathrm{m})$.

(l) Hol. Chron, vol, ii, p. 16r. (m) Browne Willis. 


\section{$[446]$}

T H E

$\begin{array}{lllllllllll}A & N & T & I & Q & U & I & T & I & E & S\end{array}$

O F

\section{NOR T H U M E R L A N D, \&c.}

\section{$\begin{array}{llllllll}\mathrm{J} & \mathrm{O} & \mathrm{U} & \mathrm{R} & \mathrm{N} & \mathrm{E} & \mathrm{Y} & \text { III. }\end{array}$}

From Berwick to Cornbill, by Etall, Wooler, the Vales of Whittingham, Rotbbury, Witton, Wallington, Bolbam, Belfay, and Pont-Eland, to Newcafle upon Tyne.

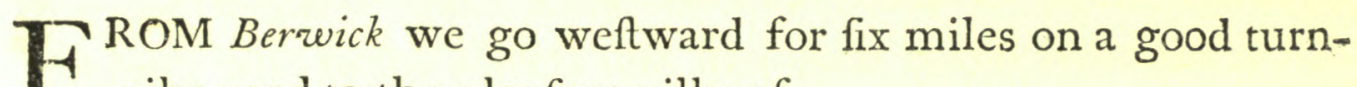
1 pike-road to the pleafant villa of

Norbam, i. e. the North Hamlet, the antient Ubbanford (a), which was built by $E_{g g}$ frid, Bifhop of Lindisfarn, A. D. 830 ; and gives its name to a large tract of country called Norham/hire. Eg frid built a noble church in it, to which he removed the royal remains of Ceolwulf from Lindisfarn, the firt of our princes who retired from a throne to a monaftery. He gave the impropriation and advowfon of it, and the whole villa, alfo the village of Shorefrogod,

(a) Northain. Rog. Hoveden.

Cainden's Brit. p. 862. 
and other villages before mentioned, to his fee (b). It ftands on the north fide of the village. The middle ifle is only now ftanding. The foundations of a building were lately difcovered at the eaft end, and a ftone found with the following infcription.

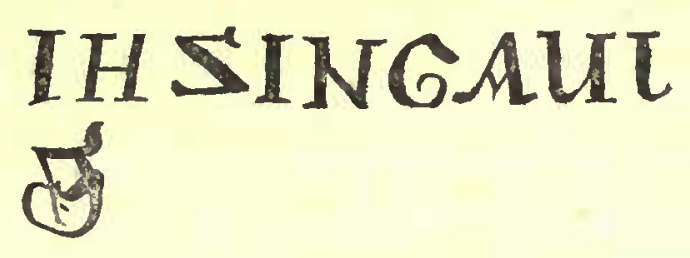

Above it, in a nitch, is the effigies of St. Peter, with the keys; alfo of St. Cutbbert, and King Ceolturlph, holding a fceptcr; the three patrons of Norbam-church. On the reverfe is this infcription.

\section{PALR』חh-MUI}

On the ravage of Lindisfarn by the Danes, St. Cutbbert's body was removed hither, where it remained till the time of King Ethelred. The village confifts of one long and wide ftret on the banks of the Trueed, to the eaft of which, on a rocky eminence, is

Norbam-Cafle, which was built by Ralph Flambard, Bifhop of Durbam, 22 K. Henry I. IIII (c). The Treed fetches a circuit under it round a little ifland, called the Shingles, in moft delightful murmurs. Alexander II, King of. Scotland, made his perfonal fubmiflion in it to King fobn, 1209 , at the price of a great fum of gold, leaving for pledges two of his daughters. He came before it with a mighty army, 1216, with which for the fpace of forry

(b) See Lindisfarn, or Holy Ifand.

(c) Hol. Chron. vol. ii. p. 42 . Browne Willis. 
days he attempted to take it, but in vain, being forced with $d$ ifgrace to raife the fiege. After his death, a parliament was fummoned to meet at Norbam, roth May, 19 K. Edward I, 1291. The king refided in the caftle. The nobility, prelates, and knights of both kingdoms, affembled before him on a green plain, on the banks of the Treed, directly oppofite to the caftle, fays the record, to confider of the fucceffor to the Scotch fcepter, to which he put in his claim; his title being hiftorically declared and publinhed by the Bifhop of Durbam (d).

In the following reign it was befieged by the Scots, who ereeted two forts againft it, one in the church of Norbam, and the other at Upfitlington, but by the bravery of its captain, Sir Tbomas Grey, of Heton, and the arrival of the Lords Percy and Nevill with a body of forces to its relief, they were forced to defift from their enterprize, and retire (e).

They laid fiege to it again in the fame reign, and took it. K. Edward came before it with a large army, 1322, and recovered it, after a fiege of ten days $(f)$.

It was befieged by Games, King of Scotland, I 3 K. Henry VII, 1497 , but was refcued by the Earl of Surry, with an army of 20,000 men $(g)$.

(d) Congregatis ex oppofito caftri de Norham, ex alia parte fluminis Truede in quadam area viridi, epifcopis, pralatis, comitibus, et baronibus, aliifquè nobilibus viris, jus ad diEtum regnum vindicantibus, \&zc. Rot. de Superioritate Regis Anglia in Turri Lond. Blady's Compl. Hift. of England, vol. ii. p. 19.

(e) Hol. Chron. vol. i. p. 222.

(f) vol. ji. p. $33^{2}$.

(g) $\mathrm{p} \cdot 782-3$. 


\section{ANTIQUITIES OF NORTHUMBERLAND.}

It was feized by the Scots in the following reign, but was recovered by the prowefs and policy of Mr. Franklin, archdeacon of Durbam, for which he had a coat of arms given him, $22 \mathrm{~K}$. Henry VIII, $153^{\circ}$ (b).

It was repaired by bithop Tunfal in the reign of Q. Mary. It is now through age and neglect become a perfect ruin. Some of the vaults and prifons remain, part of a fide-wall of the chapel, and a large tower at the north-caft of it; under which a pleafant fountain iffues out of the rocks.

The manours of Norbam and Norbam/Bire, with the fitherics in the river Tweed, and all their franchifes, were granted to Q. Elizabeth by Richard Barnes, bifhop of Durbam, who made no fcruple to rob St. Cutbbert, to make round portions for his daughters (i). Her majeity granted the caftle, the tithes, and demefins of Norbam to Sir Robert Cary, Earl of Monmouth, for his own life, and the lives of his two fons. His lordhip fold them for $6000 \mathrm{l}$. and the furniture of the caftle for $800 \mathrm{l}$. to George Hume, Earl of Dunbar; a nobleman, fays Lord Orerry, of an excellent character (k).

The manour of Norbam is now in the poffeffion of Sir Thomas Haggerfon, of Itaggerfton, Bart. The caftle, and its demefins, confifting of ro3o acres, as furveyed about the year $175 \mathrm{I}$, and extending eaftward on the banks of the Tweed near two miles, be-

(b) Athen, Oxon. vol. i. p. 703.

Reg. Dunelm.

Vifitat. of Thomas Tonge, Norray, \&c.

(i) Bronine Willis's Survey of the Cathedr. of Durb.

(k) Monmouth's Memoirs, p. 114, and p. 128, and p. 197-8.

VoI. II.

$\mathrm{M} \mathrm{m} \mathrm{m}$

long 
long to Robert Fenwick, of Lemington, Efq, in right of his wife, Mrs. Fenwick, one of the daughters and coheirs of the late William Ord, of Sandy-bank, Efq. They are held of the lord of the manour, paying only the caftle-rent.

A fithery in the Tweed, near the caftle, called Halywell, for one night and one day in a legal manner, was adjudged by the commiffioners appointed to fettle all claims and differences on the borders, 1553 , to be the property of Lord Hume, his heirs, and affigns (l).

A mile below Norham, the Trued forms an ifland of fourteen acres, by a den, called St. Thomas's Den; the Trueed mufical by a fall from a mill-dam, in the border-idiom, named The Call, from its murmurs, as from a cafcade.

A little to the weft of it, is a lofty terrace above the Trueed, where it forms a kind of ferpentine canal; the feat of fames Ker, of Ker's-field, Efq; on the other fide, and a craggy cliff, inaccerfible by human feet, the folitary recefs of Cormorants, and feveral fpecies of Hawks, particularly in the breeding-feafon.

Near half a mile further down the river, on the left hand of the road, two fmall Urns were found in a gravel-pit, called The Crooks, and feveral human bones by them. One of them is now in the poffeffion of Francis Blake, of Twizell, and the other of Henry Collingrood, of Cornbill, Efqrs.

About 100 yards from it, is a pedental of a crofs, with fome of its broken fragments; alfo another about 200 yards in a direct

(l) Bp. Nicbolfcn's Border-Laws, p. Iog. 


\section{ANTIQUITIES OF NORTHUMBERIAND.}

line from it, and a pleafant mount with a courfe of ftone-fteps round it, an antient fepulture, or barrow. The croffes were erected by the road formerly leading from 7ilmouth-chapel to the villa, church, and caftle of Norbam.

Half a mile from the Crook, is

Twizell $(m)$, which was the lordhip and villa of Sir William Ridell, 4 K. Edward III, who had alfo the hamlets of Dudbow and Grindon, which he held of the bifhop of Dutbam by the annual rent of twenty marks, and doing fuit and fervice to his court at Norbam (n). It was afterwards in the poffeffion of a branch of the antient family of the Selby's; of Sir Fobn Selby, a commifioner for enclofures of the eaft marches, $6 \mathrm{~K}$. Edward VI (0), and deputy-warden of the eaft marches under Henry Lord Hunflon in the reign of Q Elizabeth $(p)$; Sir William Selby, of Grindon, being at the fame time mafter of the ordnance at Berwick (q). Sir Foln claimed a fithery in the river Treed, called Tilmontb-haugh finhery, but by the commiffioners appointed to adjut and fettle all claims and differences on the borders, I553, it was adjulged to be a Scotch fifhing, belonging to the priory of Coldftream, leafed to Alexander. Hime of Maders-tom, and that the lord of the manour of Twizell had only a right to ufe and occupy a ring-net, and to ftand on a place, called Fillifpotte, upon the fouth fide of the river $(\%$. His

(m) Twizell. Rot. Efcaetr. Northumbr.

Twille. Lal. Itin. vol. vii.

(i) See Tilmouth.

(0) Bp. Nicholfon's Border-Laws, p. 337 .

(p) Monmoutb's Memoirs, p. 113 .

(a) Id. p. s.3t.

(r) Border-laws, p. 110 . 
fon Willian Selby had the manours of Prankfon, Moneylaws, Shotion, Lowick, and half of the forent of Cheviot $(s)$. Truizell is now the feat of Francis Blake, Efq; F. R. S. fon of Robert Blake, Efq; by the third daughter of Sir Francis Blake, of Ford-caftle, Knt. lately repaired, with handfome additions, chiefly in the Saxon-Gotbic Atile; the river Till in a winding current gliding under it, crofted by a ftone-brige of one frong and beautiful arch, as defcribed by Leland (t), and faid to have been built by a lady of the Selby-family, nearly femicircular, 90 fect, 7 inches, from bafe to bafe, in height from the top of the battlement $4^{6}$ feet, 2 inches. Under the houfe is a range of rocks, cavernofe, fringed with various petrifications of mois, and other fmall plants, formed by drippings of water fiom the roof and crevices; a natural alcove in one part of it, the mofs-plants on its fides variegated and gilded by thofe petrifying drops, a Thort, upright ftone in the center in party-coloured lapideous cloathing, and hollow at the top by their continual falling; a fine view, through the arch of the bridge, of a floping bank of hawthorn, in blofrom beautiful; the north-weft fide of the brielge adorned with large quantities of Pellitory of the Wall; an upright rock, of a great fize, and tapering to the top, about twenty feet high, a little below the bridge, on the edge of the Till; a fountain near it, confecrated to St. Helen, and by it an antient fepulture, faid to have belonged to the family-chapel.

The two noble brothers, Sir 7bomas Percy, the fixtb Earl of Northumberlan?, and Sir Henry Percy, defeated the Siots at Grindon, 5

(s) Willielmus Selby, arm. filius Johannis Selty, militis, tenet in capite maneriun de Eranxton, ac manerium five capitale meffuagium vocat. Moncjlaws, ac manerium five dominicum de Shotton, ac manerium de Lowick, ac melietatem forefta de Cheviot.

Efcaet, de anno ${ }_{4}$ Car. I.

(1) Lel. Irin, vol. vii. p. 62.

Q. Mary, 
Q. Mary, 1558, and purfued them over the Till at Twizell, alfo over the Tweed at Chapel-ford, where many of them were drowned. On a rifing ground near Grindon, about a quarter of a mile fouth from Sandy-bank, and in fight from it, are four upright ftoncpillars, funeral-memorials of the chieftains flain in that action (u).

On the other fide of Twizell-bridge, is

Tilmouth, a mediety of the manour of which belonged to Sir Furdan de Ridell, I K. Edward I (v); and the whole manour to Sir. William Ridell, high theriff of Narthumberland, $8 \mathrm{~K}$. Edward II (w); alfo to his fon, Sir William Ridell, 4 K. Henry III ; held of the bifhop of Durbam by half of a knight's fee, and doing fuit and fervice to his lordfhip's court at Norbam, and paying the caftle-rent, viz. $20 \mathrm{~s}$. per ammum. The fecond Sir William died in that year, and left three daughters and coheirs, viz. Ifabell married to Sir Alan de Clavering, Conftantia to Fobn de Kingston, and Gobanna to Gerard de Woodrington (x). Sir Alan's Lady furvived him, and

(u) Hol. Chron. vol. i. p. 363 .

(v) Furdanus de Ridell tenet medietatem de Tilmouth per dimid. marc. Veniat et fiet miles. Efcaet. de anno I $E l$ l. I.

(w) See Swinburn-caftle.

(x) Dicunt juratores, fuper facrum, quod Willielmus Ridell obiit feifitus in dominico, ut de feodo, de manerio de Tilmouth, cum pertinentiis, except. una carticuta terre tradita unæe cantariæ in perpetuum, et duobus terris hufoandriæe c'nas Hugo Ridell tenet in eodem manerio, et excepta tertia parte ejufdem manerii quam Emnh, quæ fuit ux.r Wilielmi Ridell (vicecomitis Nortbumbr. 8 Ed. II.) tenet in dotum de hixreditare prad (ti Wilieini ; et quod tenuit dietum manerium de domino epifcopo Duncimice per fervitium medietatis unius feodi militis, et faciendo fectam ad curiam de Norbam, et reddendo per omnia pro cuftodia caftri de Norlam viginti folidos, et folebat dictum mancrium valere por annum in onnibus exitibus, 
and held this manour for her life. The reverfion of $\mathrm{it}$, and of the manour of Upsetlington, were granted by Sir Robert Clavering, for the term of his own life, to Alexander, archbifhop of York, who granted them back to his fon, Sir Fobn Clavering, and his heirs, 49 K. Edward III $\left(y^{\prime}\right)$.

bus, tempore pacis, exceptis pradictis carucutis terræ, et duabus terris hubbandria, et dote Emme pradictx, fexdecem libras.

Et idem Willielmus fuit feifitus de manerio de Twizcll, et hamlettis de Dudhow, et veteri Grindon, quæ funt de pertinentiis ejufdem manerii ; et tenuit cund. manerium, et hamletta, de diỗo domino epifcopo Dunelmia per fervicium viginti marcarum per annum, et faciendo fectam ad curiam de Norbam; et valuerunt per annum tempore pacis in omnibus exitibus prater pradictas viginti marcas, viginti fex libras, et fex folidos.

Et prædiclus Villielmus fuit feifitus, de duabus partibus manerii de Upfetlington, cum pertinentiis, et tenuit dictas duas partes de dilo domino epifcopo per fervitium faciendi fectam ad curiun de Norbam, et valuerunt per annum, tempore pacis, $\mathrm{x} l$. xiii s. ivd.

Et omnia predicta maneria funt deftructa per Scotos, ita quod nihil valeant, \&c. Et donina Jfabella qua fuit uxor Alami de Clavering, et domina Confantia uxor domini Z Fbannis de King/fon, et domina Fohanna uxor domini Gerardi de Widlrington, funt filiz et heredes pradicti thiliclmi propinquiores. Et pradicta Ifabella fuit ætatis xxx annorum, et domina Conylamia fuit atdis xxvi annorum, et domina fobanna fuit xtatis xxii annorum.

Inquifit, de anno $4 E d$. III.

(y) Sciant, \&c. quod nos Aiexander permiftione divina Ebor. archiepifcopue, Anglice primas, et Anglia fedis legatus, dedinus, \&ac. Roberto de Clavering, militi, reverfionem manerii de Tilmouth, cum pertinentiis, \&c. quod quidem manerium domina - de S! :velin, quondam uxor Alani de Clavering, tenet ad terminum vitæ fure; ac etiam reverfionem mano. rii de Upfetlington, cum pertinentiis fuis; quod quidem manerium Henticus de Eflington tenet ad terminum vite fux, quas quiden reverfiones habuimus ex dono et feoffamento pradicti Raberti de Clavcring, militis prout in carta per ipfum inde nobis confecta contiretur; habend. sic. pradicto Roberto de Clavering, militi, ad terminum vitx fure, fine valto feu deftrictione inde facienda; et facienso capitali domino feodi illius fervicia inde debita, et de jure confueta. Et poft deceffum prædicti Roberti Clavering, militis, volumus et concedimus, quod omnes pradictz reverfiones, cum acciderint, \&c. remaneant fobanni filio domini Roberti 
It continued in the poffeffion of the Clavering-family for many generations. By an inquifition taken at Norbam, I $\mathrm{K}$. Hewry VIII, before Robert Lord $O_{g} l e$, it was found that Robert Clavering died feifed of Tilmouth, and of a fifhery in the river Till; and that fobn Clavering, his father, granted his lands in Dudbow, and Green-laws, to Richard Bifhop of Durbam, for the ufe of the faid Fobn and Ifabell his wife, and the longer liver of them, the reverfion to his next heirs in fee; and that the third part of Tilmonth was afligned by the faid Richard, Bithop of Durbam, to the faicl Ifabell; and that all the faid lands and firhery were held of the bifhop in focage, and that fobn Clavering was fon and heir to the aforefaid Robert, then of the age of fiftecn. Fobn Clavering died, i6 December, $28 \mathrm{~K}$. Henry VIII, when it was found by an inquifition taken at Norbam before Sir William Eure, Knt. that he held his villa and lands of Dudbow, his hamlet of Greenlawes, and his villa and lands of Tilmouth, in fce, by focage-fervice, of the

Clavering, militis, et hæredibus de corpore fuo legitimè procreatis, in perpetuum. Et fi contingat quod prædiatus Fohannes de Clavering obierit fune hxrede, \&c. practictie reverfiones, \&c. remaneant Thoma fratri ejufdem Jobannis de Clavering, et haredibus mafculis de corpore fuo legitime procreatis, in perpetuum. Et fi contingat quod prædictus Thomas obierit, \&c. remaneant Roberto de Clavering, fratri fuo, et hxedibus mafculis de corpore fuo legitimè procreatis. Et $f_{1}$ contingat quod pradictus Robertus obierit, \&c. remancant Rogero, fratri fuo, et haredibus mafculis, de corpore fuo legitime procreatis. Et fi contingat quod prædictus Rogerus obierit, \&c. volumus quod prædictæ reverfiones prædictorum maneriorum cum omnibus pertinentibus fuis, prædicto Roberlo de Clavering, militi, et haredibus fuis, integrè revertantur. Et nos vero prædictus Alexander, Ebcr. archiepifcopus, prædictas reverfiones prædictorum maneriorum cum acciderint, prædicto Roberto de Clavering, militi, in forma pradicta, contra omnes gentes warrantizabimus et defendemus in perpetuum. In cujus rei teftimonium præfenti cartæ noftræ figillum noftrum appofuimus. His teltibus, dom. Rogero Heron, Willielmo De la vale, Bertrana Monboucher, Thoma Colvill, militibus, Nichalao Raymes, et Fobanne Heron; et aliis. Data apud Tilmouth Die Lunæ proxime poft feftum Sandi $\mathrm{Fa}^{-}$ coli, apoftoli, anno regni regis Edvardi III, poft conqueftum Anglice xlix.

Carta de anno 49 Ed. III:

(z) Inquifit. de anno $10 \mathrm{Hen}$. VIII. 
Bifhop of Durbam; and that Robert Clavering was his fon and heir, then about five years of age (a). He died, 3 oth November, 25 Q. Elizcleth; and was fucceeded by his fon and heir, Robert Clavering, then about twenty-eight years of age (b).

He died, 18th March, 42 Q. Elizabeth; and was fucceeded by his fon and heir, Fobn Clavering, at the age of thirteen years and eleven months (c). Tilmouth now belongs to Francis Blake, of Truizell, Efq; and others.

\section{A little higher up the Till, is}

Heton, which was the feat and manour of the antient family of the Greys; of Sir Thomas Grey, captain of Norbam-caftle in the reign of K. Edward II (d); of Sir Thomas Grey, his fon, captain of

(a) Juratores dicunt fuper facrum, quod Fohannes Clavering, arm. die quo obiit fuit feifitus in doninico fuo, ut de feodo, de villa et terris de Duabou cum hamlet. de Grcen-laws, cum pertinentiis, in comit. de Norham; et de villa et terris de Tilmouth, cum pertinentibus, in comit. prædicto, de dom. epifcopo Dunelmia, per fervicium focagii, \&c. Dicunt etiam juratores fuper facrum, quod prædilus fohannes Clavering obiit fexto decimo die Decembris,' anno regni regis Henricioczavi, viceflimo octavo; et quod Robertus Clavering eft filius et hæres propinquior prædici Gobannis, et eft ætatis quinque annorum, et amplius.-

Inquifit. capta apud Norham, coram dom. Willielno Eure, milite, Efcaetore Epifcopi Duntm. anno viceffimo octavo, Regis Henrici oczavi.

(b) Juratores dicunt fuper facrum, quod Robertus Clavering, arm. die quo obiit fuit feifitus in dominico fuo, ut de feodo, de et in duodecem mefluagiis, decem eotagiis, centem acris terræ, octoginta acris prati, centum acris pafturæ, trecentis acris moræ, cum pertinentiis, in villis, et terris de Dudbow, Green-laws, et Tilmouth, quæe tenentur de Ricardo epifcopo Dunelmize in libero focagio, \&ce. Quodque predictus Robertus Clavering obiit trieeffimo die Novembris, anno regni dominæ noftre Elizabethe reginæ nunc, \&c. viceflimo quinto. Et quod Robertus Clavering eft filius et hæes propinquior dicti Robcrti Clavering, et eft xtatis viginti et odto annorum.

Inquifit. de anno 26 Eliz.

(c) Ingrifit. capta apud Dunelm, anno 42 Eliz.

(d) See Norbam. 
the fame cafte in the reign of K. Edward III, taken prifoner in too eager and forward a purfuit of the Scots, I355 (e); of Sir Thomas Grey, a reprefentative in parliament for Northumberlind, I K. Hexiry IV, and captain of Wrark-cafte, taken by the Scots in his abfence, who, after plundering it, pulled it down to the ground; the borders then afflicted with a great mortality $(f)$. He was in great favour with K. Henry V, the glory and pride of the Englifs nation, and the fcourge of France, for conf piring whofe death he was executed. His confederates werc Richard Larl of Cambridge, Edward Duke of York, and Henry Lord Scrope of Muß Jam, who were alfo executed. The largeft fhare of difgrace fell upon Sir Thomas and Lord Scrope. Sir Thomas was a privy counfellor. Lord Scrope was lord treafurer, and admitted into the highef confidence, and neareft intimacy with the King. The folemn gravity of his countenance, the attractive graces of a moden and chafte converfation, full of zeal for virtue and goodnefs, fo won the king's heart, that he placed him the neareft of all men to his bofom and perfon, and was for the molt part fwayed by him in every thing of moment $(g)$.

Heton afterwards camc into the poffeffion of Sir Ralph Grey, who, with K. Henry VI, Henry Lord Percy, the Earl of Weftmorland, and others, was invefted witi the high and honourable Order of Knight of the Garter by the Duke of Bedford, regent of England (b). He was captain of the caftles of Wark and Roxbrough:

(e) Hol. Chron. vol. i. p. 242.

(f) - vol. ii. p. 514.

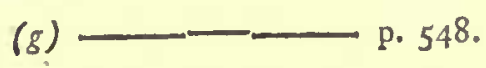

(b) -

VOL. II. 
458. ANTIQUITIES OF NORTHUMBERLAND.

the laft of which he defended with an eminent courage for twenty days, 15 K. Henry VI, 1436, againt the forces of Fames, King of Scotland, till the arrival of fuccours under Henry Percy, the fecond Earl of Nortbumberland, on the fight of which the Scots fled with precipitation; many of them flain and taken prifoners (i). He was appointed captain of Bambrough-caftle by the houfe of Lancafer, in which he was taken prifoner after his retreat from the battle of Hexbam, and beheaded at Doncafer, his fword being firt broke over his head, \&c. for breaking his oath of fealty to the houfe of $\operatorname{rork}(k)$.

In the reign of K. Henry VIII, it belonged to Sir Edward Grey (l) ; and afterwards to William Lord Grey of Wark $(m)$. It is now in the poffeflion of the Earl of Tinkervill. The caftle was a ftrong building, nearly fquare; a court on the weft fide, called The Iyon's Court; on the north fide, a vault that roo horfe might ftand in. It is now in ruins. King Fames IV, of Scotland, invefted it with his army before the battle of Floddon-field, but could not take it. In digging for ftones, two wells were difcovered by the workmen, in which were found four pewter plates, with part of the arms of the Greys engraved upon them; alfo one bow made of yere. They came inta the poffeffion of Mr. Gregfon, of Wark upon Tweed.

Below Tilmouth, by the confluence of the Till into the Trueed, is

Tilmoutb-Chapel; finall, and in ruins; the altar-window remaining, and a bafon in a rich of the fouth wall; on the north

(i) Hol. Chron. vol. ii. p. 6r5.

(k) - $\mathrm{p} .666$.

$\begin{array}{ll}\text { (l) Lel. Itin. vol. vii. p. 6r. } & \text { (m) See Wark upon Tweed. }\end{array}$ 
fide, the foundations of the minifter's houfe confpicuous; the fituation moft delightful, on a fmall peninfula floping to the two rivers.

On the weft fide of the chapel, on the banks of the Tweed, is a remarkable curiofity, a ftone-boat, of as fine a flape as a boat of wood, in which St. Cutbbert is faid, by tradition, to have failed down the Tweed from Melrofs to this chapel. It is ten feet long: within; three feet and a half in diameter, in the middle; eighteen inches deep; four inches and a half thick.

Half a mile wert from Tilmouth, on the left hand of the Berwick-road to Cornbill, is a ftone-crofs, called Tilmoutb-Crofs; below which, on the north fide, is an intrenchment, nearly fquare, called The Haly Chefters; a great part of it overgrown with furz.

Oppofite to Linnel-Honfe, and about a quarter of a mile from Combill-bridge, on the brink of the Tweed, is the veftigies of a fort, trenched round, callcl The Cafle Stone-Nich; a guard to the ford crofs the river.

The bridge over the Tweed is a modern ftructure, confifting of fix arches, of white freettone; the firft foundation-ftone laid in May, $176_{3}$, by Lord Home; $4000 \mathrm{l}$. given towards building it by the parliament.

At a fmall diftance from the bridge, is

Cornbill, which was the villa of William de Cornhill, I K. Edward $\mathrm{I}$ (ii). It now belongs to Henry Collingwood, Efq; high theriff of

(w) Willielmus de Cornbill tenet villam de Cornbill in Efcambio, et Horncliff, et reddit. inde per ansum xviii marc.

Efcact. de anno I Ed. I. 
Nortbumberland 1766 , and to Francis Blake of Twizell, Efq; The church ftands nearly in the middle of it; lately rebuilt, finall, but neat, the roof cieled; dedicated to St. Helen, a fpring hard by carrying her name. In digging up the old foundations two fmall urus were found by the workmen, the genuine contents not certainly known, being thuffled out in a ftruggle by the finders of them, thinking they had got a treafure.

In the church-yard is the following infcription on the tomb of an old man, an empyric, at Treizell.

Eheu! quis mortis jam retardabit falcem? Archiater ille inclytus, ad pontem Twigiri, Gacubus Purdy, non vacat xgris.

Obiit ipfe 4 to die Decembris, A. D. I752, ct ætat. 81. Et cum conjuge Fana, nepteque Eleanora, fub hoc lapide tenetur.

At bono fis animo viator-fortafle vivas. Superftes Jacobo viget natus Samuel, fub patrio lare artes exercens patrias: Si quæris fanitatem, hunc adi.

The ftreet from the church forms a wide avenue, at the foot of which is Mr. Collingrwood's feat; on the top of a large flope; the gardens to the weft; a fine view from a terraced lawn of the fertile vale below it, through which the Tweed takes its courfe in a winding current; of the market-town of Coldftream, on its oppofite banks, at which Margaret, the Queen Dowager of Scotland, fifter to K. Henry VIIl, was met by Lord Dacres, lord warden of the marches, and conducted to Harbottle-caftle, 26th Auguft, I $5^{15}(0)$; of the handfome modern feat of Mr. Pringle, with an octangular tempiato, on the banks of the river; of the baronial

(o) Hol. Chron. 
ANTIQUITIES OF NORTHUMBERLAND. 46r

- villa and cafle of Wark, of Mr. Compton's fcat by his villa of Carbam, and Sbidlaw; Sunney-laws, Preffen, Learmouth, Old Many-laws; the whole bounded by a femicircular range of hills, of the Hirfel-law, Hume-Cafle, both the property of the Earl of Hume; Stichbill, the feat of Sir Robert Pringle, Bart. Eilding-bills, within about a mile of the famous abbey of Melrofs, Hofe-law, Limpot-law, Stand-alone-bill; the hills of Yetbolm, Hure-lare, and Cheviot, i. e. the chicf of all the hills for height and magnitude, overtopping all the reft, giving a molt extenfive and beautiful land and feaprofpect on a clear day.

A quarter of a mile fouth-caft from Cornbill, is an incampment, the molt remarkable of any north of the Roman wall, for extent, variety of military works, covered ways, large and fpacious, with numerous curvatures, clefended by ranges of terraced hills, and a morafs at feveral angles and fides of the hills; many of them exploratory and fepulchral, of the ufual figure, conic; the hollows remaining, and filled with water, from which the earth was taken for raifing them. They were the funeral repofitories of great chieftains; the common men being buried without any fuch diftinetion, many of their remains being digged up on the ridge of a hill, called Bleak Lands, oppofite to the medical fpring.

Two miles weft from Combill, on the banks of the Tweed, and in fight, is

Wark-Cafle, which was the barony of the antient family of Ros (p), barons of Helmfley in Yorkfbire. Robert de Ros, in the reign of K. Henry II, married one of the daughters of Willian
(p) Ros.
Roos.

King 
King of Scotland; Euftace de Vefcy, Baron of Alnwick, marrying another daughter. His fon and fucceffor (q), Robert de Ros, and Fols $n$ de Baliol, were guardians of the new married pair, Alexander, King of Scotland, and Margaret, eldeft daughter of K. Henry III, 125 I. For their undue behaviour towards their royal charge in denying them focial intercourfe, they were punifhed, on the information of a phyfician fent from the Englifh court. Robert de Ros had his lands feifed for the King's ufe. Folon de Baliol came off by a compliment of money. K. Henry and his Queen took a journey to Edenburgh, to fee them in poffeffion of all their withes $(r)$.

William de Ros, fucceffor to Robert (s), on the death of Alexander, King of Scotland, was a competitor for his crown, with William de Vefcy, Baron of Ahwick, Florence Earl of Holland, Patric de Dunbar, Robert de Pinkeny, Nicholus de Sauls, Patric Goligbtly, Robert Bruce, and Foln Baliol, $20 \mathrm{~K}$. Edward I, $1292(t)$. He was one of the three barons of Northumberland in the famous lift of Britifs Iords who made that noble ftand againt the papal ufurpation, in claiming the kingdom of Scotland as a ficf to the fec of Rome, $29 \mathrm{~K}$.

(9) Robertus de Roos tenet baroniam de Warke in capite de domino rege per fervic, duor. feod. milit, et omnes anteceflores fui tenuerunt per cund. fervic. pont tempus domini regig primi Henrici, qui eos fcoffavit. Et defeodo illo nulla et alienatio, \&c. - Tefta de Novills

(r) Hol. Chron. vol, ii. p. 251, \& p. 283 ,

(s) Willielmus de Roastenet in capite de domino rege Wark, Leremouth, Myndrom, Carhan, Prefficn, Moneylawes, Downham, Paufton, Shotton, Kitham, Holthill, Neuton, et alteram Neuton, Langton, Lilburn, IJderton, Weperdon, Rofdon, Sbawdon, Tílington, Bolton, Abberwyke, Bittlefton liferior, grangium de Sturton, et medietatem de Glanton, per duo feoda et dimid, feodi de veteri fcoffamente,-

EScaet. de anno I Ed.I.

(1) Rym, Fasd. Angl, tons. il.

Sec Berwikh. 
Edward I, 130I; the other two barons being Robert Fitz-Roger, Baron of Warkworth and Clavering, and Fobn de Greyflock, Baron of Morpeth (u).

Fobn Lord Ros, Baron of Wark and Helmfley, was one of the twelve guardians of the kingdom in the minority of K. Edward III $(v)$.

Thomas Lord Ros was fummoned by writ to parliament, I K. Richard II, $1577(w)$.

William Lord Ros vas fummoned to the parliament at Wefminfter, 6th October, I K. Henry IV, $1399(x)$.

The year following, by an inquifition it was found, that the caftle, manour, and villa of Wark belonged to Sir Thomas Grey, of Heton $(y)$, who was fummoned by writ to the parliament at $W e f-$ minfter, 6th October, the preceeding year; and was one of the committee to receive the renuntiation of $\mathrm{K}$. Richard II, at the tower, being procurator-general or proxy for the Nortbern members. He was high theriff of Nortbumberland, 9th of K. Henry IV $(z)$; his arms, gules, a lyon rampant, within a border engrailed,

(u) Rym. Fœd. tom. ii. p. $873,874,875$.

(v) Parliament. Hift. of Engl. vol. i. p. 19r.

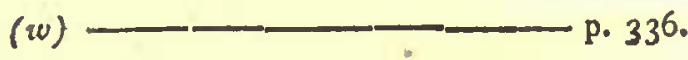

$(x) \longrightarrow$ vol. ii. p. 99 .

(y) Thomas Grey, miles, obiit feifitus de et in caftro, et manerio, et villa de Wark fupes Twedam. Efcaet. de anno 2 Hen. IV.

(z) Efcaet. de anno 9 Hen. IV. 


\section{ANTIQUITIES OF NORTHUMBERLAND.}

argent (a). They were poffeffed: with the caftles of Heton and Cbillingham, and other eftates, by Sir Ralpb Grey, high theriff of

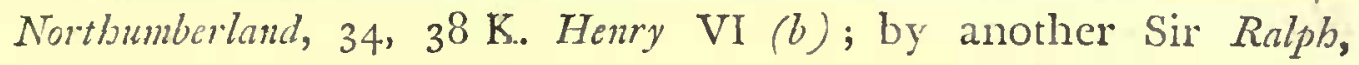
high theriff of Nortbumberland, 5 Q. Elizabetb (c); by his fon and heir, Sir Tbomas Grey, high theriff of Nortbumberland, I 6 th of the fame reign (d); by Sir William Grey, created a baronet, isth June, I7 K. Fames 1, I619. He was a reprefentative in parliament for Nortbumberland the year following. He was raifed to the peerage by the ftile and title of Lord Grey of Wark, I th February, 2 I K. Fames I. His lordhip married Anne one of the daughters and coheirs of Sir Gobn Wentworth, of Gosfield, in Effex. He was fummoned to parliament, I K. James I, 1623; alfo I \& I6 K. Charles I, I525, I640. He was a lieutenant general of the parliamentarny under Lord Fairfax, i 9 K. Charles I, I643. On their fright and confternation by the news of the defeat of their forces at Atberton-moor, near Bradford, in Yorkfhire, in the fame year, in July, he was called upon to go to Scotland, to invite the Scots to their affiftance. His lordhip, cither from his dillike to a feavoyage, there being no fafe paffage by land for the royal army, or for fear of putting himfelf beyond a pofibility of pardon

(a) Fuller's Worthies.

(b) Efcact. de annis $34,3^{8}$ Hon. VI.

See Heton.

(c) Efcaet. de anno 5 Eliz.

(d) Thomas Grey, de Chillingham, ftat in fua minoritate, et eft in manu regine Elizabethe; tamen ejus pater, Dominus Radulşbus Grey, obiit feifitus de et in caftro, manerio, et villa de Wark fuper Twedam, et Wooler, de ct in caftro, mänerio, et villa de Chillingham, Neuton, North Middleton, South Middleton, Akeld, Ycvering, Reveley, Hethpole, Dodington, Fenton, Learmouth, Black Heddon, Presfen, Mindrum, Elfdon, Elter-chapel, Antechefters, Truliope, Rake-fide, Kylham, Nefbet, Eworth, cum medietate villa de Howick, et Hawkell, cam terris in villa de Bambrough.

Efcaet. de anno ro Eliz. 


\section{ANTIQUITIES OF NORTHUMBERLAND. 465}

from the king, if he prevailed, by going on fuch an errand, refufed. He was fent to the Tower for his difobedience. His commiffion of lieutenant general was taken from him, after a final and pofitive declaration that he was not able to go on account of his health. He was releafed foon after, without a petition, but his commiffion not reftored. He acquired fo much favour as to be fpeaker of the upper houfe, and to be entrufed with the court of the Dutchy of Lancafter, jointly with Lentball, tine other fpeaker, $21 \mathrm{~K}$. Charles I, :645. In I647, he was made keeper of the Great Seal of England, jointly with Sir Thomas Widdrington, with a falary of $1000 \%$. per annum. His brother, Colonel Grey, was killed in the fame year at Munfer, in Ireland, in the fervice of the parliament (e). His lord hip died, 29th July, $26 \mathrm{~K}$. Charles II, I674. He was fucceeded in honour and eftate by his fon and heir, Ford Grey, who was created Vifcount Glendale, and Earl of Tankerville, $7 \mathrm{~K}$. William III, 1695. He married Mary, the fourth daughter of George Earl of Berkley, by whom he had one daughter, Mary, married to Charles Bennet, Lord Offulfon. He died, I Q. Amm, 170I; and with him the Earldom and Vifcounthip. The barony and eftate came to his only brother, Ralph Grey, governor of Barbudoes. He died 2oth June, $1706(f)$. Lady offulfon, his niece and heir, died in May, 17ro. She had three fons, and three daughters, by Charles Lord Offulfion (g). His lordhip was created Larl of Tankerville, r gth October, I K. George I, r7it. He was made chief juftice in Eyre of all his majefty's forefts, chaces, parks, and warrens fouth of Trent, and Knight of the molt noble Order of

(e) Parliament. Hift. of Engl.

(f) Le Neve's monumenta Anglicana, vol. i. p. 120.

$(g)$ p. 204 .

VoL. II.

0 o 0

the 
the Garter, 26th February, I720-2I. His fon, the late Corles. Earl of Tankerville, was lord lieutenant of the county of Northumberlant, and of the town and county of Newcafte upon Tyne, and Knight of the Order of the Thiftle. He died in March, I753; and was fucceeded by his fon, Charles Earl of Tankerville, the prefent poffeffor of Wark-caftle, \&c. his feat at Chillingham. His lordfhip married Elizabeth the daughter of Sir Fobn Afley, Bart. in October, 1742 .

The caftle is at the weft end of the village, on a high mount of difficult accefs, circular, feemingly raifed by art with earth and fone; part of the foundations ftill remaining, and a fragment of the building, looking at a cliftance like a column; fome courfes of the outer-wall entire on the north fide, of afhler-work; under it a walk, called, The Maiden-walk; i. e. the Military way, or walk under the Maiden or fortrefs; five yards broad, and fortyeight yards long. It is a beautiful terrace, edged with a fteep precipice, fhaded with trees; the Trueed gliding under it in deep and hollow murmurs.

On the weft fide are the outworks, now called the Kemb; i. e. the camp of the militia defigned to kemb or fight an enemy; Kemb being a word often ufed by the bordcrers when they threaten in a paffionate tone to beat an affailant_- They will kemb him-i. e. drub him heartily.

This intrenchment is half a mile long, meafured; the breaftworks and covered ways ftill fair and confpicuous, the ditches deep, and the rampier high, of earth and flone; two fmall mounts at nearly an equal difance, one about midway, and the other at the extremity, a linear trench through them at top ; another 
other mount of the fame form between the laft and the river. Near the firft mount is part of the foundations of a chapel, now called, Gilly's Nich, from its fituation by a port-way, and its detlication to St. Giles; many grave-ftones about it, fome ftanding, and others flat; one large flat one, of freeftone, over a Knight Templer, a crofs fculptured upon it between two fwords.

On the fouth fide of the rampier, near the caftle, is a piece of ground, called, The Battle-place. Oppofite to it is a terraced hill, called, Gallozes-hill, the place of execution of criminals; a circular mount near it to the weft, called, The Gallows-bill-know; the burial-place after execution; a human fkelcton found a few years ago in digging for limeftone, interred within a few fect of the furface.

The caftle was burnt by the $S_{\text {cots, } 7}$ K. Richard II, ${ }_{3} 8_{3}$.

It was befieged by the Scots under the command of the Duke of Albany, ${ }_{5}$ K. Henry VIII, 1523. Sir Williain Lifte was then governor. They croffed the Tweed in the night, to the number of two or three thoufand, on Saturday the laft of October, with heavy cannon, battering it to the fecond of November, when entering the breaches, and being mafters of all the wards, but the inner one, called, The Dungeon, Sir William and his garifon flew three hundred of them, befides fuch as died of their wounds and were drowned; the Duke repaffing the Tweed; the Earl of Surrey being at hand to the relicf of the garifon. It was reputed a ftrong fortrefs in that reign (b). A few year's ago, a cannon was found among the rubbifh.

(b) Le'. Itin. vol. vii. p. 61, 62 . 
Near a mile weft from Wark on the banks of the Trueed, is

Carbam-Lall, the feat of Antbony Compton, Iifo; a modern building, to which he hath made large and handfome additions, and great improvements about it by planting.

A little higher up the river, and in fight, is his villa of

Carbam; at the weft end of which, almott on the brink, by a flexure of the Treed, and at the eait end of the church, was an abbey of Black Canons, fubordinate to the priory of Kirkbam, in Yorkfoire. The villa, Iordhip, advowfon and impropriation of the living, belonged to that priory; as did the villa and manour of Titlington, two parts of the tithes within the lordfhips of Mindrum and Bolton, a manfion-houfe in Wark, the advowfons and impropriations of Ilderton and Kirk Neruton, \&c. (i) The abbot

(i) Thurfino Die gratia Ebor. Archiepifc. et Ga'frido eadem gratia Dunelm. epifcopo, et fuccefforibus eorun, Walterus Ejpec, et Adelina uxor ejus, falutem. Sciatis nos conceffiffe et dediffe Deo et ecclefix S. Trikitatis de Kirkbam, et canonicis ibidem Deofervientibus, confenfu Henrici regis Anglorum, et confenfu noftro et auxilio, \&cc. in liberam et perpetuam elemofinam; videlicet, in Northumberland, totam villam de Carram fuper Twedam fluvium, et ecclefiam ejufdem villæ, cum omnibus cidem villæe et eidem ecclefiæ pertinentibus in terris et aquis, in pratis et pafcuis, in pafturis et molendinis, in divifis et confuetudinibus : et unam manfuram in $W$ ark; et totam villam in Titlington, cum omnibus eidem pertinentibus in Bofco at Plano, in pratis et in pafturis, et molendinis, in divifis, et confuetudinibus; et ecclefiam de Ilderton cum omnibus eidem pertinentibus; et ecclefiam de Nuton in Glendale, cum omnibus eid $\mathrm{m}$ ecclefix pertinentibus: $\mathrm{Et}$ omnes meas dominicas decimas, et nominatim decimam denariorum de cenfu terrarum mearum in Northumberland: Et duas partes decimæe de Dominio de Mindrum et de Bolton, et de molendino de Bollon, et fi dedero alicui homini aliquam de terris fupra nominatis, femper decima remanebit ecclefix Sanctx Trinitatis de Kirkham.

Carta fundat. prioratûs de Kirkham, in agro Eboracer/s, Ex regiftro de Belvoir, citat. Monaft. Angl. vol. ii. p. sos. 
of Carban was allowed $13 l$. per annum, as mentioned in the Lincoln-taxation, I9 K. Edward I, I29I. The abbey was burnt by the Scots, $24^{\text {th }}$ of the fame reign, I296. They alfolaid the villa of Preftfen in athes. Other villages in the neighbourhood met with the fame fate, which caufed K. Edwart, who then lodged at Coldftream, to come to Wark-caftle ( $k$ ). He afterwards took fevere vengeance on their leader, Sir 1 illiam Wallafe. In 44 K. Edward III, ${ }_{37}$ o, the Scots being on the point of croffing the Trved at this village loaden with Engliff plunder, were attacked by Sir Fohn Lilbiln, and his brother. The engagement was long and obftinate. At length, Sir Yobn and his brother were defeated, and borls talien prifoners. Here was a fmall tower in it, which is mentioned by Leluml, who calls it " a little tower of defence againft the Scots (l)." The village is fmall, but wcll built; many plantations of young foreft-trees about it, thriving and vigorous; the church fmall, lately repaired.

The minifter's houfe is at the north-eaft end of the village; neat and convenient ; of ftone, and partly hewn work; built by the prefent incumbent, Mr. Richard Wallis, A. M. late fellow of

Sciant præfentes et futuri, quod cgo Walterus E/pec dedi et concefi canonicis de Kirkham, totum manerium de Titlington, et ecclefiam de Ilderton, cum omnibus eidem ecclefix pertinentibus, et totam teram Ulfkili, clerici: Et ccclefiam de Carram fuper Twedam fuvium, cum omnibus eidem ecclefixe pertinentibus, ct totam villam de Carram, cum oninibus eidem villæ pertinentibus, et terris ct aquis, in pratis et pafcuis, pifcariis, molendinis, et in divifis, et in confuetudinibus ejufdem villa: Et totam terram Ulfkilli, clerici, quam de me tenebat in eadem villa, ficut alii liberi homines ejufdem villa per eafem divifas. Et omnes meas dominicas decimas, et nominatim decimam denariorum de cenfu terrarum mearum de Nortbumberland. Et fi dedero alicui aliquam ex terris illis, femper decima remanebit ecclefix S. Trinitatis de Kirkbam.

Carta fecunda fundat. priorat. de Kirkham. Ex cartulario de Rivall, in Biblioth. Cotton. fol. 136. b. citat. Monaft. Angl. vol, ii, p. 106.

(k) Hol. Chron. vol. ii. p. 297 .

(l) Lal. Itin. vol. vii. p. 62. 
Queein's College; in Oxford. At the eaft end of it is a fmall, but fertile glebe.

On the fouth fide of the village, is a fmall hamlet, belonging to Mr. Compton, on a hill, called

Shidlaw, a contraction of Shield-law; a guard-hill, and exploratory; from which is an extenfive and beautiful profpect into Siotland.

A mile above Carbam, a ftrcamlet, called, Ryding-burn, empties itfelf into the Treed, which is the boundary between the two kingloms of England and Scotland to the weft.

We now turn fouthward on the Etall-road from Cornbill, about two miles from which, on the right hand, in Brankfon-wett-field, is a large upright pillar, of whinftone, fix feet, feven inches high, and thirteen feet in diameter towards the bafe; a memorial of the great victory obtained over K. Fames IV, of Scotland, by the Earl of Surrey, on Friday, th of September, 5 K. Henry VIIJ, I $5: 3$.

This battle is called, The battle of Brankfon, from the chicf fcene of action being near that village; alfo the battle of Floddon, from the Scotch intrenchments being on Floddon-hill, out of which they were drawn forcibly, as it were, to an engagement, by the Earl of Surrey's cutting off their retreat homewards. Among the flain was their fovereign, with his natural fon, Alexander, Archbifhop of St. Andrews, who had the learned Erafmus for his tutor; alfo two other Scotch prelates, four abbots, twelve Earls, feventeen lords, a great number of knights and gentlemen, and about eight 
eight thoufand, or as fome fay, twelve thoufand common men. According to Sir Fobn Froifart, K. Fames fell near Brankfon, where he was found the next day by Lord Dacres. On the higheft part of Floddon-hill, near it, is a natural rock, called the King's chair, from which he had a good view of his own, and of the Englifi army, and of the country round him.

In the time of the battle the thieves of Tynedule and Tiviotale were not idle. They rifled the Englifh tents, and took away many horfes, and other things.

The day after the battle, the ftandards, and twenty-two pieces of ordnance, taken from the Scots, were carried by the victors to Etall, among which were feven, for their handfomenefs, called, The Seven Sifters. The general, Sir Thomas Howard, Earl of Surrey, was created Duke of Norfolk the year following for his fer$\operatorname{vice}(m)$.

We next pafs through the village of Crookbam, where the Diffenters have a handfome meeting-houfe, and crofling the river Till at the Willow-Ford, coine to

Etall, a pleafant villa, one of the manours of the Barony of Wooler, of which it was held by the antient family of Manner's, anceftors of his Grace the Duke of Rutland; by Sir Robert de Manners, I K. Edward I ( $n$ ), who was captain of Norbam-caftle, I K. Edward II, and the fcourge of the Scots on their invafion of the borders under the command of the Earls of March and Sou-

(m) Hol. Chron. vol. ii. 825 to p. 829 .

(n) Robertus Manners tenet Etall per dimidium feodi milit. vet. feoffamenti Baron de Wooler. Ercaet. de anno I Ed. I. 


\section{ANTIQUITIES OF NORTHUMBERLAND.}

therland, I4 K. Edward III (0). He was in that year a reprefentative in parliament for Nortbumberland, with Sir William Felton ( $p$ ). The year following he built the caftle of Etall. He married the daughter and heir of Sir Henry Strother of Newton, in Glendale; by whom he had Sir Robert de Manners, who was upon an inqueft at Morpeth, I oth March, 22 K. Richard II (q), and upon another at Bambrough, with Sir Fohn de Fenwick, and Roger de Horfley, before Sir Thomas Grey, of Wark, 31 ft March, i 3 K. Henry IV ( $r$ ). His fucceffor, Sir Robert de Manners, was upon an inqueft at the caftle of Nerucafle, with Sir William Lumley, and Bertram Harbottle, 29th Oetober, 3.3 Henry VI (s); and upon another at the fame caftle, with Sir Folm Swinburn, Sir William Bowes, Robert de Nevill, and Robert de Folbury, in June, 4 K. Edward IV ; in which year he was high theriff of Nortbumberland ( $t$ ). He was a zealous friend to the houfe of rork. He marched at the head of 400 men to oppofe the landing of Queen Margaret and her friends at Bambrough, whom he compelled to alter their courfe for Berwick upon Tweed, before the fatal battle near Hexham. He married Eleanor the eldeft daughter and coheir of Thomas Lord Ros, by whom he had two fons, and two daughters, viz. George, Edward, Elizabeth, and Cecilia. George married Ann the daughter of Sir Thomas Sellinger, by Amu Dutchefs of Exeter, fifter of K. Edward IV; by whom he had five fons, and five daughters, viz. Thonas, Oliver, Antbony, Richard, Fobn, Elizabeth, Catharine, Eleanor, Cacilia, and Ann (in).

(o) Barne's Hift, of K. Ed. III.

(p) See Feltor.

(9) Efcaet. de anno 22 Ric. II. n. 39.

(r) Efcaet. de anno ${ }_{3}$ Hen. IV. n. 20.

(s) - 33 Hen. VI. n. 17.

(1) - 4 - $E d$. IV.

(í) Lel. Itin. vol. i. p. 102. 
Sir Thomas Manners, Lord Ros, of Etall, was created Earl of Rutland, 17 K. Henry VIII, 1526 ( 2 ).

Sir Roger Manners, Kt. of this antient family, an ormament of the court of Q. Elizabeth, gave four fcholarhips to Corpus Chrifi college, in Cambridge, famous for its library over the chapel, the donation of one of its learned fons, Sir Nicluolis Bacon, Kt. keeper of the great feal and privy counfellor to Q. Litizabeth; an excellent repofitory of antiquities, the library of the monatery of StokeClare, in Suffolk, being preferved and placed in it by Archbifhop Parker, its venerable warden, and an eminent antiquary.

Etall, was found by an inquifition to be in the poffeflion of the crown, 10 Q.Elizabeth(w). It came afterwards into the pofieffion of Sir Robert Carr, Kt. fecond fon of Sir William Carr, of Greenbead, Bart. on whofe death it was under fequeftration by the parliament for eleven ycars and a half, but was reftored to his fon, William Carr, and Mrs. Margaret Carr, by compofition, I sth February, $1653(x)$.

(v) Hol. Chron. vol. ii. p. 892 .

(w) Domina Regina Elizabctiba feifita eft de et in caftro, et manerio, de Etall, cum villa; de et in medietate de Riplington, Tritlington, cum certis terris in Whaton, Hawkuvil, St?:= fordham, Matfin-eaf, Hugh, Fenham, Howtell, ct Homeldon, ut de corona.

Efcaet. de anno Io E:

(x) Upon the application of Mrs. Margaret Carr, and William Carr, and upon the peru fal of feveral warrants and orders of the committees of fequeftration in the time of the late ufurped powers, as alfo on the report of Sir Peter Balle, Kt. her late majefty's attorney general, to whom the bufinefs was referred, it appears, That the faid manour of Etall was under fequeftration for xi years and a half, and was not difcharged thereof until the $15^{\text {th }}$ of February, 1653 , and that on the payment of the whole compofition-money, being 539 l. 8 s. 7 d. and considering the whole matter both as to the legality and equity thereof, it is thought fit,

Vor. II.

P p p

and 
It is now the villa and feat of William Carr, Efq; father-in-law of the right honourable the Earl of Errol; by a countefs of whofe family the county of Bucban, in Scotland, is defcribed, and all its remarkables accounted for $(y)$. His feat is at the eaft end of the village, lately rebuilt, after a genteel defign; the fouth front appearing to great advantage through an avenue of trees on the approach to it from the caftle of Ford; a flower-garden, lawns, gravel-walks, clgings of flowers and thrubs before it, encompaffed by a dwarf-hedge of holly; the ftreet of the villa forming an avenue from it weftward to the ruins of the old caftle on the banks of the Till, part of two large towers ftill remaining, the coat-armorial of the builder, Sir Robert de Manners, above the entrance of one of them, obfured by the weather and age.

The vale by the Till appcars in great beauty to the fouth and fouth-weft, many hills and mountains in fight; the hills of Brankfon and Floddon; the two mountains confecrated to the Saxon god Torr, and carrying his name; the hill called Yevering-Bell, from its bell-like thape; the two Cheviots, Akeld, and Himbletonhills.

and accordingly ordercd, That the faid Mrs. Carr, and William Carr, together with the faid manour of Eitall, be, and is henceforth acquitted and difcharged, and his majefty's auditor is hereby defired and required to difcharge tho faid manour of the faid compolition, and, to grant a Quictus for the fame unto the fee-fermer thereof: Is difinrged, and the above named Mrs. Corr and Willism Carr, together with the faid manour of Etall, and the tenants of the fame, from the payment of the faid arrear of $539 \% .8$ s. 7 d. are accordingly frecd and abfolutely acquitted, xxi April, 1673.

Francis Allworth, Auditor.

[Ardcaconry of Richmond.]

MS. penes Guliılmum Carr, Arm. de Etall.

1736. fol. p. 20.

Within 
Within the manour of Etall are coals, freeftone, flate, marle; alfo limeftone, and a fmall machine, moved only by an inch and a half of water, to preferve it from drowning; great improvements, by enclofing and planting, by Mr. Carr; the plantations in a variety of fituations, nine on eminences; oaks remarkably vigorous and healthy on a fandy flope, eaft of the village.

Four miles eaft from Etall is a remarkable hill, called The Watch-Law, exploratory, as the name imports, to obferve the motions of an enemy, and to alarm the country by fire from a beacon; of a regular and pleafant flope on all fides; a fea and land profpect from it very extenfive, to all points, particularly of Scotland; part of five Scotch counties feen from it on a clear day, and hips at fea at a great diftance.

A mile eaft from the Watch-lare, is

Barmore, which was the villa of William Mufchampe, i K. Edward I ( $z$ ); of George Mufchampe, Io Q. Elizabeth, high Theriff of Nortbumberland, 38, 42 of the fame reign (a); and of William Mufchampe, high theriff of Nortbumberland, 20 K. Fames I (b). It was lately in the poffeffion of Colonel Bladon, the ingenious tranflator of Cafar's Commentaries, and uncle to Sir Edward Hark, firtt lord of the admiralty.

At this village the lords marchers of the northern counties were affembled, 5 K. Henry V, 1417, with roo,000 men againft

(z) Willielmus Mufchampe tenet Barmore per quartam partem unius feodi veteris feoffamenti baronia de $\mathrm{W}$ ooler. Efcaet. de anno I $E d$. I.

(a) Efcaet. de annis, ro, 38, 42, Liliz.

(b) - anno $20 \mathrm{Fac}$. I. 


\section{ANTIQUITIES OF NORTHUMBERLAND.}

the Scots, who retreated upon hearing of fuch a mighty army coming againt them (c). The Lord Horeard and his fon lodged at Barmore-Wood the night after the battle of Brankfon (d).

A mile fouth from Etall, is

Forl, which was the villa and manour of Odonel de Ford, I K. Edward I (c), who married Cacilia the youngeft daughter and coheir of Robert de Mufchampe, baron of Wooler. His daughter and heir marriad Sir William Heron, whofe anceftor, William de Heron, wiss infeoffed in the barony of Heron, by K. Henry I, which was poffeffed by Fordan de Heron in the reign of K. Henry III ( $f$ ), who was fucceeded by this Sir William (g). His fon, Sir William Heron, built the caftle of Ford, $12 \mathrm{~K}$. Henry III. He acquired a grant from the crown of a weekly market and an annual fair at Ford; alfo liberty of free warren in this and his other lordhips. He was captain of the caftles of Bambrough, Pickering, and Scarbrough; alfo warden of the forefts north of Trent, and high theriff of Nortbumberland for cleven years together, in the fame reign(b).

(c) Hol. Chron. vol. ii. p. 560 .

(d) -

(e) Odonill de Ford tenet Ford, Crookham, Skimmerfon, et tertiam partem de Hethpole, per: unum feodum veteris fecffamenti baronia de Wooler.

Efcaet, de anno I Ed. I.

(f) Fordanus de Heron tenet in capite de domino rege baroniam fuam per fervicium unius fcodi milit. et omnes anteceffores fui tenuerunt per eund. fervicium poft tempus regis Henric: primi qui cos feoffavit. Et de illo tenemento sulla alienatio eft, \&ic. Tefta de Nerill.

(g) Willielmus Heron tenet in capite de domino rege Hadfon, Chirton, Benton parvam, Colweil, Swynelurne parvam, et Flatworth, per unum feodum milit. de veteri feoffamento.

Efcaet. de anno $1 E d$. I.

(b) Madvx's Hift, of the Excherg. p. 647 . 
His fucceffor, Sir William Heron, had fummons to parliament among the barons, $44 \mathrm{~K}$. Edward III. He was ambaflador to France, and fteward of the king's houlhold, in the reign of $K$. Henry IV. He died, 2oth October, 5th of the fame reign. On the 8th of April, the year following, he was found by an inquifition to be in poffeffion of the manour of $E / f e t$, and other lands, at the time of his death, and that Sir Fobn Heron, fon of Sir Fobn Heron, his brother, was his fucceffor and heir (i). This Sir fobn

Twas

(i) Dicunt juratores fuper facrum (viz. Thomas Hefolricge, Gabannes Camblow, Willielmus de Cramlington, Ricardus de Crawcefer, et alii) quad IVillielinus Heron, miles, fuit feifitus in dominico fuo die et tempore quo obiit de manerio de Éghet, cum pertinentibus, et de centum et 60 acr. terræ in Clifton et Callwell, et centum et I4 acr. terræe in Dudbow. Eft de feodo talliato fibi et hæredibus mafculis de corpore fuo exeuntibus. Et dicunt juratores fuper facrum fuum, quod predictum manerium una perinentibus, cum prædictis terric, remaneret Gerardo Heron, militi, et hæredibus mafculis corpore fuo exeuntibus, ex dona et feofiumento Willielmi Merrington et Rngeri Shilbottle. Item, quod fi præaictus Gerardus obiere: fine hærede mafculo de corpore fuo exeunt. quod ex tunc prædictum maneriuin, cum pertinertibus, et terris prædictis, remaneret Willielno Feron, arm. et hæredibus mafculis de corpore fuo exeunt. Item, quod fi contigerit prædictum Willielmum Heron obire fino haredibus mafculis de corpore fuo exeunt. quod ex tunc prædictum manerium, cum pertinelitibus, et cum teris antedictis, remaneret Nicholno Heron, arm. et hæredibus mafculis de corpore fuo exeunt. Liem, quod fi contingerit,prædictum Nicholaum Heron, arm. obieret fine hæede mafculo de corpare fuo exeunt. quod ex tunc prædictum manerium, cum pe tinentibus, et cum terris antedictis, remaneret certis hæredibus prædiati Willielmi Heron, militis, in perpetuum. Et dicunt etiam quod prædietus Willielmus Heron, miles, Gerardus Herm, et Williclmus Heron, arm. mortui funt fine hæredibus mafculis de corporibus eorum exeuntibus. Et dicunt quod prædictus Nicbolaus Heron adhuc eft fuperfes. Et dicunt etiam quod prædictum manerium et terre, cum fuis pertinentibus, tenentur de Fobanne le Scrope, et Elizabetha uxore ejus, ut de jure ipfius Elizabeths, per fervicium militare, ut de baronia de Mitford; quad manerium et terrx, cum fuis pertinentibus, valent per annum in omnibus exitibus ultra reprifas viginti marcas, Sterling. Et dicunt etiam quod pradictus. IVillieinus Heron, miles, obiit 20 die menfis Octobris ult. preterit. Et dicunt etiam quod Fohannes Heron, miles, filius Go- $_{0}$ 
was high theriff of Northumberland, 19, 20, 22, 30, 35, K. Henry VI $(k)$, to whom he was a zealous and faithful friend in his ftruggles with the houfe of rork, for which he was attainted, I K. Edward IV. His attainder was afterwards taken off. In the 17 th of K. Henry VIII, Sir William Heron of Ford, was high theriff of Northumberland ( 1 ). He died, 28th June, $27 \mathrm{~K}$. Henry VIII. It was then found by an inquifition, that he was in the poffeffion of the caftles and manours of Ford, E/het, and Simonburn; and that Elizabeth Heron, a minor, daughter of his fon, William Heron, killed by Foln Manners, of Etall, for which he was fined by the crown, was his fole heir $(n)$. She married Thomas Carr, Efq; of Etal ( $n$ ). brother of William Carr, Efq; a reprefentative in parliament for Northumberland, 3 I Q. Elizabeth (0). His daughter and heir marricd Sir Francis Blake, Knt. whofe daughter, Mary, married Edward Delaval, Efq; ( $p$ ), anceftor of Sir Fobn Huffey Delaval, Bart. the prefent poffeffor of Ford-Caftle.

From the baronial family of the Herons of Ford, were defcended the Herons of Cbipchace, Bokenfield, Meldon, and Riplington.

bannis Heron, militis, defuncti, fratris prædicti Willielmi Heron, defuncti, eft hares ejus propinquior, et $x$ tat, anno 30 , et amplius.

Inquifit. capta apud caftrum dom. regis de Novo Caftro fuper Tynam, coram Ricardo Cliderhow, efcaetore dom. regis in comit. Northumbr. 8 die Aprilis; 6 Hen. IV.

Ex bundello efcaetr. Turri Londin. No. 21.

(k) Efcaet. de annis prædictis.

(l) - de anno i 7 Hen. VIII.

(m) - 27 Hen. VIII.

(n) Bifhop Nicholfon's Border-Laws, Append. p. 343.
(o) Browne Willis.
(p) See Nerwburn. 
The village ftands on an eminence, on the eaft fide of the Till; confining of one irregular flrect, the caftle on the north fide, lately repaired after a handfome manner; a variety of good views from the battlements, particularly of the winding courfe of the river below it, the bridge over it, and the improvements made on its banks, and the neighbouring plain, by inclofures, tillage, and planting on little eminences; alfo of the feveral ranges of the neighbouring hills and mountains, with the anticnt karns and intrenchments on their tops.

At Broom-ridge, a mile fouth from the village, and in the parifh, are the lines and intrenchments of the brave Saxon king Athelfan, who obtained a compleat victory over the confederate forces of Conftantine, King of Scotland, Eugenius, King of Cumberland, and Anlaf, the Dane, 928. In this battle K. Athelftan lolt his two near linfmen, Elwin and Ethelftan, valiant young noblemen. Conflantine efcaped into Scotland, and Anlaf to Dublin.

At a place, called Haltwell-Szeire, near: Fenton, half a mile fouth from Broom-ridge, Sir Henry Percy, brother to Sir Thomas Percy, the fixth Tarl of Northumberland, was defeated by the Scots under the command of the Earl of Botbwell, 5 Q. Mary, 1558; the Scotch forces confifting of 1000 horfe. Two Englifs captains of light horfe, Carr and Errington, were taken prifoners.

We crofs the Till at Ford by a ftone-bridge of one large and ftrong arch, and come to

Milfield, a fmall village, where the Saxon kings of Bernicia, after the death of K. Edwin, fometimes refided; on the fouth fide of which is a fpacious and beautiful plain, formerly overgrown with broom, famous for the defeat of a large party of the Scots before 


\section{ANTIQUITIES OF NORTHUMBEKLAND.}

before the battle of Brankfon, by Sir William Bulmer, of Bramfpethcaftle, who commanded the forces of the bihoprick of Durbam. The Scots had concealed themfelves among the broom. Five or fix hundred of them were killed, and four hundred taken prifoners. They afterwards called the road through the plain, The ill $\operatorname{Road}(q)$.

About two miles fouth-weit from Milfield, on the north fide of the rivulet of Glen, is

Copeland-Cafle, or North-Copeland, which was the feat of the antient family of the Wallaces; of Edward Wallace, or Wallafe, in the reign of K. Edward IL * of William Wallace, in the beginning of the reign of Q. Elizabeth, fon-in-law of John Swinbnrn, of EdlingbamCafle, Efy; (r); of George Wallace, 17 K. Fames I, 1619, who in that year rebuilt the caftle; the date of the year, and the initial letters of his own and his wife's name on one of the chimneypieces in it; of the late Ralph Wallace, Efq; ftore-keeper of the garrifon of Berwick upon Tweed, who fold it to the late Sir Chaloner Ogle, Knt. an admiral in the Britifonavy; and is now in the poffeffion of the Rev. Dr. Nerwton Ogle, of Kirkley (s).

On the fouth-weft fide of the Glen, at a fmall diftance, and in fight from Copeland-Cafle, is

(q) Hol. Chron. vol, ii. p. 825 .

- MS. penes comitem de Tankerville apud caftrum de Chillingham.

(r) Copeland.

Coupeland.

Cowpland. See Knarefdale-Hall.

(s) See Kirkley. 
Fevering, a mean village, which that learned antiquary Dr. Gale, imagined was the Roman ftation Glanoventa ( $t$ ), but no Roman antiquities have ever yet been difcovered at it, of any kind, to favour fuch an opinion; which is grounded only on its fituation by the Glen, which gives its name to the vale of Glendale. It was a royal manour of the Saxon kings, called, by Bede, Ad Gebrin, at which they fometimes refided, till they removed to Melmin or Milfield (u). It was the refidence of King Edrvin and his Queen Ethelburga for thirty days after their converfion to the Chritian faith by the addrefs and preaching of Pautinus, who attended them hither, and converted great numbers of their people, who were baptized in the neighbouring river. Edwin was flain by two tributary princes, Penda and Cedwall. His queen fled for refuge by fea to her brother, Eadbald, King of Kent, who took her under his protection, and made Panlius bifhop of Rochefs?.

At this village the Scots, after a long engagement, were defeated on St. Mary Mardalen's day, $3 \mathrm{~K}$. Henry V, 14I5, by Sir Robert Husufranvil, captain of Roxbrough-Cafle; the Earl of Weftmorland then lord warden of the marches. Above fixty Scotchmen were flain, and one hundred and fixty taken prifoners. A thoufand of them were purfued upwards of twelve miles $(v)$. On the fouth fide of the village, midway between the hill and the road from twisk Neruton to Woaler, is an unwrought column of whinfone exected in memory of it, of a vaft magiaitude; in height fourteen feet, and four inches; in diameter at the bafe as many; and towards the middlc, eleven feet, and feven inches.

(t) Gale's Antoninus, p. I15.

(u) Bult, 1. ii. c. I4.

Cainden, p. $86 \mathrm{I}-2$.

(v) Hol. Chron, vol. ii. p. 548 .

Vor. II.

Qq

A.bout 
About two hundred yards weft from this column, is a high hill, called Yevering-Bell, from its bell-like thape; the top of an oblong figure; a karn on the eaft fide, with a circular trench ; many circular foundations of buildings upon the fides or lopes of both ; the whole cncompaffed with a wall of whinftone of a great breadth and length, fallen down by age and tempefts; the work feemingly of the pagan Danes, for their priefthood and nobles to affemble on, for legilation, for levotion, and for fepulture.

Half a mile fouth-wweft from Yerjering-Bell, is another karn, compofed of a large conic heap of fmall whinfones. It is called Tom Tallor's Grave. Hard by, to the eaft, is a clufter of broken rocks, called Tom Tallon's Crag, from its fituation near the karn.

On the top of Neruton-Torr, Eaft Torr, or Green Torr, juft by, is another kam; alfo one on the top of Wef Torr ; hills facred to the pagan god Thor, or Gupiter. There is alfo a karn on the weftern point of Cheviot; alfo another upon the hill, called Wbitelawe, a mile to the fouth-eaft from Yevering-Bell, from which it is in fight; as are all the reft.

A mile went from revering, is

Kirk-Newton, a fmall village, one of the manours of the barony of Wark, of which it was held by the antient family of the Strothers; by Sir Henry Strother in the reigns of K. K. Edward II, III; by William Strother, in the reign of K. Edward VI; by Mark Strother; Efq; high Theriff of Nortbumberland, I K. George I. It now belongs to Fobn Strotber Kerr, of Fowbary, Efq.

Two miles weft from Kirk-Neruton, is 
Pafton, the feat and manour of Gabriel Selby, Efq; of the antient family of the Selbys of Truizell. It ftands on the fouth fide of the rivulet of Boremont, on a rifing ground, well heltered with tall foreft trees.

On a hill to the fouth-weft of Pafon, called The Hare-law, i. c. the hill or ftation of the army, is a circular intrenchment, with a double rampier and fors. Under the hill, on the welt fide, is a hamlet which takes its name from it. It gives a fine view of a narrow vale weftward, through which the Bow-mont takes its courfe, fo called from its bending or winding courfe under the mountains, joined by the ftreamlet of Shotton, within about ten yards of the boundary between the two kingdoms of England and Scotland.

Two miles fouth from Yevering, by the road to Wooler, is

Humbledon(w), a fmall village, on an eminence, under which a great victory was obtaincd by $k$ ary Lord Percy, a d feorge Farl of March, over the Scotch under the command of Arhibald Earl of Douglas, on Holyrod-day in the harvet, $3 \mathrm{~K}$. Hen.y I. 2. Farl Douglas's forces confifed of 10,000 men. He poffefled t. "Hs, but Lord Percy, firnamed Ifotpur, cutting off his retreat w. land with the plunder he had acquired in Nortbumberland, he wus forced to come to an engagement on the plain. With him were molt of the barons, knights, and gentlemen of Fife and Lotbian, who efcaped by flight, 2ad of June, the year before, from the

(w) Humbledon. Efcaetr. Northumbr.

Homeldor. Rym. Foed. 
battle of Nifbet, in the Merfe, in which fell mont of the Lothianyouth. A great part of them were either flain or taken ptifoners. Among the latter were the Earls of Fife, Murrey, Angus, Atboll, and Monteith. Earl Douglas received five wounds, and loft an eye. Five hundred Scotcbmen in the purfuit were drowned in the Trweed. The field of battle is called Red-Riggs, from the bldod fpilt on it $(x)$. By the fide of the road, under Humbledon-Bauks, is an upright pillar of whinftone erected in memory of it; in height, fix feet, fix inches, and a half; in diameter, twelve fect.

By Humbledon-burn, on the flope of a hill, is an intrenchment, called, Green Cafle.

On a hill, called Humbledon-Hugh, is a circular intrenchment, and a large karn; both Danifh.

A poor woman of this village, wife of Thomas Rutlidge, a daylabourer, was delivered of four children, three girls, and one boy, on Saturday, 3 If March, 1764 ; all baptized. She had two children at a birth the year before.

Two miles fouth from Humbledon, is

Woller (y), a fmall market-town, which was the barony of the Mufchampes; of Robert de Mufchampe in the reign of K. Henry III

(x) Hol. Chron, vol. i. p. 254, 255 vol. ii. p. 520 .

(y) Wooler. Bp. Gibfon, in Camden. Woller. Bp. Kennet. 


\section{ANTIQUITIES OF NORTHUMBERLAND.}

(z); and of his fon, Robert de Mufchantipe, I K. Edward I (a), whofe three daughters and colreirs mitried the Earl of Strathern, in Scotland, Odonel de Ford, and Walter de Huntercombe. It was afterwatds the matrour of the Greys, of Wark; and now belongs to the Eatl of Tankerville. It ftands on a rifing ground to the caft of Cheviot, above a fmall trout-ftream. It confifts of feveral ftreets and lanes, viz.

$\begin{array}{ll}\text { Teucer-Hill, } & \text { Ramfey's South Lanc, } \\ \text { Windy-Row, } & \text { Scotch-Gate, } \\ \text { Temple's-Holc, } & \text { Cherviot-Bank. }\end{array}$

The market-place is in the center; the market on Thurfdays. It hath two annual fairs, 26 th April, and bth of October. The church was lately rebuilt by a brief. The ninifter of it at the reformation was Mr. Fohn Lomax, M. A. of Emanuel College, in Cambridge; who not complying with the act of Uniformity was filenced, and retired to North Shields, where he practifed phyfic and furgery, and kept an apothecary's thop, there being none there at that time $(b)$. The mother-church is faid to have been at Fenton, a village on the eaft fide of the river Till, now in ruins; and in this parifh, though enclofed by the parifh of Chatton, on

(z) Robertus de Mufchampe tenet in capite de domino rege Baroniam de Wooler per quatuor feod. milit. et omnes anteceffores fui tenuerunt per eund. fervicium poit tempus domini regis Henrici primi, qui eos feoffavit; et de feodo illo nulla eft alieriatio, \&c. Teita de Nevill.

(a) Robertus de Mufchampe tenet in capite de domino rege Woller, Heathpoole, Lowicke, Felford, Etall, Ford, cum Kymmerfon, membro fuo, Crookham, Hedderlaw, Brankfton, Iieddon, Akeld, Cowpland, Yevering, Humbledon, Barmore, Ditching, Middleton, Fenton, Yêfingfon, Tricklington, Boldden, Howburn, Ulchefter, et medietatern de Elwick. per quatuor feoda milit. de veteri feoffamento.

Efcaet. de anno I Ed. I.

(b) Bithop Kennet's Hift. Regift. p. qc6. 
all fides. On a round hill, are the ruins of an old tower. Here was an hof pital dedicated to St. Mary Magdalen (c)

Mr. Handyfide, who had a Premium of $10 l$. 10 s. from the fociety for the encouragement of arts, for the fecond beft painting in Enamel, exhibited in March, 1764 , was a native of this town.

At Cattle-Well, near Wooler, is an intrenchment, called, The Maiden-cafle.

At Trodden-Gares, near it, is another intrenchment; alfo a Karn, called, Trodden-Karn.

Three miles eaft from $W o o l e r$, is

Horton-Cafle, which was the feat of a younger branch of the Greys of Heton; of Thomas Grey, I 2 K. Henry VI (d); of Sir Ralph Grey, high theriff of Nortbunberland, I 2 K. Henry VII (e); of Sir Thomas Grey, a reprefentative in parliament for Nortbumberland, I Q. Mary, 1553; and high theriff, 6 K. Edward VI $(f)$; of Sir Ralph Grey, Kt. high Theriff of Nortbumberland, $9 \mathrm{~K}$. Fames I (g); of $\mathrm{Ne}_{\mathrm{c}}$

(c) Efcaet. de annis, 22 Ric. II.-14 Her. IV.

(d) Fuller's Worthies, p. 3 ro.

(e) Efcaet. de anno I2 Hen. VII.

(f) Thomas Grey, de Hortsn, miles, fuit feifitus de et in manerio et caftro de Horton, ac etiam de et in villa de Horton, et Dicbon, Howton-bouffe, cum medietate villæa de Nefbet, cum certis terris in Morwick, Togfdon, Eaft Chevington, Wef Cbevington, et Yefington, cum medietate.forefle de Cheviot, et Elwick. Écaet. de anno ro Eliz.

Bp. Nicbolfon's Border-Laws, p. 213 .

(g) Efcaet. de anno o fac. I. 
vill Grey, Efq; I. K. Georse I. It is now in the polfefion of Sir Harry Crey, of Howick, Barr.

A mile fouth from Horton-cafle, on the weftern banks of the Till, is

Fowbury, a fmall village, which was the manour and feat of William de Fonbury, I K. Edward I (b) ; of Sir Robert de Forebury, $6 \mathrm{~K}$. Fuward IV, in which year he and Sir George Lumley were reprefentatives in parliament for Nortbumberland, who are filed in the writ, Milites gludiis cincti (i); of William de fowbury, I6 K. Henry VIII, 1524. In that year his fon and heir took two hundred Scotchmen prifoners on their return from plundering the countrypeople going to Bervick-fair, on Trinity Sunday, 20 May (k). In the 24 th of the fame reign the Scots plundiered the village (l). It afterwards came into the noffefion of the Strothers of Kirk-Neruton. It now belongs to Fobn strother Kerr, Efq; high theriff of Northumberland, $\mathrm{x} 74$.

Two miles fouth from Fowbury, is

Cbillingbam-Cafle, which was the feat and manour of the Greys of Wark (m); and is now in the poffefion of the right Honourable the Earl of Tankerville. It ftands on a rifing ground, and is kept in good repair. In one of the ground-rooms is a marble

(b) Willielmus Fowbury tenet Fowbury, Caldmarton, et Hezelrigge, per unum feod, milit. veteris feoffam. baronia de Alnwick.

Efcaet. de anno I $E d$. I. .

(i) Efcaet. de anno 6 Ed. IV.

(k) Hol. Chron. vol. ii, p. 883 .

(l)

(m) See Wark. 
chimney-piece wherein a live Toad was difcovered in fawing the block in two; the Nidus of the toad vifible, till plaiftered over by the order of the late Lord Tankerville. In the fame room is a painting of it, from which the late Mr. Warburton took a drawing, and prefixed to it the following verfes.

\section{Heus Stagyrita!}

Tuo fi velis quid mirabilius Euripo,

Huc venito.

Fluant, refluantqùe Maria, ct fit Lunaticus

Qui fuo triniam fpoliat honore.

En tibi novi quid, quod non portat Africa,

Nec fabulofis Nilus arenis,

Ignem, flammamque puran,

Aura tamen vitali cifam!

Caxco e recefsû fciffi, qual vides, faxi,

Obitetrici lucem Lithotoni dedere manus

Vivo Bufoni.

The church is on the north fide of the caftle, dedicated to St. Peter. At the north-eaft end of the chancel, behind the Farl of Tankerville's feat, is a beautifu! mifed tomb of alniulker over one of the knightly family of the Greys and his lady, with their effigies, recumbent, and in a praying poture; curiouly umamented with fculptures of the holy family, in niches. Abore it, on blue marble, is his coat armorial, with the following motto, in French.

De bon vauloir, ferver le roy.

On a rocky eminence, at the head of Cbillinglom-park, is a circular double intrenchment, called, Ros-Cafle. 


\section{ANTIQUITIES OF NORTHUMBERLAND.}

At the bottom of Hebburn-wood, a mile fouth from Chillingham, is another, of the fame form.

At New Town, a mile weft from Chillingham, is a ftone-crofs, twelve feet high. The common people call it, The Hurle-ftone.

A mile from New Town, is

Weft Lilburn, which was the villa and feat of the antient family of the Lilburns; of Fobn Lilburn, 18 K. Edward II (n); of Sir Fohn Lilburn, who was twice taken prifoner by the Scots; firf, with his brother in an engagement at the village of Carbam, $44 \mathrm{~K}$. Edward III, $1370(0)$; and afterwards at the battle of Otterburn, $12 \mathrm{~K}$. Richard II, $1388(p)$ : of Sir Tbomas Lilburn, a reprefentative in parliament for Nortbumberland, I2 K. Henry VI (q). In later times it was poffeffed by the antient family of the Clennels, of Clennel; by Percival Clennel, Efq; I K. George I; by the late Thomas Clennel, Efq; and now by his nephew, Henry Collingwood, of Cornbill, Efq. It ftands on the eafl fide of the Wooler-road, and in fight, on a rifing ground, on the north lide of a fmall fream. At the weft end is the ruin of an old tower, alfo of $a^{\circ}$ chapel. At the eaft end is Mr. Collingrwood's feat, a neat, modern building.

Three miles from Lilburn, on the right hand of the road, on a hill, is

Ilderton, a fmall village, one of the manours of the barony of Wark, of which it was held by the antient family of the Ildertons;

(n) Johannes Lilburn obiit feifitus de et in manerio de Wef Lilburn.

Efcaet. de anno 18 Ed. II.

(a) See Carbam.

(p) See Otterburn.

(q) Fuller's Worthies, p. 310.

Vol. II.

$\operatorname{Rr} r$ 
490 ANTIQUITIES OF NORTHUMBERLAND.

by Henry de Ilderton. I K. Edward I (r), who alfo held the Three Middletons by the annual rent of 1 . 10 s. per annm, of the barony of Beanly (s); by Sir Thomas de Ilderton, high theriff of Nortbumberlanl, $50 \mathrm{~K}$. Edward III ( $t$ ), who was at the fiege of Bervick upon Truech, I K. Richard II, I378, and acquired great honour by his valour (ai); by Sir Thomas de Ilderton, high theriff of Northumberland, $21 \mathrm{~K}$. Henry, VII ( () ; by Thomas de Ilderton, $6 \mathrm{~K}$. Edward VI (wo) and 10 Q. Elizabeth $(x)$; by Fobn de Ilderton, in the reign of K. Charles I; by the late Thomas Ilderton, Efq; who died in January, 1762 , and was fuccecded by his fon and heir, Thomas $\mathrm{Il}-$ derton, Efq.

On Rofedon-edge, on the fouth fide of Ilderton, is a large fquare intrenchment.

There is alfo another in fight from it on Bewick-hill, on the eaft fide of the rivulet of Bramifh, femicircular, with a double fofs and vallum; a fteep precipice to the weft ; an extenfive profpect from it on a clear day. A hollow way leads to it from the fouth, twelve feet and a half broad, edged on one fide with large ragftones, fet edgeways in the earth.

(r) Eicaet. de anno $49 H i n$. III.

(s) Hinricus de Ilderton tenet tres Middlotons per redditum xxxs. per ann. Baronia de Biarlay.

(t) Elcaet. de anno 50 Ed. III.

(ii) Hol. Chron. vol, ii. p. $42 \mathrm{r}$.

(v) Efcaet. de anno 2i Hen. VIr.

(20) Bp. Nicholfon's Border-Laws, p. 337.

(x) Thomas Ilderton fuit feifitus de et in.licerton et Rofedon, cum terris in Branton, et Shipley.

Efcaet, de anno to Eliz. 
By Harup-burit, half a mile to the eaft of it, is a fmaller, femicircular alfo. It feems to have been a kind of an out-guard on that fide.

\section{A mile fouth-eaft from Ilderton, is}

Rodbam, the feat and manour of the antient family of the Rodbams; of William de Rodham, 49 K.Henry III $(y)$; of Wrilliam de Rodham, $3 \circ \mathrm{K}$. Edward III, who married the daughter and fole heir of Thomas de Efplee ( $z$ ) ; of Sir Fabn de Rodbam, who was flain at the battle of Towton, I K. Edward IV, $1_{4} 6_{1}$; of Fobn de Rodham, $6 \mathrm{~K}$. Edward VI (a); of Robert de Rodlsam, 10 Q. Elizabeth (b); of Foln de Rodham, in the reign of K. Charles I; of the late Rodhan, Efq; and now of his fon and heir, Edward Rodham, Efq; brother of Robert Rodham, Efq; a captain in the royal navy, born ${ }_{5}$ th March, 1719-20, who married Lucy Mary, eldeft daughter of the Honourable George Clinton, uncle to Henry the prefent Earl of Lintcoln, 24th April, 1749, at Stenwich, in Nerw England. She died, gth

(y) Efcaet. de anno 49 Hen. III.

$10 E d$. I. n. 18.

(z) Dicunt juratores fuper facrum fuum, viz. Ricardus de Cramlington, Ricardus del Parn, Robertus de Elond, et alii, coram IVilliclmo De la vale, efcaetore dom. regis Eclvardi tertii, in com. Nortbumbr. quod Thomas de Efplce obiit die Jovis xx, præterit. xxx Ed. IlI. Et dicunt quod uxor Willielmi de Rodham eft filia et hxes predicti Thont, et eft xtatis xxx ann. et amplius,

Inquifit. capta apud caftrum de Novo Cafro fuper Tynam die Sabbati in feptimabs pafchæ anno regis Edvardi tertii xlvii.

Ex bundello efcaetr. Turri Lond. de anno 48 Ed. III. n. 23.

(a) Bp. Nicholfon's Border-Laws, p. 337 .

(b) Bobertus Rodham fuit feifitus de et in Rodham et farva Howghton, cum terris in Renningson, et Broxbam.

Efcact. de ro Eliz. 
December, I750, at New York, in North America, at the age of twenty-one years, and nine months, and was buried there. The feat-houfe is modern and handfome, on the fouth fide of a deep gill, on an eminence; an agrecable profpect of the vale under it.

On Hedgley-Moor, on the left hand of the road, is a wrought fone pillar, fixed in a pedeftal, called, Percy's crofs, from its being erected to the memory of Sir Ralph Percy, who was flain in an engagement with Lord Montacute, $3 \mathrm{~K}$. Edwurd IV, $146_{3}$, before the battle of Hexham-field (c). 'The Percy and Lucy arms are cut upon it in relief, ftill very fair.

A little beyond Percy's crofs, on the banks of the rivulet of Bramifh, is,

Brondon-White-Honfe, which was the feat of a younger branch of the Collingwoods of Eflington (d); and of Lancelot Allgood, of Newcafle upon Tyne, Efq; in I701; on whofe death it came to his nephew, Ifaac Allgood, Efq; father of the prefent poffeflor, Sir Lancelot Allgood, of Nunwick, Knt (e).

We crofs the Bramijh by a new ftone-bridge, above which, on the right hand, and in fight, is

Branton, a fmall village, fuppofed by $\operatorname{Dr}$. Gale $(f)$ to be the Roman ftation Bremenium, now fixed at Rochefter in Reedfale (g). Here the diffenters have a very handfome meeting-houfe.

Four iniles weft from Branton, on little Cheviot, is a large Karn.

(c) Hol. Chron. vol. ii. p. 666.

(d) Bp. Gibfon in Camden.

(e) See Simonburn.

(f) Gale's Antoninus.

(g) See Rocbefler. 


\section{Two miles eaft from Branton, is}

Beanley (b), which was the barony of the Earls of Dunbar (i). It was taken Fom Patric Earl of Dunbar by K. Edward III, for being in arws with the Scots againft him. He gave it to Henry Lord Percy: and it is now in the poffeffion of his Grace the Duke of Northisizlerlind.

On $\quad r$ ioor is a large circular intrencliment, in fight from Bervir in Rofedon-cáge.

A is it from seculcy, is

Egli, hi, a fmall village, which was the feat and manour of Luke $\mathrm{O}_{i}$ te rin; io Q. Llizabeth $(k)$; of Henry (igle, Eiq; one of the fecuefirators of the lands in Nortkmuerland for the parliament, I) K. Charles I, 1643 (l); alfo a reprefentative in parliament for

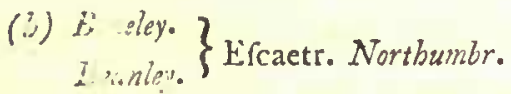

(i) Connes Patricius tenet Baroniam de Beneley per fervicium Inbrough et Outbrough inter regione; Angliae et Scotice. Preterea, tenet tres villas in Chinagium pro quibus reddit dom. regi fur $\approx \mathrm{nn} . \mathbf{x x x}$. Et eund. fervic. omnes anteceffores fui tenuerunt poft tempus regis Henrici primi qui eos feoffavit. Et de feodo illo nulia eft alienatio, \&c. Tefta de Nevill.

Patricius comes de Dunbar tenet in capite de dom. rege Beanley, Shipley, Edlingham, Brandon, Branton, Hedgley, Middleton cum Rodham membro fuo, Middleton et Middleton-hall, Harup, Lemington, Witton et Long Witton, Stanton cum Leverchild memhro fuo, $W y n d-$ gates, 'Horlley, reddens Domino regi pro tritus Middletons predictis xxx s. per manus vicecomitis comitatus prefati; et pro aliis villis dietus comes facit Inbrough et Outbrough per Angliam et Scotiam.

Efcaet, de anno I El. I.

(in) Efcaet. de anno to Eliz.

See Bp. Nicholfon's Border-Laws, p. 338 .

(l) Parliament. Hift, of Engl. vol. xii. p. 233. 
Northumberland, 5 K. Charles II, I653; of Henry Ogle, Efq; high Theriff of Nortbumberland, 6 Q. Ann, 1707; of Fobn Ogle, Efq; high theriff of Nortbumberland, 10 K. George II, 1737; and now of Ralpis Ogle, Efq.

On Glanton-hill, on the right hand of the road, is

Glanton-Pike, a mount fo called from its conic form, exploratory; on which was alfo a beacon to alarm the country by fire in times of public danger; an extenfive profpect from it; the hill, called Dun's Law, in Scotlaud, being feen from it on a clear day.

In a place, called, The Deer-ftreet, by Glanton-weft-field, as a mafon, by the order of Mr. Mills of Glanton-pike was digging for fone in the year 1716 , he difcovered a ftone-chent, upwards of three feet in length, and two in breadth, with a ftone cover, with nothing in it; but as his fon, now living, was working down an uneven piece of ground, he difcovered three more fuch chefts with covers, containing fine eatth and two urns in each, with fome charcoal, and human bones carrying the marks of fire. Near them were two more urns, one large, and the other very fmall. On being expofed to the air they all fell to pieces, except one, which Mr. Mills preferved, fince broke. They were of very ordinary pottery.

A quarter of a mile north from Glanton-weft-field, Mr. Mills's fervant, as he was making a fence a few ycars ago, turned up a Britifh Securis or Celt at the bottom of a clod, well preferved; now in my poffeffion. It is of the old mixed brafs.

Few inftuments have more exercifed the thoughts of antiquaries than this; fome contending for its being a weapon of 
war: $(m)$ and others nor. Mr. Hern fancies it to be a Roman chiffel, ufed in making their Aggeres, and that it was preferred to iron from the reputed facrednefs of the metal of which it was made. From there being no mention of it by Bonani (n), by Monfieur de la Chaufje ( 0 ), or by Spon ( $p$ ), and no veltiges of it among the Roman arms on the Trajan or Antonine pillar, or among the ruins. of Herculaneum, the ingenious Cornifh antiquary, Mr. Brlafe, is inclined to think it not of foreign tranfmarine origin, but the work of Britifh-Romans, or artifts taught by them, for an offenfive miffive weapon $(q)$. According to the late learned and fagacious Dr. Stukeley, it was ufed by the Druid priefthood in their Sacra, being their hatchet, fixed to the end of a ftaff, with which they cut the Mifletoe for Yuletide, our Chriftmas, and Oak-boughs for their fertival of the autumnal equinox ( $v$ ).

From Glanton-hill we have a fine profpect of the vale of Whittingbam, wherein on the left hand of the road, and on the north fide of the rivulet of $A h n$, is

Bolton, a fmall villa, where was an hofpital founded by Robert de Ros, Baron of Wark, before the year 1225, for a mafter, and three chaplains, thirteen leprous men, and other lay-brethren; dedicated to St. Thomas the Martyr, or the Holy Trinity; fubordinate to the abbey of Ryeval, and the priory of Kirkbam, in York-

(m) Rowland's Mona Antiqua, p. 86.

Plot's Staffordsire, p. 403.

(n) Mufeum Kercherianum,

(0) Mufeum Romanum.

(p) Mifcell. curieus.

(9) Antiq. of Cornwall, chap. 13. p. 263, \&c,

(r) Caraus. vol. ii. p. 163. 


\section{ANTIQUITIES OF NORTHUMBERLAND.}

Bire (s). He gave it the villa, lordhip, impropriation and advowfon of Bolton, and a wafte of 140 acres; a corn-mill and a tenement at Mindrum; lands at Pafton, and at Kilham. He gave it the villa, manour, impropriation and advowfon of Straunfon, and his eftates of the two Pauntons within that lordfhip, near Grantham, in Lincolnfhire. He alfo gave it an eftate at Elwell, in Swancland, in rorkfbire, with pafturage for 300 theep, near the river Humber; a corn-mill, and a tenement, at Middleton, near Dalton; and lands at Garton; both in the county of rork ( $t$ ). The mafter, chaplains, and brethren of the hofpital, were to keep a good table, drefs neatly, and provide themfelves with all neceffaries and conveniences out of their annual revenues, and apply the remainder to the relief of the poor, and helplefs ftrangers. At the diffolution it came with the manour and villa into the pofferfion of the Collingruods of Effington. It belonged to Sir Cutbbert

(5) Carta Raberti de Ros de fundatione eidfdem, citata in is naft. Ang?. vol. ii. p. 458, 459.

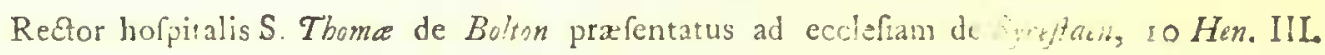
Colled. Drlfurth, ex rotulo Hug. Wills, $\mathrm{H}_{i}$ ilic. Linccln.

Huppitale regium S. Trinitatis de Bo.ton, juxta Alnwick. Pat. 3 Ed. Lil.

Leprofi de Bolton. Lel. Collectan. vol. i. p. 199.

Carta hopitalis S. Thome de Bolton, I I K. Hen. III. m. 90.

Confirmat. cartæ hofpitalis S. Thome de Bolton, 2 Ed. III. n. 95.

De patronatu hofpitalis S. Thome de Bolton abbat. de Ryeval, \&c. clauf. 4 Ed. III. m. I. et ctauf. 5. p. 1. m. 29. in Dorfo.

(t) De poffers. hofpitalis Thoma Martyris de Bolton, viz. de Bolton, et de Kilham, et Straunflon juxta Grantbam, et tenem. in Pafon, Etall, et Swarland, et paft. 300 ovium juxta .Humber, et tenem. in Garion, \&c. carta ir Hen. III. m. 9o. in Cedula.

Vid. Tann. Notit. Monaft. fo. p. 395 . 
Collingwood, 10 Q. Elizabeth (li); and to Robert Collingrwood, I $4 \mathrm{~K}$. Charles I $(v)$.

In the 2d Q. Ann, 1702, it was the feat and manour of William Brown, Efq; high theriff of Northumberland in that year; and of $\mathrm{Ni}$ cbolas Brown, Efq; high theriff of Northumberland, I 748 ; and now of his fon-in-law, Mattbew Forfer, Efy; a younger branch of the houfe of Etherfon (w), high theriff of Nortbumberland, I 765 .

Before the battle of Brankfon, Sir Thomas Howard, Earl of Surrer,

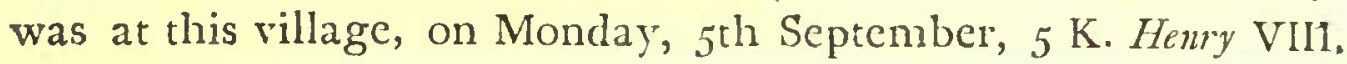
I513; where all the noblemen and gentlemen met him with their retinues, to the number of $26,000 \mathrm{men}$; among whom were the Lords Clifford, Coniers, Ogle, Scrope of Upfal, Lumley, Sir William Percy, Lionel Percy, Sir George Darcy, Sir William Bulmer, of Brampeth-caftle, and Richard Tempeft (x).

At Shawdon-new-houfes, two urns were digged up a few years ago in making a fence; of ordinary pottery; one of them large and bellied, now in the poffeffion of James Hargrave, of Sbawdon, Efq; high theriff of Nortbumberland, $173^{8}$.

Two miles from Bolton, on an eminence, between the two roads from Whittingbam and Rotbunry to Alnwick, is

(u) Gutbbertus Collingwood, miles, fuit ficiftus de et in manerio de Bollon.

Efcaet. dé anno ro Eliz.

(v) Robertus Collingwood, arm. confanguineus et hæres Cutbberti Colitingwood, militis, tenet in capite per fervicium militaro mancrium de Bolton, ac duo neffuagia in Bromin-park, as quinque melluagia in Titlington.

Efcaet, de anno $14 \mathrm{Car}$. I.

(w) See Etherfon.

(x) Hol. Chron. vol. ii. p. 826 .

Vol. II. 


\subsection{ANTICUITIES OF NORTHUMBERLAND.}

Lemington, the feat of Robert Fenrerick, Efq; high theriff of Northumberland, 1753; whofe father, Nicbolas Fenwick, Efq; was a reprefentative in parliament for the corporation of Newcafle upon Tyne, for many years. It is a handiome modern ftructure, of white frceftone, and hewn wo:k; the gardens to the north-eaft, wherein is a pinery; an agreeable profpect from it wettward of the vale of Whitting bam; a large plantation on the brow of a hill to the eaft.

A milc fouth-weft from Lemington, by a freamlet, and in fight from the Rothlury-road to Alnwick, is

Fdlingthm-Calde, which was the feat and manour of Sir Roger Inaftings, knt. who bore a captain's commiffion in the expedition againtl the Moors, 1 K. Henry VIII, I509; as did Sir Ralpb de Ildertoil $(y)$. It came afterwards into the poffefition of Thomas Swinburn, Son of Folnn Srcinburn, of Nafferton-ball, Efq; as was found by an incuifition, 10 Q. Elizabeth (z). He was fucceeded by his fon, George Srvinburn, who had two fons and three daughters, by Margaret the daughter of - Haggerfon, Efe; of Haggerfon; the younger fon married to the daughter of Robert Raymes, of Shortflat, Ef,; the cldef daughter, Margaret, to Roger Procter, of Shawdon, Efq; the fecond daughter to Sir George Heron of Chipchace, Knt. and the third daughter to Robert Rodbam, of Rodbam, Efq; Heirs male failing in Gobn Sruinbun, fon of Thomas, in the reign of K. Charles I, and his eldeft fifter and fole heir, Margaret, marry-

(y) Hol. Chron. vol, ii. p. 808 .

(z) Thomas Swinbarn fuit feifitus de ct in mancrio de Edlinghan, Abberzuick, Neaton, Hugh, Nafferton, et M. Batington, de et in tribus partibus de Blaik Hedilon, cum terris in Fawnes, Bromenore, Hixham, et Morpeth.

Efcaet. de anno 10 Eliz. 
ing William Swinburn, of Cap-Heaton, Efq; thofe two houfes were united (a); now in the polfeffion of Sir Edward Swinburn, Bart.

\section{We pafs on through the village of Whittingham, weftward, for a mile, to}

Efington, which was the villa and manour of the antient family of the Eflingtons; of Alan de Eflington, $23 \mathrm{~K}$. Henry III (b); of his fon, Jobn de Eflington (c), who had alfo the manour of Framlington, as was found by an inquifition taken at the caftle of Neresafle, $49^{\text {th }}$ of the fame reign (d); and by another taken at $R \Delta t b-$ bur'y,

(a) Fobannes Swinburn, Arm. filius Thoma, tenet de rege in capite per fervicium placita coronx cuftodiendi in Northumbr. manerium de Nafforton; ac tenet in capitc xii meffitag. five tenem. in le Hugh, ac diveras terras ibidem, ac tenet de rege, ut de manerio de Prudhow per fervic. milit. capitale meffuag. in Magna Bavington, ac vi meffrag. five tencm. ilidem; ac tenet in capite per fervic. milit. capitale meffuag. in Abberwick, ac villam de Abberwick.

Elcaet. de anno 14 Car. I.

MS. penes Dom. Edvardum Swinburn, de Capp Heaton, Baroncttum.

(b) Alanus de Efington tenet de Domino Rege villam fuam de Eflington in Dringagintm per fer*icium XI s. per annum, et debet Marchet. ausilium, et portabit truncos ad cuftrum de Bambrough, et faciat confuetudinem fpectantem ad dringagium. Ae de predicta villa nil alienatum eft vel datum in liberum maritagium, elemofinam, aut de alio ullo modo quo dom. sex, sic.

Toita de stevill.

(c) Faharnes de Efington tenet Efington in capite de dom. rege in dringazium, et reddit per annum $x 1$ s. et facit talia fervicia, qualia Willielmus de Calieley facie, foilicet truncagium caftello de Bambicugh, et debet talliare deminicis regis cum marchet et hariot, \&c.

Certificat. Hur. de Bolbeck, vicecom. Nortbumbr. Temp. H. III.

(d) Dicunt juratores fuper facrum firum, (viz. Alexander de Tittington, Mrillininus de Hezthigge, Wilizelmus de Glanton, Robertis de Whittinghann, Yoobn de Lranton, Willitimus de

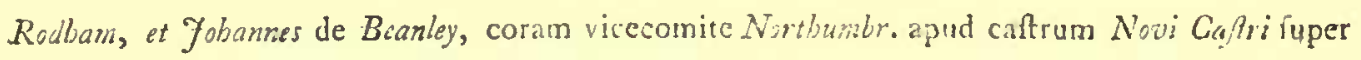

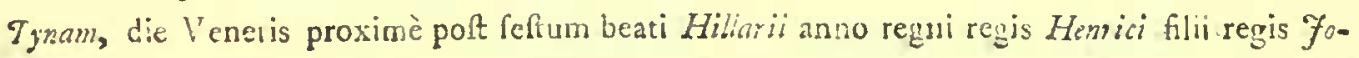


bury, 2 I K. Edward I (e) ; of Robert de Elington, his fon, announced in the latter inquifition to be his heir, and to be upwards of the age of twenty. In I th of K. Henry IV, a mediety of it was poffeffed by Thomas de Hezelrigge, fon of William, and brother of 1)onald de Hezelrigge, anceftor of the Hezelrigges of Nofeley, in Leirefterfsire. He had alfo the manour of Whittingham $(f)$. In $36 \mathrm{~K}$. Henry VIII, it was the feat and manour of the knightly family of the Collinguoods, by whom it was poffeffed through a long fucceflion; by Sir Jobn Collingrwood, high theriff of Nortbumberland in that year $(g)$; by Sir Robert Collingrwood, high theriff of Northumberland, 5 K. Eidward VI (b) ; by. Sir Cutbbert Collingwood, high, theriff of Nortbumberland, I 0, 22 Q.Elizabeth (i); by Robert Collingwood,

Bannis quadragefrmo nono,) quod Fobannes de Efington, filius Alani de Efington, eft propinquior hæres Foiannis de Efington, defuncti, qui tenuit manerium de Framlington de dom. Rogero Bertram per fervicium unius feodi milit.

Ex bundello efcaetr. Turri Losd. de anno 49. Hen. III. n. 18:

(e) Juratores dicunt fuper facrum fuum, (viz. Henricus de Warton, Nicolaus de Wartong W'alterius de Warton, juxta Rotbbury, Gobannes Gallon de Truwick, et alii, coram Roberto de Normanville apud Rotbbury dic dominica a die pafchre in tres fepiimanas anno regni regis $E d-$ rardi vicefimo primo,) quod Folbannes de Eflington tenuit mancrium de Efington per fervicium quatuor librarum reldit ûs ad fcaccarium Domini regis de Novo Caftro, et xlvis, ad caftrum de. Bambrough, pro trunc gio, et xiv d. pro conagio; et fecit fectam ad caftrum Novi Caftri; et pro terris de Franlington fecit tantum homagium Roberto de Stotville, et fectam curix de Miftord; et dicunt quod Roberius de Eflington, filius prædicti fohannis, eft hæes ejus propinquior, et ell ce xtate viginti annorum, et amplius.

Ex bundello efcactr. Turri Lond. dé anno 2 I Ed. I. n. 23.

(f) Thomas Hzalrigge, filius Willilmi, fratris Donaldi Hezelrigge, tenet medietatem manesii de Efington, \&c. de rege in capite; et manerium de Whittingham de rege in capite, \&c. Mich. Fin, de anno xiv. Hen. IV.

(g) Efcaet. de anno 36 Hen. VIII..

(b) - $5 E d$. VI.

(i) - - $10 \& 22$ Eliz. 


\section{ANTIQUITIES OF NORTHUMBERLAND. 50I}

wood, I4 K. Cbairles I (i); by George Collingruood, 26 K. Charles II; by George Collingrwood, I K. George I.

It is now the feat and manour of the right honourable Henry. Lord Ravenfworth, to whom it gives the title of Baron. His Lordfhip's feat is modern and handfome, in a low fituation, on the north fide of the Aln, which forms a canal of a confiderable length; a grafs-lawn between it and the houfe, and flopes of flowering thrubs on its oppofite banks; a plantation of thriving young foreft-trees on the fouth fide of the road, on a rifing ground, above which is a terrace extending eaft and weft, and a feat to reft on; from which is a view of the greatcft part of the vale of Wbittingham, of the octagon-grove at Calleley, called The Star, of the caftle-hill by it, of the villa and church of Whittingham, of Glanton, Titlington, Sbazudon, Bolton, Broom-Park, Lemington, and of the woods of Shawdon and Widewood; the vale being enclofed, as it. were, with hills and rocky eminences, with an opening to the eaft beyond Widewaod, well cultivated, and terminating the profpect.

\section{A mile fouth from Elington, is}

Calleley, which was the villa of Willian de Calleley $(k)$ in the beginning of the reign of K. Henry III; and of his fon, Gilbert de Cal-

Cutbbertus Collingwood fuit feifitus de et in manerio de Eflington, et Bolton, de farva Ryle, magna Ryle, et Titlington, cum medietate villa de Whittingham, cum terris in Nethicrton, et villa de Glanion.

Efcaet. de anno Io Eliz.

(i) Robertus Collingwood, arm. filius Thome, tenet de rege, at de caftro de Bambrough, per fervic. dringagii, ro meff. et molendinum aquat. in Efington, ac manerium de Whittingham, ac diverfa meff, in Barton, Thrompton, et parva Ryle, et tenet in capite diverfa melf. in Broom-. Park, et Tillington. Efcaet. de anno ${ }_{4}$ Car. I.

(k) Willielmus de Calleley tenet in capite de dom. rege Calleley et Yitlington in dringagium, et reddit dom. regi per annum xxxs. et facit fervicium truncagii caftello de Bambrough; et debet 


\section{5o2 ANTIQUITIES OF NORTHUMBERLAND.}

Cilleley, in the fame reign (l), who granted it, with the manour of Yetlington, to Robert Fitz-Roger, Baron of Warkworth and Claver-3 ing; which grant was confirmed by the crown, 6 Augult, $55 \mathrm{~K}$ : Hcury III (mi). His Lordhip gave them to his fon, Roger, and his

youngeft

debet talliari cum dominicis regis; ac debet heriton et marchet, et reddere de retlington per anxum xxivs. fed hoc fervicium non pertinct ad tenentes dicti Willieimi.

Certificat. Hug. de Bolbeck, vicecom. Nortbumbr.

(1) Gilbertus de Calleley tenet in capite de dom. rege duas villas, viz. Calieley et $Y_{a t l i n g t o n}$ per fervicium xxxs. per annum de chinagio; et debet dare marchet et auxilium, et qualibet altera die a claufaura Pentccoftes ufque ad feftum S. Petri ad Vincula invenirit unam caricatam carientem truncos ad caftellum de Banbrough, viz. cum uno trunco adjuncto pro onore fuo, et debet fectam curia comitis Nortbumbr. et interim nullum alium fervicium debet. Et otmnes anteceffores fui pradictas villas per eundum fervicium tenuerunt polt tempus Willielmi baftardi regis Angite, et de tenemento illo nil elt alienatum per maritagium vel elemofnam, aut aliquo alio modo unde dominus rex minus habeat de fervicio fuo.

Tetta de Nevill.

(m) Hrnticus Dei gratia rex Anglia, dominus Hibernia, et dux Aquitanice, archiepifcopis, epifcopis, abbatibus, prioribus, comitibus, baronibus, jufticiariis, vicecomitibus, prapofitis, miniftris, et omnibus ballivis, et fidelibus fuis, falutem. Infpeximus cartam quam Gilbertus, filius Willidmi, de Calleley, fecit Roberto, flio Rogeri, filii Jobannis, de tota terra fua quara habuit in Cal'ily et Yitlington in com. Nortbumbr. in hac verba. Sciant prafenies et futuri quod ego Gibertus, filius Ifillidmi, de Calleley, dedi et concefl et hac prafenti carta confirmavi Roberlo, filio Rogeri, filii Jobnnnis, totam terram meam quam habui, rel hahere potui, in Northumbr. feilicet in Callcley et Yetlington, fine aliqưo retenimesto, et aliqua diminutione, cum omnibus efeactis dictis feodis, de cetero accidentibus nomine dotis, et quncunque alio modo aliquid alio tempore aecidere potuit eifdem feodis, et naxime in viis, femitis, bofcis, pratis, pafcuis, pafturis, aquis, molendinis, Angnis, homagiis, ferviciis, wardis, villenagiis, vinariis, foffutis, fepibus, releviis, et in omnibus libertatibus et aframentis nominatis, et non nominatis, prodictis follis pertincutibus, fune aliquo culu pertinere valcntibus, tenend. et habend. pradizo Roberto et hæredibus fuis, vel fuis affignatis, de dom. rege in capite, adeolibere ct quicte, p'enarie et honorifice, ficuti ego unquam liberius, quie.ius, plenius, melius, et homorificentius prsenominatam terrara habui, tenui et poffedi, ficuti carta dom regis t ftatur, et proportat. quam quidam cartam ego prædiclus Gilbertus pradicto $R$ n'erts deliveravi faciendo fervicium dom. regi, ficut pradicta dom. regis teftatur et proportat. p.o omnibus fervici, confuctudinibus, exallionibus, fecularibus demandis, et onnibus 
youngeft and feventh fon, Alan de Clavering. Roger died, $34 \mathrm{~K}$. Edward I, in the poffefion of Calleley, and left one claughter, Margery, a minor, in ward to the crown (n), who alfo died without iffue; and his brother, Alan, according to the fettlement, fucceeded to both manours, at the age of twenty-eight years (o).

aliis rebus qua poflnt exigi de predictis feodis fine a'iqua occafione intervenicnte. Et ego prænominatus Gilbertus, et hæredes mei, totam prædictam tcram curn omiibus pertinentibus fuis, libertatibus, ct afiamentis, ut fuperius præferiptun eft, pradico Roberto ct haredibus fuis, vel fuig aflignatis, contra omnes homines et foenisas, Cbrifianss et fudloos, per predicta fervicia warrantzabinus, acquictabimus, et in perpetuum defendem!s. Fr ut hiec mea donatio, conceflio, warantizatio, defenfio, acquietatio, et prefentis cartir mex confirmatio, rata, et ftbilis, et inconcufla in perpetuum permaneat, banc premen cattan figilli mei impreffione duxi roborandum. His teftibus, dom. Rogero de Mcriky, Rogero Bcrtran, Ada de Fefmont, tune viccomite Northumbr. Roberts de Infula, Fohanne de Halton, Thoma de Fenwick, Fobanne de Efington, Fobanne de Plifis, Thoma de Rile, Ada Barret, Roberto de Camboite, Thoma de Ogle, Gerardo de Widdrington, militibus, Henrico de Selon, Rogero de Widdringian, et aliis. Nos autem prædictam donationem, concefionem, et confirmationem, ratus habentes et gratas eas pro nobis et hæredibus noftris, quantum eft in nobis, concedimus et confirmamus, ficut prædicta carta rationabiliter teftatur. His teftibus, $\mathcal{F}_{1-}$ banne de Warrena, comite Surrey, Rogero de Leyburne, Rogero de Somery, Elia de Rabaync, Mattheo de Lovayne, Galfrido de Percy, Petro Everard, et aliis. Data per manum noftrum apud $W^{\prime}$ efmonafer. fexto dic Augufti, anno regni noftri quinquagchimo quinto.

Ex rotulo cartarum de anno $55 \mathrm{Hcn}$. III, pro Roberto, filio Rogeri, filii Fobrannis.

(n) Juratores dicunt fuper facrum fuum, quod Rograrus de Clavering tenuit die quo obiit in com. Nortbumbr. de dom. rege in capite villam de Calleley, in qua eft capitale mefluagium, 230 acr. terræ arabilis in dominico, 10 acr. prati, 23 bondagia, feprem cotagia ct molendinum aquaticum. Et dicunt quod tenuit prædietas terras \& tenementa de dom. rege in capite per fervicium medietatis octo marcarum et xvi $d$. per annum ad feaccarium Novi Cafri fuper Tynam folvendi, et per fervicium dimidium marcæ pro difafforeftatione forefte eidem fcaccario pro cornagio folvendi, et faciendi fectam comitatûs, et per fervicium $x v d$. eidem fcaccario pro cornagio folvendi. Et quod Margeria eft filia ct hæeres prædicti Rogeri propinquior. Efcaet, de anno $34 E d$. I.

(0) Juratores dicunt fuper facrum fuum, quod dux partes medietatis manerii de Calleley, cum pertinentibus, in com. Northumbr. Sunt in manu dom. regis per mortem Margeria filia 
He was brocher to Fobn Lord Clavering, who granted the reverfion of his baronies to the crown ( $p$ ). He died, 2 K. Edward III, and was fucceeded by his fon, William de Clavering, then in the 24 th year of his age $(q)$. He died in the fame reign, as did his wife, Matilda. He was fucceeded by his fon, Sir Robert Clavering, as was found by an inquifition at his mother's death, $26 \mathrm{~K}$. EdwardIII. He was then of the age of twenty-fix years ( $r$ ). He dicd,

et hæredis Rogeri de Clavering, defundi, ratione minoris ætatis ejufdem Margeria. Et dicunt quod prædictæ dux partes manerii de Calleley reverti debent Alano de Clavering, fratris prædicti Rogeri, per formam donationis quod Robertus, filius Rogeri, filii Gohannis, dudum dedit prafato Ragero et Alano conjunctinı, \&c. eo quod predieta Margeria obiit fine hærede de corpore fuo exeunte. Et quod idem Alanus eft ætat. xxviii annorum.

Efcaet. de anno $35 E d$. I.

(p) See Warkuortio.

(q) Juratores dicunt fuper facrum fuum, quad Alanus de Clavering tenuit in dominico fuo, ut de feodo, die quo obiit de dom. rege in capite manerium de Yetlington, cum pertinentibus, per fervicium tertic partis unius feodi milit. et per fervicium reddendi per annum ad feaccarium dom. regis Novi Caftri fuper Tynam xlvii s. per annum ad duo fefta S. Cutblierti. Item, pro cornargio xivd. Iten, pro fin. curize vis. viii $d$. et pro forefta vs. ad eofdem terminos. Et dicunt quod tenuit die quo obiit manerium de Calleley de dom. reze in capite, per fervicium tertia paris unius feodi milit. et per fervicium reddendi ad feaccarium dom. regis Novi Cafri fuper Tynan xviii s. per annum: I:em, pro cornagio iv $d$. ob. et pro fine curiæ ii s. ii $d$. ob. et pro forefta $\mathrm{xx} d$ ad duo fefta pradicta Et dicunt quod Willie'mus de Clavering eft fillus et hæres prædicti Alani de Clavering, et eft ætat. xxiv. annorum. Efcact. de anno 2 Ed. III.

(r) Juratores dicunt fuper facrum fuum, quod Matilda qux fujt uxor Willielmi Clavering, qqux diem claufit extremum, tenuit in dominico fuo, ut de feodo de dom. rege in capite die quo obiit manerium de Calleley in com. Nortbumbr. cum pertinentibus, exceptis fexaginta ncris terre et prati in codem manerio, per homagium et fidelitatem, et per fervicium lx s. per annum, et per fervicium xiv $d$. pro cornagio, et per fervicium vis. viii $d$. pro bofcis et terris fuis deafforeftandis; qux quidem fervicia prædicta annuatim redduntur dom. regi, et folsuntur ad manus. vicecomitis com. pradicti qui pro tempore fuerit ad opus regis; et etiam per fectam ad com. Northumbr. et per fervicium xvi s. reddend. annuatim dom. regi ad manus 
died, I7 K. Richard II ; and was fucceeded by his fon, Sir Fobn Clavering. Sir Fobn was then in the thirtieth year of his age (s). He was high theriff of Nortbumberland, 4 K. Henry IV; his arms, quarterly, or and gules, a bend fable. He died, 4 K. Henry VI. He was fucceeded by his fon and heir, Robert de Clavering; then of the age of twenty-three years ( $t$ ). He died, 3 I K. Henry VI; and was fucceeded by his fon, Robert de Clavering, then upwards of twenty years of age. His fon, Foln de Clavering, fucceeded him, who died, 2 K. Henry VII. He was fucceeded by his fon, Robert de Clavering. He died, 10 K. Henry VIII. He was fucceeded by his fon, Fobn de Clavering, who diecl, 16th December, $28 \mathrm{~K}$. Henry VIII. He was fucceeded by his fon, Robert de Clavering,

conftabularii fui caftri de Bambrough, ad opus ejufdem dom. regis pro truncagio. Et dicunt quod Robertus de Clavering, filius præfatæ Matildw, eft hæres ejus propinquior; et eft ætat. xxvi. annorum.

Efcaet. de anno $26 \mathrm{Ed}$. III.

(s) Juratores dicunt fuper facrum fuum, quod Robcrtus Clavering, miles, fuit feilitus in dominica fuo ut de frodo die quo obiit de villis de Calleley et Yetington cum omnibus fuis pertinentibus in com. No thumber et eas tenuit de dom. rege in capite reddendo dicto dom. regi, et hæredibus fuis ad fcacl in fum per manus vicecomitis Northumbr. qui pro tempore fuerit vil. ad feftum S. Cuthber Nartio et Septembre, et pro truncagio facicnd. caftro de Bamburg ad eadem fefta xxxi... Sit quod fohannas Clavering, miles, eft ejus propinquior hæres, ætat. xxx annorum.

Efcact. dc anno 17 Ric. II.

See Tilmouth.

(t) Juratores dicunt fuper facrum fuum, quod Fohannes Clavering, miles, obiit feifitus de maneriis et villis de Calleley et retlington, in com. Nortbuanlr. quæ tenentur de dom. rcge in capite per homagium, fidelitatem, et per fervicium vi $l$. per annum, et ii s. iv $d$. per ann. pro cornagio; et infra metas foreftx pro terris fuis deafforeftandis, xiii s. iv $d$. qux quidem fervicia folvuntur annuatim vicecomiti Nortbumbr. qui pro tempore fucrit, ad opus dom. regis, et per fectam ad comitatum Northumbr. et per fervicium xxxii s. per annum reddend. dom. regi annuatim per manus conftabularii caftri dom. regis de Bambrough pro truncagio. Et quod Robertus de Clavering eft filius et hares prædicti Fobannis, xtat. xxiii annorum.

Efcaet. de anno 4 Hen. VI.

VOL. II. 
who died $25 \mathrm{Q}$. Elizabeth. He married Ann, one of the daughters and cohcirs of Sir Thomas Grey, of Horton-Caftle ( $v$ ), by whom he had four fons, viz. Robert, Fobn, Fames, and William. Fobn was rector of Gamlinghay, in Cambridgefhire; Fames was lettled at Newcaftle upon Tyme. He was theriff of that corporation, 42 Elizabeth, I599; of which he was alfo mayor, $5 \mathrm{~K}$. Fames $\mathrm{I}, 1607$; and, 16 th of the fame reign, I6I8( $w$ ). He was advanced to the honour of knighthood. Iie was anceftor of the late Sir Fames Clavering, of Axwellpark, Bart. father of the prefent Sir Thomas Clavering, Bart. of George Clavering, of Greencroft, Efq; and of Colonel Ciavering, fonin-law to the right honourable the Earl of Delazvar. Willian, the youngeft fon, was bred to the army. Robcrt, the eldent, married Mary the daughter of Sir Cutbbert Collingrood, of Efington, by whom he had four fons, viz. Fobn, Robert, William, and Fames. He was high theriff of Nortbumberland, 28 Q. Elizabeth $(x)$. He died, 4 ad of the fame reign $(y)$. His fon and heir, Sir Gobn Clavering, Knt.

mar-

(v) See Horton Cafle.

(x) Bsurne's Hift. of Newcafle upon Tyne, p. 227-28.

(y) Efcaet. de anno 28 Q. Eliz.

(x) Juratores dicunt fuper facrum fuum, quod Robertus Clavering diu ante obitum fnum fuit feifitus in dominico fuo, ut de feodo, de et in manerio de Calleley et Yetlington, cum per-

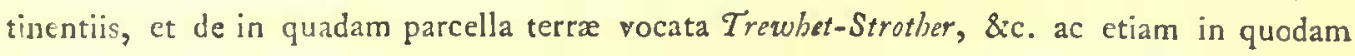
annuo redditu duorum folidorum exeunte de uno burgagio et duabus parcellis terræ vocatis Butts of Lands, \&ze. ac etiam de et maneriis de Tilmouth et Dudbow, in comit. de Norbam, infra libertatem et precinctum comitatus palatini epifcop. Dunelm. Dicunt etiam quod prædißus Robertus per ultimam voluntatem et teftamentum fuum dedit et legavit Marice uxori fuæ inter alia prædictum manerium de Yetlington, \&cc. dedit etiam filio fuo Fohanni prædictum manerium de Dudhow, alias Dudboe, et hæredibus fuis mafculis de corpore fuo legitime procreatis; et pro defectu hæredum, Roberto Clavering, fecundo filio dicti Roberti, et hæredibus mafculis; et pro defectu hæredum Willielmo Clarering, tertio filio dicti Roberti, et hæredibus makculis; et pro defe@u hæredum facobo Clavering, quarto filio, \&c, et pro defectu hære- 
married Ann, the daughter of Sir Thomas Riddel, of Fenbam, Knt; by whom he had nineteen children $(y)$. He was a zealous friend to K. Charles I, in all his diftreffes, for which he incurred the difpleafure of the parliament, and was caft into prifon. His eldeft fon, Sir Robert Clavering, Knt. raifed, at his own charge, two regiments for his Majefty, one of horfe, and another of foot; alfo fome troops of dragoons; with which he ferved his Majelly in perfon, under the command of the Marquis of Nerucafte, and had a fhare in the victory obtained over the parliament-forces at Athelfon-moor, in Yorkfhire. He received the honour of knighthood for his bravery. He was alfo made commander in chief of the two counties of Nortbumberland and Durbam, then in the poffeffion of the Scots, whofe forces he vanquifhed, took the caftle of Morpeth, and the fort of South Sbields, by affault; and afterwards directed his march to York, with a defign to join Prince Rupert for the relief of that city. By the interpofition of the enemy, he did not accomplith his aim till after the battle of Marfon-moor. He was then feized with a fever, of which he died, in the twentyfixth year of his age, unmarried. His father furvived him, who died, $22 \mathrm{~K}$. Charles I, 1646. He was fucceeded by his third fon, Ralph Clavering; whofe fon and heir, Fobn Clavering, married Ann the daughter of the right honourable William Lord Widdring

dum, Johanni Clavering, de Gamlinghay; in comit. Cantab. rectori fratri diati Roberti, et hadredibus fuis, \&c. et pro defectu hæredum, Facobo Clavering ad tunc vicecomiti Novi Caftri, fratris dicti Roberti, \&c. et pro defectu hæredum, Fobanni Clavering, flio diati Facobi fratis, \&ic. et pro dcfectu hæredum facobo Clavering, filio fecundo domini facobi fratris, \&zc. et pro defectu hæredum, Radulpho Clavering, de Bowlefden, \&xc. et pro defeßtu hæeredum mafc. \&c. dicti Radulphi, tunc rectis hæredibus mafculis ipfius Roberli, \&xc. in perpetuum. Dicunt etiam quod prædictus Robertus obiit apud Calleley xviii die Martii anno regni dom. Elizabether, reginæ; xlii; et quod Fohannes Clarering eft filius et hases ejus propinquior, ct ætat. xiii annorum, et iv menfium. Inquifit. capta apud Nov. Cafhrom fuper Tynam, anno 44 Eiiz.

(y) Mr. Warburton, Somerfet-heraid. 
ton, Baron of Blankney, by Elizabetb Berty, heir to Sir Peregrine Berty, and niece to the right honourable the Earl of Lindfey, lord high chamberlain of England, by whom he had Ralph Clavering, father of the late Clavering, and grandfather of the prefent porcellor of Calleley and retlington, Ralpb Clavering, Efq.

His feat of Calleley is on the fouth fide of a fream of the fame name, in a low fituation; built on to an old tower, to which he hath made handfome additions; a large and elegant diningroom in it, with two mufic-galleries. The ftreamlet takes its courfe between two flopes, on one of which, to the north, is the garden; and on the other, to the fouth-eaft, an octagon-grove, called The Star; a paddock of deer between it and the houfe. At a finall diftance, to the fouth-eaft, is a high conic hill, called Caftle-hill, on which is a circular intrenchment with veftiges of buildings; an extenfive profpect from it of the vales of Coquet, Whiting ham, and Glendale.

A mile weft from Calleley, is

Little-Ryle, the villa and feat of a younger branch of the Collingwoods of Eflington; of Alexander Collingruood, high theriff of Northumberland, 1725; who built a handfome feat at Unthank, hard by, now the feat of his fon and heir, Alexander Collingrwood, Efq; high theriff of Northumberland, 176r.

Three miles fouth-weft from Little Ryle, is

Cartington, which was the feat and manour of the antient fami:y of the Ratcliffs; of Sir Edward Ratcliff, high theriff of Northumberland, I 7 K. Henry VII (z); of Sir Cutbbert Ratcliff, high theriff of

(z) Efcaet. de anno iz Hen. I7. 
Nortbumberland, I9 K. Henry VIII (a); of Sir George Ratcliff, high Theriff of Nortbumberland, 5, 6, Q. Mary (b). It was afterwards the feat of Sir Edward Widdrington, Bart. who raifed a regiment of horfe for the fervice of K. Charles I, by whom he was created a Baronet, 8th Augult, 1642. His eftate was fequeftered by the parliament, 1652. His eldeft daughter and coheir, Mary, married Sir Edward Cbarleton, of Hezleyfide, Bart. She died, 8th April, 1703, aged $7 \mathrm{I}$. His third daughter and coheir, Catharine, married Ricbard-Francis Sberburn, only fon of Sir Nicbolas Sherburn, of Stoniburf, in Lancafhire, Bart. She was born on Sunday, 3d December, I693; died on Monday, 8th June, 1702 (c). Lady Charleton founded and endowed a fmall almfhoufe in the village, for four antient poor widows in the parifh of Rotbbury. The manourhoufe is an old tower, now poffeffed, with part of the villa, by Giles Allcock, of Nerucafle upon Tyne, Efq; It ftands on an eminence, from which, four miles to the north-weft, we have a good view of.

Bittlefdon (d), which was the feat and villa of Sir Walter Selbye, governor of Lidell-Caftle on the borders, I 6 K. Edward III, I342; in which year, on the 5 th of October, it was taken by David King of Scotland, in his march into England with an army of

(a) Efcaet. de anno ig Hen. VIII.

(b) - 5 et 6, Mar.

Georgius Ratcliff, miles, fuit feifitus de et in caftro, manerio, et villa de Cartington, \&c. Efcaet. de anno 10 Eliz,

Vide Dillor.

(c) Le Neve's Monum. Angl. vol. i. p. 44 .

(d) Bidlefton. Efcaetr. Nortbumbr,

Bytilfden. Bp. Nicbolfon.

Bittlefdon. 
40,000 men, one half confifting of veterans, and the other half of militia, raifed by the towns and boroughs, for their inexperience, called Hoblers; Sir Walter being beheaded after it was taken for refufing to furrender (e). In $6 \mathrm{~K}$. Edward VI, his villa was in the poffeffion of Percival Selbye, who was one of the commiffioners for the enclofures upon the middle marches in that year. It now belongs to Thomas Selbye, Efq. His feat is at the head of a gradual flope; a freamlet behind it, falling at irregular difances from large rocks in a winding courfe through a deep gill, overlooked by the high hills of Sowndon, Silverton, and Hardon, from the two laft of which is a view of the fea on a clear day; a garden to the eaft, with a flew-wall of brick, 110 yards in length; a fine profpect from it of the pleafant vale of Coquet, terminated to the fouth-eaft, the fouth, and fouth-weft, by a femicircular ridge of hills; Simonfide-hill ftanding nearly in the center, overlooking the reft, of an oblong figure.

Three miles from Bittlefdon, on the banks of the Coquet, is

Clenell, the feat and manour of the antient family of the Clenells; of Thomas Clenell, $18 \mathrm{~K}$. Edward I; in which year he obtained a grant of free warren in this manour, and his manour of Elfien ( $f$ ); of William Clenell, I $2 \mathrm{~K}$. Henry VI $(g)$; of Percival Clenell, 6 K. Edward VI (b); of Luke Clenell, high theriff of Northumberland, 1727; of the late Clenell, Efq; on whofe death it came to his two daughters and coheirs.

A mile below Clenetl, on the fouth fide of the Coquet, is

(c) Hol. Chron. vol. i. p. 240.

(f) Sce Elfilon,

(s) Fuller's Worthies, p. 310.

(b) Bp. Nicbolfon's Border-laws, p. 330 . 
Harbottle-Gafle (i), which was held by the Humfranvils, Barons of Prudbow, by the fervice of keeping Reed/dale free from thieves and wolves ( $k$ ); by which fervice they alfo held the cafte and manour of Otterburn (l). This fervice was adjudged to be the fervice of Great Serjeanty, I 7 K. Henry IV. In that year, the court of efchequer ordered a fearch to be made in the rolls, to find their yearly value. Upon which it was found by an efchcator's inquifition, that they were then worth $6 l .19 \mathrm{~s} .8 \frac{1}{2} \mathrm{l}$. per anmm; whereupon Walter Tailboys, heir to Robert Ifumfranvil, was adjudged to pay the king that fum annually $(\mathrm{m})$. They were both in the poffeffion of the crown, $3 \mathrm{~K}$. Edward IV, by the attainder of Sir William Tailboys, after the battle of Hexbam-field. They were alfo in the crown, 10 Q. Elizabeth. The caftle and manour of Harbottle are now in the poffeffion of Percival Clenell, Efq. The caftle ftands on an eminence, overlooking the river Coquet, now in ruins. It was fo ftrong, $24 \mathrm{~K}$. Edward I, 1296, that the Scots in their march through Reedfdale to Hexbam in that year befieged it in vain for the fpace of two days (n). It was alfo a good caitle, $6 \mathrm{~K}$. Henry VIII, 1515 ; in which year, Margaret, Quecn Dowager of Scotland, daughter to K. Henry VII, mother to K. Fames V, grandmother to Q.Mary, and great grandmother to K. Fames VIth of Scotland, and Ift of England, retired to it by the appointment of her

(i) Harbottle, i. e. the ftation of the army. Camden.

Herbotell. Madox.

(k) Tefta de Nivill.

See Prudhow.

(l) See Otterburn.

(ai) Mich. Fin. anno 17 Hen. VI. Rot. I. b.

Madox's Baron. Angl. p. 244.

(n) Hol. Chron, vol, ii. p. 29g. 
brother, K. Henry VIII, after her marriage with Arcbbold Douglas, Earl of Angus. In this recefs her daughter, Lady Mary Douglas, was born, I518; afterwards married to the Earl of Lenox, $3^{6}$ K. Henry VIII, I 544 (0).

A mile below Harbottle-caftle, on the fame fide of the Coquet, is

Halyfone, a fmall villa, where Paulinus is faid to have baptized many thoufand Saxons on their converfion to Chriftianity $(p)$. Here was a priory of fix or eight Benedictine nuns, founded by Humfranvil, of Harbottle-cafle; who gave them the villa, impropriation and advowfon of Halyfon. Alice de Alneto gave them one toft and clofi in Hedrefon, now Etherfon. Roger Bertram, Baron of Mitford, gave them the whole wafte of Baldwinfwood, with liberty of grinding all their corn raifed upon it at any of his mills in the parifh of Mitford, multure-free, with liberty of pafture on the commons of Newton and Thropbill; which grants were confirmed to them, $25^{\text {th }}$ September, 39 K. Henry III, I255 (q). They had Corfonbope and Sintill. They had forty acres

(o) Hol. Chron. vol, ii. p. 838.963 .

(p) Camden's Britan. p. 859 .

Lol. Itin. vol. vii. p. 59.

(q) Rex archiepifcopis, \&x. Salutem. Sciatis nos pro falute animæ noftræ, et animarum antecefforum et hæredum noftrorum conceffife, et confirmaffe Prioriffee et monialibus de Halyfane donationes fubfcriptas, videlicet de dono Alefice de Alncto totam terram quam ipfa Alefia tenuit in villa de Hedrefone; fcilicet tres bovatas terræ cum una tofta et crofto, et cum omnibus libertatibus et afiamentis ad prafatam villam pertinentibus. Et de domo Rogeri Bertram totum bofcum qui vocatur Baldiwinefwode per has divifas; fcilicet a campo foffati monialium ex auftrali parte defcendentis in Sillefdoneburne, et per Sillefdoneburne afcendendo verfus occidentem ufque ad divifas de Thorntone, et fic per vetus foffatum verfus aquilonem ufque divifas $R_{0-}$ geri de Merlay, et fic per illas divifas ufque divifas de Stantone verfus orientem, et fic ufque ad 
of land in Keftron $(r)$. They had the impropriation and advowfon of Allenton, near Harbottle-cafle (s); where they had an hofpital ( $t$ ). They had the impropriation and advowfon of Caifonfide. They had alfo the advowfon of Harbottle chapel. Thefe two livings, and Halyftone, were confolidated by Richard Kellow, Bifhop of Durbum, by the defire of the Lord Richard Hunfranvil, their patron, who was admitted into holy orders to be their chaplain and vicar, for this good reafon, that the paftoral duties might be difcharged with honourable zeal and piety (u). They had foul

forlatum dictarum monialium verfus aquilonem, cum lib ro introitu ct exitu fine aliqua retenemento, et cum omnimodo afiamento, et omnibus commoditatibus et utilitacibus tam in xdificiis quam in omnibus aliis quæ predict moniales infra pradictas divifas facere volusrint vel potuerint, et cum libera multura bladi provenientis de eoden bofco ad molendina ipfius Rggeri in parochia de Midford, et cum communa ad cmnimoda averiaipfarum monialium in communibus pafturis de Nezvione et Throplill tunc habitis extra divifas earundem nonialium, ficut carte piedictorum Aige et Rogeri quas predicta monilles inde babent rationabiliter 'teftantur. Quare volumus, \&c. Dat, per manum noftann apud Nevum Cufrum fuper T)nan xxv die Septembris. Carta 39 Hen. III. m. 2. citat. Monaft. Angl. vol. i. p. 476.

(r) Priorifa de Flalyione tenet Haly/gone, Corfonboge et Sentill, in elemofinum, et nullum fervicium facit provincia de Riddifali. Ac tenet xl acras terræin Keftron, in elenofinam, et iullum facit ferviciur.

Efcaet. de arno I Ed. I.

(1) Pat. 50 Ed.III. p. 2. m. 32.

(t) Hofpitale de Aiwynton tenet molendinum et ferman de Sadburie per donationem Pbilippi Epifcopi Dunelm. et confirmationem dom. regis in puram et perpetuam elemofinam, et valet $\mathrm{xx}$ s.

Efcaet. de anno I Ed. I.

(u) Ricardus Epifcopus Dunolmen, is confolidavit ct univit ccclefian de Carfanfet, ct capellatn de Harbotell, ecclefiæ de Halyfane, et monialibus ibidem Deo fervientibus, \&c. Statuens quod de cætero unum et idem beneficium ecclefiaticum de Halyfane nuncupetur, et fructus ejufdem in proprios ufus veftros liberè converterentur. Sed ne animarum cura dicto beneficio, nec ejus partibus depereat, feu quomodo libet negligatur, nobilis viri domini Ricardi de Umfranvill advocáti et patroni veftri ordinatione, fuper hoc habita, ftatuimus, quod fit ibidem vicarius, \&c. Datum nono die Februarii Ann. Don. MCCCXI.

Regeft. Dunslm, citat. Monatt. Angl. p. 476.

VoL. II.

U u u

houfes 
houfes in Nerucafle upon Tyne (v). In the Lincalin-taxation, 20 Edzuard $\mathrm{I}$, their tem poralities are rated at $24 l$. At the diffolution, their

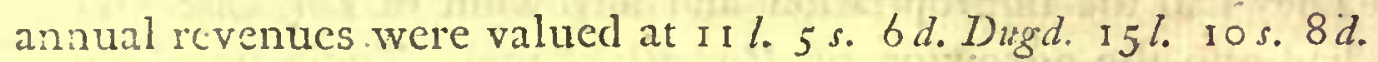
Speed (w). The fite of the priory, manour, and villa of Halyfone, were in the poffeflion of the crown, to Q. Elizabeth $(x)$.

Below Halyfone, on the north fide of the Coquet, is

Heppell, which was the barony of Ivo Tailboys in the reign of K. Henry JII $(y)$, and continued in his family down to the latter cnd of the reign of K. Edward III (z); when it came into the poffelfion of the Ogles of Ogle-Caftle, and was poffeffed by Cutbbert Lord Ogle, to Q. Elizabetb (a). It now belongs to his Grace the Duke of Fortland.

On the hill between Thropton and Rotbbury, is a circular intrenchment, with a clouble fofs and rampier, called Old Rotbbury:

(v) Barrie's Hitr. of Newc. p. 142 .

(w) Sp. Tamser's Notit. Monaft. ful. p. 394.

(x) Dom. Reina Elizaletha fuit feifita de et in manerio et villa de Halyfone, \&ic.

Ercaet. de anno ro Elizo

(y) Io, Tailbsis tene: in capite de dom. rege baroniam fuam de Heppell cum uxore, quxe fuit Willielmi de Bradford, quam nune habet ex cono dom. regis per fervicium unius feodi militis. Et omnes anteceffores tenuerunt prædictam baroniam in chinagium, \&c.

Tefta de $N$ evill.

(z) - Tailloys obiit feifitus de mancrio de Hopsell, Bickerton, Tofon et Tofjon, Flotertoil, Warton, et medictat. de Tricwhelt, per unum icul. veteris feoffamenti.

Efcact. de anno $43 E d$. III.

Ogle obiit feifitus de et in manerio de Hloppils. Efcaet. de anno 47 Ed: III.

(a) Sce Botball. 
an afylum and refuge in times of public danger, like the hills, called Cafle-Hill, and Ros-Caftle, before mentioned; ufed alfo as guard hills on the eftablifhment of a night watch before the union of the two kingdoms.

\section{About a mile from old Rotbbury, is the villa of}

Rotbbiry, which was the barony of Robert Fitzroger, Baron of Warkworth and Clavering, $6 \mathrm{~K}$. Fobn, by whom he was infeofled in that year; and had a grant at the fame time of a weekly mor ket on Thurfday, and an annual fair, to continue for thee doy viz. the even, and the day of St. Mattbew, and the day afi:with all rights, duties, cuftoms, tolls, and ftailages belonging :o a fair; alfo a free foreft, with all liberties, franchifes, and privileges belonging to it, except the goods of felons (b). Fobn, the lant Lord Clavering, granted the reverfion of it to the crown, $6 \mathrm{~K}$. Edzuard I (c). It was given to Henry Lord Percy, 2 K. Eirward III (d);

(b) Rot. Clauf. de anno 6 Joh. m. I4.

Robertus, filius Rogeri tenet in capite de dom. rege baroniam de Rotbeburie, cum pertinentibus, per fervicium unius feodi milit. quam dom. Foljannes rex ei dedit, et cum carta fua confirmavit. Et eft de illo tenemento nulla alienâtio, \&rc___ Tefta de Novill.

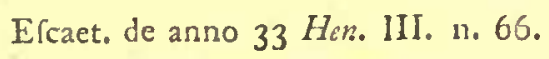

Matth. Paris annal. fub anno 33 Hen. III. 1249.

Heres Fobannis, filii Roberli, tenet de dom. rege in capite villam fuam de Rotheburie, Thrompton, Snyter, et novam Villam per unum feod. milit. veteris feoffamenti.

Efcaet. de anno I Ed. I.

Placita de juratis et affifis, apud Novum Caftrum fuper Tynam in com. Nortbumbr. anno -2I Ed. I. Rot. 7.I.

(c) Rot. Clauf. de anno 6 Ed. I. m. II.

(d) Pat, de anno 2 Ed. III. p. I. m. 20.

See Warkworth. 
516 ANTIQUITIES OF NORTHUMBERLAND.

and is now in the poffeflion of his Grace the Duke of Northum berland. It is in a low, but romantic fituation; the Coquet paffing by it on the fouth fide, croffed by a neat ftone-bridge of three arches; a beautiful vale opening gradually to view to the weft, enclofed almoft with hills and ridges of broken rocks. It confifts of three irregular ftreets, viz.

\section{Ratten-row, Market-1treet, Church-gate.}

The Market-crofs is nearly in the center. It hath three annual fairs; on Whitfon-Monday, 2I September, and on Thurfday before All-Hallows day. The church is in the form of a crofs, dedicated to All.Saints; a large clock and two bells in the tower; the floor within the communion-rails of chequer-work, of white freetone, and blue marble; the altar venerable. Againft a pillar by the fouth door is the effigies of a man in armour cut in ftone, ftanding, and in relief, with a piftol in his right hand, and a powder-bag at his belt; his head broken off. Near it is a funeral monument to the memory of George Fletcher, Efq; high Theriff of Northumberland, I710, who died within the year; $25^{\text {th }}$ January. He left to the parifh of Rotbbury 61 . per annum, for ever, out of his lands at Spital, for maintaining a fchool at Rotbbury. On the north fide of the chancel is a mural inonument of blue marble with the following infeription.

Near this monument lyeth the body of the ruly virtuous Miatron, Mary, wife of Gobu Thomlinfon, rector of Rothbury, who departed this life, Ost. $30 t h$, 710 . Aged 70 years. 


\section{ANTIQUITIES OF NORTHUMBERLAND.}

\section{Alfo,}

on her right fide, is interred the body of the faid Reverend Mr. Fobn Thomlinfon, a worthy benefactor to this parifh, who was rector above $4 \mathrm{I}$ years, who departed this life, May 23d, I720. Aged 69 years.

Bèlow it is the following infcription, on a fmall mural ftone of the fame. kind.

Benefactions of the Rev. Mr. Thomlinfon to the parifh of Ratbbury, \&c.

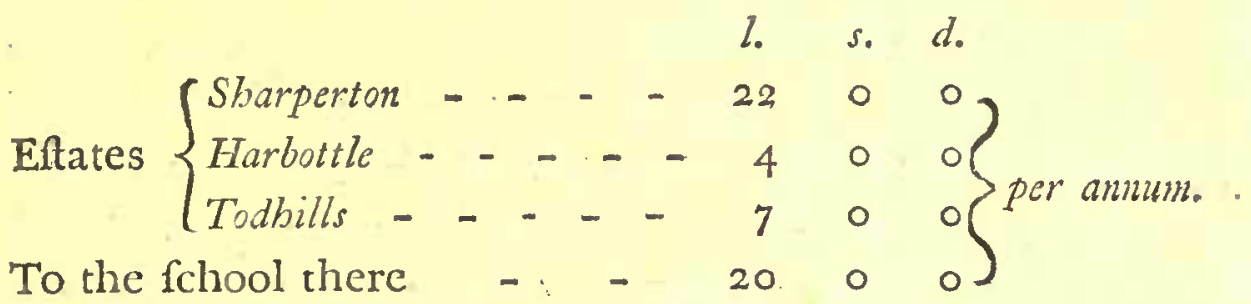

Building the fchool-houfe -1000.0

To the vicars of Wigton - $\quad$ - 130

Further augmentation - - 25000

To the fchool there - $\quad 100.0$

Building a college of matrons at

Wigton - - - - 200 0 0

Towards its endowment - - $35 \circ 0$

$$
\text { - - IOI 10 } 0
$$

On the brow of a hill on the fouth fide of the river, is

Whitton-Tower; the Humfranvil-arms on the weft fide; now the rectory-houfe. It was repaired by its late rector, the learned Dr. Thomas Sbarp, archdeacon of Nortbumberland, fon of. Dr. Sharp, archbihop of York, and father of Dr. Fobn Skarp, the prefent 
Archdeacon of Nortbumberland. It was alfo repaired by the prefent rector, the Revd. Mr. Birdmore, canon-refidentiary of York.

\section{Three miles bélow Rotboury, is.}

Brinkburn-Priory, founded in the reign of X. Henry $\mathrm{I}$, and dedicated to St. Peter (a), by Willian de Bertram, baron of Mitford, with the approbation of his Lady and his three fons.

His lordhip placed in it Black Canons or Canons Regular, of the order of St. Auftin, from the monaftery of St. Mary de Infula, and endowed it with lands out of his waftes, confirmed both by his Lady, Huwys and Roger, his elden fon and heir. He gave it Thornbaugh, Forderhangh, Papwirthbangh, Heley, and Over-Heley, and the woods belonging to them, alfo a wood to the eaft of Heley, extending from Linchburn to the river Coquet. To this gift he added another, viz. an annual prefent of twenty finhes out of his fifhery of Coquet ( $b$ ).

His grandfon, Roger, gave it 140 acres in his waftc-lands in Evenasd, with a large fhare of his waftes near Framlington, alfo liverty to cut timber out of his woods in the forets for its neceffary ufes, with the privilege of having game. Prince Henry of Scotlml, Earl of Northumberland, gave it a falt-work at Warkworth. He and his fon, William de Warren, of the family of the Earls of Waren, by the mother's fide, and named after them, confirmed

(a) St. Peter and St. Paul, in Pat. 15 K. Fienry VI.

(b) Monaft Angl. vol. ii. p. 203. Vide Cartam citat. ex regiftro hujus prioratus de Brinkburn penes Dom. Will. Howard de Nawortb caftro, 23Jan. 1638. fol, x.

Carta' 2 Goh. p. 1. m. fr. et'Pat. Hen. VI. p. I. m. 7. 
to it all its poffeffions and privileges (c). They were alfo confirmed by feveral royal charters (d). Half of the manour of Nethertyrwhyt belonged to it $(e)$; alfo the appropriations and advowfons of Long Horfley and Felton $(f)$. About the time of its fuppreffion it had ten canons. Its annual revenues were then valued at $68 \mathrm{l}$. I $9 \mathrm{~s}$. I $d$. Dugd. 77 l. Speed. It was granted to Gobn Earl of Warwick, $4 \mathrm{~K}$. Edward VI (g). In the fame reign it came into the poffeflion of George Fenwick, Efq; a commiflioner $\frac{1}{10}$ enclofures upon the middle marches $(b)$, by defcent from the antient family of the Fenwicks, of Fenwick-tower. In the reign of K. Charles 1, it belonged to Coloncl George Fenwick, in the fervice of the Parliament, and governor of Berwick upon Trueed. He was prefented with a $1000 \%$. for his fervice in Ireland, 164.7 . The next year he, and Colonel Lilburn, and Mr. Sanderfon, defeated Sir Richard Tempefl, and took feveral officers and gentlemen of note prifoners. With his horfe, and fome dragoons, he relieved Holy Ifland, and took Fenbam-cafte, garrifoned by the Scots after their defection. Cromwell, on taking Edenburgh, I650, made him go-

(c) Vide cartas Henrici et Willielmi comit. Nortbumbr. citat. in Monaft. Angl. vol, iid. p. 203, 204.

(d) Ibid Vide cartam, 43 Htn. III.

Regiftr. prædict. hujus priorat. MS.

Excerpta ex eodem inter collectan. Rog. Dodfurth, vol. 45 . fo. I.

Carta, 37 Hen. III. m. 16. de libertatibus.

- (e) Pat. 2 I Edvardi I. m. Plac. in comit. Nortbumbr. affiz. rot. 19. pro medietat. manerii de Nethertyrwbyt. Rot. 25 Dorfo; quo war. Rot. 7 . bis.

(f) Pat. io Ricardi II. p. I. m. 3. pro ecclef. de Horfley appropriand. ordinat, vicaria de Felton, in ecclef. Dunelm. A. D. I 314.

(g) Bp. Tanner's Notitia Monafica, fo. p. 39 r.

(b) Bp. Nicholfon's Border-Laws, p. 330 . 
vernor of it. He fummoned the governor of Hume-Caftle to furrender to General Cromwell. "The governor anfwered, "he knew "not Cromwell, and for his caftle it was built upon a rock." The ordnance playing againft it, he fent Colonel Fenwick thefe verfes:--

I William of the wafte,

Am now in my caftle,

And awe the dogs in the town

Shan'd garre me gang down.

Brecches were made in his cafte, and many rich goods were fpoiled. Gallant William was forced to furrender; the foldiery ordered to fhare his goods, except fome furniture and bedding for the accommodation. of his Lady.

The Colonel was a member for Berwick, and one of the parliament-commiffioners to treat with the Scots. Hc, and Sir. Artbur Hezeligge, Bart. Thomas Bowes, Henry Tempeft, and Fames Clavering, Efqrs; were five of the ninety-fix members not fuffered by Oliver Cromwell to fit in his packt parliament, 16.56.

On the fale of the lands of the Bithoprick of Durban by the parliament, he purchafed the borough of Sunderland, and the manour of Houghton le Spring, gth November, I649, for 2851 l. as. $6 d$. and parcels of land in Riebope, ift Fune, 1650 , for 2091 l. 1.6 s. 3 d. (i).

In the church of Berwick, a monument is erected to his memory with this infcription:-

(i) Broune Itikis. 
ANTIQUITIES OF NORTHUMBERLAND.

Col. Geo.

Fenwick of

Brenkburn, Efq;

governour of Berwick

in the year 1652 , was

a principal inftru-

ment of caufing this

church to be built,

and died March, isth

1656 .

A good man is a public good.

The laft male-branch of this family was George Fenwick, Efq; whofe daughter and heir, Elizabeth, married Roger Fenwick, of Stanton, Efq; by whom he had four children, the eldeft of which, Fobn Fenwick, marrying Margaret one of the daughters and coheirs of William Fenwick, of Bywell, Efq; occafioned the union. of the two antient houfes of Brinkurn and Stanton to that of Bywell, now all three poffeffed by Willicm Fenwick, of Bywell, Efq;

Brinkburn-Priory Atands under a hill, on the extreme point of a peninfula, by the north margin of the river Coquet, which in murmuring rills wathes part of it, and the garden-walls; cdged on the other fide with a femicircular ridge of thaggy rocks, covered with ivy, and a variety of plants-and fhrubs; among them the monntain-a $/$, and wild guelder-rofe, which with their white flowers, and fcarlet fruit, add greatly to the beauty of this agreeable folitude.

This venerable pile, and part of the church, in the cathedral form, have been entircly demolifhed, and the flones converted to VoL. II. 
build a dwelling-houfe, now alfo in decay. The large fquare Tower of the church, a fmall fpire or fteeple, many noble pillars and arches, fome of the fide-walls, and the dormitory, lately converted to a cellar, are ftill ftanding. The church-bell was removed to Durbam. The walls are fringed with various plants, with Pellitory of the Wall, and the greater Celandine, and among them the tall flowering Elder lives and flourifhes in ftrength and vigour*.

Six miles fouth-weft from Rotbbary, we crofs the rivulet of Font by a flone-bridge of one arch, and from the brow of the hill, above the fmall hamlet of Ew/ee, on the left hand, we have a profpect of

Netber-Witton, the feat and manour of the antient family of the Thorntons; of Roger Thornton, the celebrated patron of the corporation of Nereaftle upon Tyne (k), who died, $8 \mathrm{~K}$. Henry VI, 1429, after building his caftle or Tower of Witton (l); of Sir Roger Thornton, his fon, who married Elizabeth the daughter of Fobn Lord Greyfock, Baron of Morpeth ( $m$ ), and was high theriff of Nor-

- Since this was written, a Brief has been obtained for rebuilding part of this facred fabric.

\section{(k) Sce A'cuica, fle.}

See the chipter of aminent men, in vol. I.

(1) Anno domini 1429, in craftino circumcifonis, obiit Rogerus de Thornton, burgenfis villa Nivi Cafri, \& Dominus de Witton, qui caftrum ibidem conftruxit, et dedit nobis plumbum, quo operitur navis ecclefix noftra; pro quo Ragero et Agnete uxore ejufdem, et liberis, dicinus quotidiam miflam pro defundtis; et jacent in ccclefia omnium fanctorum in Novo Cafro.

Ex Martyrologio Novi Monaferii, de fundatore et præcipuis benefactoribus ejufdem; citat. Monaft. Angl. p. 916-17-18.

(m) Anno Domini 1440, in vigilia S. Katb. Virginis obiit Elizab. uxor Rageri Thornton, armigeri, qua fuit filia domini Johannis baronis de Crayporke___ Ibid. 
thumberland, 29, 36 K. Henry VII (n); his daughter Elizabeth marrying Sir George Lumley, of Lumley-Cafle, high fheriff of Nortbumberland, 2, 3, 8, 9, I0, I K. Edward IV; in the $4^{\text {th }}$ of which reign he was a Confervator of the Peace and Trewe between England and Scotland, and had the honour of knighthood (o); of Roger Thornton, 6 K. Edward VI ( $p$ ); of Sir Nicholas Thornton, Knt. whofe eftate was fequeftred by the parliament, 8th November, $4 \mathrm{~K}$. Charles II, 1652; of the late James Thornton, Efq; who left two daughters and coheirs. The old caftle is now in ruins. The prefent feat is a genteel modern ftructure, of white freeftonc, with a flat roof; the gardens to the weft; a plintation on a large flope to the eaft and north-eaft; a grafs-lawn before the fouth front; the parochial chapel by the footh-weft corner, dedicated to St. Giles; a paddock of deer between the foot of the lawn and the trout-Atreams of the Font, on the north fide; both fides of the rivulet beautifully thaded with wood; the village fmall, and irregular.

In fight from the fame place, to the eaft of Nether Witton, on the brow of a hill, and on the fame fide of the rivulet of Font, is

Stanton, which was the feat and villa of a younger branch of the Fenwicks, of Fenwick-Tower; of Sir Ralph de Fenwick, high Theriff of Northumberland, 7 K. Henry VIII $(q)$; who with Sir Jobrt de Fenwick, of Wallington, and other gentlemen, acquired great

(n) Efcaet. de annis, 29, $36 \mathrm{Her}$. VI.

(0) Bp. Nicholfon's.Border-Laws, p. 6r.

(p) -

(q) Efcaet. de anno 7 Hen. VIII. 
honour by their valour in an expedition againft the Scots, $5^{\text {th }}$ of July, I6th of the fame reign, 1524 ; when with 900 men they defeated, after a long and obftinate engagement, 2000 Scotchmen; in the fine country of the Merfe, and took 200 prifoners; Sir Ralpb being unfortunately taken prifoner, with feven others, in the purfuit, and fix more of his company flain; among the latter; a valiant young gentleman, of the name of Heron $(r)$ : of Ralph de Fenwick, 6 K. Edward VI, a commiffioner in that year for the enclofures upon the middle marches (s); of Richard de Fenwick, 10 Q. Elizabeth (t); of Willian de Fenwick (u); of Roger Fenwick, and of his fon, Fohn Fenzuick, Efqrs; (v). It is now in the poffeffion of William Fenwick, of Bywell, Efq; (w).

From the top of the hill, called, Liniel-Law, above Exulee, „by. a plantation, is an extenfive land and fea profpect.

At the foot of Liniel-Law, on the right hand, is a femicircular lake, between two young plantations; a rill entering it from the north, called, White Den-Sike.

From the lake we afcend a hill, called, Codgey-Crag, and come paft a large plantation on the left hand, and a park, called Rothe-

(r) Hol. Chron. vol. ii. p. 883 .

(s) Bp. Nicholfon's Border-Laws, p. 33r.

(t) Richardus Fenwick fuit feifitus de et in manerio et villa de Stanton, Abjheels, Limekinfeld, ac de et in medietate ville de Long Witton, cum terris in Farnelaw, Trubetly-Sheels, Efrenden, et Corupon.

Efcaet. de anno Io Eliz.

(u) Willielmus Fenwick, arm. filius Richardi, tenet in capite per fervic: milit. manerium de Stanton, cum pertinentibus. Efcaet. de anno 14 Car. I.

(v) See Brinkburn. (w) See Byruello. 
ley-Park, in which, on a rocky eminence, is an artificial Tower; two jaw-bones of a Whale by the entrance, feventeen feet and fix inches long; alfo two thoulder-blades of a Whale, three feet, fix inches long, and three feet broad; an extenfive land and feaprofpect from it. 'The park is full of deer and game. By the road-fide, at a fmall diftance from the Tower, is

Rotheley, a fmall, but well built, pleafant villa, on a rifing ground, belonging to Sir Walter Calverley Blacket, Bart. who built the Tower, raifed the plantations, and formed the femicircular lake before-mentioned, in imitation of nature.

From Rotbeley, two miles to the eaft, we have a view of

Long Witton, an irregular villa on an eminence, at the eaft end of which is the feat of William Sruinburn, Efq; brother of Fobn Swinburn, of Newcafle, Efq; who was high Theriff of Nortbumberkand, I755. It is a neat ftructure, well fheltered to the north by tall foreft trees; a plantation and thrubbery on each fide ; a grafslawn before it, to the fouth, from which is a molt beautiful and extenfive profpect; a pleafant walk from it fouthward by a gradual defcent for about a mile to a neat garden, under a bank of oaks by a rivulet; a fmall rill croffing it towards the middle, called, The Den-Burn; a grafs-terrace by the rivulet, the oppofite banks covered with bruthwood; about 150 yards of fire-wall in it, producing excellent fruits; a gardener's lioufe overlooking it from the brow of a hill by the road, farhed, and of grotto-work. Below it, to the north-eaft, is a winding-path through the bank of oaks to a ridge of rocks, under which are three medical fountains, called, Thurfon-wells.

A little lower down, the rivulet is croffed by the Roman caufway, vulgarly called, The Devil's caufway, a branch of the Hereman- 
ftreet ; very fair for a confiderable length in a pafture by the roadfide above the hill.

On the fouth fide of the rivulet, by the caufway, is a bank of wood belonging to the vicarage of Hartburn, cut into many agreeable walks. On the edge of the rivulet is a grotto, cut out of a rock. Some pleafing objects are let in here and there through the trees, the Latebra dulces $(x)$; as a falling ftream, the gothic Tower and the church at Hartburn, the rocks by Thurfonwells, and Mr. Swinburn's feat of Long Witton. This romantic folitude was formed by the prefent incumbent, the Rev. Dr. Sharp, archdeacon of Nortbumberland.

We now pafs on from Rotheley to Harterton-burn, croffed by a new ftone-bridge of one arch, and come to

Camboe $(y)$, i. e. the camp or fort on the hill, which was the villa and feat of Sir Robert de Camboe, high theriff of Nortbumberland, 28, 29, $30 \mathrm{~K}$. Henry III $(z)$. It is now in the poffeffion of Sir Walter Calverley Blacket, Bart. It is a fmall, well built, pleafant villa, with gardens and enclofures before it on gradual flopes, and a profpect from it of the fea.

Near a mile from Camboe, is

Wallington, one of the manours of the Barony of Bolbeck, (a), of which it was held by John Grey, commonly called Fobn de
(x) Hor. Epift. 16.
(y) Camhow.
Camhoe.

(z) Efcaet. de annis $28,29,30 \mathrm{Hen}$. III.

(a) See Bolbeck. 
Wallingtoin, $20 \mathrm{~K}$. Edward II (b), and 39 K. Edward III (c); alfo by Robert de Wallington, whofe only daughter and heir, Fobanna, married William le Strother; on whofe death it came, with its dependences, to Sir Fobn de Fenwick, of Fenwick-Tower, who married his youngeft daughter and coheir, Mary, in the reign of K. Henry IV. It was poffeffed by his family through a long fucceffion; by Gobn de Fenwick, I K. Henry VI (d); by Sir Henry de Fenwick, 28 th of the fame reign, in which year he was one of the confervators of the peace and trewe between the two kingdoms of England and Scotland (e); by Sir Gobn de Fenrevick, I6 K. Henry VIII $(f)$; by Sir William de Fenwick, high Theriff of Nortbumberland, 20, 3 I Q. Elizabeth $(g)$. He married Grace the daughter of Sir Fobn Forfer, Lord warden of the middle marches; her other fifter marrying Francis Ruffel, fon to the Earl of Bedford. His fon and heir, Sir Fobn Fenwick, Knt. was high Theriff of Nortbunberland, I 7 K. Fames I ; and created a baronet, 9th June, 4 K. Charles I, 1628. He was a reprefentative in parliament for the borough of Cockermouth, and made his election for the county of Nortbunber-

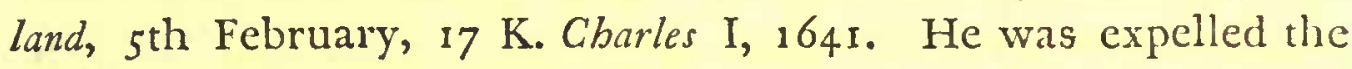
houfe, 22d. January, 1643 , for non-attendance, and giving his fervice to his fovereign, and William Fentuick, Efq; was chofen in

(b) Efcaet. de anno 20 Ed. II. n. 40.

(c) 39 Ed.III. n. 17 .

(d) Fuller's Worthies, p. 310.

(e) Bp. Nicholfon's Border-Laws, p. 34 . (f) See Stanton.

(g) Willielmus Fenwick, arm. fuit feifitus de mancrio de Fenwick et villa, et in manerio de Wallington et Walker, Cambow, Harterton et Harterton-Hall, Catcherficle, et medietate de Rybill, Greenlighton, et Gunnerton, et Hawick, cum certis terris et tenementis in Eaft Matfon, et de et in una villa vocat. Ejhenden, juxta Botball, et L. Wjiton et Hawick. Efcaet de anno ro Elix. 20 et $3^{1}$ Eliz. 
his room. He was taken prifoner the year following, with fome other gentlemen, thirty hoife, and arms, and a fumpter with rich clothes, between Nortlampton and Banbury, by the forces of the parliament, then called, Nerw. Nodles, from their eftablifhing their armies on a new model. His fon, Jobn Fenwick, was flain in the fame year at the battle of Marfon-moor. In the year. 164.5 , he was high theriff of Northumberland, and at the head of the militia for the parliament, having made his peace with them. The royalifts are faid to have had an intention of giving him correction, by furprizing him and the militia, but were prevented on his receiving private notice of their defign (b). He was readmitted to his feat in parliament for Northumberland, 26th June, 1646 , by a majority of 124 voices againt 73 (i). He firf married Catharine the daughter of Sir Henry Sling $\beta y$, by whom he had one fon, Fohn, above-mentioned, and two daughters, Catharine and Elizabeth. He afterwards married Grace the daughter of - Liorrain, of Kirk Herle, Efq; by whom he had two fons, William and Alin, and one daughter, Grace. His fon and heir, Sir Willian Fenwick, Bart. was a reprefentative in parliament for Northumberland, $6,8 \mathrm{~K}$. Charles II. He firn married Grace the daughter of Henry Stcpleton, of Wrishall, in Yorkflire, Efq; by whom he had one fon, Folm, and two daughters, the eldeft of whom, Grace, married Sir Thomas Lorrain, of Kirk Harle, Bart. He afterwards married Morgaret the daughter of Willian Selby, of Nervcafle, Efd; fifter to Sir George Silly, Knt. by whom he had two fons, and five daughters, viz. Willicm and Roger, Elizabeth, Dorothy, Ann, Margaret, and Mary. Iis fon and heir, Sir Fobn Fenwick, Bart. after the great fire of London, $18 \mathrm{~K}$. Charles II, 1666, built the great hall in Chrift's

(b) II'billock's Memor. p. 143 .

(i) Parliament.-Hilt of Engl. vol. ix. p. 23, 35 . 
Hofpital, in which the boys dine and fup. He married the right Konourable Lady Mary eldeft daughter of Charles Howard Earl of Carlifle, who after his execution for treafon on Tower-hill, $28 \mathrm{th}$, January, $8 \mathrm{~K}$. William III, 1696 , erected a monument with the following infcription to his memory in the cathedral church of rork.

This monumental pillar is erected and dedicated by the right honourable the Lady Mary Fenwick, eldeft daughter to Charles Howard Earl of Carlifle, as a teftimiony of refpect to the memory of Sir Fobn Fenwick, baronet, of Fenwick-calte in the county of Northumberland, her deceafed hufband; by whom the had four children, one daughter, and three fons: Fane, her eldeft, died very young, and was buried in a vault in the parith cluurch of St. Nicholas, in Nervaftle upon Tyze. Charles, having attained the age of fifteen years, died of the fmall pox : Willian was fix years old, and Howard a year and a half, when they departed this life. Thefe three fons do all lie with their father in the parith church of St. Martin in the Fields, London; near the altar, where he was intèrred January $28 \mathrm{th}, 1696$, aged 52 .

Lady Fenwick died, 27th October, 1708 , in the fifticth year of her age $(k)$.

Sir Fobn fold this, and other lordfhips, to the fecond Sir William Blacket, of Nerweafle upon Tyne, Bart. who was ligh Theriff of Northumberland, I689. He was fucceeded by his fon, Sir Willian Blacket, Bart. who died, 29th February, 1728. His only daughter and heir married Walter Calverley, Efq; fon and heir of Sir Walter Calverley, of Caiverley, in Yorkßire, Bart. (b), now Sir Walter Calver-

(k) Draki's Antiq. of York, p. 503 .

(l) Thorefoy's Tupogr. of Leeds, p. 116, I17, 118.

Voc. II.

Y y y 
ley Blacket, Bart. 27th Auguft, 1729. Sir Walter was high fheriff of Nortbumberland, 1732 ; and a reprefentative in parliament for the corporation of Newcafle upon Tyne from February 1734 , to the prefent timie. His feat is a modern genteel ftructure, of white freeftone and hewn work; a large garden to the eaft, in which is a pinery; alfo hrubberies, pieces of water, plantations, and other ornaments; a park-like field before it to the fouth, with a gradual hope to the rivulet of Wanfeck, croffed by an elegant ftone-bridge of three arches; an iflet above it ; the rivulet falling: below it in broken murmurs from artificial flopes of pebbles, forming a ferpentine canal between them for a confiderable fpace, in imitation of nature, bcautifully rural.

From Wallington, a mile and a half to the fouthwert, on the fouthern banks of the Wanfeck, we have a view of

Little Harle, one of the manours of the barony of Prudhow'; of which it was held by Gohndc Fenwick, 6 K. Edward VI (m). It came afterwards into the poffeffion of the Aynley's of Shaftoe (il); and is now the feat and lordhip of Gawein Aynley, Efq; who was high theriff of Northumberland, 1749. His feat is built on to an anticnt Tower, well preferved, with neat apartments in it; grear improvements about it by gardening, plantations, and enclofures.

We have alfo a view from Wallington of

(im). Bp. Nichalfon's Border-Laws, p. 274.

Jobiannes Finuick de parva Horle, fuit feifitus de et in parva Harle, cum centis terris in Donum, North Middleton, ac de et in certis terris in Llaigdon, Hawick, et in villa de Gum nerton. Efcaet. de anno 10 Eliz.

(n) Willichnus Aynfigy fuit feifitus de et in cap'tali.mefluagio de Eaft Shaffoe, et villà de Welt Shafios.

Efcaet, de anno io Eliz. 
Kirk-Harle, one of the manours of the barony of Bolbeck; which, with a mediety of the barony, and a mediety of ShotleyBire; belonged to Sir Robert de Harle, fon of William de Hurle, in the reign of K. Edward III, as was found by an inquifition, 38 th of the fame reign (o). It was afterwards poffeffed by the antient family of the Lorrains; by Robert Lorrain in the reigns of King Edward VI, Q. Mary, and part of Q. Elizabeth ( $p$ ), who was infidioufly and cruelly flain near his own houle by the banditti, called, Mofs-troopers, for his manly and firited endcavours to bring them to juftice; a ftone-pillar crected in memory of it, ftill ftanding: by Thomas Lorrain, wis fon and heir, a firm and zealous friend to K. Charles I (q); who dicd, 24th October, I K. Charles II, at the age of 35 , and was interred in the fouth inle of St. Nicholas's church in Nerwaffle upon Tyne: by his fon, Thomas Lorrain, who was created a baronet, 26th September, $16 \mathrm{~K}$. Charles II, I664. He married Grace the eldeft daughter of Sir. William Fenvick, of Wallington, Bart. by whom he had fourteen fons, and five daughters. His fon and heir, Sir William Lorrain, Bart. firf married the daughter of Sir Fobn Laurence, by whom he had noiffue. He afterwards married the daughter of Richard

(0) Robertus de Harle, miles, filius et hæres Williclmi, obiit feifitus de et in medietate basoniz de Bolbeck, viz. Bywell, de et in medietate de Styford, Brome-haugh, Shotlcy, villa de Heley, et manerio de Kirk-harle, \&c.-

Eicaet. de anno 38 Ed. III.

Willielmus baro de Greyplock, filius et hæres Radulphi, dedit Roberto de Harle, militi, medietatem de Shotleyfoire in Efcambium pro medietate villx de Angerton.

Ex Autographo perantiquo.

(p) Robertus Lorrain fuit feifitus de et in manerio de Kirk Horle, cum gleba ecclefiæ ibidem, cum terris in Trewick.

Efcaet. de anno yo Eliz.

(9) Thomas Lorrain, filius Roberti, tenet de rege, ut de baronia de Bolbcck, per fervicium milit. manerium five capitale mefluagium de Kirk Harle, ac unum meffuagium five tenem. in Greatulawo, ac tertiam parten villa de Trewbet, ac duo mefluagia et terras ibidem.

Efcret, de anno 14 Car. I. 
Smith, of Enderby, in Leiceflerßire, Efq; by whom he had two fons, and four daughters, viz. Richard, Charles, Grace, Dorothy, Mary; and fane. His eldeft fon died in his life-time. His younger fon and fucceffor, Sir Charles, was high theriff of Northumberland, 1743. He left four fons, now in their minority, the eldeft, Sir William, fucceeding him in honour and eftate; and his fecond fon to the feat and eftate of Richard Smith, of Enderby, Efq; abovementioned. The whole parifh of Kirk Harle belongs to. Sir William, except Harvick, feparated from it on all fides, of which he has only a part. His feat is in a low fituation; rebuilt by his. grandfather, Sir William; well,heltered by tall foreft-trees.

\section{Four miles from Wallington, on the left hand of the road, is}

Bolham, a fmall, irregular villa, on a rifing ground, which was the barony of Sir Walter de Bollam, Son of Sir Gilbert, to whon it was granted by K. Fohn; and was poffeffed by his fon, and Fobn and Fames de Calcey, in the reign of K. Henry III (r); and by Alice de Bolbam, and Fames de Calcey, and his wife Alice, I K. Edward I (s). We find a mediety of it afterwards poffeffed by the antient family of the Raymes's; by Robert Raymes, high fheriff of Northumberland, 20, $2 \mathrm{I}$ K. EdwardIII (t); by William Ray-

(r) Jobamms et facobus de Calcey tenent de dom. rege in capite baroniam fuam de Bolam, cun filio Wa'teri, filii Gilberti, de dono dom. regis Fohanni, per fervicium iii. feod. milit. Et omnes antecefiores fui per eund, fervicium tenuerunt poft conqueftum Anglia, et de illo tenemento nulla eft alienatio, \&rc.

Tefta de Nevill.

(s) Alicia de Bolam, Facobus de Calcie, et Alicia uxor ejus, tenent in capite de dom. rego Bolom, cum fuis membric, viz. Lighton, Rougblies, Burnton, Tbornbrough, Cowpon, parvam Whittington, Ayden, cum caftro, Belfowe, Bradford, Trewick, Denum, et Tunfall, per, tria coda militaria veteris feoffamenti.

Efcaet. de anno i $E d$. I.

(t) Elcaet. de annis, 20, 2 I Ed. III. 
mes, I 6 K. Richard II (u), and 3 K. Henry IV (v); by Edward Raymes, 35 K. Henry VI (w); by Robert Raymes, a commiffioner for enclofures upon the middle marches, $6 \mathrm{~K}$. Edward VI $(x)$, and high theriff of Nortbumberland, II Q. Elizabeth (y); by Henry Raymes, Efq; I4 K. Charles I $(z)$.

In the church of Bolbam is the effigies of a Knight Templer cut in ftone, in the ufual habit and attitude. At a fmall diftance from the villa is the Campus fceleratus, called, Gallorv-bill, ufed by the barons for the execution of criminals, before the Furca, or power of hanging, was taken from them.

There is a fquare piece of ground in the villa with a double trench; in length 120 yards, and in breath 80 ; a raifed portway leading to it. It was the keep or fort for the fecurity of the town, which tradition fays was antiently fo large, that it: confilted of 200 houfes, flated.

(u) Efcaet. de anno 16 Ric. 11 .

(v) 3 Hen. IV. n. 2 I.

(w) 35 Hen, VI.

(x) Bp. Nicbolfon's Border-Laws, p. 332 .

Robertus Raymes fuit feifitus de et in medietate manerii de Bölam, cum villa, et de et in Shortflat, South Middleton, cum medietate de Aydon, cum.castro, L. Witton, et certis terris in Hawkwell, et Stamfordham.

Efcaet. de anno ro Eliz.

(y) Efcaet. de anno II Eliz.

(z) Henricus.Raymes, arm. confanguineus et hares Roberti, tenet in capite unum capitale meffuagium, vocat. Shortfat, ac duo mefluagia et terras ibidem, ac medietatem manerii de Aydon, cum caftro, et fex mefluagia et terras ibidem. Efcaet. de anno 14 Car. I. . 
On Bolbam-moor, the Roman caufway, a branch of the Hercmanftreet, is very fair; nine feet broad, and saifed near a foot above the common level of the ground. By the fide of it is a cefpitious mount, with two upright ftone-columns; funeral and relious memorials.

On the north-eaft fide of the fame moor, is a rock trenched round, with foundations of buildings.

On the right hand of the road, near Shortfat, we have a view of

Cap-Heaton ( $a$ ), the feat and manour of the antient family of the Swinburns; of Sir William Swinburn, I 2 K. Henry VI (b), whofe anceftor, Sir Thomas Swinburn, with Lord Berkley, and Henry May, Efq; took fourteen French thips carrying provifions and ftores to their fleet in Milford harbour, 6 K. Henry IV, I405 (c): of Sir Fobn Swinburn, 4 K. Edward IV (d); of Sir Fobn Swinburn, a reprefentative in parliament for Nortbumberland, I Q. Mary, 1554(e); of Sir Thomas Swinburn, 1o Q. Elizabeth (f), high theriff of Nortbun-

(a) Cap Heaton.

Great Heaton.

Heaton Caftle.

(b) Efcaet. de anno i2 Hen. VI.

Fuller's Worthies, p. 310.

(c) Hol. Chron. rol. ii. p. 531 .

(d) Efcaet. de anno 4 Ed.IV.

(e) Briwne Willis.

(f) Thomas Swinburn, miles, fuit feifitus de et in manerio de Cap-Heatow, White.Houfe, Slaterford, tertia parte de Brenkley, medietate de Cbollerton, cum terris in Haughton, et Bowfdon, ac in villa de Ingram.

Efcaet. de anno ro Eliz. 
berland, 4 K. Charles I $(g)$; of William Swinbarn, Efq; i4 K. Charles I. (b), whofe eftate was fequeftred by the parliament; of his fon; Sir Fobn Sivinburn, created a baronet, 27 th September, $12 \mathrm{~K}$. Charles II, I660. He married Ijabell the daughter of Sir Henry Lawefon, of Brough, in Corkfsire, Bart. by whom he had thirty children, eighteen of whom lived to be men and women. His fon, Sir Yobn Swinburn, Bart. married Mary the daughter of Antbony Englefield, Efq; of Whitenights, near Reading, in Berkghire. His eldef fon, Sir Fobn Szwinburn, Bart. died unmarried, in April, 1762; and was fucceeded by his brother, the prefent Sir Edward Swinburn, Bart. His feat is modern and handfome, built about the year 1668 ; the former feat being an old caftle, a fair building, according to Leland (i), moted round. Before the fouth front is a grafs-lawn, and a large park-like enclofure, with fmall clumps of foreft-trees, the fpire of the tempiato at Belfay appearing through them from one view, and the precipice and villa of Harnbam from another.

In the time of Sir Foln Swinburn, Bart. father of the late Sir Fobn, fome Ronan facra and coins were found by his labourers in. making a caft for a hedge in a lane near his feat, called Silver-

(g) Efcaet. de anno 4 Car. I.

(b) Willielmus Swinburn, arm. filius Thome, tenet de manerio de Piudhow, per forvicium militare, maneria de Chollerton et Cap-Heatoll, et Grange de White-Houfe juxta Cap Heaton: ac tenet in capite per fervic. milit. diverf. hamlett. mefluag. terras, et tenem. in Tynedale, vocat. Haughton, et Haughton-Strother, Ruhburn, Edburn, Leop heath, Otterftanley, Buteland, Gofton, Dtiden; ac tenet de rege, ut de manerio de Mitford, per fervic. milit. diverfa meffuag. terras, ct tenem. in Brcnkley; ac tenet in capite per fervic. milit. diverfa mefluag, terras, et tenem. in Lowick, ct. Bradford, jufta Belfow.

See Edingbam-cantle:

Efcact. de anno 1.4 Cian. I.

(i) Lel. Itin. vol. vii. p.61.

lane, 


\section{6}

ANTIQUITIES OF NORTHUMBERLAND.

lane, from that difcovery. They fecreted all the coins, and fold them. The facra, or facrificing veffels, were of filver. They fold molt of thefe likewife, after breaking the bottoms out of fome, and the handles and ornaments off others. They prefented thefe following to Sir Gobn, now in the poffeffion of Sir Edward.

1. A Sympalum, weighing 26 ounces.

2. The bottoms of three others; one weighing a little more than a pound, the other half a pound.

3. The handles of three more, with beautiful figures in relicf, and gilt. Upon one is like the buft of a Roman emperor; two fmaller figures on cach fide, one a fhepherd holding a crook in his left hand, two or three theep lying by his fide; the other refembles a poor man looking towards the emperor in a fupplicatory attitude, his body bending, and refting upon a ftaff, feemingly with both hands, with fomething like a bundle on his back. Below, on the middle of the handle, is a winged Mercury, in a fitting pofture, with a Caduceus in his right hand, his left inclining on a bench or feat, grafping fomething like a ball, with a cock under him, in the attitude of crowing. At the bottom are two other deities, ftanding; one a Diana, in a loofe robe, holding a fpear in her right hand, a dog looking up in her face, her left hand refting on her hip; the other is a Silenus, naked to the feet, holding a bunch of grapes in his right hand, and a nympian or water lilly in his left, with a canthera or jolly flaggon by him, fwelling with the grape at the brim.

On another handle are the figures of three animals flain for facrifice; one a lion, another a ftag, and a third a wild boar. 
On the third handle is the figure of a prieftefs before an altar facrificing, holding incenfe in her right hand, and a Thyrfus in her left; above her head, is like the head of a bearded emperor, and at the bottom two other fmaller figures.

4. Part of a handle, whercon is a figure of Mars, in armour; and below, a Flamen before the altar of a temple in a grove fitcrificing; gilt, and in relief.

5. A figure of Hercules and Antaus wrehling-

Herculis Antæum procul a tellure tenentis (i).

finely executed; the lyon's fkin and club lying by them, on the left hand.

6. A Neptune, naked to the waint, in a reclining porture, holding his trident in his right hand, and an anchor in his left.

The lane, in which thefe antiquities were found, is only about a mile from the Roman caufway. They feem by the workmanfhip to be as antient as the time of Agricola, who made the grand roads in Britain, and in whofe time the Romans wore beards, as expreffed in the two figures; it not being the cuftom for that polite people to wear any from the 454 year of the city till the emperor Hadrian ( $k$ ). The Roman Hercules, and his two rival heroes in gymnaftic feats, Thefeus and Perithous, are fet in no very favourable light by the virtuous Mantuan, who reprefents them as trying their ftrength in Pluto's regions, and doing acts of violence there; intimating, that the fpirit and temper men die in, attend them beyond the grave (l).

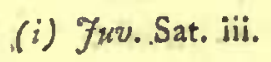

(k) Monf. Spon's Refearches curieus.

(i) Virg. Ea. vi. ver. 392, \&c. 


\section{$53^{8}$ ANTIQUITIES OF NORTHUMBERLAND.}

Near the Roman caurtway, in fight from the road by Shoriflat, and from Cap-Heaton, is

Harnbant, or Hernhan, i. c. the hamlet by the military way: Harn or Hern being a contraction of the Roman Hermen, from Hermes, Mercurius, the goct of travellers, and Cuffos Manium and highways; and of the Saxon Hereman or Hareman, a military roatl. It ftands on an eminence, and has been a place of great ftrength and fecurity; a range of perpendicular rocks of rag-ftone on one fide, and a morafs on the other; the entrance by a nariow declivity to the north, which in the memory of fome perfons now living had an iron-gate. The manour-houfe is on the fouth-went corncr of the precipice, built on to an old torver. In the reign of K. Charles II, it was the feat of Colonel Pritip Babington, governor of Berwick upon Tweed. 'He married Catharine the widow of Colonel George Fenritck, of Brinkburn (m). She was the eldeft daughter of Sir Arthur Hezelrigge, of Nojely, in Leiceferfoire, Bart. by Dorothy Greenville, fifter to Robert Lord Brook. She was born at Brooke-houfe, in London, in November, 1635. She was interred in a lead-coffin, the next day after her death, in a vault cut out of the folid rock below the old tower, now belonging to Mr. Thomas Leighton, by whofe favour I faw the fepulchral grot, in company with the Rev. Mr. George Fenwick, vicar of Bolham, 1760 ; moft of the coffin then remaining, and fome of the bones. On a pane of glafs in the middle window of Mr. Leigbton's houfe her name and the colonel's, with the date of the year, are written with a diamond.

Philip Babington, Sept. 5, 1668.

K. Babington, Sept. 7, 1658.

(m) See Binkburn. 
On another

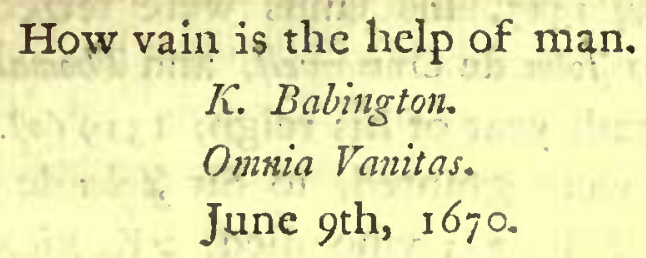

It is faid, the was denied Chriftian burial by an excommunication for contempt of ecclefiaftical cenfure, which was the reafon of her fepulture in the curious grot in the rock. The colonel furvived her, and marrying again, had feveral children; the youngeft of whom he named after her, Catbarine, who married a gentleman in rork/bire, in whofe poffeffion is the pedigree of his family, wherein are portrayed the chiefs of it in full length, and among them Sir Foln Babington, one of the fix young knights chofen by K. Henry IV, when in France, to go upon a defperate enterprize, which by his own petition he undertook himfelf, ufing thefe words on his taking leave of the king, Foy eft tous, i. e. Faith is all, brandifhing his fword. Having performed it, beyond all human expectation, the king gave him for his cret, a flaming dragon's head, with this motto, Foy eft tous, proceeding from its mouth; with which he ftands diftinguirhed among his familychieftains, in armour.

Two miles from Harnban, on the right hand of the road, near the $3^{\text {th }}$ mile-ftone, and in fight, is

Belfay (n), the feat and villa of the antient family of the Middletons; of Sir Fobn de Middleton, in the reign of K. Edward II,

(n) Beljizw.

$\left.\begin{array}{l}\text { Belfo. } \\ \text { Belfay. }\end{array}\right\}$ Rot. Efcaetr. Nortbumbr. 


\section{$54^{\circ}$ ANTIQUITIES OF NORTHUMBERLAND.}

who being leagued with the king's enemies, the Scots, Sir Gilbert de Middleton, and Walter Selby, I3 7 , his lands were feized for the king's ufe, and given to Fohn de Crombwell, and Thomas de Bambrough, clerk, 3d April, i 2 th year of his reign, I319(0). On the death of Crombwell, they were granted, to Sir Fobn de Striveling, 12th June, 34 K. Edward III ( $p$ ); who dicd, 2 K. Richard II ( $q$ ).

(0) Rcx omnibus ad quos, \&cc. Saluten. Sciatis pro bono et laudabili fervicio quad dilectus nofter Fobannes de Crombell nobis impendit, et ad recompenfum centum marcarum térræ per ann. quas fibi promifimus providere nuper de affenfu prælatorum, comitum, baronum, et aliorum pro cura de regno noftro nobifcum in ultimo parliamento noftro apud Eboracum exiftent. dedifimus ct conceflimus pro nobis et hæredibus noftris predicto Fobanni manerium de Burnton in parochia de Emeldon, cum medietate villæ de Preflon, cum pertinentibus, in comit. Nortbumbr. et mcdietatem villa de Belfsw, in eodem comit. quæ fuerunt Fohonnis de Midlleton; ct qua ad manum efcaetoris nofti per forifcum ipfius Fobannis de Middleton, pro eo, quod Scotis inimicis et rebellis noftris, contra nos, et fidem noftram, adhælit, devenerunt, habend. et tenend, prædicto Fobanni, et hæredibus fuis mafculis de corpore luo legitimè procreatis, de capitalibus dominicis feodorum illorum per eadem fervicia, per quæ manerium et medietates prædictre, cum pertinentibus, antiq; ad manum noftrum per forifcum prædicti $\mathcal{F}_{0-}$ bannis de Middleton, ut præmittitur, devenerunt, tenebantur, in perpetuum, falvire cujuflibet. Et $f_{1}$ idem Folonnes de Crombuell fine harede mafculo de corpore fuo legitime procreato obicrit, tunc manerium et mcdietates prædi尺tx, cum pertinentibus, ad nos et hæred bus noftris integre reverterentur. In cujus, \&c. Telte rege apud Eboracum, 3 die Aprilis per ipfum regem, Ed. II. Anno regni 12.

Pat. 12 Ed. II. p. 2. m. 16.

(p) Rex ommibus ad quos, \&c. Saluten. Sciatis quod cum nobis 8 vo dic Oetobris, ant no regni noftri Anglice nono, pro bono fervicio quod dilectus et fidelis noftr 5 Fohannes.de Strivelin nobis impenderat, conceflumus pro nobis et haedibus noftris maneria de-Bcllow et Nezvl.nds, cum pertinentibus, ac omnes alias teiras et tenementa, et redditus, cum pertinen. in: Belfow, Burnton, Prefon, Warnbam, et villa Novi Cafri fuper Tynam, ac alibi in comit. Northrimbr. qux fuerunt Fohannis de Middleton, qui contra d m. Edvardzm nuper regem Anglia patrem noftrum Sectis inimicis. ipfius patris noftsi adhrefit, et qua Fobannes de Crombwell, et 7\%om is de Bambrough, clericus, tenuerunt ad terminum vita eorum, ex conceffione ipfius patris noftri, quæe etiam poft mortem ejufdem . Fshanris de Crombruell et Thoma de Bambrough, ad nos, et hæredibus noftris severti debuerunt, prefato fobanni de Strivelin et hæredibus fuis remanerent in perpetuum, ut in litteris noftr's parcntibus inde confectis plenius continetur, 
This villa and other lands were afterwards reftored to the family, and were poffeffed by Sir Gobn de Middleton in the reign of K. Hen$r y \mathrm{~V}$, who was infeoffed in the manour and villa of Burnton, near Bumbrough, \&c. conjunctly with his wife Chrifian, as was found by an inquifition after their deaths, roth of the fame reign : by their fon and heir, Sir Golm de Middleton, then upwards of forty years of age $(r)$; and returned among the gentlemen of Northumberland

per fervicia debita et confueta in perpetuum, fimiliter cum exitibus, et proficuis inde a tempore mortis prædicti Fohannis de Crombwell, qualitercunque præceptis. In cujus, \&xc. Tefte icsé apud Wefmonaf. 12 die Junii.

Per ipfum regem et confilium.

Pat. 34 Ed. III. p. 2. m. 3I.

(q) Juratores dicunt fuper facrum ruum, viz. Robertus de Clavering, Chr. Robertus De la val, Chr. Alexander de Creffwell, \&c. Quod fohannes de Striveling, Chr. obiit anno 2do regis. Ricardi II, feifitus communiter feoffatus cum uxore fua de manerio de Burnton, in comit. Northumbr. \&ac, quod quondam fuit Fobannis de Middleton, Chr. et quod tenetur de dom. comite Nortbumbr. per fervic. milirare.

Inquifit. ex bundello efcaetr. Turri Lond. n. 49. capta apud Novum Cafrum fuper Tynam Die Jovis in craftino S. Michaelis Archangeli, anno 2 do regis Ricardi II, coram Gilberto de Curwen, efcaetr. dom. regis in com. Nortbumbr. Cumbr. et Wefmorl.

(v) Dicunt juratores fuper facrum fuum, viz. Robertus Lifle, Chr. Fobannes de Whitfield, Nicholaus Turpin, Simon de Weltden, et Adam de Killingworth, Quod Chriftiana, nuper uxor: Fohannis de Middleton, militis, defuncti, tenuit die quo obiit communiter feoffata, cum prædicto Fohanne, nuper viro fuo, manerium et villam de Burnton, juxta Banabrough in comic. Northumbr. et advocationem cantariæ capellæ dicti manerii, et fervicium Roberti Herbottle, qui Rabertus tenet in dicto manerio iv mefluag. et iv terras hußand. eifdem meffuagiis pertinentes in villa de Prefon, juxta Doxford, pro homagio, fidelitate, et fecta curire dicti mancrii de Burnton, de tribus feptimanis in tres feptimas, et per redditus xii $d$. per ann. et per fervicium molendi omnimodo blada dictis terris crefcentia ad molendinum de Burnton, ac reparandi et fuftentandi dietummolendinum quoties et quando neceffe fuerit, quæ rata portione dictarum terrarum ficut alii tenentes ibidem tenentur reparare fecundum tenorem certarum terrarum inde confectarum: Et fervicium Willielmi Heron, de Whittingham, qui teret de dicto manerio de Burnton unum tenementum in Prefton, ct unam terram hußand. cum perti-

nen. 
berland by the commiffioners, $12 \mathrm{~K}$. Henry VI(s): by Sir Fobn de Middleton, high Theriff of Nortbumberland, I K. Edward IV $(t)$, and a reprefentative for it in parliament, 12 th of the fame reign : by Thomas Middleton, a commiffioner for enclofures upon the middle marches, 6 K. Edward VI (u); by Robert Midaleton, to Q. Elizabetb $(v)$; by Thomas Middletoth, one of the parliament-commiffincrs for fequeftring lands in Nortbumberland, $19 \mathrm{~K}$. Charles $\mathrm{I}_{\text {; }}$ $1643(w)$; by Sir William Middleton, created a baronet, 24th Oetober, I4 K. Charles II, I662; mentioned by bilhop Kennet for his kindnefs to a non-conforming minifter at the reftoration, $\mathrm{Mr}$. Calvert, A. M. of Clare-Hall, in Cambridse, whom he made his

non. cidem tenemento ibidem pertinen, pro homagio, fidelitate, et fecta curia, ut pradici. tur, et fer redditus iii d. per ann. Et fervicium molendi, et reparandi, ut proedictum èn : Et ferviciun Henrici Heron, militis, defunsi, qui tenet de dicto manerio unum tenementum ibidem in Prefon per fervicium, et pro redditu iiid. per annum. Et fervicium Fohannis de Horßey, qui tenet villam de Scranwood, cum pertinentibus, in dicto manerio de Burnton, per fervicium falvendi inde per annum iii s. iv $d$. Et dictum manerium de Burnton, cum fuis pertinentibus, tenentur de Henrico comite Nerihumbr. ut de dominico fuo de Alnwick; et vaJent per annum, his diebus, xls. et non amplius propter deftructionem Scctorum, et fterilitatcm patriæ. Et dicunt quod Fobannes Middleton, miles, eft hæres propinquior et filius dictorum, Fohannis Middleton, militis, defuncti, et Chrifiane uxoris ejus, et eft ætatis Ix auno et amplius.

Inquifit. ex bundello efcaetr. Turri Lond. n. 54. capta apud caftrum dom. regis de Novo Cafro fuper Tynam, in coinit. Northumbr. Die Jovis proximè polt feftum Da minica in Ramis Palmarum, anno ro regis Hevrici V.

(s) Fuller's Worthies, p. 310.

(t) Efcaet. do anno I Ed. IV.

(u) Bp. Nicbalfon's Border-Laws, p. $33^{2}$.

(v) Robertus Middleton, arm. fuit feifitus de et in manerio de Belfow, Harecheferilaw, parw.a Sevinburn, medietate villa de Bradford, cum medietate parfonagii de Mitford.

Efcaet. de anno ro Elix.

(wi) Parliament. Hitt. of Engl. vol, xii, p. 233. 
Chaplain, and tutor to his only fon, after the cleath of Sir William Strickland, of Boynton, in whofe family he had been chaplain and tutor from the time of his leaving his parifh of Topcliffe, in York Bire, till hïs coming to Sir William $(x)$ : by his fon, Sir Fobn Middleton, Bart. high theriff of Nortbunberland, 1 O Q. Ann, I 7 I ; by the late Sir William Middleton, Bart. who reprefented Nortbumberland in fix parliaments, and was one of the oldeft members of the houfe of commons at the time of his death, I Oetober, 1757 ; by the prefent Sir Fobn Lambart Middleton, Bart.

Sir Fibn is named Lambart from his mother, Frances Lambart $(y)$, daughter of Foln Lambart, of Calton, in Yorkflbire, Efq; defcended from William Lambart, who married Gundred, granddanghter to K. William I, widow to Roger Beaunont, Earl of Warwick, of the fame name with her mother, wife to William count de Warren, whom the king enriched with many feigniories. This Lady, of the blood royal, was mother both to Walleron Earl of Warwick, and to Henry de Lambart, ftandard-bearer to K. Henry II, A. D. 1167 ; between whom and a Scotch knight, Sir Alexander Olyfard, fome difference arifing, to be decided in the ufual way, by combat, the King of Scots, by his royal interpofition and favour, effected a reconciliation, on the requelt of $\mathrm{K}$. Henry $(z)$. He mar-

(x) Bp. Kennet's Hifr. Regift. p. 899 .

(y) Lambart.

Lambert.

Lambard.

Lamberd.

(z) Rex Scotic univerfis in Cbrifo ecclefix fidelibus, falutem:- Sciant omnes ad quos literæ iftre pervenient, quod anno ab Incarnatione Domini, MCLXVII ${ }^{\circ}$. in prefentia mea, et venerabilium virorum, clericorum, et laicorum apud Stryvelyn, talis facta 


\section{ANTIQUITIES OF NORTHUMBERLAND.}

married Alice, fifter to Willian Maundeville, Earl of EJex, by whom he had Foljn Lambart, Efq; who was prefented with a very confiderible eftate by his uncle, the Earl, at Skipton, in Yorkfloire (a), afterwarls the feat of the family till their removal to Calton. He was father to Sir Edmund Lambert, Knt. and to Thomas Lambart, Theriff of London, 7 K. Henry III, 12 I 3 ; and grandfather to Edmund Lambart, Efq; who married into the family of Calverley, of Calverley in YorkAsire, lately the feat and eflate of Sir Walter Calverley, Bart. and of his fon, Sir Walter Calverly' Blacket, of Wallington, in this county, Bart.

cft compofitio inter Hsuricum de Lambart legatum ab Anglia, et A'exandrum de Olyfard, mili$\mathrm{tcm}$, quos ad judicium finaliter per me fiendum Henricus rex Anglice totaliter referebat in caufa duellii ipfis conceffi par marifchallum Anglie proprie quafdam accufationes per unum adverfus alterum habitas, et fidei interpofitione utrinque firmata, fcilicet, quod coram me venict uterque eoruin armatus, paratus ad congreflum, et me fuadente totam calumniąm yqualin quifque habebat adverfus alterum confeftim deponet et remittet ex corde, et dignitas utriufque lalva crit, et jungent dextras, et fuper evangelia jurabunt $S e$ in æaternam futuros veros amicos, falvo officio quod feorfim gerunt adverfus regem fuum. Et omnia hre facta funt in prafentia mea. His teftibus, Ingelram epilcopo Glafcuenfi, Nicholuo Cancellario, Richardo capellano, David de Olyfard, Willielmo Dolepen, Thoma de Maundevill, Willielmo de Latimer', Petro de Colvill, Bernardo filio Briani, Rogero Camerario, Alexandio de Nevill, et multis aliis, Siolis et Anglis.

(a) Omnibus fanctax patribus ecclefix filiis has literas yifuris et audituris Williclmus de Maundevill, comes de Efex, falutem in Domino. Novit univerfitas veftra pio amoris et cognationis Intuitu conceffife et hac prafenti carta mea confirmafte Fobanni de Lambart, qui tuit flius Henrici de Lambart, et Alicia, fororis mex, et haredibus fuis, onnia illa tenementa qua Golfridus de Mandevill, comes, frater meus, eis dedit io villis de Evcruyke, Skip$k n$, et Broughton, in terris, bominibus, in redditibus, in pratis, in marifcis, in pafturis, in warrenis, et in aquis, et omnibus aliis rebus, locis, et libertatibus, infra villas et extra cum liberis introitibus et exitibus, et onnibus aliis pertinentibus, ficut carta fratris mei, comitis, teftatur: habenda et tenenda libere, folute, et quicte ab omnibus fervitiis, et exactionibus. Et ut hac mea conceffio et cartæ confirmatio firma fit et ftabilita, prefentem paginam figilli mei munimine corroboravi. Teftibus his, Henrico de Lambart, Waltero de Preflon, Radulpho Anfrill, Facobo de Cone, Nigello de Fridmanfell, Fufcono de Eure, Galfrida de Lifler, Petro de Coce, et aliis. 
In 8th K. Henry IV, John Lambart was appointed Jenefcal or furveyor general of all the honours, lordhips and cafles, of the right honourable Henry de Bellomonte, Lord Folkingbam, within the counties of York and Lincoln (b).

Jobn Lambart was in great creclit with K. Hcnry VMI, and employed by him on feveral occafions; was appointed fecretary to the embaffy of the Earl of Southampton into Scotland, and foon after made fecretary to the council eftablifhed in the North parts (c).

There

(b) Sciant prafentes et futuri nos Fienricus de Bellomsnte dominus de Folkirgham, dediffe et hac prefenti carta mea confirmafe Fobanni Lambart, de Prefon, in com. Ebor. confanguineo meo, officium fenefcalli mei omıium mancriorum, dominiorum, ct caftellorum noftroruminfra comitar. Lincoln. et Elor. una cum feodo fex marcarum communiter folut. pro com. Ebsr. et decem narcarum pro com. Lincoln. percipiend. annuatim et proficuis et perquifitis curiæ ibidem crefcent. labend. et tenend. prædictum officium et feoda fex marcarum, et deccm marcarum domino Fobanni de Lambart, et affignatis fuis, durante vita ipfus fobamis. In cujus rei teftimonium huic præenti cartæ figilum noftum appofuimus. His teftibus, Gohanne Tame, Willielnzo Wikes, militibus, Henrico WVikes filio ejus, Thsma Clagmsnt, Albino de Enderby, Willieino Mitchell de Fijkney, 'fobanne Willians, et multis a'iis, anno regni regis Henrici IV, poft conquefum $\delta$ vo. in fefto Tranfitionis S. Theme Mariris.—MS. penes F. L. Middleton, baronettum, de Belfay.

(c) The copies of certain letters of $\mathrm{K}$. Henry VIII, to Gobn Lambarts fon of Chrifopber. Ms. in the poffeffi $n$ of Sir Fohn Lambert Middliton, Bart.

Signed, Hinry Rx.

A warant Forafmuch as we fend this bearer Fobn Lambart, Gent. (fon of Cbriftsin paper, and 7 pher Lambart, of Skipton) with all pollible diligence upon certain our figned with the weightie affaires in:o fundrye partes of this owre realme, owre pleaPRVY SEAL. fuie and high comaudment is that immediatelie upon the fight hercof, ye ree him furnifhed from tyme to $t$, me of furficient and able horfes for his journey at pryce reafonable, when and as often as he fnall have caule, as yowe and every of yowe will anfwer "for the contrary at yowre mon cxtreme perills. givin under our fignet at owre caftell of Wyndfor the 20 th day of ociobc', the 27 th yearc of our reynge.

To all and fingular owre Mayors, Bayliffs, Sherifts, and Conitables, and to all other officers, Minitters, and Subjects, and to every of them.

Vor. II. 


\section{There twere four of the family honoured with the Order of} Knighthood; Sir Edmond, of Skipton, above-mentioned, in the

reign

$\left.\begin{array}{l}\text { A Lctter figned by } \\ \text { the King and directed, } \\ \text { both without and with } \\ \text { the Subfcription. }\end{array}\right\}$

Signed Henry Rx.

We greet yowe well; lettinge yowe weete that whereas we have directed and fent with others owre right cruftie and entgrely beloved cofyn and counfellor the earle of Soutbampton to owre towno of Nizucafice upon Tyne, there to meste and trcate with certaine commiffioners thyther to be fent from the King of Scotland our nephewe, for and touchinge an univerfal peace to be concluded between us, and owre fayd Nephewe, and both our realms for ever. Owre pleafure and high commandment is, that upon his receit hereof yowe prefently furnifh yowrefelfe to make yowre repayre to owre layde cofyn of Southampton, fo foon as yowe may underftand of his begng at Torke in his way thitherwards, thenceforth to be further employed as yowe thall be immediatelye commanded by us, or directed by him, wherein we will yowe to ufe yowre beft endeavour and dilizence, whereof we are well perfuaded already, and as yowe tender owre fervice, and hereof fayle ye not, as yowe will anfwer the contrary. Given at owre honour of Hampton Courte the tenth day of June in the xxxviiith year of owre reigne.

Direked on

the outfide and

the infide.
To owre truftee and

welle beloved Yobn

Lanibart, Gent. fonne of

Chrifopher Lambart, of

Skipton.

$\left.\begin{array}{l}\text { A Mandate, } \\ \text { disceted by a } \\ \text { Subleription, } \\ \text { Minfia. }\end{array}\right\}$

Signed Henry Rx.

by the Kinge.

Wee grectc you well; lettinge yowe weete that forafmuche as owre right truftee and well beloved cofyn and counfellor the Earl of Soutbampion is departed this lyfe in lis journey into Scotland, (upon whofe foule Ihefu have mercye!) and that dyvers and fundrie inftructions, letters, directions, papers, wrytings, and other notes touching owre fervice, wherein owre faide cofyn and counfellor was lately there, and into the north parts of our realm ymployed, whereby havinge put into yowre handes, and therc lefte, and are fo ftill remayning. Owrepleafure and high commandment is, that upon the fight hereof yowe make yowre ymmediate repaire unto us, bringing with yowe all the faide inftructions, letters, diredions, pafers, wrytings, and other notes whatfoever, received either from us or from him touchinge that fervice to be difpofed of, at owre pleafure. And hereof fayle ye not at yowre perill. Dated at owre pallace of Wefminfor the xxvith daye of October, in the xxxivih yeare of owre reygne.

To owre well beloved Foln Lambart, Gent, fonne of Chi ifopher Lambart, of Skiptsn. 
reign of K. Henry III ; Sir Foln Lambart, of Skipton; whole daughter, Sufanna, married Henry de Wake, third fon to Sir Adan de Wake, Knt. néar Pomfret; Sir Thomas his fecond fon; another Sir Thomas of Old Town in this county, fon to Alan Lambart, of Skipton, Eff]; whore fecond fon, Godfrey, of Long Preflon, married Allen, coufin to Sir Fohn Clifford, Lord Clifford, in the reign of K. Henry IV, great grandmother to Thomas Lambart, of Skipton, Efq; who married Ellen daughter and heir of Thomas Wykes, of Flitby, Efq; with whom he had a confiderable eftate both in Craven and Somerfet/fire, an award being made to compel her father to approve her marriage, done without his confent (d).

Fobn

$\left.\begin{array}{l}\text { A mandate } \\ \text { in paper direeted, } \\ \text { ut infra, and fealed } \\ \text { with the Signet. }\end{array}\right\}$

Signed Herry $\mathrm{Rx}$, by the King.

We greete yowe well; lettinge yowe weete that forafmuch as we have conceived gond lykinge of our truftie and well beloved $F_{0}$ onn Lambart, Gent. (fon of Chrilopher Lambart, of Skipton) of whofe readinefs and promptnefs in fervice we have had private knowledge for certayne years pafte. And whereas we have received divers complaints agaynit our nowe fecretarye of owre coun. fell eftablifhed in the norch partes. Owre pleafure and high commandment is owre fayde former fecretarye to be removed, and that yowe fee the fayde Foln Lambart placed in that office, and that you admit and receive him as our fecretarye of owre counfell in the north partes by thefe prefents fo to continewe at owre pleafure, and unill you receive further com. mandment from us; and hereof we will yowe not to fayle. Given under owre fignet, at owre pallace of Hefminfer the xxvth daye of November in the xxxyth yeare of owre reigne.

To owre right truftie and entyrely beloved cofyn and counfellor Charies Duke of Suffilk owse lyevetenant in the north partes, and to our counfe! there eftablifhed.

(d) Deed of Award, viz.

To all chriften people to whom this prefent writinge fhall come, fe, rede, or hearde. Forarmuch as ther has been certaine variance, debate, and ftrife, had and moved betwixt Thomas Lambart of Skipton, Gent. Fonn of $\mathcal{F}$ (isn Lambart of Prefon, deceafed, and Thomas Wikes of Fittby, Gent. for and touching the weddinge of Ellen the only daughter of the faid Thomos Wikes, which the faid Thomas Lamuart wedded at kirk core without his love and his leave gitten or afken before; for the which variance and ftrife hath the faid parties ffanden bounden 


\section{ANTIQUITIES OF NORTHUMBERLAND.}

Fobn Lambart, Efq; the famous general in the parliament-army, was of this antient family, who married Frances the daughter of Sir William Lifter, of Thornton, in Craven, and was great grandfather to Sir Golnn Middleton of Bellicy. In the geneological tabledone at the general's expence, are many curious portraits and. drawings of feals of their progenitors; a portrait of K. William $\mathrm{I}$; of William Count de Warren, his fon-in-law; of Rager Beaumont Earl of Warwick, and of Gundred his countefs; of Henry Lambart, flandarl-bearer to K. Henry II ; of the fame Henry, and Sir Alexander Olyfard, both in armour, and on horfeback, equipped for a: duel; of three young gentlemen, brothers, Charles, William, and Simmel, grandfons to Sir Edward Dymocke, to whom the court of

efther to other to fulfill arid holde the award and doome of hus Richard Cockfon, the vicar of the kirk of Batoley, IVilliam Blackburne, canon of Botton, Willian Dawefon, preft, and Thymas Ferrand, Gent. Whereupon we awarde, ordaine, and dome, the faid parties to ba accorded and frendful for evermore, and that the faid Thomas Lambart thall for evermore do knowledge to the faid Thomas Wikis as his fadder in lawe, and thall geve as good a childes part to lit:le Cbrifer his fonn, gitten by the faid Ellen in lawful wedlock, as to his. toilser fonnes called folm and gitten and born by his fuft wyfe in that wedlock, and thall make the faid Chripopher his heire (if his brother die) before the fifters that are of the hale blood to the alder barnes, and the faid Ellen fhall go to Flitby to alde Mrs. Wikes her gran. dam, ard to her fader and moder, and afk all their bleffinge and forgeveneffe for God and our Lady fake, and they fhall forgeve her, and fpeake to her afterwards as to their awne barnc. And we ordaine, awarde, and dome alfo as follows, that the faid Thomas Wikes fnall geve to his daughter Eilen no other childes part than he voutis ineet, but if his forn lienry IVikes.do cie before him, the raid Ellen and her barnes fliall be heires, and he Mall charge his faid fonn Harry uppon his bleffinge never to hinder this awarde. And if Harry do live longer than his fadir, the fadir Thall give his land in Flitby, (alias Fiafoby) and Skipton to his fon Thomas Lambart, or Cbrifer his grandbarne, and bid Harry that he fhall not make away that in Simerfetfire. And we charge them on God'sname to fulfill all this upon payne of curfes of haly kyrke. In witneffe of this our awalde, we the faid Richard Cockfon, William Blackburn, William Dorufon, and Thomas Forrant, have fett our feales gyfien the xivth daye of February in the yeere of the reigne of Kinge Eliwarl the Fourth, the one and. twenticth. 
claims adjudged the office of the king's champion, at the coronation of K. Charles II, on St. George's day, $23 \mathrm{~d}$ April, I66r, in right of his manour of Scrivelfby, in the county of Lincoln.(e). The painting is neat, and the colours well preferved ; the defcent. clear and perfpicuous, attefted by Camden, St. Gearge, Segar, and Trefrell, of the college of arms.

The villa of Belfay ftands on the flope of a hill; the family-feat built on to an old tower; a domeftic chapel among a clump of trees in a ficld to the fouth-eaft.

From the rath mile-ftone, on the left liand of the road, we have a view of

Whalton, a pleafant villa, which was the barony of Wilter Fitz William; alfo of Robert de Crammavill, from whom it was taken together with the barony of Warkworth, $6 \mathrm{~K}$. Folnn, and both given to Roger Fitz Rager, by whom it was poffefled in the reign of. K. Henry III ( $f$ ), and by his fon Fobn Fitz Robert, Lord Clavering,

I.K.

(e) Antiqua familia Lambartorum per multas propagines et diverfas utriufque fortuna vicifitudinibus, a Villielmo augufto rege ufque in hunc diem deducta, iniquis aliquanio temporum fluctibus jactata et continuata, prafertim in agro Eboracenfs, una cum caolefcentium et conjugium infigniis gentilitiis adornata, ufque ad Thoman Lambart, arnigerum, qui jam degit in agro Lincolnienfr, cui nuplit Sufanna filia Edvardi Dymocke, equitis aurati, multis nominibus viri ornatiffmi, ex qua fufcepit divina bonitate tres filios, Corolum, Willitmum, et Samuelem, quos feciales noftrijure lucido, et ordine perfpicaci, genus fuum poffe et debere refcre ad numerofam multitudincm comituum, basonum, heroum nobilium, equitumque auratoruın, clariflimæ dignitatis tam unius quam alterius profapix, genuina fatentur feriê, et ftemmatis perquam fplendidi clypeis antiquifimis teftificantur, tandemque obfignatis rabulic hæc omnia palam demonfrare rogati, æquum et operæ pretium ducunt.

MS. penes F. L. Middleton, de Belfog, baronettum.

(f) Rot. Clauf. de anno 6, Foh. m. 14.

Vid. Warn'worth. 
1.K. Edward I $(g)$. We afterwards find it in the poffeffion of the Scropes of Mafham; of Sir Henry le Scrope, $20 \mathrm{~K}$. Edward III (b); of Sir Stephen le Scrope, in the reign of K. Richard II; of Sir Henry le Scrope, $8 \mathrm{~K}$. Henry IV (i); of Sir Gobn le Scrope in the reign of K. Henry V; of Sir Thomas le Scrope, his fon and heir, $25 \mathrm{~K}$. Henry VI ( $k$ ). It ftands on the flope of a hill; a beautiful profpeet from it into the vale below.

A mile fouth from Walton, in fight allo from the 12 th mile: Atone, on the left hand, is

Ogle-Cafle, which was the feat and manour of the antient family of the Ogles; of Humplorey de Ogle at the conqueft by K. William I, confirmed to him with all its antient privileges by Walter

(f) Robertus, filius Rogeri, tenet in capite de dom. regc baroniam de thalton per fervicium trium feodorum milit. quam dom. rex Fobnnnes ei dedit, et cum carta fua confirmavit ; etomnes anteceffores fui per eund. fervic. tenuerunt. Ac de jllo tenemento nulla eft alienatio aut donatio, unde dom. rex minus habeat de fervicio fuo.

Tefta de Nerill.

(g) Fobannes, filius Roberti, tenet in capite de dom. rege Whalton, cum fuis membris, viz. Riplington, Newbam, et Huntlawe, Denton, Newbiggen fuper mare, Edington, South Gosfarth, Fawdon, Burroden, Ogle, Horton cum Stickley et Hartford membr. Woodrington, Brunsone et Druridge, membris de Woodrington, per tria feoda militaria, de veteri feoffamento.

Eícaet. de anno I $E d$. I.

(b) Henricus le Scrope, filius et hares Galfridi le Scrope, dat xv ls. pro relievo fuo de manerio de Whalton, cum pertinentibus, in comit. Nortbumbr.

Trin. Fin. anno $20 E d$. III.

(i) Henricus le Scroje, Chr. filius et hreres Stetbani le Scrope de Mafbam, Chr. tenet de dom. rege in capite manerium de Whalton et $N_{c}$ wham, cum pertinen. in comit. Northumbr. per fervicium trium feod. milit.

Rot. Mich. Fin. anno 8 Hen. VI.

(b) Thomas le Scrope, filius et hares Fobannis le Scrope, de Mafham, miles, tenet de rege in capite mancrium de Wbalton, in comit. Northumbr. de rege in capite.

Rot. Mich. Fin, anno $25 \mathrm{Hcn}$. VI. 
Fitz William, Baron of Whalton (l); of Thomas de Ogle, in part of the reign of K. Henry III ( $m$ ), and I K. Edward I ( $n$ ); of Sir Robert de Ogle, in the reign of K. Edward III. He married Eleanor the daughter and fole heir of Sir Robert Bertram, baron of Botball; by which marriage thofe two antient houfes were united. He was high bailiff of the dominion of Tynedale, as attefted by his patent, bearing date I I K. Edward III. He built the caftle of Ogle by leave from the crown, and had alfo a grant of free warren (0). He was with the king at Stanbope park, I327. He was alfo at the battle of Nevill's crofs, $1346(p)$. His brother, Sir Alexander Ogle, Knt. was flain, 29th K. Edward III, 1355, in defence of the caftle of Berwick upon Tweed, of which he was captain (q). His Lady Eleanor, Baronefs of Botball, furvived him, and married Fobn de Hatfield ( $r$ ). His grandfon, Sir Robert de Ogle, by his fon Sir Robert, fucceeded him, and had the barony

(1) Walter Fitz William came into England with the Conqueror, who gave him the barony of Walton, and the faid Walter by his deed, without date, granted to Humthrey de Oyle all fuch lands and liberties as he or any of his predeceffors had before the coming of the Normans into England.

From an antient pedigree at Rothall-Caftle, tranfcribed by Robert Treffuell, SmerfitHerald, A. D. 1598, by the favour of Cuthbert Lord Ogle.

(m) Certificat. Hugon, de Bolbeck, vicecom. Nortbumbr. Temp. Hin. Ill.

(n) Thomas de Ogle tenet Og'e, et medietatem de Burreden, per feodum et dimidium feodi, veteris feoffamenti, baronia de Whalton.

Ef́caet. de amno I Ed. I.

(0) Ex Rot. Cart. de anno is Ed. JII. m. 16.

(p) Hol. Chron. vol. ii. p. 375 .

(q) See Berwick.

(r) Rot. Pafchx Fin, anno 40 Ed. III. 


\section{ANTIQUITIES OF NORTHUMBERIAND.}

of Heppell, as was found by an inquifition, 47 K. Edward III (s). The two baronies and caftes were poffeffed by his pofterity for many generations; by Sir Robert de Ogle, who married Foanna the youngeft daughter and coheir of Sir Alan de Heton, of Elingham, Knt. as was found by an inquifition, 21 K. Ricbard II ( $t)$; by Sir Robert de Ogle, high theriff of Nortbumberland, I 6 K. Henry VI (u). by Sir Robert Lord Ogle, who was fummoned to parliament, I K. Edward IV, by the ftile and title of Baron Ogle, of Ogle; and married Ifabell the daughter and heir of Sir Alexander Kirkby, Knt. by Owen Lord Ogle, his brother, who was fummoned to parliament, I K. Richard III; and married Eleanor the daughter of Sir William Hilton, of Hilton-caftle, in the Bifhoprick of Durbam: by Ralph Lord Ogle, who was fummoned to parliament, I K. Henry VIII ; and married Margart the daughter of Sir IVilliam Gafcoigne, of Gawthrp, in Yorkfbire, Knt. and was at the battle of Brankfon or Floddon-Field, I5 I3: by Robert Lord Ogle, who married Anne the daughter of Sir Thomas Lumley, of Lumley-Caftle, in the Bifhoprick of Durbam: by Robert Lord Ogle, who firt married Dorothy the daughter of Sir Henry Widdrington; and afterwards marricd Fane the daughter of Sir Cutbbert Ratcliff, of Cartington,

(s) Efcaet. de anno 47 Ed. III.

vid. Heppel.

(t) Vid. Elingham.

Robertus Ogle, filius et hares Roberli Ogle, militis, et fobama uxor ejus, tenent mane-

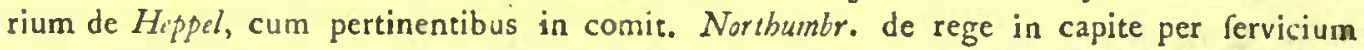
unius feodi milit. ac tertiam partem medietatis manerii de Lowick, cum pertinentibus in comit. pradicto de rege in capite, per fervicium fextæ partis unius feodi militis.

Rot. Hillar. Fin. anno 4 Hen. VI.

(vi) Efcaet de anno $16 \mathrm{Hen}$.VI. 
(v); and was flain in an expedition againf the Scots, with Sir Ralph Eure, warden of the eaft marches, at Halidon-Rigg, or: Panyer-Hugh, 37 K. Henry VIII, 1545: by Robert Lord Ogle, who was fummoned to parliament, i Q. Mary, I553; and married Fane the daughter and heir of Sir Thomas Maleverer, of Allertos, Knt. (w): by Cuibbert the feventh Lord Ogle, his brother, who was fummoned to parliament, 23 Q. Elizabeth. His lordhip married Catharine the daughter and cohcir of Sir Reginall Carnaby, Knt. by whom he had two diughters, Joanna and Catbarine. Jounna married the honourable Edward Talbot, Efq; younger fon to the Earl of Sbrewsbary, a reprefentative in parliament for Northumberland, 27, 28 Q. Elizabeth. She dicd without iffue. Catbarine married Sir Charles Cavendifh, Knt. She was created baronefs of Ogle. Her fon, Sir Willian, was raifed through all the degrees of the peerage till he was Duke of Nervaflle, for his exemplary virtues, and diftinguined loyalty to the throne. His baronies of Oyle, Botball, and Heppell, \&c. are now in the poffeffion of his Grace the Duke of Portland $(x)$. His caftle of Ogle has been long in ruins; the fituation pleafant, on the fouth ficle of the flow trout-Atream of Blyth.

From the Ioth mile-ftone, on the left hand, we have a view of

Lirkley $(y)$, one of the manours of the barony of Mitford, of

(v) From an antient pedigree of the Ogles, of Ogle, in the cuftody of William Ozle, of Cawey-Park, Eliq.

(w) From the fame pedigree, which in the account of the marriage of thefe two Lords differs from that given in the geneological table in Botball-church.

$(x)$ Sie Bctball.

(y) Kirklawe. Firkley.

VOL. II.

$\mathrm{B} b \mathrm{~b} b$

which 
554 ANTYQUITIES OF NORTHUMBERLAND.

which it was held by the antient family of Eure $(z)$, by prefenting annually a barbed arrow on St. Fohn Baptift's day at the court of Mitforl, if demanded. Fobn de Eure aiding the Scots againt K. Edreard II, his lands were feifed after his death by the crown, 35 K. Edward III, then in the poffeflion of his fon, Sir Yobn de Eure (a). They were afterwards reftored to his family, and poffeffed by Sir Ralsb de Eure, a reprefentative in parliament for Northumberland, 5 K. Richard II, with Adomar de Valence, Larl of Pembroke; who died, $10 \mathrm{~K}$. Henry V (b): by his fon, Sir William de

Eure,

(z) Eure.

Evrc.

Evers.

(a) Ego Willieimus de Neffefcld, efcactor dom. regis in comit. Eborac. et Nortbumbr. fecunduin tenorem brevis dom. regis Eduardi III, huic fchedulo attachati, vobis certifico, quod inveni pir inquifitionem coram me ex officio meo captam, Quod Fobanncs de Eure, defunctus, ten'it in feodo die adhafionis Scotis inimicis dom. Edwardi nuper regis Anglia, manerium de Kirklawe, cum pertinentibus, fimul cum quibufdam terris et tesementis in parva Berwick, Throple, Newuton-Underwood, Mitford, Benrigge, et Calverdsn-Darreyne, cum pertinentibus, in dieto comit. Northumbr. una cum homagiis liberorum tenentium, et aliorum dicto manerio, ct tenem. portinen. quod quidem manerium, terra, tenementa, homagia et fervicia, cum pertinentibus, in comit. Nortbunbr. valent per annum, omnibus exitibus, juxta v:rum valorem eorum, quadragin:a et duas libras, fex folidos, et fex denarios. Et quod YGhannes de Ewe, Chr. polt nortem prædicti Fobannis, patris fui, manerium, terra, teinementa, hom Idco capi in manum dom. regis manerium, terras, tenementa, homagia et fervicia predicta, cum pertinentibus pradiel is, et ea de caufa adhuc in manu regis exiftunt.

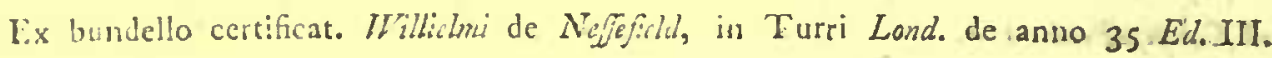
ก. 112 .

(b) Dicunt juratores fuper facrum fuum, viz. Fobames de Harle, Willietmus Bednall, Willialmus Bennet, Simon de IVeltden, Thanas Hezeligge de Swareland, Robertus Mufgrave, Willielmus Garr, Jubannes De ia volk, et alii, Quod Raululphus de Eure feifitus fuit die quo obiit in dominico fuo, ut de feodo, fibi et hæredibus fuis, in perpetuuın, de manerio de Kirklawe, villa de Eerwisk fuper Montem, manerio de Darrcs.Hall, villa de Cnlverdon-Darres, et de vil- 
Eure, high sheriff of Northumberland, 15 K. Henry VI (c); by Sir Ralph de Eure, high theriff of Nortbumberland, I 9 K. Henry VII (d). He was lord warden of the eaft marches, $28 \mathrm{~K}$. Henry VIII; his power and authority eminent; the scots, for twenty miles on the borders, paying him the utmoft deference, and living in peace and order the whole time of his government. It is recorded of him, that before his appointment to it he defended the cafte of Scarbrough with fuch valour and refolution for fix weeks, that he preferved it from being taken by the northern rebels, with the help only of his friends, tenants, and fervants, out of duty and affection, living for twenty days on bread and water.

He joined the Englifi, army at Leith, in Scotland, 36 K. Henry VIII, 1544, under the comsinand of Edward Seinour, Ear! of Hertford, with 5000 light horfe, which laid wafte all the country about Edenburgh for feven miles round, fupplied the arny with great ftore of cattie, and carried off many valuable things which they found concealed, belonging to the inhabitants of that city; the army at their departure burning the pier and the town of Leith to

lis de Throple, Neuton.Undervoood, et de quinta parte villa de Benrigge, de parco et molendino de Mitford; et quod dicta maneria, villæ, Brc. tenentur de Henrico da Porcy, de Atboll, Chr. ut de domirtico fuo de Mitford, in focagio, viz. reddendo unam fagittan barbatam die Sancti Fobannis Battifee, fi petatur, pro omni fervicio. Item dicunt quod pradictus Radulphus tenuit die quo obiit xii burgagia et octoginta acras terre in Mitford, qua tenentur de predicto Herrico de Percy, ut de dominico fuo de Mitford, in focagio. Ei dicunt quod pra?dietus Rádulpbus obiit Die Martis proxime ante feftum Sancti Georgii, Martiris, ult. praterit. Et quod Willielmus de Eure, miles, filius prædicti Radilphi, eft hæres cjus propinquior, et elt xtat. xxvi anno, et amplius.

Inquifit. capta apud Morpeth Die Martis proxime ante feftum Nativitatis Sancti Goban- nis:Baptifla, anno to Hen.V; ex bundello efcaetr. Turri Lond. n. 28.

(c) Efcaet. de anno ${ }_{5}$ Hen. VI.

(d) 19. Hen. VII. 


\section{$55^{6}$ ANTIQUITIES OF NORTHUMBERLAND.}

the ground, and the moft confiderable caftles and towns in their way to Berzuick, with the lofs only of forty men, entering that town, 18 th May.

Sir Ralph burnt the town of Fedworth the fame year; and reentering Scotland with 4000 men, 37 K.' Heirry VIII, 1545, was flain at Halidon-Rigg, or Panier-Hugh, with Lord Ogle, \&c. being furrounded in a manner by the Scots under the command of the Earl of Arran; his death caufing an univerfal forrow, his very enemies refpecting him $(e)$.

His fon, Sir Willian de Eure was raifed to the peerage in the fame reign. He was deputy warden of the eaft marches, $6 \mathrm{~K}$. Edward VI (f). He was one of the generals of the army fent againft Scotland under the Earl of Suffex, I2 Q. Elizaleth, 1570, commanding the rereward. His fucceffor,

William Lord Eure, fuccecded Sir Fobn Forfer in the government of the middle marches. His Lordhip finding himfelf abufed by his officers whom he trufted, and that the thievifh borderers did juft what they pleafed, and he could not tell how to help it, he obtained leave, on his follicitation, to refign $(g)$.

Firkley has for fome time been the lordhip and feat of a branch of the noble family of $\mathrm{Ogle}$, and is now in the poffeffion

(e) Hol. Chron. vol, ii. p. 943 i. $962-3 ; 9.68$.

(f) Bp. Nicholfon's Border-Laws.

Willielmus Dominus Exre fuit feifitus de et in manerio de Kirklawe, Berwick-bill, parva Eallerton, Ratbeley, Newton.Underwood, Edingten, et medietate de Tbrocklawe, cum certis terris in Mitford, et molendino aquatico ibidem, cum hamlet, de Sturton.

Efcaet. de anno 10 Eliz.

(8) Menmouth's Memoirs. 
of the Rev. Dr. Newton Ogle, nephew to the late admiral Ogle, and fon-in-law to the right Revd. Dr. Thomas, bifhop of Winchefer.

\section{A little beyond the 7 th mile-ftone is the villa of}

Pont-Eland, which from its name was thought by Canden to be the Roman town, Pons Ailii (b), fince fixed by a late eminent antiquary at Nerveafle upon Tyne (i). After the conquent it belonged to the Barons of Mitford, and was in the polfeffion of Adomar de Valence, Earl of Pembroke, roK. Edward II (k). A peace was concluded at it between the two kingdoms of England and Scotland, 28 K. Henry III, 1244 (l); in which the prior of Tynemonth was a principal negotiator. It ftands on the banks of the rivulct of Pont, in a low fituation. The church is in the form of a crofs.

(b) Camden's Brit. Edit. I722. p. 855 .

(k) Dicunt juratores fuper facrum fuum, quod Adomarus de Valentia, comes $P_{e m b r}$, tenuit in dominico fuo, ut de feodo, die quo obiit, manerium de Pont E!ant, cum pertinentibus, quibufdam tenementis in Parva Eland; Claverdon, et Merdesfen, quæ funt de pertinentibus dicti manerii, de dom. rege in capite.

Item dicunt, quod eft quidam parcus, cujus proficuus, ut in paftura, folcbat valere per anıum, tempore pacis vi s. iv $d$. et modo nihil pro defeclu animalium.

Et quod eft ibidem unum molendinum aquaticum, et folebat valere per annum tempore. pacis $\mathrm{x} l$. et modo non valet per annum nifi xxvis. iv $d_{0}$

Item, quod placita et perquifita curiz in dicto manerio, et pertinen. folebant valete per annum in tempore pacis vi s. viii $d$. et modo nihil.

Et dicunt, quod Fahannes de Haffings, xtat, xxx anno, Foanna uxor comitis de Atboll, xtat. xxvi anno, et Elizabetba Cumin, foror ejufiem Foanne, xrat. xvi anno, funt confanguin. et propinquiores hæredes prædicti Adonari.

See Mitford. Inquifit. capta apud Norzin Cäfrum, i4 Sépt. anno ro Ed. IT.

(1). Camden. 
$55^{8}$ ANTIQUITIES OF NORTHUMBERLAND.

In the Lincoln-taxation, made about A. D. I29I, there is a valuation of the rectory of Pont Eland, wherein it is reprefented as a collegiate church; viz.

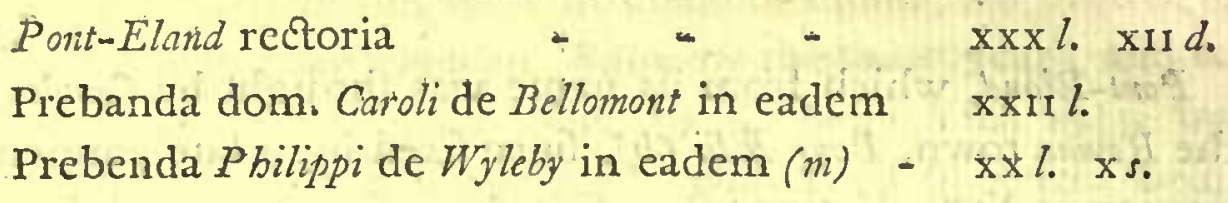

At the welt end of the church is a gallery. On the front is the following infcription in gold letters.

Mr. Richard Coates, died January $3 \mathrm{~d}$, I 79 .

And left his whole effects at or about $70 l$. per ann. to the :parifh of Pont Ifland for a charity-fchool ; the Rev. Mr. Byne, vicar of Pont Ifland, the Rev. Mr. Forfter of St. Fobn's in Nerwcafle, and Mr. Charles Clark, attorney in Nerucafle, being (with their fucceffors) left truftees for ever to fee it juftly applied.

On the fouth end of the gallery is another infeription in black letters.

Mrs. Barbara Coates built the fchool-houfe, and ereeted this gallery, at her own charge, after her hulband's deceafe.

I am informed, that $27 \%$ per ann. is all that is applied to the ufe of this fchool; and that the late vicar and archdeacon, Dr. Robinfon, filed a bill in chancery againt the truftees, who, after an expence of upwards of $50 \%$ dropt his fuit; and gave it as his opinion, that the abufe could only:be remedied by a commiffion of charitable ufes, which might extend to the whole diocefe.

(m) : Bißop Tamner's 'Notit. Monalt. föl. p. 396.

On 
On the north fide of the chancel is a flat fepulchral ftone over Cutbbert Ogle, of, Kirkley, Efq; who died, 14th January, 1655 .

Within the communion-rails, near the altar, is a flat funeral - Atone, of blue marble, with this infoription.

\section{Sub hoc Marmore:}

Sitx funt mortales Reliquiix

Rèvi Viri Henrici Byne, A. M. Coll. .

Merton apud $O$ xonienfes olim focii;

Hujus Ecclefix Parochialis de Pont-

eland modo Vicarii ; Supremo tandem

Die functi $x \times v{ }^{\circ}{ }^{\circ}$. Novembris Anno

Salutis humani MDCCXXXI ${ }^{\circ}$. Cujus

Memorix facrum hoc Monumentum pofuit,

Deflens.

\section{A. B.}

Near it is another with the following infcription.

Patris juxta cineres requiefcit

Anna Byne,

Forma et indole fpectata virgo.

Egregias natura dotes elegantiorum

Arrium ftudio excoluit;

Docilis, ut vix clidiciffe videretur ;

Adolefcentulam dignitas matrondlis,

Rufticantem decor aulicus,

Venuftare celebrem rara modeftia;

Quoquioiveftigia flectebat, fubfequebantur,

Sociarum virginum delicias et invidia major;

Dum ad apicom foemineæ laudis feftinabat,

A. D. I $741^{\mathrm{mo}}$. TEtatis $18{ }^{\circ}$ 
Variolis oppreffa moítales exuvias Amabilis puella fubtus depofuit,

Forma inviolabili renovanda.

Elizabetha tali forore haud indigna,

Funefti contagio confors ætat. anno $16^{60}$.

Juxta occubuit.

Dilectis fororibus

Ifabella frvi morbi fola vißtrix,

Hortante inatre mætiflima,

Hoc faxum $P$.

By thefe two flat funeral-ftones, there is alfo one with this infcription.

Thomas Robinfon, S. T. P.

Hujus parochix per xxx annos vicarius,

Prebendarius Peterburgenfis, nec non Landavenfis,

Et Nortbumbrienfis archidiachonus.

Vividum fuit illi ingenium,

Literis humanioribus tam probe excultum,

Ut ad feria licet attentus negotia,

Gratiis nihilominus litaret.

Infirma a teneris valetudo,

Aliis fibi defidiæ caufa,

Illi nulla obftitit

Quo minus fibi mandata munia

Gnaviter obiret.

- Fidelis verbi minifter,

Ampiger in pace confervanda jufticiarius,

Archidiachonus vigilatiflimus,

Adeo ut fi majora erant credenda,

Haud indignus videretur. 


\section{ANTIQUITIES OF NORTHUMBERLAND. 565}

Qux fupererant interea,

Ita domi componebat omnia,

Ut non inopinanti tandem, vel trepidanti,

Sed expectanti ultra,

Mors amica obvenirit,

Anno $x$ tatis $\mathrm{Lx}^{\mathrm{m}}{ }^{\mathrm{m}}$.

Salutis MDCCLXImo.

On the welt fide of the church-yard is a Sarcopbagus or ftonecoffin, digged up in making a grave; fix feet and four inches in length within, and feventeen inches over at the fhoulders.

A little beyond the 5 th mile-ftone, a winding road branches off on the left hand, from a porter's lodge, to

Wolfington (n), which was one of the manours of the priory of Tynemoutb, and was in the poffeftion of the crown, 10 Q. Eliza$b e t h(0)$. It was afterwards in the poffeffion of the family of the Femifons; and was the feat of Ralph Femifon, Efq; high fheriff of Nortbumberland, 1717. It is now the feat and manour of Matthere Bell, Efq; an alderman of the corporation of Nerucaftle upon Tyne, of which he was mayor, 1757 .

Four miles and three quarters more bring me to the end of my journey-to Nerveaftle, the Pons Ėlii, as has been before obferved, of that brave people, the Romans: A people, but for whofe coming, we might for ages, perhaps, have lived without the

(n) Wolsington. Rot. Northumbr.

Wifington. - Vulgo.

(o) See Tynemouth.

YoL. H. 
562: ANTIQUITIES OF NORTHUMBERLAND.

liberal arts, and all the graceful refinements that felicitate fociety: A people, who of great conquerors became, as it were, our fervants, to teach us how to live, like fociable and rcafonable beings, to refcue us from the bondage of favage ignorance, to polifh our manners, and to learn us by that beft of leffons, their own example, both how to poffefs a country, and how to adorn it $(p)$.

So fenfible were the inhabitants of Britain of the benefits derived from that great and renowned people, in the courfe of 500 years, that they nothing fo much lamented as the departure of the Roman Eagle: whofe grief and fituation is beautifully expreffed in a fine feal found at Floddon-field, by the river Till, reprefenting Britannia half naked, fitting upon rocks, and leaning alfo upon them with her right hand, taking hold with her left of the wing of an eagle, which has one foot upon the rocks, and the other on Britania's knee, where flic is cloathed $(q)$. It came into the poffeffion of the late Countefs Cowper $(r)$.

(p) Hax eft in gremium victos qux fola recepit, Humanumqùe genus communi nomine fovit, Matris, non dominæ, ritû, civefqùe vocavit Quos domuit, nexûqùe pio longinqua revinxit. Cloud. Paneg. iii. in Stitionem.

(2) See Gordon's plate of medals. in Itin. Seft. fig. 1.

(r) Horf. Brit. Rom. P. 75 . 


\section{[1]}

\section{APPENDIX OF INSTRUMENTS.}

\section{Vol. I. Numb. . \\ $N O R \mathcal{T H U M B R .}$}

A parliamentum apud Wefminft. anno R. Ricardi II. poft conA queftum Anglia 5to. Adomarus de Atbol, et Radulphus de Eure, milites gladiis cincti, electi fuerunt pro comitatu Northumbrie effe ad parliamentum prædictum, et quilibet eorum habuit pro expenfis fuis quolibet die iv $s$. de villis fubfcriptis, viz.

\section{Warda de Tyne-dale.}

Pro burgo de Corbrig vs, pro villis de Langley, ii s. Blenkinropp, xviii $d$. Widen cum Redepeth, ii s. Fetherfonehaugh, xviii $d$. Haiden, cum Haiden-Brig, iii s. Allerweth, ii s. Wardon, xviii $d$. Fourftanes, ii s. Birtley, iv s. Colwell, $x l d$. Barensford, iii s. Gunwarton, ii s. Eaft Swynburn, ii s. Chipches, iis. Chollerton, iii s. Shildon, vii $d$. Thockrington, iii s. Magna Bavington, iii s. Parva Bavington, ii s. Kirk-Heton, ii s. Whelpington, cum membris, ivs. Weft-Harle, xiis. Kirk-Harle, xl $d$. Cropton, xii $d$. Hawyke, xii $d$. Denum, ii $s$. Shaftowe, ii $s$. Magna Heton, iii s. Harnham, ii s. Bradford, iii s. Belfowe, iiis. Bechfield, xviii $d$. Black-Heddon, ii s. Dalton, ii s. Stamfordham, et Hugh, iv s. Hankwell, iis. Echwyke, ii s. Inghowe, iii s. Ryell, iii s. Magna Whitington, iii s. Parva Whitington, xii $\boldsymbol{l}_{\text {. }}$ Weft-Matfen, iiis. Eaft Matfen, ii s. Tenwyke, iii s. UlkC C C C 2 flon, 
fton, xviiid. Heddon fuper Murum, ii s. Hedwyne Eaft, xiid. Hedwyne Welt, xii $d$. Whitchefter, ii s. Houghton, xii d. Rouchefter, ii s. Horfley, iii s. Ovyngeham, xiid. Whithill, xviii $d$. Nebit, ii s. Hatton, iii s. Clarewood, xiid. Wyden, ii sol Nafferten, ii s. Ovynton, iii s. Berehill, ii s. Bywell, iii s. Acomb, ii s. Neuton, iii s. Stelling, xii d. Stiford, cum Operedon, iiis: Thornburg, ii s. Weft Swynburn, ii s. Devilftone, iii s. Slaveley, iiis. Duxfield, iv d. Mickley, ii s. Hedley, ii so Shot-. ley, ii s. Cronkley, iii s. Faulder-lawe, ii s: Whittenftall, iii s. Newland, ivd. Hyndley, iis. Bromeley, ii s. Brome-halg, ii.s. Eltringlam, iis. Prudhowe; iis.

Totus fummus Wardæ prxdictx, ix.l. vs. iv.d:

\section{Warda de Coket-dale.}

De burgo de. Alnwike, iv s. de burgo de Felton; iii s. iv d. de burgo de Rothbury, iii s. iv d. De villis de Framlyngton, ii $s$. vid. Swarland, iis. Acton, xviiid. Hayfand, iis. Gyfnes, iis. Berling, xviiid. Brotherwikc, xviiid: Stritton, xiid. Over-Bufton, ii s. Nether-Bufton, xviii d. Welion, iis. Bilton, ii s. Shilbothell, et Whithill, iiis. Rugley; ii s. Swynley, xiid. Glantley, xii $d$. Overgars, xii $d$. Witton, xviii $d$. Newton, xviiid. Magna Toffon, ii.s. Parva Toffon, xiid. Snytter, ii s. Thropton, ii s. Warton, iis. Flotterton, xviiid. Bikerton, ii s. Kef rern et Werg-hill, ii s. Heppell, ii s. Whernham, ii s. Sharperton, ii s. Shirmoundune; xiid: Allenton, iis: Clenehili, -xviiid. Kydland, xii d. Betlifden, ii s. Burowdon, ii s.. Tirwhet, iii.s. Thirwhet, iv.d. Cartyngton, xii $d$. Netherton, iis. Crawood, ii.s. Lourebotell, ii s. Calleley, iis. Yetlington, ii.s. Parva Ryle et Unthank, iis. Alnham, ii s. Prendwike, iis. Magna Ryle, ii s. Ellington, iis. Whittingham, ii s. Barton, xiid. 
Thrumpton, iis. Edlingham et Neuton, iii s. Lemockton, Aleberwicke, xviiid. Bolton, iis. vid. Shaweden, xviiid. Glanton, ii s. Titlington, xviii d. Beneley, ii s. Highlawe et Craweley, ii s. Brandon, ii s. Branton, iis. Ingram, ii s. Reveley, xviii d. Rodom, xiid: Ilderton, iis. Weperden, xiid. Rofdene, xviii d. Magna Lilburn, iis. Middelton et Middelton, iis: Folbery et Caldmarton; iii s.. ivd. Chatton, iii s. iv.d. Chivelyngham et Upfetlington; iiis s. ivd. Fawedon, ii s.

Totus Summus Wardæ prædictx, vii $l i$. ix s.

\section{Warda de Glen-dale.}

De burgo de Wooler, iiis. iv d. de villa de Middelton, xiid. Homeldon, ii s. Akeld, iis. Yevering, iis. Langton, iis. . Coupland, iis. Newton, iis. Weft Newton, xiid.. Hethpool, Killom, iis. Holthall, ii s. Downham, ii s. Palixton, ii s. Myndrom, iii s. Heddon, xviiid. Shotton, xviiid. Preften, ii s. Wark, iis. Learmouth, ii s. Branxton, ii s. Etall, ii s. Crookham, iis. Hederlaw, ii s. Ford, ii s. Kimmerfon, ii s. Bollifdon, ii s. Lowyke, ii s. Bayremore, iis. Howburn, iis. Hefilrig, ii s. Dodyngton et Nefbet, ivs. Eworth, iis.. Weterwood, ii s. Hetton, xviild. Horton, xviiid. Ly-m ham, iis.

Totus fummus hujus Warda, lxxivs, iv $d$.

Warda de Bamburg.

De Burgo de Bamburg, v s. de Burgo de Neuton, xii d. de Burga : dè Alnemouth, ii s. de villâ de Lefbury, iiis. vid. Haukell, iis. vid. Magna Houghton et Bulmer, iv s. Parva Houghton, ii s. Howyke, . ii s. Denwyke, xiid. Renynton et Brockley, ii s... Rocke, xwiii $d$ : Charleton South, ii s..Charleton North, xiid. Weft Dichburne, xii d. 
Eaft Dichburn, xii d. Ellingham, ii s. Ofberwyke, xviiid. Prefton; iis. Doxford, iis. Neuham, ii s. Lucker cum Hopyn, iii s. Warneford, xii d. Edrefton, ii s. Mulsfen, xviii d. Bradford, xviii $d$. Belford, iii s. Yeffington, iir. Dychaunt, ii s.. Middelton cum Unthank, iis. vid. Ulchefter, ii s. Spindlefton, ii s. Budill, ii s. Shofton, iii s. Sunderland, ivs. Bednell, iii s. Swynhowe, iii s. Tughall, iiis. Elford, ii s. Fleteham, ii s. Burnton, iis. Fallowdon, iis. Elwyke, xiid.

Totus Summus hujus Wardæ, iv li, xs. vid.

De libertate Fohamis ducis Lancaft. viz.

De villa de Emeldon, iv s. Neuton, fuper Mare, ii s. Crawcefter, ii s. Dunftane, ii s. Stamford, iiis. Shepeley, ii s. Burton, ii s. Warneham, N. ii s. et Warneham, W. ii s. Neuton fuper Moram, iis. Cartington, xii $d$. Lilburne, iis. Yerdhill, ii s. Fenton, ii s.

Totus Summus, $\operatorname{xxx} s$

In libertate de Riddifdale, Nill.

De libertate de Hextoldefham, Nill.

In libertate Prioris de Tyne-mouth.

De villa de Tynemouth, Milnton, cum Shceles, Chirton Eaft, Prefton, Munkfton, Whitley, Mureton, Erefdon, Bakworth, Seghall, Wolfington, Diffyngton, Elfwyke, Wylom, Herford, Cowpon, Bebfide, Weltden, Hauxlawe, Ambell, Eglynham, Bewyke, Lilburne, Flatworth, Middle Chirton, Weft Chirton. 
Warcla de inter Nortls.

De Burgo de Warkworth, iii s. de Burgo de Morepath, vis. De Burgo de Newbigin, vi s. de villa de Seton, ii s. Woothorn, iiis. Hirft et Lyne-mouth, ii s. Ellington, Crefwell, et Wyden, iiis. ivd. Efhenden, xviii $d$. Auld-More, xviii $d$. New-More, xii $d$. Shepewefh, xiid. Weteworth, ii s. Bothell et Langhirf, iis. Pegfworth, iis. Heborne, iis. Benrige, xii d. Highlawe, xii $d$. Pigden, xii $d$. Newton-Underwood, ii s. Throphill, it s. Thorneton, iis. Angreton, et Hertburn, iiis. Bolam et Trewyke, iiis. South Middelton, ii s. Middelton-Morell, ii s. Rotheley et Newton-Grange, ii s. Camhoe, iis. Wallington, xvirid. Hertwayton, et Weft Hertwayton, iii s. Lighton, xii $d$. Wotton, ii s. Witton, iii s. Stanton, ii $s$. Ritton, xviiid. Wyndgates et Gererdley, iis. Horfley et Toiburn, iiis. Efpley, xii $d$. Fenrother, xviii $d$. Tritlington, xviii $d$. Erefdon, xii $d$. Efchet et Bokenfelde, 'iii s. Thrathrefton, iis. Aklington, ii s. Morwyke, xviii $d$. Togefden, ii s. Hadfton, ii s. Ealt Chevington, ii s. Weft Chevington, ii s. Woodrington et Drurige, iis. Lynton, xii $d$.

Totus Summus hujus Wardæe, Civs. $\mathrm{x} d$.

Warda de inter South.

De burgo de Mitford, iis. Molefdon, xii d. Meldon, iis. Shílvington, ii s. Edington, xii $d$. Ogle, iii s. Twizel, ii s. Saltwyke, iis. Diffington, iii s. Neuham, iii s. Milburn cum Grange, iii s. Dudden Eaft, xii $d$. Dudden Weft, xii s. Stranwell, xii $d$. Hepfcotes, ii s. Stannington et Bellafis, iii s. Coupon, ii s. Bepfide, iis. Ncufom: et Horton, iii s. Hertford et Stiklawe, iiis. ivd. Seton Delavale. iv s. Hertlawe, ivs. Haliwell, iii s. Cramlinton et Whitlawe, iiis. iv $d$. Clifton et Caldwell, iiis. Shotton, iii s. Blakeden, xviii $d$. Brinklawe, ii s. Berwike, iis. vi $d$. Pont-eland, iii s. Caluerton Valence, xviii $d$. Kirklawe et Caldcotes, ivs. Diffington-Delavale, iis. Neultam, xviiid. Preftwyke, ii sa Mersfen, ii s. Donyngton, 
xviii d. Black Calverton, iis. 'Calverton Darreynes, ii s. Weft Burneton, ii s. Eaft Burneton, xivii $d$. Fawedon, xii $d$. Weteflade North, xviii $d$. Weteflade :South, xviii $d$. Burrowedon, xii $d$. Gosford North, ii s. Killingworth, iis. Benton Magna, iis. Benton Parva, xviii d. Walker, xviii d: Biker, iis. Heton, iis. Jefmont, xviiid. South Gosford, iis. Kynton, ii s. Benwell et Fenham, iis. Denton et Newbigin, ii s. Whalton et Riplinton, ii s. vid. Horton-Grange, xii $d$. Newburne, Wallbotell, Throklawe, Dewlawe et Butterlawe, iv.s.

Totus Summus hujus Wardæ, vi $l i$, viii s. viii $d$.

\section{No. 2. Vol. II.}

The Foundation-deed of Hayden-Bridge School.

7 HIS indenture made the feventeenth day of June, in the 1 firft year of the reign of our Sovereign Lord fames the Second by the Grace of God of England, Scotland, France, and Irclant, King, defender of the faith, \&c. Anno Dom. 1685 , between Jobn Shaftoe of Nether Warden in the county of Nortbumberland, clerk, of the one part, and William Shaftoe of Cary-Coates in the faid county, gent. nephew of the faid Fobn Shaftoe, Fobn Armftrong of Wood-Sbields in the faid county, Gent. Fobn Bacon of Staward in the faid county, Gent. Farrer Armftrong, fon of the faid Fobn ArmArong, Nicholas Maughen of Whinnetly in the faid county, Yeoman, and Fobn Atkinfon of Haydon-bridge in the faid county, Yeoman, and Ralph Sbaftoe, of the other part, Witnefleth, that the faid Fobn Sbaftoe for the fettling of the meffuages, lands, and tenements hereinafter mentioned to the honour and glory of ALMIGHTY GOD in the education and inftruction of youth in the knowledge 
of his word, and for and towards the maintenance of poor diftreffed proteftant families, and for putting out to apprentices poor children, and for divers other good caufes and valuable confiderations him the faid Jolnn Shaftoe hereunto moving, lath granted, alienated, fold, releafed, and confrimed, and by thefe prefents doth for himfelf and his heirs, grant, alien, fell, releafe, and confirm unto the faid William Shaftoe, Jobn Armftrong, Fobn Bacon, Farrer Armftronj, Nicholas Maugbin, Gobn Atkinfon, and Ralph Shaftoe, their heirs and affignes for ever all that his manor, lordhip, or capital meffuage of Mufphen, alias Moufen, with the appurtenances, and alfo all thofe towns, villages, and ham. lets, of Lioufen and Nerwlands, with all lands, tenements, hereditaments, and appurtenances whatfoever, to them and every of them belonging, or in any wife appertaining, fituate in the parifh of Bambrough and county of Nortbumberland aforefaid, and all the tithes of corn, grain, pig, goofe, calf, and all other ecclefiaftical right within the manour, lordhip, or capital mefluage of Mufphen, alias Moufen, and Nerland a forefaid (the tithe of wool and lamb, and the water-corn-mill there, called Moufen-mill, only excepted) together with all and fingular houfes, edifices, buildings, barns, byers, ftables, dove-coates, orchards, garths, gardens, lands, tenements, meadows, leafones, feedings, partures, commons, and common of pafture, and turbary, waftes, waft-grounds, heaths, moors, whinnes, quarrys, woods, underwoods, and trees, water, fifhings, rents, reverfions, fervices, eafements, ways, paths, paffages, profits, commodities, hereditaments, and appurtenances, whatfoever to the faid manour, lordhip, or capital mefluage, meffuages, townfhips, villages, and hamlets belonging or in any wife appertaining, or to or with the fame now or at any time heretofore held, ufed, occupied, or enjoyed, or accepted, reputed, taken, or known to be as part, parcell, or member thereof; and the reverfion, and reverfions, reVOL. II.

D d d d mainder, 
mainder, and remainders, of all and fingular the premifes, and every part and parcel thereof, and all his the faid Fobn Shaftoe's eftate, right, title, intereft, ufe, poffeffion, claim, property, and demand whatfoever of, in, and to the premifes, or any part, or parcell thereof (the faid William Shaftoe, Jobn Armftrong, Fobn Bacon, Farrer Armftrong, Nicholas'Maughen, Fobn Atkinfon, and Ralph Shaftoe, being in actual poffeffion of all and fingular the premiffes; by virtue of a deed or bargain and fale bearing date the day next before the date of thefe prefents, whereby the premiffes are demifed to them, their heirs, and affigines, for the term of ond whole year, to commence from the day next before the making thereof, and of the ftatute for transferring ufes into poffeflion, to the end that they might be enabled to take a grant, releafe, or confirmation thereof to them, and their heirs for ever; to have and to hold the faid manor, lordhip, or capital meffuage, towns, townfhips, villages, or hamlets, meffuages, lands, tenements, and premiffes, and all and fingular other the premiffes above, herein, and hereby granted, alienated, releafed, and confirmed, or mentioned, or intended fo to be, with their and every of their appurtenances, unto the faid William Sbaftoe, Fobn ArmArong, Fobn Bacon, Farrer Armftrong, Nicholas Maughen, Fobn Atkinfon, and Ralph Shaftoe, their heirs, and affignes, for ever to the feveral ufes, intents, and purpofes neverthelefs in thefe prefents mentioned, expreft, and declared, and upon the feveral trufts hereinafter mentioned, and in them, and their affignes, repofed; (That is to fay) to the ufe and behoof of the faid Yobn Shaftoe, and his anlignes for and during the term of his natural life, withour impeachment of or for any manner of wafte, and from and after his death and deceafe; then all and fingular the abovementioned premiffes unto the fad William. Shaftde, Gobn Armftrong, Foln Bacon, Farrer Armftrong, Nicholas Maugben, Jobn Atkinfon, and Ralph Saftoe, their heirs and aflignes, and the furvivour or furvi- 
vours of thein who thall be living at the death of the faid Jobn. Shaftoe, to thefe feveral intents and purpofes, and upon the fereral trufts and confidences hereafter mentioned in them repofed; (That is to fay) upon truft and confidence in them the faid $W_{i}$ liam Sbaftoe, Fobn Armftrong, Foln Bacon, Farrer Armftrons, Nicholas Maughen, John Atkinfon, and Ralpb Shaftoe, and the furvivours of them, and their aflignes, repofed; That they the faid truftees, and the furvivours of then, or the major number of them, or the furvivours of them who thall be living at the time of the deceafe of the faid Fobn Shaftoe, thall with all the convenient fpeed that may be after the death of the faid Fobn Sbaftce, fett, lett, or demife all and every part of the faid premiffes for any number of years, as to them fhall fecm meet, referving the full improved rents at four qualterly payments; and that they, or the furvivours of them, or the major part of them, thall annually elect, and choofe one of them which thall be thought moft fit to receive and pay the faid in nts and profits, according to the difpofition and appointment he after expreffecl, which perfon fo elected fhall enter into bond to iny one or more of them the faid truftees, or furvivour, or furvivours of them, in double the computed yearly value of the faid premiffes for the true payment and difpofing of all the faid rents and profits of the faid premiffes to the ufes and purpofes herein after mentioned, and give a juft account thereof to the reft of them the faid truftees, or the furvivours of then, or their affignes, within one month after demand thereof, retaining for the trouble therein for the year twenty fhillings, and twenty fhillings more to defray his and the other truftees expences one whole year in meeting os otherwife concerning the truft in them repofed. And upon turut and confidence in them the faid truftes, and the furvivours of them, and the heirs and affignes of the furvivours of them, who $D \mathrm{~d} d \mathrm{~d} 2$ Alat 
thall be truftecs, repofed, That they the faid truftees, and the furvivours of them and their affignes, or the major number of them, Thall with the one moiety of the faid rents and profits of the faid premifles, as foon as there is fufficient, purchafe a convenient parcel of land in Haydon-Brilge aforefaid to themfelves, and fettle the fame in like manner as the above faid premiffes thall be vefted at the time of the purchafe thereof, and the ufes herein mentioned, and thall thereupon ereet and build a houfe for a free grammar fchool-houfe, and keep an Englifls fchool, and a dwelling-houfe for the matter of the fame feliool, and thall by a note by them, or the furvivours of them, or the major part of them, figned, elect, and choofe, by the advice and examination of fome reverend divines, an able fcholar, being an Univerfity-fcholar, of the degree of Mafter of Arits, and of good life and converfation, approved by the:Bifhop or Archdeacon of the diocefe, by figning the fame note; and one ufher; to be approved of by the Minifter of the parifn of Warden; who thall teach and infruct any number of boys, girls, and young men, who are or thall be born within the chapelry of Haydon, or at Wood-Sbields in the chapelry of Newbrongh, both in the parifh of Warden, and county of Nortbunberland, and thall pay unto the wher of the fame fchool yearly ten pounds, and no more, out of the moiety of the rents and profits of the faid premiffes at four quarterly payments, and the refidue of the moiety of the rents and profits of the fame premiffes, the moiety of the necellary charges of gathering and receiving the fame deducted, thall pay yearly to the mafters of the faid grammar-fchool, at four payments, as the fame thatl be had in, and received, for their maintenance and falary: and upon the like truft and confidence, that they the faid truftees, and their affignes who thall betruftees, and feized of the fitid premiffes, doltake-fecurity to 
fome two of them at the leaft, from fuch to keep the faid hotife and fchool-houfe in good and fufficient reparation, and leave it fo in repair. And that if fuch mafter or uhler, as thall at any time be cliofen, (fhall wilfully and obftinately neglect the duty of their or either of their places, or thall become unfit for the faine by any means whatfoever; that then the faid truftees, and thofe who fliall at any time hereafter be truftees and feized of the faid premiffes, or the major number of them, thall and may, by writing tunder their hands fhewing the caufe thercof, Acclare fuch mafter and tufher to be unfit, and put him or them outs and thereupon, and upon the death of either of them, to elect another in manner aforefaid. And that the faid truftees, and fuch wlio fhall at any time hereafter be truftecs, and feizcd of the faid eftate, thall not permit the under-mafter or ufher to take for the teaching of any boy or girl, who thall be born within the chapelry of Haydon and Woid-fseels aforefaid, above one penny for every quarter of the year for teaching and inftructing them in the Latin and Greck tongues, upon pain of forfeiting: and being turned out of their faid places : and upon further truft in them the faid truftes, and thofe who: thall be truftees, and feized of the faid premifles, repofed, That if by the death of the faid matter and ufher, and either of them, or other vacancy, the falary or ftipend of the faid mafters, and either of them, fhall lie and remain in the hands of fuch receiver or truftees to be chofen as aforefaid, that they fliall from time to time, as often as fuch accidents happen, in fuch vacancy of a mafter, therewith or with part thereof, repair, new-build, or amend, the fchool-houre, and dwelling-houfe, to be built as aforefaid, and the clear overplus of fuch fums fo as aforefaid coming unto the faid grantees or truftees hands, fhall be by them diftributed amongt the poor hereafter mentioned, sand as is hereafter directed. And upon this further truft and confidence in them the: 
faid trufte; and fuch other perfons who thall be truftees, and feized of the faid premifles, repofed, That they, or the major number of them, do, and thall pay and diftribute the other moicty of the other remaining moiety, or the fourth part of the whole clear rent of the premifles (a fourth part of the necelfary charges for receiving the fame being deducted) for ever halfycarly among poor proteftant families within the faid chapelry of Haydn and Wood-gseels aforefaid, according to their feveral, necellities, and the difcretion of the faid grantees or truftecs, or. thofe who thall at any time be truftees or grantees, or the major number of them: and the other fourth part, the remainder of the rents and profits of the faid premifles, to be difpofed of yearly for putting out to trades poor proteftant children, born, or to be born, wichin the chapelry of Haydon, or any of the owners tenants or farmers at Wood-Jeels aforefaid, at the difcretion of the faid truftees, or thofe who thall be truftees, or the major number of them: Provided always, and it is. the true intent and meaning of thefe prefents, and of all the parties hereunto, and thefe prefents, are upon the further truft and confidence in them the faid truftees, and furvivour or furvivours of them, and in all and every other perfon or perfons who thalt be truftees and feized of the faid premiffes, repofed, That as foon as it fhall happen any three or more of the faid grantees or truftees, or of any other truftees who thall at any time hereaftei be feized of the above-mentioned premiffes, hall dye, then the furviving grantees or truftees thall, with all convenient fpeed, that may be, elect and choofe three or more to make up the; number of feven to be truftees, and fill up the vacancy of thofe who are dead, and fhall convey over the premilfes to fome perfon or perfons by them, or the major part of them, agreed on, the fee and inheiritance of the faid premifles, who thall immediately. reconvey, to the old truftees, and fuch new truftees as thall be elected, 
elected, the faid premiffes, to the ufe of themfelves, and the faid other grantees or truftees to be elected, and for the ufes and benefits above in thefe prefents mentioned and declared, and fo from time to time when only four truftees are furviving. They; or fuch as thall furvive, thall continually and with all fpeed join with themfelves three or more other grantees or truftees of the premiffes in manner and form aforefaid, as by the counfell learned in the law may be advifed; to the intent, that the fee and inheritance of the faid premiffes, and the rents, iffues, and profits, may for ever hereafter be difpofed of to the ufes, intents, and purpores, and in fuch fort, manner and form, as is above in thefe prefents mentioned, expreffed, and declared: And, laftly, upon this further truft and confidence in them the faid truftees, and their affignes, who thall be truftees, repofed, That if it thall at any time hereafter happen any difference fhall arife concerning election or putting out of the fchoolmafter, ufher, fcholar, poor, or objects of charity, or concerning any matter whatfoever by them to be done as truftees by virtue thereof, fo that they the faid truftees are divided in their votes, that then the bithop or archdeacon of the diocefe shall have the cafting vote, and then that they the faid truftees fhall do and perform according as either of them thall approve of: In witnefs whereof the parties aforefaid to thefe prefents interchangeably have fet their hands and feals the day and year firf above written.

\section{An Anecdote annexed to the faid Deed.}

FOHN Shaftoe, clerk, granted to Patrick Crow, Gent. all that meffuage, hamlet, village, or tencment, with its rights, $\mathrm{mem}^{-}$ bers, and appurtenances, commonly called and known by the name of Newland, fituate, lying, or being in the faid county of Northumberland, and now or late in the pofferfion and occupation of 
Gilbert Swinoe, or his under-tenant, or aflignes, together with feren ftints or beaft-gates, and liberty of depafturing at all times in the year for feven beafts, or fints, in and throughout the clemefne-lands, of Musfen, alias Monfen, in the faid county of Nortbumberland; together alfo with two horfes grafs, and thirty theep's grafs, or liberty of depafturing, feeding, and going, at all times in the year. for two horfes or mares, and thirty theep, in and throughout the town-fields of Musfen, alias Mouen, aforefaid, in the faid county of Northumberland; and alfo all that water-corn-mill, with its rights, members, and appurtenances, fituate, ftanding; and being in Musfen, alias Moufen, aforefaid, commonly called or known by the name of Moufen-mill, now or late in the poffeffion or occupation of the faid Gilbert Sxinoe or his affignes; and alfo one cow's grafs, with a calf, or follower, and two horfes, or liberty of depafturing and feeding one cow, with a calf, or follower, and two horfes ar mares, at all times in the year, in and throughout the faid town-ficlds of Musfen, alias Moufen, aforefaid, in right of, and as belonging to the faid watci-corn-mill.

\section{Vol. II. No 3 .}

Mr. Shaftoc's Will.

T $N$ the name of God, Amen. I Jobn 'Shaftoe, of Nether Waiden I in the county of Nortbumberland, clerk, being in good health of body and of found and perfect mind and memory, praife be therefore given to ALMIGHTY GOD, do makeand ordain this my prefent laft will and teftament in manner and form following; (that is to fay) firft and principally I commend my foul into the hands of AlMigHT Gop, hoping through the merits of the death and paffion of my Saviour JESUS CHRIST, to have full and free pardon and forgivenefs of all $\mathrm{my}$ fins, and to inherit ever- 
lafting life, and my body I commit to the earth to be decently buried at the difcretion of my executors hereafter named, and as touching the difpofition of all fuch temporal eftate as it hath pleafed Almighty Gon to beftow upon me, I give and difpofe thereof as followeth. Firf, I give and bequeath to the chapelry of Haydon one annuity or annual rent of twenty pounds per annum for ever, to be paid out of my lands, tenements, and hereditaments of Moufin in the county of Nortbumberland, at the feafts and terms of Martinmas and Penticof yearly by equal portions, the firtt payment thereof to begin at fuch of the faid feafts as thall next happen after the death of me the faid Fobn Shaftoe, and not before, for the ufe of a Grammar-School to be kept at Haydon-bridge, and maintenance of poor families in the faid chappelry of Haydon, equally to be divided (viz.) ten pounds por annum to the faid fchool, and ten pounds'per annum to the faid poor families. Item, 1 give and bequeath to the faid chappelry of Haydon, in the faid county of Nortbunberland, one other annuity of twenty pounds per annum for ever, to be iffuing or going out of thefe engagements or mortgages I have of the lands and eftate of Sir Fobn Heron, Bart. late deceafed (viz.) ten pounds per annum thereof towards the kceping of the faid grammar fchool, and the other ten pounds to the ufe of the faid poor families in the faid chappelry, at the feafts of Martinmas and penticoft yearly by equal portions, the firtt payment thereof likewife to begin at fuch of the faid featts as thall next happen after the death of me the faid Folon Shaftoe. Item, I give and bequeath an augmentation of ten pounds for cver to the parinh church of Slaley in the faid county of Nortbumberland, to be paid out of the faid engagements or mortgages of the faid Sir Fabn Heron's eftate, at the feafts and terms aforefaid, and I do hereby ordain and appoint Mr. Arcbdeacon, and Mr. Fobn Rowell, and their fucceffors, executors for all the faid monies for the aforefaid charitable and pious ufes, and I do Yos. II. Ece $R$ hereby 
Vol. II. No. 3 .

hereby nominate and appoint Fobn Bacon, of Staward, in the aforefaid county, Efq; Fobn Aikinfon of Haydon-Bridge; and Nicholds Maugbam of Tedcafle, both in the aforefaid chappelry of Haydon, yeomen, truftecs and governors of the faid money bequeathed by me for the faid fchool and poor of Haydon chappelry, and when any of them thall die, the furvivors to elect a third perfon with them in, and at all time and times after my death to provide a fufficient fchoolmafter for the faid fchool, and diftribute the faid monies fo bequeathed to fuch needful and poor families as they thall think fit in the faid chappelry. Item, I give and bequeath to my nephew Mr. Ralpb Shaftoc; of Carycoats, the fum of eight hundred pounds out of engagements and mortgages of Sir Folm Heron's eftate, the intereft thereof to be paid him at feafts and terms above-faid. Item, I give and bequeath unto my nepherw Mr. Jobn Sbaftoe, fon of my brother Mr. Charles Shaftoe of Carycoates the fum of two. hundred pounds out of the faid engagements or mortgages of Sir Fobn Hcron's eftate, the intereft thereof to be paid him at the feafts and terms aforefaid. Item, I give and bequeath to my faid brother Charles Shaftce's five daughters, that are now unmarried the fum of eight hundred pounds in manner and form following (viz.) Five hundred pounds thereof out of the faid engagements or mortgages of Sir Fobn Heron's eftate, the intereft thereof to be paid them at the feafts and terms above-mentioned; and other three hundred pounds to be paid by my fon Daniel Sbaftoe, his heirs or affigns, out of my lands and hereditaments of Moufin, the faid eight hundred pounds to be difpofed of among them as their father and mother think fit. Item, I give and bequeath unto Fobn Atkinfon of Haydon-bridge, my clerke, and fervant, the fum of four hundred pounds for the ufe of his children that are now unmarried (viz.). Two bundred pounds thercof upon a 
mortgage of Gabriel Read's eftate of Trough-end, Efq; with all my title and intereft to the fame, and one other hundred pounds, part thereof upon a mortgage of Mr. Ralph Fenwick's of Bavington, with all my title and intereft to the fame; and one other hundred pounds to be paid him or them by my fon Dariel Shaftoe, his heirs or affigns, out of my lands and hereditaments of Moufin, immediately after my death. And my will and pleafure is, that the faid Fobn Atkinfon thall diftribute all the faid four hundred pounds amongt his faid three children, (viz.) Fobn, Mary, and Margaret, as he thinks fit and convenient. Item, I give and bequeath to my fon Daniel Shaftoe, and to his heirs for ever, all my lands, tenements, and hereditaments of Moufin aforefaid, he and they paying and difcharging all fuch legacies as I have bequeithed and given in this my laft will and teftament, to the ufes and perfons aforefaid, to be paid out of the faid eftate of Mouf $\mathrm{m}$. And I give to the faid Fobn Bacon, Efq; and Fobn Atkinfon, my truftees aforefaid for the faid pious and charitable ufes, each of them a guinea for a token, to be paid by my executors. Item, all the reft of my goods and chattells, ready money, bills and bonds, and all debts whatfoever, in whofe hands foever, I give to my loving brother Charles Shaftoe of Carycoates, and Fobn Shaftoe of Bavington, Efq; equally to be divided betwixt them, whom I make my joint executors of this my laft will and teftament, and of the execution of the fame-excepting only for the pious and charitable ufes. And I do revoke and difannull, and make void all former wills and teftaments, as witnefs this thirteenth day of May, in the year of the reign of our fovereign Lord and Lady William and Mary, by the grace of GoD King and Queen of England, Scotland, France,' and Ireland, defenders of the faith, \&c. Amiog; Domini 1693. 
Signed, fealed, and delivered by the faid Fobn Shaftoe, as and for his latt will and teftament, in the prefence of us.

Foseph rellowley,

Thomas Shaftoe,

Gohn Shaftoe, Junr.

William Errington, Jun:

Be it known unto all men by thefe prefents, that whereas I Fobn Shaftoe, of Nether-Warden, in the county of Nortbumberland, clerk, have made and declared my laft will and teftament in writing, bearing date with thefe prefents, I the faid Fohn Shaftoe clo by this Codicil confirm and ratify my faid laft will and teftament, and do give and bequeath-unto $A n n$, the daughter of $W_{i l}$ liam Errington of Bradley, in the faid county, yeoman, the fum of one hundred pounds of good Englifh money, and my will and meaning is, that this Codicil be adjudged as part of my laft will and teftament, and that all things contained and mentioned be truly and fully performed, as full and amply in every refpect as if the fame were declared and fet down in my faid laft will and teftament within written. In witnefs whereof I have hereunto fet my land and feal the day and year within written, 1693.

Sealed and clelivered $\}$ in the prefence of us $\}$

Fobn Shaftoe, Junr.

Ralph Shaftoe,

Folm Atkinfon. 


\section{Number 4 .}

\section{Giles Heron's Will.}

In the name of God, Amen, I Giles Heron, late of Lee-ball, and now of Wark, in the parifh of Simonburn, and county of Nortbumberland, yeoman, being well of body and of perfect mind and remembrance, do willingly and with a free heart render and give again, into the hands of my Lord Gop and Creator, my fpirit, which he of his fatherly goodnels gave unto me, when he firft fafhioned me in my mother's womb, making me a living and reafonable creature, nothing doubting but for his infinite mercies fet forth in the precious blood of his dearly beloved Son Jesus Christ, our only Saviour and Redeemer, he will receive my foul into his glory, and place it in the company of the heavenly angels and bleffed fpirits; and as concerning my body, even with algood will und free heart I give it over, commending it to the earth whereof it came, nothing doubting but according to the articles of my faith and the great day of the general refurrection, when we thall appear before the judgment feat of Chris'r, I thall receive the fame again by the mighty power of God wherewith he is able to fubluc all things to himfelf, not a corruptible vile and weak body as it is now, but an incorruptible ftrong and perfect body in all parts like unto the body of my Lord and Saviour JESUS CHRIST; and as touching the difpofition of all fuch temporal eftate, as God of his great goodnefs hath given unto me; I do by this my laft will and teftament give and difpofe thereof as followeth. Firt, I think it a good work of charity, and commendable before Gon, to diftribute the greateft part of the fame to pious and charitable ufes, and it is rather my defire 
defire to fee fome part for fuch ufes fettled in my lifetime, than to leave it by and according to the direction of any other perfon or perfons to be done after my déath, and confidering the great neceffity of a free fchool for the cducation of children of all and every the inhabitants within the faid parifh, and the inhabitants of Chipchace, Birtley, and Birtley-Sbeels within the parih of Chollerton, I do therefore give and bequeath unto the parith of Simonburn the fum of two hundred pounds now in the hands of William Clarleton of Hefleyflde, and Cutbbert Cibarleton of Lee-ball, in the faid county, Gent. received by them of me for the ufe abovementioned, and for no other ufe or purpofe what foever. And my will and pleafure therefore is, that my truftees, namely George Heron, Fobn Reed, Thomas Dobfon, Thomas White, and Edward Robfon, all of Humfaugh, William Sinitb of Wefterbaughton, Robert Elliot of Haughton-Strotber, William Liddle of Long-Rigge, and Nicholas Ridley of Eals, do immediately in my name (in cafe the faid William Charleton, and Cutbbert refufe to pay the faid fum of two hundred pounds) profecute and implead the faid William Charleton, and Cutbbert Charleton, and their fureties or any of them, for the faid fum, in any court of common law or chancery, and upon the receipt thereof that they my faid truftees and Cbriftopher Charleton of Hetherington, Reginald Charleton of Motebill, and Edward Dodd of Eff, or the major part of them, together with the parfon of Simonbum-parifh, for the time being, do choofe and appoint an able and fufficient fchoolmafter, fuch as thall be approved on by the lord bifhop of the diocefe of Durbam, and fo from time to time upon the death or removal of fuch fchoolmafter, fuch another to refide and teach a fiee fchool at the town of Wark in the faid parith for ever and that the faid truftees thall make the beft advantage and profit of the faid fum, they upholding the principal as aftock, and the profits and intereft thereof they thall receive at two terms in the 
year (that is to fay) by half yearly payments, and at the faid terms by equal portions, they thall pay the intereft fo received unto the fchoolnafter of the faid free fchool for the time, that he fhall difcharge the duty of an able fchoolmatter in manner as aforefaid; and my mind is, that the parfon of Simonbum, for the time being, and his fucceffors with my truftees aforefaid, and Chrifopher Charleton, Reginald Charleton, and Edward Dodd, and the furvivours of them, thall be the governors of the faid free fchool, and thall have the prefenting of a fchoolmatter as aforefaid, and that all bonds or fecurities to be taken for the faid monies thall be taken in their names, and in cafe of the deceafe of them or any of them, then the parfon and the furvivours of them the faid truftees, fhall, in convenient time, elect and choofe one or more of fuch able and fit inhabitants of the faid parifh of Simonburn, to fupply the place or places of fuch dying truftees, who thall fucceed them therein. Item, all the reft and rcfidue of my goods and chattels, as well real as perfonal, and my ready money, mortgages, rent charges, bills, bonds, book-debts, debts due upon fimple contract, in whofe hand or hands focver they be, I give unto the faid truftees firft before named merely in truft for the ufe of the poor of the faid parifh of Simonburn (that is to fay) that they may to the beft of their fkill make the beft, fureft, and greateft advantage and profit thereof upon good fecurity for intereft, and the faid advantage and profit they thall receive, pay and diftribute among fuch poor, needy and indigent perfons of the fame parifh of Simonburn, as they fhall judge moft neceffitated and proper for it, at two feafts or terms of payment, (that is to fay) All Saints Day and Good Friday, by even and equal portions, .but the principal to be always kept intire and upheld as a ftock for the end aforefaid; and my will and pleafure is; that if there be any indigent perfons within the faid parifh of 
Simonburn of the name of Heron, or coming from any other parifh to inhabit or refide in the faid parifh, that they thall have a proportion of the faid diftribution in the firf place. And further my will and defire is, that if there happen to be any furpluffage remaining of the faid profits, intereft or confideration-money, that then the fame fhall-be employed on or towards the binding of fome one or more of the children of fome of the poor inhabitants of the fame parifh of Simonburn, to be apprentices to fuch trades and in fuch places as the faid parfon and my truftees or the major part of them thall think fit, and if any of the faid children thall happen to be of the name of Heron, that they fhall be firft provided for; and my will is, that my faid truftees fhall yearly make an account of their diftributions and payments aforefaid, and of the reft of their truft, to the parfon and churchwardens of the faid parifh of Simonburn at Penticolt, which thall be regifted in the parifh book. And I do hereby name and appoint the faid George Heron, Fobn Reed, Thomas Dobfon, Thomas White, Edward Robjon, William Smith, Robert Elliot, William Liddle, and Nicholas Ridley, my executors in truft for the ufes aforefaid, for the better performance of the faid trufts, and I revoke all former wills. As witnefs my hand and feal this three and twentierh day of September, in the one and thirtieth year of the reign of our fovereign Lord Charles the fecond by the grace of God, King of England, \&c. Annog; Dom. 1679. Signed, fealed, publithed, and declared by the within named Gyles Heron, as and for his laft will and teftament, in the prefence of us Robert Delaval, George Ridley, Thomas Teafdaile, Tim. Pye, Peter Barrell.

G YLES HERON.

Collatione fideli facta, concordat hæc copia cum originali, exiftente apud me

Gab. Newboufe, Regifter. 


\section{TYPOGRAPHICAL ERRATA. \\ Vol. II.}

JoURney I. Pagge 4. for turf or fuel, read turf for fuel.

p. 5. for cornelian, read, carnelian.

p. I6. at the bottom (d), for turris, read terris.

p. 25. for via vacinalis, read via vicinalis.

p. 33. at the bottom (v), for denariat. read denarios.

p. 39. at the bottom $(f)$, for cornargium, read cornagium.

- - p. 4 I. at the hottom (i), for libræ, read liberæ.

- _ - p. 79. at the bottom (n), for Brect. read Bracton de legibus Anglice. Lib، iir.

p. 90. for externum, read extcrnaruin.

p. 133. at the bottom (c), for per annum $\mathrm{x}$, read per annum $\mathrm{x}$.

p. 139. at the bottom (b), for dat regi $v$, read dat regi $v$ s.

p. ib. for dat regi $x$. read dat regi $x l$.

p. ib. for per fervicium $x$. read per fervicium $x l$.

p. 164. at the bottom ( $z$ ), for de dimid. feod. read et dimid. feod.

p. ib. for vallem prædit. read vallem prædict.

- p. ib. for per annum $\mathrm{xx}$, read per annum $\mathrm{xx} s$.

- p. 176. for Cleolfridi Abbatis, read Ceolfridi Abbatis.

- p. 196. for the fairs and Lammas, read the fairs of Lammas.

p. 22. I. for orati, rend orate.

- p. 247. for Helourne, read Hebburne.

JoURNEX II. p. 285. at the bottom (s), for Baelcampo, read Bellocampo.

- p. 286. at the bottom (u), for uxor, read uxore.

p. 299. at the bottom (v), for comitæ ceftriæ, read comite ceftriæ.

- p. 295. at the bottom (0), for pers ipfo, read per ipfos.

p. 330. at the bottom (c), for cum iurris, read cum terris.

p. 349. at the bottom ( $w$ ), for penes met, read penes me.

_- $\mathrm{p} .353$. at the bottom $(f)$, for valorum prædictarum, read valorem prædictarum.

p. 357. at the bottom $(f)$, for comitiffe, read comitifle.

p. 378 . dele the reference (l).

p. 402. for at his caftle, read at this caftle.

p. 405. for prior of Nofill, read priory of Nofill.

JoURNEY III. p. 449. at the bottom (b), for Norray, read Norroy.

p. 49 I. at the bottom (b), for Bobertus, read Robertus: and for Roxham read Broxbam.

p. 498. for Procter, read Proctor.

p. 503. at the bottom ( $n)$, for medietatis, read medietatem.

p. 532. at the bottom $(r)$, for Fohanni, read Fobannis.

p. 547. for Allen, read Ellen:

VoL. II, 


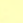


DA

670

N8W2

v.2
Wallis, John

The natural history and antiquities of Nor uhumberland

PLEASE DO NOT REMOVE CARDS OR SLIPS FROM THIS POCKET

UNIVERSITY OF TORONTO LIBRARY 
